RICHARD ROMANCINI

\title{
O campo científico da Comunicação no Brasil: institucionalização e capital científico
}

\section{Volume I}

Tese apresentada ao Programa de Pósgraduação em Ciências da Comunicação da Escola de Comunicações e Artes da Universidade de São Paulo, como requisito parcial para a obtenção do título de doutor em Ciências da Comunicação, na Área de Concentração Teoria e Pesquisa em Comunicação

Orientadora: Prof ${ }^{\mathrm{a}} \mathrm{Dr}^{\mathrm{a}}$ Maria Immacolata Vassallo de Lopes 


\section{Errata}

Pág. 3 - Linha 28 - onde se lê nas superação, leia-se na superação

Pág. 5 - Linha 3 (nota 3) - onde se lê buscarim, leia-se buscariam

Pág. 12 - Linha 1 - onde se lê das proposição de Lakatos,), leia-se da proposição de Lakatos)

Pág. 12 - Linha 28 - onde se lê existem instância, leia-se existam instâncias

Pág. 30 - Linha 5 - onde se lêm se objetivar-se-á, leia-se objetivar-se-á

Pág. 52 - Linha 7 - onde se lê deixarim, leia-se deixariam

Pág. 53 - Linha 10 - onde se lê transdiciplinaridade, leia-se transdisciplinaridade

Pág. 57 - Linha 1 (nota 20) - onde se lê contorversas, leia-se controversas

Pág. 61 - Linha 15 - onde se lê transdiciplinaridade, leia-se transdisciplinaridade

Pág. 71 - Linha 10 (nota 24) - onde se lê quea, leia-se que a

Pág. 75 - Linha 4 - onde se lê operamde, leia-se operam de

Pág. 85 - Linha 6 - onde se lê Liede Filho, leia-se Liedke Filho

Pág. 97 - Linha 19 - onde se lê sermarcados, leia-se ser marcados

Pág. 142 - Linha 19 - onde se lê, $C N P q$ (seguinte, leia-se CNPq (seguindo

Pág. 144 - Linha 17 - onde se lê pode-se dizer a área a Comunicação tende a receber menos investimentos que as áreas aqui vistas, como já disse, leia-se pode-se dizer que a área a Comunicação tende a receber menos investimentos que as áreas aqui vistas, como já se disse,

Pág. 145 - Linha 30 - onde se lê aos investimento, leia-se aos investimentos

Pág. 146 - Linha 26 - onde se lê irãoresponderá, leia-se irão responder

Pág. 156 - Linha 9 - onde se lê sedidados, leia-se sediados

Pág. 160 - linha 11 - onde se lê posicionamente, leia-se posicionamento

Pág. 167 - Linha 5 - onde se lê se explicam, leia-se se explica

Linha 10 - onde se lê nomeclatura, leia-se nomenclatura

Pág. 179 - Linha 9 - onde se lê tem como, leia-se têm como

Pág. 180 - Linha 5 - onde se lê produção feitos coordenados por, leia-se produção coordenados por

Pág. 183 - Linha 10 - onde se lê alcancaram, leia-se alcançaram

Pág. 186 - Linha 7 - onde se lê internalização, leia-se internacionalização

Pág. 218 - Linha 14 - onde se lê etapas próximas de uma ciência próxima da idéia de "ciência normal", leia-se etapas próximas de um estágio de "ciência normal"

Pág. 219 - Linha 16 - onde se lê da, leia-se dá

Pág. 224 - Linha 3 - onde se lê gerados novos., leia-se gerados novos argumentos.

Pág. 228 - Linha 2 - França, Hohfeldt, Martino garantem tem essa, leia-se França, Hohfeldt e Martino garantem essa

Pág. 232 - Linha 3 - onde se lê do matéria, leia-se do material Linha 12 - onde se lê digitáveis, leia-se digitávamos

Linha 21 - onde se lê é, leia-se $e$

Linha 25 - esse material tem tem, leia-se esse material tem

Pág. 233 - Linha 12 - onde se lê da ciências sócias, as citações formam em, leia-se das ciências sociais, as citações foram em

Pág. 235 - Linhas 3 e 5 - onde se lê uniautorias, leia-se uniautorais

Pág. 236 - Linha 4 - onde se lê dois, leia-se duas

Pág. 237 - Linha 1 - onde se lê 7.11, leia-se Tabela 7.11

Pág. 238 - Linha 4 - onde se lê, relativos as citações, leia-se relativos às citações 
Linha 7 - onde se lê, A Tabela 12 não mostra um padrão de aumentou, leia-se A Tabela 7.12 não mostra um padrão de aumento

Pág. 239 - Linha 1 - A variação, leia-se Há variação

Pág. 242 - Linha 3 - onde se lê na primeiro, leia-se na primeira

Linha 26 - onde lê usados pesquisa, leia-se usados na pesquisa

Pág. 246 - Linha 11 - onde se lê bem citado vários, leia-se bem citado em vários

Linha 12 - onde se lê Levy, leia-se Lévy

Pág. 245 - Linha 5 - onde se lê existe, leia-se existem

Pág. 251 (numerada como 231) - Número de página correto - 251

Pág. 252 - Linha 6 - onde se lê tem, leia-se tem, leia-se têm

Linha 12 - onde se lê áera, leia-se área

Pág. 254 - Linha 5 - onde se lê existe, leia-se existem

Linha 6 - onde se lê Mello, leia-se Melo

Pág. 255 (numerada como 247) - Número de página correto - 255

Pág. 256 - Linha 7 - onde se lê mantém-se, leia-se mantêm-se

Pág. 257 (numerada como 249) - Número de página correto - 257

Pág. 258 - Linha - onde se lê Comunicação e demandaria, leia-se Comunicação demandaria

Pág. 259 - Linha 20 - onde se lê interaturar, ler interatuar

Pág. 260 - Linha 3 - onde se lê compreener melhor o acentuado de capital, leia-se compreender melhor o acentuado grau de capital

Linha 6 - onde se lê mais maior, leia-se maior

Linha 11 - onde se lê transdiciplicinar, leia-se transdisciplinar

Linha 28 - onde se lê é externa, leia-se são externas

Pág. 261 - Linha 10 - onde se lê espero - leia-se esperamos 
Narrar-se-ia toda uma vida se se fizesse a narrativa de todas as portas que se fecharam, que se abriram, de todas as portas que se gostaria de reabrir.

Mas é o mesmo ser aquele que abre uma porta e aquele que a fecha?

Gaston Bachelard (1988, 255) 
Richard Romancini

O campo científico da Comunicação no Brasil:

institucionalização e capital científico

Banca Examinadora

Presidente:

Prof $^{\text {a }}$ Dr $^{\text {a }}$ Maria Immacolata Vassallo de Lopes

Membros:

São Paulo, de de 2.00 . 


\section{Agradecimentos}

Apesar do risco de parecer demagógico, gostaria de agradecer em primeiro lugar à minha orientadora. Nesses quase dez anos de convivência, aprendi lições que vão muito além da vida acadêmica.

Agradeço também a meus pais e ao meu irmão pela compreensão e auxílio. Vários amigos também tornaram essa trajetória menos árdua: Alejandra Nicolosi, Cláudia Lago, Cláudia Mogadouro, Claudemir Viana, Fabiano Cataldo, Gustavo de Carvalho, Lílian Escorel, Luciana Félix, Mariana Klinke Pandolfi, Patrícia Horta, Ricardo Bergamo e Valdinete de Souza.

Os professores doutores Alberto Efendy Maldonado (UNISINOS), Antonio Adami (UNIP), Ana Paula Goulart (UFRJ), Anna Lúcia Enne (UFF), Antonio Albino Canelas Rubim (UFBA), Dione Moura (UNB), Eduardo Duarte (UFPE), Fernão Ramos (UNICAMP), Jiani Adriana Bonin (UNISINOS), Denise Araújo (UTP), Márcio Simeone (UFMG), Paulo Rocha Dias (UNILESTE-MG), Sandra Reimão (UMESP), Vera França (UFMG) merecem minha lembrança pela colaboração na coleta de dados dos PPGCOM, de modo geral, a partir da indicação dos estudantes que fizeram esta tarefa sob minhas orientações. A estes estudantes de graduação, Bruno de Moraes Castro (UFMG), Daniele I. B. Consolino (UNICAMP), Débora R. Ertel (UNISINOS), Débora de Morais (UNB), Érika Mendonça (UFPE), Patrícia Petreca (UMESP) Ragi Gonçalves (UTP) e Sara G. M. Uchôa (UFBA), meu muito obrigado.

Agradeço também aos professores doutores Elisabeth Saad Corrêa (USP) e José Luiz Aidar (PUCSP), que participaram da banca de qualificação desse trabalho e contribuíram com sugestões. Também gostaria de lembrar dos professores Afrânio Mendes Catani, José Marques de Melo e do saudoso professor Octavio Ianni, com os quais tive o prazer de aprender durante disciplinas ao longo do doutorado.

Anna Paula Muniz, Carolina Alves Marra, Daniele C. Lima, Graziella Oliveira, Nádia Marques e Cristine Vargas Pereira, bolsistas e ex-bolsistas de IC do NUPEM, colaboram também de modo fundamental. Agradeço em particular à última, que me acompanha desde o mestrado, e a quem peço desculpas pelas “broncas” em momentos de menor tranqüilidade.

Agradeço ainda ao CNPq, pela bolsa de doutorado, no último ano de realização do trabalho, tornando-o possível. 


\section{RESUMO}

ROMANCINI, Richard. O campo científico da Comunicação no Brasil: institucionalização e capital científico. São Paulo, 2006. Tese (Doutorado) - Escola de Comunicações e Artes, Universidade de São Paulo.

\section{RESUMO:}

A pesquisa tem como objeto a área dos estudos de Comunicação no Brasil. Como desenvolve-se basicamente no meio acadêmico, foram privilegiados aspectos e dados relativos a todos os Programas de Pós-Graduação em Comunicação (PPGCOM) reconhecidos pela CAPES no ano de 2004.

Buscou-se discutir a possível conformação de um "campo científico” (Bourdieu) da Comunicação, a partir da análise de dados institucionais, quanto à inserção de sua pesquisa no sistema de C\&T do país, sua auto-representação e seu “capital científico”. Este último aspecto foi analisado através de um estudo bibliométrico de teses e dissertações dos PPGCOM. Buscou-se desenvolver uma metodologia para a análise de áreas ou disciplinas científicas e, para tanto, faz-se uma reelaboração do modelo de Galtung (1965), sobre a interação entre grupos acadêmicos.

Quanto aos resultados, constatou-se uma circulação relevante de “capital científico” entre os pesquisadores da área, sendo esse um elemento que mostra que o grupo de investigadores não se encontra num modelo "segmental” de interação. Existem indícios de um modelo “conflitivo-construtivo”, o que favorece a consolidação do campo científico da Comunicação.

Identificou-se também a existência de um “núcleo disciplinar”, composto por autores dos PPGCOM que recebem número significativo de citações bibliográficas em várias das subáreas da área da Comunicação.

Palavras chave: Campo científico - Comunicação - Capital científico - Bibliometria Pesquisa em Comunicação 


\begin{abstract}
The research has as its object the area of Communication Studies in Brazil. As it is developed basically in the academic field, it was privileged the aspects and data related to all the Postgraduates Programs in Communication (PPGCOM) recognized by CAPES in the year 2004.
\end{abstract}

This research tried to argue about the possible conformation of a "scientific field" (Bourdieu) in the Communication, by analyzing institucional data referring to the insertion of its research in the C\&T's system in its country, its self-representation and its "scientific capital”. This last aspect was analyzed in a bibliometric study of thesis and dissertations of the PPGCOM. It tried to develop a methodology for the analysis of scientific areas and disciplines and for that one re-elaboration of Galtung's model (1965) about the interaction between academics groups.

About the results, it was evidenced a relevant circulation of "scientific capital" between the researchers of this area. This is an element that shows a group of investigators who is not placed in a "segmental" model of interaction. There are indications of a "conflictiveconstructive" model, which favors the consolidation of a scientific field in the Communication.

The research also identified the existence of a "discipline nucleus", composed by authors of the PPGCOM, who receive a significant number of bibliographical citations in the several sub-areas of the Communication Area.

Keywords: Scientific Field - Communication - Scientific Capital - Bibliometry Research in Communication 


\section{Sumário}

\section{VOLUME I}

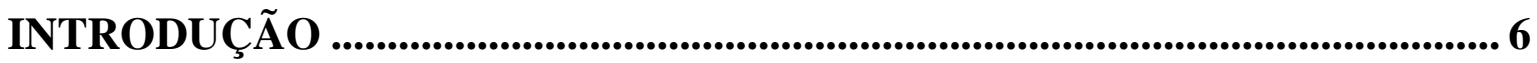

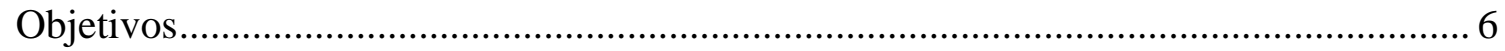

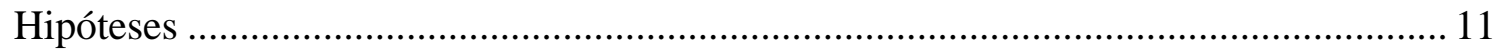

Justificativas do estudo .............................................................................................. 13

Estrutura do trabalho e metodologias empregadas …………………………………….... 21

CAPÍTULO 1 - A ciência e o projeto científico ……................................................ 24

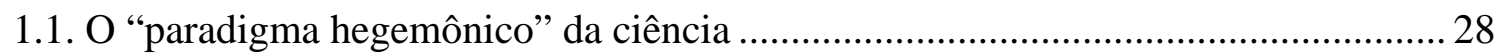

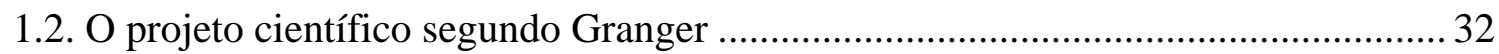

\section{CAPÍTULO 2 - As ciências sociais, as ciências da comunicação e as novas} epistemologias da ciência .............................................................. 36

2.1. Ianni: a ciência como uma das narrativas da modernidade ........................................ 38

2.2. Passeron: as ciências sociais como espaço "não-popperiano" ..................................... 42

2.3. Kuhn: discussão de suas idéias à luz do exposto …………………………………........ 45

2.4. Santos, Morin: novos conteúdos para a definição da ciência ...................................... 50

2.5. O que a reflexão precedente aporta ao estudo ……………………………………....54

\section{CAPÍTULO 3 - O conceito de campo científico: preliminares teórico-} metodológicas de seu uso na investigação .................................... 64

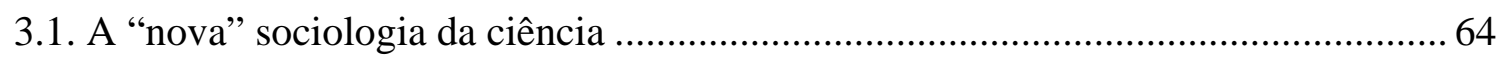

3.2. Bourdieu: o conceito de campo em seu projeto sociológico ....................................... 70

3.3. As propriedades dos campos, campo e capital científicos e o progresso da razão... 75

3.4. O conceito de campo em abordagens da sociologia da ciência sobre a área da Comunicação

3.5. O modelo de Galtung sobre a interação entre grupos acadêmicos e o conceito de campo: possibilidades de integração

\section{CAPÍTULO 4 - Perfil Institucional das Ciências da Comunicação no Brasil:} histórico e indicadores de inserção na área científica ............. 90

4.1. A institucionalização das ciências sociais no Brasil e a Comunicação 91

4.2. A pós-graduação em Comunicação no Brasil. 100 
4.3. A população estudantil dos PPGCOM ...................................................................... 108

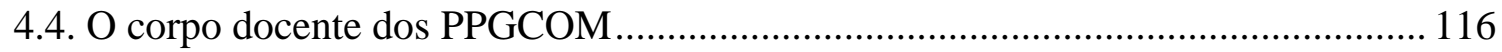

4.5. O fomento à pesquisa: bolsas e investimentos realizados pelas agências governamentais....

4.6. Síntese análitica sobre os dados referentes ao perfil institucional da área da Comunicação

\section{CAPÍTULO 5 - Padrões de associação, pesquisa e produção nas Ciências da}

Comunicação no Brasil................................................................... 148

5.1. Os Grupos de Pesquisa em Comunicação no Diretório do CNPq .......................... 149

5.2. As Associações Científicas dos pesquisadores da Comunicação............................ 164

5.3. As publicações periódicas técnico-científicas da área da Comunicação................. 168

5.4. A produção bibliográfica e os projetos de pesquisa dos docentes-pesquisadores.. 175

5.5. A produção (teses e dissertações) dos PPGCOM - 1974-2004.. .............................. 180

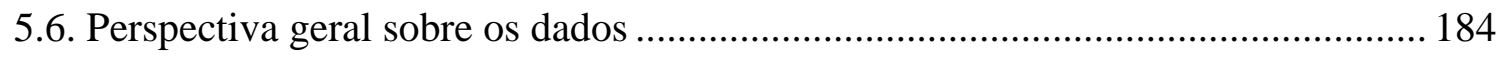

\section{CAPÍTULO 6 - Organização e representação dos discursos da Comunicação} e de sua produção científica................................................ 188

6.1. A representação da pesquisa realizada: propostas de taxonomia ........................... 191

6.2. Análise da produção científica: teses e dissertações .............................................. 200

6.3. Análise das Áreas de Concentração e Linhas de Pesquisa dos PPGCOM ............. 210

6.4. Os "programas de pesquisa” em Comunicação ........................................................ 218

\section{CAPÍTULO 7 - O capital científico da Comunicação em suas referências .... 221}

7.1. Os estudos métricos e a citação como medida do capital científico........................ 222

7.2. Análise bibliométrica da bibliografia de acesso aos PPGCOM ............................. 226

7.3 Análise bibliométrica da bibliografia das Teses e Dissertações dos PPGCOM: metodologia e características gerais do padrão de citações ..................................... 231

7.4. O “capital científico” da área da Comunicação evidenciado nas referências das teses e dissertações.. 


\section{ÍNDICE DE QUADROS}

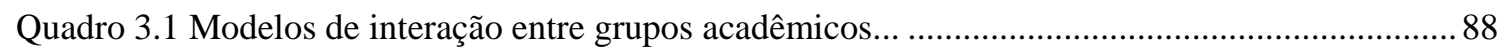

Quadro 6.1 Exemplo típico de dupla categorização de trabalho em subáreas......................................203

\section{ÍNDICE DE TABELAS}

Tabela 4.1 - Escolas/Cursos de Graduação em Comunicação no Brasil..............................................94

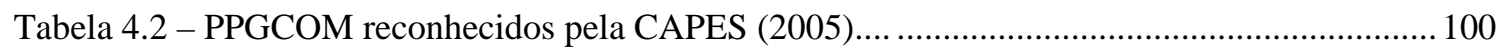

Tabela 4.3 - Ano do Início dos Cursos de Mestrado em Comunicação............................................... 101

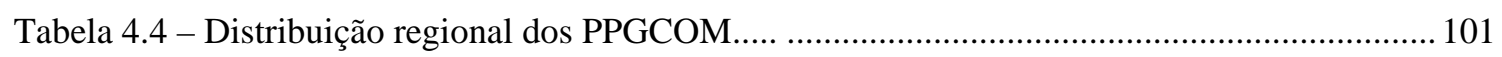

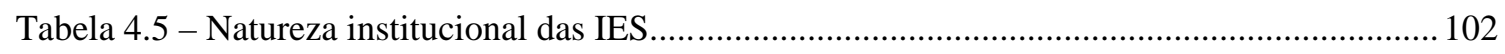

Tabela 4.6 - PPGCOM na América Latina por país e nível.............................................................. 107

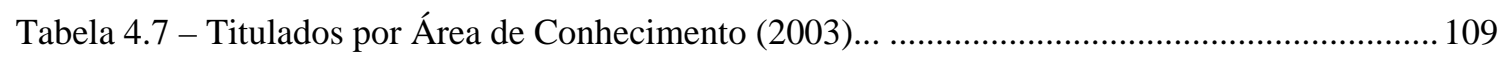

Tabela 4.8 - Titulados em Ciências Sociais Aplicadas e Ciências Humanas (2003)........................... 110

Tabela 4.9 - Titulados em Comunicação, Economia, Arquitetura e Urbanismo, História e............... 112

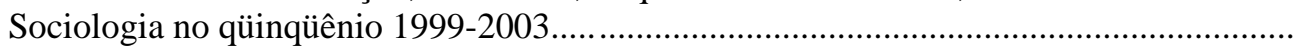

Tabela 4.10 - Docentes dos PPGCOM distribuídos por tipo de vínculo institucional.........................117

Tabela 4.11 - Titulação (Doutorado) dos professores colaboradores dos PPGCOM (2004).............. 119

Tabela 4.12 - Titulação (Doutorado) dos professores permanentes dos PPGCOM (2004)................. 120

Tabela 4.13 - Titulação (Doutorado) dos professores permanentes dos PPGCOM (2004), por ano

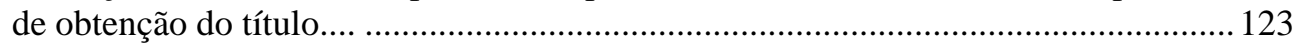

Tabela 4.14 - Países em que os professores permanentes dos PPGCOM (2004) obtiveram o título de doutor, por ano....................................................................................................... 124

Tabela 4.15 - Áreas de doutorado dos primeiros docentes dos PPGCOM e dos atuais docentes permanentes (2004)...

Tabela 4.16 - Titulações pós-doutorais obtidas pelos professores permanentes dos PPGCOM (2005)...

Tabela 4.17 - Países das instituições nos quais foram feitos os Pós-Doutorados pelos docentes permanentes dos PPGCOM (2005)...

Tabela 4.18 - Bolsas de Formação no País do CNPq e da CAPES - distribuição por programa e Grande Área de conhecimento...

Tabela 4.19 - Bolsas de Formação no Exterior do CNPq e da CAPES - distribuição por programa e Grande Área de conhecimento.

Tabela 4.20 - Bolsas de Pesquisa do CNPq: distribuição por modalidade e Grande Área de conhecimento.

Tabela 4.21 - Bolsas de Formação no país do CNPq e CAPES: distribuição por área de138 conhecimento.

Tabela 4.22 - Bolsas de Formação no Exterior do CNPq e CAPES: distribuição por área de conhecimento.

Tabela 4.23 - Bolsas de Pesquisa do CNPq: distribuição por área de conhecimento......................... 140

Tabela 4.24 - Bolsistas de Produtividade em Pesquisa no CNPq.................................................. 140 
Tabela 4.25 - Investimentos realizados pelo CNPq por linha de ação segundo Grande Área do conhecimento - 1999-2004.

Tabela 4.26 - Total dos investimentos realizados pelo CNPq em bolsas e no fomento à pesquisa por área do conhecimento - 1999-2004..

Tabela 4.27 - Investimentos (em mil reais) realizados pelo CNPq em bolsas e no fomento à pesquisa por área do conhecimento - 2001-2004.

Tabela 5.1 - Grupos de Pesquisa no Diretório do CNPq, por Grandes Áreas (1993-2004).

Tabela 5.2 - Grupos de Pesquisa no Diretório do CNPq, por Áreas de Conhecimento (1993-2004)..

Tabela 5.3 - Distribuição dos pesquisadores e doutores segundo a Área de Conhecimento predominante nas atividades do Grupo (Censo - DGP/CNPq 2004).

Tabela 5.4 - Grupos de Pesquisa em Comunicação segundo o número de pesquisadores doutores (Censo - DGP/CNPq 2004).

Tabela 5.5 - Grupos de Pesquisa em Comunicação, por Instituição (Censo - DGP/CNPq 2004) .... 153

Tabela 5.6 - Distribuição Regional dos Grupos de Pesquisa em Comunicação ...................................156

Tabela 5.7 - Natureza das IES dos Grupos de Pesquisa em Comunicação............................................ 156

Tabela 5.8 - Número de Linhas de Pesquisa dos Grupos de Pesquisa em Comunicação .................... 157

Tabela 5.9 -Linhas de Pesquisa dos Grupos de Pesquisa em Comunicação

Tabela 5.10 - Grupos de Pesquisa (exceto de Comunicação) que utilizam o termo "comunicação" como parte do nome, da LP ou palavra-chave.

Tabela 5.11 - Associações científicas do campo da Comunicação (2006).. 166

Tabela 5.12 - Temáticas dos NP da INTERCOM e GT da COMPÓS (2006)... 167

Tabela 5.13 - Periódicos brasileiros de Comunicação: responsáveis pela edição.. 169

Tabela 5.14 - Periódicos brasileiros de Comunicação: divisão por regiões.. 170

Tabela 5.15 - Periódicos brasileiros de Comunicação: divisão temática. 171

Tabela 5.16 - Projetos de pesquisa em desenvolvimento pelos docentes dos PPGCOM .. 175

Tabela 5.17 - Publicações dos docentes permanentes dos PPGCOM. 177

Tabela 5.18 - Média de publicações dos docentes NRD6 de 2001 e permanentes dos PPGCOM de 2004..

Tabela 5.19 - Produção PPGCOM - Dissertações (Mestrado) e Teses (Doutorado) (1974-2004) ... 181

Tabela 5.20 - Produção PPGCOM - Dissertações (Mestrado) e Teses (Doutorado) (1974-2004) ... 182

Tabela 5.21 - Produção de Dissertações (Mestrado) e Teses (Doutorado) por PPGCOM (1974-2004) 183

Tabela 6.1 - Classificação Atual da Área de Comunicação no CNPq 192

Tabela 6.2 - Classificação da área da Comunicação proposta por Lopes, Braga e Samain no 193 âmbito da COMPÓS.

Tabela 6.3 - Classificação da área da Comunicação, para efeito da TAC, proposta pela área ao $\mathrm{CNPq}$

Tabela 6.4 - Classificação das teses dos PPGCOM em subáreas . 204

Tabela 6.5 - Classificação das dissertações dos PPGCOM em subáreas..............................................205

Tabela 6.6 - Classificação da produção (teses e dissertações) dos PPGCOM em subáreas ............... 207

Tabela 6.7 - Interfaces entre subáreas, conforme a classificação dos trabalhos . 208 
Tabela 6.8 - Áreas de Concentração e Linhas de Pesquisa dos PPGCOM (2006) ............................. 212

Tabela 6.9 - Classificação das Linhas de Pesquisa dos PPGCOM por Subáreas..................................2. 216

Tabela 7.1 - Autores nacionais e estrangeiros nas bibliografias de acesso dos PPGCOM ................ 226

Tabela 7.2 - Autores nacionais e pertencentes a programas em Comunicação nas bibliografias de acesso dos PPGCOM..

Tabela 7.3 - Autores de PPGCOM nas referências das bibliografias para ingresso nos Programas -

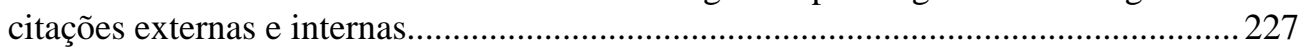

Tabela 7.4 - Autores nacionais indicados nas bibliografias para ingresso nos PPGCOM..................228

Tabela 7.5 - Autores estrangeiros indicados nas bibliografias para ingresso nos PPGCOM............. 229

Tabela 7.6 - Média de citações nas Dissertações e Teses dos PPGCOM ............................................233

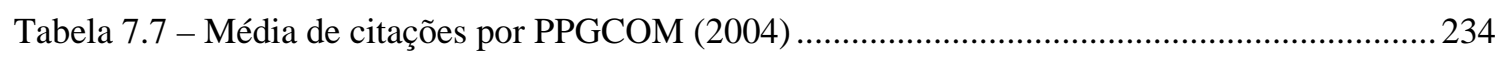

Tabela 7.8 - Tipos de documento pela nacionalidade dos autores (amostra -\%) ................................ 235

Tabela 7.9 - Tipos de documento pela temporalidade das citações (amostra -\%) ............................... 236

Tabela 7.10 - Tipos de documento pela língua utilizada (amostra -\%) ............................................... 236

Tabela 7. 11 - Tipos de documentos pela nacionalidade dos autores (amostra -\%) ............................ 237

Tabela 7.12 - Citações a autores nacionais e estrangeiros na teses dos PPGCOM............................. 238

Tabela 7.13 - Citações a autores nacionais e estrangeiros, por PPGCOM (2004)...............................239

Tabela 7.14 - Citações a autores nacionais e de docentes dos programas, por PPGCOM (2004) .... 240

Tabela 7.15 - Citações a autores nacionais em 1977, 1983, 1990 e 1997, por PPGCOM ................. 241

Tabela 7.16 - Autores estrangeiros mais citados em 1977, 1983, 1990 e 1997, por PPGCOM ........243

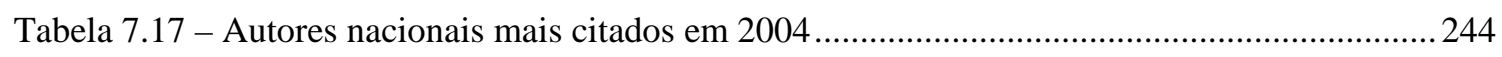

Tabela 7.18 - Citações a autores estrangeiros, por PPGCOM (2004) - autores mais citados ........... 245

Tabela 7.19 - Citações a autores de PPGCOM (2004) - autores mais citados ................................... 247

Tabela 7.20- Citações a autores-docentes dos programas, por PPGCOM (2004), contagem com exclusão das auto-citações - autores mais citados.......................................................... 249

Tabela 7.21 - Influências / circulação do conhecimento entre os PPGCOM ........................................251

Tabela 7.22 - Autores dos PPGCOM mais citados por subáreas da Comunicação ............................ 253

Tabela 7.23 - Autores nacionais mais citados por subáreas da Comunicação ..................................... 255

Tabela 7.24 - Autores estrangeiros mais citados por subáreas da Comunicação................................. 257

\section{ÍNDICE DE GRÁFICOS}

Gráfico 5.1 - Periódicos brasileiros de Comunicação (1965-2003)...................................................... 168 


\section{VOLUME II}

\section{Anexos}

\section{Dados estatísticos}

Pesquisa e Formação de Recursos Humanos no Brasil: Distribuição do Fomento por agência.

Bolsistas de Produtividade em Pesquisa do CNPq em Comunicação, por instituição .. 282

\section{Grupos de Pesquisa}

Grupos de Pesquisa em Comunicação da área e de Artes (cinema) no Censo 2004 do Diretório de GP do CNPq....

Linhas de Pesquisa dos GP em Comunicação (AP: Comunicação e AP: Artes/cinema) classificadas por subáreas.

GP (exceto de Comunicação) que utilizam o termo “comunicação” como parte do nome, da LP ou palavra-chave desta

3. Ata da Reunião com proposta de entidades e representantes da

Comunicação sobre a TAC - com lista de subárea e especialidades.

4. Detalhamento da classificação das teses e dissertações dos PPGCOM (2004) em subáreas

Detalhamento da classificação das teses em subáreas.

Detalhamento da classificação das dissertações em subáreas

5. Lista das Áreas de Concentração e Linhas de Pesquisa dos PPGCOM, produção dos mesmos (teses e dissertações) dos anos de 1977, 1983, 1990, 1997, 2004, submetida à análise bibliométrica, projetos de pesquisa desenvolvidos pelos docentes dos Programas e relação dos docentes USP 324

UFRJ 361

UNB 375

PUCSP 382

UMESP 405

UNICAMP 414

UFBA. 420

PUCRS. 428

UNISINOS. 439

UFRGS 449

UFMG 454 


UFF

\section{Bibliografia de acesso aos PPGCOM}

Tabela com autores e obras referidas nas bibliografias para ingresso nos PPGCOM .. 485

7. Listas de autores mais citados nas teses e dissertações dos PPGCOM de 1977, 1983, 1990 e 1997 distribuídos por Programa

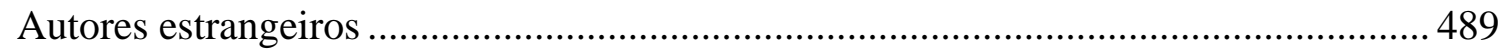

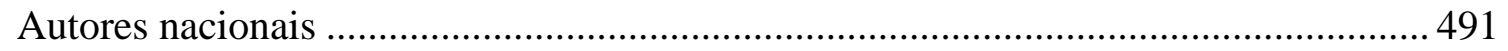

8. Listas de autores mais citados nas teses e dissertações dos PPGCOM de 2004, distribuídos por Programa

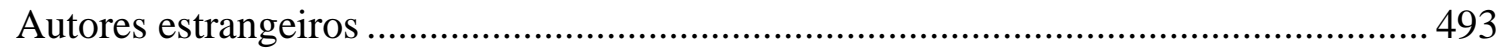

Autores nacionais ……………………………………………………………. 496

Autores pertencentes aos PPGCOM........................................................................... 498

\section{Cálculo amostral do corpus de citações}

Fórmula e amostragem das teses e dissertações ............................................................505 


\section{Lista de abreviaturas e siglas}

\section{INSTITUIÇÕES DE ENSINO}

CEFET/PR - Centro Federal de Educação Tecnológica do Paraná (PR)

ECA - Escola de Comunicações e Artes da USP (SP)

ECO - Escola de Comunicações da UFRJ (RJ)

ESPM - Escola Superior de Propaganda e Marketing (SP)

FLACSO - Facultad Latinoamericana de Ciencias Sociales (Santiago - Chile)

FEEVALE - Centro Universitário Feevale (RS)

FTC - Faculdade de Tecnologia e Ciências de Salvador (BA)

FURB - Fundação Universidade Regional de Blumenau (SC)

MACKENZIE - Universidade Presbiteriana Mackenzie (SP)

PUCCAMP - Pontifícia Universidade Católica de Campinas (SP)

PUCMG - Pontifícia Universidade Católica de Minas Gerais (MG)

PUCSP - Pontifícia Universidade Católica de São Paulo (SP)

PUCRJ - Pontifícia Universidade Católica do Rio de Janeiro (RJ)

PUCRS - Pontifícia Universidade Católica do Rio Grande do Sul (RS)

UCB-DF - Universidade Católica de Brasília (DF)

UAM - Universidade Anhembi Morumbi (SP)

UEL - Universidade Estadual de Londrina (PR)

UEM - Universidade Estadual de Maringá (PR)

UEMG - Universidade Estadual de Minas Gerais (MG)

UEPB - Universidade Estadual da Paraíba (PB)

UEPG Universidade Estadual de Ponta Grossa (PR)

UERJ - Universidade Estadual do Rio de Janeiro (RJ)

UESB - Universidade Estadual do Sudoeste da Bahia (BA)

UFAL - Universidade Federal de Alagoas (AL)

UFAM - Universidade Federal do Amazonas (AM)

UFBA - Universidade Federal da Bahia (BA)

UFC - Universidade Federal do Ceará (CE)

UFES - Universidade Federal do Espírito Santo (ES)

UFF - Universidade Federal Fluminense (RJ)

UFG - Universidade Federal de Goiás (GO)

UFJF - Universidade Federal de Juiz de Fora (MG)

UFMG - Universidade Federal de Minas Gerais (MG)

UFMS - Universidade Federal de Mato Grosso do Sul (MS)

UFMT - Universidade Federal de Mato Grosso (MT)

UFPE - Universidade Federal de Pernambuco (PE)

UFPI - Universidade Federal do Piauí (PI)

UFPR - Universidade Federal do Paraná (PR)

UFRGS - Universidade Federal do Rio Grande do Sul (RS)

UFRJ - Universidade Federal do Rio de Janeiro (RJ)

UFRN - Universidade Federal do Rio Grande do Norte (RN)

UFSCAR - Universidade Federal de São Carlos (SP)

UFS - Universidade Federal de Sergipe (SE)

UFSM - Universidade Federal de Santa Maria (RS)

UFV - Universidade Federal de Viçosa (MG)

UMESP - Universidade Metodista de São Paulo (SP)

UNB - Universidade de Brasília (DF)

UNEB - Universidade do Estado da Bahia (BA)

UNESP - Universidade Estadual Júlio de Mesquita Filho (SP)

UNICAMP - Universidade Estadual de Campinas (SP)

UNICEUB - Centro Universitário de Brasília (DF)

UNICID - Universidade Cidade de São Paulo (SP)

UNICRUZ - Universidade de Cruz Alta (RS)

UNIFOR - Universidade de Fortaleza (CE)

UNIMAR - Universidade de Marília (SP)

UNIMEP - Universidade Metodista de Piracicaba (SP)

UNINOVE - Universidade Nove de Julho (SP)

UNIP - Universidade Paulista (SP)

UNIPAC - Universidade Presidente Antônio Carlos (MG) 
UNIPAR - Universidade Paranaense (PR)

UNISANTOS - Universidade Católica de Santos (SP)

UNISO - Universidade de Sorocaba (SP)

UNISUL - Universidade do Sul de Santa Catarina (SC)

UNIT - Universidade Tiradentes (SE)

UNIVALI - Universidade do Vale do Itajaí (RS)

UNIVAP - Universidade do Vale do Paraíba (SP)

UNIVÁS - Universidade do Vale do Sapucaí - MG

UNOCHAPECO - Universidade Comunitária Regional de Chapecó (SC)

UPF - Universidade de Passo Fundo (PR)

URCAMP - Universidade da Região da Campanha (RS)

USP - Universidade de São Paulo (SP)

UTP - Universidade Tuiutí do Paraná (PR)

\section{ASSOCIAÇÕESIAGÊNCIAS/ÓRGÃOS}

Abracorp - Associação Brasileira de Pesquisadores de Comunicação Organizacional e Relações Públicas

ABPC - Associação Brasileira de Pesquisadores em Cibercultura

ALAIC - Asociación Latinoamericana de Investigadores de la Comunicación

ANPOCS - Associação Nacional dos Programas de Pós-Graduação em Ciências Sociais

BIREME - Centro Latino-Americano e do Caribe de Informação em Ciências da Saúde

CAPES - Coordenação do Aperfeiçoamento de Pessoal de Ensino Superior

COMPÓS - Associação Nacional dos Programas de Pós-Graduação em Comunicação

CNPq - Conselho Nacional de Desenvolvimento Científico e Tecnológico

EMBRAPA - Empresa Brasileira de Pesquisa Agropecuária

FACEPE - Fundação de Amparo à Ciência e Tecnologia do Estado de Pernambuco

FAPEMIG - Fundação de Amparo à Pesquisa do Estado de Minas Gerais

FAPERGS - Fundação de Amparo à Pesquisa do Estado do Rio Grande do Sul

FAPERJ - Fundação de Amparo à Pesquisa do Rio de Janeiro

FINEP - Financiadora de Estudos e Projetos

FIOCRUZ - Fundação Oswaldo Cruz

FORCINE - Fórum Brasileiro de Ensino de Cinema e Audiovisual

FUNCAP - Fundação Cearense de Apoio ao Desenvolvimento Científico

IAMCR - International Association for Media and Communication Research

INTERCOM - Sociedade Brasileira de Estudos Interdisciplinares da Comunicação

MCT - Ministério da Ciência e Tecnologia

MEC - Ministério da Educação

PORTCOM - Rede de Informação em Comunicação dos Países de Língua Portuguesa

REVCOM - Coleção Eletrônica de Revistas em Ciências da Comunicação

SBPC - Sociedade Brasileira para o Progresso da Ciência

SBPJor - Associação Brasileira dos Pesquisadores em Jornalismo

SOCINE - Sociedade Brasileira de Estudos de Cinema

\section{OUTROS}

C\&T - Ciência e Tecnologia

Gr / GP - Grupo de Pesquisa

GT - Grupo de Trabalho

Li - Líder de Grupo de Pesquisa

LDB - Lei de Diretrizes e Bases da Educação

LP - Linha de Pesquisa

NP - Núcleo de Pesquisa

PG - Pós-Graduação

PIBIC - Programa Institucional de Bolsas de Iniciação Científica

PICDT - Programa Institucional de Capacitação Docente e Técnica

PNE - Plano Nacional de Educação

PNPG - Plano Nacional de Pós-Graduação

PPG - Programa de Pós-Graduação

PPGCOM - Programas de Pós-Graduação em Comunicação

PROF - Programa de Fomento à Pós-Graduação

PROEX - Programa de Excelência Acadêmica

Prossiga - Programa de Informação para Gestão de Ciência, Tecnologia e Inovação do Instituto Brasileiro de Informação em Ciência e Tecnologia

PROSUP - Programa de Suporte à Pós-Graduação de Instituições de Ensino Particulares

SciELO - Scientific Electronic Library Online

TAC - Tabela de Áreas do Conhecimento 


\section{Introdução}

Seria interessante começar esse trabalho com uma narrativa que envolve o autor (e por isso a primeira pessoa se impõe). Pois bem, antes ainda da metade do curso de doutorado, combinara assistir com uma amiga ao filme Raízes do Brasil, o documentário de Nelson Pereira dos Santos sobre Sérgio Buarque de Hollanda. Marcamos o encontro no próprio cinema. Era um dia de chuva e como estava indo de ônibus ao encontro, preocupei-me com um possível atraso, o que me fez caminhar boa parte do cruzamento da Consolação com a Paulista até a Rua Augusta em passo acelerado. Por sorte, chegara a tempo (antes de minha amiga), e bem pouco depois notei que uma moça que estava comigo no ônibus também iria ver este filme. Por uma circunstância que agora não recordo, ela possuía ingressos extras e me ofereceu dois (eu havia dito que esperava alguém).

Agradeci e nos dirigimos à fila que começara a se formar. Iniciamos uma conversa no qual fiquei sabendo que ela era estudante de Filosofia na USP e ela, por sua vez, demonstrou interesse em saber o que eu pesquisava, quando soube que eu cursava o doutorado em Comunicação ${ }^{1}$. Tentei explicar que procurava pesquisar como determinados "agentes" compunham, ao longo do tempo, o “campo de pesquisa em Comunicação”, em outros termos, como se dava a construção da área cientificamente. Ela parecia ouvir atentamente, porém, ao fim de minha breve dissertação pareceu refletir um pouco, antes de indagar-me, com o que julguei um tanto de ironia “filosófica” e desdém, mas também certo interesse: “Mas a Comunicação é uma ciência?”.

Realmente me vi surpreendido e um tanto paralisado, e quando iria esboçar a resposta, a fila começou a andar! Pois bem, era impossível segui-la, já que esperava minha amiga que ainda não chegara. No entanto, essa pergunta irrespondida (não revi a moça ao fim do filme, nem nunca mais) sempre esteve em minha cabeça, durante todo esse tempo. Oxalá, ao longo dessa tese eu consiga tirar o máximo proveito dessa pergunta, não tão ingênua e maliciosa assim.

\footnotetext{
${ }^{1}$ Sempre que o termo referir-se à disciplina será grafado em letra inicial maiúscula, para distingui-lo dos objetos de estudo da área, bem como suas práticas profissionais e demais possíveis sentidos.
} 
Com efeito, Roberto Schwarz (1987) nota, num inteligente ensaio, que muitas vezes as perguntas mais banais encerram um questionamento importante em sua aparente (e por vezes real) despretensão. Uma pergunta desse tipo ("Para que servem as ciências sociais no Paraguai?”, conforme o exemplo do autor) pode atingir questões de fundamento, que se desdobram em indagações igualmente densas. A pergunta sobre a natureza científica da Comunicação, pois, implica aclarar um entendimento sobre o que é uma ciência, tendo em conta tanto suas características intrínsecas quanto o ambiente que a torna possível, e o que seria esta potencial ciência da Comunicação neste quadro.

Neste trabalho, pois, submeto esta indagação a recortes temáticos, expostos nessa introdução, com objetivo de explorar a natureza do “campo" da Comunicação, no sentido que Bourdieu dá a esse termo, analisando sua natureza e especificidades. As dificuldades do trabalho naturalmente, não são poucas.

Vamos à primeira e fundamental questão - que, em razão disso, acaba percorrendo todo estudo. Aqui, naturalmente, essa indagação só pode receber uma tentativa de resposta, que, por um viés irônico, é certo, sinaliza impasses e caminhos importantes, que ultrapassam a própria Comunicação, ainda que a pergunta seja dirigida a ela.

Pois bem. O que se está dizendo ao dizer “comunicação”, como um campo específico de conhecimento científico: Adorno, Lazarsfeld ou Abraham Moles? Aristóteles, Jakobson, Pierce, Greimas ou Umberto Eco? Harold Lasswell, Norbert Weiner, Armand Mattelart ou McLuhan? Baudrillard ou Martín-Barbero? Edward T. Hall ou Stuart Hall? Walter Benjamin? Desde que foi realmente lançada como disciplina e profissão na primeira metade do século XX, sobretudo pelos norte-americanos, a autoproclamada área das "Ciências da Comunicação" não foi perturbada apenas por uma proliferação de teorias, métodos, teses e técnicas. Isso afinal era de se esperar: a própria polissemia que envolve o termo “comunicação” torna-o passível de múltiplas abordagens. A área é impelida por caminhos fantasticamente diferentes em função de idéias fantasticamente diferentes sobre aquilo a que "se refere", como costumamos dizer - o tipo de conhecimento, o tipo de realidade e o tipo de objetivo que se espera que ela alcance. Vista de fora, pelo menos, a Comunicação não parece um campo único, dividido em escolas e especialidades da 
maneira habitual. Parece um sortimento de investigações díspares e desconexas, reunidas numa mesma classe pelo fato de todas se referirem, de um modo ou de outro, a tal ou qual coisa a que se chama "processo de comunicação". Dezenas de personagens à procura de um texto.

O parágrafo precedente, na verdade (e é essa sua natureza irônica), consiste numa paródia de um texto do antropólogo Clifford Geertz (2001) sobre a Psicologia. No entanto, essa operação discursiva tem a vantagem de, ao mesmo tempo em que retrata uma situação que parece verdadeira (no que tem de caricatural, e num olhar sobretudo exterior, "vista de fora”, como diz Geertz) sobre a área da Comunicação, mostrar que essa condição não lhe é totalmente específica. De fato, quanto mais se avança na leitura da produção atual das diferentes ciências sociais e humanas sobre suas “epistemologias locais”, mais se percebem similaridades - em graus diversos, evidentemente - com o contexto exposto (o da Psicologia e da Comunicação).

Exemplos bastante ilustrativos dessa tendência são encontrados em algumas análises sobre o estado contemporâneo de diferentes áreas. Entre outras, a História que, de acordo com Cardoso (1997), apresenta uma tensão entre um paradigma “moderno” e outro "pósmoderno", a Antropologia, dividida em correntes que questionam ou insistem na centralidade do trabalho de campo na disciplina (“contra ou pró-etnografia”, conforme Peirano, 1992). Além de áreas de estudo mais recentes, como a Educação, na qual se fala, nem sempre positivamente, em uma "diversificação e diversidade da teoria” (Oliveira e Alves, 2006). Todos esses casos encontram-se na discussão nacional e não foram resultado de uma busca sistemática, é provável que outros campos produzam discursos similares.

De outro lado, é possível pensar, mais globalmente, no caso da Sociologia: “locus privilegiado do dissenso de avaliação, ligado à incomensurabilidade de práticas heterogêneas e à dispersão das línguas teóricas: a maioria das sínteses unificadoras só se constrói na excomunhão recíproca” (Passeron, 1995, 75). O tema da “crise” da sociologia, e das ciências sociais como um todo é recorrente, como mostra também a discussão de Merton (1979b [1975]), que acreditava, entretanto, nas superação de tal estado. 
Essa exemplificação colabora com a identificação de um elemento crítico comum às ciências humanas, situação não exclusiva da área da Comunicação. O problema é lido em diferentes chaves, que oscilam entre extremos de frustração e crítica à inexistência de um único "paradigma” a unificar determinado campo e o elogio ao pluralismo teórico e metodológico, quiçá um viés interdisciplinar, de determinada área ou disciplina. Num caminho intermediário e talvez mais realista, são feitas diferentes reflexões epistemológicas e propostas. Há, por exemplo, o reconhecimento de que a existência de múltiplas vias interpretativas exige de cada posição a explicitação de seus fundamentos, senão o embate entre cada uma das perspectivas, naquilo que corresponde às suas zonas de compatibilidade (quanto a questões empíricas, por exemplo) ou comensurabilidade (em termos da estrutura conceitual eventualmente similar das proposições). Ou seja, por meio do debate projeta-se algum aprimoramento ou desenvolvimento num determinado campo de investigação. Mais e melhores pesquisas sobre problemas definidos com um grau de precisão, ainda que com certa heterogeneidade, mais elevado.

De qualquer forma, parece-nos claro que as interpretações sobre o conhecimento social nos dias atuais mostram bem menos certezas do que outrora. Invoca-se, ademais, a estreita relação entre o "tempo histórico" (de aceleradas mudanças nos dias de hoje, como sabemos) e o "tempo lógico" da ciência ${ }^{2}$. A articulação entre esses tempos, de modo mais constante e tenso nas ciências do homem do que nas ciências lógico-formais e da natureza, fazem com que autores como Passeron (1995) identifiquem no cerne do raciocínio das ciências sociais o reconhecimento de seu caráter de ciências históricas. Assim, é reforçada a idéia de que "seus enunciados não podem ser desindexados dos contextos de que são tirados os dados que têm um sentido para suas asserções” (idem, 87).

Em outra possibilidade interpretativa, essa situação exigiria, em tempos de acentuadas transformações, a reformulação ou abandono de terminados conceitos, bem como a necessidade de novas elaborações e sínteses - como ocorre na discussão de Ianni (1996), sobre a "globalização" como "novo paradigma das ciências sociais". A esse contexto podem acrescentar-se ainda as discussões que envolvem a ciência como um todo em busca de novos valores, fundados, por exemplo, na “complexidade” (Morin) ou na "pósmodernidade” (Sousa Santos).

\footnotetext{
${ }^{2}$ Victor Goldschmidt (1963) discute essa recorrente visão da realidade da ciência.
} 
Dessa forma, os analistas tendem também a apresentar menos segurança sobre o futuro e a noção de "progresso” aplicada às ciências, em particular às humanas, do que já houve em décadas anteriores. (Ou então, como mostraremos, a própria noção de “progresso" é redefinida.) De qualquer forma, é certo que ninguém mais enunciaria, ao menos com tanto segurança, como Merton no fim da década de 1940, a otimista necessidade e possibilidade de "esquecer” os clássicos e os fundadores de determinada área de estudos nas ciências sociais. A proposição de que um progresso continuado, garantido pelo labor cotidiano tornado cumulativo, permitiria construir teorias sobre o mundo social melhor formuladas, mais gerais e integradas, a partir de mais específicas e convergentes "teorias de médio alcance”, tem certamente ainda apelo entre parte dos cientistas. Mas isso não faz com que a idéia de que os clássicos possam ser deixados de lado, vistos como "superados", tenha muitos partidários.

Ao contrário, pode-se inclusive caracterizar, se não positiva pelo menos intrinsecamente, as ciências sociais como possuidoras do “dom da eterna juventude” (Schwartzman, 1971). Neste caso, vários autores retomam uma idéia cara a Weber (1991), a respeito das “disciplinas históricas”, que são duplamente condicionadas: os fatos que estudam estão situados num tempo/espaço específico e estes são dotados de um "valor” ou "sentido" também histórico. A releitura ou revalorização da sociologia do conhecimento de Mannheim também está ligada a este quadro: o conceito de "conhecimento relacional”, com efeito, chama a atenção para as "construções conceituais que emergem no fluxo da experiência histórica” (Mannheim, 1976, 105)³ . As diferenças de ênfase, nesse enfoque, aqui são igualmente bastante variadas, há desde os que acreditam que esse aspecto não altera a unidade profunda da ciência, quanto os que insistem nas diferenças entre as "duas culturas” científicas do que em suas convergências.

O contexto dessa discussão não é simples, pois as premissas de que partem muitos dos estudiosos são irreconciliáveis. Encarar as ciências sociais a partir da lógica e da epistemologia mais tradicional das ciências formais e naturais (por exemplo, impondo a noção de "falsificabilidade" popperiana como meta de toda construção de conhecimento)

\footnotetext{
${ }^{3}$ É interessante notar que, em parte, essa revalorização vem se dando a partir de uma nova leitura do conceito de "conhecimento relacional". Enquanto em Mannheim ele se aplicaria fundamentalmente às ciências históricas, os autores do chamado "programa forte" da sociologia da ciência buscarim operacionalizá-lo para mostrar que todo o conhecimento científico é histórico e socialmente ancorado, "relacional".
} 
projeta um ideal científico para as ciências sociais bastante diferente do que quando se admite, igualmente em diferentes graus, que elas possuem especificidades, ligadas tanto ao seu objeto, quanto ao tipo de raciocínio utilizado e às suas normas de produção de conhecimento válido.

É suficiente dizer, nesse momento, que essa discussão não é improdutiva ou impertinente para este trabalho: na verdade, implica, muitas vezes, uma tomada de posição por parte do pesquisador. É por isso, pois, que iniciamos a Introdução desta pesquisa com estas breves reflexões que posicionam o marco do estudo em relação àquilo que lhe interessa fundamentalmente: a constituição de um campo de estudo (a Comunicação) num momento, se não de “crise”, certamente de repensar a ciência e o fazer científico.

\section{Objetivos: uma visão “de dentro”}

Será necessário retomar alguns dos pontos vistos até aqui, na continuidade do trabalho, em nível mais local e específico, bem como com maior aprofundamento. Deve-se ainda situar melhor essa discussão a respeito da temática que a relaciona à Comunicação. Será isso que permitirá, ademais, avançar para a explicação do que o tema da ciência, dos limites disciplinares, bem como de outros problemas conexos, aporta para as questões principais da pesquisa. Por isso, voltamo-nos agora especificamente aos objetivos, hipóteses e justificativas do trabalho. Por fim, apresentamos a estrutura que será assumida nos capítulos do estudo.

Como foi dito, a área de estudos em Comunicação parece mostrar uma série de divisões, possíveis inconsistências, sobretudo no alto grau apontado, no nosso entender, quando vista de fora. Isso é resultado, em grande parte, dessa perspectiva externa. Não que o que ocorra realmente seja o oposto disso: uma área de pesquisa "plenamente madura”, que possua um linguajar teórico e metodológico, ou um "paradigma” comum, bastante coerente e aceito sem discussão por todos os seus praticantes. A verdade está em algum ponto desse espectro - e nas nuances que ele admite, sendo que os extremos desse continuum podem ser inclusive redefinidos. E devem ser mesmo, no contexto de uma discussão mais ampla, 
que indague sobre esse processo no tempo atual, e o vincule a reflexão sobre a ciência que se faz hoje.

De qualquer forma, é interessante ressaltar que um olhar “de fora” captura, por vezes, principalmente o “exótico”, anômalo ou extravagante sob o parâmetro de outro contexto Isso é natural a qualquer área de pesquisa e entre as próprias disciplinas existem olhares nos quais se manifesta um estranhamento em relação às práticas de outros grupos.

O que se percebe como "exótico" não é necessariamente falso, porém, como demonstra todo o discurso da Antropologia clássica, somente uma visão interna (daí metodologias como a observação participante etc.) do fato social permitirá elaborar uma efetiva compreensão do que de faro ocorre em determinado contexto. Pois no processo de obtenção de conhecimento sob esse olhar “interno” há uma redefinição de categoriais mentais que modifica o próprio olhar do observador. Em suma, adquire-se uma percepção mais exata de diferenças e similaridades entre diferentes culturas, que não se deixam ver pelo olhar distanciado.

Ressaltamos, nesse aspecto, menos uma filiação antropológica do que uma postura próxima ao do sentido de que Fausto Neto (2002, 33) falava, num encontro de pesquisadores da pós-graduação da área, quanto à necessidade de

"nos vermos por dentro", de nossas estruturas, de nossos projetos, e procedimentos. Há a necessidade de uma dinâmica que nos permita elaborar a compreensão de nosso próprio debate interno, ou o projeto interno de cada programa [de pós-graduação] enfim de um próprio campo. Qual é a nossa causa? ${ }^{4}$

Assim, a perspectiva assumida busca compreender o que tem significado - com ênfase no estado atual da área - o "conhecimento em Comunicação” para os seus praticantes (esse “projeto interno” de que fala Fausto Neto, levado a cabo pelos pesquisadores); bem como, construir um olhar ao mesmo tempo próximo e crítico em termos dos esforços relativos à constituição da Comunicação como uma disciplina de pesquisa. A proximidade explica-se tanto do ponto de vista da relação sujeito-objeto quanto do estudo de elementos "internos" da área. E se colabora, também pode constituir um sério obstáculo à obtenção de um

\footnotetext{
${ }^{4}$ Para fazer justiça à reflexão do autor, deve-se notar que ele também falava na necessidade complementar da área da Comunicação no Brasil “deixar-se ver, de fora” por diferentes lentes e sistemas de leitores.
} 
conhecimento válido, por isso a necessária tarefa de buscar recortes metodológicos e aportes teóricos que auxiliem a investigação.

Vamos primeiro, pois, explicitar a temática e os objetivos da pesquisa. O desdobramento de cada um dos termos relevantes do título da tese será útil para esta tarefa. O trabalho intitula-se O campo científico da Comunicação no Brasil: institucionalização e capital científico. Assim, o âmbito de problemas a ser desenvolvido, implica na consecução das seguintes tarefas:

1) Utilizar o conceito de “campo científico”, conforme os trabalhos de Bourdieu, para discutir o quanto o mesmo pode ser válido para a área de estudos em Comunicação no Brasil. Conforme discutiremos esta é uma escolha e uma estratégia, dentre outras possíveis abordagens de uma sociologia do fazer científico, que tem potencialidades interpretativas importantes em termos da compreensão de um grupo de pesquisadores e suas características - buscando superar visões “internalistas” ou “externalistas” sobre a ciência.

2) Como o conceito de “campo" não está separado de uma noção sobre ciência e nem ao debate sobre ela, assim é necessário discutir determinados parâmetros definidores dessa atividade. Por conseguinte, os conteúdos que caracterizam a produção do conhecimento científico devem ter ênfase, bem como a descrição de propostas de "novas epistemologias” - para os quais, por contraste, é necessário descrever as tradicionais. Isso tem relevo ainda por refletir-se na discussão ocorrida no próprio espaço interno da Comunicação.

3) O “campo científico”, de maneira geral, possui um conjunto de aspectos institucionais que lhe garantem existência, um sentido prático e coletivo. Estes elementos não são “dados”, mas sim construídos pelos agentes da pesquisa ao procurar garantir condições para desenvolver seu trabalho. Dessa forma, busca-se descrever e analisar traços institucionais da construção realizada até aqui - e, quando possível, em comparação com a diacronia do campo e do contexto latino-americano ou internacional dos estudos em Comunicação. Essa tentativa de traçar um “quadro contextual” no qual se realiza a investigação na área decorre do fato de que é nesse espaço que são dadas as condições de produção e circulação do "capital científico" gerado na área. Um elemento 
importante deste quadro, diz respeito ao fato de que é a partir dele que os agentes do grupo constroem (auto)representações e pressuposições sobre o conhecimento válido (por exemplo, os “programas” e “linhas” de pesquisa) na área, além de compor um campo semântico e um léxico (que pode ser observado pelas citações feitas). Por conseguinte, isso determina a própria natureza do “capital científico” produzido e em disputa.

4) Com efeito, o conceito de "capital científico", também derivado de Bourdieu, é outro componente central da tese; assim uma tarefa importante é a tentativa de procurar analisar esse capital. Isso ocorrerá principalmente por meio da análise das referências bibliográficas utilizadas pelos pesquisadores. Existem aqui duas estratégias de análise que já é pertinente mencionar: 1) a análise bibliométrica de Teses e Dissertações da área e 2) a análise de conteúdo de Linhas de Pesquisa, das produções científicas e das taxonomias que os pesquisadores tentam produzir. O que se espera é que essas estratégias ajudem a notar as convergências, bem como as disputas que caracterizam o espaço de discussão.

5) Procuramos, numa tarefa seguinte, articular esses elementos de análise ao modelo de Galtung (1965) sobre a interação entre grupos científicos. Ainda que tenha que ser feita uma adequação aos termos conceituais que torne válida a aproximação com a noção de campo, esse modelo oferece princípios de legibilidade aos dados, em nosso entender, bastante interessantes e compatíveis com o marco mais geral. Em particular, o modelo é útil para o entendimento, a partir da interação efetiva que poderemos evidenciar pelas citações e convergências disciplinares nas Linhas de Pesquisa e nas Teses e Dissertações. Nesse sentido, é interessante refletir e utilizar uma noção como a de “programa de pesquisa” (Lakatos, 1979), pois embora não se possa utilizá-la num sentido estritamente lakatiano, oferece também um princípio de legibilidade para os dados, a partir de uma definição mais aberta do que a original.

6) É importante ressaltar, finalmente, no plano dos objetivos e tarefas da tese, que da combinação das estratégias metodológicas realizadas resultará um modelo para compreensão/avaliação de uma área científica. Este é o objetivo central. Temos claro que tanto as análises sócio-históricas da institucionalização de uma área, quanto as técnicas bibliométricas e de análise de conteúdos de dados de produção e de 
autorepresentação dos Programas (Linhas de Pesquisa que estruturam Áreas de Concentração) têm limites. Elas não são capazes de dizer "tudo" sobre a natureza de um campo de estudos, porém, aportarão elementos significativos e, em sua combinação, podem propiciar marcos de inteligibilidade sobre o estado de uma área de conhecimento. Com efeito, para a área da Comunicação no Brasil, o trabalho representa um empreendimento inédito - principalmente quanto à abrangência nacional comparada que possui. Quanto ao quadro mais geral da produção científica no país, é possível que existam outras propostas de modelo de inteligibilidade de áreas de pesquisa. No entanto, a nossa combinação metodológica é um resultado específico da tese, e a proposta poderá talvez ser apropriada, em parte ou no todo, por pesquisadores de outras áreas.

Em resumo, o objetivo principal conduz à produção de um diagnóstico sobre a área da Comunicação no Brasil hoje, a partir dos marcos conceituais citados, procurando, desse modo, responder à indagação forte da pesquisa - a Comunicação constitui um campo científico, em que medida, com quais características?

Os objetivos secundários são dois. De um lado, a elaboração de análises a respeito da configuração institucional do campo da Comunicação hoje, de sua auto-representação (dados Linhas de Pesquisa e taxonomias propostas) e dos indicadores de Teses e Dissertações (bibliométricos e de conteúdos dos trabalhos). De outro lado, a produção e aplicação de um modelo para o estudo de áreas de conhecimento - que será discutido em termos de suas possibilidades e limites. 


\section{Hipóteses}

Conforme etapas preliminares da investigação demonstraram (discutidas em particular nos Capítulo 4 e 5) é possível notar um estágio de institucionalização alcançado pela área de estudos em Comunicação no Brasil, que o correlaciona, ao menos parcialmente, à noção de "campo científico", de Bourdieu. Esse fato alicerçou a hipótese geral de que se estruturou, ao menos parcialmente, um campo científico da Comunicação no Brasil, tal como em outros países, com estruturas sócio-culturais, similares ao Brasil, em particular, o México.

A essa institucionalização segue-se atualmente uma tendência crítica ao estado de conhecimento da área, e portanto pode-se dizer, a partir da teoria dos campos, que o campo científico da Comunicação encontra-se no âmbito geral do campo científico brasileiro numa posição de menor legitimidade, pois: "Diversamente de uma prática legítima, uma prática em vias de consagração coloca incessantemente aos que a ela se integram a questão de sua própria legitimidade” (Bourdieu, 1992, 155).

Paradoxalmente e ao mesmo tempo, é essa preocupação com a legitimidade, com os fundamentos científicos da área, que instaura - de acordo com nossa primeira hipótese específica, as condições necessárias para a edificação do "campo científico" em padrões de maior autonomia. Isso ocorre na medida em que a situação de disputa pelos agentes que se inserem no campo a respeito do discurso dominante e legítimo favorece a autonomia e construção de conhecimento interno à área. E estas disputas propiciarão o acúmulo de capital científico. Será esta, pois, nossa segunda hipótese específica: a de que existe um acúmulo de capital científico produzido no campo da Comunicação no país.

Falar na existência de um capital científico comum pressupõe que existe um padrão de interação entre os agentes que atua em favor da existência do campo. Por isso, tem-se a terceira hipótese secundária: de que o padrão de interação assumido pelos pesquisadores da área da Comunicação tem um perfil de "conflito-construtivo" (conforme reconceitualização do modelo de Galtung, 1965).

O quanto o capital que circula é mais ligado à disciplina como um todo, adquirindo legitimidade como seu núcleo de base ou pelo menos configurando diferentes "programas 
de pesquisa” (conforme uma discussão/reconceitualização das proposição de Lakatos,) é um questionamento importante. No entanto, podemos postular quase como uma certeza que não existe um “paradigma” predominante nos estudos em Comunicação. Porém, acreditamos que será possível perceber, pela análise do capital científico referente às citações, a existência de determinados “programas de pesquisa”, válidos para a área em geral, e que agrupam determinados autores. Esse aspecto é, pois, nossa quarta hipótese específica.

Seriam esses capitais acumulados em diferentes subáreas de pesquisa ou tradições de investigação, com maior ou menor integração num nível mais geral, que dariam identidade ao campo da Comunicação. É possível pensar, ademais, que no embate entre esses “programas” que os critérios principais de pertencimento ao campo da Comunicação seriam estabelecidos e, dessa forma, contribuiriam para uma maior integração ou fortalecimento do mesmo. Naturalmente, isso aconteceria desde que os "programas” atuem com algumas zonas de contato e consensos mínimos, e não isolados (condição que a análise pretende verificar).

Tal questionamento forma a quinta e última hipótese específica, de que havendo um capital local e a última exposta, em seu desdobramento lógico, no sentido de que havendo um (hipótese segunda) capital local este circula internamente no subcampo da pesquisa - que é observado na pós-graduação.

Destacamos essa categoria de capital científico, pois é ela que, não só sustenta nossas hipóteses, mas permite, no desenho da investigação, articularmos muitos dos aspectos dos subcampos, para procurarmos perceber o grau de construção de um discurso legítimo na área. Esse capital científico será observado principalmente por meio da análise bibliométrica e da análise de conteúdo de diferentes materiais, conforme o âmbito que se pretende estudar. Com efeito, a análise documental e dos trabalhos científicos - além do índice de reconhecimento que têm estes trabalhos em função de sua incorporação por meio de citações em outras pesquisas - pode mostrar como os mesmos garantem legitimidade e fundam hierarquias de prestígio em áreas do conhecimento como a Comunicação. 
Dessa forma, os objetivos e hipóteses da pesquisa expostos convergem para o estado atual do campo da Comunicação no Brasil, de modo a perceber o quanto os termos fundamentais do conceito de campo, segundo Bourdieu, encontram-se na área de estudos. De outro lado, a investigação propõe um certo modelo de análise para a área científica, de maneira mais geral, que - em seu teste e discussões nessa pesquisa - resulta numa proposta a ser criticamente apropriada por outros pesquisadores.

\section{Justificativas do estudo}

Para qué hacer investigación y para quién, son siempre dos interrogantes que hay que plantearse antes de definir cómo hacer la investigación. Desde dónde investigar y hacia dónde apuntar con la investigación son otros dos interrogantes que hay que hacerse de manera explícita en la producción de conocimiento, y específicamente en la definición de cualquier política de investigación.

Orozco Gómez $(1997,85)$

Mesmo através de um acompanhamento superficial das referências em Comunicação, é possível notar um aumento expressivo, nos últimos anos, de análises reflexivas sobre essa área no Brasil. De certo modo, o movimento também é internacional - embora a tendência local reflita com algum atraso o debate no exterior. Assim, pode-se dizer que na década de 1980 a trajetória de crescimento do campo (número de pesquisas, temáticas abordadas etc.) parecia apontar para sua consolidação. É por isso saudada por seus pesquisadores, como mostram vários artigos em número de 1983 do Journal of Communication significativamente intitulado "Ferment in the Field".

A despeito de críticas e reticências sobre o estado do campo, o que transparece como tom geral desse número é um panorama de crescimento da pesquisa, como de fato ocorreu. Isso contrariava a idéia formulada pelo pesquisador (pioneiro no desenvolvimento da "análise de conteúdo” em Comunicação) Bernad Berelson que, em 1958, afirmara que a área tenderia a “definhar” (whithering away), com o desinteresse por ela de pesquisadores pioneiros, na tradição norte-americana (como Paul Lazarsfeld, Kurt Lewin e outros), em favor das disciplinas de origem dos mesmos (Ciência Política, Psicologia etc.). 
A formulação de Berelson foi tomada como um mote para esse número do Journal of Communication - que os artigos contrariavam. Nesse sentido, chama a atenção a analogia do pesquisador norte-americano Wilbur Schramm (1983) que via a história do campo de estudos da Comunicação como uma espécie de oásis num deserto, no qual muitos (sociólogos, psicólogos, cientistas políticos, lingüistas etc.) haviam passado. No entanto, segundo ele, depois de muito tempo, alguns - os pesquisadores que se identificaram com o “oásis” - passaram a nele residir e faziam projetos nesse sentido: são criados departamentos e carreiras, oferece-se um treinamento específico etc. Tais planos indicam o desejo de enraizamento no “oásis”, vontade de mapeá-lo e ocupá-lo em diferentes direções. Essa parece ser, grosso modo, a tônica do "fermento no campo": mais institucionalização e pesquisas na área, em variadas linhas, o que se explica em razão também de demandas tecnológicas e novas circunstância sociais ${ }^{5}$, que requeriam produção de conhecimento.

Porém, uma década depois a mesma revista publica um volume (com dois números) chamado "The Future of the Field", no qual dessa vez muitos textos apontam para dificuldades correntes, que poderiam comprometer o futuro do campo de estudos. $\mathrm{O}$ subtítulo do número chamava a atenção para um núcleo de questionamento e tensão - que os artigos refletiam - forte: "Between Fragmentation and Cohesion”. A subdivisão da disciplina acadêmica da Comunicação em tradições diversas, sua fragilidade teórica e continuidade da dependência conceitual de certas disciplinas das ciências sociais, entre outros pontos, faziam com que o campo, nesse balanço, pudesse ser "caracterizado mais pela fragmentação do que pela fermentação” (Rosengren, 1993, 9). O isolamento e falta de contato entre as tradições de pesquisa atuantes na área fariam com que houvesse pouco confronto e cooperação entre elas.

Ao mesmo tempo, as proposições sobre teorias substantivas, modelos formais e dados empíricos seriam com freqüência não somente incompatíveis, mas inexistentes. Ou seja, a interpenetração entre estas esferas, entendida como vital para a maturidade de um campo de estudos, por propiciar processos de confrontação e cooperação entre diferentes escolas de pensamento, estaria sendo negligenciada nas emergentes tradições de pesquisa em Comunicação. Está é a opinião de Rosengren (1993), por exemplo, que vê nisso um

\footnotetext{
${ }^{5}$ A adoção e consolidação da TV em larga escala era uma delas.
} 
paralelo com o que estaria ocorrendo no âmbito das humanidades e das ciências sociais naquele momento (idem, 10).

Posições como essa, no debate travado então, foram relativizadas (ou relidas) por outros argumentos. A pertinência lógica da constituição da Comunicação como “disciplina” é questionada (Sheperd, 1993); interpreta-se o estado de incerteza teórica da área a partir de uma transformação mais geral das ciências humanas, que afetaria também a Comunicação (Craig, 1993). Propõe-se, ainda, a superação de uma suposta situação de "dissenso mitologizado como tolerância” pelo desenvolvimento cooperativo de uma "teoria da comunicação comunicacional” (Dervin, 1993, 47). O que se observa, portanto, é que os ocupantes do “oásis” mostravam diferentes concepções sobre como traçar as fronteiras do território, quais os melhores caminhos e meios de conhecê-lo. Eram bem menos otimistas do que haviam sido na década anterior e apresentam diferentes visões sobre quais seriam as tarefas mais prementes. O consenso situava-se, sobretudo, no plano da insatisfação com o estado do campo ou da própria pertinência do debate nos termos em que ele era colocado.

Aqui, nesse exemplo histórico do contexto internacional, o que importa notar é a existência dessa franca zona de dissenso, com maior ou menor descontentamento segundo cada autor. Por outro lado, no todo, essa discussão resulta numa franca esfera de debate sobre os fundamentos de cientificidade do campo.

No Brasil, o movimento de autocrítica e reflexão sobre a investigação realizada pelos pesquisadores em Comunicação ganha mais força a partir de meados da década de 1990. Não que antes não tivessem sido publicados trabalhos metacientíficos, como inventários gerais de produção (Marques de Melo, 1984), patrocinados por associações de investigadores da área; ou balanços do estado da pesquisa, geralmente levando em conta as temáticas abordadas (Marques de Melo, 1983); ou os estudos mais genéricos (Capparelli, 1980, Dencker, 1988) e relatórios de diagnóstico (estes também genéricos), levados a cabo por encomenda governamental (ligada à representação da área do CNPq, como Capparelli e Marques de Melo, 1990). No entanto, é bastante minoritária essa preocupação, quando expressa em termos quantitativos em comparação a outros temas de pesquisa, até o momento referido. 
Assim, em revisão da pesquisa brasileira em Comunicação das décadas de 1960 e 1970, realizada por investigadores da área (Marques de Melo, 1983), são discutidos 14 temas (“jornalismo impresso”, “rádio”, “televisão”, “música popular”, entre outros), mas nenhuma linha teórica ou metodológica. Aliás, como mostra Lopes (2000), a produção especificamente teórica e metodológica da área da Comunicação tende historicamente a ser baixa: numa amostra de trabalhos, das primeiras produções até 1995, apenas 2,5\% do total dos textos registrados tinham estas características, conforme a categorização elaborada ${ }^{6}$.

Não que faltassem até esse momento modelos teóricos à pesquisa, mas eram sobretudo importados, com uma produção local pequena e de baixo impacto. Alguns pesquisadores, como Lima (1983) apontavam as diferentes concepções de “comunicação” concorrentes e a necessidade de desenvolver a teoria na área, levando "em conta a realidade concreta e histórica da sociedade [brasileira] para a qual se destina” (Lima, 1983, 98). Porém, malgrado o terreno aparentemente pouco propício a reflexões como essa, o volume da produção voltada ao conhecimento do campo - sobretudo com uma perspectiva mais crítica -, aumenta e se diversifica principalmente a partir de meados dos anos de 1990.

Os amparos ou promoções institucionais para esse tipo de investigação continuam importantes, porém, parece que a própria demanda por este tipo de reflexão aumentou, bem como o número de pesquisadores ligados ao tema. Pode-se dizer que a discussão dos tempos recentes mantém preocupações anteriores quanto à análise de tendências de pesquisa e perspectivas da investigação (por exemplo, Kunsch e Dencker, 1997). Mas o leque temático ampliou-se, passando a discutir aspectos antes pouco problematizados, como o “objeto da Comunicação” (Weber, Bentz e Hohfeldt, 2002) ou sua “epistemologia” (Lopes, 2003) - em ambos os casos, reuniões de artigos de pesquisadores da área dos Programas de Pós-Graduação em Comunicação (PPGCOM), no âmbito de encontros de sua associação (COMPÓS) voltados a essas temáticas. E mesmo recentes mestrados da área passam a inventariar a produção e analisar problemáticas de pesquisa, autores e conceitos utilizados nos PPGCOM, particularmente na região Sul (Soares, 2004, Vanz, 2004).

\footnotetext{
${ }^{6}$ A despeito disso, ocorre a curiosa situação de que o registro de projetos de pesquisadores aponta a especialidade de "Teoria da Comunicação" como a que contempla mais projetos. Eram 24 (50\% do total) em 2004. Isso, como será discutido no Capítulo 6, deve-se a problemas de classificação/organização da pesquisa, que se refletem numa taxonomia da área desatualizada e pouco adequada.
} 
Também a produção de Grupos de Trabalho em congressos da área espelha essas preocupações que atravessam o debate latino-americano sobre o campo (caso do livro de Lopes e Fuentes, 2001, que reúne papers do GT da Asociación Latinoamericana de Investigadores de la Comunicación - ALAIC). Com efeito, é válido reafirmar que essa tendência geral, de repensar o campo de estudos em Comunicação, atinge vários países como a discussão do Journal of Communication também evidenciou. Por outro lado, também é interessante apontar desde já que é no espaço latino-americano que se situa o principal ambiente de interlocução sobre essas questões, no caso dos pesquisadores brasileiros. Isso é natural, dada às várias semelhanças estruturais entre os países e o modo de configuração da área da Comunicação nos mesmos.

A respeito das análises elaboradas, deve-se notar que nelas há uma recorrente crítica ao estado da área, no seu âmbito científico, em especial no caso brasileiro. Os aspectos negativos e criticados são diversos, em parte similares aos abordados no debate internacional, em parte mais específicos. Entre os comuns, estão a crítica à ausência de marcos conceituais internos consistentes ou mesmo acordos dos pesquisadores sobre a natureza do campo de modo a permitir seu progresso (Martino, 2001a), dicotomia entre a pesquisa realizada (no nível de estudos pós-graduados) e a concepção mais técnica de saber que predomina na graduação (Capparelli e Stumpf, 2001; Lima, 2001).

Já entre as questões vistas com reservas, de um ponto de vista mais local, são discutidos pontos como: a dispersão temática da pesquisa para além de questões estritamente comunicacionais (ou, conforme a terminologia adotada em relatórios de avaliação, “pertinentes à área”) (Peruzzo, 2002; Capes, 2001), predomínio de um padrão discursivo (ensaio) menos científico do que o do artigo (Gomes, 2003). Embora esse tema possa ser visualizado também no plano internacional como o embate, entre os que têm uma concepção de ciência “dura”, “empírica” (dependendo do contexto) e os que defendem uma concepção “teórica”, “interpretativa” (também com variação nos termos conforme quem o enuncia).

No marco da Justificativa desse trabalho, porém, menos pertinente do que apontar todas as perspectivas críticas, os tipos de enfoque e modalidades de investigação teórica ou 
empírica que sustentam cada uma das argumentações nos trabalhos citados, importa perceber a existência dessa possível esfera de discussão que colabora com o amadurecimento da área. Assim, ressaltamos que o trabalho proposto situa-se num âmbito parecido com as das preocupações que animam este tipo de debate interno e que talvez estejam configurando uma linha de pesquisa, no nosso entender bastante importante para a área da Comunicação. Pois na noção bourdieana de “campo científico” é central a idéia da força do debate interno como sendo o próprio conflito científico que pode dar forma ao campo. “Se há uma verdade, é que a verdade é um objeto de luta”, nota Bourdieu (1983, 74). Acreditamos, pois que e a irrupção de trabalhos como os mencionados é um elemento para fortalecer a disciplina. Ao invés de apenas insistir sobre o caráter “jovem” ou recente da área, no âmbito das ciências sociais (daí o caráter pouco "maduro”), nota-se um alargamento da discussão e do confronto de posições para temas que, ou eram pouco discutidos, ou eram tomados como consensuais.

Ao mesmo tempo, esta tese situa-se no contexto de um debate atual, e é nossa convicção que ele traz elementos novos - que se não são originais, pelo menos possuem uma perspectiva de aprofundamento temático e síntese para a discussão travada até aqui. Sustentamos, pois, que a utilização dos conceitos de “campo científico” e “capital científico” representam possibilidades de compreensão de problemáticas da pesquisa, sobretudo em articulação com dados empíricos que o estudo irá produzir e analisar. Com efeito, faltam informações e dados sobre nossa área de estudos, pois freqüentemente eles estão dispersos ou são de produção relativamente complexa e trabalhosa. Busca-se ainda analisar estas informações a partir de um contexto de discussão sobre a natureza da Comunicação, contexto que não é "estabilizado", comum a todos os praticantes da disciplina, justamente pelo estado de disputa no campo.

Para Martino (2001), a epistemologia contemporânea contemplaria três formas possíveis de abordagem sobre a natureza e objeto do campo de estudo da Comunicação. Uma de natureza empírica - "tomando como base de análise as instituições relacionadas com a comunicação” -, outra de natureza lógico-formal - pela definição, nesses termos, do objeto de estudo - e, por fim, uma abordagem "no tempo, isto é, através de uma análise diacrônica, procurando situar a gênese do campo dessa disciplina” (Martino, 2001, 83). O 
autor observa que a primeira definição - não normativa - apresentará dificuldades devido à diversidade de respostas que tende a encontrar, indicando

uma constelação de práticas sociais, em si mesma testemunha de importantes variações no sentido do termo comunicação, que ainda que estejam supostamente ligadas de maneira mais ou menos coerente, dificilmente se deixam sintetizar em um conceito unívoco e em todo o caso pouco formalizado. (Martino, 2001, 84)

A definição formal ou ideal, por sua vez, não estaria descomprometida com o que efetivamente é pesquisado, no entanto, procuraria aliar a observação in loco dos processos de formação de entendimento dos sujeitos com uma atividade especulativa. Os dados da investigação empírica alimentam e regulam as reflexões elaboradas, impedindo abusos nas elaborações. Porém aspectos como a polissemia do termo “comunicação” e a questão da interdisciplinaridade do objeto, tornam também uma definição formal-ideal inalcançável.

Por essas razões, para o autor, estes dois caminhos, que acabam conformando um sistema, são insuficientes para construir uma definição do que seria a natureza e o objeto da Comunicação. Assim, o âmbito privilegiado nesta reflexão de Martino (2001) é o da análise da "gênese do campo", isto é, as novas práticas comunicativas, cuja análise deveria ser o centro da disciplina, explicando seu objeto. Interessa mais destacar aqui, como o autor também observa, que os outros âmbitos não são improdutivos - embora não possam resolver plenamente as questões de base da disciplina.

O presente estudo é mais relevante não uma suposta “estabilização" normativa sobre os objetos e natureza da área - que a proposta de Martino intenta -, mas sim compreender, a partir da articulação entre o dado empírico e a discussão teórica, tendências da produção e a interação entre pesquisadores, que dariam maior ou menor concretude ao conceito de campo. O que o projeto procura - e isso sim, deve-se avaliar - é compreender certo momento de interação/tensão entre os que participam do debate constitutivo do campo, num contexto científico também marcado pelo debate. Há uma dialética implícita ao modelo do “campo científico” entre a organização institucional e a ordem intelectual alcançada. Em poucas palavras, quanto mais autônomo e organizado é um campo, mais ele tende a concentrar suas discussões em critérios internos de validação. Os debates e conflitos gerados nas discussões internas são admitidos, porém é necessário que existem instância de interação, bem como o desejo dos participantes de realizar realmente os debates. 
Pelo que foi dito, acreditamos que a questão da importância relativa de uma investigação dentro do presente contexto histórico esteja bem equacionada, pois nos ajudar a justificar a escolha do tema em análise, no plano da carência de determinado conhecimento por certa área, em termos da necessidade de conhecimento da área sobre a si mesma.

O potencial de uso social da investigação por determinados grupos (o “quem”), como elemento de discussão e compreensão dos mesmos (o "por quê"), por conseguinte, foram aspectos nos quais procuramos refletir ao delinear o projeto de pesquisa. Esperamos, assim, que os dados e análises sobre o “campo científico da Comunicação” possam retornar aos próprios grupos mobilizados em torno desse debate e estimulá-lo.

Em resumo, é esse o sentido da epígrafe de Orozco: quando à tarefa de produção de conhecimento conjugam-se condições e a oportunidade para que o mesmo resulte útil para determinado grupo, o sentido da investigação realça-se. 


\section{Estrutura do trabalho e metodologias empregadas}

Além da preocupação com vetores internos a um campo como a Comunicação, deve-se considerar que existe o pertencimento do mesmo a um universo mais amplo, no qual hoje se como dissemos a discussão sobre a natureza da ciência. Assim, nos parece importante discutir certos elementos do atual debate sobre a essa atividade, pois o mesmo tem repercussões na definição de conceitos como o de "disciplina”, “campo de estudos”, “interdisciplinaridade”, entre outros.

Por essa razão, à estrutura do trabalho apresenta-se em 7 capítulos. O Capítulo 1 - A ciência e o projeto científico aborda traços caracterizadores da ciência de modo geral, no que se pode entender como a sua definição “moderna”. Nesse sentido, recorremos à noção de "projeto científico" (Granger, 1989), bastante esclarecedora quanto aos aspectos que caracterizam o paradigma tradicional e tendencialmente unitário de ciência.

\section{O Capítulo 2 - As ciências sociais, as ciências da comunicação e as novas} epistemologias da ciência destaca idéias sobre a diversidade da ciência e dos produtos do conhecimento. Ao entender a Comunicação como subcampo das ciências sociais, devemos nos aproximar do debate sobre a natureza das mesmas. Tomamos autores como Ianni e Passeron, confrontando as idéias de ambos com algumas noções retiradas do trabalho de Kuhn, que são argumentos correntes na discussão sobre a ciência. Isso encaminha a apresentação das propostas de "novas epistemologias” da ciência (nos trabalhos de Sousa Santos e Morin, principalmente). Pode-se assim, no último tópico do capítulo, retirar uma síntese de problemas que dizem respeito ao campo da Comunicação nesse contexto de debate científico.

\section{No Capítulo 3 - O conceito de campo científico: preliminares teórico-metodológicas} de seu uso na investigação é feita a apresentação e discussão dos conceitos de Bourdieu de interesse ao estudo. Preferimos, atuando comparativamente, mostrar brevemente certas tradições de trabalho em sociologia da ciência, em particular as recentes, de modo a evidenciar os aportes próprios dos conceitos desse autor para o trabalho. Em particular, objetiva-se tornar mais claros os ângulos de observação do possível "campo científico da Comunicação” que são analisados posteriormente. Daí, a apresentação, nesse capítulo ainda do modelo de Galtung. 


\section{No Capítulo 4 - Perfil Institucional das Ciências da Comunicação no Brasil: histórico}

e indicadores de inserção na área científica procuramos situar a Comunicação no âmbito mais geral da institucionalização das ciências no Brasil - pois esse é um elemento de conformação do campo. Assim, como proposto no estudo de Fuentes (1998) sobre a Comunicação no México, e no modelo de Bourdieu, é importante um viés comparado, “relacional”, da área da Comunicação com outras, em particular as ciências humanas. É esse o sentido da breve historiografia e da compilação e análise de dados que se segue. Ao mesmo tempo, entendendo a pesquisa em Comunicação no Brasil como eminentemente ligada ao sistema de Pós-Graduação (PG), tem-se a necessidade de reconstruir certos aspectos que são constitutivos do mesmo na atualidade. Objetiva-se ressaltar aspectos do quadro institucional da educação superior e da PG no Brasil que são elementos conformadores do campo de investigação em Comunicação. Ainda neste mesmo capítulo o sistema da PG em Comunicação será caracterizado em linhas gerais.

\section{O Capitulo 5 - Padrões de associação, pesquisa e produção nas Ciências da}

Comunicação no Brasil dá continuidade a essa perspectiva de análise mais institucional, enfocando outras instâncias (Grupos e Projetos de Pesquisa, Publicações Técnicocientíficas) constitutivas da área. Ao fim, são feitas considerações mais gerais sobre os dados, buscando interpretar mais profundamente os mesmos.

\section{No Capítulo 6 - Organização e representação dos discursos da Comunicação e de sua} produção científica, utilizamos a análise de conteúdo (discutida nesse contexto), para compreender a representação e a auto-representação que o campo procura assumir, por meio de três materiais: as propostas de taxonomia científica da área (demandas por agências de fomento), as temáticas das teses e dissertações do ano de 2004 de todos os Programas em Comunicação, as Linhas de Pesquisa dos PPGCOM. De certo modo, tal análise da continuidade ao vínculo entre institucionalização e debate epistemológico realizado nos capítulos antecedentes e procura, a partir da discussão da noção de “programa de pesquisa”, que poderá ser válida.

No Capítulo 7 - O capital científico da Comunicação em suas referências bibliográficas, é feita uma análise do capital científico do campo através de estudos bibliométricos sobre: a) a bibliografia obrigatória nos exames de ingresso nos diferentes 
PPGCOM; b) a produção (Teses e Dissertações) de todos os Programas da área em um ano (2004). Para dar um viés diacrônico ao estudo, evidenciando a formação das referências bibliográficas da pesquisa em Comunicação, também são discutidos dados bibliométricos de Teses e Dissertações de outros quatro anos (1977, 1983, 1990 e 1997). Objetiva-se retirar dessas análises elementos para discussão do referencial bibliográfico de base atualmente utilizado: quão fragmentado ou não ele é; para quais referências consensuais que podem ser agrupadas em conjuntos de autores que os "programas de pesquisa” aponta; que tendências de pesquisa projeta, bem como áreas que podem ser visualizadas. Pelo viés relacional dos dados, no qual os PPGCOM e os autores são as unidades de análise mais importantes, será possível discutir ainda o modo de circulação e reprodução do conhecimento, o que naturalmente relaciona a análise às interações grupais no grupo. Temos um interesse especial pelos autores nacionais, possíveis elaboradores de um conhecimento (“capital científico”) para a área da Comunicação. Nesse capítulo buscamos também discutir a própria técnica bibliométrica em seus limites e possibilidades para o objetivo da tese e outros possíveis usos.

No Capítulo de Conclusões é feita uma recapitulação das análises e diagnósticos do campo da investigação em Comunicação no Brasil, procurando elaborar uma síntese sobre o estado atual do mesmo, no sentido do conceito de “campo científico” adotado. Notamos, por fim, que a contribuição proposta remete tanto à produção de um conjunto de dados que são bastante precários na área, pois a tradição de estudos da produção científica de abordagem das citações não é muito comum, quanto à integração dos mesmos numa interpretação mais ampla sobre a configuração atual do campo científico da Comunicação. Por fim, os resultados da estratégia metodológica e o quanto ela se mostrou útil para compreender as questões de interesse, são também parte do produto da tese e por isso merecem, igualmente, consideração analítica nessa conclusão. 


\section{Capítulo 1}

\section{A ciência e o projeto científico}

A definição da "ciência” nunca é neutra, já que, desde que a ciência dita moderna existe, o título de ciência confere àquele que se diz "cientista" direitos e deveres. Toda definição, aqui, exclui e inclui, justifica ou questiona, cria ou proíbe um modelo.

(Stengers, 2002, 35)

A despeito de qualquer definição prévia, a pesquisa histórica sobre o "novo" tipo de conhecimento gerado, a partir pelo menos do século XVI, não deixa dúvida - instaurou-se um novo modelo de pensamento, uma relação com o mundo e um conhecimento deste diferente de formas do passado: a ciência. O pensamento e a racionalidade humanos possuíam antes, como a filosofia, a matemática ou a geometria comprovam, outras formas de expressão, e continuam a ter. No entanto, as características centrais da observação e da experimentação, aliadas às explicações matemáticas, assumiram um papel preponderante na forma específica de pensamento que é a ciência moderna.

Por conseguinte, foi o aperfeiçoamento do conhecimento científico, lastreado em pressupostos sobre a possibilidade de contínuas descobertas com base na experimentação e presumível caráter progressivo e cumulativo desse saber - que permitiu à humanidade um crescente domínio sobre a natureza (Soares, 2001a, 64-5). E daí aos próprios empreendimentos humanos e a aspectos da sociedade. Tal poder é decorrente de uma forma de conhecimento capaz de obter explicações e previsões relativas ao mundo empírico, permitindo a construção de modelos e teorias.

A ciência, desse modo, despertou uma renovada capacidade do homem atuar sobre o mundo. As dimensões técnicas e tecnológicas do trabalho humano sobre o real foram maximizadas pela capacidade da compreensão científica. O contexto intelectual que forjou a Revolução Científica esteve, pois, no século XVIII, na base de novas concepções sobre o 
conhecimento que resultaram tanto na Ilustração francesa quanto na Revolução Industrial inglesa (Soares, 2001a, 66). A partir da ciência moderna, o domínio humano sobre a natureza ocorreu de modo contínuo. E se o caráter especializado do discurso científico afastaria o homem comum da compreensão do mesmo, as realizações científicas tornar-seiam tangíveis, praticamente onipresentes. Elas estão ao alcance dos olhos e da experiência de todos, já que modificaram os modos de vida e as práticas sociais, provocando inúmeras transformações nos modos de vida.

A ciência não buscou, pois, apenas compreender o mundo, assumiu também a tarefa de transformá-lo. O exercício de Latour (1994) de ler o jornal e nele encontrar a ciência, a tecnociência, a proliferação dos elementos “híbridos” criados por estas dimensões humanas e naturais imbricadas é fruto de um olhar intelectualizado e crítico. Ao mesmo tempo esse autor parodia a provável perplexidade do homem comum sobre isso, ou seja, a transformação provocada em toda parte pela atuação do conhecimento científico. Os efeitos sociais da ciência respondem, pois, por grande parte da ideologia de sua justificação.

Voltando a essa breve descrição do processo de desenvolvimento da ciência, nota-se, ainda em sua historiografia, que ela buscou separar-se das formas tradicionais de saber, construindo suas próprias e específicas regras de funcionamento e validade. Elaborou-se, assim, uma outra modalidade de discurso sobre o mundo, criando, como nota Japiassú (1997, 7), “um novo regime de verdade: a chamada 'racionalidade científica ocidental’”, que privilegia aspectos como a precisão e a independência da razão frente a quaisquer outras forças, como a fé. Desse aspecto decorre o elemento mais relevantemente simbólico do conflito que opôs a Igreja a Galileu, permitindo caracterizar a emergência da ciência, a partir dessa "ruptura inaugural” (Bourdieu, 1983). Um nítido momento da separação entre esses campos, que indicaria um rumo de crescente autonomização da ciência. “Aos poucos os 'modernos' distinguem-se dos antigos, inclusive porque não mesclam teologia nem mitologia com filosofia, ciência e arte” (Ianni, 2004, 14). Este processo foi capaz de dotar a atividade científica de uma especificidade que tornou característica sua forma de pensamento e trabalho. 
Dinâmica e contextualmente característica, é verdade, pois o âmbito das respostas, bem como o do conceito de "ciência” a que determinado contexto diz respeito, é histórico. O que ocorre tanto no plano interno do o discurso aceito como científico, quanto externo, ou seja, nas relações entre ciência e sociedade. Daí, tanto a mudança “revolucionária” ou as “rupturas epistemológicas”, derivadas de disputas e debates numa disciplina, quanto o fato de que os juízos sobre o pensamento científico estão, eles mesmos, envoltos em determinado ambiente social. Não por acaso, pois, o primado dessa autonomia e especialização do conhecimento científico pode hoje ser criticado, a partir de questões como a perda da dimensão filosófica, política e ética, conforme discute um autor como Morin (2005).

Desse modo, reforça-se o postulado de que o discurso científico possui, internamente, uma historicidade - que pode ser vista na sua dupla dimensão de “espaço de respostas” e “espaço de pesquisas” (Raymond apud Japiassú, 1997, 32-33). Exemplificando a primeira dimensão, a explicação de um fenômeno decorre de certo conjunto teórico adquirido, que também depende de formas de demonstração definidas. Porém, tanto um (a teoria) quanto o outro elemento (ou seja, as formas de demonstração) variam segundo a história. Na segunda dimensão, que mostra de modo mais evidente o caráter histórico da atividade científica, nota-se que cada problemática constitui uma relação entre um espaço teórico e um espaço real, e isso submete a ciência a outra exterioridade.

Em suma, o real estudado é variável historicamente, podendo ser visto sob diferentes ângulos em momentos diversos. Novamente nas palavras de Morin (2005), esse é um dos aspectos da "complexidade” da ciência, pois ela é uma atividade “inseparável de seu contexto histórico e social” (Morin, 2005, 8), e o influxo desse contexto faz com que ela, ora se associe à técnica ou à tecnociência, ora se localize no coração da universidade, das sociedades e dos Estados. “A ciência não é científica. Sua realidade é multidimensional” e seus efeitos são “profundamente ambivalentes” (idem, 9).

Por isso existe um nexo entre o elemento filosófico e o científico no desenvolvimento da atividade intelectual, e “a filosofia de uma época impõe certas idéias”, como nota Cournout (apud Japiassú, 1997, 44). Ainda que a ciência possa rejeitar essas idéias (através do debate), o que se destaca é o caráter indissociável entre o pensamento científico e o mundo 
que o cerca. A autonomia da ciência é sempre relativa e o ideal de uma pura atividade “desinteressada” de obtenção de conhecimento e verdade é, sobretudo, uma representação, um “tipo ideal”, no sentido weberiano. Mesmo que esse "tipo” seja almejado por muitos, sua plena concretização é improvável tanto pela historicidade que marca a produção da ciência, quanto pelo caráter social que esta atividade comparte com outras realizações humanas.

Este ponto é bem reconhecido por um sociólogo como Merton (1970[1949]), que, ao descrever características que corresponderiam ao "ethos" da ciência moderna (universalismo, ceticismo organizado, desinteresse e comunismo), observou que elas eram principalmente aspirações ideais. Normas que esperadas, mas, ainda que legitimadas com base em valores institucionais e internalizadas pelos cientistas, tais regras são transgredidas por vezes no cotidiano dos cientistas. Assim, os trabalhos de análise empírica da ciência de Merton ressaltaram "as negociações e mediações relativas aos aspectos contingentes do processo real pelo qual se empreende a atividade científica” (Kropf e Lima, 1999).

Vale a pena também ser novamente observada, a contigüidade, realçada por diferentes autores, entre períodos de "revolução" cultural (como o Renascimento e Iluminismo) e a aparente expressão da mesma em criações científicas (bem como em artísticas ou filosóficas). Tal aspecto é que justifica a relação entre o “espírito da época” e suas manifestações culturais - entre elas, a ciência. "O pensamento e a imaginação guardam sempre alguma contemporaneidade com os movimentos da realidade sócio-cultural, histórica; mobilizando figuras e figurações da linguagem, signos e símbolos”, nota Ianni (2004, 21).

É esse, por conseguinte, o nexo "histórico" de uma epistemologia como a bachelardiana, na qual a reflexão que busca compreender o processo de objetivação das ciências - o juízo sobre a maior ou menor cientificidade dos conceitos - é feito a partir do estado mais sancionado, retificado do saber. Conhecimento "sancionado", mas ainda assim dinâmico, pois o valor de conhecimento científico, como ressalta essa epistemologia, dá-se de modo descontínuo e sempre aberto a novos desdobramentos no tempo. Por isso essa epistemologia não-cartesiana, como Bachelard a chamava, embasa o "novo espírito científico”, e está “por essência, e não por acidente em estado de crise” (Bachelard, 
1988/1934, 83). Com efeito, as noções de base da atividade científica devem ser continuamente revistas; o conhecimento científico procede a partir de contínuas revisões. As “verdades científicas” decorrem da retificação de erros ou aproximações mais ou menos precisas ao conhecimento. A razão polêmica é a razão constituinte dessa epistemologia, de modo a que se possa inferir um conhecimento mais válido sobre o real.

Feita essa breve explanação, e notando que este não é um trabalho histórico sobre o desenvolvimento da(s) ciência(s) ${ }^{7}$, é certo que algumas perguntas se impõem para os propósitos desse trabalho. É possível caracterizar a “ciência”? Quais são exatamente as vantagens e a utilidade dessa operação para o presente trabalho?

\subsection{O “paradigma hegemônico” da ciência}

Quanto à primeira pergunta, concordando com Sousa Santos (2003), diríamos que o modelo de racionalidade científica cristalizou, ao longo do tempo, certas concepções sobre a natureza e a especificidade do conhecimento produzido pela ciência. E, por conseguinte, existe um conjunto de idéias que formam um núcleo dentro da tradição científica que chega aos dias de hoje. Este padrão é chamado pelo autor de "paradigma dominante" ou "hegemônico". Os pontos de vista são, em grandes linhas, convergentes, e daí as aproximações que faremos aqui com o as idéias de Morin (2005).

Com efeito, esses autores apontam aspectos similares, vistos como problemáticos na definição de características tradicionais da ciência. Estes aspectos poderiam ser superados em um novo paradigma científico amplo. Os discursos de Sousa Santos e Morin, aos quais é possível acrescentar a reflexão Wallerstein, são trabalhos de cientistas cujo foco investigativo está mais voltado às ciências sociais e humanas. Porém, a tendência não é de um discurso em tom “apocalíptico” de “adeus à razão” ou um ceticismo radical. No caso desses três autores, muitas de suas propostas encontram respaldo em coletivos bastante abertos ao debate (Sousa Santos, 2004) em que participam cientistas de todas as áreas. Existe ainda uma remissão a propostas de cientistas de outros campos que manifestam

\footnotetext{
${ }^{7}$ Uma síntese bastante qualificada, nesse sentido, encontra-se em Soares (2001).
} 
certo acordo quanto à necessidade de rever os conteúdos da ciência. Não se trata, pois, de um chamado à "guerra das ciências”, nem de uma rejeição ao conhecimento ou à atividade científica de tom irracionalista.

O esclarecimento é oportuno já que uma leitura polêmica ou ligeira de certos textos ou discussões sobre a "guerra das ciências" pode levar a um entendimento pouco realista sobre o esforço de tais autores. O que produz implicações simplificadoras a propósito de uma questão relevante: as possibilidades de debates produtivos acerca do intercâmbio de idéias e mesmo conjunção entre as diversas ciências, por exemplo: discussões de “paradigmas”, trocas e empréstimos conceituais etc. Exemplar de equívoco interpretativo foi a inclusão do livro Um discurso sobre as ciências de Sousa Santos na bibliografia do texto "pós-moderno" que desencadeou o chamado caso Sokal ${ }^{8}$. Essa conhecida polêmica foi interpretada pelo autor como uma atualização do tema das “duas culturas” (Santos, 2004a).

Seja como for, é claro que posicionamentos como os de Santos ou de Morin, e mesmo o de Sokal, demarcam um debate sobre a natureza da ciência, atualmente em particular. Tendo em vista a dimensão histórica dessa atividade, realçada em várias circunstâncias de nossa discussão, compreende-se o valor desse debate. Por isso, respondendo à segunda pergunta de nossa reflexão sobre a pertinência desse tema, acreditamos que vale a pena refletir sobre esses pontos, em resumo, caracterizar o debate científico contemporâneo. Se as chamadas Ciências da Comunicação lutam para se afirmar como "científicas" - e se questiona seu mérito enquanto um "campo científico" - o que se entende sobre essa atividade e qual o estado atual das discussões sobre o contexto epistêmico mais amplo?

Deve-se considerar, em primeiro lugar, que o espaço epistemológico da ciência como um todo apresenta sinais de (auto)questionamento. Os teóricos e os pesquisadores da área da Comunicação não escapam a esse quadro, e seus esforços para instaurar, consolidar ou

\footnotetext{
${ }^{8}$ Esse evento, como se sabe, remete ao físico Alan Sokal, que encaminhou e teve publicado, em 1996, um artigo na revista Social Text. Recheado de absurdos - em particular quanto a teorias matemáticas e físicas, que eram aproximadas a conceitos sociológicos, o texto era, na verdade, como revelou pouco depois o autor, uma paródia. Com este gesto, Sokal pretendia chamar a atenção sobre a suposta perda de rigor intelectual nos estudos das ciências humanas nos EUA. Porém o que poderia ser um debate mais denso sobre esse aspecto de crítica resultou numa escaramuça intelectual mais típica, e estéril, da "guerra das ciências". Para uma recapitulação desse evento, ver Sokal e Bricmont (1999) e Sousa Santos (2004a).
} 
elevar o estatuto científico da área são também afetados por este contexto. É por isso que essa discussão merece ter relevo em nosso trabalho.

Voltando à definição do “paradigma hegemônico” ou “paradigma de simplificação” da ciência, deve-se notar que nele o conhecimento é fruto da observação e da experimentação, conforme a tradição referida. A partir desses aspectos se objetivar-se-á obter um conhecimento mais rigoroso da natureza - e, pela mesma via, da sociedade. O primado seria do princípio da universalidade, expulsando, de acordo com Morin (2005), aspectos locais e singulares. Por isso, conforme a reflexão de Santos (2003), as qualidades intrínsecas dos objetos são desqualificadas em favor da sua quantificação. No paradigma dominante conhecer significa quantificar e o que não pode ser medido é considerado cientificamente irrelevante.

Busca-se, no paradigma dominante, reduzir a complexidade dos fenômenos a partir da observação de regularidades. O que é importante destacar é que o modelo de conhecimento produzido transbordou, a posteriori, para a sociedade, condensando-se inicialmente no positivismo oitocentista. Deste modelo de aplicação à sociedade do conhecimento científico decorreu o advento das ciências sociais. E, pela adoção do modelo das ciências naturais, a identificação das ciências sociais com o plano empírico. Tratar-se-ia de aplicar à sociedade os mesmos princípios metodológicos e epistemológicos relativos ao estudo científico da natureza. Tarefa bem simbolizada pelo nome de "física social” com que se designou inicialmente este estudo científico da sociedade. Essa gênese das ciências sociais é corroborada pela análise de Wallerstein $(1996,1997)$, que acentua também a clivagem estabelecida no século XIX entre as nascentes ciências sociais e a filosofia.

Note-se que a clivagem a propósito das formas de conhecimentos continuamente se acentua, ao longo do tempo, e a expulsão da metafísica e outros discursos que não alcançariam estatuto científico assume importância capital na obra de um dos mais influentes filósofos da ciência do século XX, Karl Popper. Para esse autor (Popper, 1980), a distinção ente a ciência e a não-ciência se dá precisamente a partir do reforço a aspectos como a formalização, precisão, amplitude explicativa, que definiriam o pensamento científico moderno. Além disso, culminando os elementos citados, haveria ainda o critério decisivo nessa demarcação entre ciência e da não-ciência para esse autor: a noção de 
falsicabilidade (ou refutabilidade), ou seja, a capacidade das teorias propostas preverem um acontecimento ou situação que as invalidassem.

A influência de Popper nas ciências sociais, incluindo a discussão e aceitação de muitas das críticas desse autor, em particular à psicanálise e ao marxismo, é um fato. Muitos cientistas sociais, de bom grado, aceitam a qualificação de "popperianos” ainda hoje, isso porque, além da força lógica dos argumentos de Popper, existe esse antecedente de valorização da quantificação e previsão nas ciências do homem. É possível, conforme observou-se, distinguir no desenvolvimento das ciências sociais, no positivismo ${ }^{9}$, uma tendência que preserva uma atitude de estudo dos fenômenos sociais como fenômenos da natureza.

Contudo, como afirma Sousa Santos (2003), uma outra vertente buscou afirmar o estatuto metodológico próprio das ciências sociais. Este foi justificado, seja devido à dificuldade de reduzir os fatos sociais a dimensões externas e quantificáveis, seja pela percepção de obstáculos ou características inerentes aos fenômenos sociais. Entre estas características específicas do conhecimento social estariam a dificuldade de construir teorias que, de modo metodologicamente controlado, propusessem modelos de prova; bem como o fato de que o caráter histórico e cultural do conhecimento, ao ser aplicado pode mudar o comportamento dos fenômenos estudados.

Enquanto à primeira versão se associa o nome de Durkheim, nesta, assentada na tradição filosófica da fenomenologia, Weber ocupa papel central. No entanto, ainda seguindo Sousa Santos (2003), ambas as concepções de ciência social apresentadas podem ser vistas como pertencentes ao paradigma (dominante) da ciência moderna. Embora a segunda concepção represente já seja um sinal de crise que prepara a irrupção de um “paradigma emergente”.

\footnotetext{
${ }^{9}$ Entretanto, a caracterização do pensamento popperiano sobre a ciência como "positivista", no sentido mais lato desse termo, é incorreta pelo viés teórico-formal de seus postulados, o que o faz certamente um representante do positivismo lógico. Ademais, há o fato de que sua filosofia da ciência possui elementos críticos à pretensão de um saber absoluto e estático. A conclusão de A lógica da investigação científica é clara nesse ponto: “A exigência da objetividade científica torna inevitável que todo enunciado científico permaneça provisório para sempre” (Popper, 1980, 123). E, reforçando essa postura não mecanicista em relação às próprias ciências humanas, em sua crítica ao "historicismo", Popper discorre contra a incorporação de modelos biológicos deterministas, como análogos de processos históricos.
} 
Antes de apresentar essa idéia de "crise do paradigma moderno" e a emergência de novas propostas, no capítulo seguinte, faremos uma descrição que sintetiza uma caracterização do projeto científico, a partir de Granger (1989). A questão que justifica essa discussão é a seguinte: a postulada ruptura entre "paradigmas" científicos modifica esse projeto da ciência? A resposta a essa questão implicará em diferentes posturas a propósito da "crise" e, portanto, quanto à significação e valor da possível mudança.

\subsection{O projeto científico segundo Granger}

O filósofo Gilles-Gaston Granger (1989) defendeu a existência de uma unidade na ciência, que seria compatível com a diversidade de suas manifestações e de seus métodos. Segundo o autor, a história da ciência mostra a necessidade de conciliar a unidade do pensamento científico com a autonomia de constituições regionais. Seria impossível supor uma unidade da ciência a partir da redutibilidade dos diferentes tipos de objeto, mas dois traços essenciais poderiam caracterizar todo o empreendimento da ciência: $1^{0}$. Que 0 conhecimento científico só pode conhecer estruturas, $2^{\circ}$. Que a lógica clássica tem um papel central na constituição do objeto científico, portanto as contradições que um esquema apresenta devem ser vistas como prejuízo epistemológico e não sinal do dinamismo do real, e por isso são um convite para a modificação do esquema representativo.

Dessas idéias pode-se retirar a noção de que é possível reconhecer em todo o conhecimento científico uma produção de esquemas abstratos de representações do vivido, que o autor denomina "modelos". Tais modelos se diferenciam por corresponderem a diferentes momentos de um "fenômeno técnico" (o "objeto" da ciência, que é dado a conhecer por esta representação estrutural geral). O aspecto mais central dessa reflexão é a idéia de que o conhecimento por modelos é o elemento característico da ciência.

De outro lado, existem objetos que não podem ser determinados por apenas um tipo de modelo, "mas que chamam a convergência ou a superposição de muitos tipos. É certamente o caso dos fatos chamados humanos, provavelmente também aqueles dos fatos biológicos” (Granger, 1989, 140). Daí, para a compreensão do que está além das diferenças 
de procedimento, Granger procura descrever o projeto da ciência, que mostraria a unidade e originalidade do modo científico de conhecer. O autor discute as especificidades e as dificuldades das ciências do homem, em relação a este ponto. Todavia, afirma que esse “projeto unitário da ciência não poderia ser contraditório com a pluralidade das ciências, nem com o estágio de desenvolvimento aos quais, umas e outras chegaram” (idem, 144).

Apresentaremos brevemente agora os três grandes temas desse projeto, conforme a discussão de Granger (1989). O primeiro aspecto é que a ciência visa uma realidade, em oposição a suscitar ou descrever um imaginário. Sendo que, na perspectiva da ciência, a “realidade” estaria referida a dois grandes traços: reconhecimento à livre manifestação do pensamento e certa convergência das operações desse pensamento. Em segundo lugar, o projeto científico está baseado na procura por uma explicação, e não simplesmente pela codificação de uma prática, dependendo, pois, menos de um resultado. Nisso o conhecimento científico diferencia-se da técnica. Explicar, para Granger, relaciona-se com a inserção de um sistema de conceitos num sistema mais vasto, supondo que as relações entre os conceitos sejam claramente colocadas e exprimidas num sistema simbólico. $\mathrm{O}$ terceiro elemento do projeto é que a ciência deve se submeter a critérios explícitos de validade, o que está relacionado a dois aspectos. O primeiro deles, com a necessária lógica do discurso científico, que segue fundamentalmente as regras da lógica clássica. Há também a pertinência empírica, como critério de validade relativa à semântica que regula a linguagem e permite enunciar protocolos para que, em relação aos enunciados perceptivos, se possa em princípio definir o verdadeiro do falso.

O formalismo utilizado deve permitir deduzir conseqüências das proposições em causa, sendo as mesmas suscetíveis de serem confrontadas com enunciados perceptivos da linguagem. Trata-se, pois, da noção de que os enunciados devem ser demonstráveis ou refutáveis, sendo, nesse sentido, uma versão, “enfraquecida” como salienta Granger (1989, 150), da proposta popperiana para a definição da ciência. Esse enfraquecimento decorre, conforme o argumento do autor, pela defesa de que nem todo enunciado seja demonstrado e refutado do mesmo modo, para evitar excluir do âmbito científico "princípios” que não se encaixem nos critérios expostos, mas que exerçam uma ação reguladora. 
O projeto coloca, para o autor, uma fronteira entre o pensamento científico e outras formas de conhecimento com pretensões científicas (a pseudociência ou a ciência que traz marcas da ideologia, isto é, formas de apreensão do vivido não reguladas pelo projeto científico) ou sem essa pretensão (o mito, a arte etc.).

Reafirmamos que essa discussão do "projeto científico" tem sentido em nosso trabalho a partir da reflexão sobre novas propostas de definição da ciência, ou seja, o terreno epistemológico no qual se situa a reflexão sobre a Comunicação como campo de conhecimento. As novas propostas parecem responder a insatisfações convergentes sobre o conhecimento produzido no marco da ciência, e projetam supostos novos "paradigmas" para a ciência. Eles possuiriam, todavia, um "projeto científico” diferente do exposto? Se sim, qual? Essa questão é abordada no final do próximo Capítulo, enfocada do ângulo dos praticantes da Comunicação. Antes, evidentemente, será feita a exposição dessas idéias renovadoras da ciência.

Notamos, porém, que não temos a pretensão de dar uma resposta absoluta a esses questionamentos, porque isso demandaria uma leitura extensiva/intensiva das obras de epistemologia que formulam questões críticas ao paradigma moderno. E isso, por si só, demandaria outro trabalho acadêmico. É claro que é possível pensar que se o termo “paradigma” é entendido no sentido forte é esperado algum nível de mudança em termos dos “projetos”. Uma mudança paradigmática nunca é trivial, implicando, conforme o sentido kuhniano do termo, em uma alteração perceptiva complexa. Aliás, essa alteração é imaginosamente bem ilustrada pelo exemplo favorito de Kuhn: a figura do coelho e do pato, num só desenho. Porém, sob determinado olhar (o paradigma) só se observa um. Ou pato, ou coelho. Daí, a incomunicabilidade entre perspectivas paradigmáticas. Isso aconteceria? Ademais, mais importante dentro do marco de nosso trabalho, a constituição da Comunicação como campo científico, é pensar nas implicações das possíveis “apropriações” dessas propostas que são realizadas pelos pesquisadores da área. Daí podese discorrer sobre possíveis interpretações que se aproximem mais ou menos do projeto científico, conforme a formulação de Granger.

Resta ressaltar que os critérios do projeto científico também são atinentes às ciências sociais, e assim, se não chegam a ser completos obstáculos, demarcam as tentativas de 
produção de um conhecimento científico nessa área também, segundo o autor. Naturalmente, Granger não vê as ciências sociais fora dessa moldura da prática científica, assim as ciências sociais estariam contempladas no ideal de unidade da ciência que o “projeto científico” coloca.

No próximo capítulo, antecedendo à descrição da idéia de “crise do paradigma moderno" discutiremos mais as concepções científicas nas ciências humanas e, para tanto, utilizaremos alguns dos trabalhos de Octavio Ianni (1992, 1994, 1997, 1998, 2003, 2004) e a discussão sobre as ciências sociais como modalidade de raciocínio ou espaço científico, mas “não-popperiano”, conforme defende Jean Claude Passeron (1995).

Deve-se, notar desde logo que as idéias dos autores discutidos a seguir (Ianni e Passeron), são congruentes com o ideal de “projeto científico". Pois, ao fim e ao cabo, a presente tese postula tanto uma unidade mais profunda da ciência, quanto a noção de que existem critérios de rigor para atividade, que são relativamente similares entre os contextos semânticos dos dois autores e Granger, e estariam dentro de uma racionalidade moderna.

Desse modo, como evidenciaremos, Ianni e Passeron abordam as especificidades do conhecimento nas ciências humanas em termos correlativos que aproximam suas reflexões sobre as ciências sociais aos conteúdos do projeto científico grangeriano. O que pode ser visto, por exemplo, no uso da “compreensão” como substituta da "explicação” nas ciências sociais, conforme a discussão de Ianni (2003), evidenciando um critério racional de base comum. 


\section{Capítulo 2}

\section{As ciências sociais, as ciências da comunicação e as novas epistemologias da ciência}

Os trabalhos de Ianni que discutiremos a seguir são relevantes não só pelo caráter de síntese do problema da natureza das ciências sociais Ademais, ele faz uma interessante formulação do conhecimento científico como uma, entre outras, das "narrativas" com as quais os homens procuram produzir formas de autoconsciência.

É importante notar que o tema da ciência como "narrativa” não é novo em discursos sobre a ciência e, talvez pelo poder da analogia, foi também utilizado por autores diversos, como Lyotard (1996) e Greimas (1976). Quanto ao primeiro verifica-se uma abordagem relativista sobre o conhecimento científico, como uma "narrativa" entre outras da modernidade à qual se segue a metacrítica da atividade científica. Para Lyotard, a ciência deveria encaminhar-se, na ausência ou crise dos consensos legitimadores da modernidade, na direção de práticas heterogêneas e variadas, não totalizantes, capazes de abarcar idéias como "acaso" e “indeterminação”. Esse discurso teria como legitimação o conceito de "performatividade”, ou seja, o desempenho da ciência para a ação no mundo. Em resumo, trata-se de uma abordagem “pós-moderna” em relação à atividade científica, que interpreta positivamente o abandono de grandes narrativas centralizadoras e totalizantes. A pluralidade proposta estaria, segundo o autor, mais de acordo com o estágio do sistema econômico e social do mundo atual, e certamente guardaria pouca relação com o "projeto científico” de Granger. Essa posição não é a de Ianni. Já Greimas (1976), a partir de seu modelo actancial, aborda o tema da "narrativa", tanto como uma característica de todo o tipo de discurso (inclusive o científico), quanto do cientista como um Sujeito em busca de um Objeto (conhecimento).

De qualquer forma, ressaltada a particularidade da noção de "narrativa" por Ianni, evidenciada a seguir, observamos que o autor também reflete sobre o tema das 
"humanidades” nas ciências - retomando em um de seus textos uma discussão clássica, no contexto da "guerra das ciências”, sobre as “duas culturas” científicas. Ianni procura vincular, numa perspectiva congruente com sua posição mais ampla sobre o tema, a ciência ao contexto social marcado pela globalização na contemporaneidade. Esta temática de interesse do sociólogo dá margem a uma reflexão epistemológica sobre o sentido da mutação histórica para as ciências sociais.

É a partir desse aspecto que ganha interesse a postura de Passeron, pois para esse autor o "raciocínio sociológico" (das ciências sociais) distingue-se do das outras ciências (da natureza e lógico-formais) exatamente por essa indexação a contextos espaço-temporais. Após a discussão das idéias desses autores, elas serão confrontadas com determinadas noções sobre a ciência, conforme a influente formulação de Thomas S. Kuhn (1976), realçando divergências significativas entre esses autores e entre aspectos que permitem problematizar a discussão específica de nossa tese. 


\subsection{Ianni: a ciência como uma das narrativas da modernidade}

Em uma fórmula breve, é possível tornar as narrativas que compõem a vasta biblioteca da modernidade, a despeito de suas distintas linguagens, como diferentes formas de esclarecimento, envolvendo possibilidades diversas de articulação da autoconsciência de uns e outros, a respeito da realidade e do imaginário, do visível e do invisível, apreendendo o ser e o devir, o fluxo das coisas, gentes e idéias, bem como as volições e as ilusões. (Ianni, 2004, 19)

O contraponto "ciência e arte” foi o mote a partir do qual Ianni (2004) avaliou que "no que refere às possibilidades de conhecimento, logo se coloca [...] o desafio de reconhecer que as criações científicas, filosóficas e artísticas podem ser vistas como 'narrativas"” (idem, 16). Assim, a despeito das demarcações, subdivisões e especializações, nem sempre por motivações internas ${ }^{10}$, que cada uma dessas áreas apresenta, essa semelhança, em termos da forma "narrativa”, permite uma zona de confluência e similaridade. De modo que a convergência e as fertilizações recíprocas são evidentes em diferentes momentos, apesar das especificidades de linguagem, conceitos e categorias mobilizados em cada uma das “narrativas”. No entanto, mesmos nesses parâmetros, há também, por vezes, influências mútuas.

O que importava para Ianni era notar, de um lado, essa similaridade - e por vezes convergência - entre as diferentes "narrativas” (ciência, filosofia, arte) que, cada qual a seu modo, e principalmente nas mais notáveis, taquigrafavam a vida social, a realidade e modos de ser, configurando formas de esclarecimento e reconhecimento da realidade. Fato que, para o autor, marcaria singularmente o mundo moderno.

Ao mesmo tempo, as reflexões do autor dirigem-se para as formas específicas que essas narrativas possuem, tanto nas diferenciações entre elas, quanto em termos de especificidades internas. Por isso Ianni procura mostrar os diferentes "estilos de pensamento" que se instauram nas "narrativas”, configurando formas de conhecimento próprias. Ainda, como se ressaltou, com uma similaridade profunda quanto à busca de

\footnotetext{
${ }^{10}$ Para o autor, a "pulverização" das ciências sociais e das artes decorre, pois, não somente da especialização do vocabulário de cada uma das diferentes narrativas que se instauram, mas também são resultado da crescente institucionalização das atividades de ensino e pesquisa, das influências do positivismo e das induções do mercado (Ianni, 2004, 15).
} 
esclarecimento sobre o mundo e, nesse ponto, a reflexão do autor se afasta decididamente do positivismo.

Essa distinção entre “estilos de pensamento” é clara na reflexão do autor sobre o tema que C. P. Snow, num livro de grande repercussão publicado originalmente em 1959, chamou da cisão entre "duas culturas”, de um lado as "ciências" (as ciências naturais) e de outro as "humanidades” (ciências humanas e artes).

A rigor, o que foi e tem sido dito a propósito de "duas culturas" seria possível traduzir por "dois estilos de pensamento", formas de conhecimento distintas, mas sempre formas de conhecimento, esclarecimento. São modos de apreender, descobrir ou surpreender o dado e o significado, a situação e a configuração, a objetividade e a subjetividade, o modo de ser e a possibilidade, a vivência e a consciência; compreendendo a aparência e a essência, as partes e o todo, o presente e o passado, o singular e o universal. (Ianni, 2003, 5)

Porém, ao falar das diferenças entre estes estilos de pensamento e ao ressaltar que são ambas formas legítimas de conhecimento, o autor não nega as possibilidades de diálogo entre as mesmas. Ianni demarca com clareza o horizonte social de toda reflexão humana, aspecto que coloca limites à ciência, no plano da atuação desta sobre o mundo social e natural. E é nesse ponto que se encontra a sua crítica mais relevante à posição "humanista" de Snow sobre esse mesmo tema.

Com efeito, detalhando a posição de Snow, deve-se reconhecer que este autor não foi um apologista da "guerra das ciências". Ao contrário, tanto no texto inicial da conferência que daria origem à primeira publicação, quanto na releitura do tema e dos debates que se sucederam, a ênfase de Snow (1995) está no lamento à falta de comunicação entre as “duas culturas”. Ele buscou demonstrar a existência de um fosso que se estabelecera entre as ciências e humanidades e que tinha implicações práticas. Bastante inserido no debate da época, a tese de Snow era que a ciência seria uma possível forma de ajudar a diminuir os desníveis entre países “ricos” e “pobres”. A “revolução científica” poderia ser reproduzida nos países menos avançados, de modo a reduzir as desigualdades sociais. Esta possibilidade, todavia, era dificultada pela divisão entre as “duas culturas” analisadas.

Entretanto esta tese, como critica Ianni, em sua formulação de um otimismo humanista algo ingênuo esquece que “os 'pobres' foram e continuam sendo fabricados [pelo sistema comandado pelos países centrais], desde o colonialismo e o imperialismo, entrando depois pelo globalismo” (Ianni, 2003, 4). Ou seja, pode-se dizer que faltou a Snow um 
componente de reflexão social, sobre as dimensões de poder que se enlaçam no conhecimento. Esta concepção “neutra” a respeito do saber infiltra-se na própria ciência social, como já se sugeriu, através do modelo do positivismo.

Na explanação de Ianni sobre os gêneros de pensamento social, vale a pena enunciar aquilo que o autor postula como elemento caracterizador da diferença entre os estilos de pensamento das ciências naturais e sociais. Aquelas têm como princípio explicativo a “causação funcional”, e suas interpretações são “principalmente 'quantitativas', envolvendo índices, indicadores, variáveis, experimentos, testes, leis e modelos, sempre com base no princípio da causação funcional” (Ianni, 2003, 17). Já nas ciências sociais, ainda que parte delas procure adotar os pressupostos explicativos das ciências naturais, desenvolveu-se um outro estilo de pensamento, assim, passaram a basear-se principalmente na compreensão e suas interpretações seriam “principalmente ‘qualitativas', apreendendo regularidades e descontinuidades, situações e tendências, relações e processos, envolvendo tanto estruturas como tensões e contradições sociais” (idem).

Observa-se que nessa caracterização há também uma contraposição entre o funcionamento de um "paradigma hegemônico”, como descrito por Sousa Santos. Tal aspecto é observado aqui de modo mais detido em seu funcionamento nas ciências do homem e outra vertente epistemológica menos próxima à ortodoxia.

Assim, os dois outros estilos de pensamento, ou "paradigmas" das ciências sociais - além do positivismo, que se desenvolve resultando em uma "teoria sistêmica" -, derivam da fenomenologia e da dialética hegeliana (Ianni, 2003). E, com princípios explicativos diferentes da "causação funcional”, abriram novos horizontes para a reflexão social. A fenomenologia, preocupada com as articulações entre objetividade e subjetividade, linguagem e hermenêutica, a partir do uso do princípio explicativo da "conexão de sentido" (ou “compreensão”). E a dialética hegeliana, desenvolvida por Marx e outros, privilegiando princípios como aparência e essência, singular e universal, tendo como base explicativa a "contradição".

Para Ianni, além dessas há outras formas de compreensão do mundo representadas pela arte. O artista trabalha e produz a partir de dilemas sentidos em outros níveis pelos 
cientistas e demais sujeitos. Essa forma de criação cultural representaria um tipo de conhecimento com a possibilidade de gerar uma "singular forma de esclarecimento, que pode ser denominada de 'revelação', com a qual se propicia o encantamento” (Ianni, 2003, 18).

De qualquer forma, admitindo a historicidade desses estilos de pensamento, em alguns de seus trabalhos, Ianni (1994, 1997, 1998) buscou refletir sobre as implicações epistemológicas da forma histórica da "globalização", pois essa etapa provoca uma "ruptura histórica de amplas proporções para as ciências sociais” (Ianni, 1998). Assim, o objeto das mesmas passa a ser também a sociedade global. E nesta, dimensões sociais, políticas, culturais, demográficas, entre outras, adquirirem uma significação não apenas internacional ou transnacional, mas planetária ou global.

A alteração nos âmbitos históricos, ao provocar mutações no “objeto” das ciências sociais, justifica uma readequação da teoria, já que seu estoque cognitivo não possui todos os conceitos que taquigrafem o social. Por isso, a importância, nesse estágio, de noções e metáforas como "aldeia global”, “mundialização”, “cidadão do mundo”, entre outras. Ao mesmo tempo, conceitos já estabilizados pelas tradições teóricas das ciências sociais, tendo sido construídos com referencial o “estado nação”, precisam ser reconstruídos ou ressignificados.

Acostumadas a refletir sobre o estado nacional, as ciências sociais são agora desafiadas a construir um "paradigma” relacionado com os novos tempos globais. Ianni pensa a "globalização" como um macroconceito, que por isso é um descritor de uma série de mudanças e transformações. Daí, também, um diagnóstico como o de Chauí $(2001,107)$, que acredita que a “chamada ‘crise de paradigmas’ não é uma crise teórica, mas resultado de mudanças da base material da sociedade que fizeram desaparecer os antigos objetos das ciências sociais”. Fica implícito, porém, que a crise tem conseqüências no plano das explicações das teorias construídas para entender os “novos tempos”.

Por isso, a afirmação de Ianni (1998) de que "se é verdade que as ciências sociais nascem com a nação, talvez se possa afirmar que elas renascem com a globalização”, não parece exagerada. No entanto, essa nova configuração social exige o aprofundamento de aspectos 
constitutivos da metodologia dessas ciências, como o método comparativo e uma proposta mais ousada, o recurso à “multidisciplinaridade”. Essa orientação é desejável pela característica multidimensional dos fenômenos sociais sob o regime global. Os objetos de pesquisa nesse “paradigma social” possuem características que tensionam diferentes aspectos da realidade, ou melhor, permitem perceber diferencialmente, e buscam explicar esses mesmos aspectos, seja em termos de “causação", “conexão de sentido” ou “contradição”.

Em resumo, de acordo com Ianni (1998), a “originalidade e a complexidade da globalização, no seu todo ou em seus distintos aspectos, desafiam o cientista social a mobilizar sugestões e conquistas de várias ciências”. Tal aspecto tem uma implicação importante para as Ciências da Comunicação, como aponta e discute Lopes (2004, 2003a). Portanto, em função, tanto da importância do argumento, quanto da organização do discurso aqui adotada, esse aspecto será abordado no último tópico desse capítulo. Antes, como já dissemos, será feita uma breve descrição das idéias de Jean Claude Passeron sobre as ciências sociais.

\subsection{Passeron: as ciências sociais como espaço "não-popperiano"}

Outra forma de interpretar as diferenças de raciocínio entre as ciências sociais e as da natureza/lógico-formais é a feita por Passeron, numa linha que, em certa medida, dá continuidade ao clássico trabalho em ciências sociais - O ofício de sociólogo (Bourdieu et al., 1999) -, com o qual esse autor colaborou. Neste livro, a reflexão epistemológica é vista como um fator interno às próprias investigações, dentro da perspectiva próxima ao "racionalismo aplicado" de Bachelard, e tem base na ruptura com o senso comum, auxiliada pelas teorias e recursos de inteligibilidade disponíveis no campo em estudo. Dessa operação segue-se, por conseguinte, à construção do objeto científico, contra a ilusão do saber imediato. Esses são os principais critérios de validade e de rigor da ciência, permitindo construir um modelo de análise do mundo social que dialoga criticamente com os dados empíricos de uma investigação. Tal atitude garantiria, assim, um espaço de cientificidade ao discurso das ciências sociais, que deveria ser tanto mais rigoroso quanto 
maiores fossem as tentações de produzir um saber "relativista" ou mundano (não científico). Em resumo, antes de discutir sociologia do "campo” (inclusive o científico) de Bourdieu, no próximo capítulo, pode-se dizer que é essa a posição desse coletivo. E caracteriza, utilizando os termos de Stengers (2002), a "ruptura epistemológica” com o senso comum, com concepções ou pré-noções não rigorosas, com tudo aquilo que precede a ciência, é o conceito central na definição dessa atividade.

O aspecto central da reflexão epistemológica sobre as ciências sociais feito no trabalho de Passeron diz respeito à fenomenalidade histórica constituinte do seu objeto. Essa característica faz com que o conceito de "raciocínio sociológico" seja misto, oscilando entre dois pólos: o da contextualização histórica e o pólo do raciocínio experimental. O pólo do raciocínio experimental, análogo às ciências naturais, é um modelo de aspiração, mas nenhum pesquisador das ciências sociais pode mantê-lo,

talvez nem do começo ao fim de uma frase, a partir do momento que fala de fenômenos históricos. O estatístico pode, mas apenas enquanto raciocínio sobre a forma de relação entre dados. Quando fala do mundo histórico, o raciocínio estatístico já é um raciocínio sociológico. (Passeron, 1995, 83)

A amarração aos contextos faz com que a historicidade do objeto seja o "princípio de realidade” das ciências sociais, o que dificulta a generalização e a universalização dos discursos científicos. As variáveis nas ciências sociais (sexo, idade etc.) não têm o mesmo sentido que na Física, por exemplo. Como nota o autor, ainda que Galileu ignorasse o “contexto newtoniano” (e depois o “einsteiniano”) em suas medidas, a generalidade de uma fórmula, como “e $=1 / 2 \mathrm{gt}^{2,}$,11 estabelecida experimentalmente, continua universal na prática. Isso porque a teoria que gerou o protocolo de experiência esgotava as variáveis pertinentes para formular a lei, remetendo-a a um contexto supostamente constante. A lista de variáveis, como o valor da aceleração, no exemplo, designa e controla o contexto experimental.

Desse modo, quando são descobertas singularidades no real e se localizam novas medidas, um novo paradigma, mais geral, que explicará teoricamente as particularidades, produzirse-á uma inteligibilidade aumentada na ordem da grandeza que limitava a universalidade do paradigma anterior. É o conjunto de efetivos "protocolos”, “variáveis”, “contexto

\footnotetext{
${ }^{11}$ Essa é a fórmula para o cálculo da altura da queda de um corpo, onde e = altura, $\mathrm{g}=$ gravidade e $\mathrm{t}=$ tempo.
} 
constante” e "descrições definidas” que permite às ciências experimentais desindexar as leis construídas de contextos espaço-temporais.

Já nas ciências sociais, por mais que haja esforço de esgotar as variáveis, medi-las e testálas com rigor, a relação entre as elas não permitirá produzir enunciados universais fora de um contexto. Isso porque os conceitos, ou variáveis, estão sempre vinculados a coordenadas espaço-temporais. Como sintetiza Ortiz, a propósito da reflexão de Passeron:

a pesquisa sociológica procede por veredas teóricas que sempre recomeçam porque nunca estão definitivamente separadas da "literalidade" dos enunciados que lhe conferem sentido. Não é possível, portanto, partir de uma teoria geral, uma série abstrata de conceitos, e ser capaz de deduzir o que se encontraria na realidade. Por isso o método comparativo - a capacidade de estabelecer relações - é fundamental; o cientista social não possui um laboratório para fazer experiência, a própria noção de experiência, tal como se dá nas ciências naturais, lhe escapa. O caminho da abstração requer, então, um esforço comparativo ou relacional constante. Ademais, o objeto das ciências sociais está em permanente mutação, ele é também histórico. (Ortiz, 2004, 15)

Essa impossibilidade experimental, bem como a crítica do idealismo vinculado à adoção acrítica do método experimental, é que faz com que Passeron defenda o raciocínio sociológico como um espaço afirmativo “não-popperiano”. O que não quer dizer que o conhecimento produzido seja "historicista” (não-científico), já que a estenografia que as ciências sociais produzem dá margem a uma interpretação sistemática do mundo, definindo as formas de relacionamento de suas teorias, científicas por isso, com o empírico. Ainda que para isso se deva diversificar a definição de conhecimento científico, distinguindo da verdade das proposições sua veracidade.

Nesse mesmo sentido, as ciências sociais estariam condenadas a um uso móvel e alternativo dos conceitos ditados por seu projeto de elaborar perfis comparados de relações e sistemas de relações, tão variados quanto os princípios de descrição, categorização e comparação que ela pode sucessivamente mobilizar. Assim, a ação reguladora de um paradigma (no sentido kuhniano) seria inviabilizada. Os conceitos construídos pelas ciências sociais são poliformos (muito gerais) ou estenográficos ${ }^{12}$, ligados a contexto de pesquisas, dando margem a um pensamento que é

sempre uma tradução, algo intermediário entre o ideal de universalidade (que é necessário) e o enraizamento dos fenômenos sociais. Ora, contexto e língua conjugam-se

\footnotetext{
${ }^{12}$ É interessante notar, como observa Ortiz (2004), que a aproximação entre escrita estenográfica e prática sociológica feita por Passeron é similar à idéia de taquigrafia do social, com a qual Ianni (1997) definiu a tarefa da sociologia.
} 
mutuamente. O discurso das ciências da natureza se justifica porque consegue reduzir a linguagem, depurá-la de sua malha sociocultural, algo impensável quando se deseja compreender a sociedade ${ }^{13}$. (Ortiz, 2004, 15)

\subsection{Kuhn: a ciência e os paradigmas}

Feita essa apresentação das idéias de Ianni e Passeron, é importante fazer uma contraposição das mesmas à clássica e influente formulação de Thomas S. Kuhn (1976) sobre a ciência. Kuhn formulou uma caracterização a respeito dessa atividade e, em particular da mudança científica, num modelo descontínuo, no qual longos períodos de “ciência normal”, regidos por determinados “paradigmas”, são, a partir da irrupção de curtos surtos "revolucionários", sucedidos por outra fase de "ciência normal”. Esta diferencia-se da anterior por incorporar agora o novo paradigma.

Kuhn definiu o conceito de paradigma como uma "matriz disciplinar” extraída de uma classe de realizações científicas universalmente reconhecidas, fornecendo, durante algum tempo, problemas e soluções modelares para as comunidades científicas que os adotam. Ele unifica a pesquisa realizada, num sentido convergente. $\mathrm{O}$ paradigma, por isso, define 0 âmbito de problemas considerados pertinentes, os “quebra-cabeças” (puzzles) que devem ser resolvidos em seu âmbito e os fatos aos quais diz respeito. Implica ainda em certas regras e critérios a serem empregados. O paradigma cria o método de validação da ciência, e nesse sentido Kuhn diverge radicalmente da proposta de conjecturas e refutações de Popper.

O paradigma, que unifica teorias e práticas, serve como uma medida para perceber o grau de cientificidade numa área de saber. A cristalização do paradigma numa ciência evidencia sua maturidade. Existiriam ciências “maduras”, constituídas em torno de um único

${ }^{13} \mathrm{O}$ foco central do texto de Ortiz envolve uma outra dimensão contextual das ciências sociais, diferentemente das da natureza: a linguagem. Com efeito, para o autor, a supremacia do inglês como língua de comunicação nas ciências não faz com que esse idioma possa se tornar a língua franca nas ciências sociais. Isso porque "a construção do objeto social se faz por meio da língua, [e] como ele encontra-se ainda referido a um contexto histórico-geográfico específico, a produção em ciências sociais deve manter uma pluralidade de idiomas na sua confecção" (Ortiz, 2004, 23). O autor fornece um sugestivo exemplo pessoal a propósito da elaboração do conceito de "mundialização", possível graças ao uso do português e que remete a um âmbito semântico diferente, conforme a definição construída, por exemplo, de global culture. 
paradigma, com vocabulário e protocolos de compreensão comuns e outras "imaturas", sem um paradigma de base. Nas ciências "pré-paradigmáticas" a situação seria a da existência de diferentes concepções sobre a natureza do conhecimento e tipo de trabalho, com maior ou menor grau de divergência entre as concepções de cada grupo ou indivíduo.

O paradigma corresponde também a uma "visão de mundo" que unifica a prática dos cientistas, fornecendo uma racionalidade implícita às práticas científicas. O principal problema do conceito é seu caráter circular, reforçado pelo autor: “o paradigma é aquilo que os membros de uma comunidade partilham e, inversamente, uma comunidade científica consiste em homens que partilham um paradigma” (Kuhn, 1976, 220). Pode-se dizer que o "funcionalismo kuhniano almeja caracterizar as atividades típicas da investigação científica em suas fases e funções e não como produtos avaliáveis à luz de tal ou qual critério universal” (Oliva, 1994, 75).

Outro aspecto criticado é a noção de "comunidade científica” de Kuhn, que o aproxima de Merton no ideal de um grupo no período da "ciência normal”, com poucos conflitos, já que os pesquisadores evitam o dissenso em prol do desenvolvimento da "comunidade”. Essa noção de “comunidade” é criticada por corresponder a uma idealização que mascara as disputas pela autoridade científica.

De qualquer forma, a postura kuhniana teve a vantagem de evidenciar pelo menos certos aspectos conflitivos na situação da crise paradigmática, principalmente. Apesar da ambiência funcionalista suposta na "comunidade" caracterizada como consenso. Ao mesmo tempo, o estudo das relações de imbricação entre as estruturas sociais e a construção dos fatos científicos pareceu (em certa leitura da obra de Kuhn) tornar-se bastante viável. Disso decorreu a influência do autor para abordagens de superação do conflito entre visões “internalistas” e "externalistas” sobre a ciência ${ }^{14}$.

\footnotetext{
${ }^{14}$ Como discute (Pessoa Jr., 1993), a sociologia da ciência "internalista" acredita que a ciência deveria ser estudada em suas disputas e formulações no plano eminentemente lógico-cognitivo do discurso científico, e está relacionada a uma filosofia da ciência "ortodoxa" que tem em Popper um autor representativo. A perspectiva "externalista", por sua vez, enfatiza os elementos sociais que estão presentes na construção da ciência. Dentre as várias vertentes dessa tradição, destaca-se a que se fundamenta numa filosofia da ciência "globalista", que recebe esse nome pela preocupação ampla em relação ao fazer científico, indo além de aspectos lógicos. Kuhn é considerado um representante dessa filosofia da ciência.
} 
É importante notar, porém, conforme discute Assis (1993), que ao falar de “ciência” Kuhn refere-se às ciências naturais, mesmo em termos da diferenciação entre ciências "maduras” e "imaturas". Assim, ele "não diz como as ciências sociais (e as humanidades) poderiam tornar-se ciência e também não diz que isso poderia ser sequer interessante ou útil” (Assis, 1993, 187). Isso porque seu objetivo não foi o de normativamente definir o que seria uma ciência, seus métodos e critérios de separação de outras atividades - essas questões, para Kuhn, seriam dadas na prática. "O objeto principal de Kuhn [...] é criar uma imagem convincente - um bom objeto de comparação - da atividade científica” (idem). A despeito disso, as idéias de Kuhn foram encampadas por muitos teóricos e pesquisadores em relação às ciências sociais na discussão da cientificidade desse campo. Talvez, como argumenta Assis $(1993,148-53)^{15}$, pela contraposição que as idéias de Kuhn apresentavam às de Popper, bem como pelo apoio argumentativo que essas idéias propiciavam a uma imagem “científica” das ciências sociais.

Desse modo, ganha contorno a definição das ciências sociais como "imaturas”, fato que dificultaria o trabalho comum do grupo, que primeiro deveria resolver suas pendências internas, antes de chegar a produzir ciência num marco mais colaborativo e aberto às “crises de sentido" de um paradigma unificado. Seriam estas que explicariam a troca de um paradigma por outro e a mudança ou progresso na ciência.

O controle do conhecimento produzido também seria prejudicado em situação nãoparadigmática, já que a crítica interna é potencialmente menos rigorosa. Isso porque os trabalhos seguiriam princípios de validação divergentes, conforme as diferentes teorias e metodologias utilizadas por cada escola/corrente de pensamento existente. Ademais, a

\footnotetext{
${ }^{15}$ No trabalho de Assis (1993) há a menção ao fato, relevante, do contexto em que o trabalho de Kuhn surge: como uma monografia para a Enciclopédia Internacional da Ciência Unificada. Esse projeto englobaria também as ciências sociais, sendo que a física forneceria um modelo de utilização da linguagem ao qual todas as linguagens intersubjetivas dos demais domínios de objetos poderiam se ajustar. Desse modo, seria possível projetar uma unificação da linguagem científica que proporcionaria uma ampla comunicação entre todos os domínios de objetos científicos. Porém, ao colocar no centro da mudança científica a "revolução", Kuhn colocou a idéia em impasse. Isso porque na situação de mudança de paradigma haveria não a comunicação irrestrita, mas incomensurabilidade (isto é, a ausência de padrões de medida comum) e a conseqüente incomunicabilidade. Como, de acordo com Kuhn, essa situação ocorreria no âmbito mesmo da física (e também química), compreende-se bem o alcance da polêmica produzida por seu estudo, assim como a crise na idéia de unificação. Com efeito, esse tema, como nota Epstein (1988), é uma das "balizas" do estudo kuhniano. Portanto, essa é outra via de compreensão do alastramento da discussão sobre a cientificidade das ciências sociais. Num texto posterior ao seu livro mais conhecido, Kuhn discorreu sobre a possível adequação das ciências humanas ao seu modelo, e foi bastante cauteloso a esse respeito, se disse "totalmente incerto" sobre a possibilidade de isso ocorrer (Kuhn, 2006, 272).
} 
inexistência de uma unificação interna quanto à natureza dos problemas, métodos e conceitos tornaria a área com pretensão à cientificidade permeável a critérios de legitimação externos ao grupo de cientistas.

A situação exposta poderia resultar tanto em múltiplos debates entre os participantes de cada um dos grupos sobre a validade de cada proposta quanto em seu oposto, isto é, na ignorância e desinteresse em relação a trabalhos diferentes dos próprios. Ou seja, no limite negativo a situação seria de completa ausência de comunicação, ou isolamento dos grupos, impermeáveis a trocas entre si, o que perpetuaria o estado "imaturo" de uma área científica.

Pode-se dizer, confrontando os posicionamentos aqui expostos, de uma certa leitura de Kuhn, com fins de verificação da "cientificidade" das ciências sociais, que Ianni e Passeron divergem desse autor. Cada um a seu modo, mais ou menos explícito, conforme pontos de interesse destacados a seguir.

Com efeito, Ianni já parte do princípio de que os "paradigmas”, transversais às diferentes disciplinas das ciências sociais são variados, a despeito da definição de paradigma utilizada por Ianni ser relativamente similar à de Kuhn:

uma teoria básica, uma fórmula epistemológica geral, um modo coerente de interpretar ou um princípio explicativo fundamental. Envolve requisitos epistemológicos e ontológicos, caracterizando uma perspectiva interpretativa, explicativa ou compreensiva, articulada, internamente consistente. (Ianni, 1992, 34)

Por outro lado, os princípios explicativos dos paradigmas das ciências sociais são variados e Ianni diverge de Kuhn no sentido de que há diferenças entre as próprias ciências, que, entretanto, não seriam mais ou menos “científicas” por isso. Tratar-se-iam de "estilos de pensamento”, modos de conhecer o mundo e o social diferenciados. Ianni também ressalta a importância da articulação entre história e teoria social, ao falar sobre a "globalização", aspecto que também é enfatizado por Passeron. Por outro lado, deve-se reconhecer que a proposta de Kuhn teve o inegável mérito de inserir a história na explicação da mudança científica, resultando, daí, um franco desenvolvimento da história e da sociologia da ciência, a partir de diferentes leituras de sua obra. 
Quanto às divergências existentes entre o pensamento de Kuhn e Passeron, observa-se que para este autor as ciências sociais assumiriam um maior realismo epistemológico em sua auto-compreensão como ciências históricas, nas quais a comparação e a análise não ofereceriam mais do que um substituto aproximado do método experimental. Desse modo, estariam livres de muitas ilusões derivadas da busca por sínteses intelectuais que produziriam mais virtudes negativas, como o dogmatismo e o academicismo, do que verdadeiras unificações conceituais.

Longe de significar um "vale tudo” epistemológico, esta posição reforçaria conceitos já antes abordados por este autor e outros, em O ofício de sociólogo (Bourdieu et al., 1999). Embora já tenhamos nos referido a essas idéias, a recapitulação é válida, ou seja, acentuamos a "vigilância" do pesquisador perante seus atos teórico-metodológicos, a importância da crítica e da reflexividade internas ao discurso produzido. Tais aspectos estão relacionados à preocupação com a descrição dos atos científicos efetuados. Para tanto, claro, exigi-se evidentemente um domínio dos recursos teóricos e metodológicos que determinado campo apresenta em estado disperso. Portanto, durante a feitura de uma investigação, o pesquisador das ciências “não-paradigmáticas” deve

avaliar pelos critérios de suas próprias necessidades o valor operatório dos esquemas [...] [que] são os mesmos [meios] que garantem a estabilidade provisória de seu sentido e de suas funções lógicas num trabalho particular de pesquisa. Só o conhecimento da diversidade de papéis que desempenharam conceitos e métodos nos procedimentos de invenção ou de argumentação permite ao mesmo tempo que o pesquisador mantenha aberto o campo de abrigo teórico onde, na ausência de uma teoria constituída [acrescentaríamos, "paradigma"], ele deve alimentar suas necessidades de construção e de controlar a coerência semântica da interpretação que constrói, trabalhando conceitualmente o seu material de observação. História de teorias, história de métodos, história de investigações são aqui instrumentos da vigilância semântica. (Passeron, 1995, 53)

Resta finalmente notar que entre Ianni e Passeron há a uma diferença sobre a noção de “paradigma” nas ciências sociais. Ianni fala na existência de múltiplos paradigmas nas ciências sociais cuja existência pode ser justificada, segundo Lopes (1990, 31-5) em similaridade com os argumentos do autor no potencial heurístico por eles demonstrado para a explicação do capitalismo. Como nota a autora, a esse sistema macroestrutural histórico corresponderiam a construção de paradigmas que, em sentido lato, "são fundamentalmente sua tradução científica” (idem, 35). 
Já Passeron descrê da utilidade do conceito de paradigma para as ciências sociais, argumentando que a memória teórica dessa área nunca é deixada de lado, o que, conforme o modelo de Kuhn, ocorre na sucessão dos paradigmas. Passeron afirma que mesmo a existência de uma especialização relativa de programas de pesquisa nas ciências sociais, em disciplinas especializadas como a economia ou demografia, não chega a constituir um paradigma. Isso acontece pois as vastas séries de planos descritivos e interpretativos que substituem não podem ser reduzidos a poucos operadores, que estruturem um paradigma.

\subsection{Sousa Santos, Morin: novos conteúdos para a definição da ciência}

De fato, o conflito das ideologias, dos pressupostos metafísicos (conscientes ou não) é condição sine qua non da vitalidade da ciência [...]. A idéia de que a virtude capital da ciência reside nas regras próprias do seu jogo de verdade e do erro mostranos que aquilo que deve ser absolutamente salvaguardado como condição fundamental da própria vida da ciência é a pluralidade conflitual no seio de um jogo que obedece a regras empíricas lógicas.

(Morin, 2005, 25)

Discutiu-se até aqui modelos da atividade científica, caracterizações da mesma que, segundo nossa avaliação, fazem com que as ciências sociais possam ser localizadas em determinada posição quanto ao "paradigma dominante” da ciência, fora ou dentro, em diferentes localizações significativas do mesmo espaço. Numa das concepções, as ciências sociais são vistas como incluídas no modelo a partir das naturais (positivismo); em outra, constituindo um domínio científico (estilo de pensamento) diverso, mas igualmente no marco do conhecimento científico moderno (Passeron e Ianni). Por fim, as ciências sociais podem ser encaradas como um discurso não-científico (Popper e certas interpretações de Kuhn) com maiores ou menores possibilidades de ascender ao status da racionalidade da ciência.

Porém, outras discussões sobre a ciência colocam a questão dos conteúdos caracterizadores dessa atividade e das relações da mesma com as ciências sociais na contemporaneidade. Em outros termos, num contexto de discussão mais incisivo sobre uma "crise" de paradigmas, situação essa que, por sua vez, atravessaria toda a ciência. 
É assim com a proposta de Sousa Santos (2003). Como nos baseamos amplamente nesse autor para descrever o "paradigma dominante”, começaremos agora a descrever o que ele entende por esta crise que ensejaria o surgimento de um "paradigma emergente" nas ciências. Tal paradigma embrionário seria resultado de uma pluralidade de condições que, ao fim de um processo do qual o autor só aponta os indícios, resultaria em uma ciência “pós-moderna”. Notamos novamente que a proposta de Sousa Santos é correlativa à de Morin, que propõe um "paradigma complexo”.

Santos distingue entre as condições de crise do "paradigma dominante" aspectos sociais e teóricos. No plano social, ocorre a relativa perda de capacidade de auto-regulação da ciência, mais solidária aos poderes políticos, sociais e econômicos. Esse aspecto tem minado as noções de autonomia e desinteresse da ciência, cada vez mais comprometida com a tecnologia.

Quanto às condições teóricas, a questão central é que o próprio sucesso do paradigma científico moderno criou as condições para a percepção de suas limitações. O aprofundamento do conhecimento, segundo o autor, mostra a fragilidade dos pilares de sustentação do mesmo. Desse modo, várias conquistas da ciência moderna, como a física de Einstein e as investigações de Gödel, germinaram a crise paradigmática. Da mesma forma, Morin (2005) vê nos avanços das ciências, naturais e humanas, uma condição de criação do "paradigma complexo".

O empobrecimento do conhecimento calcado num rigor exclusivamente matemático, cuja medida é questionada pelos avanços científicos, e caricaturizaria no limite os fenômenos, é por isso questionado, por ambos os autores. Por fim, conforme a recensão de Santos, também se observa uma parcelização do objeto no paradigma moderno, representada nas crescentes divisões da ciência, que produz um conhecimento não centrado em totalidades orgânicas. Por isso, os

fatos observados têm vindo a escapar do regime de isolamento prisional que a ciência os sujeita. Os objetos têm fronteiras cada vez menos definidas; são constituídos por anéis que se entrecruzam em teias complexas com os dos restantes objetos, a tal ponto que os objetos em si são menos reais que as relações entre eles. (Santos, 2003, 56, grifo nosso) 
Nesse ponto estratégico, Morin também defende a idéia de um conhecimento que opere de maneira dialógica, comportando associações de noções complementares, concorrentes e antagônicas, buscando o todo - nas associações entre as partes. Daí, o recurso a um paradigma que faça com que os domínios científicos comuniquem-se sem restrições, permitindo o exercício pleno da transdisciplinaridade. Esta deveria agir contra a fragmentação e parcelamento dos conhecimentos, operando num nível histórico no qual sujeito e objeto deixarim de ter uma relação de exterioridade e o conhecimento se enraíza na cultura com a qual interage.

Morin afirma ainda que o paradigma de complexidade não produz nem determina uma inteligibilidade, seu papel seria somente incitar a inteligência/estratégia do sujeito pesquisador, que deveria considerar a complexidade da questão estudada. Incitaria, assim, a “distinguir e fazer comunicar em vez de isolar e de separar” (Morin, 2005, 334).

Pode-se dizer que os postulados com que Santos caracteriza o "paradigma emergente" que preludia a "ciência pós-moderna” são bastante próximos aos do "paradigma complexo". Entre outros pontos, a idéia de que o conhecimento científico-natural é também científicosocial, o que, nas duas propostas epistemológicas projeta uma ética relativa à ciência. Desse modo, existiria a possibilidade de aproximação entre as ciências em termos conceituais, aspecto que prepararia a "progressiva fusão de ciências naturais e sociais" (Santos, 2001, 71). As interfaces entre as disciplinas/domínios de conhecimento seriam buscadas para construir um objeto mais amplo, que abarcasse o todo, sendo ao mesmo tempo local. Por fim, esse conhecimento postularia uma “dupla ruptura epistemológica”, a primeira de tipo tradicional contra o senso comum. No entanto, a segunda seria justamente a superação de uma ciência distinta deste, através da produção de um conhecimento prático esclarecido.

Finalizando esse tópico, cabe lembrar a aproximação de Morin com a Comunicação. Como se sabe, desde cedo em sua carreira acadêmica, ele se interessou por questões ligadas à comunicação. Assim, produziu estudos sobre o cinema e suas estrelas (Morin, 1970, 1989), bem como sobre a cultura de massa (Morin, 1975, 1986). E o quanto essa perspectiva, hipoteticamente, relaciona-se ao desenvolvimento de sua proposta de um "pensamento 
complexo” é uma questão instigante. O seu aprofundamento, entretanto, escapa ao centro de nossa discussão. Mas vale notar o quanto a "sociologia do presente” (Morin, 1986), proposta numa obra que "trata tanto da nova visão do espírito do tempo, quanto do novo espírito do tempo" (idem, 19), destila a idéia de uma "ciência do acontecimento" e, no mesmo sentido, uma "ciência do devir" ${ }^{\text {, }}$. Com efeito, na própria introdução deste livro ele enuncia um projeto que "em sua amplitude, parece ameaçado pelo risco de delírio e de confusão mental: o leitor, epistemologicamente sedentário, poderá mesmo tachá-lo de ficção científica” (ibidem, 18). Esse projeto não é outra coisa senão um esboço do que seria o "paradigma da complexidade”, notando-se já a preocupação com a transdiciplinaridade, a discussão das possibilidades de trocas entre as ciências, a validade dos conceitos em diferentes contextos disciplinares, entre outros pontos.

\footnotetext{
${ }^{16}$ É válido notar que essa discussão, presente no Volume II de $O$ espírito do tempo (Morin, 1986) é retomada, com as mesmas palavras, mas num contexto mais amplo, em Ciência com Consciência (Morin, 2005). O próprio Morin $(1986,14)$ nota o caráter de esboço de uma "teoria geral da sociologia e, mais amplamente, da ciência do homem” que encontraria expressão mais acabada em obras posteriores.
} 


\subsection{O que a reflexão precedente aporta ao estudo}

O tema da comunicação permanece decisivo, mas só faz plenamente sentido quando é tomado em conexão com outros fenômenos socioculturais e políticos: que significa comunicar? Como se comunicar?

(Morin, 2003, 7)

Buscou-se até o momento caracterizar algumas discussões relevantes sobre a ciência de maneira geral e as ciências sociais em particular, de modo a retirar subsídios para a investigação sobre um suposto campo específico, o da Comunicação. Assim, para a continuação de nosso estudo, é necessário retirar do que foi discutido até aqui todas as possíveis implicações úteis quanto ao nosso objeto e problema da pesquisa.

Porém, isso não pode ser feito sem que sejam demonstrados, ainda que sinteticamente (cabendo ao decurso do trabalho fornecer mais elementos de justificação) certos aspectos que são de fato, não de juízo. De outro lado, é preciso que nos posicionemos quanto a elementos que envolvem uma efetiva valoração - ou, conforme os termos até aqui utilizados, a própria adequação a um paradigma de inteligibilidade, que exclui outros por incomensurabilidade.

Partimos do fato de que as Ciências da Comunicação (ou tal projeto) no Brasil são provenientes de um impulso advindo das ciências sociais, em particular da sociologia ${ }^{17}$, e desse modo são particularmente afetadas pelos seus argumentos, conceitos e esquemas de interpretação. Assim como pela própria natureza do trabalho e discussões sobre a validade do conhecimento produzido nesse âmbito, e daí a importância da reflexão anterior. A constatação pode parecer trivial, mas o baixo desenvolvimento da "teoria da comunicação" matemática ou biológica entre nós não significa que elas não poderiam ter se constituído no enfoque preferencial do campo científico da comunicação.

\footnotetext{
${ }^{17}$ A denominação "especialidade da Sociologia” era, pois, a classificação em que geralmente tinham que se enquadrar os pesquisadores (alguns ainda hoje atuantes) da área, nas tabelas de conhecimento de agências de fomento, antes do surgimento da rubrica "comunicação", quando solicitavam auxílio a projetos (Lopes, 2003b, 7). Mais importante ainda: o impulso cognitivo de pesquisas sobre os meios de comunicação, teorias e enfoques sobre a "cultura de massa" ou "indústria cultural" produzidos pelos trabalhos sociológicos. Nesse sentido, um pesquisador, que depois se afastou relativamente da temática dos meios de comunicação Gabriel Cohn - teve fundamental importância, tanto pelas orientações (de futuros professores/pesquisadores da área), quanto pela reflexão teórica (Cohn, 1973) e compilação de trabalhos que, ainda hoje, são lidos pelos pesquisadores e estudantes (Cohn, 1975).
} 
Aliás, a teoria da informação ou teoria matemática da comunicação chegou a ser introduzida nos estudos, mas pode ser considerada um "programa de pesquisa” senão totalmente deixado de lado, que foi pouco desenvolvido. A análise bibliométrica mostrada no capítulo 6 a partir de um corpus de teses e dissertações da área, é prova cabal disso.

O problema da comunicação é que ela faz, conforme a rica sugestão de Moragas (1985), uma "provocação às ciências sociais”, que se instaurou como área de estudo e conquistou autonomia no Brasil, sobretudo institucionalmente (como se verá no Capítulo 4) frente às outras ciências sociais muito cedo. Ou seja, isso se deu antes do surgimento preciso de um “campo científico”18. Muitos dissensos da área dão-se na própria trajetória já institucionalmente autonomizada, mas cognitivamente, em termos do campo científico com baixa legitimidade.

Desde logo uma explicitação desse fato se dá pelo dissenso sobre a natureza do conhecimento que se deve produzir. Há concordância na inserção do campo entre as “ciências sociais”, no entanto, não quanto à natureza específica dos estudos comunicacionais, seja num modelo mais "básico”/“formativo” ou num mais “aplicado”, em razão do tipo de conhecimento a produzir. Isso tem significativas conseqüências quanto à inserção da área nos sistemas de política científica e captação de recursos. Ademais é um aspecto que repercute na procura de validação quanto a seus discursos e práticas.

A discussão tem uma dimensão política inegável e faz parte, tanto da política externa do campo (relativa à sua natureza e diferenciação em relação a outros), quanto interna. Ainda, existem também possíveis conflitos sobre o próprio entendimento de cada um dos termos “aplicado” e "básico”, bem como a opção sobre a melhor inserção do conhecimento que deve ser produzido pelos praticantes da área. Definindo a partir de Schwartzman (1997, 121), os termos "básico" como o conhecimento mais ligado ao saber acadêmico e de crítica social que caracterizam as ciências sociais brasileiras tradicionalmente, e o conhecimento “aplicado” como uma tecnologia social passível de ser implementada, notam-se que projetos surgidos a partir dessas concepções podem animar iniciativas científicas muito diferentes.

\footnotetext{
${ }^{18}$ As coordenadas desse conceito, que dão precisão a esse fato, são discutidas no próximo capítulo.
} 
Isso até que seria de se esperar, pois, de um lado, a área de estudos no Brasil começa a surgir a partir da demanda por profissionais das “novas profissões sociais”19 e do mercado, e - desde os EUA, mas influenciando muitos outros espaços de pesquisa, como o brasileiro - surge também a partir da promessa da investigação dar respostas a interesses mais sociais que acadêmicos. Esse era o elemento que justificava a "pesquisa administrativa" ou a “investigação técnica da comunicação”. Ora, esse aspecto já era visto como um problema pertinente, do ponto de vista do conhecimento, desde Merton (1970, 548):

A questão de saber se esta investigação técnica das comunicações para as massas tornase mais tarde independente ou não das suas origens sociais, é em si mesma um problema de interesse para a ciência da sociologia. Em que circunstâncias adquire a investigação provocada pelos interesses do mercado e dos militares uma autonomia funcional em que as técnicas e os resultados entram no domínio da ciência social?

Como resolver esse duplo dilema - conhecimento "prático" ou "básico” e a natureza do conhecimento “técnico”? Em primeiro lugar, para relativizar já em parte a questão, diríamos que também sociólogos, antropólogos e outros cientistas sociais das áreas mais tradicionais desenvolvem e envolvem-se com “tecnologias sociais” (pesquisa de opinião, antropologia de ambientes corporativos etc.). Porém, é claro que isso ocorre de modo menos intenso ou evidente do que os profissionais que estão estreitamente vinculados a um campo de produção econômico-simbólica e a uma atividade profissional específica, caso do setor de comunicação. Assim, nas ciências sociais mais tradicionais há um compromisso preferencial com a produção de um saber mais voltado ao rigor interno do contexto acadêmico, isto é, à chamada ciência "básica”. Mas, como também nota Schwartzman (1997, 7), essa divisão do conhecimento entre disciplinas formativas e aplicadas

não se deve a uma divisão "natural" dos objetos da natureza, mas a diferentes tradições de trabalho, estabelecidas por razões históricas e institucionais. Elas não consistem, simplesmente, em corpos de idéias e conceitos diferenciados, mas em grupos sociais concretos, cada qual com histórias, valores, normas e hábitos de trabalho próprios.

\footnotetext{
${ }^{19}$ A expressão é de Schwartzman (1997) que afirma que essas profissões (ou "ciências sociais aplicadas", como ele diz), como jornalismo, administração, biblioteconomia e comunicação, surgem a partir de perspectivas ou pretensões profissionalizantes no campo social. Porém, num diagnóstico severo do autor: "abandonam a pretensão intelectual das ciências sociais mais estabelecidas [...] [e] não chegam a constituir um conteúdo cognitivo consistente nem a possuir um perfil profissional definido” (Schwartzman, 1997, 122). Discordamos do autor, pois seu juízo peremptório prejudica a análise e mostraremos, no caso da Comunicação, que não há um abandono de pretensões acadêmicas por parte do grupo de docentes e pesquisadores como um todo.
} 
De outro lado, seguindo Janine, é interessante notar, a respeito da dimensão prática das ciências humanas, que nelas não há "uma exterioridade entre a pesquisa em ciência básica e sua aplicação tecnológica” (Janine, 2003, 90). Isso acontece, pois o uso do conhecimento do homem sobre o homem representa uma possibilidade de eficácia na "construção do mundo humano” (idem) no plano individual, psicológico e social. Daí, a ação “aplicada” de um conhecimento gerado anteriormente, e de fundo "básico", em dimensões como a mudança social ou a cultura. O que ocorreria, por exemplo,

na colaboração intelectual na imprensa brasileira, concorrendo para fortalecer um espaço democrático em nossa opinião pública. Aplicações dessa ordem [...] constituem o output de Humanas mais próximo do que é tecnologia, para as demais ciências. (Janine, 2003, 91)

A formulação é sofisticada e abrangente, mas certamente muitos dos praticantes do campo da Comunicação (por exemplo, Melo, 2003 e Barros, 2003) destacam antes o componente de “tecnologia social” que a área deve ter. Para outros pesquisadores, posição subjacente à maioria dos textos publicados sobre o $\operatorname{campo}^{20}$, a Comunicação deve produzir um conhecimento mais próximo do mais tradicional das ciências humanas, isto é, "básico" (ainda que, acreditemos, com a dimensão “prática” no que Janine aponta).

Embora essa diferença em termos da orientação da área represente uma variação entre projetos isso não necessariamente deveria levar a distensões agudas. Uma via de superação dessa dicotomia pode se dar pela análise da atividade científica proposta por Stokes (2005). Para esse autor não há uma polarização relativa ao objeto de pesquisa, entre uso e conhecimento, pois o eventual uso se articula à busca do conhecimento. Na divisão de tendências da ciência em quadrantes propostas por esse autor, no primeiro deles, a questão do uso não é levada em consideração na escolha do objeto (pesquisa "básica” sem intenção de aplicação imediata, “quadrante de Bohr”). No segundo quadrante (o "quadrante de Pauster”21, pesquisa “básica-aplicada”), o objeto é produto de preocupações quanto a questões centrais e, simultaneamente, s possibilidades de aplicação. O terceiro quadrante (de Edison, da pesquisa “aplicada”) considera somente a aplicabilidade dos resultados. Por

\footnotetext{
${ }^{20}$ Como exemplo concreto, quantificando posições contorversas, na coletânea de reflexões sobre o campo organizada por Lopes (2003), dentre os 19 textos, somente dois enfatizam o conteúdo “aplicado” da Comunicação.

${ }^{21}$ Como se sabe, Pauster rejeitava a distinção entre ciência pura e aplicada, tendo cunhado a frase hoje clássica: "Só existem a ciência e as aplicações da ciência” (apud Reis, 1995).
} 
fim, num quarto quadrante, explora-se um problema particular, desconsiderando a preocupação de produzir um conhecimento generalizável ou aplicável.

Se a pesquisa em Comunicação tendesse ao segundo quadrante - parece-nos que o consenso sobre a localização da mesma no primeiro é difícil -, com o rigor que lhe é devido, poderia haver uma negociação entre os grupos. Claro que a localização é tendencial e feita grosso modo, pois os espaços representam idealizações da atividade científica. O grande problema seria a pesquisa tender ao quarto quadrante, um estudo puramente idiográfico e frequentemente com finalidade de divulgação. É a pesquisa sobre a pesquisa que pode responder sobre o atual estado da investigação e, consequentemente, averiguar a localização maior ou menor da área em uma das situações representadas por quadrantes ideais. Todavia, esse objetivo escapa ao nosso trabalho demandando outra metodologia.

Mais agudo do que esse problema "básico versus aplicado" é, no nosso entender, a problemática sobre o conhecimento, que Schwartzman $(1997,125)$ formula nos seguintes termos:

em que medida os conhecimentos novos [entre os quais inserimos o da Comunicação], que recebemos de toda a parte e que são cada vez mais indispensáveis se quisermos participar de maneira menos marginal no mundo em que vivemos, conseguem ou não fincar raízes, e em que condições.

Aqui, "fincar raízes", implica principalmente no desenvolvimento de competências e conteúdos cognitivos, que vão além da institucionalização. Porém, em nossa interpretação do conceito de campo científico, embora a institucionalização não seja condição suficiente da sua efetiva autonomização, ela tem aspectos positivos. Ou seja, para a consolidação de um campo efetivamente “científico”, a institucionalização é algo virtualmente favorável por propiciar aspectos que salientaremos no próximo capítulo.

Seria no campo científico, utilizando argumentos racionais, que se desenrolaria o embate entre as propostas dos praticantes da área. Ora, seria o embate e discussão quanto a propostas possivelmente divergentes que poderiam produzir uma "razão polêmica" aspecto fundante de qualquer campo científico. E ela que mostra a existência, ou melhor, gera a ilusio científica, isto é, algo em disputa sobre o que vale a pena "lutar” ou “jogar”. Ao contrário, se a divergência (ou a ignorância da mesma) leva à incomunicação entre os 
pesquisadores e ao silêncio, trata-se de uma competição na qual sequer os "jogadores" estão interessados em compartir um mesmo campo. Em outros termos, é necessário que haja um consenso básico, pelo menos quanto às "regras" do jogo, que possibilita a participação de todos, em diferentes posições. É nesse ponto que a articulação entre o conceito de “campo” e o modelo de Galtung (1965) sobre os tipos de interação entre grupos de cientistas tem especial validade. Disso trataremos no Capítulo 5.

Por outro lado, algo importante a salientar desde já é que a tomada de posição teórica conduz a certas conseqüências. Assim, estando mais próximos das noções sobre as especificidades do conhecimento das ciências sociais - assim como pelo uso conceitual do termo campo, que não estigmatiza o conflito, ao contrário -, nos afastamos daqueles que utilizam o trabalho de Kuhn para analisar a área. Na verdade, entendemos que esse ponto de vista pode produzir resultados viciados: é fácil mostrar que as ciências sociais não são uni-paradigmáticas. É o caso específico de um trabalho que usa o “paradigma” kuhniano para analisar os estudos em Comunicação no mundo (Otero, 2006), que chega a essa conclusão. Isso não quer dizer que haja falta de honestidade intelectual, ao contrário, muitos dos argumentos críticos são sérios e pertinentes e devem ser levados em conta pelos pesquisadores em qualquer debate sobre a área da Comunicação. No entanto, a generalidade da crítica, autorizada pela "busca” do paradigma inexistente, bem como, pelo estatuto de síntese de “estado da arte” da pesquisa, leva à relativa desconsideração do específico em prol de uma crítica genérica. Por isso, não há uma exemplificação dos argumentos com casos concretos de investigação que permitissem desenvolver os argumentos com a profundidade devida.

Ao final da leitura, parece que só resta à investigação em Comunicação retroagir ao positivismo - as referências a DeFleur vão todas nessa direção: elogio a autores funcionalistas como exemplos exclusivos da melhor pesquisa em Comunicação; recomendação de viés quantitativo à pesquisa, em prol de "validação e confiabilidade na medição"; busca do "acúmulo" em termos mertonianos. Talvez o desafio de criticar as ciências da Comunicação fosse melhor equacionado numa superação dessa concepção de ciência, bem como pela atenção mais detida aos impasses que se notam hoje, através do debate e de uma argumentação mais construtiva. No entanto, no marco positivista assumido pelo autor, esta atitude não e favorecida. 
Ao fim (ou desde o início?) chega-se à mesma receita de outros cientistas sociais que partem de Kuhn para analisar áreas de estudos de Humanidades. Receita que Feyerabend (apud Epstein, 1988, 78) bem ironiza:

Mais de um cientista social comentou comigo que finalmente ele tinha aprendido como tornar científico o seu campo, isto é, como melhorá-lo [...]. A receita, de acordo com essas pessoas, é restringir a crítica, reduzir o número de teorias compreensivas a uma e criar uma ciência normal.

O que não se percebe é que essa crítica termina numa tomada de posição igualmente “ideológica”, no sentido de que as concepções aprioristas (e positivistas) sobre a natureza do trabalho científico tendem a prejudicar as análises e resultar em um diálogo de surdos, pelo tom acusatório que tomam. Não por acaso, a obra de Sokal e Bricmont (1999) é vista como "clássica”. Bem se vê que a adoção de um "paradigma” sobre o que consiste a ciência tem suas conseqüências. De qualquer forma, vale ainda observar que existe uma incompatibilidade de fundo entre a noção kuhniana de “comunidade” e de “campo científico”, conforme afirma Bourdieu.

Igualmente válido é notar o fato de que o debate sobre os novos paradigmas reverbera no próprio campo da Comunicação no Brasil, por exemplo, com autores como Lopes (2004, 2004a, 2003a). A autora utiliza a noção de ruptura histórico-epistemológica causada pela globalização, a partir da análise de Ianni e defende que, nesse contexto, abriu-se uma possibilidade de fundamentação epistemológica do campo científico da Comunicação. Possibilidade que, paradoxalmente, decorreria ou seria facilitada pela própria debilidade da institucionalização disciplinar do campo, desde sempre aberto a enfoques e apropriações de outras áreas. Lembrando as propostas bidisciplinares ou interdisciplinares - como a de Moragas, 1985 - que têm e tiveram influência na área, a pesquisadora nota que seria o momento de ousar um movimento em direção à transdisciplinaridade, e que esta se relacionaria ao pensamento complexo de Morin. Bem como iria conjugar-se a uma tendência, detectada e sugerida por Wallerstein (1996), de "reconstrução das ciências sociais” a partir de uma organização mais coerente do conhecimento. Ou seja, aquela que procura transpor as demarcações que são antes resultado de divisões artificiais entre domínios que estão na realidade profundamente imbricados - os âmbitos do político, do econômico e do social. Aliás, teria sido esse fato, a sobreposição de disciplinas a respeito de objetos concretos, o impulso inicial do surgimento de áreas como a própria Comunicação (Wallerstein, 1996, 73). Wallerstein também faz a defesa, cara também a 
Santos e Morin, de um combate à fragmentação do saber que a "abertura das ciências sociais” pode promover.

De qualquer modo, o “estatuto transdisciplinar” da Comunicação seria, de acordo com Lopes, convergente com a própria natureza dos problemas característicos da área. A prática da transdisciplinaridade poderia, então, “dar lugar a lógicas mais complexas e pertinentes à multidimensionalidade do objeto da Comunicação” (Lopes, 2004a). Como a autora reconhece, contudo, “a proposta transdisciplinar tem causado tensões e polêmicas, na medida em que a institucionalização de um campo supõe sua especialização disciplinar” (Lopes, 2004a), e é por isso que defende a “transdisciplinarização” ou “pósdisciplinarização” do campo proposta por Fuentes (Lopes, 2004, 9).

A proposta, de fato, enfrenta muitas críticas de outros autores da área. O que, deve-se ressaltar, representa algo bastante positivo no sentido de instaurar um debate que pode enriquecer o grupo. Talvez há pouco mais de uma década poucos pesquisadores da área tivessem interesse nessa temática. De qualquer forma, sintetizando bastante o argumento básico, alguns dos autores críticos à adoção da "transdiciplinaridade” nos estudos da Comunicação tendem a afirmar que isso seria transformar em força uma fraqueza, ou seja, seria falta de contorno e nitidez propriamente comunicacional da disciplina. Assim, por exemplo, Braga (2004), entre outros, critica o efeito já “dispersor” das pesquisas em áreas de interface que tenderiam a levar a investigação e o investigador para o pólo da disciplina ou prática social não ligadas diretamente ao campo científico da Comunicação.

Outras críticas, como a de Maldonado, enfatizam o próprio discurso sobre o paradigma da complexidade, embora, nesse caso, o autor defenda um trabalho transdisciplinar para a área:

Morin [...] [tem] uma pretensão de generalidade epistemológica que corresponderia ao summu do conhecimento humano. Detecta-se nessas proposições um problema grave de ausência de explicitação conceptual, apropria-se de formatos e idéias sem mostrar as fontes e os procedimentos de reformulação, gera-se campos de efeitos de sentido que tornam o "saber científico" um exercício cômodo de especulação e literatura. A influência de correntes literárias pós-modernas realizam estruturações semelhantes. (Maldonado, 2003, 216)

É neste ponto que retornamos à discussão do "projeto científico" de Granger face à problemática das “novas epistemologias” e da Comunicação como área de conhecimento. 
As propostas de redefinição da ciência provavelmente implicam em uma ruptura paradigmática. Qual seria o sentido dessa possibilidade para o campo da Comunicação, sobretudo no atual ambiente de transição, no qual o suposto novo paradigma ainda não se encontra consolidado?

A possibilidade mais promissora é a continuidade do debate crítico, no qual cada lado apresente seus argumentos e evidencie as possíveis fragilidades das propostas com as quais estão em desacordo. Isso levaria a uma disputa positiva, em termos de uma interação capaz de gerar outras propostas, hegemonias ou consensos no campo científico. Ao mesmo tempo, os discursos científicos produzidos a partir das novas propostas epistemológicas devem procurar explicitar claramente seus supostos. Discorrer sobre as vantagens dessa perspectiva para a produção de um conhecimento comunicacional, oferecendo elementos de "pertinência e solidez”. Lopes tem razão ao argumentar sobre a importância do

estabelecimento de um campo de discurso e práticas sociais cuja legitimidade acadêmica e social vai cada vez mais depender da profundidade, extensão, pertinência e solidez das explicações que produza, do que do prestígio institucional acumulado. (Lopes, 2004, 9)

Porém, quem julga? Sob quais critérios? Em termos mais precisos, qual o "projeto científico"? Há, é claro, a ausência de tradição e "pesquisas exemplares” dentro dessa proposta paradigmática, o que sem dúvida pode banalizar e degradar o discurso, proferido em nome do "novo" visto como novidade. Infelizmente, o campo das apropriações pode ser bastante amplo. Desde um aproveitamento produtivo das propostas para a pesquisa nas ciências sociais (e na Comunicação) e também nas naturais, cautelosamente rumo talvez a um novo "paradigma” (no sentido forte do termo), ou simplesmente a assunção de que a "racionalidade moderna” não vale a pena. Nesse extremo, fica-se a meio caminho do irracionalismo. Ou não? O paradigma proposto possui uma outra racionalidade que faz com que sequer possa ser julgado pelos critérios anteriores? Aparentemente tanto Sousa Santos quanto Morin são prudentes, em termos da viabilidade imediata de algumas de suas propostas, mas e seus leitores? E seus leitores na área da Comunicação? Se é que as propostas realmente já repercutem na pesquisa.

De qualquer modo, se na presente tese com freqüência indagamos mais do que respondemos às questões que colocamos, pelo menos um ponto será mostrado: o regime de leituras atualmente (no ano de 2004) seguido pelos estudantes dos Programas de Pós- 
Graduação em Comunicação. A partir dos dados poderemos pensar mais sobre a natureza do campo e da pesquisa em Comunicação, conforme esse "léxico" (Melo, 1999) mobilizado e conforme as referências bibliográficas apresentadas nas Dissertações e Teses dos Programas. Antes, no entanto, impõe-se a caracterização mais específica do conceito de “campo" de Bourdieu. 


\section{Capítulo 3}

\section{O conceito de campo científico: preliminares teórico- metodológicas de seu uso na investigação}

Este capítulo é dividido em tópicos que discutem, primeiro, a proposta da "nova" sociologia da ciência, mostrando trabalhos nacionais que apresentam enfoques nessa área. Num segundo momento, o tema é o aporte e o diferencial de Bourdieu para as abordagens da ciência. A seguir, são mostradas apropriações do conceito de “campo” por pesquisas na área da Comunicação e, nos dois últimos tópicos, nos voltamos a problemáticas propriamente metodológicas, o que se dá pela discussão sobre modos de articulação dos conceitos de Bourdieu e a da tese. Por fim, é apresentado o modelo de Galtung (1965) sobre interações entre grupos acadêmicos, que se procura, conforme a discussão realizada, adaptar ao trabalho. O que ocorre, sobretudo, a partir da discussão do material empírico, com o uso das técnicas bibliométricas e das análises de conteúdo, para compreender aspectos relevantes do “campo" da Comunicação.

\subsection{A “nova” sociologia da ciência}

Foi em parte a partir da abertura da sociologia da ciência para o âmbito social, autorizada pela filosofia da ciência globalista (Kuhn e outros), que, nos anos de 1970 e 80, ocorreu o que muitos denominam como a verdadeira revolução na área dos estudos sociais da ciência. Nesse contexto, outras fontes de influência foram a releitura da "sociologia do conhecimento” de Mannheim, a redescoberta de um trabalho de 1935 do alemão Ludwick Fleck, que discute a "gênese e desenvolvimento de um fato científico", e o aporte crítico aos resultados e aos fins da ciência a partir da Escola de Frankfurt, que tem como desdobramento trabalhos como os de Habermas (2001). 
Houve nesse momento, uma ruptura com o ideário modernista que sustentava as visões (internas e externas) da ciência até então. Como nota Schwartzman (2001, x) a demarcação entre o pensamento racional dos especialistas, a razão, e outras formas de conhecimento passou a ser questionada e

de repente, sociólogos e antropólogos, muitos deles oriundos das ciências naturais, começaram a observar os cientistas como quem observa os índios em suas tribos $e$ chegam à conclusão de que não existe, na verdade, tanta diferença assim entre os dois mundos, o da ciência e o do sentido comum.

A diversidade de enfoques metodológicos surgidos pode ser, de acordo com Pessoa Jr. (1997), caracterizada em três pontos: 1. Inclusão do conteúdo técnico da ciência dentro do escopo da análise sociológica, 2. Valorização de uma metodologia de análise interna dos grupos, que se concentra em suas práticas reais de produção científica. Isso conduz a estudos “microscópicos”, com ênfase na descrição antes da explicação. Objetiva-se realizar uma análise de como a ciência é “construída” e 3. Virada lingüística, ou seja, a valorização do estudo das "ações lingüísticas” na prática da ciência, incluindo desde uma abordagem semiótica das “inscrições literárias” em laboratórios até análises das negociações de significados em conversas científicas e outros contextos.

Do ponto de vista da filosofia da ciência, de teor globalista, dois aspectos fundamentam essa nova sociologia. Um deles é a noção de que não há uma distinção entre linguagem teórica e linguagem observacional, já que a observação estaria ela mesma impregnada da teoria. Assim, a observação é também uma “construção científica”. Em segundo lugar, há idéia de "subdeterminação" das teorias pelos dados empíricos. A escolha da teoria diz respeito não só à “adequação” aos dados empíricos, mas também a aspectos circunstâncias, externos ao "conteúdo da ciência”. Estes dois pontos abrem espaço para a análise da “negociação do consenso, a construção dos significados das teorias”, como nota Pessoa Jr. $(1997,7)$.

Em relação às abordagens teórico-metodológicas, existe uma variedade de enfoques que apresenta maior ou menor grau de ruptura com o trabalho mais tradicional da sociologia da ciência. Entre outros correntes de pesquisa, destacam-se o "programa forte” ou Escola de Edimburgo, associado aos sociólogos David Bloor e Barry Barnes, a etnografia e o construtivismo social, bem como as etnometodologias, marco no qual foi produzido aquele que é considerado o primeiro clássico da antropologia da ciência contemporânea, a obra 
Laboratory Life, publicada originalmente em 1979, de Latour e Wooglar $(1997)^{22}$. Neste trabalho, mostrando o diálogo entre diferentes vertentes, há uma importante apropriação e reinterpretação de Bourdieu, na abordagem “quase-econômica” feita da ação dos cientistas.

O "programa forte" corresponde a mais ambiciosa (macrossociológica) e radical formulação da "nova” sociologia da ciência. Pode-se dizer, sucintamente, que ele propõe, em primeiro lugar, daí o termo "forte", assumir e explicar sociologicamente o conhecimento, ainda que o projeto reconheça formas não-sociais nos processos cognitivos. Afirma-se, assim, que "programa forte” intentaria, via sociologia da ciência, "socializar a epistemologia” (Hesse apud Crespi e Fornari, 2000, 203).

A ciência é definida como um "sistema de crenças", cuja diferença e particularidade se deve ao tipo de coletivo que a sustenta. Ela é vista como uma crença social e coletiva, não individual ou particular, e que é produzida e reproduzida, em determinado grupo, a partir de uma causalidade social. Os princípios teóricos que sustentam essa abordagem do conhecimento científico são fornecidos, principalmente, pelo segundo Wittgenstein, a partir do qual "Bloor desenvolve uma teoria do conhecimento afirmativa do caráter eminentemente social dos processos cognitivos. Por sua vez, Barry Barnes analisa as afinidades da obra de Kuhn com o pensamento de Wittgenstein” (Melo, 1994, 186).

A partir da leitura de Wittgenstein, certos autores defendem que o conhecimento científico é igual a outras "práticas cognitivas de sentido comum, isto é, um jogo lingüístico particular, conexo com determinada forma de vida e, portanto, como uma praxis eminentemente social” (Crespi e Fornari, 2000, 185). Não existiria fundamento último para a prática científica, pois os próprios “fatos” são uma construção da gramática que os enuncia.

Ao “programa forte” e suas realizações no plano teórico e na pesquisa empírica, somam-se outras abordagens que possuem, todavia, um alcance menos amplo. Embora também tragam contribuições importantes para a reflexão sobre a ciência, como estudos microssociológicos, de análise das formas de organização e criação de "verdades" no

\footnotetext{
${ }^{22}$ Uma descrição dessa e outras tendências da "nova” sociologia da ciência é, sucintamente, realizada no trabalho de Pessoa Jr. (1997) e também por Crespi e Fornari (2000), já o ensaio de Melo (1994) analisa em detalhe o "programa forte".
} 
laboratório, estudo das interações entre os pesquisadores etc. Um exemplo desta outra abordagem é o trabalho de Bruno Latour (1994) que tenta mostrar que a crença em separações absolutas entre natureza e sociedade, sujeito e sociedade não explicam totalmente o trabalho dos cientistas - principalmente, como eles realmente trabalham. $\mathrm{O}$ desenvolvimento das tecnologias irá produzir "híbridos" que pertencem à natureza e à cultura ao mesmo tempo. O autor enfatiza ainda, numa conclusão mais geral, o quanto o trabalho científico sempre esteve imerso nesses dois âmbitos, que a sociologia tentou separar em suas investigações. Decorre dessa argumentação o corolário de que "jamais fomos modernos”, as separações radicais entre natureza/cultura, bem como entre indivíduo/sociedade, de fato, nunca ocorrem totalmente, e não são levadas a sério na prática das pesquisas. A ciência deveria, para Latour, ser explicada levando-se em conta o contexto de coletivos e redes que produzem “constituições” de verdade, cujo método antropológico permitiria comparar.

De qualquer modo, seja por meio do "programa forte" da sociologia inglesa, da etnografia da ciência ou de suas combinações e matizes, houve o paradoxal efeito de relativização das certezas a respeito do conhecimento científico. E isso ocorre, como nota Schwartzman (2001) justamente, num momento em que a ciência assume um papel central na vida econômica e social.

Porém, longe de tornar-se uma via exclusiva, a "nova” sociologia da ciência recebeu uma série de críticas por seu suposto irracionalismo e obscurantismo. Qual seria o específico “conteúdo da ciência”? Os princípios relativistas não se aplicaram a essa própria sociologia? Seria possível integrar efetivamente as pesquisa de nível micro e macrossociológico numa conceitualização geral? Sem nos estendermos aqui nas minúcias do debate, notamos somente que a "nova” sociologia da ciência é, no momento atual, possuí também aspectos relevantes, como o mérito de evidenciar o fato de que a prática científica é diferente de seus sistemas de justificação (Schwartzman, 2001).

Tal conclusão leva, de um lado, a um fortalecimento de uma perspectiva institucional, como na sociologia da ciência mertoniana, mais reflexiva, na medida em que a "verdade" científica é vista como sendo essencialmente resultado das construções sociais. Estas estão implicadas na organização dos agentes, na alocação de recursos, na prioridade a 
determinados objetos e métodos etc., em suma, a aspectos que são vistos, sob novas perspectivas, como importantes para compreender a ciência.

É possível notar, discorrendo sobre a influência na pesquisa local desses enfoques na que a institucionalista praticada por Schwartzman, é um exemplo de sintonia com tais preocupações (Schwartzman, 2001, 1984). Não sem razão, Miceli (1999) denomina a vertente de estudos iniciada por este autor como um argumento "organizacional e institucionalista” que consegue em determinados momentos "politizar” a análise.

Outros trabalhos interessantes e relativamente recentes são os de Figuerôa (1997) e Melo $(1999)^{23}$. No primeiro caso trata-se de um estudo que objetiva reconstruir a trajetória da institucionalização das ciências geológicas no Brasil, através da análise histórica, no entanto, trata-se de uma historiografia renovada pelos novos marcos de entendimento da ciência, por meio dos quais é possível "redescobrir” um fazer científico num país periférico, ao contrário do que sugeriam as análises tradicionais. Ao mesmo tempo, desenvolve-se um argumento sobre os contextos sociais da atividade de pesquisa que mostra a continuidade temporal de espaços institucionais e a relação dessa investigação com o Estado, configurando um quadro em que, ao contrário do que se poderia supor, é a partir da pesquisa de caráter aplicado que a área de estudo se institucionaliza.

Já o trabalho de Melo intenta delinear um panorama da produção em ciências sociais no Brasil nos anos de 1990. Para tanto utiliza métodos bibliométricos, aplicados em Teses e Dissertações, em ementas de disciplinas de cursos de Pós-Graduação e artigos publicados em revistas especializadas, de modo a traçar um mapa dos domínios pesquisados. O que é interessante nessa perspectiva é a discussão sobre o significado das citações, como conformadoras de um "léxico" das ciências sociais - aspecto que, desde já notamos, será de interesse para a análise de nosso corpus empírico. Porém, este "léxico", dentro de uma concepção construtivista de ciência, corresponde, a partir das discussões do autor e em especial do aporte de Latour (2000), ao entendimento das citações como um recurso retórico. A citação é algo mais do que uma medida exclusiva de "valor" de um trabalho, ele representa também, com freqüência, a adesão a determinado espaço cognitivo.

\footnotetext{
${ }^{23}$ Ademais, seria possível falar sobre o caso da "sociologia dos intelectuais", que oferece até mais exemplos, como os trabalhos em Miceli $(2001,1995)$. Tais estudos são, no nosso entender, convergentes a essa tradição local aqui referenciada.
} 
Aliás, a concepção da ciência adotada problematiza essa idéia de “valor”, embora não invalide tal conclusão. O que ocorre é que é, a partir de um argumento mais voltado ao "léxico" que se produz, as citações são analisadas e inter-relacionadas dentro do quadro contextual da institucionalização das ciências sociais no Brasil. Assim, revelam diagnósticos sobre linhagens tradicionais e áreas de pesquisa emergentes, mostrando, ao fim, um "elevado grau de consenso quanto a autores e obras que constituem as referências obrigatórias de antropólogos, cientistas políticos e sociólogos” (Melo, 1999, 171).

Estes exemplos mostram, em linhas bem gerais, o desenvolvimento e o estado em que se encontram os estudos sociais da ciência no país, ou seja, num estágio pós-kuhniano, recebendo maior ou menor influência da "nova” sociologia da ciência. É a perspectiva da ciência como prática, todavia, que se fortalece, no nosso entender. E esta concepção "tem como corolário a idéia de que é impossível investigar o conhecimento à margem da ação cotidiana dos indivíduos” (Melo, 1999, 53). Dessa forma, tendências puramente internalistas ou externalistas têm menos vigor que olhares mais "reflexivos" sobre o objeto (a ciência), cujo conteúdo social tende a ser mais evidenciado e correlacionado aos elementos de construção/justificação do discurso científico. 


\subsection{Bourdieu: o conceito de campo em seu projeto sociológico}

Uma análise que tentasse isolar uma dimensão puramente política nos conflitos pela dominação no campo científico seria tão falsa quanto o parti pris inverso, mais freqüente, de somente considerar as determinações "puras" e puramente intelectuais dos conflitos científicos.

Bourdieu $(1994,124)$

Discutimos até o momento a trajetória da sociologia da ciência, realizando uma avaliação positiva dos ganhos críticos das posições mais recentes, bem como, apontamos trabalhos brasileiros nesta linha. O que é mais importante agora, porém, é comentar as possíveis rupturas e aportes do conceito de “campo". Este conceito não foi abordado de modo explícito nos trabalhos mencionados, ainda que ele seja, também, inspirador da nova sociologia da ciência, como vimos no trabalho de Latour.

É importante notar ainda que a noção de “campo”, a partir do enfoque de Bourdieu, tem sido recorrente em textos recentes sobre a área (Marques de Melo, 2003, Ferreira, 2003, Prado, 2003, Ferreira, 2004, Barros Filho e Sá, 2004, entre outros). No entanto, é também freqüente que haja uma baixa explicitação do mesmo, quando ele não é utilizado de um modo muito lato (significando "área” de estudos) ou como sinônimo, por exemplo, de “comunidade”, no sentido kuhniano. Isso tem implicações porque ele é um conceito que, numa investigação qualquer, representa uma unidade de análise. Enquanto conceito, se insere numa trama teórica que lhe dá sentido e numa fundamentação que exclui determinados entendimentos sobre a ciência.

Não significa que é a única possível via de análise da atividade científica, no entanto, o que é necessário frisar é, de um lado, a necessária busca de rigor conceitual. É só a partir dessa busca por rigor que se pode pensar em qualquer tipo de combinação com diferentes teorias e conceitos sobre a prática científica. Isso evita o risco do ecletismo pouco produtivo na investigação.

Assim, antes mesmo de começar a descrever o conceito de "campo" em sua perspectiva macro, vale acompanhar o raciocínio de Hochman (1994), que compara diferentes conceitos/unidades de análise sobre as práticas científicas: de Kuhn (comunidade), 
Bourdieu (campo), Latour (ciclo de credibilidade) e Knorr-Cetina (arena transepistêmica).

Conforme o autor:

A comunidade científica é autônoma, fundada no consenso, estável e tem, como comunidade, uma finalidade última. No campo científico, um mercado científico, também um lugar autonomizado, a dinâmica da competição, do conflito por crédito, encontra-se condicionada pela estrutura social, onde o "progresso da razão" resulta da competição por acumulação e reprodução de capital simbólico. Quando alguns autores [Latour e Knorr-Cetina] vão ao laboratório ver como funciona a ciência normal encontram uma organização da prática científica mais dinâmica, mais competitiva e plural, instável, na qual indivíduos concorrem pela produção de informações relevantes, que serão convertidas ou modificadas. Uma competição cujo resultado é sempre indeterminado. (Hochman, 1994, 228)

Como ressalta o autor estamos diante de abordagens que se preocupam com dimensões analíticas diferentes, ainda que não sejam enfoques irreconciliáveis ou, utilizando um termo caro à sociologia da ciência, incomensuráveis. Dito isso, voltamo-nos aos conceitos de Bourdieu.

Para entender a formulação de campo social, é pertinente notar que o conceito de campo (científico, literário, cultural etc.) é central na sociologia de Bourdieu, junto com o conceito de habitus, como uma instância capaz de realizar a mediação entre o agente e estrutura social. Tal aspecto remonta ao projeto do autor de uma sociologia da prática que busca superar tanto o subjetivismo fenomenológico quanto o objetivismo estruturalista ou positivista. O conceito de campo científico remete então a uma "teoria geral" sobre os campos sociais $^{24}$, que pretende explicar a lógica comum dos mesmos. Apesar das formas irredutíveis e específicas assumidas por cada um dos grandes campos (do poder e de produção simbólica) existem homologias estruturais e funcionais entre eles, ou seja, semelhanças em termos de sua constituição e funcionamento, conferindo eficácia ao método comparativo, pois o estudo de um caso particular é o de uma configuração possível

\footnotetext{
${ }^{24}$ Uma apresentação sucinta e didática sobre a teoria dos campos é feita por Lahire (2002), que argumenta, porém, que a proposta de Bourdieu não possui generalidade a todos os espaços sociais. Isso porque, embora o conceito de campo seja adequado a âmbitos de atividades profissionais (ou públicas) e, mais precisamente, àqueles que envolvem uma competição por prestígio, nem sempre os indivíduos interatuam com os mesmos interesses nestes espaços sociais. Ademais, os indivíduos circulam em diferentes campos (são, por exemplo, produtores num campo e amadores em outro), de outro lado, nem todos os âmbitos de sociabilidade seriam organizados com a mesma lógica dos campos (a família, por exemplo). Outra discussão do conceito de campo e, em específico e com maior aprofundamento, do campo científico é feita por Garcia (1996). A riqueza da teoria, medida pelas influências e capacidade de produzir novas inteligibilidades e interpretações faz com quea teoria do campo, em diferentes áreas (literatura, campos simbólicos em geral, cultura, educação etc.), possua literatura vasta. Com efeito, a posição central, de "clássico contemporâneo/moderno", que Bourdieu ocupa na área das ciências sociais, pode ser avaliada por sua freqüente posição entre os autores mais citados em levantamentos de bases de dados nas ciências sociais.
} 
do(s) campo(s). É isso que, ao mesmo tempo, induz e permite a transferência de noções entre eles, pois dá fundamento à hipótese da relação de homologia estrutural.

Assim, a transferência e circulação de conceitos de um campo a outro, dentro da teoria dos campos sociais, é um modo de compreender invariantes e a forma específica com que as propriedades dos campos revestem-se em cada um dos mesmos, em um determinado momento histórico. Isso ocorre, por exemplo, com o uso de termos da economia (capital, troca, monopólio, oferta, demanda etc.), que são transferidos aos demais campos.

Porém, interessa determinar, para compreender a estrutura de campo, qual a forma assumida por determinada categoria invariante, de modo que, se o “capital” prevalecente no campo econômico é a posse material e de bens econômicos, nos campos de produção simbólica este aspecto assume outra forma. Trata-se de um capital simbólico, relativo à posse de uma "autoridade" e "legitimidade" derivadas de hierarquias que se constroem e são internalizadas em cada campo específico (literário, científico etc.), em função de “regras” do mesmo. Desse modo, as possibilidades de “reconversão” de um capital a outro são sempre parciais e limitadas. Um mestre da alta costura, ao tentar transferir seu capital em termos da alta cultura, terá uma conversão do mesmo a uma taxa desfavorável, exemplifica Bourdieu (1983, 90). "Falar de um capital específico é dizer que o capital vale em relação a um certo campo, portanto dentro dos limites desse campo” (idem).

Das regras inscritas no campo, deriva o habitus, um conceito claramente associado ao de campo. Ele refere-se à incorporação pelo agente de valores, normas e princípios sociais (através da atuação de instâncias como a família, a escola, a classe social, o grupo etc.), funcionando como uma "estrutura estruturante” para as atitudes, a despeito da intenção do indivíduo, do elemento de reprodução dos grupos sociais (através da interiorização de normas e esquemas de ação) e dos próprios campos. A educação é destacada por Bourdieu, ao lado da socialização familiar, como o principal meio de inculcação desse conjunto de atitudes, permitindo a transmissão de códigos de decifração a um círculo fechado de agentes.

No entanto, o habitus não é, estrito senso, o código produzido, mas seus princípios de apreensão e reprodução pelos agentes. Assim, tal ou qual “discurso” produzido em 
determinado campo não é, em si mesmo, o habitus, mas sim as regras que o geraram, permitindo que ele seja decodificado da forma correta e de modo diferente dos "discursos" de outros campos. Por exemplo, o “estilo” de um texto do campo da filosofia tende a ter uma discursividade diferente do texto do campo jornalístico ${ }^{25}$ que, por sua vez, possui regras diferentes dos textos do campo literário etc.

Os campos são ainda espaços - regidos por diferentes princípios e habitus - onde é travada a luta pelo capital específico. E, por conseguinte, outra instância pela qual se dá a reprodução social, num nível macrossociológico, pois “o campo não é resultado das ações individuais dos agentes”, mas resultado interativo entre “as estratégias dos agentes que o compõem e [em relação com] o sistema de transformação ou conservação da sociedade global” (Ortiz, 1994, 20).

Do esquema teórico esboçado resulta o pressuposto de que as análises exclusivamente internas (no plano discursivo ou organizatório) ou externas (em termos sócioinstitucionais, na articulação do campo e o macro-contexto social) tendem a obscurecer aspectos da dinâmica de um campo. E, mais que isso, as análises que tendem a estabelecer formas de compreensão ancoradas nestas separações seriam pré-científicas, pois o modo de pensamento relacional, que está no cerne da sociologia proposta, estaria na essência da ciência moderna (Bourdieu, 1996, 207). Portanto, o estudo da dinâmica de um campo, conforme se depreende das análises e exposições de método de Bourdieu, sobre o campo artístico e científico, está fortemente ligado à construção da estrutura de relações objetivas existentes entre as realidades sociais.

Daí decorre a ruptura de Bourdieu com as sociologias da ciência em suas vertentes mais tradicionais e também sua crítica ao “programa forte”. Esta postura é bem evidenciada em um artigo significativamente intitulado “A dupla ruptura” (Bourdieu, 1996). Nele, ao mesmo tempo em que nota o mérito de Merton por procurar analisar sociologicamente a ciência, Bourdieu propõe uma ruptura com dois tipos de representação social a propósito

\footnotetext{
${ }^{25}$ Em Barros Filho e Sá (2004), a utilização do conceito de habitus é pertinente na análise da prática profissional do jornalista, na qual se tende a seguir a concepção mais estrita do conceito. Porém no caso do estudo das teorias de comunicação (na segunda parte desse livro), o histórico sobre as teorias do campo comunicacional apresentado diz menos respeito ao conceito, já que o ajuste entre a estrutura e o agente que o habitus propicia é menos "reflexivo" que uma instância teórica, embora possa derivar dela
} 
do trabalho científico. Uma, que não seria lograda por Merton, quanto às representações ideais que os intelectuais constroem e oferecem de si mesmos e que são vistas como elementos tanto descritivos quanto normativos por certa sociologia ciência - como a questão do ethos científico, conforme a proposta de Merton (1970 [1945]).

De outro lado, há para Bourdieu a necessidade de uma ruptura com a visão “ingenuamente crítica” proposta pelo "programa forte”. O centro da crítica a esta proposta é que o campo é dotado de regras próprias de funcionamento e que

O ultra-radicalismo de uma denúncia sacrílega sobre o caráter sagrado da ciência, que tende a lançar suspeita sobre todas as tentativas de fundar, ainda que sociologicamente, a validade universal da razão científica, leva naturalmente a uma espécie de niilismo subjetivista [...]. Lembrar a dimensão social das estratégias científicas não é reduzir as demonstrações científicas a simples exibicionismos retóricos; invocar o papel do capital simbólico como arma e alvo de lutas científicas não é transformar a busca do ganho simbólico na finalidade ou na razão de ser únicas das condutas científicas; expor a lógica agonística de funcionamento de um campo científico não é ignorar que a concorrência não exclui a complementaridade ou a cooperação e que, sob certas condições de concorrência e da competência é que podem surgir os "controles" $e$ os "interesses de conhecimento" que a visão ingênua registra sem se perguntar pelas condições sociais de sua gênese. (Bourdieu, 1996, 86, grifos nossos) 


\subsection{As propriedades dos campos, campo e capital científicos e o progresso da razão}

Os campos, conforme a proposta de Bourdieu, devem ser apreendidos, pois, nos modos como se situam em diferentes hierarquias simbólicas e sociais, interagindo entre si, bem como internamente (nos seus embates), estabelecem distinções e operamde modo específico em cada estágio de seu desenvolvimento (com maior ou menor autonomia frente a demandas de outros campos; maior ou menor legitimidade científica, em momentos diversos, etc.).

As próprias diferenças entre os campos estão ligadas a essa dinâmica dupla. É por isso que Bourdieu observa nas diferenças entre ciências exatas e naturais e as ciências sociais uma tendência maior à autonomização das primeiras, justamente pelo favorecimento a aspectos que estão fora da lógica interna do próprio campo. As expectativas e interesses que os grupos dominantes têm sobre as ciências naturais e exatas favorecem mais à autonomização (Hochman, 1994, 228). Daí, novamente, a importância do caráter relacional da análise. Com efeito, deve-se, como já assinalado, falar numa teoria dos campos sociais, pois os mesmos possuem interconexões.

De qualquer forma, sistematizando os elementos fundamentais da definição de campo realizada por Bourdieu, em diferentes trabalhos ${ }^{26}$, nota-se que o mesmo possui os seguintes aspectos:

- Um campo é um microcosmo incluído num espaço social (macrocosmo) global; ele possui suas regras e normas próprias, cuja validade é tanto maior quanto melhor sucedido for o processo de autonomização do mesmo;

- É um espaço de lutas entre os diferentes agentes que se posicionam diferencialmente em seu espaço (conforme sua origem e trajetória), lutando pela apropriação/redefinição de um capital específico; este capital é desigualmente distribuído, o que corresponde a posições dominadas e dominantes dentro do campo;

\footnotetext{
${ }^{26}$ Bourdieu, 1968, 1983, 1983a, 1992, entre outros.
} 
- Um campo define-se pela demarcação dos objetos de disputas e dos interesses específicos que são irredutíveis aos objetos de disputas e aos interesses próprios de outros campos - “não se poderia motivar um filósofo com questões próprias dos geógrafos”, nota Bourdieu (1983, 89);

- O funcionamento do campo implica na existência desses objetos de disputa e de pessoas prontas para disputar o jogo, dotadas de um habitus que as tornem capazes do conhecimento e do reconhecimento das leis imanentes do jogo, dos objetos de disputas etc. E, no campo científico, o que está em jogo é o monopólio da “autoridade científica”, ou seja, um capital particular que confere poder ao produtor que o exerce, em relação aos mecanismos constitutivos do campo (por exemplo, o tipo de ações e objetos de interesse pertinentes, bem como as teorias, técnicas e métodos considerados legítimos). Em resumo, “a definição do que está em jogo na luta científica faz parte do jogo da luta científica” (Bourdieu, 1983, 128).

- As estratégias dos agentes (em termos de conservação ou subversão do estado do campo) remetem às posições (dominados/dominantes) mencionadas;

- Quanto maior a autonomia de campo, mais os produtores particulares só poderão esperar o reconhecimento de seus produtos pelos seus pares, que também são seus concorrentes. Isso decorre, entre outros pontos, do processo de especialização que torna a linguagem dos campos eruditos cada vez mais complexa e esotérica.

- Apesar das disputas, e portanto do caráter de mercado conflitivo do campo, os agentes têm interesse na existência do mesmo. Mais que isso: exige-se uma disposição constituinte, que é uma adesão tácita a uma crença, uma illusio, quanto aos móveis de interesse, suscitados e produzidos pelo próprio jogo/campo. Com efeito, a illusio exigida por um campo “constitui a condição indiscutida da discussão. Para se lançar à discussão dos argumentos, é preciso acreditar que eles mereçam ser discutidos e, de algum modo, acreditar nos méritos da discussão” (Bourdieu, 2001, 124).

O que ressaltamos é que Bourdieu apresenta um esquema de funcionamento da ciência como prática social fundada no conflito, na polêmica (antes do que no consenso da “comunidade”) entre os agentes envolvidos na definição do “capital científico”. Este 
aspecto é estrutural a um campo social, tornando mais legível as posições assumidas pelos agentes, bem como as "estratégias" de luta que dão forma ao campo. A noção de “estratégia”, entendida como a série de ações que o membro do campo realiza, em função de um habitus adquirido, para obter e maximizar os lucros específicos de um determinado campo (Bourdieu, 1990) também integra o conjunto de conceitos articulados na análise dessas instâncias.

Nesse sentido, afirma-se o caráter político de todas as posições, mesmo aquelas que resultam em avanços científicos. Mas assumir os pressupostos da teoria do campo não é o mesmo que adotar uma postura relativista, pois se espera que quanto maior for a autonomia do campo em relação a demandas e capitais específicos de outros campos, maior o grau de auto-regulação do mesmo. "Quanto mais heterônomo é um campo, mais imperfeita é a competência [científica] e é mais legítimo que os agentes façam intervir forças não científicas na lutas científicas” (Bourdieu, 2003, 85) ${ }^{27}$.

Em outros termos, resumindo a lógica dos campos científicos, Garcia (1996, 70, grifo nosso) nota:

É assim que fins particulares de reconhecimento e legitimidade dos produtores individuais acabam se transformando, por uma lógica própria do funcionamento do campo, em algo proveitoso para o progresso da ciência, ou seja, a ampliação do conjunto de conhecimentos científicos. A idéia de objetividade também é construída no interior do campo científico, segundo os mesmo princípios. A objetividade das práticas científicas e seus produtos e os critérios que a definem são fruto de um consenso que se constrói segundo critérios discutidos no interior do próprio campo.

Assim, deve-se ressaltar o princípio profundamente racionalista que está na base da idéia da autonomia dos campos e, portanto, a defesa do processo de autonomização dos mesmos, enquanto mecanismo de "progresso da razão". É a disputa entre os agentes de um campo que permite os avanços no conhecimento - num processo de “revolução permanente” na ciência moderna, estribado na ruptura contínua que seria, para Bourdieu, o verdadeiro princípio de continuidade dos campos (e daí sua crítica ao funcionalismo kuhniano).

\footnotetext{
${ }^{27}$ De outro lado, é justamente na posição de membro de um campo (científico ou da produção simbólica) que Bourdieu passou a defender a intervenção do intelectual na vida pública - exemplificando com o próprio caso de Zola, que defendeu Dreiffus em nome dos princípios universais que o campo literário elaborava e não como um político comum. Daí também a defesa radical da autonomia dos campos (Bourdieu, 1996b).
} 
Desse modo, deve-se notar ainda que a inserção na política e da disputa, na estrutura dos campos, não conduz à idéia de que o campo científico é, por isso, pura estratégia. O que é criticado por Bourdieu é sempre o recurso a recursos alheios ao campo específico. A razão estratégica dos agentes num campo não é sempre uma razão instrumental. Bourdieu, de fato, salienta muitas vezes a ilusão do desinteresse com que os agentes investem suas ações, mas afirma também que a maximização do lucro (específico) se dá, num campo com plena autonomia. Nessa situação existe a obediência a necessidades imanentes, exigências inscritas como critérios de pertencimento ao campo (apropriação do habitus, acúmulo de capital específico etc.). Se Bourdieu $(1983,74)$ afirma que se "há uma verdade, é que a verdade é um objeto de luta”, isso não deve ser lido como uma declaração relativista. Mas sim que essa luta é necessária ao próprio mecanismo de produção da "verdade” científica e dá maior aproximação à razão, que é sempre histórica. De modo que,

é importante que o espaço onde é produzido o discurso sobre o mundo social continue a funcionar como um campo de luta onde o pólo dominante não esmague o pólo dominado, a ortodoxia não esmague a heresia. Porque neste domínio, enquanto houver luta, haverá história, isto é, esperança. (Bourdieu, 1983, 53)

É por isso que não é possível aceitar uma premissa como a de Montardo (2005) que ao discutir o “campo” (a partir de Bourdieu) científico da Comunicação e as possíveis incorporações de teorias como a das mediações, num composto com o "paradigma da complexidade”, afirma que a “dinâmica do campo científico [...] diz respeito ao paradigma da ciência clássica, disjuntor e simplificador” (Montardo, 2005, 4). E o campo científico, por essa natureza, tenderia a ter um compromisso menor com a "verdade" do que com o “vínculo científico” (idem, 3). A “verdade” no campo científico não é una e imóvel, mas sim processual, nos próprios termos da defesa da luta no campo científico, feita por Bourdieu. Se é possível discutir, como faz a autora, a "pertinência da emergência de um novo paradigma, capaz de, ao menos, questionar os critérios que regem as relações de conhecimento em nossa sociedade” (idem, 6), não é aceitável que os critérios de valor de novas propostas científicas sejam alheios ao campo científico. Igualmente, nos termos da proposta de Bourdieu em sentido estrito, não se justifica a idéia de que o campo acadêmico da comunicação possue uma incompatibilidade estrutural com o campo científico, como defende a autora. O fato de a Comunicação transitar por diversos saberes (idem, 5) não justifica essa idéia. 
Retomando, porém, a discussão de Bourdieu, observa-se que a autonomização dos campos nunca é absoluta, quer dizer, existem dimensões de contato entre diferentes campos sociais que serão constitutivas da própria definição de cada um deles ao longo de sua história. Dessa maneira, o conceito possui grande valia na análise do processo de constituição de uma disciplina científica, em particular no caso da Comunicação - que possui fortes subcampos de ensino e pesquisa e relações com o conjunto da sociedade igualmente densas, dada a importância que a dimensão da comunicação assumiu na sociedade contemporânea.

O que o conceito tem de mais importante é atentar para o fato de que nos processos de institucionalização social do campo científico da Comunicação existe uma relação de mútua articulação entre elementos cognitivos (internos ao campo) e sociais (externos). Relação que é, ademais, complexificada pela interface entre os campos, de modo que, por exemplo, demandas profissionais, de políticas econômicas ou educativas afetam o tendencial campo científico.

É importante também explicitar os tipos de capital científico. Bourdieu é claro ao afirmar que nos campos de produção simbólica existe um recalque das determinações materiais das práticas simbólicas. Assim, cada campo instaura - o que fortalece sua autonomia - um tipo de capital atinente a algum dos seus estados, é claro que desse capital podem decorrer vantagens efetivamente materiais, mas, enquanto tal, estas têm apenas valor interno ao campo a partir de reconversões, por exemplo, o dinheiro gasto num processo de formação de um agente. Assim, nas fases iniciais, o modo de obtenção do capital científico é idêntico a outras formas de capital social: depende de uma acumulação primitiva iniciada na formação escolar e terá continuidade após o início da vida profissional. Já nesta fase, no caso dos cientistas, irá basear-se no reconhecimento obtido pelos trabalhos, títulos, publicações etc. que permitam obter determinada posição no campo.

Desse modo, ao longo de uma trajetória acadêmica os interesses e as determinações científicas fundem-se e ensejam diferentes estratégias de investimento dos participantes de um campo. “Toda escolha científica é uma estratégia política de investimento dirigida para maximização de lucro científico, isto é, o reconhecimento dos pares-competidores” (Hochman, 1994, 210). As próprias escolhas dos cientistas (em termos de objetos, posições 
teóricas etc.) podem ser analisadas por essa lógica: assim, Bourdieu nota a existência de três possibilidades estratégicas básicas. A primeira de conservação (da ortodoxia do campo), por parte dos dominantes; a segunda, de sucessão, numa ascensão "interna” aos limites do campo, a partir de uma carreira previsível que conta com lucros futuros, e, por fim, as estratégias de subversão, no qual haveria também uma estratégia de ascensão, mas a partir da ruptura com os detentores da autoridade científica. Tais estratégias se relacionam às posições ocupadas pelos agentes e a chance de êxito de cada uma delas depende desta mesma posição. Com efeito, nesse modelo de "mercado científico" proposto por Bourdieu, está implícita uma disputa pela autoridade científica para a acumulação do capital. Sendo a autoridade científica a capacidade de um agente impor uma definição de ciência que lhe permita ocupar um lugar dominante na hierarquia científica.

No entanto, como já se afirmou, o reconhecimento se dá a partir dos pares-concorrentes, em estágios de avançada autonomização do campo, pois só estes "detêm os meios de se apropriar simbolicamente da obra científica e de avaliar os seus méritos” (Bourdieu, 1983, 127). Assim, caracterizando mais o capital científico, este pode, segundo Bourdieu assumir duas grandes formas:

De um lado, um poder institucional ou institucionalizado que está ligado à ocupação de posições importantes nas instituições científicas, direção de laboratórios ou departamentos, pertencimento a comitês de avaliação etc. [...] De outro, um poder específico, "prestígio" pessoal que é mais ou menos independente do precedente, segundo os campos e instituições, e que repousa quase exclusivamente sobre o reconhecimento pouco ou mal objetivado e institucionalizado, do conjunto de pares ou da fração mais consagrada dentre eles. (Bourdieu, 2004, 35)

Para o autor, naturalmente, a segunda definição corresponde a uma forma mais "pura” de capital científico, enquanto a primeira forma seria mais “institucional”. O autor reflete sobre as razões que explicam a freqüente dissociação entre os detentores de formas de capital científico "puras” e “institucionais” e conclui que esse aspecto também possui motivos práticos. No entanto, postula que, conforme o peso relativo de cada um desses capitais num campo, quanto mais os campos "são heterônomos, maior é a defasagem entre a estrutura de distribuição no campo dos poderes não-específicos (políticos); por um lado, e por outro, a estrutura da distribuição dos poderes específicos - o reconhecimento, o prestígio” (Bourdieu, 2004, 41-2). A mensuração desses capitais é sugerida pelo autor em 
termos de, por exemplo, indicadores de citações ${ }^{28}$, número de traduções etc., para a forma mais “pura” e o controle de instâncias de reprodução do campo: assento em comissões de concursos, em órgãos de política científica etc., para a outra. No caso de uma estruturação totalmente invertida (quando aqueles que têm o poder político não possuem prestígio) há uma situação menos autônoma num campo. E isso gera vários defeitos possíveis, como o uso de capitais não-científicos na competição, tendência aos dominantes apresentarem estratégias destinadas antes a reproduzir sua posição do que a fazer avançar a ciência.

Antes de, a partir desse referencial, discutir uma estratégia de mediação operacional de nossa pesquisa, gostaríamos de comentar o modo como o próprio Bourdieu põe em prática seus conceitos no seu principal trabalho empírico sobre o campo científico, o livro Homo academicus, no qual é feita a análise do campo universitário francês. Isso ocorre através da análise do modo como diferentes faculdades (Medicina, Direito, Ciências e Letras) situamse em relação ao campo do poder, ou seja, operando tanto em termos das homologias entre campos, quanto realizando um estudo relacional, aspecto caro ao autor. Ao combinar análises estatísticas com base em dados sobre o recrutamento dos docentes, origem social dos mesmos, tendências políticas, entre outros indicadores, a estudos das trajetórias dos agentes, o trabalho demonstra o fato de que o campo universitário francês é homólogo ao campo político, articulando-se com este conforme diferentes situações em cada um dos campos disciplinares. Existem aquelas faculdades que se situam em termos cientificamente dominantes (Ciências e Letras) que são politicamente dominadas e as que, ao contrário, são menos autônomas em relação ao campo do poder, porém, socialmente dominantes, na medida em que colocam em ação os usos políticos do conhecimento - sendo esses os grupos recrutados pelas classes dominantes (faculdades de Medicina e Direito). Estas faculdades, por isso mesmo, possuem menor autonomia científica. Tais diferenças se refletem na própria concepção que ambos os grupos elaboram sobre a ciência, e portanto no capital específico que será valorizado em cada uma das instâncias. Enquanto o grupo mais autônomo tende a reforçar seus critérios de legitimidade e prestígio a partir de elementos internos ao campo (publicações, reconhecimento pelos pares), o grupo menos autônomo reforça a ligação dos agentes com o poder externo na distribuição da legitimidade no interior do próprio campo científico. Cada grupo de faculdades situa-se em

\footnotetext{
${ }^{28}$ Podemos, pois, destacar novamente que esse é o elemento básico do "capital científico” a ser analisado no Capítulo 7.
} 
relação a esse quadro contextual e movimenta-se em relação à posição que ocupa no quadro geral. A análise de Bourdieu recorre à reconstituição destes diferentes pontos de vista existentes nas tomadas de posição. Esse seria, para o autor, um meio de compreender a validade de diferentes argumentos. escapando ao relativismo de considerar todas as posições como "equivalentes”, na medida em que permitem articular os posicionamentos aos lugares ocupados no campo pelos agentes, para melhor interpretá-los.

A partir da formulação de Bourdieu, percebe-se o mundo científico como imerso em esferas práticas. O desenvolvimento de cada um dos campos envolve não só o limite da autonomia alcançada pelo mesmo ou as estratégias dos agentes, mas também os elementos estruturais que presidem sua reprodução. Esta, por sua vez, está relacionada a uma trajetória que tem, todavia, relação com os embates que ocorrem no presente, no espaço do campo. 


\subsection{O conceito de campo em abordagens da sociologia da ciência sobre a área da Comunicação}

Antes de apresentar a proposta metodológica de nosso estudo, nos parece importante discutir o uso da noção de campo em estudos sobre a área da Comunicação quanto a sua organização disciplinar. Em primeiro lugar, nota-se a convergência de autores (Fuentes, 1998, Lopes, 2003a) quanto a salientar a tríplice configuração do campo amplo da Comunicação, constituído pelos seguintes âmbitos (ou subcampos): o acadêmico (área de produção do conhecimento científico) ${ }^{29}$, o ensino superior (subcampo educativo, ao qual cabe a reprodução do conhecimento) e o das práticas profissionais do mercado (no qual ocorre a aplicação do conhecimento). A partir daí, vislumbra-se uma estruturação interna do mesmo, processada em termos da articulação entre as instâncias mencionadas, bem como entre configurações específicas que subsistem em cada subcampo, por exemplo, os sistemas de avaliação oficial dos cursos de graduação e de Pós-Graduação.

O contexto externo, por sua vez, é dado pelo ambiente social mais geral que afeta o campo da Comunicação, ou seja, os campos (como o político ou o científico global ou o de outras disciplinas) com os quais ele se relaciona e é afetado. Naturalmente, incluem-se nesse conjunto, aquelas condições culturais, políticas e econômicas de uma dada realidade que são mais ou menos propícias ao desenvolvimento autônomo de determinado campo.

Quanto à articulação dessas instâncias de determinação da pesquisa na área da Comunicação, a investigação de Fuentes (1998) sobre o caso do México é modelar. Parte de uma pergunta central sobre "quais são e como operam os fatores socioculturais determinantes da confluência entre as configurações do conhecimento (saberes práticos, instrumentais, formais) e as práticas que exercem os agentes 'investigadores acadêmicos' na constituição do campo acadêmico da comunicação no México” (idem, 16). O autor, utilizando o aporte de Bourdieu e da teoria da estruturação de Giddens, reconstrói historicamente o processo de constituição dos estudos de Comunicação no país. E procura, ao mesmo tempo, integrar passado e presente em “modelos" futuros do campo, nos quais se projetam cenários tanto de reestruturação disciplinar (conduzindo a uma legitimidade

\footnotetext{
${ }^{29}$ Como nota Fuentes $(1998,138)$ há também um campo de produção de conhecimento na investigação “profissional”, mas no México, similarmente ao Brasil, não há interação entre universidades e a instância do mercado, que possui lógicas específicas. Desse modo, as investigações profissionais geralmente não circulam entre os acadêmicos que, por sua vez, raramente colaboram nas investigações das empresas de comunicação.
} 
acadêmica e social da área) quanto de “inércia conformista”, de não superação de impasses.

Num breve resumo dessa investigação, Fuentes estuda três contextos relevantes para a estruturação do campo da investigação acadêmica no México: o cognitivo, o sociocultural e o institucional, em suas inter-relações e em termos de dinâmicas externas e internas. Isso ocorre, pois, de modo coerente com o marco teórico, seria indispensável analisar como "os fatores 'externos' se internalizam e os 'internos' se exteriorizam” (Fuentes, 1998, 49). Tal posição se objetiva na análise do sistema de ensino e organização da pesquisa no México; das associações acadêmicas e publicações voltadas à Comunicação (a partir de enfoques basicamente documentais e quantitativos) e do perfil ideológico ou formação discursiva do grupo de pesquisadores e questionários aplicados a um grupo significativo de investigadores.

O caso brasileiro possui muitas semelhanças com o mexicano, daí o interesse pela pesquisa de Fuentes: são ambas sociedades periféricas, nas quais a área da Comunicação cresce, em particular no caso do ensino de graduação, atendendo a demandas sociais, a pesquisa se institucionaliza, mas o estatuto científico e acadêmico é questionado.

Porém, o autor parte de um conhecimento e vivência em relação ao tema que permite este nível de complexidade descritiva e analítica, o que não é o nosso caso em relação ao conhecimento da área da Comunicação no Brasil. Dessa forma, nos pareceu que emular o marco conceitual e estratégias operatórias dessa investigação para o caso brasileiro não seria a melhor opção. No entanto, apropriar-se de elementos da mesma que possam aclarar o estudo do caso brasileiro, bem como utilizá-la em termos comparados, nos parece bastante importante.

Iremos, agora, discutir, aquilo que na nossa investigação pode ser considerado o principal modelo de mediação entre o marco teórico do campo científico e os "métodos técnicos" mais específicos (análises de conteúdo e bibliométricas). Ele servirá ainda à análise dos dados sócio-históricos com os quais se traçará o perfil institucional atual da área da Comunicação no Brasil, nos Capítulos 4 e $5 .$. 


\subsection{O modelo de Galtung sobre a interação entre grupos acadêmicos e o conceito de campo: possibilidades de integração}

Não se pode fazer a ciência avançar, e não apenas em um caso, a não ser à condição de fazer com que teorias opostas se comuniquem, teorias que muitas vezes se constituíram umas contra as outras.

Bourdieu $(1983,20)$

Num texto relativamente recente (Liede Filho, 2003) sobre possibilidades de análise do campo da sociologia recuperou-se uma contribuição importante do sociólogo norueguês Johan Galtung $^{30}$ (1965). Ao analisar a sociologia latino-americana na década de 1960, este autor propôs um modelo ou matriz de inelegibilidade bipolar a respeito dos tipos de interação em uma "comunidade acadêmica”. As interações básicas entre os pesquisadores seriam o dentro do "modelo conflitivo" e o "modelo de contato", a partir dessa matriz, que tem implícita a idéia de cooperação kuhniana ${ }^{31}$.

No "modelo conflitivo", os grupos não possuem fins comuns e o que predomina é a ausência de contato, indício de uma baixa cooperação e estágio imaturo do grupo acadêmico-científico. Ao contrário, no "modelo de contato" o grupo reconhece fins comuns, existe cooperação entre os membros do mesmo e, assim, há uma busca de relações entre os participantes, o que tende a promover uma melhora do padrão geral de trabalho. Nesse modo de interação, o grupo demonstra possuir maior maturidade e um desenvolvimento científico de nível mais elevado. Galtung sugere ainda a existência de um terceiro modo de interação, caracterizado pela tentativa de um dos grupos em prejudicar o outro $^{32}$.

Liedke Filho (2003) relê o texto de Galtung efetivamente sob uma perspectiva kuhniana, mas, no nosso entender, não segue o raciocínio original do autor, em todas as suas

\footnotetext{
${ }^{30}$ O sociólogo norueguês Galtung (1930) fez sua formação nos EUA, tendo sido aluno de Lazarsfeld e Merton. Foi ligado à FLACSO (Facultad Latinoamericana de Ciencias Sociales), e os cursos dados por ele na instituição, nos anos de 1960, foram a base para um influente, na época, livro de teoria e metodologia da investigação social escrito por ele (Ansaldi, 1991, 42). Autor de vasta obra, hoje Galtung é consultor da ONU e se dedica principalmente a temas ligados à sociologia da resolução de conflitos.

${ }^{31}$ É possível que Galtung tivesse lido A estrutura das revoluções científicas (cuja primeira edição é de 1962), no entanto, Kuhn não é explicitamente citado.

${ }^{32}$ Exemplificando esse modelo de alternativa extrema, Liedke Filho $(1997,235)$ lembra os processos de cassações que ocorreram durante os regimes autoritários na América Latina, nos quais houve o apoio de setores das próprias comunidades atingidas ou de comunidades intelectuais próximas.
} 
conseqüências. Com efeito, para Galtung, o problema não era a unificação paradigmática (que iria caracterizar o modelo de contato), mas sim o insulamento de cada grupo ou a hostilidade entre eles. Por isso, o autor afirma que "a ciência tem melhores possibilidades em um ambiente de diversidade e pluralismo, mas somente se faz uso dessa diversidade” (Galtung, 1965, 93).

De qualquer modo, Liedke Filho contribui para enriquecer o Modelo de Galtung sobre a interação entre grupos, propondo duas outras alternativas: a de caráter "segmental" e a estabelecida num modelo "cooperativo-competitivo". No primeiro destes, ocorreria a existência de circuitos particulares de produção, distribuição e consumo de produtos acadêmico-científicos por correntes ou disciplinas, sem um mínimo de interesse de conhecimento ou diálogo com outros circuitos. O autor exemplifica historicamente um caso como esse na sociologia latino-americana dos anos 60 e 70, quando os sociólogos nacionalistas, os funcionalistas-modernizantes e os marxistas "não se liam” entre si. De outro lado, o que o autor chama de modelo cooperativo-competitivo é aquele no qual, dentro de um campo disciplinar ou entre campos disciplinares, existe convivência e diálogo democrático. Há, nessa situação, paradigmas diferentes, mas as diferenças ideológico-teóricas e prático-políticas seriam potencializadas de modo positivo em termos dos desempenhos individuais e coletivos. São observações de modo geral pertinentes, que nos sugerem aportes, aos quais voltaremos.

Entretanto, é mais interessante, para nós, discutir a compatibilidade entre a proposta de Galtung e o marco teórico de Bourdieu, ou seja, a sociologia do campo. Consideramos que o modelo de Galtung é válido para tentar caracterizar internamente um campo científico do mesmo modo, desde que se pense que o modelo de contato admite o conflito, isto é, que este se dá pelo menos a partir de um mútuo reconhecimento (o “contato”) e uma illusio do grupo. Desse modo, na verdade, esse modelo se sobrepõe ao que Liedke Filho chama de “cooperativo-competitivo”. Para efeito de nosso trabalho nomearemos tal modelo como “conflitivo-construtivo", enquanto o outro será chamado de "conflitivo-destrutivo”. O caráter positivo ou negativo reflete-se nas metas científicas do campo - ou seja, um progresso da razão, nos termos de Bourdieu - no qual o debate e o controle cruzado entre os grupos são fundamentais para que possam emergir "verdades científicas”. 
De outro lado, consideramos válida a proposta do modelo "segmental” de Liedke Filho, que, evidentemente implica em um certo nível de debilidade no campo científico de uma área qualquer, por sua fragmentação e tendencial baixo nível de debate. Sendo assim, no quadro abaixo, a partir das descrições dos autores mencionados é feito um continuum que resume as possibilidades de interação entre os grupos, indicando da menor à maior possibilidade de fortalecimento do campo científico em Comunicação. Após esse quadro, discutiremos como avaliar o estado do "campo da Comunicação” a partir desse modelo em relação às estratégias de pesquisa do trabalho. 
Quadro 3.1. Modelos de interação entre grupos acadêmicos (a partir de Galtung, 1965 e Liedke Filho, 2003)

\begin{tabular}{|c|c|c|c|}
\hline & $\begin{array}{l}\text { Modelo conflitivo- } \\
\text { destrutivo }\end{array}$ & Modelo segmental & $\begin{array}{l}\text { Modelo conflitivo- } \\
\text { construtivo }\end{array}$ \\
\hline $\begin{array}{l}\text { Relação com } \\
\text { a imagem } \\
\text { geral do } \\
\text { outro grupo }\end{array}$ & $\begin{array}{l}\text { Não há fins comuns } \\
\text { (inexistência de um } \\
\text { campo científico); os fins } \\
\text { são mutuamente } \\
\text { excludentes. } \\
\text { Ajudar (interagir com) o } \\
\text { outro é prejudicar a si } \\
\text { mesmo. } \\
\text { Modelo de jogo de } \\
\text { "soma zero" }\end{array}$ & $\begin{array}{l}\text { Poucos fins comuns - no } \\
\text { limite somente a } \\
\text { manutenção da situação. } \\
\text { Campo científico débil. } \\
\text { A questão da ajuda } \\
\text { (interação) mútua não é } \\
\text { colocada. } \\
\text { Insulamento dos grupos } \\
\text { faz com que não exista } \\
\text { "jogo comum" }\end{array}$ & $\begin{array}{l}\text { Há certo número de fins } \\
\text { comuns (existência de } \\
\text { um campo científico), e } \\
\text { os fins que parecem } \\
\text { mutuamente excludentes } \\
\text { podem redefinir-se. } \\
\text { Ajudar (interagir com) o } \\
\text { outro é também ajudar a } \\
\text { si mesmo. } \\
\text { Modelo de cooperação } \\
\text { (jogo), "não soma zero" }\end{array}$ \\
\hline $\begin{array}{l}\text { Implicação } \\
\text { metodológica }\end{array}$ & $\begin{array}{l}\text { Um grupo é inútil para o } \\
\text { outro, as diferenças são } \\
\text { tão grandes que o } \\
\text { diálogo não é necessário } \\
\text { nem útil. }\end{array}$ & $\begin{array}{l}\text { A utilidade do outro } \\
\text { grupo é meramente em } \\
\text { termos das demandas } \\
\text { externas, que a união } \\
\text { pode facilitar. } \\
\text { Em termos de diálogo, } \\
\text { este não é evitado, mas } \\
\text { também não é } \\
\text { perseguido. }\end{array}$ & $\begin{array}{l}\text { Um grupo é útil para o } \\
\text { outro, precisamente em } \\
\text { função das diferenças, } \\
\text { pode assinalar os } \\
\text { defeitos do próprio } \\
\text { pensamento. }\end{array}$ \\
\hline $\begin{array}{l}\text { Implicações } \\
\text { pra contatos }\end{array}$ & $\begin{array}{l}\text { Deve-se evitar o contato; } \\
\text { o outro grupo não } \\
\text { merece, representa algo } \\
\text { tão intrinsecamente } \\
\text { ruim, que não se deve } \\
\text { ajudá-lo (ter contato com } \\
\text { ele) } \\
\text { Deve-se desconfiar, } \\
\text { ocultar as próprias } \\
\text { descobertas, porque o } \\
\text { outro grupo poderia } \\
\text { roubá-las. }\end{array}$ & $\begin{array}{l}\text { Os contatos têm pouco } \\
\text { valor, pois, dada as } \\
\text { diferenças entre os } \\
\text { grupos, dele não } \\
\text { poderão resultar } \\
\text { discussões ou debates } \\
\text { comuns. }\end{array}$ & $\begin{array}{l}\text { É necessário buscar o } \\
\text { contato, apesar das } \\
\text { diferenças podem ser } \\
\text { promovidos fins comuns } \\
\text { que serviram (no debate, } \\
\text { conflito de idéias) para a } \\
\text { melhora dos grupos, } \\
\text { tendo assim um valor } \\
\text { mais alto. }\end{array}$ \\
\hline
\end{tabular}

É preciso notar que os textos em itálico no quadro foram redigidos por nós, para ajustar mais perfeitamente essa adaptação do modelo de Galtung, incorporando sugestões de Liedke Filho, no marco teórico do campo de Bourdieu que rege nosso trabalho. Além disso, a redação do “modelo segmental” também é nossa. 
O que merece considerações agora é como evidenciar os tipos de interação a partir dos dados produzidos nesta pesquisa. É interessante, então, recapitularmos quais serão estes dados. Nos próximos dois Capítulos é feita uma descrição e análise mais voltada à institucionalização da área da Comunicação no Brasil. São utilizados dados da historiografia das ciências sociais e da Comunicação, bem como indicadores quantitativos diversos sobre essa área. Nesse sentido, a utilização do modelo de interação é menos propícia para os objetivos de observar o nível de amadurecimento interno do "campo da Comunicação”. Porém, a respeito dos dados dos Capítulos 6 e 7, será possível operar com mais produtividade tal modelo. Isso porque veremos como se dá (ou não) a convergência entre temáticas de produção e Linhas de Pesquisa (Capítulo 6) dos PPGCOM, indicando, pois, certas possibilidades de adequação maior ou menor a um dos modelos indicados.

Por fim, no Capítulo 7, onde se analisa o “capital científico” da área da Comunicação, em termos da referência bibliográficas de teses e dissertações, em estudos bibliométricos, será possível notar o intercâmbio dos textos e das citações. Trabalhando com os PPGCOM como unidade básica, poderemos notar como se comportam os autores nos diferentes Programas da área que comporta, o que permite observar aspectos sobre a "interação" do grupo a esse respeito, como o grau de referências partilhadas e o reconhecimento dos autores da Comunicação dentro do campo científico..

Deve-se notar que uma dificuldade para produzir uma análise mais precisa será a falta de um viés comparado - tanto internamente de maneira temporal, quanto em comparação com outras áreas. De qualquer forma, acreditamos que será possível perceber determinados níveis de interação, os quais poderão ser possivelmente associados a algum dos tipos do modelo adotado. 


\section{Capítulo 4}

\section{Perfil Institucional das Ciências da Comunicação no Brasil: histórico e indicadores de inserção na área científica}

Toda institucionalização é também um combate cujo destino depende também de quem o realiza.

Mattelart $(1999,28)$

Este capítulo tem por objetivo a elaboração de um perfil institucional da área da Comunicação no Brasil, especificamente de seu campo de pesquisa articulado ao ensino, entendendo que os suportes dessas atividades fornecem elementos para a compreensão das características da área, em outros termos, são fatores da configuração do “campo”. Por outro lado, a comparação com outras áreas de conhecimento nacionais, e com países que possuem também sistemas de ensino/pesquisa em Comunicação na América Latina permite obter uma melhor avaliação do estado desse espaço de produção de conhecimento no país. Ademais, o recurso à comparação diacrônica, quanto de fatores que têm marcado o modo de constituição da área, aponta para questões relativas às suas características atuais.

Ao considerar-se um "sistema institucionalizado" como "simultaneamente um sistema de comunicação, de recompensa e de alocação de verbas” (Pessoa Jr., 1993, 4) é possível compreender as possibilidades do trabalho sobre características institucionais de uma área de investigação. Aqui, tendo como foco a área da Comunicação, estamos próximos de trabalhos como os que vêm sendo realizados no Brasil em áreas como a física (Rezende, 1994), saúde (Barata; Goldbaum, 2003), ciências da informação (Población, 2001, 2005) e as ciências sociais (Werneck Vianna et al., 1995, Miceli, 2001 e Martins et al., 2002).

De outro lado, recorreu-se, por vezes, à literatura sobre o ensino superior brasileiro e latino-americano - hoje bastante volumosa, e que inclui, entre outros trabalhos, Cunha (2003), Trindade e Blanquer (2002) e Soares (2002), utilizada, com parcimônia, em particular na primeira seção do texto, onde aspectos históricos relativos à conformação ou 
autonomização institucional da área da Comunicação têm relevo. Houve ainda uma coleta de informações, sempre as mais recentes possíveis, utilizadas ao longo do texto, de fontes oficiais, como Conselho Nacional de Desenvolvimento Científico e Tecnológico (CNPq), do Ministério da Ciência e Tecnologia (MCT); da Coordenação de Aperfeiçoamento de Pessoal de Nível Superior (CAPES), órgão do Ministério da Educação (MEC). Estas instituições de âmbito nacional, ambas criadas em 1951, são, junto com as Fundações de Amparo à Pesquisa dos estados, criadas posteriormente (a FAPESP, por exemplo, começou a funcionar em 1962), as principais apoiadoras da pesquisa no país.

\subsection{A institucionalização das ciências sociais no Brasil e a Comunicação}

Há convergências nas análises relativas ao processo de institucionalização das ciências sociais no Brasil - da qual a área da Comunicação pode ser entendida como um ramo particular, mais tardio ${ }^{33}$-, quanto ao fato das mesmas terem se beneficiado das políticas públicas para o desenvolvimento científico e tecnológico. Igualmente, costuma-se periodizar essa institucionalização em dois períodos: um entre 1930 e 1964, e o outro a partir desta data. Ambos estão associados ao "impulso alcançado pela organização universitária e [...] à concessão de recursos governamentais para a montagem de centros de debate e investigação que não estavam sujeitos à chancela do ensino superior” (Miceli, 2001, 91).

Nota-se, portanto, que história das ciências sociais no país, diferentemente dos países capitalistas centrais, não possui uma trajetória caracterizada pela migração de uma reflexão social feita no âmbito da sociedade civil para a Universidade, mas tem neste espaço seu marco. Com efeito, tal padrão de desenvolvimento é interpretado criticamente, em termos da virtual dissociação entre os cientistas e os temas da reforma social e os interesses populares, que repercutem em questões doutrinárias, perfil dos objetos estudados, entre outros pontos (Werneck Vianna et al., 1995, 29; Miceli, 2001, 92).

\footnotetext{
${ }^{33}$ Esse aspecto pode ser demonstrado, entre outros aspectos, pelo exame da área de formação dos primeiros docentes e orientadores dos Programas de Pós-graduação em Comunicação (PPGCOM).
} 
Ambos os períodos da institucionalização caracterizam-se por contextos de ditadura. No primeiro, a do Estado Novo, e no segundo, a ditadura militar. Por conseguinte, é notável o paradoxo da instalação e consolidação das ciências sociais em tais circunstâncias, na medida em que o conhecimento que seria produzido "pouco poderia valer para regimes políticos de exceção” (Werneck Vianna et al., 1995, 29). Todavia, são justamente os projetos de reforma e expansão do ensino superior os responsáveis principais pela constituição de um sistema nacional de ensino e pesquisa nas áreas de humanas e sociais.

Nesse sentido, fazendo ainda um breve retrospecto das políticas públicas para o setor da educação e da pesquisa na PG, nota-se que o primeiro Plano Nacional de Pós-Graduação (PNPG) é elaborado em pleno regime militar (PNPG - 1975-1979). Ele teve como objetivo trazer para o controle estatal o planejamento da expansão da pós-graduação, que havia ocorrido até aquele momento de modo parcialmente espontâneo, por pressão de motivos conjunturais. Este Plano estimulou a concessão de bolsas para alunos de tempo integral, realizou a extensão do Programa Institucional de Capacitação Docente (PICD) e propôs a admissão de docentes pelas instituições universitárias, para a ampliação da pós-graduação. Já o II PNPG (1982-1985), elaborado na última fase do regime militar, enfatizou a questão da qualidade do ensino, buscando a consolidação de mecanismos de avaliação, instância que existia embrionariamente desde 1976, com a participação da comunidade científica. O III PNPG (1986-1989), elaborado no início da Nova República ${ }^{34}$, enfatizou o desenvolvimento da pesquisa pela universidade e a integração da pós-graduação ao sistema de ciência e tecnologia, propondo, entre outros pontos, a reestruturação das carreiras docentes universitárias, a fim de valorizar a produção científica. A partir de discussões iniciadas em 1996 foram elaborados textos para a formulação do IV PNPG, porém circunstâncias adversas (restrições orçamentárias e baixa articulação entre as agências) fizeram com que o Documento Final redigido não se concretizasse num Plano Nacional de Pós-Graduação. Apesar disso, algumas questões que foram abordadas pelo Documento acabaram refletindo-se em políticas da CAPES ao longo do período, como a expansão do

\footnotetext{
${ }^{34}$ Nesse período histórico, deve-se destacar não só a continuidade dos esforços anteriores - prejudicados, porém, pelo contexto de crise fiscal -, mas também o fato de que o próprio texto da Constituição de 1988, no Art. 207, determine que as universidades obedeçam ao princípio de indissociabilidade entre ensino, pesquisa e extensão. De outro lado, chama a atenção o fato de que, apesar de não terem ocorrido acréscimos substanciais nas dotações para o ensino de pós-graduação e a pesquisa, desde essa época, houve um aumento de produtividade nesses setores. Assim, mesmo com o decréscimo no investimento da CAPES por aluno matriculado (-42\%) e por aluno titulado (-67\%) no período 1995-2003, houve um aumento significativo nesses quesitos. O número de publicações em periódicos indexados também cresceu (CAPES, 2004, 41-2).
} 
sistema, mudanças no sistema de avaliação e busca de inserção internacional da pósgraduação.

Finalmente, o mais atual PNPG (2005-2010) (CAPES, 2004) faz um diagnóstico da PG que reconhece os avanços alcançados, mas critica a "rigidez" (com uma quase absoluta seqüencialidade entre mestrado/doutorado e baixa permeabilidade a demandas diferenciadas) de modelos que passou a caracterizar o sistema, contrariamente às primeiras resoluções e normas sobre a pós-graduação ${ }^{35}$.

Dessa forma, as principais propostas desse Plano dizem respeito à flexibilização do modelo de pós-graduação, de modo a permitir o crescimento do sistema; incorporação de profissionais de perfis diferenciados, para atender demandas acadêmicas e não-acadêmicas. Além disso, recomenda-se a necessidade do sistema atuar em rede para diminuir os desequilíbrios regionais na oferta e desempenho da pós-graduação e atender às novas áreas de conhecimento. A respeito da expansão da PG, o Plano propõe que a esta se dê a partir de quatro vertentes: 1) a tradicional capacitação do corpo docente para as instituições de Ensino Superior, 2) a qualificação dos professores da educação básica, 3) a especialização de profissionais para o mercado de trabalho público e privado e 4) a formação de técnicos e pesquisadores para empresas públicas e privadas. Em especial quanto às duas últimas vertentes, enfatiza a necessidade de estímulo ao “mestrado profissional”.

Em resumo, a partir dessa retrospectiva, pode-se concluir que a política de pós-graduação no Brasil tentou inicialmente capacitar os docentes das universidades, depois destacou o desempenho do sistema de pós-graduação, a seguir, o desenvolvimento da pesquisa na universidade, reforçando a pesquisa científica e tecnológica. Atualmente, para manter a expansão do sistema, enfatiza a necessidade de flexibilizar o modelo de PG e torná-la mais permeável a demandas da sociedade (CAPES, 2004, 15).

\footnotetext{
${ }^{35}$ Vale notar - ainda que não tenhamos a preocupação em detalhar a legislação, normas e resoluções que procuraram configurar o sistema de PG no Brasil - que um marco orientador da montagem do sistema de PG, conforme especialistas como Bortolozzi e Bergmann (s.d.), é o Parecer 977/65 (o "Parecer Sucupira", elaborado pelo Prof. Newton Sucupira) do Conselho Federal de Educação. O Parecer, inspirado no modelo norte-americano de PG, recomendava que este fosse utilizado como fonte de orientação para o sistema brasileiro. Porém, mesmo reconhecendo o baixo prestígio acadêmico que os mestrados brasileiros recebiam por parte dos norte-americanos e europeus, defendia este título. $\mathrm{O}$ argumento era que a autonomia desse nível da PG proporcionava maior competência científica ou profissional àqueles que não desejassem a carreira científica. De outro lado, esse Parecer já afirmava que o título de mestre não deveria ser uma condição indispensável para o ingresso em curso de doutorado.
} 
Sobre o tema das políticas públicas para a PG, o que é importante notar é que os pesquisadores da Comunicação ou os que migraram para ela aproveitaram, do mesmo modo que os das ciências sociais de maior tradição, os impulsos dessas políticas. Assim, começariam a construir instituições que abrigassem a pesquisa, já a partir dos anos de 1970.

De outro lado, o esforço foi facilitado pela pré-existência de cursos universitários ligados às profissões da área da Comunicação (Jornalismo, Cinema etc.), surgidos a partir do final dos anos de 1940. Houve ainda um aumento da demanda por esses profissionais por parte do mercado de trabalho no setor que, induzido pelo modelo de desenvolvimento adotado, adquiriu características industriais. Assim, como mostra Tabela 4.1, a seguir, as graduações da área cresceram progressivamente. No início, predominavam os cursos de Jornalismo, só a partir de 1963, com a criação do curso da Faculdade de Comunicação de Massa, na Universidade de Brasília (agregando estudos em Jornalismo, Cinema, Publicidade e RádioTelevisão), se difundiria o modelo "Escola de Comunicação”, ou seja, a nucleação de diferentes habilitações da área num mesmo âmbito.

Tabela 4.1 - Escolas/Cursos de Graduação em Comunicação no Brasil

\begin{tabular}{l|c|c}
\hline Ano & $\mathrm{N}$ & $\%$ \\
\hline Até 1950 & 8 & 1,5 \\
\hline 1960 & 23 & 3,5 \\
\hline 1970 & 58 & 9,5 \\
\hline 1980 & 66 & 10,5 \\
\hline 1990 & 120 & 19,0 \\
\hline 2005 & 348 & 56,0 \\
\hline Total & 623 & 100,0 \\
\hline
\end{tabular}

Fonte: Marques de Melo (1999) e Rojas e Ronderos N. (2005)

O já notável crescimento da oferta de cursos na passagem da década de 1960 à de 1970 (aumento de 252\%), evidenciado pela Tabela 4.1, se sustentaria nos anos posteriores, e o número de Escolas atualmente existentes, em termos percentuais, é maior do que toda a oferta anterior (56\% contra 44\%). O aumento verificado demandou a formação de um corpo docente para atender os cursos universitários e, por sua vez, influiu no poder de barganha dos que se voltaram à área da Comunicação, frente aos órgãos do governo responsáveis pela alocação de recursos para o setor de ensino e investigação. 
Pode-se dizer, que, analogamente à área de ciências sociais que conseguiu consolidar sua continuidade institucional mostrando-se empenhada "em contribuir na formação de docentes para o ensino secundário [na década de 1930]” (Miceli, 2001, 98), o que imperou foi a preocupação com a docência, no caso da Comunicação, com formação para a docência superior. A crítica de Werneck Vianna (1995) a este modelo de institucionalização das ciências sociais, por caracterizar-se pela precedência do ensino em relação à pesquisa, é pertinente. No entanto, é indiscutível o papel do ensino superior na expansão da PG.

Há uma realidade e um potencial de crescimento de matrículas no ensino de graduação como um todo, devido a uma confluência de fatores que permitiram ultrapassar a estagnação da década de 1980. Assim, no período 1990-2000, houve um crescimento da ordem de $75 \%$ na taxa de matrícula. Entre os aspectos, que permitiram falar numa “revolução silenciosa” (Schwartzman, 2000) no ensino superior, estão: o aumento das taxas de conclusão do ensino médio; as exigências do mercado de trabalho e as vantagens sociais e econômicas proporcionadas pela obtenção de um diploma de curso superior. Tais pontos mostram possibilidades para o crescimento da oferta de educação e, em conseqüência, para a formação de docentes qualificados. Assim, o texto do PNPG (20052010) nota que

a taxa bruta de matrícula se aproxima de $16 \%$ - 3,89 milhões de alunos matriculados [...] - o que evidencia a necessidade de sua expansão, considerando as metas do PNE. Por outro lado, deve-se assinalar que, no ano de 2003, dos 254.153 docentes que atuavam nesse nível de ensino, somente 54.487 (21,5\%) possuíam o doutorado e 89.228 (35,1\%) apenas o mestrado. (CAPES, 2004, 25)

Dessa forma, é possível prever ainda a continuidade do crescimento no setor educacional de graduação em Comunicação, tanto no plano do número de instituições, quanto no número de matrículas. Isso demandará novos docentes com títulos acadêmicos mais qualificados. Com efeito, é nas IES privadas - que já em 2003 detinham 73\% das matrículas no ensino de graduação - que existe o menor percentual de professores titulados no corpo docente. Nas IES do setor privado com fins lucrativos, conforme dados de 2003, apenas 9,3\% dos docentes eram doutores e 38,7\%, mestres. Já nas universidades federais $43,3 \%$ dos docentes possuíam o doutorado enquanto 28\%, somente o mestrado (CAPES, 2004, 25-6). 
Por outro lado, a despeito da estagnação das últimas décadas, o mercado de trabalho da comunicação, ou a expectativa profissionalizante, é o principal responsável pela dinâmica do ensino de graduação. Deve-se notar, em reforço a esse ponto, que as profissões da área (jornalista, publicitário etc.), surgidas num processo de institucionalização de ocupações através do ensino e regulamentações, consolidam-se, adquirindo estratificações internas em termos de atividades, prestígio e poder. Ainda que o caráter complexo do setor de comunicação, que envolve múltiplas competências, inviabilize (ao contrário do que ocorre em medicina ou direito, por exemplo) o monopólio das atividades pelos profissionais formados na área. Assim, existe um espaço para a competição interprofissional.

Mas, embora não haja o monopólio sobre o setor ocupacional, que seria um critério importante, de acordo com autores como Collins (apud Bonelli, 1993, 35), para perceber o poder de uma profissão, existem outros aspectos que evidenciam elementos de reforço da mesma. Desse modo, conforme ainda as delimitações básicas dos sociólogos voltados às profissões, afirma-se que adquirir um “conhecimento formal, abstrato, de nível superior é o consenso que se destaca” (Bonelli, 1993, 33), na demarcação profissional. Assim, o "profissionalismo" articula a formação especializada com o mercado, visto como um espaço onde diferentes corporações disputam posições. Em razão disso, importa notar que, apesar das críticas do setor midiático aos formados nos cursos de Comunicação e também dos próprios acadêmicos da área (ver Marques de Melo, 2000), os egressos têm conquistado espaços nos postos de trabalho da área e as Escolas, como visto, têm aumentado.

Do ponto de vista das informações sobre os formados e o mercado de trabalho, os dados não são recentes. Contudo, a mais ampla pesquisa realizada sobre o tema (Lopes, 1998a), mostrou que, entre os egressos dos anos 1989-1993, de 40 das 98 Escolas então existentes, 62\% trabalhavam na área de comunicação, enquanto 38\% estavam em "desvio" ocupacional (ou seja, abandonaram a área de formação em Comunicação por outra). Ainda que a situação de “desvio" não seja desprezível, os cursos de Comunicação pareciam atender a uma demanda profissional do mercado, ao inserir parte majoritária de seus formados no mesmo. 
Do ponto de vista da produção de conhecimento em Comunicação, em sua articulação com o ensino superior, o ponto mais importante a notar é justamente essa característica do curso de graduação resultar de uma profissionalização de ocupações antes aprendidas na prática. Tal aspecto, somado ao modelo norte-americano (instrumental e profissionalizante) de ensino adotado na graduação, no início e com continuidade até hoje, apresenta impasses e justifica diagnósticos críticos, como o de Lima (2001, 36):

essa profunda identificação entre ensino de graduação em comunicações e as práticas profissionais de jornalista, primeiro, e publicitário e relações públicas, posteriormente, é, sem dúvida, mais um fator que contribui para a existência de um universo teórico desarticulado e conflituoso no campo de estudo das comunicações

Notemos, porém, que a crítica a este aspecto é generalizada em termos mundiais, já que o

pragmatismo que caracteriza os estudos operatórios impregna cada vez mais as maneiras de se expressar da comunicação. Disso resulta que a área, como um todo, experimente uma crescente dificuldade em se libertar de sua imagem instrumental, conquistando uma verdadeira legitimidade como objeto de pesquisa integral e tratado como tal, com o distanciamento indissociável de um procedimento crítico. (Mattelart e Mattelart, 2005, 190)

No caso específico do Brasil, os conteúdos curriculares das graduações tendem a sermarcados por uma intencionalidade profissional, preocupada com a formação de peritos, expertos ou especialistas, "capazes de intervir na sociedade a partir do horizonte de inserção profissional específico” (Loviloso, 2002, 131). A natureza do currículo tende, pois, a ser diferente daquele mais voltado ao contexto acadêmico, no qual se forma antes para a pesquisa e a docência numa área do que para a intervenção social.

Digno de nota, justamente pela excepcionalidade, é o surgimento, a partir dos anos de 2000, de novos desenhos curriculares e também habilitações na área da Comunicação, como a habilitação em Midialogia da UNICAMP (iniciada em 2004) e o curso de Estudos Culturais e Mídia da UFF (com primeira turma em 2005). Nestas experiências, observa-se uma redefinição do curso de graduação em termos de um currículo acadêmico. Vemos esse processo de diferenciação, concordando com Loviloso (2002), como expressões de uma oferta menos geral no ensino de graduação na área. O autor exemplifica com o caso oposto de um curso de matemática que se volta à formação do perito em estatística.

No entanto, aceita a premissa de que é a demanda profissional que explica principalmente o crescimento das graduações, a questão do modo como se dá a circulação e reprodução do conhecimento gerado na PG da área não deixa de ser importante. Ao contrário, a 
articulação entre essas instâncias tenderia a ser produtiva. Seria um sinal de maturidade e consistência do campo científico da Comunicação, em sua relação com o subcampo do ensino, se a investigação realizada fosse efetivamente estudada e incorporada às ementas de cursos e currículos. Se bem equacionada essa questão, teríamos um indício pelo menos de um "campo maduro [que] se reconhece nos acordos que definem seu chão e os expressa no currículo de formação” (Loviloso, 2002, 128).

Isso está ligado não só a uma pesquisa voltada diretamente ao universo das profissões, mas ao "fundo comum" teórico que aportam os acadêmicos para a compreensão dos objetos, práticas e processos comunicacionais. Enfim, ao conhecimento que, sendo ou não produzido a partir de um interesse “aplicado”, possa tornar-se “aplicável”, em termos, tanto do ensino e sua intervenção social ("tecnologia social”), quanto para a sociedade (“esclarecimento social”). Ao mesmo tempo, é um desafio romper a dicotomia entre estudos “operatórios” e “críticos”, por meio, por exemplo, da exigência de reflexividade e rigor em qualquer investigação realizada na área. Essa preocupação também deve se constituir em termos da inculcação de um habitus no formando desde as graduações.

Por outro lado, a natureza profissional do currículo e da maioria do setor de graduação tem implicado em tensões e disputas entre diferentes áreas/habilitações quanto ao conhecimento válido produzido pela área. Argumentos profissionais ou pragmáticos mesclam-se a argumentos epistemológicos sobre o que se deve aprender/produzir e refletem-se, por sua vez, na estruturação de currículos. Essa é uma tendência na qual - na falta de consensos mínimos - a construção/fortalecimento do campo científico é também prejudicada. Pode resultar numa negativa fragmentação cognitiva, justificada, a partir do horizonte das profissões, por supostas impossibilidades de produção de conhecimento em Comunicação.

Como se enfatizou, os argumentos políticos e epistemológicos têm um peso importante na configuração de um campo científico, pois os agentes tendem a definir suas concepções sobre a ciência e o conhecimento a partir de seus interesses. E, na situação comentada, segundo nos parece, isso é claro. É na discussão e disputa, a um só tempo política e epistemológica, que se projeta a construção de consensos para a área da Comunicação de modo geral e também quanto à relação do campo científico com o subcampo do ensino de 
graduação. O relacionamento entre os mesmos - que pode ser avaliado, por exemplo, pelo número de Iniciações Científicas da área, análises das ementas dos cursos -, é uma condição importante para a superação dos impasses e dicotomias apontados.

De qualquer forma, voltando à dinâmica do mercado de trabalho, avalia-se a importância da mesma para o ensino de graduação pelo fato de que são os países com uma indústria cultural mais desenvolvida na América Latina os que possuem o maior número de Escolas de Comunicação. Conforme o levantamento de Rojas e Ronderos N. (2005, 49), o Brasil ocupa o primeiro lugar (348 Escolas, 35\% do todo), seguido pelo México (321, 31\%) e, bem depois, a Argentina, a Colômbia (55 Escolas, 5\% cada) e o Chile (54, 5\%), com os outros países perfazendo os restantes 19\% (193 Escolas). Porém, é importante notar que o Brasil possui uma das menores taxas de escolarização no ensino de graduação na América Latina $^{36}$.

As condições referidas - demandas da docência e de um setor de atividade econômica/ mercado de trabalho, somadas às políticas públicas de educação superior - impulsionaram o desenvolvimento dos cursos de PG em Comunicação, discutidos a seguir.

\footnotetext{
${ }^{36}$ Para efeito de comparação, os dados do biênio 1994-95 mostravam que, entre o grupo etário de 20 a 24 anos, o país possuía 11,4\% de estudantes em cursos de educação superior. Os três países com maior taxa de matrícula eram a Argentina (38,9\%), o Uruguai (29,9\%) e a Costa Rica (29,3\%) (García-Guadilha, 2002, 51). A despeito das referidas mudanças ocorridas em tempos mais recentes, o Brasil ainda está distante dos países que conseguem matricular mais estudantes percentualmente.
} 


\subsection{A Pós-Graduação em Comunicação no Brasil}

Tabela 4.2 - PPGCOM reconhecidos pela CAPES (2005)

\begin{tabular}{|c|c|c|c|c|c|}
\hline IES & Programa & UF & Mestrado & Doutorado & Tipo \\
\hline USP & Ciências da Comunicação & SP & 1972 & 1980 & Pública Estadual \\
\hline UFRJ & Comunicação & $\mathrm{RJ}$ & 1973 & 1983 & Pública Federal \\
\hline UnB & Comunicação & DF & 1974 & 2002 & Pública Federal \\
\hline PUCSP & Comunicação e Semiótica & SP & 1978 & 1981 & Privada Confes. \\
\hline UMESP & Comunicação Social & SP & 1978 & 1995 & Privada Confes. \\
\hline UNICAMP & Multimeios & SP & 1986 & 2000 & Pública Estadual \\
\hline UFBA & Com. Social e Cult. Contemporânea & BA & 1990 & 1995 & Pública Federal \\
\hline PUCRS & Comunicação Social & RS & 1994 & 1999 & Privada Confes. \\
\hline UNISINOS & Ciências da Comunicação & RS & 1994 & 1999 & Privada Confes. \\
\hline UFRGS & Comunicação e Informação & RS & 1995 & 2001 & Pública Federal \\
\hline UFMG & Comunicação Social & MG & 1995 & 2003 & Pública Federal \\
\hline UFF & Comunicação & RJ & 1997 & 2002 & Pública Federal \\
\hline UTP & Comunicação e Linguagens & PR & 2000 & - & Privada \\
\hline UFPE & Comunicação & PE & 2001 & - & Pública Federal \\
\hline UNIP & Comunicação & SP & 2001 & - & Privada \\
\hline UNIMAR & Comunicação & SP & 2002 & - & Privada \\
\hline UNESP & Comunicação & SP & 2002 & - & Pública Estadual \\
\hline PUCRJ & Comunicação & $\mathrm{RJ}$ & 2002 & - & Privada Confes. \\
\hline UERJ & Comunicação & RJ & 2002 & - & Pública Estadual \\
\hline UFSM & Comunicação & RS & 2005 & - & Pública Federal \\
\hline ESPM & Comunicação com o Mercado & SP & 2005 & - & Privada \\
\hline
\end{tabular}

Fonte: Capes/MEC (2005)

Conforme mostra a Tabela 4.2, existiam em $2005^{37}$, reconhecidos pela CAPES e em funcionamento 21 PPGCOM, sendo que a maioria (12 programas, correspondendo a 57\% do todo) oferecia os cursos de mestrado e doutorado, enquanto os demais (9: 43\%) só possuíam curso de mestrado. Vale observar a durabilidade dos cursos: salvo a experiência de um mestrado na Universidade Metodista de Piracicaba - UNIMEP (referida por Santaella, 1999), os programas que surgiram perduraram. Outros aspectos, como a dinâmica de crescimento da oferta e a distribuição regional, são evidenciados nas tabelas seguintes.

${ }^{37}$ Em 2006, mais quatro PPGCOM foram aprovados pela CAPES: o da Universidade Anhembi-Morumbi (UAMSP) da Pontifícia Universidade Católica de Minas Gerais (PUCMG), da Universidade Federal de Juiz de Fora (UFJF) e da Universidade Federal de Goiás (UFG). Como eles ainda não estão em funcionamento, não os colocamos na tabela e nem faremos observações sobre eles. Porém, é interessante notar que a maioria (três) é da região Sudeste. 
Tabela 4.3 - Ano do Início dos Cursos de Mestrado em Comunicação

\begin{tabular}{l|c|c}
\hline Ano & N & $\%$ \\
\hline Até 1974 & 3 & 14,5 \\
\hline De 1975 a 1990 & 4 & 19,0 \\
\hline De 1991 a 2000 & 6 & 28,5 \\
\hline De 2001 a 2005 & 8 & 38,0 \\
\hline Total & 21 & 100,0 \\
\hline
\end{tabular}

Fonte: Capes/MEC (2005)

Desde a criação do primeiro curso de mestrado (USP, 1972) até 1974 surgiram 3 PPGCOM com cursos deste nível (14,5\% dos mestrados criados). Para efeito de comparação, é interessante notar que até 1970 já existiam 7 cursos de mestrado em ciências sociais (Werneck Vianna et al., 1995, 29). Voltando aos dados da Comunicação, de 1975 a 1978 passaram a ser oferecidos mais dois cursos (PUCSP e UMESP) e apenas um curso surgiu durante a década de 1980 (UNICAMP, 1986). Dessa forma, são as décadas de 1990 e a seguinte que imprimiram um crescimento mais vigoroso à pósgraduação da área. Com efeito, no último período, de cinco anos, foram criados mais mestrados (8 cursos, 38\% dos mesmos) do que em qualquer outro dos períodos de tempo mostrados.

Assim, pode-se dizer que a dinâmica de crescimento da pós-graduação sustenta-a em parte, ou seja, a PG tem atuado na reprodução/incremento do sistema na área. Se, de um lado, isso se deve à absorção de docentes que se transferem dos programas mais tradicionais, de outro lado, corresponde à entrada no sistema de novos docentes.

Tabela 4.4 - Distribuição regional dos PPGCOM

\begin{tabular}{l|c|c|c|c|c|c}
\hline Ano/Região & CO & NE & NO & SE & S & Total (n) \\
\hline Até 1974 & 1 & - & - & 2 & - & $\mathbf{3}$ \\
\hline De 1975 a 1990 & - & 1 & - & 3 & - & 4 \\
\hline De 1991 a 2000 & - & - & - & 2 & 4 & $\mathbf{6}$ \\
\hline De 2001 a 2005 & - & 1 & - & 6 & 1 & $\mathbf{8}$ \\
\hline Total (n e \%) & $\mathbf{1 ( 4 \% )}$ & $\mathbf{2 ( 1 0 \% )}$ & - & $\mathbf{1 3 ( 6 2 \% )}$ & $\mathbf{5 ( 2 4 \% )}$ & $\mathbf{2 1 ( 1 0 0 \% )}$ \\
\hline
\end{tabular}

Fonte: Capes/MEC (2005)

A maioria dos PPGCOM situava-se na região Sudeste, com um total de 13 dos programas (62\% dos mesmos). Neste caso, os PPGCOM concentravam-se em São Paulo, com 8 programas (USP, PUCSP, UMESP, UNICAMP, com mestrado e doutorado, e UNIP, UNIMAR, UNESP e ESPM, somente com curso de mestrado), e Rio de Janeiro, com 4 
(UFRJ, UFF, PUCRJ e UERJ, os dois primeiros com mestrado e doutorado e os dois últimos com mestrado), enquanto Minas Gerais possui um (UFMG), com nível de doutorado relativamente recente (2003). À exceção do Espírito Santo todos os estados da região Sudeste possuíam centros de pós-graduação na área. O peso da região Sudeste e a conseqüente distribuição desigual dos programas de PG nas regiões do Brasil na área de Comunicação espelhavam uma situação geral. Assim, em 2004, 54,9\% dos cursos de mestrado e 66,6\% dos de doutorado do país situavam-se nessa região (CAPES, 2004, 31).

Por outro lado, a dispersão regional da PG em Comunicação se dá, sobretudo, a partir da década de 1990 e está mais voltada à região Sul (o que também ocorre no Brasil como um todo), que possuía, em 2005, 5 programas, em dois estados: Rio Grande do Sul (PUCRS, UNISINOS, UFRGS, com mestrado e doutorado e UFSM, com curso de mestrado; estes programas somaram 24\% do todo) e Paraná (UTP, curso de mestrado). Por fim, a região Nordeste possui 2 programas nas federais da Bahia (UFBA) e de Pernambuco (UFPE), que somou $10 \%$ do todo, sendo que o primeiro PPGCOM possuía os dois níveis de titulação, enquanto o segundo apenas o mestrado. Já a região Centro-Oeste, tinha um único programa, com curso de mestrado e doutorado, em Brasília, na UNB (correspondendo a 4\% do total). Nota-se ainda que não havia nenhum PPGCOM na região.

Tabela 4.5 - Natureza institucional das IES

\begin{tabular}{l|c|c|c|c|c}
\hline Ano/IES & $\begin{array}{c}\text { Pública } \\
\text { Federal }\end{array}$ & $\begin{array}{c}\text { Pública } \\
\text { Estadual }\end{array}$ & $\begin{array}{c}\text { Privada } \\
\text { Confes. }\end{array}$ & Privada & Total (n) \\
\hline Até 1974 & 2 & 1 & - & - & $\mathbf{3}$ \\
\hline De 1975 a 1990 & 1 & 1 & 2 & - & $\mathbf{4}$ \\
\hline De 1991 a 2000 & 3 & - & 2 & 1 & $\mathbf{6}$ \\
\hline De 2001 a 2005 & 2 & 2 & 1 & 3 & $\mathbf{8}$ \\
\hline Total (n e \%) & $\mathbf{8 ( 3 8 \% )}$ & $\mathbf{4 ( 1 9 \% )}$ & $\mathbf{5 ( 2 4 \% )}$ & $\mathbf{4 ( 1 9 \% )}$ & $\mathbf{2 1 ( 1 0 0 \% )}$ \\
\hline
\end{tabular}

Fonte: Capes/MEC (2005)

O início da pós-graduação em Comunicação é caracterizado pelo papel das instituições públicas federais, que somavam, em 2005, 8 programas (38\% do todo) e estaduais (4 programas, $19 \%$ dos cursos). Num segundo momento, as privadas confessionais passam também a criar cursos, sendo o tipo de instituição com o segundo maior número (5 programas, 24\% dos mesmos). É só a partir de 2000 (com a UTP) que o setor privado não confessional passa a ofertar pós-graduações em Comunicação, porém ele é o que mais cresceu, em termos de oferta, nos últimos anos, possuindo, em 2005, 4 PPGCOM (19\% do 
todo). Esta, por sinal, tem sido uma tendência do sistema de PG no Brasil nos últimos anos, pois embora o segmento público seja responsável por $82 \%$ da oferta dos cursos de mestrado e por $90 \%$ dos cursos de doutorado, o setor privado cresceu, passando de 87 cursos para 346 no mestrado e de 44 para 96 no doutorado, no período de 1996 a 2004 (CAPES, 2004, 28).

É possível concluir, conforme os dados apresentados, que ainda existe margem para expansão, em termos do número de programas, do ensino de pós-graduação em Comunicação, ressaltando que isso se deve, por um lado, à incompleta formação de uma rede nacional de ensino/pesquisa - que abranja todas as regiões do país e com maior equilíbrio entre as mesmas. Situação na qual talvez sejam ainda criados outros programas fora das capitais de alguns estados.

De outro lado, as políticas do Ministério da Educação para o ensino superior continuam sendo um incentivo à expansão - ou, no mínimo, a que os atuais programas completem o ciclo de formação pós-graduada, ou seja, os 9 PPGCOM que só possuíam em 2005 o mestrado instalem também cursos de doutorado. Isso ocorre porque nas IES sob controle direto do MEC - as universidades federais - foram implantados ao longo do tempo regimes de carreira docente que incentivaram à formação de nível pós-graduado. Ao mesmo tempo, o Ministério atua no sentido de garantir números mínimos de docentes com o título de mestre ou doutor em todas as IES do país ${ }^{38}$.

Com efeito, sabe-se que parte da clientela da PG das IES privadas consiste, muitas vezes, justamente em indivíduos pertencentes ao corpo docente da graduação dessas instituições. Porém, principalmente para essas IES, dada sua menor tradição, haverá o desafio da continuidade e estabelecimento de diferenciais acadêmicos capazes de garantir a continuidade dos programas, passada uma fase inicial de "formação interna" de quadros. O regime de concorrência que se estabelecesse nas regiões Sudeste e Sul tende a provocar um acirramento da competição por alunos e verbas públicas para pesquisas, o que deve

\footnotetext{
${ }^{38}$ A Lei de Diretrizes e Bases da Educação (LDB - Lei 9.394/96) indica que, nas universidades, pelo menos um terço dos docentes deve ter este nível de titulação, além de que também um terço possua dedicação integral. E o projeto de reforma universitária do Ministério da Educação, atualmente numa etapa final de discussão, eleva a proporção para metade do corpo docente nas universidades e introduz a exigência de um terço nos centros universitários e nas faculdades.
} 
produzir efeitos na estruturação dos cursos e, consequentemente, do subcampo de ensino de PG.

Nesse sentido, note-se que o formato "mestrado profissional" ainda não foi adotado por nenhum dos programas. É possível que isso ocorra, dependendo das condições de oferta e demanda que se verifiquem no futuro próximo. Porém, as atuais Áreas de Concentração dos programas, de modo geral, não demonstram um viés para esse tipo de curso, cuja interface com os interesses da formação profissional e do mercado são evidentes. Uma análise das Linhas de Pesquisa dos programas (conforme se poderá ver no Capítulo 6) torna mais clara essa afirmação. Por outro lado, a produção de teses e dissertações (discutida também no Capítulo 6) apresenta, em parte, preocupações quanto aos meios e aspectos profissionais que talvez a enquadrem no formato "profissional” - aspecto, porém, que merece maior debate. Inclusive em suas relações com o padrão de conhecimento que deva ser considerado pertinente ao campo de estudos.

Loviloso $(2002,137)$ argumenta, por exemplo, que um dos possíveis acordos que poderiam ser construídos na área, a fim de aumentar a identidade acadêmica da mesma, seria o reconhecimento da vontade da formação de peritos em pós-graduações profissionalizantes, que seriam orientadas para a inovação em termos de processos e produtos da comunicação mediada. Neste caso, a pesquisa iria desempenhar um papel de mediação para se atingirem os objetivos. É provável que esse argumento encontre respaldo no grupo de pesquisadores da área. Restaria, é claro, que o projeto fosse assumido por determinados sujeitos.

A continuação da proposta do autor, porém, é mais controversa. Segundo ele, deve-se presumir que as PG são apenas um modo prático e artificial de organização de portadores de diferentes saberes disciplinares, interessados na comunicação mediada. Tais estudos, contudo, podem ser realizados também em outras áreas disciplinares. Assim, dever-se-ia apostar "que a organização prática [na área da Comunicação] possibilite que cheguemos, talvez algum dia, a acordos sobre teorias e os objetos” (Loviloso, 2002, 137). O autor chega, assim, até a criticar a escolha de pesquisadores pela formação em Comunicação. “A titulação não deve importar pois é um critério meramente formal. O significativo é o compromisso com a pesquisa na área que se expressa na produção e no conhecimento" (idem, 140, grifo nosso). A “epistemologia prática” ao qual o autor refere-se seria, 
portanto, centrar os olhares na prática dos seus participantes, mais do que na relação sujeito/objeto dos fenômenos que, supostamente, entrem no campo de pesquisa.

O problema desse argumento, no nosso entender, é que tende a acomodar os conflitos. Isso porque, ao invés de colocar as diferentes posições em confronto, fixa posições talvez irreconciliáveis sem que se dê conteúdo mais forte ao que se possa entender como “compromisso com a pesquisa na área”. Ora, se de fato admite-se que outras disciplinares podem abordar a comunicação mediada, porque seria necessário que houvesse uma área que talvez nada acrescentasse? Claro, os termos de Loviloso não são esses, trata-se somente de uma radicalização do argumento. Todavia, em nosso juízo, essa proposta tende favorecer - dada a já ampla margem que mesmo a pesquisa da comunicação mediada admite - um modelo segmental de organização do grupo. Seria, pois, algo debilitante a um fortalecimento do campo científico. Ficam prejudicados elementos como o controle entrecruzado interno ao grupo, dada a possível ausência de contatos.

A despeito da real importância da análise do que se pesquisa e de como é feita a investigação no campo científico da Comunicação, proposta por Loviloso, isso deve ensejar igualmente propostas sobre consensos teóricos, e as margens aceitáveis de dissenso, como o autor também afirma. Mas talvez seja mais útil que a questão seja colocada em termos de uma agenda efetiva, não em “algum dia”. Isso não significa resolver os impasses de uma hora para outra. Mas é por isso mesmo que se, como o autor nota, os “enredos e intrigas se montam em contextos institucionais” (Loviloso, 2002, 137), seria útil utilizar esses mesmos contextos - em seus âmbitos de debate e discussão críticos - para avançar em propostas de fortalecimento do campo científico da Comunicação, neutralizando ou minimizando o aspecto negativo dos “enredos e intrigas”.

Finalizando as observações sobre os PPGCOM, os dados apresentados sugerem ainda que, no estágio atual, a formação dos pesquisadores nos dois primeiros níveis de titulação da PG em Comunicação tende a ser feita no próprio país, preferencialmente. Isso corresponde a uma situação mais geral, na qual uma rede de ensino de qualidade já instalada possui maior autonomia e capacidade de formação. Assim, as políticas das agências de fomento estimulam antes o doutorado feito no Brasil, com estágio no exterior (bolsa sanduíche), do que a realização plena deste curso no exterior. Situação diferente do que ocorria até pelo 
menos os anos de 1980. Com efeito, um levantamento sobre a titulação de pesquisadores cadastrados no diretório de grupos de pesquisa do CNPq mostrou que $40 \%$ dos titulados até 1985 doutoraram-se no exterior, enquanto, entre os que se formaram na segunda metade dos anos 90, menos de 20\% havia obtido este título fora do país (Velloso, 2004, 585).

Nesse aspecto - de autonomização do doutorado com respeito ao exterior, pela capacitação interna - vale notar o papel “formador” dos primeiros PPGCOM, em particular o da USP e o da UFRJ. Estes programas ainda hoje, junto ao programa da PUCSP, são os que mais titulam mestres e doutores. É possível pensar, desse modo, que uma das razões que explica o intervalo de tempo entre o crescimento da dinâmica de criação de programas e os primeiros cursos se deve ao tempo de realização de mestrados e doutorados no país. Essa interpretação é convalidada em parte pelo grande número de docentes atuais dos programas que possuem doutorado em Comunicação feito no Brasil - conforme se mostra no tópico seguinte.

Também significativo é o fato de que a maior parte dos egressos de mestrado (53\%) e de doutorado (64\%) em Comunicação, dos anos de 1994-1998, passaram a dedicar-se de modo integral a carreiras universitárias (Lopes, 2001, 139). Esses percentuais podem ser comparados com os de Velloso (apud Capes 2004, 45), que mostram que os destinos dos egressos formados na PG na década de 1990 são variados (administração/serviços públicos, consultorias, empresas públicas ou privadas, entre outros), porém, a universidade também era o destino principal para os mestres (34,5\%) e mais ainda para os doutores (68,8\%). Como se nota, o "valor" acadêmico do mestrado, como instrumento de acesso a carreiras acadêmicas, era maior em Comunicação - provavelmente pela carência de doutores naquele momento - do que de modo geral.

Já os índices dos egressos de doutorado em Comunicação e da PG como um todo que se encontravam em ocupação nas universidades era mais próximo, nos dois contextos (64\% em Comunicação e 68,8\% na PG de modo geral). É possível que hoje o percentual de egressos de mestrado com carreira universitária seja mais similar à média geral. A respeito desses dados, é importante notar ainda que o diagnóstico sobre os destinos profissionais é 
um dos argumentos do PNPG 2005-2010 para estimular a flexibilização do sistema. Aspecto que admite duas interpretações, como discute Velloso (2002, 609):

Para alguns, ela significaria ampliar a oferta da modalidade profissional, voltada para o trabalho fora da academia e tipicamente com caráter terminal; para outros significaria, no interior de programas com vocação acadêmica, ampliar o leque de opções ofertadas, conforme o provável destino do estudante. Escolhas apropriadas seguramente dependem da área envolvida - ou grupo de áreas.

Por fim, antes de prosseguir para o próximo tópico, no qual são caracterizados os agentes do sistema de ensino e pesquisa, é importante notar - conforme mostra a Tabela 4.6, com dados de 2005 - que há uma situação similar à do ensino de graduação em Comunicação, no tocante à conformação dos PPGCOM na América Latina.

Tabela 4.6 - PPGCOM na América Latina por país e nível

\begin{tabular}{l|c|c|c|c}
\hline Países / Cursos & Mestrado & Doutorado & Total (n) & Total (\%) \\
\hline Brasil & 12 & 19 & 31 & $\mathbf{2 8}$ \\
\hline México & 25 & 6 & 31 & $\mathbf{2 8}$ \\
\hline Argentina & 15 & 4 & 19 & $\mathbf{1 7}$ \\
\hline Chile & 7 & - & 7 & $\mathbf{6 , 5}$ \\
\hline Peru & 4 & - & 4 & $\mathbf{3 , 5}$ \\
\hline Bolívia & 4 & - & 4 & $\mathbf{2 , 5}$ \\
\hline Cuba & 2 & 1 & 3 & $\mathbf{2 , 5}$ \\
\hline Venezuela & 3 & - & 3 & $\mathbf{2 , 5}$ \\
\hline Costa Rica & 3 & - & 3 & $\mathbf{2 , 0}$ \\
\hline Porto Rico & 2 & - & 2 & $\mathbf{1 , 0}$ \\
\hline República Dominicana & 1 & - & 1 & $\mathbf{1 , 0}$ \\
\hline Colômbia & 1 & - & 1 & $\mathbf{1 , 0}$ \\
\hline Equador & 1 & - & 1 & $\mathbf{1 , 0}$ \\
\hline Uruguai & 1 & - & 1 & $\mathbf{1 0 0 , 0}$ \\
\hline Total (n e \%) & $\mathbf{8 1}(\mathbf{7 3 , 0 \% )}$ & $\mathbf{3 1}(\mathbf{2 7 , 0 \% )}$ & $\mathbf{1 1 1 ( \mathbf { 1 0 0 , 0 } \% )}$ \\
\hline
\end{tabular}

Fonte: Rojas e Ronderos N. (2005)

O Brasil e o México possuem o mesmo número de cursos (31, correspondendo a 28\% cada), diferenciando-se, porém, quanto ao doutorado: bem maior no Brasil do que no México (19 cursos versus 6). O terceiro país em número de cursos é a Argentina, com 19 (17\%) no todo (15 de mestrado e 6 de doutorado). Estes três países, portanto, concentram a grande maioria dos cursos (73\%). Um grupo de países em posição intermediária é composto pelo Chile (7 cursos de mestrado), Peru e Bolívia (ambos com 4 mestrados), Cuba, que se singulariza por possuir um curso de doutorado e possui 2 de mestrado, Venezuela e Porto Rico (ambos com 3 cursos de mestrado) e Porto Rico (2 mestrados). Este grupo totaliza $23 \%$ da oferta de cursos de pós-graduação. Um último conjunto é 
formado pelos países com apenas um curso de mestrado em Comunicação (República Dominicana, Colômbia, Equador e Uruguai), que corresponde a 4\% do total de cursos.

De outro lado, a comparação do número de estudantes da PG na América Latina, durante o biênio 1994-95, mostrava que o Brasil tinha bem mais estudantes desse nível. Assim, os 15.672 alunos de doutorado brasileiros correspondiam a 71\% do total (de 22.094 alunos) e os 38.949 alunos de mestrado equivaliam a 38\% do todo (101.968). O único país que se aproximava do Brasil era justamente o México, sobretudo em relação ao número de alunos de mestrado (31.190, ainda assim menor que o brasileiro), já os matriculados em doutorado eram bem menos (2.151) (García-Guadilha, 2002, 52-3). Tal aspecto explica parcialmente o próprio dado da Tabela 4.6 sobre a oferta de cursos pós-graduados de Comunicação.

\subsection{A população estudantil dos PPGCOM}

As instituições não funcionam sem agentes que garantam sua reprodução e potencial expansão, no caso dos PPG, a população estudantil e o corpo docente dos mesmos. O número alcançado por esses sujeitos indica ainda o peso ocupado pela PG da área dentro do sistema geral. Assim, esse tópico concentra-se na análise de dados sobre os titulados da área e o próximo abordará o corpo docente dos PPGCOM. Vale reforçar, que a área da Comunicação historicamente situa-se, dentro das taxonomias das agências de fomento, na Grande Área de Ciências Sociais Aplicadas. A expressão que essa Grande Área alcança no sistema é mostrada na Tabela 4.7. A tabela seguinte, por sua vez, detalha as áreas que compõem as Grandes Áreas voltadas às ciências sociais e humanas. 
Tabela 4.7 - Titulados por Área de Conhecimento (2003)

\begin{tabular}{l|c|c|c|c|c}
\hline Área do Conhecimento & $\mathbf{M}$ & $\mathbf{D}$ & $\mathbf{P}$ & Total (n) & Total (\%) \\
\hline Ciências Sociais Aplicadas & 4.532 & 736 & 622 & 5.890 & $\mathbf{1 6 , 5}$ \\
\hline Ciências Humanas & 4.480 & 1.283 & 80 & 5.843 & $\mathbf{1 6 , 5}$ \\
\hline Ciências da Saúde & 3.926 & 1.549 & 260 & 5.735 & $\mathbf{1 6 , 0}$ \\
\hline Engenharias & 3.514 & 1.023 & 284 & 4.821 & $\mathbf{1 3 , 5}$ \\
\hline Ciências Agrárias & 2.567 & 1.026 & 10 & 3.603 & $\mathbf{1 0 , 0}$ \\
\hline Ciências Exatas e da Terra & 2.358 & 913 & 50 & 3.321 & $\mathbf{9 , 5}$ \\
\hline Ciências Biológicas & 1.919 & 1.028 & 8 & 2.955 & $\mathbf{8 , 0}$ \\
\hline Lingüística, Letras e Artes & 1.606 & 415 & 9 & 2.030 & $\mathbf{5 , 5}$ \\
\hline Ensino \& Multidisciplinares & 1.094 & 121 & 329 & 1.544 & $\mathbf{4 , 5}$ \\
\hline Total & $\mathbf{2 5 . 9 9 6}(\mathbf{7 3 , 0 \% )}$ & $\mathbf{8 . 0 9 4}(\mathbf{2 2 , 5 \% )}$ & $\mathbf{1 . 6 5 2}(\mathbf{4 , 5 \% )}$ & $\mathbf{3 5 . 7 4 2}$ & $\mathbf{1 0 0 , 0}$ \\
\hline
\end{tabular}

Fonte: Capes/MEC (2005) - M: mestrado, D: doutorado, P: mestrado profissional

Em relação aos dados de 2003, o contingente de titulados na Grande Área de Ciências Sociais Aplicadas foi quase o mesmo que na de Ciências Humanas, cerca de 5,8 mil, correspondendo a 16,5\%, cada, do todo. Ambas ocupam, portanto, o primeiro lugar quanto ao número de titulados no período, seguidas de perto pela Grande Área de Ciências da Saúde (16\%), Engenharias (13,5\%), e num grupo intermediário, Ciências Agrárias (10\%), Ciências Exatas e da Terra (9,5\%) e Ciências Biológicas (8\%).

Observa-se ainda, na comparação entre as duas grandes áreas no topo, um maior número de alunos formados no doutorado em Ciências Humanas do que em Ciências Sociais Aplicadas (1.283 versus 736), o contrário ocorre quanto ao mestrado profissional, com peso bem maior nesta do que nas Humanas (622 alunos contra 80). A soma percentual dos títulos nas grandes áreas de Ciências Sociais e Humanas, de maneira geral (incluindo Lingüística, Letras e Artes), é de 38,5\%, contra 57\% das outras Grandes Áreas, com a exclusão de Ensino \& Multidisciplinares (4,5\%). 
Tabela 4.8 - Titulados em Ciências Sociais Aplicadas e Ciências Humanas (2003)

\begin{tabular}{|c|c|c|c|c|c|}
\hline Áreas & M & D & $\mathbf{P}$ & Total (n) & Total (\%) \\
\hline Ciências Sociais Aplicadas & 4.532 & 736 & 622 & 5.890 & 50,0 \\
\hline Direito & 1.797 & 243 & 0 & 2.040 & 17,5 \\
\hline Administração & 1.062 & 87 & 410 & 1.559 & 13,0 \\
\hline Economia & 425 & 101 & 201 & 727 & 6,0 \\
\hline Comunicação & 496 & 172 & 0 & 668 & 5,5 \\
\hline Arquitetura e Urbanismo & 283 & 50 & 0 & 333 & 3,0 \\
\hline Serviço Social & 226 & 44 & 0 & 270 & 2,0 \\
\hline Ciência da Informação & 64 & 19 & 0 & 83 & 1,0 \\
\hline Planejamento Urbano e Reg. & 106 & 10 & 11 & 127 & 1,0 \\
\hline Desenho Industrial & 38 & 0 & 0 & 38 & 0,5 \\
\hline Turismo & 31 & 0 & 0 & 31 & 0,5 \\
\hline Demografia & 4 & 10 & 0 & 14 & 0,0 \\
\hline Ciências Humanas & 4.480 & 1.283 & 80 & 5.843 & 50,0 \\
\hline Educação & 1.883 & 419 & 0 & 2.302 & 20,0 \\
\hline Psicologia & 809 & 223 & 0 & 1.032 & 9,0 \\
\hline Sociologia & 415 & 206 & 12 & 633 & 5,0 \\
\hline História & 433 & 193 & 0 & 626 & 5,0 \\
\hline Geografia & 323 & 75 & 0 & 398 & 3,5 \\
\hline Filosofia & 249 & 77 & 0 & 326 & 3,0 \\
\hline Antropologia & 107 & 35 & 20 & 162 & 1,5 \\
\hline Ciência Política & 119 & 28 & 36 & 183 & 1,5 \\
\hline Teologia & 142 & 27 & 12 & 181 & 1,5 \\
\hline Arqueologia & 0 & 0 & 0 & 0 & 0,0 \\
\hline Total (n e \%) & $7.667(78,0 \%)$ & $1.882(19,0 \%)$ & $292(3,0 \%)$ & $9.841(100,0 \%)$ & 100,0 \\
\hline
\end{tabular}

Fonte: Capes/MEC (2005) - M: mestrado, D: doutorado, P: mestrado profissional

A constituição de um grupo geral para as Ciências Sociais e Humanas, composto pelas Grandes Áreas de Ciências Sociais Aplicadas e Ciências Humanas, evidencia o já referido equilíbrio quanto ao número de titulados de ambas. O número de áreas dessas Grandes Áreas também é similar (11 em Ciências Sociais Aplicadas, e 10 em Ciências Humanas). E o desdobramento da Grande Área de Ciências Sociais Aplicadas mostra que ela não compreende somente áreas com menor tradição acadêmica - que se poderiam chamar de os "novos conhecimentos” da modernidade, pois, se não, Economia ou Direito não estariam inclusas na mesma. Ela possui, como elementos de unidade, o fato de que as áreas agrupadas possuem campos profissionais voltados ao mercado, caracterizando-se, assim, por um teor de conhecimento, em tese, mais "profissional" do que "propedêutico". O contrário ocorre com a Grande Área de Ciências Humanas (a despeito, de algumas áreas, como a Educação, possuírem também dimensões de intervenção social). Não é por outro motivo, aliás, que os titulados em mestrados profissionais são em número bem mais elevado na área de Ciências Sociais Aplicadas do que em Humanas - 622 e 80, respectivamente. 
Por outro lado, deve-se notar que o conjunto de áreas reunidas em Ciências Humanas tende antes ao sentido de "ciências sociais" do que o de "humanidades" - conforme o sentido desses termos no mundo anglo-saxão (vide Schwartzman, 1997, 59-60). As “humanidades”, nesse sentido, estariam mais contempladas na Grande Área Lingüística, Letras e Artes.

Um dado geral que a Tabela 4.8 mostra é que são formados mais mestres (no formato acadêmico e profissional) do que doutores. Estes somam 1.882 titulados (19\%), enquanto os que cursaram mestrados foram 7.667 (78\%) no modelo acadêmico e 292 (3\%) no profissional. Percebe-se ainda que nenhuma área titula mais no nível de doutorado do que no mestrado, o que dá margem a continuidade do fluxo de estudantes para o grau mais elevado.

Já em termos de posicionamento das áreas quanto aos titulados (notando que o que interessa perceber é como a área da Comunicação se situa nesse quadro), o primeiro lugar, no todo, é ocupado pela área de Educação, que formou 1.883 mestres e 419 doutores, que somam 2.302 titulados (20\% do percentual total de titulados nas duas grandes áreas). Em segundo lugar, vem uma área das Ciências Sociais Aplicadas, Direito, titulando 2.040 estudantes (17,5\% do total), sendo 1.797 em cursos de mestrado e 243 em doutorados. A seguir, mais uma área das Ciências Sociais Aplicadas, Administração, que possui como diferencial frente às outras áreas grande número de titulados no formato mestrado profissionalizante (410), e forma 87 doutores e 1.062 mestres, totalizando 1.559 egressos (13\%). Ainda no grupo das áreas que mais titularam, Psicologia ocupa a quarta posição, com 1.032 concluintes de curso de PG (9\% do todo), sendo 809 de mestrado e 223 de doutorado.

Com 5,5\% do total de titulados (496 mestres, 172 doutores, num total de 668 egressos) neste conjunto a área da Comunicação situa-se num grupo intermediário, composto por áreas que alcançam entre 6\% do total de alunos (Economia), 5\% (Sociologia e História), 3,5\% (Geografia), 3\% (Arquitetura e Urbanismo, e Filosofia). Um último grupo pode ser composto pelas oito áreas que titulam de $2 \%$ (Serviço Social) a menos: 1,5\% (Antropologia, Ciência Política e Teologia), 1\% (Ciência da Informação e Planejamento Urbano e Regional) e 0,5\% (Desenho Industrial e Turismo). 
Para efeito da análise de tendências, e em razão da maior semelhança numérica quanto ao número de titulados, observada em 2003, com os titulados em Comunicação, optou-se pela comparação com duas áreas das Ciências Sociais Aplicadas (Economia e Arquitetura e Urbanismo) e duas das Ciências Humanas (História e Sociologia). Os resultados são mostrados na Tabela 4.9, a seguir.

Tabela 4.9 - Titulados em Comunicação, Economia, Arquitetura e Urbanismo, História e Sociologia no qüinqüênio 1999-2003

\begin{tabular}{|c|c|c|c|c|c|c|c|c|c|c|c|c|c|c|c|}
\hline \multirow{2}{*}{$\begin{array}{l}\text { Titulados } \\
\text { por Ano I } \\
\text { Áreas }\end{array}$} & \multicolumn{3}{|c|}{1999} & \multicolumn{3}{|c|}{2000} & \multicolumn{3}{|c|}{2001} & \multicolumn{3}{|c|}{2002} & \multicolumn{3}{|c|}{2003} \\
\hline & M & D & $\mathbf{P}$ & M & D & $\mathbf{P}$ & M & D & $\mathbf{P}$ & M & D & $\mathbf{P}$ & M & D & $\mathbf{P}$ \\
\hline Comunicação & 282 & 87 & 0 & 350 & 100 & 0 & 411 & 105 & 0 & 522 & 178 & 0 & 496 & 172 & 0 \\
\hline Economia & 281 & 55 & 8 & 344 & 74 & 29 & 365 & 75 & 38 & 391 & 93 & 90 & 425 & 101 & 201 \\
\hline $\begin{array}{l}\text { Arquitetura e } \\
\text { Urbanismo }\end{array}$ & 163 & 41 & 0 & 192 & 37 & 0 & 198 & 29 & 0 & 231 & 55 & 0 & 283 & 50 & 0 \\
\hline Sociologia & 264 & 134 & 0 & 275 & 140 & 0 & 265 & 151 & 0 & 423 & 161 & 10 & 415 & 206 & 12 \\
\hline História & 300 & 121 & 0 & 371 & 121 & 0 & 406 & 173 & 0 & 533 & 200 & 0 & 433 & 193 & 0 \\
\hline
\end{tabular}

Fonte: Capes/MEC (2005) - M: mestrado, D: doutorado, P: mestrado profissional

Quanto aos dados da Tabela 4.9, sobre a titulação em várias áreas no qüinqüênio 19992003, deve-se notar primeiramente que esse espaço de tempo diminui, em grande medida, o problema da análise comparada do fluxo de egressos, que pode variar bastante de um ano a outro. Assim, o que se mostra mais claramente, comparando-se os extremos de tempo, é o fato de todas as áreas apresentarem crescimento no período em questão. No caso da Comunicação, passou-se de 282 titulados no mestrado em 1999 a 496 em 2003 (aumento de 76\%), e de 87 para 172 nos egressos de doutorado (+98\%). A situação de crescimento também ocorreu, nestes graus de titulação, nas outras áreas, assim, cresceram a Economia (M: +52\%, D: +84\%), a área de Arquitetura e Urbanismo (M: +74\%, D: +22\%), Sociologia (M: +57, D: +53\%) e História (M: +44\%, D: +59\%).

Dessa forma, comparando-se essas áreas com a média geral de crescimento da PG no Brasil $^{39}$, cujo crescimento, também quanto aos alunos titulados, no nível de mestrado foi de 79,5\% e no de doutorado, 67\%, no mesmo período, nota-se que a área da Comunicação situa-se próxima desse patamar no mestrado e supera-o no doutorado. Assim, teve-se um crescimento da ordem de $76 \%$ no mestrado e de $98 \%$ no doutorado. Em termos

\footnotetext{
${ }^{39}$ Na qual foram titulados 15.380 em 1999 e 27.630 em 2003, no nível de mestrado, e 4.853 em 1999 e 8.094 em 2003, nos cursos de doutorado (CAPES, 2004, 29-30).
} 
comparados com as outras áreas similares aqui agrupadas, cresceu mais do que todas nesses níveis. Porém, isso talvez se deva ao fato de que, principalmente quando comparada a áreas mais consolidadas como Sociologia e História, possuía maior potencial. De outro lado, o que faz com que a área da Economia tenha, no todo, mais titulados do que a Comunicação é o crescimento do formato do mestrado profissional, cujo número de titulados aumentou consideravelmente (passando de 8 alunos, em 1999, a 201, em 2003).

Numa séria histórica mais ampla, de 1987 a 2003, para o conjunto de todas as áreas, o número de titulados no mestrado aumentou em 757\% e o de doutorado em 932\% (CAPES, 2004, 29-30). Nesse caso, percebe-se que a área da Comunicação teve um crescimento de 870\% nos titulados de mestrado (de 57, em 1983 a 496, em 2003), e de 1128\% (de 14 a 172) nos de doutorado, situando-se, pois, acima da média geral de titulados nesses níveis.

Considerando-se as linhas prováveis de expansão do ensino pós-graduado em Comunicação, o número de titulados nos níveis de mestrado e doutorado deve continuar a aumentar. Isso deve ocorrer, em primeiro lugar, pois 9 programas surgiram desde 2000, e três ainda não formaram turmas. Ademais, como se discutiu, há espaço para o surgimento de novos PPGCOM, bem como para a introdução do formato do mestrado profissional nos programas já existentes ou a serem criados. Dessa forma, é possível que, num prognóstico conservador, sejam criados novos cursos no Nordeste e na região Centro-Oeste. A tendência de crescimento no acesso ao doutorado, além do que já foi dito, será provavelmente incrementada pelo menor tempo de permanência de alunos no mestrado, ajustando-se às recomendações das agências.

Ao mesmo tempo, o movimento expansivo que ocorrerá na área da Comunicação, tendo como esteios a questão do ensino (de graduação e pós) e qualificação docente encontrará uma barreira no próprio limite dessas urgências: em algum momento os novos profissionais irão saturar o mercado da docência. A questão sobre o quando isso irá ocorrer é particularmente complexa dada a vocação “aberta” e receptiva da Comunicação a formados em outras áreas.

O caráter interdisciplinar que os estudos em Comunicação assumiram no Brasil, bem como a natureza dos objetos que a área aborda, desde seu início, implicou nessa atitude. Porém, a 
pergunta relevante e se a situação de concorrência que será estabelecida nos próximos anos, com maior intensidade, poderá levar a uma mudança de atitude. E, se sim, em que sentido? Notemos aqui como de questões “institucionais” decorrem aspectos "cognitivos”.

É possível imaginar, pelo menos, dois cenários para responder a essas indagações. Um no qual o docente ou pesquisador abrigado em instituições de ensino/investigação na área da Comunicação, em razão da concorrência que passará a ocorrer com mais intensidade, seja obrigado a mostrar um pertencimento ao campo de modo mais sólido ou definido (por exemplo, participando das instâncias legítimas do campo: congressos, publicações etc.), construindo nexos trans/multi/interdisciplinares de modo mais justificado - ressaltando ainda a centralidade de seu conceito de Comunicação na investigação - e produzindo um conhecimento que seja reconhecido pela área.

Nesse cenário, o campo de estudos poderia se fortalecer assumindo esse viés ainda aberto a outros saberes, em diálogo com os mesmos, a partir de uma "justificação” das interfaces válidas para os problemas comunicacionais, medida, por exemplo, a partir do "rigor" com que suas respostas aos problemas investigados caracterizem a pesquisa. Desse modo, seria cobrado menos o lugar (a titulação) de onde o pesquisador parte, do que os resultados, avaliados a partir de critérios comuns, de pesquisa.

Num outro cenário, de teor menos otimista, a disputa concorrencial por postos pode terminar assumindo teor corporativista, levando a um "fechamento" do campo em torno de um conceito de comunicação cuja hegemonia dar-se-ia menos por justificativas lógicas ou argumentos numa discussão racional do que pela possibilidade de excluir os não egressos da pós-graduação (e mesmo da graduação) da área. O movimento mais simples dessa operação seria subsumir o(s) conceito(s) que conformam os estudos de Comunicação hoje por uma definição eminentemente profissional.

Tal situação poderia ser justificada possivelmente pelo caráter “aplicado” da área conforme as taxonomias usuais e os aspectos que já discutimos. Paradoxalmente uma situação como essa levaria, se não a uma perda da dimensão de diálogo com a sociedade, à produção de um "conhecimento aplicado" potencialmente de menor impacto e menos crítico. Isso porque vários dos âmbitos sociais nos quais os pesquisadores da Comunicação 
têm logrado desenvolver uma orientação voltada à resposta de problemas sociais afinados com as questões candentes do país não um possuem arsenal teórico suficiente (em termos comunicacionais), para qualificar a intervenção. E, talvez em certas áreas, nunca possuam inteiramente - sendo imprescindível o diálogo com outras disciplinas. Num contexto mais específico, a respeito desse ponto, é possível pensar, por exemplo, em áreas como a educação e a saúde, nas quais já existe uma interação - traduzida em ações, práticas e saberes - que seria inviabilizada, em parte, por um “fechamento” da Comunicação.

Os dois cenários são talvez excludentes, quer dizer, a convivência entre características do primeiro com elementos do segundo são difíceis, quase implicando uma tensão que, se ocorrer, poderá fragmentar o campo de estudos no futuro. É claro que a prevalência de uma ou outra das posições também pode ocorrer, dependendo das posições assumidas a respeito desse tema pelos pesquisadores da área.

Mais certo, porém, segundo nossa interpretação dos dados até aqui apresentados, é que, de modo similar ao que ocorre na ciência social brasileira como um todo, a área da Comunicação poderá, num futuro próximo, apresentar um movimento expansivo em direção à pesquisa, "não mais motivado pelas urgências do ensino e da qualificação docente, mas orientado para a produção de respostas sociais, afinadas com os novos tempos”, conforme a análise de Werneck Vianna (1995, 39). Para o mesmo autor, as ciências sociais no Brasil "tem-se caracterizado pela precedência do ensino em relação à pesquisa, invertendo a trajetória de institucionalização que conheceu na Europa e na América”. Porém, com a “expansão dos cursos de doutoramento, começa a existir uma massa crítica para a pesquisa científica e a perspectiva de autonomização desta em relação à atividade de ensino” (idem).

Esta direção, a nosso ver, também poderá ser a da Comunicação. Todavia, se isso ocorrer, deverá produzir transformações nas modalidades de inserção dos pesquisadores (ao menos de parte deles), nos tipos de abrigo institucional das pesquisas, na ampliação ou redefinição de objetos e na busca de parceiras com setores sociais que demandem conhecimento sobre a Comunicação. Deverá haver, pois, a busca pelo refinamento dos mecanismos de avaliação e o estímulo à pesquisa mais claramente acadêmica ou não, bem como a construção de novos indicadores de qualidade para algumas modalidades de investigação 
que surjam a partir dos possíveis diferentes formatos voltados a um tipo de saber aplicado - como o caso do “mestrado profissional”, aliás, indica ${ }^{40}$.

\subsection{O corpo docente dos PPGCOM}

Seria possível - embora trabalhoso - estimar o universo de titulados em Comunicação que migraram para outras áreas, porém com certeza esse número não alcança grande expressão, pelo motivo de que as próprias vagas docentes nos PPGCOM são, em parcela substancial, ocupadas por titulados em outras áreas ${ }^{41}$. Dessa forma, pode-se tomar o corpo docente dos PPGCOM como um indicador seguro do mercado universitário para os titulados em Comunicação. E hoje, como se sabe, não existe corpo docente que não seja composto por titulados sem o curso de doutorado. Esta situação é diferente da de 10 anos atrás, indicando o aumento da massa crítica da área e da PG como um todo. No caso dos programas das ciências sociais, por exemplo, em 1994, cerca de 15\% dos docentes só possuíam o mestrado (Werneck Vianna et al., 1995, 40). Vale dizer ainda que os dados sobre os docentes correspondem, de modo geral, aos sobre a pesquisa científica na área, devido ao fato de que esta é feita sobretudo no contexto acadêmico.

Desse modo, a seguir, de início, objetivamos caracterizar o universo docente dos PPGCOM quantitativamente, e a partir de variáveis como a distribuição dos docentes pelos programas e o tipo de vínculo que possuem (Tabela 4.10), e a área na qual os docentes colaboradores e os permanentes obtiveram o doutorado (Tabelas 4.11 e 4.12). É realizado também um cruzamento da área na qual o doutorado foi obtido com o ano de obtenção do título, em relação aos professores permanentes. Como esta categoria é a que tem mais responsabilidade pela condução do Programa, o dado produzido é um indicador dos aportes de outras disciplinas que são trazidos para o campo da Comunicação (Tabelas 4.13).

\footnotetext{
${ }^{40}$ Uma discussão sobre aspectos do mestrado profissional, como a necessidade de incorporar docentes com experiência não-acadêmica, mas conhecimentos na área profissional em questão, é feita por Moura (S.d.).

${ }^{41}$ Um dado relativo a 1994 mostra que os docentes doutores em Comunicação em programas de pósgraduação em ciências sociais eram apenas 1,9\% do todo (Werneck Vianna et al., 1995, 41).
} 
Ao mesmo tempo, para aprofundar essa perspectiva, são mostrados os países nos quais foi obtido o doutorado (Tabela 4.14) e é feita uma comparação da área de origem dos primeiros orientadores dos PPGCOM com os atuais (Tabela 4.15). Ainda quanto ao corpo docente dos PPGCOM, na Tabela 4.16, é mostrado o percentual de títulos pós-doutorais obtidos.

Tabela 4.10 - Docentes dos PPGCOM distribuídos por tipo de vínculo institucional

\begin{tabular}{l|c|c|c|c|c}
\hline $\begin{array}{l}\text { PPGCOMI } \\
\text { Docentes }\end{array}$ & Permanentes & Colaboradores & Visitantes & Total (n) & Total (\%) \\
\hline USP & 60 & 51 & 0 & 111 & $\mathbf{2 7 , 5}$ \\
\hline UNICAMP & 11 & 8 & 6 & 25 & $\mathbf{6 , 0}$ \\
\hline PUCRS & 20 & 1 & 3 & 24 & $\mathbf{6 , 0}$ \\
\hline UFRJ & 20 & 2 & 0 & 22 & $\mathbf{5 , 5}$ \\
\hline PUCSP & 19 & 4 & 0 & 23 & $\mathbf{5 , 5}$ \\
\hline UNISINOS & 14 & 3 & 4 & 21 & $\mathbf{5 , 0}$ \\
\hline UFF & 12 & 6 & 0 & 18 & $\mathbf{4 , 5}$ \\
\hline UNESP & 12 & 7 & 0 & 19 & $\mathbf{4 , 5}$ \\
\hline UNIMAR & 13 & 3 & 2 & 18 & $\mathbf{4 , 5}$ \\
\hline UMESP & 12 & 4 & 0 & 16 & $\mathbf{4 , 0}$ \\
\hline UERJ & 11 & 4 & 1 & 16 & $\mathbf{4 , 0}$ \\
\hline UFBA & 10 & 4 & 1 & 15 & $\mathbf{4 , 0}$ \\
\hline UNB & 11 & 0 & 0 & 11 & $\mathbf{3 , 0}$ \\
\hline UNIP & 10 & 3 & 0 & 13 & $\mathbf{3 , 0}$ \\
\hline UFRGS & 9 & 3 & 0 & 12 & $\mathbf{3 , 0}$ \\
\hline UFMG & 9 & 2 & 0 & 11 & $\mathbf{2 , 5}$ \\
\hline UFPE & 7 & 2 & 0 & 9 & $\mathbf{2 , 5}$ \\
\hline UTP & 9 & 1 & 1 & 11 & $\mathbf{2 , 5}$ \\
\hline PUCRJ & 8 & 1 & $\mathbf{2}$ & 9 & $\mathbf{2 , 5}$ \\
\hline TOTAL (n e $\%)$ & $\mathbf{2 7 7}(\mathbf{6 8 , 5 \% )}$ & $\mathbf{1 0 9}(\mathbf{2 7 \% )}$ & $\mathbf{1 8} \mathbf{( 4 , 5 \% )}$ & $\mathbf{4 0 4}$ & $\mathbf{1 0 0 , 0}$ \\
\hline
\end{tabular}

Fonte: Capes/MEC (2004)

Em 2004, o total de postos docentes vinculados aos PPGCOM era 404, sendo que a maioria das vagas era assumida pela categoria dos docentes permanentes, 277 (68,5\%); o segundo grupo de postos correspondia à categoria dos colaboradores, 109 (27\%), por fim os visitantes eram 18 (4,5\%). Apenas 11 docentes apresentaram mais de um vínculo (entre os PPGCOM): 7 possuíam vínculo permanente em um programa e eram colaboradores ou visitantes em outro; um único docente apresentava triplo vínculo: permanente em dois programas e visitante em outro. Um docente era colaborador em dois, outra era colaboradora em um e visitante em outro e, por fim, um docente estrangeiro era visitante em dois programas. Feita a compatibilização dos dados com essas informações, percebe-se que o efetivo número global de pesquisadores é 392, no todo. E em relação às categorias que expressam uma vinculação mais direta com o programa (os permanentes e colaboradores), o total de pesquisadores é 378. Como os novos programas da UFSM e da 
ESPM não possuem uma relação pública (informada à CAPES) de docentes, por não terem turmas no momento, o que ocorrerá em breve, é que o número total de docentes/pesquisadores deverá se aproximar de 400 (excetuando-se os visitantes) ${ }^{42}$.

Ainda sobre a Tabela 4.10, o que chama a atenção é sem dúvida, para o ano de 2004, o número acentuado de docentes do PPGCOM da USP, 111, na soma de todas as categorias, o que corresponde a 27,5\% dentre todos os programas. Bem abaixo vinham os programas de um pelotão intermediário, de 25 a 15 docentes, UNICAMP, PUCRS (ambos com 6\% dos docentes), UFRJ, PUCSP (os dois com 5,5\%), UNISINOS (5\%), UFF, UNESP, UNIMAR (os três com 4,5\%), UMESP UERJ e UFBA (estes últimos com 4\%). Num último grupo, com menor número de docentes (de 13 a 9), os demais PPGCOM: UNB, UNIP e UFRGS (cada um com 3\% do total de docentes), UFMG, UFPE, UTP e PUCRJ (todos com 2,5).

É interessante notar, ainda, que a comparação entre os docentes NRD6 do ano de 2001, cujo número foi de 216, com os docentes permanentes de 2004 (277), mostra um crescimento no percentual de 28,2\% de um período a outro, o que se explica por ajustes nos programas e pelo início do funcionamento dos PPGCOM da PUCRJ, UERJ, UNESP e UNIMAR.

\footnotetext{
${ }^{42}$ A lista dos Docentes, por PPGCOM, encontra-se no volume de Anexos. Lembramos ainda (vide nota 37) que outros quatro PPGCOM, sem quadro docente divulgado, foram recentemente (2006) aprovados.
} 
Tabela 4.11 - Titulação (Doutorado) dos professores colaboradores dos PPGCOM (2004)

\begin{tabular}{|c|c|c|c|c|c|c|c|c|c|c|c|c|c|c|c|c|c|c|c|c|c|}
\hline $\begin{array}{l}\text { Área } \\
\text { Discipl. }\end{array}$ & $\begin{array}{l}\text { US } \\
\text { P }\end{array}$ & $\begin{array}{l}\text { UF } \\
\text { RJ }\end{array}$ & $\begin{array}{l}\text { UN } \\
B\end{array}$ & $\begin{array}{l}\text { PU } \\
\text { CS } \\
\text { P }\end{array}$ & $\begin{array}{c}\text { UM } \\
\text { ES } \\
P\end{array}$ & $\begin{array}{l}\text { UNI } \\
\text { CA } \\
\text { MP }\end{array}$ & $\begin{array}{l}\text { UF } \\
\text { BA }\end{array}$ & $\begin{array}{c}\text { PU } \\
\text { CR } \\
\mathrm{S}\end{array}$ & $\begin{array}{l}\text { UNI } \\
\text { SIN } \\
\text { OS }\end{array}$ & $\begin{array}{c}\text { UF } \\
\text { RG } \\
\text { S }\end{array}$ & $\begin{array}{l}\text { UF } \\
\text { MG }\end{array}$ & $\begin{array}{l}\text { UF } \\
\mathrm{F}\end{array}$ & $\begin{array}{l}\text { UF } \\
\text { PE }\end{array}$ & $\begin{array}{l}\text { UT } \\
P\end{array}$ & $\begin{array}{l}\text { UNI } \\
\text { P }\end{array}$ & $\begin{array}{l}\text { UE } \\
\text { RJ }\end{array}$ & $\begin{array}{l}\text { UN } \\
\text { ES } \\
\text { P }\end{array}$ & $\begin{array}{c}\text { UNI } \\
\text { MA } \\
\text { R }\end{array}$ & $\begin{array}{l}\mathrm{PU} \\
\mathrm{CR} \\
\mathrm{J}\end{array}$ & $\begin{array}{c}\text { Total } \\
\text { (n) }\end{array}$ & $\begin{array}{c}\text { Total } \\
(\%)\end{array}$ \\
\hline Comunicação & 36 & - & - & 2 & 3 & 1 & 3 & 1 & 1 & 3 & 1 & 3 & 2 & - & - & 2 & 2 & 2 & 1 & 63 & 58,3 \\
\hline $\begin{array}{l}\text { Lingüista, Let., } \\
\text { Litera., T. Lit. }\end{array}$ & 6 & 2 & - & - & - & 6 & - & - & 2 & - & 1 & 1 & - & 1 & - & - & 2 & - & - & 21 & 19,4 \\
\hline Filosofia & - & - & - & 2 & - & - & - & - & - & - & - & - & - & - & - & - & 1 & 1 & - & 4 & 3,7 \\
\hline Artes & 2 & - & - & - & - & - & - & - & - & - & - & - & - & - & 1 & - & - & - & - & 3 & 2,8 \\
\hline Sociologia & 1 & - & - & - & - & - & - & - & - & - & - & - & - & - & - & 1 & - & - & - & 2 & 1,9 \\
\hline Ci. Inform. & 2 & - & - & - & - & - & - & - & - & - & - & - & - & - & - & - & - & - & - & 2 & 1,9 \\
\hline Antropologia & - & - & - & - & - & - & - & - & - & - & - & 1 & - & - & - & 1 & - & - & - & 2 & 1,9 \\
\hline Educação & - & - & - & - & - & - & 1 & - & - & - & - & - & - & - & 1 & - & - & - & - & 2 & 1,9 \\
\hline Psicologia & - & - & - & - & - & - & - & - & - & - & - & 1 & - & - & 1 & - & - & - & - & 2 & 1,8 \\
\hline Ci. da Comp. & 1 & - & - & - & - & - & - & - & - & - & - & - & - & - & - & - & - & - & - & 1 & 0,9 \\
\hline Geografia & 1 & - & - & - & - & - & - & - & - & - & - & - & - & - & - & - & - & - & - & 1 & 0,9 \\
\hline Administr. & - & - & - & - & - & - & - & - & - & - & - & - & - & - & - & - & 1 & - & - & 1 & 0,9 \\
\hline Outros & 1 & - & - & - & 1 & 1 & - & - & - & - & - & - & - & - & - & - & 1 & - & - & 4 & 3,7 \\
\hline Total & 50 & 2 & 0 & 4 & 4 & 8 & 4 & 1 & 3 & 3 & 2 & 6 & 2 & 1 & 3 & 4 & 7 & 3 & 1 & 108 & 100,0 \\
\hline
\end{tabular}

Note-se em relação a esta e à tabela seguinte que foi feito um ajuste no número de vagas ocupadas e docentes, de modo a que o número obtido é o total de pesquisadores (ou seja, no caso de duplo vínculo na mesma categoria, descartou-se o mais recente). Dito isso, é importante notar dois aspectos principais da categoria de docente colaborador. Ela pode representar, de um lado, uma situação provisória, um período de sondagem possivelmente mútua - entre o docente e o programa, antes de uma oportunidade para o ingresso como docente permanente. De outro lado, pode ser um possível espaço para o exercício do diálogo interdisciplinar, ou entre diferentes perspectivas sobre o campo de estudo, num único programa. Isso ocorre já que o docente poderá ter vínculo em outra área (ou programa), na qual esteja eventualmente mais próximo ou consolidado. Desse modo, o vínculo do colaborador (e de visitante) poderá servir, tanto ao próprio programa, quanto ao docente para propiciar um relacionamento mais favorável à troca puramente acadêmica. Ademais, esse tipo de vínculo envolve uma carga de envolvimento menor com as tarefas operacionais.

Vistos sob esses dois ângulos, os dados da Tabela 4.11 mostram que o diálogo entre os programas da área, que a categoria dos docentes colaboradores poderia propiciar, é baixo: embora todos os programas (exceto o da UNB) possuíssem colaboradores (com destaque para o PPGCOM da USP com 50 dentre estes e, bem depois, o da UNICAMP, com 8), apenas 7 docentes foram, ao mesmo tempo, colaboradores num programa e permanentes 
em outro. De outro lado, os titulados no doutorado em Comunicação são a maioria (58,3\%) dos docentes colaboradores dos PPGCOM.

Bem depois dos titulados na própria área da Comunicação, estavam os de áreas de Lingüística, Letras, Literatura e Teoria Literária (21 docentes, 19,4\% do total), seguidos pelos de Filosofia (4: 3,7\%), Artes (3: 2,8\%), Sociologia, Ciência da Informação, Antropologia, Educação, Psicologia (2 docentes cada, ou 1,9\% do todo), Ciências da Computação, Geografia e Administração (um único docente em cada área, 0,9\%). Dessa forma, as possíveis relações interdisciplinares estabelecidas pela categoria de docente colaborador ocorrem, como se poderia esperar, com as disciplinas das Ciências Sociais e Humanidades, de modo amplamente majoritário. Nota-se que existem apenas dois doutores (um de Administração e outro de Ciência da Informação) das Ciências Sociais Aplicadas.

Tabela 4.12 - Titulação (Doutorado) dos professores permanentes dos PPGCOM (2004)

\begin{tabular}{|c|c|c|c|c|c|c|c|c|c|c|c|c|c|c|c|c|c|c|c|c|c|}
\hline $\begin{array}{l}\text { Área } \\
\text { Discipl. }\end{array}$ & $\begin{array}{c}\text { us } \\
\text { P }\end{array}$ & $\begin{array}{l}\mathrm{UF} \\
\mathrm{RJ}\end{array}$ & $\begin{array}{c}\text { UN } \\
\text { B }\end{array}$ & $\begin{array}{l}\text { PU } \\
\text { CS } \\
\text { P }\end{array}$ & $\begin{array}{l}\text { UM } \\
\text { ES } \\
\text { P }\end{array}$ & $\begin{array}{l}\text { UNI } \\
\text { CA } \\
\text { MP }\end{array}$ & $\begin{array}{l}\text { UF } \\
\text { BA }\end{array}$ & $\begin{array}{c}\mathrm{PU} \\
\mathrm{CR} \\
\mathrm{S}\end{array}$ & $\begin{array}{l}\text { UNI } \\
\text { SIN } \\
\text { OS }\end{array}$ & $\begin{array}{c}\text { UF } \\
\text { RG } \\
\text { S }\end{array}$ & $\begin{array}{l}\text { UF } \\
\text { MG }\end{array}$ & $\begin{array}{l}\text { UF } \\
\text { F }\end{array}$ & $\begin{array}{l}\text { UF } \\
\mathrm{PE}\end{array}$ & $\begin{array}{l}\text { UT } \\
\text { P }\end{array}$ & $\underset{P}{\text { UNI }}$ & $\begin{array}{l}\mathrm{UE} \\
\mathrm{RJ}\end{array}$ & $\begin{array}{c}\text { UN } \\
\text { ES } \\
\text { P }\end{array}$ & $\begin{array}{l}\text { UNI } \\
\text { MA } \\
\text { R }\end{array}$ & $\begin{array}{l}\mathrm{PU} \\
\mathrm{CR} \\
\mathrm{J}\end{array}$ & $\begin{array}{l}\text { Total } \\
\text { (n) }\end{array}$ & $\begin{array}{c}\text { Total } \\
\text { (\%) }\end{array}$ \\
\hline Comunicação & 35 & 15 & 4 & 11 & 10 & 2 & 6 & 11 & 10 & 6 & 5 & 7 & 2 & 6 & 4 & 5 & 5 & 5 & 4 & 153 & 55,4 \\
\hline $\begin{array}{l}\text { Lingüista, } \\
\text { Let., Litera., } \\
\text { T. Lit. }\end{array}$ & 6 & 4 & - & 4 & - & 7 & - & 4 & 2 & - & 2 & - & 3 & 2 & 2 & 2 & 4 & 7 & 2 & 51 & 18,3 \\
\hline Sociologia & 3 & - & 4 & - & - & - & 3 & 2 & - & 1 & 1 & - & 2 & - & 1 & 3 & - & - & - & 20 & 7,2 \\
\hline Artes & 6 & - & - & 1 & - & - & - & - & - & - & - & - & - & - & 3 & - & - & - & - & 10 & 3,6 \\
\hline Ci. Inform. & 6 & - & 2 & - & - & - & - & - & - & 1 & - & - & - & - & - & - & - & - & - & 9 & 3,3 \\
\hline História & - & - & 1 & 1 & - & - & - & - & 1 & - & - & 3 & - & - & - & - & 2 & 1 & - & 9 & 3,3 \\
\hline Antropologia & 2 & 1 & - & - & 1 & - & - & - & - & - & - & 1 & - & - & - & - & - & - & 2 & 7 & 2,6 \\
\hline Filosofia & - & - & - & 2 & 1 & 1 & 1 & - & - & - & - & 1 & - & - & - & - & - & - & - & 6 & 2,1 \\
\hline Educação & 1 & - & - & - & - & - & - & 2 & 1 & 1 & - & - & - & - & - & - & - & - & - & 5 & 1,8 \\
\hline $\begin{array}{l}\text { Cien. } \\
\text { Política }\end{array}$ & - & - & - & - & - & - & - & - & - & - & 1 & - & - & - & - & 1 & - & - & - & 2 & 0,8 \\
\hline Psicologia & - & - & - & - & - & - & - & 1 & - & - & - & - & - & - & - & - & - & - & - & 1 & 0,4 \\
\hline Ci. Biológicas & - & - & - & - & - & 1 & - & - & - & - & - & - & - & - & - & - & - & - & - & 1 & 0,4 \\
\hline Arq. e Urban, & - & - & - & - & - & - & - & - & - & - & - & - & - & - & - & - & 1 & - & - & 1 & 0,4 \\
\hline Outros & 1 & - & - & - & - & - & - & - & - & - & - & - & - & - & - & - & - & - & - & 1 & 0,4 \\
\hline Total & 60 & 20 & 11 & 19 & 12 & 11 & 10 & 20 & 14 & 9 & 9 & 12 & 7 & 8 & 10 & 11 & 12 & 13 & 8 & 276 & 100,0 \\
\hline
\end{tabular}

Fonte: Capes/MEC (2004)

Os dados sobre a área de titulação do doutorado dos docentes permanentes dos PPGCOM são em parte similares aos dos docentes colaboradores. Os titulados em Comunicação são a maioria - 153 docentes, 55,4\% do total, curiosamente um número percentual ligeiramente menor do que entre os docentes colaboradores. A seguir estão também os da área de Lingüística, Letras, Literatura e Teoria Literária (51 docentes, 18,3\% dos mesmos). Os docentes com doutorado em Sociologia ocupam o terceiro grupo, sendo em número de 20 (7,2\% do todo). Num grupo intermediário estão os que obtiveram o doutorado em Artes 
(10 docentes, 3,6\%), seguidos pelos doutores em Ciência da Informação (9 pesquisadores, 3,3\% do total), História e Antropologia (ambos com 9 doutores, 3,3\% cada), Antropologia (7, correspondendo a 2,7\%) e Filosofia (6 docentes, 2,1\%). Ainda, existem 5 doutores em Educação (1,8\%), 2 em Ciência Política (0,8\%), e 1 nas áreas de Psicologia, Ciências Biológicas, Arquitetura e Urbanismo (somando cada uma delas 0,4\% do todo).

Assim, excetuando os doutores da própria área, novamente os docentes com doutorado nas áreas das Ciências Humanas e Sociais são majoritários. E mostra-se que, entre as Ciências Sociais Aplicadas, é a Ciência da Informação o campo disciplinar que - sob o ponto de vista privilegiado - indicia maior diálogo com a Comunicação, embora com bem menos docentes do que os da área - a segunda na Tabela - de Lingüística, Letras, Literatura e Teoria Literária (51 docentes versus 9 de Ciência da Informação).

O que fica claro é que os PPGCOM têm dependido, de modo geral, de doutores formados em áreas conexas à da Comunicação. Observa-se que, dentre os 19 programas arrolados, 7 (UNB, UNICAMP, UFPE, UNIP, UERJ, UNESP e UNIMAR) possuem mais doutores em áreas diferentes da Comunicação, enquanto em 11 (USP, UFRJ, PUCSP, UMESP, UFBA, PUCRS, UNISINOS, UFRGS, UFMG, UFF, UTP) esta relação se inverte, e um dos programas (PUCRJ) tem o mesmo número de docentes com doutorado em Comunicação e em outras áreas. Isso significa, provavelmente, de um lado, um elemento de reforço ao caráter politemático, multi ou interdisciplinar do campo de estudos. Mas também sugere que o “custo de translação” para o campo da Comunicação tem sido relativamente baixo.

Em outros termos, se as disposições adquiridas pelos praticantes de determinado campo científico implicam em apreender as normas e regras básicas do campo em questão - o que se dá via formação especializada, conforme a propostas de Bourdieu -, estas não têm significado uma forte barreira para titulados em outras especialidades.

De certo modo, isso ocorre também quanto aos titulados dos PPGCOM. Em relação aos egressos dos anos 1994-1998, nota-se que 53\% dos mestres possuíam graduação em Comunicação, caso de 36\% dos doutores. E, em relação a estes, menos da metade (45\%) possuía mestrado na área. A distribuição de títulos de graduação e mestrados (diferentes de 
Comunicação) era similar à apresentada pelos docentes, com predomínio dos cursos de Artes, Ciências Sociais e Humanas (Lopes, 2001, 77-80).

De outro, os dados mostrados sobre docentes e egressos revela um aspecto ligado ainda ao modo com que seu deu a constituição do sistema de PG da área, cuja dinâmica de consolidação implicou no acolhimento a alunos/docentes de outras áreas de formação. No entanto, a Tabela 4.13, a seguir, mostra que o movimento de atração dos doutores da Comunicação para os PPGCOM tem aumentado ao longo do tempo. Aspecto que tem inclusive sido estimulado em termos nas últimas avaliações feitas por comissão de pares da CAPES, apesar de críticas como a de Loviloso (2002). 
Tabela 4.13 - Titulação (Doutorado) dos professores permanentes dos PPGCOM (2004), por ano de obtenção do título

\begin{tabular}{|c|c|c|c|c|c|c|c|c|}
\hline $\begin{array}{l}\text { Área } \\
\text { Disciplinar }\end{array}$ & $\begin{array}{l}\text { Até } \\
1979\end{array}$ & $\begin{array}{l}1980- \\
1984\end{array}$ & $\begin{array}{l}1985- \\
1988\end{array}$ & $\begin{array}{l}1990- \\
1994\end{array}$ & $\begin{array}{l}1995- \\
1999\end{array}$ & $\begin{array}{l}2000- \\
2005\end{array}$ & Total (n) & Total (\%) \\
\hline Comunicação & $\begin{array}{c}3 \\
(1,1 \%) \\
\end{array}$ & $\begin{array}{c}9 \\
(3,3 \%) \\
\end{array}$ & $\begin{array}{c}21 \\
(7,6 \%) \\
\end{array}$ & $\begin{array}{c}29 \\
(10,5 \%) \\
\end{array}$ & $\begin{array}{c}44 \\
(15,9 \%) \\
\end{array}$ & $\begin{array}{c}47 \\
(17,0 \%) \\
\end{array}$ & 153 & 55,4 \\
\hline $\begin{array}{l}\text { Lingüista, Letras, } \\
\text { Literatura, T. Lit. }\end{array}$ & $\begin{array}{c}10 \\
(3,6 \%) \\
\end{array}$ & $\begin{array}{c}5 \\
(1,8 \%) \\
\end{array}$ & $\begin{array}{c}7 \\
(2,5 \%) \\
\end{array}$ & $\begin{array}{c}10 \\
(3,6 \%) \\
\end{array}$ & $\begin{array}{c}11 \\
(3,9 \%) \\
\end{array}$ & $\begin{array}{c}8 \\
(2,9 \%) \\
\end{array}$ & 51 & 18,3 \\
\hline Sociologia & $\begin{array}{c}2 \\
(0,7 \%) \\
\end{array}$ & $\begin{array}{c}2 \\
(0,7 \%)\end{array}$ & $\begin{array}{c}1 \\
(0,4 \%)\end{array}$ & $\begin{array}{c}5 \\
(1,8 \%) \\
\end{array}$ & $\begin{array}{c}7 \\
(2,5 \%) \\
\end{array}$ & $\begin{array}{c}3 \\
(1,1 \%)\end{array}$ & 20 & 7,2 \\
\hline Artes & $\begin{array}{c}1 \\
(0,4 \%)\end{array}$ & $\begin{array}{c}1 \\
(0,4 \%)\end{array}$ & $\begin{array}{c}4 \\
(1,4 \%)\end{array}$ & $\begin{array}{c}4 \\
(1,4 \%)\end{array}$ & - & - & 10 & 3,6 \\
\hline Ci. Inform. & $\begin{array}{c}1 \\
(0,4 \%)\end{array}$ & - & $\begin{array}{c}1 \\
(0,4 \%)\end{array}$ & $\begin{array}{c}2 \\
(0,7 \%)\end{array}$ & $\begin{array}{c}2 \\
(0,7 \%)\end{array}$ & $\begin{array}{c}3 \\
(1,1 \%)\end{array}$ & 9 & 3,3 \\
\hline História & - & - & - & $\begin{array}{c}3 \\
(1,1 \%) \\
\end{array}$ & $\begin{array}{c}4 \\
(1,4 \%) \\
\end{array}$ & $\begin{array}{c}2 \\
(0,7 \%) \\
\end{array}$ & 9 & 3,3 \\
\hline Antropologia & - & $\begin{array}{c}1 \\
(0,4 \%)\end{array}$ & $\begin{array}{c}1 \\
(0,4 \%)\end{array}$ & $\begin{array}{c}3 \\
(1,1 \%)\end{array}$ & $\begin{array}{c}1 \\
(0,4 \%)\end{array}$ & $\begin{array}{c}1 \\
(0,4 \%)\end{array}$ & 7 & 2,6 \\
\hline Filosofia & - & $\begin{array}{c}2 \\
(0,7 \%) \\
\end{array}$ & $\begin{array}{c}2 \\
(0,7 \%) \\
\end{array}$ & $\begin{array}{c}2 \\
(0,7 \%) \\
\end{array}$ & - & - & 6 & 2,1 \\
\hline Educação & - & - & $\begin{array}{c}1 \\
(0,4 \%)\end{array}$ & - & $\begin{array}{c}2 \\
(0,7 \%)\end{array}$ & $\begin{array}{c}2 \\
(0,7 \%)\end{array}$ & 5 & 1,8 \\
\hline Cien. Política & - & - & - & $\begin{array}{c}1 \\
(0,4 \%)\end{array}$ & - & $\begin{array}{c}1 \\
(0,4 \%)\end{array}$ & 2 & 0,8 \\
\hline Psicologia & - & - & - & $\begin{array}{c}1 \\
(0,4 \%)\end{array}$ & - & - & 1 & 0,4 \\
\hline Ci. Biológicas & $\begin{array}{c}1 \\
(0,4 \%)\end{array}$ & - & - & - & - & - & 1 & 0,4 \\
\hline $\begin{array}{l}\text { Arquit. e } \\
\text { Urban, }\end{array}$ & - & - & - & $\begin{array}{c}1 \\
(0,4 \%) \\
\end{array}$ & - & - & 1 & 0,4 \\
\hline Outros & - & - & - & $\begin{array}{c}1 \\
(0,4 \%) \\
\end{array}$ & - & - & 1 & 0,4 \\
\hline Total (n e \%) & $\begin{array}{c}18 \\
(6,5 \%)\end{array}$ & $\begin{array}{c}20 \\
(7,3 \%)\end{array}$ & $\begin{array}{c}38 \\
(13,8 \%)\end{array}$ & $\begin{array}{c}62 \\
(22,5 \%)\end{array}$ & $\begin{array}{c}71 \\
(25,5 \%)\end{array}$ & $\begin{array}{c}67 \\
(24,4 \%)\end{array}$ & $\begin{array}{c}276 \\
(100,0 \%)\end{array}$ & 100,0 \\
\hline
\end{tabular}

Fonte: Capes/MEC (2004)

A Tabela 4.13 mostra que, em 2004, cerca de $1 / 4$ dos professores dos PPGCOM eram jovens doutores (67 ou 24,4\% dos docentes, com no máximo 5 anos de obtenção do título). Um número similar de docentes (71) tinha entre 6 e 10 anos desde a obtenção do doutorado (25,5\%), enquanto pouco mais da metade do total geral $(50,1 \%)$ possuía mais de 10 anos de obtenção do doutorado. A proporção, aparentemente elevada, de jovens doutores se justifica pelo crescimento da área, o que é evidenciado também pelo contínuo aumento do número de titulados/docentes em Comunicação. 
Tabela 4.14 - Países em que os professores permanentes dos PPGCOM (2004) obtiveram o título de doutor, por ano

\begin{tabular}{|c|c|c|c|c|c|c|c|c|}
\hline $\begin{array}{l}\text { Área } \\
\text { Disciplinar }\end{array}$ & $\begin{array}{l}\text { Até } \\
1979\end{array}$ & $\begin{array}{l}1980- \\
1984\end{array}$ & $\begin{array}{l}1985- \\
1989\end{array}$ & $\begin{array}{l}1990- \\
1994\end{array}$ & $\begin{array}{l}1995- \\
1999\end{array}$ & $\begin{array}{l}2000- \\
2005\end{array}$ & Total (n) & Total (\%) \\
\hline Brasil & $\begin{array}{c}8 \\
(3,0 \%)\end{array}$ & $\begin{array}{c}7 \\
(2,7 \%)\end{array}$ & $\begin{array}{c}27 \\
(10,1 \%)\end{array}$ & $\begin{array}{c}47 \\
(17,7 \%)\end{array}$ & $\begin{array}{c}52 \\
(19,5 \%) \\
\end{array}$ & $\begin{array}{c}61 \\
(22,9 \%)\end{array}$ & 202 & 75,9 \\
\hline França & $\begin{array}{c}3 \\
(1,1 \%)\end{array}$ & $\begin{array}{c}7 \\
(2,7 \%)\end{array}$ & $\begin{array}{c}4 \\
(1,5 \%)\end{array}$ & $\begin{array}{c}6 \\
(2,2 \%) \\
\end{array}$ & $\begin{array}{c}5 \\
(1,9 \%) \\
\end{array}$ & $\begin{array}{c}1 \\
(0,4 \%)\end{array}$ & 26 & 9,8 \\
\hline EUA & $\begin{array}{c}1 \\
(0,4 \%)\end{array}$ & $\begin{array}{c}4 \\
(1,5 \%)\end{array}$ & $\begin{array}{c}2 \\
(0,7 \%)\end{array}$ & $\begin{array}{c}3 \\
(1,1 \%)\end{array}$ & $\begin{array}{c}4 \\
(1,5 \%)\end{array}$ & $\begin{array}{c}1 \\
(0,4 \%)\end{array}$ & 15 & 5,6 \\
\hline Inglaterra & $\begin{array}{c}1 \\
(0,4 \%)\end{array}$ & - & - & $\begin{array}{c}3 \\
(1,1 \%)\end{array}$ & $\begin{array}{c}4 \\
(1,5 \%)\end{array}$ & $\begin{array}{c}1 \\
(0,4 \%)\end{array}$ & 9 & 3,4 \\
\hline Espanha & $\begin{array}{c}1 \\
(0,4 \%)\end{array}$ & - & - & - & $\begin{array}{c}3 \\
(1,1 \%) \\
\end{array}$ & $\begin{array}{c}2 \\
(0,7 \%) \\
\end{array}$ & 6 & 2,2 \\
\hline Alemanha & - & $\begin{array}{c}1 \\
(0,4 \%)\end{array}$ & $\begin{array}{c}2 \\
(0,7 \%)\end{array}$ & $\begin{array}{c}1 \\
(0,4 \%)\end{array}$ & - & - & 4 & 1,5 \\
\hline Noruega & - & - & - & - & $\begin{array}{c}1 \\
(0,4 \%) \\
\end{array}$ & - & 1 & 0,4 \\
\hline Bélgica & $\begin{array}{c}1 \\
(0,4 \%)\end{array}$ & - & - & - & - & - & 1 & 0,4 \\
\hline Itália & - & - & $\begin{array}{c}1 \\
(0,4 \%) \\
\end{array}$ & - & - & - & 1 & 0,4 \\
\hline Portugal & - & - & - & - & - & $\begin{array}{c}1 \\
(0,4 \%)\end{array}$ & 1 & 0,4 \\
\hline Total (n e \%) & $\begin{array}{c}15 \\
(5,7 \%) \\
\end{array}$ & $\begin{array}{c}19 \\
(7,3 \%)\end{array}$ & $\begin{array}{c}36 \\
(13,4 \%) \\
\end{array}$ & $\begin{array}{c}60 \\
(22,5 \%) \\
\end{array}$ & $\begin{array}{c}69 \\
(25,9 \%) \\
\end{array}$ & $\begin{array}{c}67 \\
(25,2 \%) \\
\end{array}$ & $\begin{array}{c}266 \\
(100,0 \%) \\
\end{array}$ & 100,0 \\
\hline
\end{tabular}

Fonte: CNPq (Plataforma Lattes - 2005).

OBS: o descompasso entre o total de docentes dessa e das Tabelas seguintes com a anterior se deve ao fato de que 10 docentes não possuíam Currículo do CNPq, e por isso não foram contabilizados.

A listagem dos países nos quais os docentes permanentes dos PPGCOM obtiveram o doutorado mostra, de um lado, o avanço contínuo na titulação neste nível no Brasil, reflexo do aumento da oferta da PG. De outro lado, em termos da obtenção do título fora do país, percebe-se que o espaço europeu foi privilegiado: 51 docentes $(18,5 \%)$ realizaram o doutorado na Europa, destacando-se a França, com 26 doutores (9,8\% do titulados nesse nível), que ocupa o segundo lugar na lista. Os EUA vêm em terceiro lugar, com 15 docentes (5,6\% do total). O título foi obtido na Inglaterra por 9 docentes (3,4\%), na Espanha por 6 (2,2\%) e na Alemanha por 4 (1,5\%). Os demais docentes realizaram o doutorado em outros países europeus (Noruega, Bélgica, Itália e Portugal), todos com apenas um titulado. É razoável supor que isso tem efeitos no âmbito cognitivo do grupo, por exemplo, em termos da literatura utilizada, possivelmente mais próxima do espaço europeu do que dos EUA. 
Tabela 4.15 - Áreas de doutorado dos primeiros docentes dos PPGCOM e dos atuais docentes permanentes (2004)

\begin{tabular}{l|c|c|c|c}
\hline \multirow{2}{*}{$\begin{array}{l}\text { Docentesl } \\
\text { Área Disciplinar }\end{array}$} & \multicolumn{2}{|c|}{ Primeiros Docentes } & \multicolumn{2}{c}{ Atuais Docentes } \\
\cline { 2 - 5 } & Total $(\mathbf{n})$ & Total (\%) & Total $(\mathbf{n})$ & Total (\%) \\
\hline Comunicação & 17 & $\mathbf{3 2 , 7}$ & 153 & $\mathbf{5 5 , 4}$ \\
\hline Letras, Teoria Literária, Literatura & 18 & $\mathbf{3 4 , 6}$ & 51 & $\mathbf{1 8 , 3}$ \\
\hline Ciências Sociais/ Sociologia & 6 & $\mathbf{1 1 , 6}$ & 20 & $\mathbf{7 , 2}$ \\
\hline Artes & - & - & 10 & $\mathbf{3 , 6}$ \\
\hline Ci. Inform. & - & - & 9 & $\mathbf{3 , 3}$ \\
\hline História / História da Arte & 3 & $\mathbf{5 , 9}$ & 9 & $\mathbf{3 , 3}$ \\
\hline Antropologia & 1 & $\mathbf{1 , 9}$ & 7 & $\mathbf{2 , 6}$ \\
\hline Filosofia & 2 & $\mathbf{3 , 8}$ & 6 & $\mathbf{2 , 1}$ \\
\hline Educação & - & - & 5 & $\mathbf{1 , 8}$ \\
\hline Cien. Política & - & - & 2 & $\mathbf{0 , 8}$ \\
\hline Psicologia & 2 & $\mathbf{3 , 8}$ & 1 & $\mathbf{0 , 4}$ \\
\hline Ci. Biológicas & - & - & 1 & $\mathbf{0 , 4}$ \\
\hline Arquit. e Urban, & - & - & 1 & $\mathbf{0 , 4}$ \\
\hline Arqueologia & 1 & $\mathbf{1 , 9}$ & - & - \\
\hline Engenharia & 1 & $\mathbf{1 , 9}$ & - & - \\
\hline Teologia & 1 & $\mathbf{1 , 9}$ & - & - \\
\hline Outros & - & - & 1 & $\mathbf{0 , 4}$ \\
\hline Total & 52 & $\mathbf{1 0 0 , 0}$ & 276 & $\mathbf{1 0 0 , 0}$ \\
\hline
\end{tabular}

Fonte: CNPq (Plataforma Lattes - 2005)

Para tentar avaliar o peso de outras disciplinas na formação do campo da Comunicação, a Tabela 4.15 compara os dados sobre a titulação no doutorado dos docentes iniciais dos 4 programas que iniciaram a PG em Comunicação (dos primeiros 8 anos de existência dos mesmos: USP, UFRJ, PUCSP e UMESP), com essa mesma variável em relação aos atuais docentes permanentes dos PPGCOM. Como se poderá notar, no Anexo (que traz a lista dos docentes), nem sempre foi possível saber a área de formação dos primeiros docentes, e por isso parte minoritária deles não está contabilizada. De qualquer forma, vale dizer que 10 destes ainda atuam em PPGCOM, o que evidencia a relativa “juventude” da área.

Em termos da comparação entre esses momentos, nota-se que a área ligada a disciplinas como Letras, Teoria Literária e Literatura foi a principal origem dos primeiros docentes (18 dos mesmos, correspondendo a 34,6\%). Isso se justifica, em parte, pelo fato de que certos programas - casos da PUCSP e UNISINOS - em Comunicação tenham derivado de outros da área de Letras. Além disso, os problemas da linguagem foram, desde o surgimento da área de estudos, focalizados pelos PPGCOM, com maior ou menor acento 
na questão dos meios de comunicação. Com efeito, na listagem atual de docentes permanentes, estas disciplinas formam uma área de titulação doutoral que hoje só é superada pela de Comunicação, somando 18,3\% dos títulos dos pesquisadores. No caso dos primeiros docentes o título de doutor em Comunicação soma um número até relativamente elevado (32,7\%) para a época. Este índice é justificado tanto pela feitura do curso no exterior, quanto pelo mecanismo do modelo de PG “europeu” (ou seja, só com defesa de tese) nas instituições que abrigariam os primeiros PPGCOM e também pela agregação dos primeiros doutores formados no país pela área. Quantos aos doutorados no exterior dos primeiros docentes, eles também foram minoritários (9 docentes fizeram doutorado fora do país, contra 43 no Brasil) e, novamente, o âmbito europeu teve mais peso (6 foram na Europa e 3 nos EUA).

As Ciências Sociais (incluindo Sociologia) em ambos os momentos foram a terceira área de titulação dos doutores - somando, na primeira situação, 11,6\%, e na segunda, 7,2\%. Deve-se notar, porém que, em particular no primeiro caso, com freqüência as pesquisas realizadas se aproximam de objetos da Comunicação ${ }^{43}$, ou a perspectiva é de uma “sociologia da comunicação”. Nota-se ainda que as áreas disciplinares em que os docentes obtiveram o doutorado são majoritariamente das Ciências Sociais e Humanas, com exceção de Engenharia (um docente, 1,9\%), quanto aos primeiros professores dos PPGCOM, e Ciências Biológicas (um docente, 0,4\%), no segundo.

Por fim, é interessante notar, enfocando o gênero dos docentes-pesquisadores, que houve um aumento percentual da participação das mulheres que somam 132 docentes (47,8\%), contra 144 homens (52,2\%). Enquanto no primeiro estágio o percentual de homens era mais expressivo (75\% contra $25 \%$ de mulheres). É provável que os docentes do sexo feminino aumentem, pois as mulheres eram, no período 1994-1998, a maioria entre os discentes formados pelos PPGOM, com 59\% (Lopes, 2001, 71). E a feminilização da área também se evidencia pelas mulheres serem majoritárias também entre os estudantes de graduação, com 66\% (cf. Lopes, 1998).

\footnotetext{
${ }^{43}$ Por exemplo, o trabalho de Paulo Emílio Salles Gomes sobre o cinema brasileiro, realizado nas Ciências Sociais da USP.
} 
Tabela 4.16 - Titulações pós-doutorais obtidas pelos professores permanentes dos PPGCOM (2005)

\begin{tabular}{|c|c|c|c|c|c|c|c|}
\hline \multirow{2}{*}{$\begin{array}{l}\text { Nível de } \\
\text { titulaçãol } \\
\text { PPGOM }\end{array}$} & \multirow{2}{*}{$\begin{array}{c}\text { Até o } \\
\text { Doutorado }\end{array}$} & \multicolumn{4}{|c|}{ Além do Doutorado } & \multirow[b]{2}{*}{$\begin{array}{c}\text { Total } \\
\text { (n) }\end{array}$} & \multirow[b]{2}{*}{ Total (\%) } \\
\hline & & $\begin{array}{l}\text { Pós-Doutorado } \\
\text { (PD) }\end{array}$ & $\begin{array}{l}\text { Livre- } \\
\text { Docência } \\
\text { (LD) }\end{array}$ & PD e LD & $\begin{array}{c}\text { SOMA } \\
\text { (PD+LD+LD e } \\
\text { PD) }\end{array}$ & & \\
\hline USP & 21 & 7 & 15 & 17 & 39 & 60 & 22,6 \\
\hline UFRJ & 11 & 8 & - & 1 & 9 & 20 & 7,5 \\
\hline UNB & 6 & 5 & - & - & 5 & 11 & 4,1 \\
\hline PUCSP & 7 & 9 & - & 3 & 12 & 19 & 7,1 \\
\hline UMESP & 8 & 2 & - & 2 & 4 & 12 & 4,5 \\
\hline UNICAMP & 4 & 4 & - & 2 & 6 & 10 & 3,8 \\
\hline UFBA & 7 & 3 & - & - & 3 & 10 & 3,8 \\
\hline PUCRS & 17 & 3 & - & - & 3 & 20 & 7,5 \\
\hline UNISINOS & 11 & 3 & - & - & 3 & 14 & 5,3 \\
\hline UFRGS & 7 & 2 & - & - & 2 & 9 & 3,4 \\
\hline UFMG & 7 & 1 & - & 1 & 2 & 9 & 3,4 \\
\hline UFF & 6 & 6 & - & - & 6 & 12 & 4,5 \\
\hline UFPE & 7 & - & - & - & - & 7 & 2,6 \\
\hline UTP & 6 & 2 & - & - & & 8 & 3 \\
\hline UNIP & 5 & 4 & - & 1 & 5 & 10 & 3,8 \\
\hline UERJ & 9 & 2 & - & - & 2 & 11 & 4,1 \\
\hline UNESP & 9 & - & 2 & - & 2 & 11 & 4,1 \\
\hline UNIMAR & 4 & 2 & 1 & - & 3 & 7 & 2,6 \\
\hline PUCRJ & 5 & 1 & - & - & 1 & 6 & 2,3 \\
\hline Total (n e \%) & $157(59,0)$ & $64(24,1 \%)$ & $186,8 \%)$ & $27(10,1 \%)$ & $109(41,0)$ & 266 & 100,0 \\
\hline
\end{tabular}

Fonte: CNPq (Plataforma Lattes - 2005)

A análise das titulações pós-doutorais do corpo docente dos PPGCOM mostra que mais da metade dos pesquisadores (157 docentes, 59\% no todo) tem no doutorado a sua titulação máxima. Os outros 109 docentes (41\%) possuem algum título superior: 64 (24,1\%) fizeram o pós-doutorado; 18 (6,8\%), livre-docência, e 27 (10,1\%), pós-doutorado e livre-docência.

É válido observar que o movimento por maior qualificação dos docentes, expresso em níveis mais altos de titulação, atinge praticamente todos os PPGCOM (a exceção é o da UFPE). Há desde aqueles nos quais a maioria dos docentes possui outro título além do doutorado (USP, PUCSP, UNICAMP e UNIMAR) até aqueles em que esta relação é igual ou menor (igual: UMESP, UFF e UNIP; menor: UFRJ, UNB, UFBA, PUCRS, UNISINOS, UFRGS, UFRMG, UTP, UERJ, UNESP e PUCRJ). O fato de que a maioria dos docentes (59\%) tenha somente o doutorado explica-se, em parte, pela quantidade expressiva (cerca de $1 / 4$ ) de jovens doutores, como visto. 
Como a titulação da livre-docência é uma exigência das universidades paulistas, este título é mais destacado nos Programas deste estado. Praticamente todas as LDs foram realizadas em IES nacionais, sendo que a USP é majoritária (há uma exceção com título obtido na Alemanha). Já em relação aos pós-doutorados, dentre os docentes que o realizaram, apenas ele ou junto com livre-docência, a maioria (71 docentes) obteve apenas um título; respectivamente, 15 e 4 docentes, realizaram 2 e 4 PDs, por fim, um docente realizou 4 pós-doutorados. Os países nos quais os PDs foram realizados são mostrados na Tabela seguinte.

Tabela 4.17 - Países das instituições nos quais foram feitos os Pós-Doutorados pelos docentes permanentes dos PPGCOM (2005)

\begin{tabular}{l|c|c}
\hline $\begin{array}{l}\text { Pós-DoutoradosI } \\
\text { Países }\end{array}$ & N & \% \\
\hline França & 35 & $\mathbf{2 9 , 9}$ \\
\hline Brasil & 25 & $\mathbf{2 1 , 3}$ \\
\hline EUA & 22 & $\mathbf{1 8 , 8}$ \\
\hline Espanha & 7 & $\mathbf{5 , 9}$ \\
\hline Alemanha & 5 & $\mathbf{4 , 3}$ \\
\hline Itália & 5 & $\mathbf{4 , 3}$ \\
\hline Portugal & 4 & $\mathbf{3 , 4}$ \\
\hline Inglaterra & 3 & $\mathbf{2 , 6}$ \\
\hline Canadá & 3 & $\mathbf{2 , 6}$ \\
\hline Japão & 3 & $\mathbf{2 , 6}$ \\
\hline Argentina & 2 & $\mathbf{1 , 7}$ \\
\hline Áustria & 2 & $\mathbf{1 , 7}$ \\
\hline Dinamarca & 1 & $\mathbf{0 , 9}$ \\
\hline TOTAL & $\mathbf{1 1 7}$ & $\mathbf{1 0 0 , 0}$ \\
\hline
\end{tabular}

Fonte: CNPq (Plataforma Lattes - 2005)

Confirmando a preferência pelo espaço europeu, no âmbito da formação, mais do que os EUA, a França é o país no qual foram realizados mais pós-doutorados pelos docentes dos PPGCOM (29,9\% dos PDs), as instituições brasileiras estão em segundo lugar (com 21,3\%). Os EUA são o terceiro país (18,8\%). A seguir, com bem menos PDs, seguem-se vários países, como Espanha (5,3\%), Itália e Alemanha (ambos com 4,3\%). Apesar dos países europeus serem predominantes, foram também realizados pós-doutorados no Canadá e Japão (os dois com 2,6\%) e em um país da América Latina, a Argentina (1,7\%).

A seguir, serão descritas as modalidades de fomento à pesquisa científica no Brasil que formam o principal sistema de suporte a esta atividade no país em termos de bolsas de 
estudo, pesquisa e auxílios para a investigação científica. O local ocupado pelas Ciências da Comunicação nessa estrutura é igualmente destacado.

\subsection{O fomento à pesquisa: bolsas e investimentos realizados pelas agências governamentais}

O estímulo à formação de recursos humanos para a pesquisa possui hoje um sistema de bolsas de estudo e pesquisa que alcança vários níveis, atingindo desde o graduando até o pesquisador sênior. O sistema é, sem dúvida, um instrumento importante para a consolidação das atividades de investigação no país. As duas principais agências de âmbito nacional - CNPq e CAPES - têm sua atuação complementada, ainda no plano nacional, pela FINEP e convênios dessas agências com outros órgãos federais (ministérios, secretarias), e por fim pela atuação das Fundações de Amparo à Pesquisa dos Estados ${ }^{44}$.

A seguir, apresentam-se dados gerais com informações estatísticas de Grandes Áreas de conhecimento sobre os programas de atuação das agências de âmbito nacional, em termos de bolsas de formação no país (Tabela 4.18) e no exterior (Tabela 4.19), e o montante de bolsas de pesquisa distribuídas pelo CNPq (Tabela 4.20).

As Tabelas seguintes (4.21, 4.22 e 4.23) irão, sob os mesmos parâmetros analisados antes em termos de Grandes Áreas de conhecimento, comparar a posição da Comunicação com outras áreas de pesquisa, aquelas que possuem um número de titulados na PG similar, tanto das Ciências Humanas (História e Sociologia), quanto das Ciências Sociais Aplicadas (Economia, Arquitetura e Urbanismo). As bolsas de Produtividade em Pesquisa são analisadas em seguida (Tabela 4.24).

Por fim, nas Tabelas 4.25, 4.26 e 4.27 são mostrados dados sobre os investimentos em pesquisa do CNPq, por Grande Área de conhecimento e determinadas áreas (entre elas a

\footnotetext{
${ }^{44}$ No Volume de Anexos encontra-se Tabela que mostra a divisão percentual de bolsas distribuídas pelas agências, nela o CNPq ocupa o primeiro lugar (50,53\%) seguido pela CAPES (31,56\%) e FAPESP $(9,41 \%)$.
} 
Comunicação). E, no tópico seguinte, faremos algumas considerações gerais sobre os dados apresentados nesse capítulo. 
Tabela 4.18 - Bolsas de Formação no País do CNPq e da CAPES - distribuição por programa e Grande Área de conhecimento

\begin{tabular}{|c|c|c|c|c|c|c|c|c|c|c|c|c|c|c|c|c|c|c|c|c|c|c|}
\hline \multirow{2}{*}{$\begin{array}{l}\text { Modalidadel } \\
\text { Grande Área }\end{array}$} & \multicolumn{8}{|c|}{ Bolsa de Formação no País - CNPq } & \multicolumn{12}{|c|}{ Bolsa de Formação no País - CAPES } & \multicolumn{2}{|c|}{ Total Geral } \\
\hline & M & D & Pós-D & IC (AI) & $\begin{array}{c}\text { IC } \\
\text { (PIBIC) }\end{array}$ & ITI & $\begin{array}{c}\text { Total } \\
(n)\end{array}$ & $\begin{array}{l}\text { Total } \\
(\%)\end{array}$ & M (DS) & $\mathrm{D}(\mathrm{DS})$ & $\begin{array}{c}\text { M } \\
\text { Integr. } \\
\text { (PICDT) }\end{array}$ & $\begin{array}{c}\text { D } \\
\text { Integr. } \\
\text { (PICDT) }\end{array}$ & $\begin{array}{l}\text { Mest. } \\
\text { Prof }\end{array}$ & $\begin{array}{l}\text { Dout. } \\
\text { Prof }\end{array}$ & $\begin{array}{l}\text { Mest. } \\
\text { Prosup }\end{array}$ & $\begin{array}{l}\text { Dout. } \\
\text { Prosup }\end{array}$ & $\begin{array}{l}\text { M (PRO } \\
\text { EX) }\end{array}$ & $\begin{array}{c}\text { D (PRO } \\
\text { EX) }\end{array}$ & $\begin{array}{c}\text { Total } \\
\text { (n) }\end{array}$ & $\begin{array}{l}\text { Total } \\
(\%)\end{array}$ & $\mathrm{n}$ & $\%$ \\
\hline $\begin{array}{l}\text { Ciências Exatas } \\
\text { e da Terra }\end{array}$ & 1.031 & 1.190 & 60 & 632 & 2.453 & 80 & 5.446 & 18,2 & 1.041 & 619 & - & 85 & 305 & 102 & 114 & 34 & 365 & 411 & 3.076 & 12,5 & 8.522 & 15,6 \\
\hline $\begin{array}{l}\text { Ciências } \\
\text { Humanas }\end{array}$ & 750 & 680 & 17 & 700 & 1.986 & 15 & 4.148 & 13,9 & 1.081 & 488 & 9 & 305 & 457 & 170 & 785 & 468 & 193 & 182 & 4.138 & 16,8 & 8.286 & 15,2 \\
\hline $\begin{array}{l}\text { Ciências } \\
\text { Biológicas }\end{array}$ & 824 & 1.038 & 69 & 849 & 2.399 & 128 & 5.307 & 17,8 & 952 & 816 & - & 51 & 387 & 245 & 65 & 26 & 171 & 236 & 2.949 & 12,0 & 8.256 & 15,1 \\
\hline Engenharias & 894 & 929 & 38 & 793 & 1.658 & 63 & 4.375 & 14,6 & 1.215 & 527 & 4 & 87 & 337 & 137 & 210 & 84 & 450 & 307 & 3.358 & 13,6 & 7.733 & 14,2 \\
\hline $\begin{array}{l}\text { Ciências } \\
\text { Agrárias }\end{array}$ & 781 & 749 & 32 & 460 & 1.977 & 104 & 4.103 & 13,7 & 1.154 & 729 & 1 & 84 & 641 & 339 & 36 & 2 & 100 & 188 & 3.274 & 13,3 & 7.377 & 13,5 \\
\hline $\begin{array}{l}\text { Ciências da } \\
\text { Saúde }\end{array}$ & 339 & 218 & 6 & 351 & 1.963 & 4 & 2.881 & 9,6 & 1.384 & 1.221 & 4 & 108 & 296 & 116 & 328 & 115 & 50 & 48 & 3.670 & 14,9 & 6.551 & 12,0 \\
\hline $\begin{array}{l}\text { Ciências Sociais } \\
\text { Aplicadas }\end{array}$ & 400 & 178 & 6 & 336 & 1.139 & 148 & 2.207 & 7,4 & 416 & 179 & 9 & 102 & 320 & 76 & 642 & 234 & 72 & 30 & 2.080 & 8,4 & 4.287 & 7,9 \\
\hline $\begin{array}{l}\text { Lingüística, } \\
\text { Letras e Artes }\end{array}$ & 195 & 193 & 2 & 195 & 684 & 4 & 1.273 & 4,3 & 440 & 245 & 3 & 133 & 141 & 68 & 179 & 86 & 48 & 45 & 1.388 & 5,6 & 2.661 & 4,9 \\
\hline $\begin{array}{l}\text { Outras Áreas I } \\
\text { Indefinido }\end{array}$ & 24 & 22 & - & 4 & 98 & 4 & 152 & 0,5 & 264 & 93 & 2 & 39 & 106 & 61 & 132 & 11 & - & - & 708 & 2,9 & 860 & 1,6 \\
\hline $\begin{array}{l}\text { Total por Agência } \\
\text { (n e \%) }\end{array}$ & $\begin{array}{c}5.238 \\
(17,5 \%)\end{array}$ & $\begin{array}{c}5.197 \\
(17,4 \%)\end{array}$ & $\begin{array}{c}230 \\
(0,8 \%)\end{array}$ & $\begin{array}{c}4.320 \\
(14,5 \%)\end{array}$ & $\begin{array}{l}14.357 \\
(48,0 \%)\end{array}$ & $\begin{array}{c}550 \\
(1,8 \%)\end{array}$ & $\begin{array}{l}29.892 \\
(100,0 \%)\end{array}$ & 100,0 & $\begin{array}{l}7.947 \\
(32,3 \%)\end{array}$ & $\begin{array}{l}4.917 \\
(20,0 \%)\end{array}$ & $\begin{array}{c}32 \\
(0,1 \%)\end{array}$ & $\begin{array}{c}994 \\
(4,0 \%)\end{array}$ & $\begin{array}{l}2.990 \\
(12,1 \%)\end{array}$ & $\begin{array}{l}1.314 \\
(5,3 \%)\end{array}$ & $\begin{array}{l}2.491 \\
(10,1 \%)\end{array}$ & $\begin{array}{l}1.060 \\
(4,3 \%)\end{array}$ & $\begin{array}{l}1.449 \\
(5,9 \%)\end{array}$ & $\begin{array}{l}1.447 \\
(5,9 \%)\end{array}$ & $\begin{array}{l}24,641 \\
(100,0 \%)\end{array}$ & 100,0 & 54.533 & 100,0 \\
\hline Total Geral (n e \%) & $\begin{array}{l}5.238 \\
(9,6 \%)\end{array}$ & $\begin{array}{l}5.197 \\
(9,5 \%)\end{array}$ & $\begin{array}{c}230 \\
(0,4 \%)\end{array}$ & $\begin{array}{l}4.320 \\
(7,9 \%)\end{array}$ & $\begin{array}{l}14.357 \\
(26,6 \%)\end{array}$ & $\begin{array}{c}550 \\
(1,0 \%)\end{array}$ & $\#$ & $\#$ & $\begin{array}{c}7.947 \\
(14,6 \%)\end{array}$ & $\begin{array}{l}4.917 \\
(9,0 \%)\end{array}$ & $\begin{array}{c}32 \\
(0,1 \%)\end{array}$ & $\begin{array}{c}994 \\
(1,8 \%)\end{array}$ & $\begin{array}{l}2.990 \\
(5,5 \%)\end{array}$ & $\begin{array}{l}1.314 \\
(2,4 \%)\end{array}$ & $\begin{array}{c}2.491 \\
(4,6 \%)\end{array}$ & $\begin{array}{l}1.060 \\
(1,9 \%)\end{array}$ & $\begin{array}{l}1.449 \\
(2,7 \%)\end{array}$ & $\begin{array}{l}1.447 \\
(2,7 \%)\end{array}$ & $\#$ & $\#$ & & 100,0 \\
\hline
\end{tabular}

Fonte: Prossiga/MCT (2005)

$\underset{\omega}{\omega}$ 
Os dados da tabela 4.18 mostram, inicialmente, que as três grandes áreas que possuem maior número de bolsas do CNPq no país são as de Ciências Exatas e da Terra (5.446 bolsa, 18,2\% do total dessa agência), Ciências Biológicas (5.307 - 17,8\%) e Engenharias (4.375 - 14,6\%). Em quarto lugar, no CNPq, situa-se a Grande Área de Humanidades, com 4.148 bolsas (13,9\%), seguida por Ciências Agrárias (4.103 - 13,7\%) e Ciências da Saúde (2.881 - 9,6\%). Com 2.207 bolsas, a Grande Área no qual está inserida a área de Comunicação, isto é, Ciências Sociais Aplicadas, totaliza 7,4\% das bolsas do CNPq no país, estando, pois, só à frente da Grande Área de Lingüística, Letras e Artes (1.273 $4,3 \%$ ) e da categoria residual "outras/indefinido" (142 bolsas, com 0,5\% do total do CNPq).

O destaque dentre as bolsas no país do CNPq é em relação à modalidade de Iniciação Científica. Assim, as bolsas do Programa Institucional de Bolsas de Iniciação Científica (PIBIC) e de IC (Auxílio Integrado) somam 18.677 bolsas, correspondendo a 62,5\% do total de bolsas dessa agência. A seguir, estão as bolsas de Mestrado e Doutorado no país, com $5.238(17,5 \%)$ e $5.197(17,4 \%)$ bolsas do CNPq, respectivamente, as bolsas de Iniciação Tecnológica e Industrial (550 - 1,8\%) e de Pós-Doutorado (230 - 0,8\% do total dessa agência).

Agora quanto à CAPES, é interessante notar, inicialmente, o número expressivo de programas oferecidos pela agência, atuando em complementaridade. Assim a bolsa de Mestrado Demanda Social - DS é a que possui mais bolsas (7.947, correspondendo a 32,2\% do total da CAPES), seguida pela de Doutorado DS (4.917 - 20\%). De modo que esse programa totaliza mais da metade das bolsas da agência (52,3\%). O Programa DS caracteriza-se por apoiar instituições de ensino públicas e gratuitas. Já a segunda modalidade de bolsa mais ofertada pela CAPES é a do Programa de Fomento à PósGraduação - PROF, que no todo CAPES (entre Mestrado e Doutorado, com maioria do primeiro nível), soma 4.304 bolsas, num total de 17,4\% da oferta da agência. Neste caso, as instituições que recebem tais bolsas não são contempladas pelo Programa DS. As bolsas do Programa de Suporte à Pós-Graduação de Instituições de Ensino Particulares PROSUP são a terceira modalidade mais ofertada, com (na soma de Mestrado e Doutorado, também com prevalência do primeiro nível) 3.551 bolsas (14,4\% do total de bolsas da CAPES). O Programa de Excelência Acadêmica - PROEX (criado em 2004 e que financia apenas PPG com nota 6 ou 7), por sua vez, concede 2.896 bolsas (10,8\% das 
bolsas da agência), com praticamente o mesmo número no Mestrado e no Doutorado. A última modalidade destacada é a do tradicional Programa Institucional de Capacitação Docente e Técnica - PICDT (1.026 bolsas de Mestrado e Doutorado, correspondendo no total da agência a 4,1\%), que financia a qualificação do corpo docente/técnico de instituições de ensino superior públicas. Note-se, neste caso, que o maior peso do Doutorado (com 994 bolsas contra 32 de Mestrado) indica maior capacitação do corpo docente da IES públicas.

Quanto ao número de bolsas de formação por Grande Área na CAPES, observa-se que a recebe mais é a de Ciências Humanas (4.138 bolsas, o que corresponde a 16,8\% do total da agência). Em seguida estão Ciências da Saúde (3.670 - 14,9\%), Engenharias (3.358 13,6\%), Ciências Agrárias (3.247 - 13,3\%), Ciências Exatas e da Terra (3.076 - 12,5\%) e Ciências Biológicas (2.949 - 12\%). Com 2.080 bolsas (8,4\% do total) as Ciências Sociais Aplicadas vem depois das Grandes Áreas mencionadas, tendo mais bolsas apenas do que a Grande Área de Lingüística, Letras e Artes (1.388 - 5,6\%). Nesta distribuição de bolsas de formação no país por grande área, é interessante notar que, numa comparação com o CNPq, as Ciências Humanas ocupam melhor posição na CAPES (são a $1^{\text {a }}$ grande nesta agência e a $4^{\mathrm{a}}$ no CNPq), já as Ciências Sociais Aplicadas têm um percentual (7,4\% no CNPq e 8,4\% na CAPES) e uma posição em relação às outras Grandes Áreas parecidos. De modo que, no somatório geral de bolsas, ocupa a mesma $7^{\mathrm{a}}$. posição (com 4.287 bolsas - 8,4\% do total geral), somente superior a Lingüística, Letras e Artes e “outras”. Já as três grandes áreas com maior número são Ciências Exatas e da Terra (8.522 bolsas - 15,6\% do total), Ciências Humanas (8.286- 15,2\%) e Ciências Biológicas (8.256 - 15,1\%).

A relação entre bolsas de Mestrado e Doutorado é um bom indicador do padrão de titulação de uma área e de sua consolidação. A diminuição da demanda do mestrado "libera” bolsas e indica crescimento do Doutorado. Dessa forma, somando-se todos os programas ofertados pelas duas agências para esses níveis de titulação, observa-se que apenas uma Grande Área já possui mais bolsistas de Doutorado do que Mestrado (Ciências Biológicas e Engenharias, com 2.412 e 2.399 bolsas, respectivamente). Enquanto é justamente a Grande Área de Ciências Sociais Aplicadas a que tem mais bolsas de Mestrado do que de Doutorado, com uma relação M/D de 0,4. As demais grandes áreas possuem as seguintes relações entre bolsistas de Mestrado e Doutorado: Ciências Exatas e 
da Terra (0,9), Ciências da Saúde (0,8), Lingüística, Letras e Artes (0,8), Ciências Agrárias $(0,8)$, Ciências Humanas $(0,7)$, Engenharias $(0,7)$. 
Tabela 4.19 - Bolsas de Formação no Exterior do CNPq e da CAPES - distribuição por programa e Grande Área de conhecimento

\begin{tabular}{|c|c|c|c|c|c|c|c|c|c|c|c|c|c|c|c|c|c|}
\hline \multirow{2}{*}{$\begin{array}{l}\text { Modalidadel } \\
\text { Grande Área do } \\
\text { Conhecimento }\end{array}$} & \multicolumn{8}{|c|}{ Bolsa de Formação no Exterior - CNPq } & \multicolumn{7}{|c|}{ Bolsa de Formação no Exterior - CAPES } & \multicolumn{2}{|c|}{ Total Geral } \\
\hline & D Pleno & D Sand & Pós-D & $\begin{array}{l}\text { Estágio } \\
\text { Senior }\end{array}$ & Aperf. & $\begin{array}{l}\text { Trein } \\
\text { no Ext. }\end{array}$ & $\begin{array}{c}\text { Total } \\
\text { (n) }\end{array}$ & $\begin{array}{c}\text { Total } \\
(\%)\end{array}$ & M & D & Pós-D & D Sand & $\begin{array}{l}\text { Grad } \\
\text { Sand }\end{array}$ & $\begin{array}{c}\text { Total } \\
(\mathrm{n})\end{array}$ & $\begin{array}{c}\text { Total } \\
(\%)\end{array}$ & $\mathbf{n}$ & $\%$ \\
\hline Engenharias & 41 & 21 & 15 & 1 & 3 & 0 & 81 & 15,7 & - & 116 & 54 & 64 & 188 & 422 & 22,5 & 503 & 21,0 \\
\hline $\begin{array}{l}\text { Ciências Exatas e } \\
\text { da Terra }\end{array}$ & 64 & 17 & 39 & - & 1 & 1 & 122 & 23,6 & - & 153 & 67 & 73 & 26 & 319 & 17,0 & 441 & 18,4 \\
\hline $\begin{array}{l}\text { Ciências Sociais } \\
\text { Aplicadas }\end{array}$ & 46 & 12 & 5 & - & - & - & 63 & 12,2 & - & 137 & 39 & 28 & 50 & 254 & 13,5 & 317 & 13,3 \\
\hline $\begin{array}{l}\text { Ciências } \\
\text { Humanas }\end{array}$ & 33 & 13 & 10 & 1 & - & - & 57 & 11,0 & - & 102 & 66 & 56 & 24 & 248 & 13,2 & 305 & 12,8 \\
\hline $\begin{array}{l}\text { Ciências } \\
\text { Biológicas }\end{array}$ & 40 & 21 & 21 & - & - & - & 82 & 15,9 & - & 79 & 41 & 43 & 5 & 168 & 8,9 & 250 & 10,5 \\
\hline $\begin{array}{l}\text { Ciências da } \\
\text { Saúde }\end{array}$ & 16 & 7 & 14 & - & - & - & 37 & 7,2 & 1 & 50 & 52 & 46 & 14 & 163 & 8,7 & 200 & 8,4 \\
\hline Ciências Agrárias & 36 & 4 & 14 & - & - & - & 54 & 10,5 & - & 58 & 18 & 15 & 42 & 133 & 7,1 & 187 & 7,8 \\
\hline $\begin{array}{l}\text { Lingüística, } \\
\text { Letras e Artes }\end{array}$ & 8 & 5 & 7 & - & - & - & 20 & 3,9 & - & 71 & 13 & 49 & 21 & 154 & 8,2 & 174 & 7,2 \\
\hline Outras áreas & - & - & - & - & - & - & - & - & - & 9 & 2 & 4 & 1 & 16 & 0,9 & 16 & 0,6 \\
\hline $\begin{array}{l}\text { Total por agência } \\
\text { (n e \%) }\end{array}$ & $\begin{array}{c}284 \\
(55,0 \%)\end{array}$ & $\begin{array}{c}100 \\
(19,4 \%)\end{array}$ & $\begin{array}{c}125 \\
(24,2 \%)\end{array}$ & $\begin{array}{c}2 \\
(0,4 \%)\end{array}$ & $\begin{array}{c}4 \\
(0,8 \%)\end{array}$ & $\begin{array}{c}1 \\
(0,2 \%)\end{array}$ & $\begin{array}{c}516 \\
(100,0 \%)\end{array}$ & 100,0 & $\begin{array}{c}1 \\
(0,1 \%)\end{array}$ & $\begin{array}{c}775 \\
(41,3 \%)\end{array}$ & $\begin{array}{c}352 \\
(18,7 \%)\end{array}$ & $\begin{array}{c}378 \\
(20,1 \%)\end{array}$ & $\begin{array}{c}371 \\
(19,8 \%)\end{array}$ & $\begin{array}{l}1.877 \\
(100 \%)\end{array}$ & 100,0 & 2.393 & 100,0 \\
\hline $\begin{array}{l}\text { Total Geral } \\
\text { (n e \%) }\end{array}$ & $\begin{array}{c}284 \\
(11,8 \%)\end{array}$ & $\begin{array}{l}100 \\
(4,1 \%)\end{array}$ & $\begin{array}{l}125 \\
(5,2 \%)\end{array}$ & $\begin{array}{c}2 \\
(0,1 \%)\end{array}$ & $\begin{array}{c}4 \\
(0,2 \%)\end{array}$ & $\begin{array}{c}1 \\
(0,1 \%)\end{array}$ & $\#$ & $\#$ & $\begin{array}{c}1 \\
(0,1 \%)\end{array}$ & $\begin{array}{c}775 \\
(32,4 \%)\end{array}$ & $\begin{array}{c}352 \\
(14,7 \%)\end{array}$ & $\begin{array}{c}378 \\
(15,8 \%)\end{array}$ & $\begin{array}{c}371 \\
(15,5 \%)\end{array}$ & $\#$ & $\#$ & 2.393 & 100,0 \\
\hline
\end{tabular}

Fonte: Prossiga/MCT (2005) 
A Tabela 4.19 mostra que, quanto às bolsas no exterior distribuídas pelo CNPq, a situação de colocação das três primeiras grandes áreas é igual a das bolsas no país nessa agência. Ou seja, em primeiro lugar está a Grande Área de Ciências Exatas e da Terra (122 bolsas, 23,6\% do total da agência), seguida por Ciências Biológicas (82 - 15,9\%) e Engenharias (81 - 15,7\%). Porém, em quarto lugar, embora próxima das duas seguintes, está a Grande Área de Ciências Sociais Aplicadas, com 63 bolsas, correspondendo a 12,2\% do total do CNPq. Em seguida estão Ciências Humanas (57 bolsas, 11\%), Ciências Agrárias (54 10,5\%), Ciências da Saúde (37 - 7,2\%) e Lingüística, Letras e Artes (20 - 3,9\%).

No CNPq, o percentual de bolsas mais elevado é o do Doutorado Pleno, com 55\% do total da agência, modalidade seguida pela bolsa de Pós-Doutorado (125 - 24,2\%) e de Doutorado Sanduíche (100 - 19,4\%). As modalidades de bolsa restantes - Estágio Sênior, Aperfeiçoamento e Treinamento no Exterior - são em pequena quantidade e pouco utilizadas pelas Ciências Sociais e Humanas.

Já quanto às bolsas no exterior distribuídas pela CAPES, a modalidade do Doutorado é também predominante, com 775 bolsas (41,3\% da agência), tendo os três tipos seguintes valores próximos: Doutorado Sandwich (378 bolsas - 20,1\%), Graduação Sandwich (371 19,8\%) e Pós-Doutorado (352 - 18,7\%). O número de bolsas de mestrado soma apenas 1 (0,1\% do total de bolsas da CAPES).

A Grande Área com mais bolsas é a de Engenharias, com 422 (22,5\%), seguida pelas de Ciências Exatas e da Terra (319 - 17\%), Ciências Sociais Aplicadas (254 - 13,5\%), Ciências Humanas (248 - 13,2\%), Ciências Biológicas (168 - 8,9\%), Ciências da Saúde (163 - 8,7\%), Lingüística, Letras e Artes (154 - 8,2\%) e Ciências Agrárias (133 - 7,1\%), com ainda 16 bolsas (0,9\%) de “outras”.

Desse modo, em termos gerais a Grande Área que possui maior número total de bolsas no exterior fornecidas por essas duas agências é Engenharias (503 - 21\%), seguida por Ciências Exatas e da Terra (441 - 18,4\%), Ciências Sociais Aplicadas (317 - 13,3\%), Ciências Humanas (305 - 12,8\%), Ciências Biológicas (250 - 10,5\%), Ciências da Saúde (8,4\%), Ciências Agrárias (187 - 7,8\%), Lingüística, Letras e Artes (174 - 7,2\%) e “outras” (16-0,6\%). 
Similarmente ao caso das bolsas no país, o Pós-Doutorado - modalidade que as duas agências oferecem -, serve como um indicador da consolidação da grande área, e observase que as Ciências Sociais Aplicadas possuem 44 bolsas desse tipo, número superior ao das grandes áreas de Lingüística, Letras e Artes (que possui 20) e Ciências Agrárias (32), e menor que as demais, entre outras, a com mais bolsas nesse aspecto, Ciências Exatas e da Terra (106) e Ciências Humanas (76).

Tabela 4.20 - Bolsas de Pesquisa do CNPq: distribuição por modalidade e Grande Área de conhecimento

\begin{tabular}{|c|c|c|c|c|c|c|c|c|c|}
\hline \multirow{2}{*}{$\begin{array}{l}\text { Modalidadel } \\
\text { Grande Área de } \\
\text { Conhecimento }\end{array}$} & \multicolumn{9}{|c|}{ Bolsa de Pesquisa } \\
\hline & $\begin{array}{l}\text { Recém- } \\
\text { doutor }\end{array}$ & $\begin{array}{l}\text { Produtivida } \\
\text { de em } \\
\text { Pesquisa }\end{array}$ & $\begin{array}{l}\text { Pesq. } \\
\text { Visit. } \\
\text { (longa } \\
\text { dur.) }\end{array}$ & $\begin{array}{c}\text { Desenvolvime } \\
\text { nto Científico } \\
\text { e Regional }\end{array}$ & $\begin{array}{l}\text { Apoio } \\
\text { Técnico à } \\
\text { Pesquisa }\end{array}$ & $\begin{array}{l}\text { Desenvolv. } \\
\text { Tecnológ. } \\
\text { e Industrial }\end{array}$ & $\begin{array}{c}\text { Especia } \\
\text { lista } \\
\text { Visitante }\end{array}$ & $\begin{array}{c}\text { Total } \\
\text { (n) }\end{array}$ & $\begin{array}{l}\text { Total } \\
(\%)\end{array}$ \\
\hline $\begin{array}{l}\text { Ciências Exatas e } \\
\text { da Terra }\end{array}$ & 90 & 1.797 & 21 & 54 & 207 & 153 & 2 & 2.324 & 19,3 \\
\hline $\begin{array}{l}\text { Ciências } \\
\text { Biológicas }\end{array}$ & 64 & 1.486 & 37 & 59 & 455 & 183 & 2 & 2.286 & 19,0 \\
\hline Ciências Agrárias & 57 & 1.163 & 4 & 77 & 296 & 102 & - & 1.699 & 14,1 \\
\hline Engenharias & 47 & 1.174 & 10 & 50 & 300 & 81 & - & 1.662 & 13,8 \\
\hline Ciências Humanas & 36 & 985 & 11 & 11 & 267 & 75 & 2 & 1.387 & 11,5 \\
\hline $\begin{array}{l}\text { Ciências Sociais } \\
\text { Aplicadas }\end{array}$ & 15 & 508 & 3 & 11 & 133 & 456 & 12 & 1.138 & 9,4 \\
\hline Ciências da Saúde & 17 & 870 & 9 & 10 & 225 & 3 & - & 1.134 & 9,4 \\
\hline $\begin{array}{l}\text { Lingüística, Letras } \\
\text { e Artes }\end{array}$ & 21 & 336 & 1 & 7 & 30 & 2 & - & 397 & 3,3 \\
\hline $\begin{array}{l}\text { Outras ÁreasI } \\
\text { Indefinido }\end{array}$ & 13 & - & - & - & 2 & 10 & 1 & 26 & 0,2 \\
\hline Total (n e \%) & $\begin{array}{c}360 \\
(3,0 \%)\end{array}$ & $\begin{array}{c}8.319 \\
(69,0 \%)\end{array}$ & $\begin{array}{c}96 \\
(0,8 \%)\end{array}$ & $\begin{array}{c}279 \\
(2,3 \%)\end{array}$ & $\begin{array}{c}1.915 \\
(15,9 \%)\end{array}$ & $\begin{array}{l}1.065 \\
(8,8 \%)\end{array}$ & $\begin{array}{c}19 \\
(0,2 \%)\end{array}$ & $\begin{array}{l}12.053 \\
(100,0 \%)\end{array}$ & 100,0 \\
\hline
\end{tabular}

Fonte: Prossiga/MCT (2005)

A distribuição de bolsas de pesquisas por parte do CNPq segue um padrão similar a das bolsas de formação, assim, as duas primeiras grandes áreas que recebem maior número de bolsas são também as de Ciências Exatas e da Terra (com 2.324 bolsas, num total de 19,3\%) e Ciências Biológicas (2.286 - 19\%). Em terceiro lugar está a Grande Área de Ciências Agrárias (1.669 bolsas, 14,1\% das mesmas) seguida de perto pela de Engenharias (1.662 - 13,8\%). A Grande Área de Ciências Humanas é a quinta em número de bolsas de pesquisa, somando 1.387 (11,5\%), enquanto as Ciências Sociais Aplicadas e Ciências da Saúde vêm a seguir com um número de bolsas parecido, respectivamente 1.138 (9,4\%) e 1.134 (9,4\%). A Grande Área de Lingüística, Letras e Artes possui, por fim, 397 bolsas (3,3\%) e “outras áreas/indefinido” somam 26 bolsas (0,2\%). 
A maioria de bolsas de pesquisa fornecidas pelo CNPq pertence à modalidade de Produtividade em Pesquisa (com 8.319 bolsas, 69\% do total), a seguir a categoria de Apoio Técnico (1.91- 15,9\%). As bolsas das modalidades de Desenvolvimento Tecnológico e Industrial (1.065 bolsas, 8,8\% do todo), Recém-Doutor (360 - 3\%), Pesquisador Visitante (96 - 0,8\%) e Especialista Visitante (19 - 0,2\%) são minoritárias, somando ao todo 12,1\%. É interessante notar o número relativamente elevado de bolsas de Desenvolvimento Tecnológico e Industrial da Grande Área de Ciências Sociais Aplicadas (456).

E pode-se tomar como indicador da institucionalização de cada Grande Área o número de bolsas Recém-Doutor (que mostram a incorporação de novos pesquisadores-docentes ao sistema) e, na outra ponta (isto é, contemplando pesquisadores consolidados), a de Produtividade em Pesquisa. Em ambos os casos, a posição das Ciências Sociais Aplicadas, comparativamente com as outras áreas, é modesta: o número de bolsas Recém Doutor é a menor entre todas as grandes áreas (15 bolsas contra, por exemplo, 36 no caso das Ciências Humanas) e, no caso da bolsa de Produtividade, só é maior que o da Grande Área de Lingüística, Letras e Artes (508 versus 336).

\section{Tabela 4.21 - Bolsas de Formação no país do CNPq e CAPES: distribuição por área de conhecimento}

\begin{tabular}{|c|c|c|c|c|c|c|c|c|c|c|c|c|c|c|c|c|c|c|c|c|}
\hline \multirow{2}{*}{$\begin{array}{l}\text { Bolsas I } \\
\text { Área de } \\
\text { Conhec. }\end{array}$} & \multicolumn{7}{|c|}{ Bolsas de Formação no país - CNPq } & \multicolumn{11}{|c|}{ Bolsas de Formação no país - CAPES } & \multicolumn{2}{|c|}{ Total Gera } \\
\hline & M & D & $\begin{array}{l}\text { Pós- } \\
\text { D }\end{array}$ & $\begin{array}{l}\text { IC } \\
\text { (Al) }\end{array}$ & $\begin{array}{l}\text { IC } \\
\text { (PIBI } \\
\text { C) }\end{array}$ & ITI & $\begin{array}{l}\mathrm{T} \\
\text { (n) }\end{array}$ & $\underset{\text { (DS) }}{M}$ & $\underset{\text { (DS) }}{\mathrm{D}}$ & $\underset{\text { (PICD) }}{\mathbf{M}}$ & $\underset{\text { (PICDT) }}{\mathrm{D}}$ & $\underset{\text { Prof }}{M}$ & $\underset{\text { Prof }}{\text { D }}$ & $\underset{\text { Pros }}{M}$ & $\underset{\text { P'ros }}{\text { D }}$ & $\underset{\text { Proex }}{\mathbf{M}}$ & $\underset{\text { Proex }}{\text { D }}$ & $\begin{array}{c}T \\
(n)\end{array}$ & $\mathbf{n}$ & $\%$ \\
\hline História & 136 & 118 & 3 & 65 & 336 & - & $\begin{array}{l}658 \\
(22 \%)\end{array}$ & 132 & 60 & - & 42 & 66 & 26 & 93 & 74 & 34 & 30 & $\begin{array}{l}557 \\
(2,3 \%)\end{array}$ & 1.215 & 2,2 \\
\hline Sociol. & 87 & 101 & 2 & 90 & 157 & - & $\begin{array}{l}437 \\
(15 \%) \\
\end{array}$ & 126 & 85 & - & 50 & 61 & 39 & 36 & 30 & 44 & 38 & $\begin{array}{c}509 \\
(2,1 \%) \\
\end{array}$ & 946 & 1,7 \\
\hline Econ & 112 & 59 & - & 25 & 260 & 15 & $\begin{array}{l}471 \\
(1, \% \%) \\
\end{array}$ & 97 & 57 & 1 & 26 & 57 & 24 & 74 & 14 & 19 & 10 & $\begin{array}{l}379 \\
(1,5 \%) \\
\end{array}$ & 850 & 1,6 \\
\hline Comunic. & 57 & 38 & 2 & 34 & 123 & - & $\begin{array}{l}254 \\
(0,8 \%)\end{array}$ & 51 & 36 & - & 21 & 28 & 6 & 91 & 60 & - & - & $\begin{array}{c}293 \\
(1,2 \%) \\
\end{array}$ & 547 & 1,0 \\
\hline $\begin{array}{l}\text { Arquit. } \\
\text { Urban }\end{array}$ & 13 & 3 & - & 68 & 126 & - & $\begin{array}{l}210 \\
(0,7 \%)\end{array}$ & 54 & 20 & 2 & 15 & 25 & 5 & 17 & - & - & - & $\begin{array}{l}138 \\
(0,6 \%)\end{array}$ & 348 & 0,6 \\
\hline Outras & 4.833 & 4.878 & 223 & 4.038 & 13.355 & 535 & $\begin{array}{l}27862 \\
(932 \%)\end{array}$ & 7.487 & 4.659 & 29 & 840 & 2.753 & 1.214 & 2.180 & 882 & 1.352 & 1.369 & $\begin{array}{l}22.765 \\
(92,3 \%)\end{array}$ & 50.627 & 92,9 \\
\hline $\begin{array}{l}\text { Total por } \\
\text { agência } \\
\text { n e \%) }\end{array}$ & $\begin{array}{l}5238 \\
17,5 \%\end{array}$ & $\begin{array}{l}5197 \\
17 \% \%\end{array}$ & $\begin{array}{l}230 \\
0,8 \%\end{array}$ & $\begin{array}{l}4,320 \\
14,5 \%\end{array}$ & $\begin{array}{l}1438 \\
499 \%\end{array}$ & $\begin{array}{l}550 \\
199 \%\end{array}$ & $\begin{array}{l}29892 \\
1000 \% \%\end{array}$ & $\begin{array}{l}7947 \\
32,3 \%\end{array}$ & $\begin{array}{l}4.917 \\
20,0 \%\end{array}$ & $\begin{array}{c}32 \\
0,1 \%\end{array}$ & $\begin{array}{c}994 \\
4,0 \%\end{array}$ & $\begin{array}{l}2990 \\
12,1 \%\end{array}$ & $\begin{array}{l}1314 \\
5,3 \%\end{array}$ & $\begin{array}{l}2491 \\
10,1 \%\end{array}$ & $\begin{array}{l}1060 \\
4,3 \%\end{array}$ & $\begin{array}{l}1449 \\
5,9 \%\end{array}$ & $\begin{array}{l}1447 \\
5,9 \%)\end{array}$ & $\begin{array}{l}24641 \\
(1000 \%)\end{array}$ & 54.533 & 100,0 \\
\hline
\end{tabular}

Fonte: Prossiga/MCT (2005)

O que é importante nesta e nas duas Tabelas seguintes é a comparação de dados da área da Comunicação com outras similares a ela, em termos do número de titulados na PG. Assim, é interessante perceber, de início, a grande variância que pode existir entre o número de bolsas concedidas a cada uma das áreas selecionadas, indo do topo (História, com 1.215 bolsas - 2,2\% do total a Arquitetura e Urbanismo, com 348 - 0,6\%). Isso se explica por fatores como a maior tradição/consolidação acadêmica de uma área e conseqüente poder de demanda. Com efeito, a relação entre bolsas de Doutorado/Mestrado apresenta números 
mais elevados nas áreas de História $(1,1)$ e Sociologia $(1,5)$, áreas que possuem mais bolsas. Comunicação está em terceiro nessa relação $(0,9)$, enquanto Economia $(0,7)$ e Arquitetura e Urbanismo $(0,8)$ possuem mais bolsas ainda no Mestrado do no Doutorado. Entretanto, a área da Comunicação só supera a de Arquitetura e Urbanismo, dentre as selecionadas, quanto ao total de bolsas concedidas por agências no país, com um total de 547 (1\% do total), contra 348 (0,6\%) daquela área.

\section{Tabela 4.22 - Bolsas de Formação no Exterior do CNPq e CAPES: distribuição por área de conhecimento}

\begin{tabular}{|c|c|c|c|c|c|c|c|c|c|c|c|c|c|c|c|c|c|}
\hline \multirow{2}{*}{$\begin{array}{l}\text { Área de } \\
\text { Conhecimento }\end{array}$} & \multicolumn{8}{|c|}{ Bolsas Formação no exterior - CNPq } & \multicolumn{7}{|c|}{ Bolsas Formação no exterior - CAPES } & \multicolumn{2}{|c|}{ Total Geral } \\
\hline & DPI & $\begin{array}{c}D \\
\text { Sand }\end{array}$ & $\begin{array}{l}\text { Pós- } \\
\text { D }\end{array}$ & $\begin{array}{l}\text { Est. } \\
\text { Sen }\end{array}$ & Aperf & $\begin{array}{l}\text { Trein } \\
\text { Ext. }\end{array}$ & $\begin{array}{l}\text { Total } \\
\text { (n) }\end{array}$ & $\begin{array}{l}\text { Total } \\
(\%)\end{array}$ & M & D & $\begin{array}{l}\text { Pós- } \\
\text { D }\end{array}$ & $\begin{array}{c}D \\
\text { Sand }\end{array}$ & $\begin{array}{l}\text { Grad } \\
\text { Sand }\end{array}$ & $\begin{array}{l}\text { Total } \\
\text { (n) }\end{array}$ & $\begin{array}{l}\text { Total } \\
\text { (\%) }\end{array}$ & $\mathbf{n}$ & $\%$ \\
\hline Economia & 18 & 3 & 1 & - & - & - & 22 & 4,2 & - & 46 & 6 & 3 & 2 & 57 & 3 & 79 & 3,3 \\
\hline $\begin{array}{l}\text { Arquit. e } \\
\text { Urbanismo }\end{array}$ & 4 & - & - & - & - & - & 4 & 0,8 & - & 22 & 7 & 7 & 18 & 54 & 2,9 & 58 & 2,4 \\
\hline Sociologia & 1 & - & 3 & 1 & - & - & 5 & 1 & - & 13 & 13 & 8 & 1 & 35 & 1,9 & 40 & 1,7 \\
\hline História & 3 & 2 & 1 & - & - & - & 6 & 1,2 & - & 13 & 8 & 6 & 6 & 33 & 1,7 & 39 & 1,6 \\
\hline Comunicação & - & 3 & 1 & - & - & - & 4 & 0,8 & - & 4 & 8 & 6 & 2 & 20 & 1,1 & 24 & 1,0 \\
\hline $\begin{array}{l}\text { Outras } \\
\text { áreas }\end{array}$ & 258 & 92 & 119 & 1 & 4 & 1 & 475 & 92 & 1 & 677 & 310 & 348 & 342 & 1.678 & 89,4 & 2.153 & 90,0 \\
\hline $\begin{array}{l}\text { Total por } \\
\text { agência (n e } \\
\text { \%) }\end{array}$ & $\begin{array}{l}284 \\
55,0 \%\end{array}$ & $\begin{array}{l}100 \\
19,4 \%\end{array}$ & $\begin{array}{c}125 \\
24,2 \%\end{array}$ & $\begin{array}{c}2 \\
0,4 \%\end{array}$ & $\begin{array}{c}4 \\
0,8 \%\end{array}$ & $\begin{array}{c}1 \\
0,2 \%\end{array}$ & $\begin{array}{l}516 \\
100 \%\end{array}$ & 100,0 & $\begin{array}{c}1 \\
0,1 \%\end{array}$ & $\begin{array}{c}775 \\
41,3 \%\end{array}$ & $\begin{array}{c}352 \\
18,7 \%\end{array}$ & $\begin{array}{c}378 \\
20,1 \%\end{array}$ & $\begin{array}{c}371 \\
19,8 \%\end{array}$ & $\begin{array}{l}1877 \\
100 \%\end{array}$ & 100,0 & 2.393 & 100,0 \\
\hline
\end{tabular}

Fonte: Prossiga/MCT (2005)

Os dados comparando áreas quanto às bolsas de formação no exterior mostram, igualmente, diferenciação quanto ao volume de cada uma delas, variando de um máximo de 79 bolsas (3,3\%), caso de Economia, a um mínimo de 24 (1\%), para a Comunicação. Porém, nota-se uma mudança no topo ocupado agora por duas áreas das Ciências Sociais Aplicadas: Economia, e Arquitetura e Urbanismo (esta com 58 bolsas - 2,4\% do total). Enquanto Sociologia e História possuem, respectivamente, 40 (1,7\%) e 39 (1,6\%) bolsas.

Isso pode significar, tanto maior dependência de formação no exterior, das áreas com mais bolsas, quanto o estabelecimento de laços internacionais em termos de formação e pesquisa. Porém, quanto ao tipo de bolsa que indicaria mais este aspecto, ou seja, a de PósDoutorado, todas as áreas mostradas, com a exceção de Sociologia, possuem números similares. Assim, Sociologia tem 16 pesquisadores bolsistas realizando o PD no exterior, contra o mesmo número de 8, em História e Comunicação, e 7 bolsas cada, no caso de Economia e Arquitetura e Urbanismo. 
Tabela 4.23 - Bolsas de Pesquisa do CNPq: distribuição por área de conhecimento

\begin{tabular}{l|c|c|c|c|c|c|c|c|c}
\hline \multirow{2}{*}{$\begin{array}{l}\text { Área de } \\
\text { Conhecimento }\end{array}$} & \multicolumn{6}{|c|}{ Bolsas de Pesquisa - CNPq } & \multicolumn{3}{c}{ Total } \\
\cline { 2 - 12 } & $\begin{array}{c}\text { Recém- } \\
\text { doutor }\end{array}$ & $\begin{array}{c}\text { Prod em } \\
\text { Pesq }\end{array}$ & $\begin{array}{c}\text { Pesq. } \\
\text { Visit }\end{array}$ & $\begin{array}{c}\text { Des Cie } \\
\text { Reg }\end{array}$ & AT & $\begin{array}{c}\text { Des Tec. } \\
\text { Ind }\end{array}$ & $\begin{array}{c}\text { Espec. } \\
\text { Visit }\end{array}$ & $\mathbf{n}$ & $\%$ \\
\hline Sociologia & 7 & 135 & 1 & 2 & 57 & - & - & 202 & $\mathbf{1 , 7}$ \\
\hline Economia & 2 & 138 & 1 & - & 19 & 28 & - & 188 & $\mathbf{1 , 6}$ \\
\hline História & 10 & 150 & - & 3 & 23 & - & - & 186 & $\mathbf{1 , 5}$ \\
\hline Comunicação & 4 & 78 & 1 & - & 19 & 3 & - & 105 & $\mathbf{0 , 9}$ \\
\hline $\begin{array}{l}\text { Arquitetura e } \\
\text { Urbanismo }\end{array}$ & 3 & 47 & - & 3 & 20 & - & - & 73 & $\mathbf{0 , 6}$ \\
\hline Outras áreas & 334 & 7.771 & 93 & 271 & 1.777 & 1.034 & 19 & 11.299 & $\mathbf{9 3 , 7}$ \\
\hline Total & $\mathbf{3 6 0}$ & $\mathbf{8 . 3 1 9}$ & $\mathbf{9 6}$ & $\mathbf{2 7 9}$ & $\mathbf{1 . 9 1 5}$ & $\mathbf{1 . 0 6 5}$ & $\mathbf{1 9}$ & 12.053 & $\mathbf{1 0 0 , 0}$ \\
\hline
\end{tabular}

Fonte: Prossiga/MCT (2005)

Como a Tabela 4.23 mostra, na comparação entre a Comunicação e outras quatro áreas, quanto às bolsas de pesquisa do $\mathrm{CNPq}$, Sociologia apresenta, nesta comparação, mais bolsas (202 - 1,7\% do total geral), seguida por Economia (principalmente pelo número de bolsas de Desenvolvimento Tecnológico e Industrial dessa área), que tem 188 bolsas de pesquisa (1,6\%). História vem a seguir com 186 bolsas (1,5\%), depois Comunicação, com 105 bolsas (0,9\%) e Arquitetura e Urbanismo (73 - 0,6\%). Uma diferenciação significativa das duas últimas áreas em relação às outras é quanto ao número de bolsas de Produtividade em Pesquisa, bem menor que das áreas no topo. Como esse tipo de bolsa possui estratificações internas e indicia a demanda e consolidação institucional da pesquisa numa área, na tabela que segue são detalhadas informações sobre a mesma.

Tabela 4.24 - Bolsistas de Produtividade em Pesquisa no CNPq

\begin{tabular}{l|c|c|c|c|c|c|c|c|c|c|c|c}
\hline \multirow{2}{*}{$\begin{array}{l}\text { Nível da Bolsa } \\
\text { de PP I Áreas }\end{array}$} & \multicolumn{2}{|c|}{ 1A } & \multicolumn{2}{c|}{ 1B } & \multicolumn{2}{c|}{ 1C } & \multicolumn{2}{c|}{ 1D } & \multicolumn{2}{c|}{$\mathbf{2}$} & \multicolumn{2}{c}{ Total } \\
\cline { 2 - 14 } & $\mathbf{n}$ & $\%$ & $\mathbf{n}$ & $\%$ & $\mathbf{n}$ & $\%$ & $\mathbf{n}$ & $\%$ & $\mathbf{n}$ & $\%$ & $\mathbf{n}$ & $\%$ \\
\hline História & 19 & $\mathbf{1 2 , 7}$ & 12 & $\mathbf{8 , 0}$ & 18 & $\mathbf{1 2}$ & 23 & $\mathbf{1 5 , 3}$ & 78 & $\mathbf{5 2 , 0}$ & 150 & 100,0 \\
\hline Economia & 9 & $\mathbf{6 , 5}$ & 10 & $\mathbf{7 , 2}$ & 17 & $\mathbf{1 2 , 3}$ & 22 & $\mathbf{1 6 , 0}$ & 80 & $\mathbf{5 8 , 0}$ & 138 & 100,0 \\
\hline Sociologia & 27 & $\mathbf{2 0}$ & 19 & $\mathbf{1 4 , 1}$ & 27 & $\mathbf{2 0}$ & 16 & $\mathbf{1 1 , 8}$ & 46 & $\mathbf{3 4 , 1}$ & 135 & 100,0 \\
\hline Comunicação & 9 & $\mathbf{1 1 , 5}$ & 7 & $\mathbf{9 , 0}$ & 11 & $\mathbf{1 4 , 0}$ & 14 & $\mathbf{1 8 , 1}$ & 37 & $\mathbf{4 7 , 4}$ & 78 & $\mathbf{1 0 0 , 0}$ \\
\hline Arquit. e Urban. & 5 & $\mathbf{1 0 , 6}$ & 5 & $\mathbf{1 0 , 6}$ & 2 & $\mathbf{4 , 3}$ & 4 & $\mathbf{8 , 5}$ & 31 & $\mathbf{6 6}$ & 47 & $\mathbf{1 0 0 , 0}$ \\
\hline
\end{tabular}

Fonte: Prossiga/MCT (2005)

A diferenciação interna na modalidade de bolsa de Produtividade em Pesquisa do CNPq resulta numa escala no qual os pesquisadores no nível 1A são os que possuem esta modalidade há mais tempo (já que o ingresso se dá no nível 2). Portanto, são os pesquisadores de maior experiência e, geralmente, conforme os critérios de ascensão assumidos pelas áreas, de maior produtividade e liderança que estão no nível 1A. Assim, é 
importante destacar não só o menor número de bolsas desse tipo em Comunicação, 78 bolsas (maior apenas na comparação com a área de Arquitetura e Urbanismo, que tem 47), mas também como se dá a distribuição entre os diferentes níveis. Observa-se, pois, que no nível 1A, o número de bolsas em Comunicação (9) é igual ao de Economia, maior que Arquitetura e Urbanismo (5) e bem menor do que em Sociologia (27) e História (19). Assim, o que se expressa, é a capacidade da área de Economia em crescer a partir do nível mais baixo, tendo um número expressivo de bolsistas no nível 2 (80), enquanto História também possui número elevado nesta categoria (78), maior mesmo que Sociologia (46). Mas, no caso da Comunicação o total é menor (37), maior apenas que em Arquitetura e Urbanismo (31). Assim, é essa diferenciação, principalmente, que vai marcar o contraste nos números totais - entre Economia e Comunicação. Porém, na comparação com História e Sociologia, nota-se que a Comunicação tem menos bolsas em todos os níveis da modalidade Produtividade em Pesquisa ${ }^{45}$.

Tabela 4.25 - Investimentos realizados pelo CNPq por linha de ação segundo Grande Área do conhecimento - 1999-2004

\begin{tabular}{|c|c|c|c|c|c|c|c|c|c|c|c|c|}
\hline \multirow{2}{*}{$\begin{array}{l}\text { Área de } \\
\text { Conhecimento }\end{array}$} & \multicolumn{6}{|c|}{ Investimentos em reais mil correntes } & \multicolumn{6}{|c|}{ Participação percentual } \\
\hline & 1999 & 2000 & 2001 & 2002 & 2003 & 2004 & 1999 & 2000 & 2001 & 2002 & 2003 & 2004 \\
\hline Ci. da Natureza & 151.503 & 176.583 & 217.697 & 203.501 & 212.523 & 286.285 & 39 & 40 & 42 & 40 & 38 & 41 \\
\hline Engs e Comput. & 87.184 & 99.653 & 128.868 & 120.614 & 119.171 & 157.999 & 23 & 23 & 25 & 24 & 22 & 22 \\
\hline Ci. Ex. e da Terra & 64.319 & 76.931 & 88.829 & 82.887 & 93.352 & 128.285 & 17 & 17 & 17 & 16 & 17 & 18 \\
\hline Ci. da Vida & 149.512 & 172.281 & 199.790 & 197.947 & 225.739 & 279.479 & 39 & 39 & 38 & 39 & 41 & 40 \\
\hline Ci Biológicas & 63.020 & 77.883 & 88.205 & 82.196 & 100.867 & 124.097 & 16 & 18 & 17 & 16 & 18 & 18 \\
\hline Ci. Agrárias & 53.614 & 57.472 & 69.012 & 72.993 & 78.432 & 92.422 & 14 & 13 & 13 & 14 & 14 & 13 \\
\hline Ci. da Saúde & 32.878 & 36.927 & 42.574 & 42.757 & 46.440 & 62.960 & 9 & 8 & 8 & 8 & 8 & 9 \\
\hline Humanidades & 85.138 & 92.796 & 107.033 & 108.528 & 114.379 & 137.915 & 22 & 21 & 20 & 21 & 21 & 20 \\
\hline Ci. Humanas & 46.207 & 50.042 & 57.176 & 58.822 & 65.239 & 77.570 & 12 & 11 & 11 & 12 & 12 & 11 \\
\hline Ci. Soc. Aplic. & 24.938 & 28.494 & 34.203 & 33.825 & 31.965 & 38.349 & 6 & 6 & 7 & 7 & 6 & 5 \\
\hline Ling., Letr. e Art. & 13.994 & 14.260 & 15.655 & 15.882 & 17.175 & 21.996 & 4 & 3 & 3 & 3 & 3 & 3 \\
\hline Total & 386.153 & 441.660 & 524.521 & 509.976 & 552.641 & 703.679 & 100 & 100 & 100 & 100 & 100 & 100 \\
\hline
\end{tabular}

Fonte: CNPq (2005)

A distribuição de recursos do CNPq ao longo do período 1999-2004 apresenta um crescimento no investimento total de cerca de 82,2\% (contra uma inflação acumulada de

\footnotetext{
45 No volume de Anexos, uma Tabela mostra a distribuição das bolsas de pesquisa do CNPq em Comunicação por Instituição, e o que se nota é a presença expressiva e majoritária das mesmas para pesquisadores de IES com PPGCOM (94,8\% das mesmas).
} 
$\left.62,40 \%{ }^{46}\right)$; em particular, chama a atenção o aumento verificado entre 2003 e 2004, de 151.038 mil. Ao mesmo tempo, nota-se grande estabilidade nos percentuais distribuídos a cada uma das Grandes Áreas e Linhas de Atuação (conforme a nomenclatura da agência), neste período. A variação nunca ultrapassa os três pontos percentuais nesses tópicos. Assim, para os dados de 2004, as Ciências da Natureza ocupavam o topo com 41\% (tendo um mínimo de 38\% em 2003), as Ciências da Vida estavam em segundo lugar nesta distribuição de recursos com 40\% (tendo um máximo de 41\% no ano anterior e um mínimo de 38\% em 2001). As Humanidades - incluindo as Ciências Humanas, Ciências Sociais Aplicadas, e Lingüística, Letras e Artes - tinham 20\% em 2004 (e um máximo de 22\% em 1999).

Dentro das Humanidades, a Grande Área de Ciências Sociais Aplicadas - nas quais está incluída a área da Comunicação - teve, em 2004, 5\% do total do investimento (apresentando um máximo de 7\% nos anos de 2000 e 2001). Ao longo do período 19992004, sempre as Ciências Aplicadas tiveram percentuais mais elevados que a Grande Área de Lingüística, Letras e Artes e menores do que as Humanas. E embora haja variância é comum que a área com menos recursos tenha a metade da imediatamente maior.

Tabela 4.26 - Total dos investimentos realizados pelo CNPq em bolsas e no fomento à pesquisa por área do conhecimento - 1999-2004

\begin{tabular}{|c|c|c|c|c|c|c|c|c|c|c|c|c|c|}
\hline \multirow{2}{*}{$\begin{array}{l}\text { Posição } \\
\text { no } \\
\text { Ranking } \\
(2004)\end{array}$} & \multirow{2}{*}{$\begin{array}{l}\text { Área de } \\
\text { Conhecimento }\end{array}$} & \multicolumn{6}{|c|}{ Investimentos em reais mil correntes } & \multicolumn{6}{|c|}{ Participação percentual } \\
\hline & & 1999 & 2000 & 2001 & 2002 & 2003 & 2004 & 1999 & 2000 & 2001 & 2002 & 2003 & 2004 \\
\hline $1^{\circ}$. & Agronomia & 25.673 & 27.395 & 30.472 & 32.726 & 33.031 & 39.377 & 6,72 & 6,27 & 5,89 & 6,49 & 6,00 & 5,61 \\
\hline $23^{\circ}$. & História & 6.489 & 6.905 & 7.850 & 7.651 & 8.660 & 10.612 & 1,70 & 1,58 & 1,52 & 1,52 & 1,57 & 1,51 \\
\hline $25^{\circ}$. & Sociologia & 6.200 & 6.645 & 8.167 & 7.865 & 8.657 & 10.386 & 1,62 & 1,52 & 1,58 & 1,56 & 1,57 & 1,48 \\
\hline $27^{\circ}$ & Economia & 6.138 & 7.995 & 9.491 & 9.264 & 8.847 & 9.818 & 1,61 & 1,83 & 1,83 & 1,84 & 1,61 & 1,40 \\
\hline $47^{\circ}$ & Comunicação & 3.081 & 3.341 & 3.385 & 3.190 & 3.560 & 4.593 & 0,81 & 0,76 & 0,65 & 0,63 & 0,65 & 0,65 \\
\hline $59^{\circ}$. & $\begin{array}{l}\text { Arquitetura e } \\
\text { Urbanismo }\end{array}$ & 1.931 & 2.086 & 2.764 & 3.916 & 2.440 & 2.944 & 0,51 & 0,48 & 0,53 & 0,78 & 0,44 & 0,42 \\
\hline $76^{\circ}$. & $\begin{array}{l}\text { Economia } \\
\text { Doméstica }\end{array}$ & 41 & 63 & 66 & 52 & 49 & 53 & 0,01 & 0,01 & 0,01 & 0,01 & 0,01 & 0,01 \\
\hline \# & Outras áreas & 332.472 & 382.643 & 455.319 & 439.879 & 485.474 & 623.555 & 87,0 & 88,0 & 88,0 & 87,0 & 88,0 & 89,0 \\
\hline$\#$ & Total & 382025 & 437.073 & 517.514 & 504543 & 550.718 & 701338 & 100 & 100 & 100 & 100 & 100 & 100 \\
\hline
\end{tabular}

Fonte: CNPq (2005)

A Tabela 4.26 mostra valores e percentuais de áreas de conhecimentos quanto aos investimentos do CNPq (seguinte a mesma lógica de tabelas anteriores, isto é, com áreas

${ }^{46}$ Conforme o IPC-Brasil. Cálculo em: http://www4.bcb.gov.br/pec/correcao/indexCorrige.asp?u=corrige .asp\&id=correcao. 
de conhecimento com números similares de titulados em comparação com Comunicação), foram inseridas, para efeito de contextualização a área que recebeu mais (Agronomia, com 5,61\% do todo) recursos em 2004 e a que teve menos (Economia Doméstica - 0,01\%). Então, demonstra-se a natural diversificação na distribuição de recurso e o fato de que a área da Comunicação, que recebia em 2004 0,65\% dos investimentos do CNPq, situa-se no terceiro quartil do ranking das áreas, na $47^{\mathrm{a}}$. colocação, quanto aos recursos recebidos, superada, portanto, pelas áreas de História (com 1,51\% dos recursos, e $23^{\circ}$. lugar), Sociologia $\left(1,48 \%, 25^{\circ}\right.$.) e Economia $\left(1,4 \%, 27^{\circ}\right.$. lugar), colocadas no segundo quartil. Comunicação só supera a área de Arquitetura e Urbanismo, situada no último quartil (59a . colocação), com $0,42 \%$ do total de investimentos. Essas quatro áreas apresentam diminuição similar no percentual de recursos recebidos na comparação entre os extremos de tempo. Assim, se somavam 6,25\% do total em 1999, passaram a totalizar 5,46\% em 2004.

Tabela 4.27 - Investimentos (em mil reais) realizados pelo CNPq em bolsas e no fomento à pesquisa por área do conhecimento - 2001-2004

\begin{tabular}{|c|c|c|c|c|c|c|c|c|c|c|c|c|c|}
\hline \multirow{2}{*}{$\begin{array}{l}\text { Posição } \\
\text { no } \\
\text { Ranking } \\
\text { (2004) }\end{array}$} & \multirow{2}{*}{$\begin{array}{l}\text { Área de } \\
\text { Conhecimento }\end{array}$} & \multicolumn{4}{|c|}{ Bolsas no País } & \multicolumn{4}{|c|}{ Bolsas no Exterior } & \multicolumn{4}{|c|}{ Fomento à Pesquisa } \\
\hline & & 2001 & 2002 & 2003 & 2004 & 2001 & 2002 & 2003 & 2004 & 2001 & 2002 & 2003 & 2004 \\
\hline $1^{\circ}$ & Agronomia & 22.703 & 20.294 & 22.720 & 28.761 & 1.948 & 2.670 & 2.040 & 1.876 & 5.820 & 9.762 & 8.270 & 8.739 \\
\hline $23^{\circ}$. & História & 6.480 & 6.468 & 7.448 & 9.237 & 525 & 557 & 424 & 359 & 845 & 627 & 788 & 1.016 \\
\hline $25^{\circ}$. & Sociologia & 6.119 & 5.781 & 6.297 & 7.561 & 441 & 499 & 199 & 450 & 1.606 & 1.585 & 2.161 & 2.375 \\
\hline $27^{\circ}$ & Economia & 5.827 & 5.435 & 5.998 & 7.113 & 1.818 & 2.786 & 1.789 & 1.302 & 1.845 & 1.043 & 1.061 & 1.403 \\
\hline $47^{\circ}$ & Comunicação & 2.816 & 2.691 & 3.217 & 4.016 & 190 & 369 & 143 & 138 & 379 & 131 & 201 & 439 \\
\hline $59^{\circ}$. & $\begin{array}{l}\text { Arquitetura e } \\
\text { Urbanismo }\end{array}$ & 1.845 & 1.766 & 1.957 & 2.290 & 391 & 582 & 264 & 241 & 528 & 1.569 & 219 & 413 \\
\hline $76^{\circ}$. & $\begin{array}{l}\text { Economia } \\
\text { Doméstica }\end{array}$ & 66 & 52 & 39 & 43 & - & - & - & - & - & - & 10 & 10 \\
\hline$\#$ & Outras áreas & 292.734 & 298.975 & 345.652 & 431.357 & 37.787 & 48.180 & 35.399 & 32.853 & 124.801 & 92.721 & 104.421 & 159.347 \\
\hline$\#$ & Total & 338590 & 341462 & 393328 & 490378 & 43100 & 55.643 & 40258 & 37219 & 135824 & $107 A 38$ & 117131 & 173742 \\
\hline
\end{tabular}

Fonte: CNPq (2005)

Esta tabela separa os investimentos do CNPq, mostrado na tabela anterior de forma conjunta. Assim, mostra para essa agência uma tendência geral de aumento dos valores para as bolsas nacionais e para o fomento, e diminuição do investimento em bolsas no exterior, aspecto compatível com o maior doutoramento no país. A área da Comunicação cresceu, na comparação entre 2001 e 2004, 42,6\% nos valores de bolsas nacionais, e 15,8\% no fomento, apresentando decréscimo de $37,6 \%$ no quesito bolsas no exterior. Porém, 
deve-se notar que como a inflação acumulada neste período foi de $40,13 \%{ }^{47}$ houve, em verdade, uma perda de valor expressa no fomento e nas bolsas no exterior e uma situação de quase continuidade de valores em termos das bolsas nacionais.

O “aumento" verificado para a Comunicação nos valores das bolsas nacionais, todavia, foi maior do que em todas as áreas mostradas, tanto a que recebe mais recursos, Agronomia (com $+17,9 \%$ ), quanto as que estão servindo como parâmetro de comparação com a Comunicação: História (+42,5\%), Sociologia $(+23,5)$, Economia $(+22,1)$ e Arquitetura e Urbanismo $(+24,1 \%)$.

Já quanto às bolsas no exterior a única área, dentre as aqui analisadas, que apresentou crescimento, embora bem menor que a inflação, foi Sociologia (+2\%), enquanto as demais tiveram, assim como a Comunicação, decréscimos, da ordem de 3,8\% (Agronomia), 23,8\% (História), 39,6\% (Economia) e 62,2\% (Arquitetura e Urbanismo). Por fim, o aumento no investimento em Comunicação no fomento $(+15,8 \%)$ foi menor do que nas áreas de Agronomia (+50,1\%), História $(+20,2)$ e Sociologia $(+47,9 \%)$, no entanto, as áreas de Economia e Arquitetura e Urbanismo apresentaram diminuição nesse tipo de investimento de, respectivamente, $31,5 \%$ e $27,8 \%$.

Em resumo, pode-se dizer a área a Comunicação tende a receber menos investimentos que as áreas aqui vistas, como já disse com número similar de titulados, com exceção de Arquitetura e Urbanismo, no caso das bolsas nacionais e no fomento (este em pequena margem maior para a Comunicação, com 439 mil versus 413). Isso se explica tanto em função da menor consolidação em termos acadêmicos, de pesquisa, quanto, em conseqüência, pela demanda. Dito isso, podemos apresentar uma síntese analítica dos dados mostrados até aqui.

${ }^{47}$ Conforme o IPC-Brasil. Cálculo em: http://www4.bcb.gov.br/pec/correcao/indexCorrige.asp?u=corrige .asp\&id=correcao. 


\subsection{Síntese análitica sobre os dados referentes ao perfil institucional da área da Comunicação}

Em primeiro lugar, realmente se destaca o fato de que se processou, ao longo do tempo, uma inserção institucional da pesquisa em Comunicação dentro do sistema local de apoio ao ensino e a esta atividade. Aspecto representado, em particular, pela criação e crescimento dos PPGCOM. Como se evidenciou, houve uma conjuntura histórica favorável, aproveitada pelos investigadores que passaram a se dedicar ao campo da Comunicação. Todavia, é uma institucionalização relativamente modesta. Assim, no sistema geral de titulados da PG, os 668 formados em Comunicação pelo PPGCOM em 2003 representaram, entre mestres e doutorados, 1,8\% do todo. Em termos somente da Grande Área de Ciências Sociais Aplicadas, naturalmente, o percentual é maior: 11\%, no entanto bem menos que as áreas dessa Grande Área que mais formaram: Direito, 2.040 (35\% da Grande Área mencionada) e Administração, 1.559 (26\%). Note-se, ao mesmo tempo, que o ritmo de crescimento das titulações tem acompanhado, e mesmo ultrapassado, a média geral. De 1987 a 2003, o crescimento do número de mestres (+870\%) e doutores (+1128\%) titulados em Comunicação ultrapassou o acréscimo percentual apresentado pelo conjunto de áreas - de 932\% para o mestrado e 757\% para o doutorado.

Ainda em termos da significação da área no sistema geral de apoio ao ensino e à pesquisa, vimos que o total de bolsas de formação no país que a área teve em 2003, 379 bolsas, representou apenas $1,2 \%$ do total, enquanto uma área, também das Ciências Sociais Aplicadas, com um número similar de titulados, como Economia, conseguiu 557 (2,3\% do todo). Essa situação de menor representatividade também se apresenta no caso das bolsas de pesquisa distribuídas pelo CNPq, em que a área da Comunicação consegue 105 (0,9\% do todo) contra 188 (1,6\%) de Economia, bem como em relação à bolsa de produtividade da mesma agência (Comunicação: 78 e Economia: 138). Nesse caso, em particular, é interessante notar a diferença entre as bolsas do nível mais baixo (nível 2) no qual o poder da demanda dos pesquisadores mais jovens da Comunicação tem sido bem menor que os de Economia, estes tinham, em 2003, 80 bolsas contra 37 da área da Comunicação.

Tais aspectos se refletem numa posição ( $47^{\circ}$. lugar dentre $76^{\mathrm{a}} .$. áreas) também modesta em relação aos investimento totais do CNPq, representando, em 2004, 0,65\% dos mesmos. A 
Economia obteve 1,4\% e áreas mais consolidadas como a História e Sociologia obtiveram, respectivamente, $1,51 \%$ e $1,48 \%$.

Por outro lado, deve-se ressaltar que o crescimento da Comunicação se fez acompanhar de uma “reprodução interna” mais significativa, ou seja, os que obtiveram titulação doutoral em Comunicação $(55,4 \%)$ e aqueles que foram formados no Brasil $(75,9 \%)$ são a maioria dentre os professos permanentes dos PPGCOM. No entanto, fica demonstrada também, a partir de dados como esses, o grande números de professores com título de doutorado relativamente recente - 49,9\% desses professores não tinham mais do que 10 anos de obtenção do doutorado, e 59\% deles tinham no doutorado o título máximo.

Quanto aos professores permanentes dos PPGCOM que obtiveram títulos doutorais em outras áreas, as preferidas foram: Letras, Teoria Literária, Literatura (51 docentes, representando 18,3\% do total de professores permanentes), Ciências Sociais/Sociologia (20 professores, 7,2\%) e Artes (10 - 3,6\%). E em relação ao provável âmbito privilegiado de diálogo internacional, a preferência pelo espaço europeu (44\%) para a feitura de pósdoutorados, mais elevado que nos EUA (18,8\%), indica uma proximidade ou interesse maior em relação à pesquisa européia.

A expansão da área em termos de ensino de graduação e pós-graduação parece segura, em função dos elementos apresentados. Porém, isso tensiona - assim como (mas bem mais que) no caso das ciências sociais - a questão da institucionalização das atividades stricto sensu de pesquisa. Em outros termos a consolidação institucional do campo científico. Tal aspecto problemático diz respeito não só ao dispêndio de esforços necessários ao possível crescimento da área de ensino, que dificulta a autonomização da pesquisa. Existem outros pontos importantes nessa mesma articulação ensino/pesquisa que deverão ser equacionados para a consolidação do campo científico.

O aspecto talvez mais importante é como os pesquisadores da Comunicação irãoresponderá às novas políticas e orientações para a PG. Como a competição por recursos tornou-se mais acirrada, o ajuste às diretrizes das políticas públicas, quanto à obtenção de recursos para esse âmbito, passou a ser mais relevante. E, como se viu, espera-se um maior 
relacionamento da pós-graduação - onde se encontra largamente ancorada a pesquisa com a sociedade, de maneira geral, e através do "mestrado profissional”48.

Se a autonomia do campo científico implica na adoção de regras próprias, numa disputa interna a esse espaço, para a validação do capital específico produzido, quais os efeitos que poderão ter essa possível tendência de ajuste às diretrizes gerais da PG? A resposta dada pelos agentes da Comunicação a esse ponto, ou seja, o tipo de ajuste às políticas, indicará o tipo de crescimento quantitativo e/ou qualitativo que a área da PG em Comunicação terá no futuro. No mínimo, deve levar para a agenda de discussões o aprofundamento da questão do "conhecimento" mais aplicável ou teórico produzido pela área e sua interface com a sociedade. Se esta discussão ocorrer apelando principalmente a elementos internos - a histórica do campo, suas pesquisas e suas discussões epistemológicas etc. - será uma oportunidade para consolidação do campo científico. Ao contrário, se numa direção heterônoma ou que derive meramente das práticas profissionais o campo científico se debilitará.

Por esse aspecto, nesse momento, mais importante até que a institucionalização da Comunicação em termos do ensino será a busca de uma maior independência relativa da pesquisa em relação a essa esfera, criando demandas específicas. Tal pesquisa, é claro, irá regressar posteriormente a currículos e agendas de ensino. No entanto, o aspecto negativo da prevalência do ensino frente à investigação, é que isso dificulta a autonomização do campo científico. Nesse caso, perdem os dois âmbitos, e a legitimação do mais amplo “campo da Comunicação”, em termos da validade e consistência do conhecimento que se produz e reproduz nesse espaço.

Com efeito, no próximo capítulo serão examinadas algumas das dimensões institucionais menos dependentes do ensino e que favorecem o fortalecimento do campo científico das Ciências da Comunicação.

\footnotetext{
${ }^{48}$ De acordo com Braga (2000), houve a preocupação da área, no âmbito da COMPÓS, em discutir esse formato. Foi produzido e encaminhado à CAPES um documento que propunha parâmetros específicos para os mestrados profissionais em Comunicação. No entanto, os possíveis esforços das IES para a realização de projetos com desse teor ainda não produziram resultados.
} 


\section{Capítulo 5}

\section{Padrões de associação, pesquisa e produção nas Ciências da Comunicação no Brasil}

Em alguns momentos, e sob determinadas circunstâncias o conhecimento tido como válido afigura-se impossível fora dos cânones científicos, abrindo espaço para a organização de instituições do saber. [...] A partir de então, a academia constitui-se no locus fundamental de legitimidade das elites intelectuais, pensada como instrumento de gênese, de onde se retiram os influxos para se construir a tradição.

(Arruda, 2001, 279)

Percebemos conforme o capítulo anterior, num diagnóstico da área da Comunicação no Brasil em sua inserção no sistema de ensino e pesquisa, uma forte vinculação entre essas duas esferas. Nesta parte do trabalho iremos caracterizar instâncias que tendencialmente favorecem maior autonomização do campo científico em relação ao ensino, mesmo que tenham alguma relação com o mesmo. Assim, inicialmente, abordaremos determinados padrões de associações dos pesquisadores da área - por meio da descrição dos Grupos de Pesquisa, Associações Científicas e publicações periódicas técnico-científicas existentes.

A seguir, mostraremos como se comporta a produção bibliográfica e projetos de pesquisa dos docentes dos PPGCOM e a produção de teses e dissertações dos mesmos. Evidentemente nos voltamos aqui para uma instância ligada ao ensino (pós-graduado), porém, face à prevalência da investigação em Comunicação ocorrer a partir desse âmbito, tais dados permitem perceber a dinâmica através do qual um processo de autonomização da pesquisa se processa ou poderá ocorrer de modo mais acentuado. Além disso, são mostradas tendências quantitativas, sobretudo, e qualitativas da produção em Comunicação. Sendo que os dados sobre as teses e dissertações serão aprofundados no capítulo posterior com uma análise temática da produção.

É necessário, antes de discutirmos cada um dos contextos de análise, fazer uma observação metodológica sobre os dados aqui apresentados. Tivemos a preocupação que os mesmos pudessem ser reconstituídos por outros pesquisadores, de modo a confirmar sua validade. 
Nesse sentido é que optamos por trabalhar com dados “oficiais” - isto é, de instituições (no caso, CNPq e CAPES) que têm a responsabilidade de prepará-los, a partir de diferentes fontes, e consolidá-los. Nem sempre isso é possível, todavia, em cada um dos tópicos a seguir desenvolvidos descrevemos a estratégia utilizada.

\subsection{Os Grupos de Pesquisa em Comunicação no Diretório do CNPq}

Para a coleta de dados dos Grupos de Pesquisa optou-se pela utilização de dados dos Censos do Diretório do GP do CNPq, em particular do de 2004, ao invés de utilizar a Base corrente, pois observamos que o sistema, que gera listas de grupos a partir de palavraschave, não recupera todos os grupos da Área de Pesquisa em Comunicação pelo termo “comunicação”. Isso foi percebido quando notamos que a busca a partir de outros termos que contemplam diversas áreas temáticas de investigação em Comunicação (por exemplo, “jornalismo”, “cinema”) trazia Grupos de Pesquisa da Área, não recuperados pelo termo “comunicação”. Grupos cuja Área de Pesquisa que, deve-se notar, estavam registrados como sendo da própria Comunicação. Como o Censo 2004 já arrola (conforme a súmula estatística em http://dgp.cnpq.br/censo2004/sumula_estat/index_grupo.htm) um número de GP em Comunicação (270) esse problema foi contornado.

Todavia, sabia-se que, por razões históricas da organização da pesquisa em Cinema, certos grupos com este tema/objeto inserem-se na Área de Artes. Aliás, são os próprios pesquisadores que registram um GP em determinada área e fornecem todos os dados sobre ele. Sendo assim, foi feita uma busca, na ferramenta do Censo 2004, na qual, utilizando-se o termo "cinema", foi anotada também a Área de Artes. Com isso, apareceram mais 67 grupos. A partir de um exame (de ementas e Linhas de Pesquisa) em todos estes para avaliar a pertinência da contagem dos mesmos numa coleta voltada à Área de Comunicação foram coletados mais 10 GP. Desse modo, somando os grupos em Comunicação anotados como da própria Área e aqueles de cinema que estavam registrados como Artes, chegou-se a um número de 280 GP em Comunicação, para o Censo 2004 do Diretório de Grupos de Pesquisa do $\mathrm{CNPq}^{49}$.

\footnotetext{
${ }^{49}$ A lista desses Grupos de Pesquisa, bem como suas Linhas de Pesquisa, encontra-se no volume de Anexos.
} 
Nas tabelas seguintes apontamos dados característicos sobre os Grupos em Comunicação, bem como, antes, um panorama mais geral dessa modalidade institucional de organização dos pesquisadores no país. Assim, inicialmente, a Tabela 5.1 mostra o número de GP por Grandes Áreas e a Tabela 5.2 compara o número de GP da Comunicação com outras disciplinas cujos números de titulados na PG são similares aos dela.

Tabela 5.1 - Grupos de Pesquisa no Diretório do CNPq, por Grandes Áreas* (1993-2004)

\begin{tabular}{|c|c|c|c|c|c|c|c|c|c|c|c|c|}
\hline \multirow{2}{*}{$\begin{array}{l}\text { Grupos de } \\
\text { Pesquisal } \\
\text { Grande Área do } \\
\text { conhecimento } \\
\end{array}$} & \multicolumn{2}{|c|}{1993} & \multicolumn{2}{|c|}{1995} & \multicolumn{2}{|c|}{$1997^{* *}$} & \multicolumn{2}{|c|}{2000} & \multicolumn{2}{|c|}{2002} & \multicolumn{2}{|c|}{2004} \\
\hline & $\mathbf{n}$ & $\%$ & $\mathbf{n}$ & $\%$ & $\mathbf{n}$ & $\%$ & $\mathbf{n}$ & $\%$ & $\mathbf{n}$ & $\%$ & $\mathbf{n}$ & $\%$ \\
\hline Ciências da Vida & 1.916 & 46,4 & 3.427 & 47,1 & 3.669 & 42,9 & 4.904 & 41,7 & 6.292 & 41,5 & 7.929 & 40,7 \\
\hline Ciências da Saúde & 502 & 12,2 & 1.210 & 16,6 & 1.419 & 16,6 & 1.832 & 15,6 & 2.513 & 16,6 & 3.371 & 17,3 \\
\hline Ciências Biológicas & 842 & 20,4 & 1.273 & 17,5 & 1.338 & 15,7 & 1.720 & 14,6 & 2.126 & 14,0 & 2.561 & 13,2 \\
\hline Ciências Agrárias & 572 & 13,9 & 944 & 13,0 & 912 & 10,7 & 1.352 & 11,5 & 1.653 & 10,9 & 1.997 & 10,3 \\
\hline Humanidades & 916 & 22,2 & 1.599 & 22,0 & 2.197 & 25,7 & 3.218 & 27,4 & 4.572 & 30,2 & 6.261 & 32,2 \\
\hline Ciências Humanas & 482 & 11,7 & 794 & 10,9 & 1.180 & 13,8 & 1.711 & 14,5 & 2.399 & 15,8 & 3.088 & 15,9 \\
\hline Ciências Soc. Aplic. & 237 & 5,7 & 468 & 6,4 & 565 & 6,6 & 930 & 7,9 & 1.429 & 9,4 & 2.120 & 10,9 \\
\hline Ciênc. da Natureza & 1.296 & 31,4 & 2.245 & 30,9 & 2.678 & 31,3 & 3.638 & 30,9 & 4.294 & 28,3 & 5.280 & 27,1 \\
\hline Engenh. e C. da Comp. & 626 & 15,2 & 1.035 & 14,2 & 1.339 & 15,7 & 1.826 & 15,5 & 2.243 & 14,8 & 2.826 & 14,5 \\
\hline Ciênc. Exat. e da Terra & 670 & 16,2 & 1.210 & 16,6 & 1.339 & 15,7 & 1.812 & 15,4 & 2.051 & 13,5 & 2.454 & 12,6 \\
\hline Total & 4.128 & 100,0 & 7.271 & 100,0 & 8.544 & 100,0 & 11.760 & 100,0 & 15.158 & 100,0 & 19.470 & 100,0 \\
\hline
\end{tabular}

Fonte: CNPq (2005)

Notas: * Em 1993, a Grande Área corresponde à Grande Área de atuação do primeiro líder do grupo. Além disso, não estão computados 274 grupos de pesquisa sem informação sobre a grande área.

** Não estão computados 88 grupos da UEM cadastrados na base após a tabulação dos dados.

O número total de grupos de pesquisa registrados no Diretório do CNPq em 2004 foi de 19.470, sendo que a maioria era da Grande Área de Ciências da Vida, que somava 7.929 grupos (40,7\%), seguida pela de Humanidades (6.261 GPs, correspondendo a 32,2\% do todo) e, por fim, Ciências da Natureza, com 5.280 (27,1\%). A área de Ciências Sociais Aplicadas, no qual era classificada a Comunicação, tinha 2.120 grupos, resultando em 10,9\% dos mesmos, em 2004.

A tabela evidencia o forte crescimento dessa modalidade de institucionalização da pesquisa e nucleação dos investigadores no Brasil, já que, conforme a análise da série histórica, houve um crescimento geral de 471,6\% no total de grupos de 1993 a 2004. Em termos percentuais, a Grande Área que apresentou mais crescimento foi a de Humanidades, passando de 22,2\% (916) do total de GPs, em 1993, para 32,2\% (6.261 grupos), em 2004. Já a área de Ciências Sociais Aplicadas quase dobrou sua participação percentual, que era de 5,7\% (237 grupos), em 1993, e passou para 10,9\% (2.132 GPs). Assim, esta área deixou 
de ser a que possui menos grupos no todo, embora só tivesse mais GPs, em 2004, que Ciências Agrárias (10,3\%), tendo portanto menos do que as das áreas de Ciências Exatas e da Terra (12,6\%), Ciências Biológicas (13,2\%), Engenharias e Ciências da Computação (14,5\%), Ciências Humanas (15,9\%) e Ciências da Saúde (17,3\%).

Tabela 5.2 - Grupos de Pesquisa no Diretório do CNPq, por Áreas de Conhecimento (1993-2004)

\begin{tabular}{|c|c|c|c|c|c|c|c|c|c|c|c|c|}
\hline \multirow{2}{*}{$\begin{array}{l}\text { GPI } \\
\text { Áreas do } \\
\text { conheciment } \\
\text { o }\end{array}$} & \multicolumn{2}{|c|}{ 1993* } & \multicolumn{2}{|c|}{$1995^{\star *}$} & \multicolumn{2}{|c|}{$1997 * \star \star$} & \multicolumn{2}{|c|}{2000} & \multicolumn{2}{|c|}{2002} & \multicolumn{2}{|c|}{2004} \\
\hline & $\mathbf{n}$ & $\%$ & $\mathbf{n}$ & $\%$ & $\mathbf{n}$ & $\%$ & $\mathbf{n}$ & $\%$ & $\mathbf{n}$ & $\%$ & $\mathbf{n}$ & $\%$ \\
\hline História & 102 & 1,6 & 115 & 1,6 & 161 & 1,9 & 200 & 1,7 & 290 & 1,9 & 364 & 1,9 \\
\hline Economia & 98 & 1,5 & 151 & 2,1 & 179 & 2,1 & 221 & 1,9 & 272 & 1,8 & 326 & 1,7 \\
\hline Sociologia & 88 & 1,4 & 100 & 1,4 & 149 & 1,7 & 187 & 1,6 & 240 & 1,6 & 296 & 1,5 \\
\hline Comunicação & 33 & 0,5 & 42 & 0,6 & 61 & 0,7 & 95 & 0,8 & 161 & 1,1 & 270 & 1,4 \\
\hline $\begin{array}{l}\text { Arq. e } \\
\text { Urbanismo }\end{array}$ & 33 & 0,5 & 53 & 0,7 & 55 & 0,6 & 100 & 0,9 & 158 & 1,0 & 205 & 1,1 \\
\hline Outras & 6126 & 94,5 & 6713 & 93,6 & 7936 & 93,0 & 10.957 & 93,1 & 14.037 & 92,6 & 18.009 & 92,4 \\
\hline Total & 6.480 & 100,0 & 7.174 & 100,0 & 8.541 & 100,0 & 11.760 & 100,0 & 15.158 & 100,0 & 19.470 & 100,0 \\
\hline
\end{tabular}

Fonte: CNPq (2005)

Notas: * Em 1993, a área corresponde à especialidade de atuação do primeiro líder do grupo. Tendo em vista que cada pesquisador pôde informar até 6 especialidades, há dupla contagem de grupos nos casos em que as especialidades informadas pertencem a diferentes áreas.

** Não estão computados 97 grupos que não informaram a área do conhecimento. Esses grupos informaram apenas a grande área, a saber: Agrárias = 6; Biológicas = 34; Saúde = 27; Exatas e da Terra = 26; Engenharias e C. da Computação = 3; Humanidades = 1 . *** Não estão computados 88 grupos da UEM cadastrados na base após a tabulação dos dados e nem 3 grupos que não informaram a área predominante.

Mantendo a idéia de, para efeito de comparação, apresentar os dados sobre a Comunicação junto com as áreas com número de titulados similares, a Tabela 5.2 mostra que o conjunto de GPs em Comunicação foi o que apresentou maior percentual no período, dentre as áreas selecionadas. Dessa forma, os GPs em Comunicação passaram de 0,5\% (33 grupos), em 1993, para 1,4\% (270), em 2004, a expressão dos grupos mais do que dobrou, portanto. A área mais próxima, nesse sentido, da Comunicação foi a de Arquitetura e Urbanismo que de 0,5\% (33) do total de grupos, em 1993, passou a ter 1,1\% (205 GPs). As outras três áreas apresentaram crescimento bem menor, História passou de 1,6\% (102), em 1993, para 1,9\% (364), em 2004, enquanto Economia foi de 1,5\% (98) grupos a 1,7\% (326) e Sociologia de 1,4\% (88) a 1,5\% (296). Esses dados sugerem que essas três áreas mencionadas já possuíam maior organização em termos de Grupos de Pesquisa, no início da década de 1990, razão pela qual o crescimento numérico nos anos posteriores praticamente só acompanhou o que ocorreu no contexto geral. A Comunicação e Arquitetura e Urbanismo, por outro lado, cresceram mais em função de uma situação inicial menos consolidada, com mais possibilidades de crescimento. 
Resta notar ainda o forte crescimento que os Grupos de Pesquisa apresentam, de modo geral. Essa modalidade de agregação de pesquisadores, eventualmente de diferentes instituições ou centros de pesquisa, cresceu, sobretudo, a partir dos anos 2000. Assim, conforme dados do CNPq, 58,1\% dos grupos do censo de 2004 tinham entre menos de 1 e 4 anos de existência.

A partir da Tabelas seguintes, descrevem-se as características dos GP em Comunicação, como o número de doutores (Tabelas 5.3 e 5.4), as instituições que os abrigam e a natureza dessas (Tabelas 5.5 e 5.7), a distribuição regional (Tabelas 5.6), a contagem e categorização das Linhas de Pesquisa (Tabelas 5.8 e 5.9). É mostrada ainda uma relação de GP de outras Áreas que também possuem a palavra “comunicação” em suas LP (Tabela $5.10)$.

Tabela 5.3 - Distribuição dos pesquisadores e doutores segundo a área do conhecimento predominante nas atividades do grupo*(Censo - DGP/CNPq 2004)

\begin{tabular}{l|c|c|c}
\hline Área & Pesquisadores & Doutores & \% de Doutores \\
\hline História & 1.921 & 1.138 & 59,2 \\
\hline Economia & 1.616 & 996 & 61,6 \\
\hline Sociologia & 1.485 & 942 & 63,4 \\
\hline Comunicação & 1.196 & 703 & 58,8 \\
\hline Arquitetura e Urbanismo & 919 & 436 & 47,4 \\
\hline Outras & 88.404 & 58.661 & 66,4 \\
\hline Total & $\mathbf{9 5 . 5 4 1}$ & $\mathbf{6 2 . 8 7 6}$ & $\mathbf{6 5 , 8}$ \\
\hline
\end{tabular}

Fonte: CNPq (2005)

Nota: * Não existe dupla contagem no âmbito de cada área.

Em termos do número de doutores participantes de GP, a área da Comunicação, comparada com áreas que titulam número similar de pós-graduandos, situa-se na mesma posição que na análise relativa ao número de Grupos. Assim, seus 703 doutores pesquisadores superam apenas os da área de Arquitetura e Urbanismo. E no topo continuam as áreas de História (1.138 doutores), Economia (996) e Sociologia (942).

Observa-se ainda que o número de 703 doutores participantes de GP em Comunicação era, em 2004, bem superior ao de docentes (permanentes e colaboradores) dos PPGCOM (378). 
Tabela 5.4 - Grupos de Pesquisa em Comunicação segundo o número de pesquisadores doutores - Censo - DGP/CNPq 2004)

\begin{tabular}{c|c|c}
\hline Número de Pesq. Doutores & Grupos & $\%$ \\
\hline $\mathbf{0}$ & 19 & $\mathbf{6 , 8}$ \\
\hline $\mathbf{1}$ & 60 & $\mathbf{2 1 , 4}$ \\
\hline $\mathbf{2}$ & 67 & $\mathbf{2 3 , 9}$ \\
\hline $\mathbf{3}$ & 47 & $\mathbf{1 6 , 8}$ \\
\hline $\mathbf{4}$ & 23 & $\mathbf{8 , 2}$ \\
\hline $\mathbf{5}$ & 22 & $\mathbf{7 , 9}$ \\
\hline $\mathbf{6 - 1 0}$ & 37 & $\mathbf{1 3 , 2}$ \\
\hline $\mathbf{1 1 - 1 8}$ & 5 & $\mathbf{1 , 8}$ \\
\hline Total & $\mathbf{2 8 0}$ & $\mathbf{1 0 0 , 0}$ \\
\hline
\end{tabular}

Fonte: CNPq (2005)

Os dados relativos à participação dos doutores como pesquisadores dos GP indicam que a maioria deles possui entre 2 a 5 (56,8\%) pesquisadores desse nível. A faixa de 0 a 1 doutor por Grupo é relativamente elevada (28,2 dos Grupos). Pode-se interpretar esse aspecto dos GP da área, em certa medida, pela relativa juventude dos doutores, muitos dos quais devem utilizar o Grupo como suporte a projetos individuais, nos quais se agrupam pesquisadores em formação.

Verifica-se ainda a grande heterogeneidade em relação ao número de pesquisadores doutores participantes dos GP. Dado o número de 105 bolsas de pesquisa do CNPq fornecidas para a área da Comunicação é possível supor também que muitos Grupos recebam recurso da agência dessa forma.

Tabela 5.5 - Grupos de Pesquisa em Comunicação (Censo - DGP/CNPq 2004), por Instituição

\begin{tabular}{|c|c|c|c|c|c|c|}
\hline \multirow{2}{*}{$\begin{array}{l}\text { GP- Class.I } \\
\text { Instituições }\end{array}$} & \multicolumn{3}{|c|}{ AP: Comunicação } & \multirow{2}{*}{$\begin{array}{l}\text { AP: Artes e } \\
\text { "outros"** }\end{array}$} & \multirow{2}{*}{ Total (n) } & \multirow{2}{*}{ Total (\%) } \\
\hline & $\mathrm{Co}^{*}$ & $e^{*}$ & $e^{*}$ & & & \\
\hline UNISINOS & 10 & 5 & 1 & 0 & 16 & 5,7 \\
\hline UFBA & 11 & 4 & 0 & 0 & 15 & 5,3 \\
\hline USP & 3 & 11 & 0 & 1 & 15 & 5,3 \\
\hline UFF & 9 & 0 & 1 & 4 & 14 & 5,0 \\
\hline PUCSP & 3 & 7 & 2 & 0 & 12 & 4,2 \\
\hline UMESP & 2 & 7 & 3 & 0 & 12 & 4,2 \\
\hline UFRJ & 7 & 3 & 0 & 0 & 10 & 3,5 \\
\hline PUCRS & 7 & 3 & 0 & 0 & 10 & 3,5 \\
\hline UFES & 0 & 1 & 8 & 0 & 9 & 3,2 \\
\hline UFMG & 2 & 1 & 0 & 4 & 7 & 2,5 \\
\hline UFSM & 0 & 5 & 2 & 0 & 7 & 2,5 \\
\hline UNIP & 1 & 4 & 2 & 0 & 7 & 2,5 \\
\hline UFPE & 0 & 5 & 1 & 0 & 6 & 2,1 \\
\hline UNESP & 0 & 4 & 1 & 0 & 5 & 1,7 \\
\hline MACKENZIE & 0 & 0 & 5 & 0 & 5 & 1,7 \\
\hline PUCMG & 0 & 0 & 5 & 0 & 5 & 1,7 \\
\hline UNIVALI & 0 & 0 & 5 & 0 & 5 & 1,7 \\
\hline UFRGS & 2 & 2 & 1 & 0 & 5 & 1,7 \\
\hline UFJF & 0 & 2 & 3 & 0 & 5 & 1,7 \\
\hline UNB & 4 & 0 & 0 & 0 & 4 & 1,4 \\
\hline PUCRJ & 3 & 1 & 0 & 0 & 4 & 1,4 \\
\hline UNICAMP & 2 & 2 & 0 & 0 & 4 & 1,4 \\
\hline UEL & 0 & 1 & 3 & 0 & 4 & 1,4 \\
\hline PUCAMP & 0 & 0 & 4 & 0 & 4 & 1,4 \\
\hline
\end{tabular}


Tabela 5.5 (continuação)- Grupos de Pesquisa em Comunicação (Censo - DGP/CNPq 2004), por Instituição

\begin{tabular}{|c|c|c|c|c|c|c|}
\hline \multirow{2}{*}{$\begin{array}{l}\text { GP- Class.I } \\
\text { Instituições }\end{array}$} & \multicolumn{3}{|c|}{ AP: Comunicação } & \multirow{2}{*}{$\begin{array}{l}\text { AP: Artes e } \\
\text { "outros"** }\end{array}$} & \multirow{2}{*}{ Total (n) } & \multirow{2}{*}{ Total (\%) } \\
\hline & Co* $^{*}$ & $e^{*}$ & $\mathrm{eF}^{*}$ & & & \\
\hline UFG & 0 & 0 & 4 & 0 & 4 & 1,4 \\
\hline UFC & 2 & 0 & 2 & 0 & 4 & 1,4 \\
\hline UERJ & 1 & 3 & 0 & 0 & 4 & 1,4 \\
\hline UNIMAR & 0 & 4 & 0 & 0 & 4 & 1,4 \\
\hline UTP & 2 & 2 & 0 & 0 & 4 & 1,4 \\
\hline FTC & 0 & 1 & 2 & 1 & 4 & 1,4 \\
\hline UFSCAR & 0 & 2 & 1 & 0 & 3 & 1,1 \\
\hline UFMS & 0 & 0 & 3 & 0 & 3 & 1,1 \\
\hline UNEB & 1 & 1 & 0 & 0 & 2 & 0,7 \\
\hline UFSC & 0 & 2 & 0 & 0 & 2 & 0,7 \\
\hline UNISUL & 0 & 1 & 1 & 0 & 2 & 0,7 \\
\hline UFRN & 0 & 1 & 1 & 0 & 2 & 0,7 \\
\hline UFS & 0 & 1 & 1 & 0 & 2 & 0,7 \\
\hline UFAM & 0 & 1 & 1 & 0 & 2 & 0,7 \\
\hline FURB & 0 & 1 & 1 & 0 & 2 & 0,7 \\
\hline UFPB & 0 & 1 & 1 & 0 & 2 & 0,7 \\
\hline UFPR & 0 & 1 & 1 & 0 & 2 & 0,7 \\
\hline UPF & 0 & 1 & 1 & 0 & 2 & 0,7 \\
\hline UNIPAR & 0 & 1 & 1 & 0 & 2 & 0,7 \\
\hline UESB & 0 & 0 & 2 & 0 & 2 & 0,7 \\
\hline UESC & 0 & 0 & 2 & 0 & 2 & 0,7 \\
\hline UNIMARCO & 1 & 0 & 0 & 0 & 1 & 0,4 \\
\hline UFV & 0 & 1 & 0 & 0 & 1 & 0,4 \\
\hline FIOCRUZ & 0 & 1 & 0 & 0 & 1 & 0,4 \\
\hline UFT & 0 & 1 & 0 & 0 & 1 & 0,4 \\
\hline UFAL & 0 & 1 & 0 & 0 & 1 & 0,4 \\
\hline UNIPAC & 0 & 1 & 0 & 0 & 1 & 0,4 \\
\hline UFPI & 0 & 0 & 1 & 0 & 1 & 0,4 \\
\hline ULBRA & 0 & 0 & 1 & 0 & 1 & 0,4 \\
\hline PUCPR & 0 & 0 & 1 & 0 & 1 & 0,4 \\
\hline UDESC & 0 & 0 & 1 & 0 & 1 & 0,4 \\
\hline UNICAP & 0 & 0 & 1 & 0 & 1 & 0,4 \\
\hline UNICEUB & 0 & 0 & 1 & 0 & 1 & 0,4 \\
\hline UNICID & 0 & 0 & 1 & 0 & 1 & 0,4 \\
\hline UNICRUZ & 0 & 0 & 1 & 0 & 1 & 0,4 \\
\hline UNIFOR & 0 & 0 & 1 & 0 & 1 & 0,4 \\
\hline UNIFRA & 0 & 0 & 1 & 0 & 1 & 0,4 \\
\hline UNIMEP & 0 & 0 & 1 & 0 & 1 & 0,4 \\
\hline UFSJ & 0 & 0 & 1 & 0 & 1 & 0,4 \\
\hline UNISANTOS & 0 & 0 & 1 & 0 & 1 & 0,4 \\
\hline FEEVALE & 0 & 0 & 1 & 0 & 1 & 0,4 \\
\hline UNISO & 0 & 0 & 1 & 0 & 1 & 0,4 \\
\hline UCB-DF & 0 & 0 & 1 & 0 & 1 & 0,4 \\
\hline UNIT & 0 & 0 & 1 & 0 & 1 & 0,4 \\
\hline UNITINS & 0 & 0 & 1 & 0 & 1 & 0,4 \\
\hline UCS & 0 & 0 & 1 & 0 & 1 & 0,4 \\
\hline UNIVAP & 0 & 0 & 1 & 0 & 1 & 0,4 \\
\hline UNOCHAPECO & 0 & 0 & 1 & 0 & 1 & 0,4 \\
\hline UNOESTE & 0 & 0 & 1 & 0 & 1 & 0,4 \\
\hline UFMA & 0 & 0 & 1 & 0 & 1 & 0,4 \\
\hline USJT & 0 & 0 & 1 & 0 & 1 & 0,4 \\
\hline UEPG & 0 & 0 & 1 & 0 & 1 & 0,4 \\
\hline PÓLIS & 0 & 0 & 0 & 1 & 1 & 0,4 \\
\hline CEFIT & 0 & 0 & 0 & 1 & 1 & 0,4 \\
\hline EMBRAPA & 0 & 0 & 0 & 1 & 1 & 0,4 \\
\hline $\begin{array}{l}\text { TOTAL } \\
(\mathrm{n} \mathrm{e} \%)\end{array}$ & $\begin{array}{c}73 \\
(26,1 \%)\end{array}$ & $\begin{array}{c}93 \\
(32,2 \%)\end{array}$ & $\begin{array}{c}101 \\
(36,1 \%)\end{array}$ & $13(4,6 \%)$ & 280 & $100,0 \%$ \\
\hline
\end{tabular}

Fonte: CNPq (2005)

Notas: * Co: Grupo Consolidado; eC: em Consolidação; eF: em Formação.

** “Outros” são os GP em Comunicação sem classificação pela natureza da Instituição.

Quanto às Instituições que abrigam os GP em Comunicação, a Tabela 5.5 mostra o alto número das mesmas, eram, em 2004, no todo, 79. A grande maioria está em Instituições de Ensino Superior (IES) e entre as 19 Instituições que possuem pelo menos 5 Grupos, 15 das mesmas apresentam PPGCOM. O CNPq realiza uma estratificação nos GP, dividindo-os 
em três categorias: Consolidados (Co), em Consolidação (eC) e em Formação (eC), o que é se faz através de um cálculo, realizado pelo órgão, envolvendo diferentes variáveis sobre o GP - número de doutores participantes, avaliação CAPES do Programa de que participam, número de bolsistas etc. Porém isso só é feito em relação aos GP vinculados a IES e, de outro lado, não era possível saber a classificação dos GP da área de Artes, de interesse aqui $^{50}$. Dessa forma, existem três Grupos (os últimos da Tabela), e outros 10 Grupos de cinema da Área de Artes não classificados em nenhuma das categorias descritas.

Assim, os GP que não receberam classificação quanto ao estágio em que se encontram foram, assim, apenas 13 (4,6\% do total), enquanto a maioria dos GP em Comunicação encontra-se na categoria em Formação (101 Grupos, correspondendo a 36,1\% do todo), a seguir estão os em Consolidação, com 32,2\% (93 Grupos) e, por fim, os Consolidados, que, com 73 Grupos, somam 26,1\% do todo.

O que se evidencia, portanto, é que em termos qualitativos os GP da área ainda estão num patamar médio, pois somente pouco mais de um quarto dos mesmos já se encontravam consolidados, conforme os dados do Censo 2004. Mostra-se ainda a clara ambiência acadêmica da pesquisa, já que apenas 3 grupos não eram vinculados a IES. Essa inserção acadêmica é reforçada pelo peso dos docentes pertencentes a PPGCOM nos grupos. Assim, verifica-se que todas as IES que possuem pelo menos 10 GP têm PPG na área. São elas, pela ordem: UNISINOS, 16 GP (5,7\% do total); UFBA, 11 GP (5,3\% do total); USP 11 (5,3\%); UFF, 14 (5,0\%); PUCSP, 12 (4,2\%); UMESP, 12 (4,2\%); UFRJ, 10 (3,5\%) е PUCRS, 10 (3,5\%).

\footnotetext{
${ }^{50}$ Isso ocorre, pois para o cálculo, utilizando a fórmula seria necessário saber (o que não é informado) qual a correspondência entre o índice do escore (que poderia ser calculado) e a classificação.
} 
Tabela 5.6 - Distribuição Regional dos Grupos de Pesquisa em Comunicação (2005)

\begin{tabular}{l|c|c}
\hline $\begin{array}{l}\text { Grupos de Pesquisal } \\
\text { Regiões }\end{array}$ & N & \% \\
\hline Sudeste & 142 & $\mathbf{5 0 , 7}$ \\
\hline Sul & 75 & $\mathbf{2 6 , 8}$ \\
\hline Nordeste & 43 & $\mathbf{1 5 , 4}$ \\
\hline Centro-Oeste & 16 & $\mathbf{5 , 7}$ \\
\hline Norte & 4 & $\mathbf{1 , 4}$ \\
\hline TOTAL & $\mathbf{2 8 0}$ & $\mathbf{1 0 0 , 0}$ \\
\hline
\end{tabular}

Fonte: CNPq (2005)

Em relação à dispersão regional dos GP, conforme destacada pela Tabela 5.6, a Região Sudeste concentra a maioria, com pouco mais da metade deles (142 GP ou 50,7\%), seguida pela Região Sul, com 75 GP (26,8\%), Nordeste, com 43 (15,4\%), a Centro-Oeste, com 16 (5,7\%) e, muito depois, a região Norte, com apenas 4 GP (1,4\% dos mesmos). Vale notar que essa desequilibrada distribuição regional reflete uma situação nacional geral. Conforme os dados do CNPq, 52,5\% dos Grupos situavam-se no Sudeste; 23,5\% no Sul; 14,2\% no Nordeste; 5,9\% no Centro-Oeste e 4,0\% no Norte.

Tabela 5.7 - Natureza das Instituições que abrigam os Grupos de Pesquisa em Comunicação (2005)

\begin{tabular}{l|c|c}
\hline $\begin{array}{l}\text { Instituiçãol } \\
\text { Natureza da Instituição }\end{array}$ & $\mathbf{N}$ & $\%$ \\
\hline Pública Federal & 114 & $\mathbf{4 0 , 7}$ \\
\hline Privada Confessional & 75 & $\mathbf{2 6 , 8}$ \\
\hline Pública Estadual & 41 & $\mathbf{1 4 , 6}$ \\
\hline Privada & 33 & $\mathbf{1 1 , 8}$ \\
\hline Comunitária/Municipal & 14 & $\mathbf{5 , 0}$ \\
\hline Instituto de Pesquisa & 3 & $\mathbf{1 , 1}$ \\
\hline TOTAL & $\mathbf{2 8 0}$ & $\mathbf{1 0 0 , 0}$ \\
\hline
\end{tabular}

Fonte: CNPq (2005)

Quanto às instituições que abrigam os GP em Comunicação, aqueles sedidados em institutos de pesquisa, como já se disse, são minoritários, apenas 3 Grupos (1,1\%). E, como mostra a Tabela 5.7, são as Instituições Públicas Federais as que possuem o maior número de Grupos, num total de 114 (40,7\%), em seguida, 75 GP (26,8\%) estão vinculados a IES Privadas Confessionais, $41(14,6 \%)$ a Públicas Estaduais, 33 (11,8\%) a IES Privadas e 14 (5,0\%) a Instituições Comunitárias ou Municipais. 
Tabela 5.8 - Número de Linhas de Pesquisa dos Grupos de Pesquisa em Comunicação

\begin{tabular}{c|c|c}
\hline Número de LP & Grupos & \% \\
\hline $\mathbf{1}$ & 117 & $\mathbf{4 1 , 8}$ \\
\hline $\mathbf{2}$ & 76 & $\mathbf{2 7 , 2}$ \\
\hline $\mathbf{3}$ & 54 & $\mathbf{1 9 , 3}$ \\
\hline $\mathbf{4}$ & 16 & $\mathbf{5 , 7}$ \\
\hline $\mathbf{5}$ & 11 & $\mathbf{3 , 9}$ \\
\hline $\mathbf{6}$ & 2 & $\mathbf{0 , 7}$ \\
\hline $\mathbf{7}$ & 4 & $\mathbf{1 , 4}$ \\
\hline Total & $\mathbf{2 8 0}$ & $\mathbf{1 0 0 , 0}$ \\
\hline
\end{tabular}

Fonte: CNPq (2005)

Quanto ao número de Linhas de Pesquisa por Grupo, 117 (41,8\%) anotam apenas uma. Seguem-se os 76 Grupos com duas Linhas (27,2\%) e com três (54 Grupos, correspondendo a 19,3\% deles). Portanto, são minoritários os Grupos com mais de três LP - 33 Grupos, equivalentes a 10,7\% deles. A partir do conjunto de dados exposto, percebe-se que o GP típico em Comunicação possui de uma a duas LP, tem entre dois e três doutores como pesquisadores, está abrigado numa IES da região Sudeste e encontra-se Em Formação ou Consolidação.

Tabela 5.9 - Linhas de Pesquisa dos Grupos de Pesquisa em Comunicação

\begin{tabular}{|c|c|c|c|c|c|c|c|c|c|}
\hline \multirow{2}{*}{$\begin{array}{l}\text { LP e GP I } \\
\text { Subáreas da Comunicação }\end{array}$} & \multicolumn{2}{|c|}{$\begin{array}{c}\text { LP em } \\
\text { Comunicação }\end{array}$} & \multicolumn{5}{|c|}{ GP em Comunicação por Região } & \multicolumn{2}{|c|}{ GP Total } \\
\hline & $\mathbf{N}$ & $\%$ & SE & $\mathbf{s}$ & CO & NE & $\mathbf{N}$ & $\mathbf{N}$ & $\%$ \\
\hline Teoria da Comunicação & 117 & 19,8 & 44 & 19 & 6 & 8 & 2 & 79 & 20,7 \\
\hline Jornalismo e Editoração & 82 & 13,9 & 25 & 11 & 3 & 10 & 0 & 49 & 12,8 \\
\hline $\begin{array}{l}\text { Comunicação Audiovisual: } \\
\text { Cinema, Rádio e Televisão }\end{array}$ & 116 & 19,6 & 39 & 21 & 4 & 9 & 0 & 73 & 19,1 \\
\hline $\begin{array}{l}\text { Comunicação Organizacional, } \\
\text { Rel. Públ. e Propaganda }\end{array}$ & 50 & 8,4 & 15 & 10 & 1 & 6 & 1 & 33 & 8,6 \\
\hline $\begin{array}{l}\text { Cibercultura e Tecnologias } \\
\text { da Comunicação }\end{array}$ & 73 & 12,3 & 24 & 11 & 1 & 12 & 0 & 48 & 12,6 \\
\hline $\begin{array}{l}\text { Medições e Interfaces } \\
\text { Comunicacionais }\end{array}$ & 154 & 26,0 & 46 & 24 & 5 & 22 & 3 & 100 & 26,2 \\
\hline TOTAL & 592 & 100,0 & 193 & 96 & 20 & 67 & 6 & $382^{*}$ & 100,0 \\
\hline
\end{tabular}

Fonte: CNPq (2005)

* As LP dos Grupos eventualmente foram categorizadas em mais de uma subárea, por isso a discrepância com o total de 280 GP.

Seria possível realizar uma categorização indutiva das Linhas dos GP, construindo categorias temáticas e classificando-as, porém preferimos utilizar a proposta feita pela Área, a partir de seus representantes, de Subáreas da Comunicação, em 2004. A proposta 
de Tabela enviada ao CNPq, atendeu a uma demanda da agência para efeito do processo de reformulação das árvores de conhecimento. A despeito de debates e do caráter inconcluso da elaboração da nova Tabela Geral de Áreas, conforme se discute no próximo capítulo deste trabalho, existe um consenso de que esta proposta traz avanços em relação à antiga árvore de conhecimento da Comunicação, que se mostra desatualizada.

A vantagem de utilizar essa proposta é que ela foi um produto da discussão e do consenso da Área, em termos de organização da pesquisa e, assim, a análise da pesquisa dos GP (a partir de suas Linhas de Pesquisa), tem a dupla finalidade de testar essa proposta, num material concreto e perceber como ela se ajusta à investigação.

De qualquer forma, em termos metodológicos, entendemos aqui cada Subárea da proposta como um campo temático ou área subdisciplinar dentro do campo mais amplo da Comunicação. Desse modo, como mostra a Tabela 5.8, foram propostas 6 Subáreas, nas quais procuramos distribuir as LP dos Grupos em Comunicação. Está tarefa foi realizada a partir de uma análise de conteúdo de títulos e objetivos das LP em conjunto com a denominação adotada pelo GP e sua ementa. Por isso, a compreensão sobre as "unidades de registro” (Bardin, 1977), isto é, as unidades de significação que foram consideradas na classificação - dentro das pré-construídas categorias, as Subáreas - levou em conta a relação estabelecida entre um LP e os objetivos gerais do Grupo. É por isso que uma linha de teor mais genérico é categorizada antes em função dos objetos e temas de investigação do GP do que por sua definição estrita - por vezes, genérica ou inexistente.

Assim, Linhas de mesmo nome foram eventualmente distribuídas em diferentes Subáreas. O princípio de subordinação da LP aos objetivos de investigação do Grupo funcionamento como o elemento de conteúdo mais definidor, em nossa categorização, pode ser exemplificado pelo caso de Linhas teóricas, históricas etc., que, quando remetiam à comunicação ou ao sistema midiático de modo geral, eram classificadas na Subárea Teoria da Comunicação. Mas se o GP tivesse um qualificativo de conteúdo que apontasse para outra Subárea (por exemplo, "história” de “outra área”) era nesta que a Linha era categorizada.

Existe também o caso em que os objetivos mais amplos do grupo fizeram com que as LP do mesmo fossem categorizadas em diferentes Subáreas, conforme a direção temática (por 
exemplo, a realização de investigações em temas audiovisuais ou da imprensa) apontada pelos títulos e objetivos da Linha.

É difícil produzir uma categorização “perfeita”, no entanto, acreditamos que os procedimentos adotados neste trabalho são análogos ao possível - no futuro próximo cadastramento/registro por parte do pesquisador de seu Grupo em alguma(s) Subárea(s) e LP, utilizando uma tabela pré-existente, ou seja, indo geralmente do maior nível (a Subárea) para o menor (a LP). E aquela, portanto, servindo para demarcar o conteúdo específico desta.

Com efeito, a melhor aproximação ao universo da pesquisa dos Grupos ocorrerá quando isso ocorrer. Mas, com os cuidados tomados aqui, acreditamos ter produzido um retrato da pesquisa em Comunicação nos GP da área, bastante veraz, conforme os parâmetros traçados. De qualquer modo, para dar transparência ao procedimento de categorização, em Anexo encontra o modo como as Linhas foram distribuídas pelas Subáreas. Com essa estratégia, foi possível também estimar o número de GP que se dedica a cada uma, eventualmente mais de uma delas, conforme se vê na Tabela 5.9.

O "retrato" produzido releva um momento da pesquisa em Comunicação, no qual certamente existe uma proliferação terminológica, em parte ligada à incorporação de novos objetos e temáticas (o “corpo”, a “identidade”, entre outros). De outro lado, essa situação reflete também um nível de consenso, relativo ao vocabulário comum, não muito elevado. E mesmo em termos epistemológicos quanto aos limites (de objetos, abordagens e temas legítimos) da pesquisa na área.

É certo que muitos pesquisadores poderiam considerar alguns dos Grupos ou LP como “impertinentes” à Comunicação. No entanto, em nenhum momento, na análise dessas variáveis, buscou-se estabelecer algum critério a respeito dos temas e abordagens considerados válidos. Tratou-se, pois, de uma verificação empírica a respeito do universo da pesquisa. Em outros termos, o que os investigadores consideram ser a pesquisa na Área.

Quanto aos resultados da classificação das LP dos GP, mostrada na Tabela 5.9, o que se percebe é que, em termos de Linhas, a Subárea com maior número é a de Mediações $e$ Interfaces Comunicacionais, com 154 (26,0\% das LP), seguida por Teoria da 
Comunicação, com 117 e, logo depois, Comunicação Audiovisual: Cinema, Rádio e Televisão, com 116 LP (respectivamente 19,8\% e 19,6\%), Jornalismo e Editoração, com 82 LP (13,9\%), por fim, Cibercultura e Tecnologias da Comunicação, com 73 Linhas (12,3\%) e Comunicação Organizacional, Relações Públicas e Propaganda, 50 (8,4\%).

O modo como os GP dividem suas LP pelas Subáreas, conforme a totalização, demonstra um índice grande de congruência entre percentuais de LP e GP. Desse modo, a despeito de muitos Grupos alocarem Linhas em mais de uma Subárea - dada a diferença entre os 280 GP efetivamente existentes e os 382 Grupos somados em termos de Linhas -, a posição de cada Subárea permaneceu a mesma, em comparação com as LP. Assim, a Área de Mediações possui 100 GP (26,2\%), com pelo menos uma de suas LP na mesma, sendo seguida por Teoria da Comunicação, com 79 Grupos (20,7\%), Comunicação Audiovisual, 73 (19,1\%), Jornalismo, com 49 (12,8\%), Cibercultura, 48 (12,6\%) e Comunicação Organizacional, 33 (8,6\%). Outro aspecto que se percebe é que o ranking geral de GP em relação às Regiões se reproduziu, de modo geral, em termos de Subáreas. Assim, salvo na Subárea Cibercultura, sempre ocorre o posicionamente superior da região Sudeste, seguida por Sul, Nordeste, Centro-Oeste e Norte. No caso de Cibercultura, os GP do Nordeste superam por uma unidade (12 versus 11) os do Sul. Outro caso significativo, também da Região Nordeste, é o número de GP da região na Subárea Jornalismo (10), próximo ao número de Grupos do Sul (11 GP). Isso é um indício interessante da coerência nacional da pesquisa.

Pode-ser notar que se os critérios mais básicos - as Subáreas - fossem outros, evidentemente, seriam percebidos aspectos diferentes dos mostrados aqui. Porém, mais importante do que fazer conjecturas sobre outras possíveis categorizações, é significativo notar que as Subáreas propostas conseguem, aparentemente, refletir a pesquisa praticada. Ou seja, nenhuma das Subáreas têm um volume de LP e GP insignificantes ou tende a concentrar-se somente em poucas regiões. 
Tabela 5.10 - Grupos (exceto de Comunicação) que utilizam o termo “comunicação” como parte do nome, da LP ou palavra-chave desta

\begin{tabular}{|c|c|c|}
\hline Grupos (por Áreas) & $\mathbf{N}$ & $\%$ \\
\hline Educação & 69 & 21,9 \\
\hline Engenharia Elétrica & 25 & 7,9 \\
\hline Ciência da Computação & 23 & 7,2 \\
\hline Ciência da Informação & 20 & 6,3 \\
\hline Enfermagem & 17 & 5,4 \\
\hline Psicologia & 13 & 4,1 \\
\hline Administração & 12 & 3,8 \\
\hline Saúde Coletiva & 12 & 3,8 \\
\hline Letras & 9 & 2,8 \\
\hline Medicina & 8 & 2,5 \\
\hline Fonoaudiologia & 7 & 2,2 \\
\hline História & 7 & 2,2 \\
\hline Lingüística & 7 & 2,2 \\
\hline Sociologia & 7 & 2,2 \\
\hline Antropologia & 6 & 2,0 \\
\hline Ciência Política & 6 & 2,0 \\
\hline Educação Física & 6 & 2,0 \\
\hline Planejamento Urbano e Regional & 6 & 2,0 \\
\hline Agronomia & 4 & 1,3 \\
\hline Artes & 4 & 1,3 \\
\hline Desenho Industrial & 4 & 1,3 \\
\hline Matemática & 4 & 1,3 \\
\hline Ecologia & 3 & 0,9 \\
\hline Filosofia & 3 & 0,9 \\
\hline Morfologia & 3 & 0,9 \\
\hline Serviço Social & 3 & 0,9 \\
\hline Biofísica & 2 & 0,6 \\
\hline Fisiologia & 2 & 0,6 \\
\hline Museologia & 2 & 0,6 \\
\hline Química & 2 & 0,6 \\
\hline Teologia & 2 & 0,6 \\
\hline Turismo & 2 & 0,6 \\
\hline Arquitetura e Urbanismo & 1 & 0,3 \\
\hline Astronomia & 1 & 0,3 \\
\hline Biologia Geral & 1 & 0,3 \\
\hline Economia & 1 & 0,3 \\
\hline Economia Doméstica & 1 & 0,3 \\
\hline Engenharia Agrícola & 1 & 0,3 \\
\hline Engenharia Biomédica & 1 & 0,3 \\
\hline Engenharia Civil & 1 & 0,3 \\
\hline Engenharia de produção & 1 & 0,3 \\
\hline Farmacologia & 1 & 0,3 \\
\hline Imunologia & 1 & 0,3 \\
\hline Nutrição & 1 & 0,3 \\
\hline Parasitologia & 1 & 0,3 \\
\hline Probabilidade e Estatística & 1 & 0,3 \\
\hline Zoologia & 1 & 0,3 \\
\hline Zootecnia & 1 & 0,3 \\
\hline TOTAL & 316 & 100 \\
\hline
\end{tabular}

Fonte: CNPq (2005)

Ao utilizar como palavra-chave da busca "comunicação" (sem especificar nenhuma área, e deixando os campos "Nome do grupo", "Nome da linha de pesquisa” e "Palavra-chave da linha de pesquisa” anotados) são encontrados 486 GP, utilizando-se a ferramenta de busca do Censo 2004 do CNPq. Feita a retirada dos Grupos de Comunicação sobram 316 que não 
são da Área. A Tabela 5.10 mostra quais são essas Áreas que trabalham alguma dimensão do termo "comunicação".

Deve-se notar que o potencial mapeamento da interdisciplinaridade, por assim dizer, externa à Área da Comunicação desses dados tem limites. Dois deles bastante claros, em primeiro lugar, em razão de que o mecanismo de busca de GP, inclusive no Censo 2004, apresentar problemas (certos GP podem não ter sido coletados), assim, é possível que existam outros GP com características similares aos coletados. Além disso, o uso do termo “comunicação” pelos GP das outras Áreas pode não ser atinente àquele que diz respeito ao atual estágio do campo científico da Comunicação.

Porém, esse aspecto pode ser relativizado, já que, de um lado, nos próprios GP que se autodefiniram como da Área não foi feita nenhuma pós-seleção, a partir de critérios definidores. De outro lado, os usos mais “exóticos” ou “exteriores” - à Área da Comunicação - da compreensão desse termo por outros campos disciplinares apontam, de certo modo, para virtualidades da “comunicação” que não são foco da Área específica da mesma.

Sendo assim, é interessante notar, na análise dos dados mostrados pela Tabela 5.10, que o termo “comunicação” aparece em todas as Grandes Áreas de pesquisa da taxonomia utilizada pelo CNPq. Conforme se observa pelos títulos e ementas dos Grupos, grande parte das questões investigadas pela Educação, nesse sentido, também o são pelos GP de Comunicação - que possui 18 LP com o termo "educação". Entre outros aspectos, a tecnologia no ensino e a relação entre mídia e educação.

Nesse caso, pois, os dados sugerem a hipótese da existência de uma área de pesquisa marcada pela confluência entre o conhecimento dessas Áreas, caracterizando possivelmente um setor de investigação inter ou bidisciplinar. Avaliar o quanto isso ocorre - ou seja, perceber se existem conceitos comuns e troca de conhecimento entre os pesquisadores, entre outros pontos - é um trabalho para investigações mais específicas, voltadas ao tema.

Ainda quanto à Grande Área de Ciências Humanas e seu interesse por temas da “comunicação”, conforme evidenciado pela análise dos GP, nota-se que ele também ocorre 
em muitas outras Áreas além de Educação. Assim, Psicologia, História, Sociologia, Antropologia, Ciência Política e Filosofia, somam 44 GP, o que corresponde a 13,9\% dos Grupos. Estas áreas possuem quanto aos temas de Comunicação abordagens e temáticas também similares à investigação feita na própria Área. Porém, é importante notar que não se tem um situação numérica que indique prevalência da investigação, no conjunto das Ciências Sociais e Humanas, nesse campo fora da Área Conhecimento de Comunicação. O que é relevante, face ao papel germinador dos campos mais tradicionais das Ciências Sociais e Humanas para a constituição da Comunicação, como um campo autônomo de investigação.

Outro dado relevante é quanto ao número de GP da Grande Área de Ciências da Saúde (com 51 GP, que somam 16,1\% do todo). Esse índice se deve principalmente às Áreas de Enfermagem e Saúde Coletiva, com 17 e 12 Grupos respectivamente. Vale notar que existem 4 LP em GP de Comunicação com o termo "saúde" e que alguns conteúdos dos GP de Saúde referidos fazem menção a temas convergentes ou com viés comunicacional pronunciado (por exemplo, comunicação em saúde, comunicação científica da saúde). Assim, parece ser possível dizer que existe situação similar, embora de menor escala, de confluência de pesquisa, àquela verificada entre as Áreas de Educação e Comunicação.

É interessante notar ainda a existência de GP em áreas como a de Ciências da Computação (23 GP, que representam 7,2\% deles) e Engenharia Elétrica (25 GP, 7,9\%). Neste caso, ainda que existam temas convergentes com a Área da Comunicação, a maior partes deles aborda a comunicação de um ponto de vista mais “técnico", utilizando termos que não aparecem nos GP de Comunicação, como por exemplo telemática, telecomunicações, interação humano-computador e processamento de comunicação. Ou seja, um ponto de vista que acabou sendo pouco utilizado como perspectiva de estudo na área da Comunicação.

Recapitulando questões relevantes já mencionadas, a análise dos GP que fazem referência à “comunicação” mostra aspectos como: a prevalência da pesquisa na própria Área, no contexto das Ciências Sociais e Humanas. Assim, existem 286 GP em Comunicação na própria área, contra 165 que fazem referência ao tema no âmbito referido; o potencial caso de campos de investigação bi/interdisciplinar (Educação/Saúde-Comunicação) e a 
existência de Áreas de pesquisa que abordam a "comunicação” num nível mais técnico, como pela Engenharia Elétrica e pela Ciência da Computação.

\subsection{Associações de Pesquisadores}

Neste diagnóstico do campo científico da Comunicação, sob um viés institucional, é relevante notar a existência de associações de pesquisadores de relevo. Duas se destacam pela importância mais geral e maior tradição: a INTERCOM - Sociedade Brasileira de Estudos Interdisciplinares da Comunicação, criada em 1977, e a COMPÓS - Associação Nacional dos Programas de Pós-graduação em Comunicação, criada em 1991. Ambas as associações consolidaram-se ao longo do tempo e realizam encontros anuais e outras atividades, como publicações de revistas científicas, a pareceria na edição de livros e apóiam outras formas de debate acadêmico etc.

Antes dessas associações, houve a ABEPEC (Associação Brasileira de Ensino e Pesquisa da Comunicação), porém esta entidade não logrou firmar-se, durando de 1972 a 1985. Segundo Rüdiger (2002), as divergências entre as diferentes tendências de pesquisa resultaram no fim da entidade; Marques de Melo (2003) também aponta para os vários conflitos entre os integrantes dessa entidade como causadores de sua dissolução.

Talvez por isso, a INTERCOM tendeu a agregar os pesquisadores de modo bastante aberto e pluralista, sendo esta, conforme a análise de Faro (1992), sua característica mais importante no início. A entidade surgiu ainda tendo uma ação voltada a questões relativas à discussão da relação entre a sociedade e a comunicação. Isso ocorre pelo próprio contexto em que foi criada, isto é, o durante do regime militar, servindo como foco não só da pesquisa, mas também de crítica social. Por outro lado, as variadas linhas de ação da INTERCOM ao longo do tempo, desde a promoção do seu congresso anual, colóquios de discussão temáticos, palestras de pesquisadores nacionais e estrangeiros, encontros que buscaram a interlocução internacional ${ }^{51}$, entre outras, tiveram fundamental importância

\footnotetext{
${ }^{51}$ São resultados dessa busca, por exemplo, o fato de que no período de 1992 a 1995, as 14 revistas estrangeiras que mais editaram artigos de docentes-pesquisadores dos PPGCOM publicaram 40 artigos dos mesmos (Capparelli e Stumpff, 1996). Outra medida deste diálogo com o exterior é dada pela presença
} 
para o estabelecimento de laços entre os pesquisadores e para o reforço institucional da Comunicação ${ }^{52}$.

Já COMPÓS é fruto, principalmente, da ambiência acadêmica da pesquisa em Comunicação, já que voltada aos PPGCOM. É válido notar, porém, que a associação análoga e modelo da COMPÓS, ou seja, a ANPOCS - Associação Nacional de PósGraduação e Pesquisa em Ciências Sociais - foi criada bem antes, em1977. Ou seja, nesse aspecto também se mostra o caráter em consolidação, ou menos consolidado, do campo da Comunicação.

Com efeito, a criação de outras associações científicas que congregam, num plano temático mais específico, pesquisadores da Comunicação e de áreas afins surgem a partir da década de 1990. Desse modo, em 1996 foi criada a Sociedade Brasileira de Estudos do Cinema e Audiovisual (SOCINE), e em 2003 a Associação Brasileira de Pesquisadores em Jornalismo (SBPJor). É interessante observar que a feitura da proposta para a Tabela de Áreas do Conhecimento do CNPq, pelos pesquisadores da área, parece ajudar a fixar a nomenclatura da Comunicação.

Assim, no ano de 2006, foram criadas a Associação Brasileira de Pesquisadores em Comunicação Organizacional e Relações Públicas (Abrapcorp) e a Associação Brasileira de Pesquisadores em Cibercultura (ABPC). Esta possui aparentemente um caráter mais interdisciplinar do que aquela, tendo sido criada por pesquisadores de Programas de PósGraduação de diferentes áreas das Ciências Humanas, Ciências Sociais Aplicadas e Lingüística, Letras e Artes no Brasil, durante o I Simpósio Nacional de Pesquisadores em Comunicação e Cibercultura, ocorrido na Pontifícia Universidade Católica de São Paulo (PUCSP). No entanto, conforme se observa pelo documento de anúncio da nova associação, a maioria dos signatários era docente de PPGCOM em 2004 (13 em 20).

brasileira em entidades como a IAMCR (International Association for Media and Communication Research), e ALAIC (Asociación Latino-Americana de Investigadores de la Comunicación). Para um relato sobre essa presença ver Marques de Melo (2003a).

52 Merece ser notada a constituição com o apoio da INTERCOM, em 2001, de uma Rede de pesquisa voltada à memória da imprensa, com vistas ao bicentenário da mesma no Brasil, a Rede Alfredo de Carvalho. Esta Rede possui outros apoios institucionais, como o da COMPÓS, e realiza um encontro anual. Porém, pelo possível aspecto circunstancial e caráter não exatamente associativo, não a arrolamos entre as associações científicas da Comunicação, abordadas nesse tópico. Igualmente não são discutidas aqui associações de teor sobretudo corporativo, como fóruns de professores e cursos de graduação. 
Note-se ainda que nem a SBPJor nem a SOCINE procuram limitar a participação na entidade a pesquisadores em Comunicação, embora estes sejam majoritários. Estas duas associações, mais consolidadas já conseguem realizar encontros anuais, com a existência de Grupos de Trabalho (GT) nesse espaço e outras atividades, e têm políticas de publicação. A SBPJor edita, desde 2005, uma revista científica em inglês (Brazilian Journalism Research), bem como anais (em formato digital) dos encontros. Já a SOCINE também publica coletâneas de seus encontros no formato livro impresso e anais em formato digital. A caracterização sintética dessas associações científicas do campo da Comunicação é mostrada na Tabela 5.11, a seguir.

Tabela 5.11 - Associações científicas do campo da Comunicação (2006)

\begin{tabular}{l|c|c|c|c|c}
\hline $\begin{array}{l}\text { Associaçãol } \\
\text { Características }\end{array}$ & $\begin{array}{c}\text { Ano de } \\
\text { Criação }\end{array}$ & $\begin{array}{c}\text { Número de } \\
\text { Associados }\end{array}$ & $\begin{array}{c}\text { Encontro Anual } \\
\text { com GT/NP }\end{array}$ & Publicações & Site \\
\hline INTERCOM & 1977 & $\begin{array}{c}1.500 \\
\text { pesquisadores }\end{array}$ & Sim & $\begin{array}{c}\text { Sim, revista } \\
\text { impressa, livros e } \\
\text { anais }\end{array}$ & Sim \\
\hline COMPÓS & 1991 & 22 PPGCOM & Sim & $\begin{array}{c}\text { Sim, revista digital, } \\
\text { livros e anais }\end{array}$ & Sim \\
\hline SOCINE & 1996 & Não Informado & Sim & Sim, livros e anais & Sim \\
\hline SBPJor & 2003 & $\begin{array}{c}253 \\
\text { pesquisadores }\end{array}$ & Sim & $\begin{array}{c}\text { Sim, revista impressa } \\
\text { e anais }\end{array}$ & Sim \\
\hline Abracorp & 2006 & - & - & - & - \\
\hline ABPC & 2006 & - & - & - & - \\
\hline
\end{tabular}

Em ambas as associações mais antigas e gerais, os formatos de discussão dos pesquisadores, adotados nos encontros, estão relacionados com temáticas do campo. No caso da INTERCOM, utiliza-se o formato do NP (Núcleo de Pesquisa), e na COMPÓS, de GT (Grupo de Trabalho). A Tabela 5.11, a seguir, mostra os campos temáticos de cada um desses agrupamentos de pesquisadores nas Associações, buscando comparar as duas a esse respeito. 
Tabela 5.12 - Temáticas dos NP da INTERCOM e GT da COMPÓs (2006)

\begin{tabular}{|c|c|}
\hline NP Intercom & GT COMPÓS \\
\hline Fotografia: Comunicação e Cultura & \multirow{3}{*}{ Fotografia, Cinema e Vídeo } \\
\hline Comunicação Audiovisual & \\
\hline Ficção Seriada & \\
\hline Jornalismo & \multirow{2}{*}{ Estudos de Jornalismo } \\
\hline Produção Editorial & \\
\hline Políticas e Estratégias da Comunicação & \multirow{2}{*}{ Economia Política e Políticas de Comunicação } \\
\hline Tecnologias da Informação e da Comunicação & \\
\hline Teorias da Comunicação & \multirow{2}{*}{ Epistemologia da Comunicação } \\
\hline Semiótica da Comunicação & \\
\hline Comunicação e Culturas Urbanas & \multirow{2}{*}{ Comunicação e Cultura } \\
\hline Folkcomunicação & \\
\hline Comunicação Científica & Comunicação e Sociabilidade \\
\hline Comunicação Educativa & Comunicação e Cibercultura \\
\hline Comunicação para a Cidadania & Estéticas da Comunicação \\
\hline Comunicação, Turismo e Hospitalidade & Cultura das Mídias \\
\hline Publicidade e Propaganda & Comunicação e Política \\
\hline Rádio e Mídia Sonora & Mídia e Entretenimento \\
\hline Relações Públicas e Comunicação Organizacional & Recepção, Usos e Consumo Midiáticos \\
\hline
\end{tabular}

A INTERCOM abriga atualmente $18 \mathrm{NP}$, enquanto a COMPÓS possui 12 GT. Uma análise elementar sobre a compatibilidade temática mostra que 5 GT e 11 NP possuem o mesmo nome (ou similares) e ementa idem (estes grupos estão no topo da tabela). De outro lado, o menor número de GT, em comparação com os NP, da COMPÓS se explicam pela adoção de uma taxonomia sintética, mais próxima a da atual configuração de LP dos PPGCOM. Assim, os conteúdos investigados pelos pesquisadores dos NP da INTERCOM certamente encaixam-se também - sob outra perspectiva - nas modalidades da COMPÓS. A maior variedade temática da INTERCOM decorre, pois, tanto da manutenção da nomeclatura de certas áreas habilitacionais (Publicidade, por exemplo) e de formatos da Comunicação (Rádio), quanto de uma relativa maior amplitude. Ou seja, o universo da pesquisa em ambas as Associações é bem menos diferente do que pode sugerir a diferenciação na nomenclatura adotada pelos NP e GT. Voltaremos a esse ponto, a taxonomia e a pesquisa na área no próximo capítulo. 


\subsection{As Publicações Periódicas Técnico-Científicas da Área da Comunicação}

Um aspecto que tem marcado o panorama da publicação na Área da Comunicação é o aumento de revistas técnico-científicas dedicadas a ela. Em levantamento sobre o periodismo técnico-científico em Comunicação (Romancini, 2004; no qual é publicada a base das revistas inventariadas), a partir de fontes diversas ${ }^{53}$, verificou-se a situação visualizada no Gráfico 5.1.

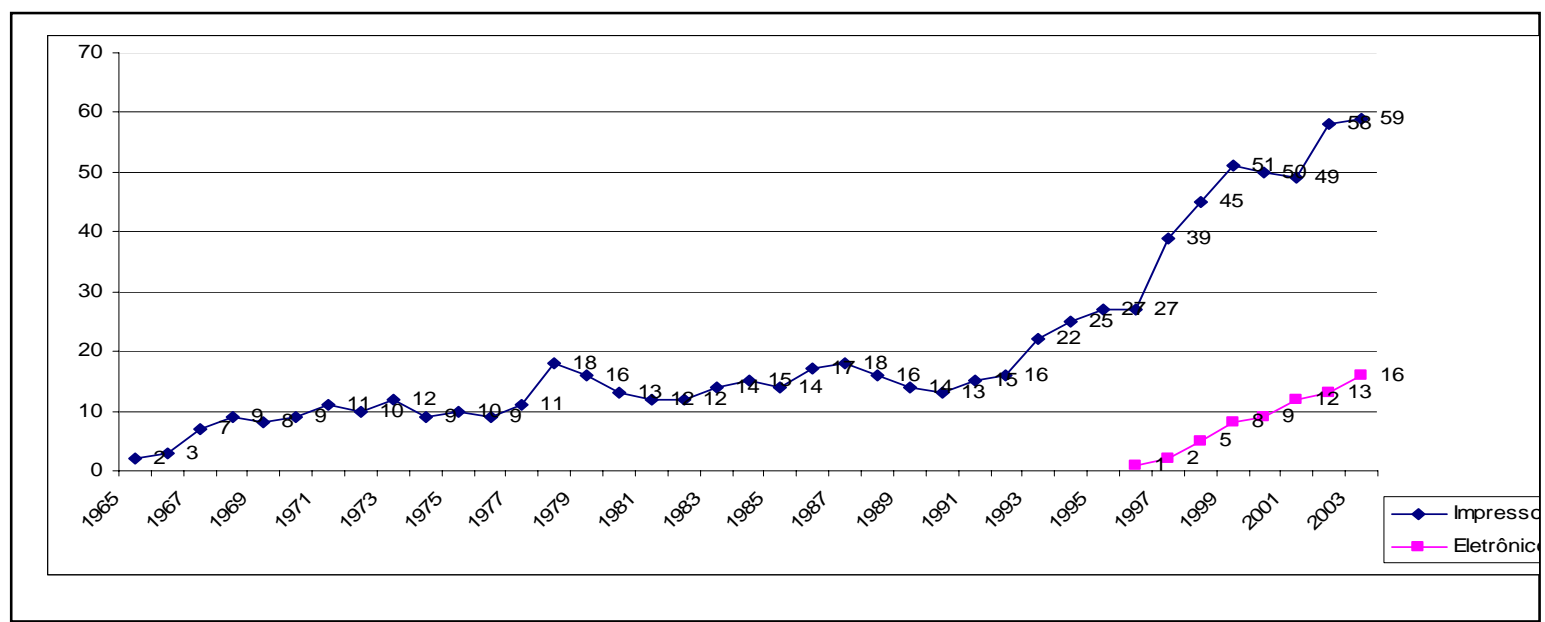

Gráfico 5.1 - Periódicos brasileiros de Comunicação (1965-2003)

O Gráfico demonstra que a dinâmica de crescimento da produção só assume um sentido cumulativo, de maior relevo, nos últimos quinze anos. Antes, diversas revistas surgiram e foram extintas, sem que a área lograsse ultrapassar um patamar muito maior que uma dezena - salvo anos excepcionais.

A dissertação de Dias (2006) utiliza os dados de nosso trabalho e faz acréscimo em sua lista de periódicos, em relação ao mesmo período. Porém, embora ela acrescente 14 revistas Qualis em Comunicação ao último período, isso certamente se deve ao fato de que a autora trabalhou com uma listagem de 2003, enquanto em nosso trabalho também utilizamos essa referência, mas com dados de 2001-2. De qualquer forma, isso tem pouco efeito para a discussão aqui realizada, na medida inclusive em que a autora corrobora a maioria de nossas afirmações em matéria de tendência, e isso é o que é o mais relevante.

53 O catálogo elaborado no âmbito do PORTCOM com periódicos em Comunicação de 1965 a 1984 (Marques de Melo et al., 1992); o levantamento sobre periódicos em Comunicação organizado por Stumpf (www.pgcom.ufrgs/nucleoinfo/sum), a lista de periódicos presente no PORTCOM (www.portcom.intercom. org.br/biblioteca/fontes_revistas.htm\#br), o Catálogo Coletivo Nacional de Publicações Seriadas (CNN) do IBICT (http://www.ibict.br/secao.php?cat=CCN) e a lista Qualis de Periódicos. 
Há um único ponto de discordância, que diz respeito ao que chamamos de "protagonismo por parte dos programas de pós-graduação na edição dos títulos” (Dias, 2006, 143), que a autora contesta. Porém, isso é uma questão que, no nosso entender, que deve ser vista na articulação entre Grupos de Pesquisa e PPGCOM, como discutido abaixo, assim mantemos nossa avaliação.

É possível, para compreender melhor a produção dos periódicos, caracterizar os esforços, em termos dos agentes produtores, em três momentos diferentes, conforme se segue:

Tabela 5.13 - Periódicos brasileiros de Comunicação: responsáveis pela edição

\begin{tabular}{l|c|c|c|c|c|c}
\hline PeríodosI & \multicolumn{2}{|c|}{$1965-1980$} & \multicolumn{2}{|c|}{$1981-1995$} & \multicolumn{2}{|c}{$1996-2003$} \\
\cline { 2 - 7 } Entidades Responsáveis pela edição & $\mathrm{N}$ & $\%$ & $\mathrm{~N}$ & $\%$ & $\mathrm{~N}$ & $\%$ \\
\hline Univ. IFaculdade (ou Depto) de Comunicação & 17 & $\mathbf{4 2 , 5}$ & 21 & $\mathbf{5 4}$ & 35 & $\mathbf{4 2 , 7}$ \\
\hline $\begin{array}{l}\text { Grupo -Entidade profissional ou empresarial I } \\
\text { Órgão público }\end{array}$ & 14 & $\mathbf{3 5}$ & 4 & $\mathbf{1 0 , 1}$ & 6 & $\mathbf{7 , 3}$ \\
\hline Grupo (Núcleo, Centro) de Pesquisa & 5 & $\mathbf{1 2 , 5}$ & 3 & $\mathbf{7 , 7}$ & 13 & $\mathbf{1 5 , 8}$ \\
\hline Programa de Pós-Graduação (ou vínculo PG) & 2 & $\mathbf{5}$ & 8 & $\mathbf{2 0 , 5}$ & 25 & $\mathbf{3 0 , 5}$ \\
\hline Associação Científica (Intercom, Compós) & 2 & $\mathbf{5}$ & 3 & $\mathbf{7 , 7}$ & 3 & $\mathbf{3 , 7}$ \\
\hline
\end{tabular}

Obs.: - Os periódicos foram agrupados numa única categoria, mas conforme sua duração, sendo eventualmente contabilizados em mais de um período. Foram excluídos os periódicos que não são da área.

A conclusão mais importante que é possível retirar da análise dos dados da tabela é que houve um significativo aumento do segmento de periódicos diretamente vinculados a Programas de Pós-Graduação. Num primeiro momento, eles correspondiam a apenas 5\% do total e hoje são 30,5\%. É possível dizer portanto que há um protagonismo da PG hoje no campo da edição na área, uma vez que existe ainda forte vínculo entre o grupo de periódicos associados a Núcleos de Pesquisa (15,8\% dos periódicos na última fase) e esta instância. Em termos mais gerais, pode-se dizer que a correlação pesquisa/pós-graduação é evidenciada pelos dados. Ou seja, do início dos anos de 1970 (início da PG na área) até o momento os acadêmicos procuraram estabelecer seus próprios meios de divulgação e foram, pelo menos em termos quantitativos, bem sucedidos. Convém notar que é provável que muitos periódicos (em particular os impressos de maior trajetória) comecem a ser editados (em termos dos responsáveis) por uma instância e migrem para outra - a pósgraduação corresponderia à etapa superior, um caso típico seria o de Geraes, órgão criado 16 anos antes do mestrado em Comunicação da UFMG que hoje o edita. 
Existe hoje uma clara indução desse periodismo da PG por órgãos de avaliação como a Capes, que, em seu documento sobre os critérios de avaliação dos programas para o triênio 2001-2003, expressa valorizar “a existência de suporte apara difusão da pesquisa realizada pela comunidade científica da área (em particular Periódico Científico)” (Capes, 2004a, 2). O item sobre a “produção intelectual” deste documento afirma ser um índice de excelência a publicação de dois artigos e/ou capítulos de livro ou um livro, ao ano por docente. A força da atual da concepção de publicação como critério de valorização do trabalho acadêmico tem ressonância na produção de revistas. Essa concepção - cuja síntese caricatural é a expressão “publish or perish” -, tem aspectos potencialmente negativos, como a edição de trabalhos irrelevantes ou imaturos, publicações “duplicadas” etc. De outro lado, a publicação aumenta e acompanha o movimento de descentralização regional dos PPGCOM, como mostra a tabela seguinte.

Tabela 5.14 - Periódicos brasileiros de Comunicação: divisão por regiões

\begin{tabular}{|l|c|c|c|c|c|c|}
\hline \multirow{2}{*}{$\begin{array}{l}\text { Períodosl } \\
\text { Regiões }\end{array}$} & \multicolumn{2}{|c|}{$1965-1980$} & \multicolumn{2}{c|}{$1981-1995$} & \multicolumn{2}{c|}{$1996-2003$} \\
\cline { 2 - 8 } Sudeste & $\mathrm{N}$ & $\%$ & $\mathrm{~N}$ & $\mathbf{2}$ & $\mathrm{N}$ & $\%$ \\
\hline Sul & 30 & $\mathbf{7 5}$ & 27 & $\mathbf{6 9 , 2}$ & 51 & $\mathbf{6 1}$ \\
\hline Nordeste & 3 & $\mathbf{7 , 5}$ & 6 & $\mathbf{1 5 , 4}$ & 16 & $\mathbf{1 9 , 5}$ \\
\hline Centro-oeste & 8 & $\mathbf{1 9}$ & 5 & $\mathbf{1 2 , 8}$ & 10 & $\mathbf{1 2 , 2}$ \\
\hline
\end{tabular}

- Obs: Periódicos com mais de um local de edição foram contabilizados em todas as regiões nas quais foram publicados. De outro lado, alguns periódicos eletrônicos não informam o local de publicação, o que corresponde à dinâmica da edição, aparentemente. Por estes dois motivos, a soma de alguns percentuais é diferente de 100.

A Tabela 5.14 mostra que a região Sudeste continua a editar mais, em termos percentuais e absolutos, embora se deva notar o crescimento das publicações da região Sul - passa de 7,5\% no início a 19,5\% no último período. A maioria alcançada e sustentada ao longo do tempo pela região Sudeste em termos de publicações se explica tanto pelo fato do crescimento da PG abranger também esta região, quanto por questões possivelmente ligadas a fatores de consumo (a região concentra mais pesquisadores e outros possíveis leitores) e know-how adquirido para a feitura de publicações.

Um último aspecto geral que é interessante observar é como temáticas diversas do campo da Comunicação são aparentemente privilegiadas pelas publicações, na periodização proposta. A Tabela 5.15, a seguir, procura expressar esse aspecto. A categorização foi feita 
a partir principalmente dos títulos dos veículos, englobando ao mesmo tempo objetos privilegiados de pesquisa e perspectivas disciplinares.

Tabela 5.15 - Periódicos brasileiros de Comunicação: divisão temática

\begin{tabular}{|l|c|c|c|c|c|c|}
\hline \multirow{2}{*}{$\begin{array}{l}\text { PeríodosI } \\
\text { Regiões }\end{array}$} & \multicolumn{2}{|c|}{$1965-1980$} & \multicolumn{2}{c|}{$1981-1995$} & \multicolumn{2}{c|}{$1996-2004$} \\
\cline { 2 - 7 } & $\mathrm{N}$ & $\%$ & $\mathrm{~N}$ & $\%$ & $\mathrm{~N}$ & $\%$ \\
\hline Comunicação & 25 & $\mathbf{6 4}$ & 22 & $\mathbf{5 6 , 4}$ & 47 & $\mathbf{5 7 , 3}$ \\
\hline Inter, Trans ou Bidisciplinares & - & - & 6 & $\mathbf{1 5 , 4}$ & 16 & $\mathbf{1 9 , 5}$ \\
\hline Jornalismo & 6 & $\mathbf{1 5 , 4}$ & 4 & $\mathbf{1 0 , 3}$ & 7 & $\mathbf{8 , 5}$ \\
\hline Cinema & 3 & $\mathbf{7 , 7}$ & 2 & $\mathbf{5 , 1}$ & 4 & $\mathbf{4 , 9}$ \\
\hline Semiótica & 1 & $\mathbf{2 , 6}$ & 2 & $\mathbf{5 , 1}$ & 2 & $\mathbf{2 , 4}$ \\
\hline Outros (especializados) & 4 & $\mathbf{1 0 , 3}$ & 3 & $\mathbf{7 , 7}$ & 6 & $\mathbf{7 , 3}$ \\
\hline
\end{tabular}

O que os dados demonstram é que o periódico sobre "Comunicação”, que contempla diversos aspectos/abordagens relativos à área, bem como uma perspectiva comunicacional, tende a prevalecer em todos os momentos, o que provavelmente se explica devido ao fato de convergirem a esse tipo de publicação um número maior e disperso de contribuições facilitando, assim, a sobrevivência do veículo. Ao mesmo tempo, é possível que esses periódicos centralizem os debates que congregam/aglutinam mais os pesquisadores da Comunicação como um todo. Não por acaso, títulos duradouros e tradicionais, como Comunicação e Sociedade e a Revista Brasileira de Ciências da Comunicação, situam-se nesse âmbito. De outro lado, certas temas e áreas, como jornalismo, cinema e semiótica possuem capacidade, desde sempre, de produzirem periódicos específicos.

A respeito da qualificação desse esforço em termos de publicação feito pela Área da Comunicação, é possível comparar o que é feito com a avaliação do chamado sistema Qualis. Este sistema, criado pela CAPES e definido como o "resultado do processo de classificação dos veículos utilizados pelos programas de pós-graduação para a divulgação da produção intelectual de seus docentes e alunos” (Capes, 2004c), também avalia periódicos da Comunicação. O resultado é divulgado nas listas do conjunto da grande área, conforme a organização da agência, de Ciências Sociais Aplicadas ${ }^{54}$. O sistema utiliza três categorias - A, B, C - ao qual se acrescentam três âmbitos de circulação - local,

\footnotetext{
${ }^{54}$ É importante notar, porém, que dentro da grande área existem várias classificações - conforme as áreas de conhecimento abrangidas por ela - assim, há uma classificação relativa à Comunicação; ao mesmo tempo, um periódico dessa área pode ser classificado por outra, eventualmente com uma avaliação diferente.
} 
nacional ou internacional - para classificar os periódicos. “As combinações dessas categorias compõem nove alternativas indicativas da importância do veículo utilizado, e, por inferência, do próprio trabalho divulgado” (idem).

O documento da Capes informa também a composição de uma Comissão Permanente de Avaliação de Periódicos, composta de um Núcleo de Avaliação, que produz o ranking anual do Qualis e, em conseqüência, informa sobre "a qualidade científica e impacto sobre a área do conhecimento dos periódicos à sua disposição” (Capes, 2004b, 2) e um Núcleo de Consultores (pesquisadores de todos os PPG), que auxilia o outro grupo na elaboração do ranking, produzindo pareceres sobre periódicos da área de competência de seus membros.

Dessa forma, a avaliação concernente a dados de 2002, classifica 11 dos periódicos nacionais de Comunicação (a avaliação pode englobar periódicos internacionais também) como em nível $\mathrm{A}^{55}$, 8 em nível $\mathrm{B}^{56}$ e 7 em $\mathrm{C}^{57}$. Assim, um total de 26 periódicos consegue algum tipo de classificação nesse sistema. Como podem ser contabilizados 62 periódicos especificamente técnico-científicos (excluídos os informativos e de divulgação) da área criados até $2001^{58}$, percebe-se que mais da metade (58\%) das publicações existentes não consegue alguma classificação no Qualis, além disso, nenhum alcançou a classificação A e circulação internacional. Portanto, ainda que o documento explicativo da Capes (2004c) frise que o Qualis não pretende “definir qualidade de periódicos de forma absoluta”, face aos dados apresentados, parece existir um espaço para a melhoria das publicações, para o qual o próprio sistema, bem como as recomendações de políticas para os periódicos a serem elaboradas pelos especialistas ligados a ele, pode colaborar.

\footnotetext{
${ }^{55}$ Comunicação \& Sociedade, Contracampo, Eptic On Line, Fronteiras, Galáxia, Lugar Comum, Revista Brasileira de Ciências da Comunicação, Revista FAMECOS (Nacional), Ciberlegenda, Geraes: Estudos em Comunicação e Sociabilidade (também classificado como C/Nacional, não é claro por qual área, bem como nesta classificação) e Sinopse - Revista de Cinema (Local).

${ }^{56}$ Cinemais, Comunicação \& Educação, Comunicação e Espaço Público, Significação (Nacional), Cadernos de Comunicação, Revista de Biblioteconomia e Comunicação, Temas: Ensaios de Comunicação e Verso \& Reverso (Local).

57 PCLA - Revista Científica do Pensamento Comunicacional Latino-Americano (Internacional), Comunicação: Veredas, Conexão, Eco e Logos (Nacional), Ensaios: Comunicação em Revista e Extraprensa (Local).

${ }^{58}$ A lista completa de periódicos que foram avaliados também se encontra disponível no site da Capes e mostra que periódicos em Comunicação criados em 2002 foram avaliados. Imaginando, porém, que exista um período natural de maturação de um periódico, preferimos trabalhar com dados até 2001.
} 
7Outro elemento que fortalece a conclusão exposta é o fato de que nenhum periódico específico da área da Comunicação tenha conseguido ser admitido pelo Scientific Library on Line (SciELO/ www.scielo.br) até o momento ${ }^{59}$. Este projeto, iniciado em 1997, numa parceria entre a Fundação de Amparo à Pesquisa do Estado de São Paulo (FAPESP) e o Centro Latino-Americano e do Caribe de Informação em Ciências da Saúde (BIREME), com o apoio do CNPq, a partir de 2002, objetiva dar maior visibilidade à ciência produzida no Brasil, melhorando sua acessibilidade e credibilidade (na medida em que o periódico deve possuir determinadas características de qualidade para ingressar e permanecer na coleção da biblioteca eletrônica de periódicos em que consiste o SciELO), por meio da Internet, e ao mesmo tempo,

criar uma base de dados que possa ser utilizada para a obtenção de informações úteis em termos de sociologia da ciência no Brasil, que permita, entre outras coisas, o estabelecimento de estratégias e de políticas de gestão científica. (Meneghini, 1998, 220)

O projeto tem sido bem sucedido na melhoria da visibilidade e acesso à produção científica brasileira, assim, de acordo com pesquisa citada em Vilhena e Crestana (2002, 21), houve um aumento médio de 132,7\% no fator de impacto de cinco periódicos brasileiros indexados no ISIS, em função do ingresso no SciELO.

Por isso, deve-se lamentar a ausência de revistas em Comunicação nesse projeto, de modo que críticas feitas ao aumento da publicação na área, em parte, se justificam, como a de um ex-representante na CAPES, que notava que

em 2003 recebi uma lista com mais de 600 títulos de periódicos científicos onde publicam os professores e alunos dos Programas de Pós-Graduação [em Comunicação], quase todos brasileiros. Depurados (havia duplicações e lançamentos errados) fiquei com uma lista de cerca de 500 periódicos. Ora, os professores dos núcleos docentes dos dezenove Programas de Pós-Graduação da área formam uma comunidade (cito de memória) em torno de 250 pessoas. Não dá para se obter densidade científica numa comunidade onde há 2 periódicos científicos por docente.

O pior é que é um número crescente, principalmente agora com as facilidades do online. Antes a tendência era cada Programa ter um periódico. Depois, os Programas passaram a ter um periódico em papel e outro (sim, outro e não o mesmo em dois formatos) on-line, agora multiplicam-se os on-line e tem Programas com três ou até quatro periódicos. (Gomes, 2004)

\footnotetext{
${ }^{59}$ De acordo com informação que obtivemos do SciELO, até 2004 cinco periódicos em Comunicação haviam tentado ingresso neste projeto, sem sucesso. A exceção, que confirma a regra, é a revista Interface Comunicação, Saúde, Educação, atualmente na coleção do SciELO.
} 
No entanto, é importante perceber que é a baixa utilização que justifica falar em "excesso”, decorrente do baixo uso e impacto ${ }^{60}$. $\mathrm{E}$ tal aspecto tem um forte ingrediente ligado à questão da visibilidade e da dificuldade de acesso. Assim, é também útil não só a continuidade das tentativas de ingresso em projeto como o SciELo, mas também projetos como o que vem sendo realizado pela Rede de Informação em Comunicação dos Países de Língua Portuguesa (PORTCOM), no sentido de construir uma base de revistas on-line, a Coleção Eletrônica de Revistas em Comunicação - REVCOM (http://revcom.portcom.intercom.org.br/). Essa iniciativa permite acessar - no formato eletrônico - a edição de revistas em Comunicação brasileiras ${ }^{61}$, utilizando a metodologia empregada no SciELO.

De qualquer modo, a situação evidenciada, de muitos periódicos sem qualificação, visibilidade e/ou impacto, não é a mais adequada. Todavia, na sua dinâmica expansiva, parece ser também um indicador do aumento da produção da pesquisa. E, de outro lado, os instrumentos como o Qualis, a partir do debate na área, podem propiciar a consolidação das iniciativas, de modo a que se mantenham as mais úteis e válidas (ou seja, as mais utilizadas) para a divulgação do conhecimento produzido. Assim, o esforço de publicação feito poderá facilitar um modelo de interação acadêmico antes “conflitivo-construtivo” do que "segmental”, quanto à circulação do conhecimento na área através de suas publicações periódicas científicas.

\footnotetext{
${ }^{60}$ Nesse sentido, a critica de Bonini (apud Dias, 2006, 145) de que o Qualis tem falhado ao não levar em conta a circulação tem relevo. Porém, utilizando-se critérios como o fator de impacto, isto é, a mensuração do número de vezes em que artigos do periódico são utilizados, isso poderia ser minimizado. A respeito de formas de cálculo do fator de impacto ver Vilhena e Crestana (2002, 20).

${ }^{61}$ Fazem parte do REVCOM, por enquanto, dez revistas, sendo oito nacionais: Contracampo, Comunicação \& Sociedade, Contemporânea, Revista Famecos, Galáxia, Iniciacom, Inovcom, Revista Brasileira de Ciências da Comunicação - Intercom, e duas de Portugal: Media \& Jornalismo e Comunicação e Sociedade.
} 


\subsection{A produção bibliográfica e os projetos de pesquisa dos docentes- pesquisadores}

A descrição dos projetos de pesquisa (Tabela 5.16) e publicações (Tabelas 5.17 e 5.18) foram feitas a partir do conjunto de relatórios CAPES (2004) ${ }^{62}$ de avaliação, elaborados com base em dados fornecidos pelos PPGCOM. Em relação aos projetos, foram realizados alguns ajustes, no sentido de não contabilizar investigações finalizadas (a lista dos projetos se encontra em Anexo nesse trabalho). Quanto às publicações, trabalhou-se com o número das que foram entendidas e contabilizadas como "pertinentes" à área pela comissão de avaliação da CAPES. Isso tem implicações nos resultados.

Tabela 5.16 - Projetos de pesquisa em desenvolvimento pelos docentes dos PPGCOM

\begin{tabular}{|c|c|c|c|c|c|c|c|c|c|c|c|c|c|c|c|c|c|}
\hline \multirow{2}{*}{$\begin{array}{l}\text { Ano de } \\
\text { início do } \\
\text { Proj. I } \\
\text { PPGCOM- }\end{array}$} & \multicolumn{2}{|c|}{ Até 1998} & \multicolumn{2}{|c|}{1999} & \multicolumn{2}{|c|}{2000} & \multicolumn{2}{|c|}{2001} & \multicolumn{2}{|c|}{2002} & \multicolumn{2}{|c|}{2003} & \multicolumn{2}{|c|}{2004} & \multicolumn{2}{|c|}{ Total } & \multirow{2}{*}{$\begin{array}{c}\text { Relação } \\
\text { Projetos/ } \\
\text { docentes } \\
\text { perm. }\end{array}$} \\
\hline & $\mathbf{n}$ & $\%$ & $\mathbf{n}$ & $\%$ & $\mathbf{n}$ & $\%$ & $\mathbf{n}$ & $\%$ & $\mathbf{N}$ & $\%$ & n & $\%$ & $\mathbf{n}$ & $\%$ & $\mathbf{n}$ & $\%$ & \\
\hline USP & 13 & 3,7 & 1 & 0,3 & 10 & 2,8 & 15 & 4,3 & 12 & 3,4 & 8 & 2,2 & 14 & 4,0 & 73 & 20,7 & 1,2 \\
\hline UMESP & 3 & 0,9 & 6 & 1,7 & 6 & 1,7 & 1 & 0,3 & - & - & - & - & 10 & 2,8 & 26 & 7,4 & 2,1 \\
\hline PUCSP & - & - & 1 & 0,3 & - & - & 2 & 0,6 & 2 & 0,6 & 3 & 0,9 & 16 & 4,4 & 24 & 6,8 & 1,3 \\
\hline UFRJ & - & - & - & - & 1 & 0,3 & 2 & 0,6 & 5 & 1,4 & 7 & 1,9 & 8 & 2,2 & 23 & 6,5 & 1,2 \\
\hline UNICAMP & 3 & 0,9 & 1 & 0,3 & 2 & 0,6 & 2 & 0,6 & 5 & 1,4 & 7 & 1,9 & 2 & 0,6 & 22 & 6,3 & 2,0 \\
\hline UNISINOS & - & - & - & - & - & - & - & - & 4 & 1,1 & 5 & 1,4 & 9 & 2,6 & 18 & 5,1 & 1,3 \\
\hline UNESP & - & - & - & - & - & - & 5 & 1,4 & - & - & 4 & 1,1 & 9 & 2,6 & 18 & 5,1 & 1,5 \\
\hline PUCRS & - & - & - & - & - & - & 1 & 0,3 & 3 & 0,9 & 8 & 2,2 & 5 & 1,4 & 17 & 4,8 & 1,2 \\
\hline UNIMAR & - & - & 3 & 0,9 & 1 & 0,3 & 5 & 1,4 & - & - & 7 & 1,9 & 1 & 0,3 & 17 & 4,8 & 1,3 \\
\hline UFPE & - & - & 4 & 1,1 & - & - & 2 & 0,6 & 2 & 0,6 & 3 & 0,9 & 4 & 1,1 & 15 & 4,3 & 2,1 \\
\hline UFBA & - & - & - & - & 1 & 0,3 & 4 & 1,1 & 3 & 0,9 & 3 & 0,9 & 3 & 0,9 & 14 & 4,1 & 1,4 \\
\hline UFF & - & - & - & - & - & - & 2 & 0,6 & - & - & 7 & 1,9 & 4 & 1,1 & 13 & 3,6 & 1,2 \\
\hline UERJ & - & - & - & - & 2 & 0,6 & - & - & 3 & 0,9 & 2 & 0,6 & 6 & 1,6 & 13 & 3,6 & 1,1 \\
\hline UNB & - & - & 1 & 0,3 & - & - & 4 & 1,1 & 4 & 1,1 & 1 & 0,3 & 1 & 0,3 & 11 & 3,1 & 1,0 \\
\hline UFMG & - & - & - & - & - & - & - & - & 4 & 1,1 & 6 & 1,7 & - & - & 10 & 2,8 & 1,1 \\
\hline UTP & - & - & - & - & - & - & - & - & 1 & 0,3 & 5 & 1,4 & 4 & 1,1 & 10 & 2,8 & 1,1 \\
\hline UNIP & - & - & - & - & - & - & - & - & - & - & 1 & 0,3 & 9 & 2,6 & 10 & 2,8 & 1,0 \\
\hline UFRGS & 1 & 0,3 & - & - & - & - & - & - & 5 & 1,4 & 2 & 0,6 & 1 & 0,3 & 9 & 2,6 & 1,0 \\
\hline PUCRJ & - & - & 2 & 0,6 & - & & 1 & 0,3 & 1 & 0,3 & 4 & 1,1 & 1 & 0,3 & 9 & 2,6 & 1,1 \\
\hline TOTAL & 20 & 5,8 & 19 & 5,5 & 23 & 6,6 & 46 & 13,2 & 54 & 15,4 & 83 & 23,2 & 107 & 30,3 & 352 & 100 & 1,3 \\
\hline
\end{tabular}

Fonte: Capes/MEC (2005)

A Tabela 5.16 pretende mostrar, num panorama quantitativo, os projetos desenvolvidos pelos docentes permanentes dos PPGCOM. Assim, é importante apontar a expressão geral dos projetos desenvolvidos ainda em 2005. O total é de 352 projetos, sendo que a maior parte deles (107, correspondendo a 30,3\%) teve início em 2004, no ano anterior foram iniciados 83 (23,2\%) e em 2002 e 2001, 54 (15,4\%) e 48 (13,2\%), respectivamente. Por

62 Estes relatórios estão disponíveis no site da agência a partir da página com todos os PPGCOM: http://www1.capes.gov.br/Scripts/Avaliacao/MeDoReconhecidos/Area/Programa.asp?cod_area=60900008\& nom_area=COMUNICA\%EF\%BF\%BD\%EF\%BF\%BDO\&nom_garea=CI\%EF\%BF\%BDNCIAS\%20SOCI AIS\%20APLICADAS\&data=18/10/2005. 
fim, os projetos, com mais de quatro anos de duração, são 62 (17,9\%). O PPGCOM que desenvolve mais projetos é o da USP, com 73 (20,7\%), número bem maior que os seguintes, devido ao índice mais elevado de docentes/pesquisadores desse programa. $\mathrm{O}$ segundo PPGCOM em projetos de pesquisa é o da UMESP, com 26 (7,4\%), seguido pelos da PUCSP (24 projetos - 6,8\%), UFRJ (23 - 6,5\%), UNICAMP (22 - 6,3\%) e, ainda com pelo menos 5\% do todo, o PPGCOM da UNISINOS e da UNESP, ambos com 18 projetos, correspondendo a 5,1\% cada do total. Os outros doze PPGCOM variam de 17 projetos (4,8\%), casos da PUCRS e UNIMAR, a 9 (2,6\%), como os da UFRGS e PUCRJ.

Quanto à relação entre projetos de pesquisa e docentes permanentes dos PPGCOM, no todo, ela é de 1,3 projeto/docente. Os programas nos quais essa relação é mais elevada são os da UMESP e UFPE (ambos com 2,1), UNICAMP (2,0) e UNESP (1,5), seguidos por UFBA (1,4), PUCSP, UNISINOS e UNIMAR (todos com 1,3), USP, UFRJ, PUCRS e UFF (com 1,2), UFMG, UERJ, PUCRJ e UTP $(1,1)$ e UNB, UFRGS e UNIP $(1,0)$. 
Tabela 5.17 - Publicações dos docentes permanentes dos PPGCOM

\begin{tabular}{|c|c|c|c|c|c|c|c|c|c|c|c|c|c|c|c|}
\hline \multirow{4}{*}{$\begin{array}{l}\text { Tipo de } \\
\text { Publ. I } \\
\text { PPGCOM- }\end{array}$} & \multirow{2}{*}{\multicolumn{4}{|c|}{$\begin{array}{l}\text { Artigo em Rev. Nacional } \\
\text { (Qualis) }\end{array}$}} & \multirow{2}{*}{\multicolumn{3}{|c|}{$\begin{array}{l}\text { Artigo em } \\
\text { Rev. Intern. } \\
\text { (Qualis) }\end{array}$}} & \multicolumn{2}{|c|}{$\begin{array}{l}\text { Capítulo } \\
\text { em Livro }\end{array}$} & \multicolumn{4}{|c|}{ Livro } & \multirow{4}{*}{$\begin{array}{c}\text { Média de } \\
\text { publicações } \\
\text { (pontos) por } \\
\text { docente } \\
\text { perm. }^{*}\end{array}$} & \multirow{4}{*}{$\begin{array}{c}\text { Média } \\
\text { de } \\
\text { pontos } \\
\text { por } \\
\text { docente } \\
\text { perm.** }\end{array}$} \\
\hline & & & & & & & & \multirow{3}{*}{$\begin{array}{l}\text { Livro } \\
\text { nac. }\end{array}$} & \multirow{3}{*}{$\begin{array}{l}\text { Livro } \\
\text { Inter. }\end{array}$} & \multicolumn{2}{|c|}{ Nac. } & \multicolumn{2}{|c|}{ Intern. } & & \\
\hline & \multirow{2}{*}{$\begin{array}{l}\text { Local } \\
\text { A-B-C }\end{array}$} & \multicolumn{3}{|c|}{ Nacional } & \multirow{2}{*}{ A } & \multirow{2}{*}{ B } & \multirow[t]{2}{*}{ C } & & & Texto & Org.I & Texto & Org.I & & \\
\hline & & A & B & C & & & & & & Integ. & Colet & Integ. & Colet & & \\
\hline PUCRJ & - & 5 & 1 & - & - & - & - & 16 & 3 & - & 3 & - & - & 3,7 & 16,0 \\
\hline UFBA & 1 & 11 & 1 & 1 & - & 1 & - & 10 & - & 5 & 2 & - & - & 3,8 & 13,7 \\
\hline UFRGS & 1 & 7 & 1 & 3 & - & 1 & - & 9 & - & 2 & - & 1 & - & 3,6 & 11,6 \\
\hline UNISINOS & 6 & 9 & - & - & - & 2 & 1 & 14 & 4 & 1 & - & - & - & 3,2 & 11,4 \\
\hline PUCRS & 7 & 10 & - & 2 & 1 & 9 & - & 16 & - & 4 & 4 & 1 & - & 3,2 & 11,3 \\
\hline UFRJ & 4 & 17 & 3 & 2 & - & 6 & - & 12 & 3 & 3 & 1 & - & - & 2,8 & 10,6 \\
\hline UFF & - & 9 & 3 & 3 & - & - & - & 9 & 1 & 1 & 3 & 1 & - & 2,8 & 9,8 \\
\hline UMESP & 2 & 5 & - & - & - & - & - & 18 & - & 3 & 1 & - & - & 2,8 & 9,5 \\
\hline UNB & 1 & 6 & 2 & 4 & - & - & - & 10 & - & 1 & - & - & - & 2,4 & 9,4 \\
\hline UNIP & 2 & 2 & - & 2 & - & - & - & 9 & 1 & 4 & 1 & - & - & 2,5 & 9,0 \\
\hline UFPE & 4 & 4 & 4 & 1 & - & - & - & 5 & - & 1 & - & - & - & 2,5 & 7,8 \\
\hline UFMG & - & 5 & 5 & 2 & - & - & - & 7 & - & - & - & - & - & 1,5 & 7,7 \\
\hline UERJ & 7 & 5 & 2 & 2 & - & - & - & 7 & - & 1 & - & - & - & 2,2 & 6,2 \\
\hline PUCSP & 13 & 3 & 2 & - & - & 1 & - & 5 & - & 5 & - & - & - & 1,8 & 5,1 \\
\hline USP & 3 & 9 & 3 & 7 & - & 2 & - & 23 & 4 & 10 & 1 & 2 & - & 1,4 & 5,0 \\
\hline UTP & - & 3 & - & - & - & - & - & 2 & - & 1 & 1 & - & - & 1,2 & 4,4 \\
\hline UNESP & - & 1 & 1 & 1 & - & - & - & 4 & & 1 & 3 & - & - & 1,2 & 3,8 \\
\hline UNICAMP & 2 & 1 & 1 & 1 & - & - & 1 & 6 & - & - & - & - & - & 1,1 & 3,4 \\
\hline UNIMAR & - & 1 & 1 & - & - & - & - & - & - & 1 & - & - & - & 0,6 & 1,8 \\
\hline $\begin{array}{l}\text { TOTAL } \\
\text { (n e } \\
\text { média) }\end{array}$ & 53 & 113 & 30 & 31 & 1 & 22 & 2 & 182 & 16 & 44 & 20 & 5 & - & 2,3 & 8,2 \\
\hline $\begin{array}{l}\text { TOTAL } \\
\text { (n e \% } \\
\text { das publ.) }\end{array}$ & & $7(4:$ & $6 \%$ & & & $\begin{array}{l}25 \\
1,80\end{array}$ & & $\begin{array}{r}1 \\
(38\end{array}$ & $\begin{array}{l}8 \\
\%)\end{array}$ & & 71 & ,6\%) & & \# & \# \\
\hline
\end{tabular}

Fonte: Capes/MEC (2005)

* De acordo com seguinte critério de pontuação: Organização de coletânea, 0,5; Artigos e capítulos, 1 ponto e livro integral, 2. No caso, a média inclui, em termos de artigos, só os de periódicos avaliados no Qualis.

** Conforme a seguinte escala de pontuação estabelecida pela área: livro internacional, 12 pontos; livro nacional, 8 pontos; artigo em periódico internacional A, 7 pontos; internacional B, 6 pontos; internacional C, 5 pontos; nacional A, 4 pontos; nacional B, 3 pontos; nacional C, 2 pontos; local de A a C, 1 ponto; capítulo de livro internacional, 6 pontos; capítulo de livro nacional, 4 pontos; organização de livro nacional, 2 pontos; organização de livro internacional, 4 pontos. Além disso, aplica-se um redutor padrão de um ponto para publicações fora da área ou que são do próprio PPG (exceto para artigos em periódico local, sendo o redutor de 0,5).

Para efeito da avaliação da produção bibliográfica dos pesquisadores dos PPGCOM mostrada se deve notar a exclusão de artigos em revistas não classificadas no sistema Qualis (descrito no próximo tópico), e produções que foram consideradas “não pertinentes” à área de conhecimento pela Comissão de Avaliação. Ademais, é necessário notar os mecanismos de pontuação das produções, pelos quais se chegam aos índices médios de pontos alcançados pelos programas e pela área como um todo.

Sendo assim, o índice de excelência recomendado nos documentos CAPES da área da Comunicação (2005) de 2 produtos bibliográficos por docente é levemente superado pela média geral de 2,3. Sete programas ficaram abaixo dessa média de 2,3 produtos/docente e 11 programas superam-na. Já o número médio do conjunto de programas quanto à pontuação das publicações é de 8,2, a metade dos programas listados (9) está abaixo desse índice, dois a mais do que na outra média observada (UFPE - 7,8 pontos e 2,5 publicações 
por docente permanente; UFMG - 7,7 e 1,5; UERJ - 6,2 e 2,2; PUCSP - 5,1 e 1,8; USP 5 e 1,4; UTP - 4,4 e 1,2; UNESP - 3,8 e 1,2; UNICAMP - 3,4 e 1,1; UNIMAR - 1,8 e 0,6), o outro grupo consiste nos seguintes PPGCOM: PUCRJ - 16 pontos e 3,7 publicações por docente; UFBA - 13,7 e 3,8; UFRGS - 11,6 e 3,6; UNISINOS - 11,4 e 3,2; PUCRS 11,3 e 3,2; UFRJ - 10,6 e 2,8; UFF - 9,8 e 2,8; UMESP - 9,5 e 2,8; e UNB - 9,4 e 2,4; , UNIP - 9 e 2,5.

Quanto aos tipos de publicações, os artigos em revistas são maioria (43,6\% em revistas nacionais e 4,8\% em revistas internacionais), destacando-se os publicados em revistas nacionais Qualis A (113 artigos do total de 227 artigos em periódicos nacionais). A segunda modalidade de publicação é a de capítulos de livro (38\%), a maioria também de edições nacionais (182 contra 16 internacionais); por fim, os livros de autoria integral ou coletânea representam 13,6\% das publicações, e novamente a maior parte é feita no país (apenas cinco livros foram publicados no exterior, contra 64 no país). As publicações (artigos, capítulos e livros) internacionais somam 44 produtos, 8,4\% do total de 521 trabalhos publicados. Assim, embora essa comparação não indique uma forte inserção internacional da publicação na área, ela não é desprezível.

Segue-se o cálculo dos índices de publicação por docente permanente ou NRD6, comparando os anos de 2001 e 2004. É importante notar que o recuo até a primeira data deu-se pelo fato dela ser a primeira que incorpora efetivamente o Qualis de periódicos da área na avaliação, o que favorece a comparabilidade entre os dados. 
Tabela 5.18 - Média de publicações dos docentes NRD6 de 2001 e permanentes dos PPGCOM de 2004

\begin{tabular}{l|c|c|c|c|c|c|c|c}
\hline \multirow{2}{*}{$\begin{array}{l}\text { Publicaçãol } \\
\text { Ano }\end{array}$} & \multicolumn{2}{|c|}{ Artigo em Revista } & \multicolumn{2}{|c|}{ Capítulo em Livro } & \multicolumn{4}{|c}{ Livro } \\
\cline { 2 - 9 } & $\begin{array}{c}\text { Nacional } \\
\text { (Qualis) }\end{array}$ & $\begin{array}{c}\text { Intern. } \\
\text { (Qualis) }\end{array}$ & Livro nac. & $\begin{array}{c}\text { Livro } \\
\text { Inter. }\end{array}$ & $\begin{array}{c}\text { Texto } \\
\text { Integral }\end{array}$ & $\begin{array}{c}\text { Org.I } \\
\text { Colet }\end{array}$ & $\begin{array}{c}\text { Texto } \\
\text { Integral }\end{array}$ & $\begin{array}{c}\text { Org.I } \\
\text { Colet }\end{array}$ \\
\hline $\mathbf{2 0 0 1}$ & 0,40 & 0,11 & $0,68^{*}$ & $0,04^{\star}$ & $0,18^{\star}$ & $0,08^{\star}$ & $0,01^{\star}$ & $0,01^{\star}$ \\
\hline $\mathbf{2 0 0 4}$ & 0,82 & 0,09 & 0,66 & 0,06 & 0,16 & 0,07 & 0,02 & 0,00 \\
\hline
\end{tabular}

Fonte: Capes/MEC (2002 e 2005)

* Ver comentário no primeiro parágrafo abaixo.

O ano de 2001 marcou, no plano dos relatórios da avaliação CAPES, um maior rigor quanto aos critérios de "pertinência” das publicações dos docentes. Desse modo, parte significativa do que era registrado nos relatórios pelos PPGCOM não foi considerado, o que implicou em diminuição dos valores anotados na Tabela acima com asterisco. O que vale notar é que utilizamos o dado consolidado, ou seja, o adotado pela CAPES (a despeito de possíveis recursos dos PPGCOM, cujo resultado não é disponibilizado).

Assim, os dados sobre o padrão médio de publicações dos pesquisadores vinculados aos PPGCOM, numa comparação entre os anos de 2001 e 2004, tem como aspecto mais expressivo o aumento da publicação em periódicos nacionais, com alguma qualificação no sistema Qualis. Assim passou-se da publicação de 0,4 artigos para 0,82 por ano. A publicação em periódico internacional sofreu diminuição, caindo de 0,11 para 0,09. Os demais índices mostram também alterações pequenas, porém, é claro que, em relação ao quesito publicações, a média da Área da Comunicação alcança uma internacionalização pequena. Já o aumento da publicação nacional pode ser correlacionado ao aumento de veículos para a publicação das pesquisas, aspecto abordado no tópico anterior.

A seguir, caracteriza-se também quantitativamente a produção de teses e dissertações em Comunicação desde a criação dos PPGCOM. 


\subsection{A produção (teses e dissertações) dos PPGCOM - 1974-2004}

A Tabela 5.19, que segue, foi produzida a partir de uma série de Catálogos dos PPGCOM - UNB (Porto, 1982), UFRJ (Silva e Cavalcanti, 1989), USP (Lopes, 2003b), sobretudo em relação à produção mais antiga, para os dados mais recentes foram utilizados os relatórios CAPES mencionados no tópico anterior e, em períodos intermediários, os levantamentos da produção feitos coordenados por Stumpf, compreendendo os anos 1992-2002 (disponível em http://www6.ufrgs.br/infotec/teses.htm), bem como consultadas as listas concernentes à produção dos PPGCOM elaboradas pelos menos (UFRJ [s.d.], UMESP [s.d.], UFBA [s.d.]) e consultas às bibliotecas digitais das IES.

A totalização dos resultados, em termos de produção por períodos e PPGCOM, é mostrada nas Tabelas 5.20 e 5.21 . 
Tabela 5.19 - Produção PPGCOM - Dissertações (Mestrado) e Teses (Doutorado) (1974-2004)

\begin{tabular}{|c|c|c|c|c|c|c|c|c|c|c|c|c|c|c|c|c|c|c|c|c|c|c|c|c|c|c|c|c|c|c|c|c|c|c|}
\hline \multirow{2}{*}{$\begin{array}{l}\text { Anosl } \\
\text { PPGCOM }\end{array}$} & \multicolumn{2}{|c|}{1974} & \multicolumn{2}{|c|}{1975} & \multicolumn{2}{|c|}{1976} & \multicolumn{2}{|c|}{1977} & \multicolumn{2}{|c|}{1978} & \multicolumn{2}{|c|}{1979} & \multicolumn{2}{|c|}{1980} & \multicolumn{2}{|c|}{1981} & \multicolumn{2}{|c|}{1982} & \multicolumn{2}{|c|}{1983} & \multicolumn{2}{|c|}{1984} & \multicolumn{2}{|c|}{1985} & \multicolumn{2}{|c|}{1986} & \multicolumn{2}{|c|}{1987} & \multicolumn{2}{|c|}{1988} & \multicolumn{2}{|c|}{1989} & \multicolumn{2}{|c|}{$\begin{array}{c}\text { TOTAL } \\
\text { (1974-1989) }\end{array}$} \\
\hline & M & D & M & D & M & D & M & D & M & D & M & D & M & D & M & D & M & D & M & D & M & D & M & D & M & D & M & D & M & D & M & D & M & D \\
\hline USP & - & - & 2 & - & 4 & - & 3 & - & 10 & - & 10 & - & 31 & - & 14 & - & 30 & - & 23 & - & 20 & 7 & 20 & 8 & 22 & 15 & 31 & 11 & 14 & 19 & 46 & 20 & 280 & 80 \\
\hline UFRJ & 4 & - & 12 & - & 7 & - & 18 & - & 23 & - & 21 & - & 32 & - & 25 & - & 14 & - & 18 & - & 7 & - & 7 & 1 & 9 & - & 11 & - & 9 & 3 & 8 & 2 & 225 & 6 \\
\hline UnB & - & - & - & - & - & - & 12 & - & 5 & - & 3 & - & 1 & - & 4 & - & 2 & - & 3 & - & 1 & - & 2 & - & 6 & - & 2 & - & 2 & - & 2 & - & 45 & - \\
\hline PUCSP & - & - & - & - & - & - & - & - & 4 & - & 4 & - & 5 & - & 1 & - & 6 & 2 & 6 & 1 & 2 & 2 & 5 & 1 & 7 & 2 & 8 & 3 & 2 & 3 & 7 & 1 & 57 & 15 \\
\hline UMESP & - & - & - & - & - & - & - & - & - & - & - & - & - & - & 1 & - & 2 & - & 5 & - & 9 & - & 6 & - & 9 & - & 5 & - & 9 & - & 7 & - & 53 & - \\
\hline TOTAL & 4 & - & 14 & - & 11 & - & 33 & - & 42 & - & 38 & - & 69 & - & 45 & - & 54 & 2 & 55 & 1 & 39 & 9 & 40 & 10 & 53 & 17 & 57 & 14 & 36 & 25 & 70 & 23 & 660 & 101 \\
\hline
\end{tabular}

Tabela 5.19 - (continuação) Produção PPGCOM - Dissertações (Mestrado) e Teses (Doutorado) (1974-2004)

\begin{tabular}{|c|c|c|c|c|c|c|c|c|c|c|c|c|c|c|c|c|c|c|c|c|c|c|c|c|c|c|c|c|c|c|c|c|}
\hline \multirow{2}{*}{$\begin{array}{l}\text { AnosI } \\
\text { PPGCOM }\end{array}$} & \multicolumn{2}{|c|}{1990} & \multicolumn{2}{|c|}{1991} & \multicolumn{2}{|c|}{1992} & \multicolumn{2}{|c|}{1993} & \multicolumn{2}{|c|}{1994} & \multicolumn{2}{|c|}{1995} & \multicolumn{2}{|c|}{1996} & \multicolumn{2}{|c|}{1997} & \multicolumn{2}{|c|}{1998} & \multicolumn{2}{|c|}{1999} & \multicolumn{2}{|c|}{2000} & \multicolumn{2}{|c|}{2001} & \multicolumn{2}{|c|}{2002} & \multicolumn{2}{|c|}{2003} & \multicolumn{2}{|c|}{2004} & \multicolumn{2}{|c|}{$\begin{array}{c}\text { TOTAL } \\
(1990-2004)\end{array}$} \\
\hline & M & D & M & D & M & D & M & D & M & D & M & D & M & D & M & D & M & D & M & D & M & D & M & D & M & D & M & D & $\mathbf{M}$ & D & M & D \\
\hline USP & 43 & 20 & 29 & 16 & 26 & 14 & 39 & 24 & 41 & 28 & 31 & 14 & 20 & 17 & 26 & 12 & 31 & 17 & 57 & 28 & 61 & 37 & 105 & 30 & 141 & 59 & 97 & 47 & 69 & 58 & 816 & 421 \\
\hline UFRJ & 19 & 2 & 16 & 5 & 25 & 9 & 20 & 7 & 19 & 13 & 38 & 13 & 38 & 10 & 21 & 20 & 40 & 12 & 58 & 21 & 57 & 23 & 69 & 34 & 50 & 35 & 49 & 35 & 21 & 16 & 540 & 255 \\
\hline UnB & 7 & - & 4 & - & 9 & - & 8 & - & 3 & - & 5 & - & 4 & - & 16 & - & 5 & - & 9 & - & 7 & - & 7 & - & 21 & - & 29 & - & 16 & - & 150 & - \\
\hline PUCSP & 9 & 2 & 18 & 2 & 39 & 3 & 18 & 7 & 21 & 8 & 26 & 7 & 23 & 27 & 41 & 22 & 35 & 27 & 58 & 28 & 55 & 28 & 72 & 34 & 77 & 56 & 121 & 53 & 53 & 44 & 666 & 348 \\
\hline UMESP & 6 & - & 15 & - & 18 & - & 18 & - & 19 & - & 19 & - & 25 & - & 25 & - & 30 & - & 25 & 4 & 47 & 5 & 26 & 2 & 46 & 11 & 26 & 6 & 18 & 8 & 363 & 36 \\
\hline UNICAMP & 2 & - & 1 & - & 2 & - & 3 & - & 9 & - & 6 & - & 8 & - & 7 & - & 13 & - & 15 & - & 19 & 1 & 30 & 2 & 15 & 2 & 21 & 4 & 14 & 6 & 165 & 15 \\
\hline UFBA & - & - & - & - & - & - & 4 & - & 3 & - & 9 & - & 9 & - & 8 & - & 10 & 1 & 8 & 6 & 8 & 2 & 6 & 3 & 19 & 5 & 10 & 10 & 18 & 8 & 112 & 35 \\
\hline PUCRS & - & - & - & - & - & - & - & - & - & - & - & - & 1 & - & 30 & - & 11 & - & 15 & - & 15 & - & 28 & - & 22 & 8 & 15 & 7 & 22 & 14 & 159 & 29 \\
\hline UNISINOS & - & - & - & - & - & - & - & - & - & - & - & - & - & - & 9 & - & 4 & - & 15 & - & 16 & - & 10 & - & 19 & 2 & 16 & 10 & 17 & 11 & 106 & 23 \\
\hline UFRGS & - & - & - & - & - & - & - & - & - & - & - & - & - & - & - & - & 6 & - & 9 & - & 13 & - & 8 & - & 13 & - & 9 & - & 15 & 2 & 73 & 2 \\
\hline UFMG & - & - & - & - & - & - & - & - & - & - & - & - & - & - & - & - & 7 & - & 7 & - & 13 & - & 8 & - & 8 & - & 15 & - & 14 & - & 72 & - \\
\hline UFF & - & - & - & - & - & - & - & - & - & - & - & - & - & - & - & - & - & - & 1 & - & 8 & - & 14 & - & 17 & - & 18 & - & 13 & - & 71 & - \\
\hline UTP & - & - & - & - & - & - & - & - & - & - & - & - & - & - & - & - & - & - & - & - & - & - & - & - & 13 & - & 20 & - & 15 & - & 48 & - \\
\hline UFPE & - & - & - & - & - & - & - & - & - & - & - & - & - & - & - & - & - & - & - & - & - & - & 8 & - & 6 & - & 12 & - & 10 & - & 36 & - \\
\hline UNIP & - & - & - & - & - & - & - & - & - & - & - & - & - & - & - & - & - & - & - & - & - & - & 20 & - & 24 & - & 22 & - & 12 & - & 78 & - \\
\hline UNIMAR & - & - & - & - & - & - & - & - & - & - & - & - & - & - & - & - & - & - & - & - & - & - & - & - & 5 & - & 3 & - & - & - & 8 & - \\
\hline UNESP & - & - & - & - & - & - & - & - & - & - & - & - & - & - & - & - & - & - & - & - & - & - & - & - & 26 & - & 13 & - & - & - & 39 & - \\
\hline UERJ & - & - & - & - & - & - & - & - & - & - & - & - & - & - & - & - & - & - & - & - & - & - & - & - & - & - & - & - & 9 & - & 9 & - \\
\hline PUCRJ & - & - & - & - & - & - & - & - & - & - & - & - & - & - & - & - & - & - & - & - & - & - & - & - & - & - & - & - & - & - & - & - \\
\hline TOTAL & 86 & 24 & 83 & 23 & 119 & 26 & 110 & 38 & 115 & 49 & 134 & 34 & 128 & 54 & 183 & 54 & 192 & 57 & 277 & 87 & 319 & 96 & 411 & 105 & 522 & 178 & 496 & 172 & 336 & 167 & 3511 & 1164 \\
\hline
\end{tabular}

M - Dissertação de Mestrado; D - Tese de Doutorado 
Tabela 5.20 - Produção PPGCOM - Dissertações (Mest.) e Teses (Dout.) (1974-2004)

\begin{tabular}{|c|c|c|c|c|}
\hline \multirow{2}{*}{$\begin{array}{l}\text { Dissertações (M) e Teses (D) I } \\
\text { Período }\end{array}$} & \multirow{2}{*}{ M } & \multirow{2}{*}{ D } & \multicolumn{2}{|c|}{ Total } \\
\hline & & & $\mathbf{N}$ & $\%$ \\
\hline 1974-1979 & 142 & - & 142 & 2,6 \\
\hline 1980-1984 & 262 & 12 & 274 & 5,0 \\
\hline 1985-1989 & 256 & 89 & 345 & 6,4 \\
\hline 1990-1994 & 513 & 160 & 673 & 12,4 \\
\hline 1995-1999 & 914 & 286 & 1.200 & 22,1 \\
\hline 2000-2004 & 2.084 & 718 & 2.802 & 51,5 \\
\hline Total (n e \%) & $\begin{array}{c}4.171 \\
(76,7 \%)\end{array}$ & $\begin{array}{c}1.265 \\
(23,3 \%)\end{array}$ & $\begin{array}{c}5.436 \\
(100,0 \%)\end{array}$ & 100,0 \\
\hline
\end{tabular}

Em relação à produção total dos PPGCOM até 2004, de 5.436 trabalhos, as dissertações de mestrado foram maioria, com 4.171 (76,6\%) estudos, contra 1.265 (23,3\%) teses de doutorado. Parte majoritária dos trabalhos (51,5 dos mesmos) foi produzida no último qüinqüênio, o que dá a medida de um crescimento mais acelerado dos estudos pósgraduados nos últimos anos. Em particular, chama a atenção o aumento na produção das teses de doutorado, as 718 teses feitas entre 2000 e 2004 correspondem a 56,8\% dos trabalhos desse nível defendidos nos PPGCOM, e representam ainda um aumento na produção de $252 \%$ do penúltimo ao último qüinqüênio. 
Tabela 5.21 - Produção de Dissertações (Mest.) e Teses (Dout.) por PPGCOM (1974-2004)

\begin{tabular}{l|c|c|c|c}
\hline \multirow{2}{*}{$\begin{array}{l}\text { AnosI } \\
\text { Programas }\end{array}$} & $\mathbf{M}$ & $\mathbf{D}$ & $\mathbf{n}$ & $\mathbf{2}$ \\
\hline USP & 1.096 & 501 & 1.597 & $\mathbf{2 9 , 4}$ \\
\hline PUCSP & 723 & 363 & 1.086 & $\mathbf{2 0 , 0}$ \\
\hline UFRJ & 765 & 261 & 1.026 & $\mathbf{1 8 , 9}$ \\
\hline UMESP & 416 & 36 & 452 & $\mathbf{8 , 3}$ \\
\hline UnB & 195 & - & 195 & $\mathbf{3 , 6}$ \\
\hline PUCRS & 159 & 29 & 188 & $\mathbf{3 , 5}$ \\
\hline UNICAMP & 165 & 15 & 180 & $\mathbf{3 , 3}$ \\
\hline UFBA & 112 & 35 & 147 & $\mathbf{2 , 7}$ \\
\hline UNISINOS & 106 & 23 & 129 & $\mathbf{2 , 4}$ \\
\hline UNIP & 78 & - & 78 & $\mathbf{1 , 4}$ \\
\hline UFRGS & 73 & 2 & 75 & $\mathbf{1 , 4}$ \\
\hline UFMG & 72 & - & 72 & $\mathbf{1 , 3}$ \\
\hline UFF & 71 & - & 71 & $\mathbf{1 , 3}$ \\
\hline UTP & 48 & - & 48 & $\mathbf{0 , 9}$ \\
\hline UNESP & 39 & - & 39 & $\mathbf{0 , 7}$ \\
\hline UFPE & 36 & - & 36 & $\mathbf{0 , 7}$ \\
\hline UERJ & 9 & - & 9 & $\mathbf{0 , 1}$ \\
\hline UNIMAR & 8 & - & 8 & $\mathbf{0 , 1}$ \\
\hline PUCRJ & - & -- & - & - \\
\hline TOTAL & $\mathbf{4 . 1 7 1}$ & $\mathbf{1 . 2 6 5}$ & $\mathbf{5 . 4 3 6}$ & $\mathbf{1 0 0 , 0}$ \\
\hline
\end{tabular}

Entre os PPGCOM, o da USP foi o que levou à defesa mais dissertações e teses, até 2004, num total de 1.597 trabalhos (29,4\%), ele é seguido pelos Programas da PUCSP (1.086 trabalhos, correspondendo a 20,0\% do todo) e UFRJ (1.026 - 18,9\%), ainda num patamar de dois dígitos quanto ao percentual de teses e dissertações realizadas. Desse modo, os três PPGCOM com maior produção foram justamente os mais antigos. Num patamar intermediário, estão PPG também tradicionais e outros mais novos, assim, seguem-se os PPGCOM da UMESP (com 452 trabalhos - 8,3\% do todo), UNB (195 - 3,6\%), PUCRS (188 - 3,5\%) e UNICAMP (180 - 3,3\%), UFBA (147 - 2,7\%) e UNISINOS (129 - 2,4\%).

Por fim, entre os PPGCOM que não alcancaram nem dois por cento do total das dissertações e teses estão PPG mais novos, muitos dos quais sem produção/implantação de doutorado. Conforme a seguinte ordem: UNIP (78 trabalhos - 1,4\% do todo), UFRGS (75 - 1,4\%), UFMG (72 - 1,3\%), UFF (71 - 1,3\%), UTP (48 - 0,9\%), UNESP (39-0,7\%), UFPE (36-0,7\%), UERJ ( 9 - 0,1\%) e UNIMAR ( $8-0,1 \%)$. 


\subsection{Uma perspectiva geral sobre os dados}

Neste tópico foram abordadas algumas instâncias institucionais menos dependentes do ensino e que, em tese, favorecem o fortalecimento do campo científico das Ciências da Comunicação. Agora é o momento de um balanço sobre esses espaços. Eles têm sido utilizados do modo mais positivo? Tem sido capazes de estabelecer uma tradição de pesquisa e de trabalho, respondendo a imperativos cognitivos do grupo? Ou têm funcionado antes como mecanismo de “entrincheiramento ideológico” (Schwartzman, 1997) dos pesquisadores?

Antes de propor uma interpretação mais geral, é interessante recapitular alguns dos dados mais relevantes. Em relação aos Grupos de Pesquisa da área cadastrados no Diretório do CNPq, pode-se observar um crescimento dos GP da área que passaram de 33 (0,5\% do total dos grupos cadastrados no Diretório do CNPq), em 1993, para 270 (1,4\%), em 2004. Este crescimento superou percentualmente o de áreas mais consolidadas, como Sociologia (1,5\% do total de GP em 2004) e História (1,9\%), porém não foi suficiente para ultrapassar tais áreas ou mesmo Economia (1,7\%). Além disso, o número de doutores participantes dos GP é significante menor. Comunicação tem 703, contra 1.138 em História, 942 em Sociologia e 996 em Economia. Ao mesmo tempo, o espaço institucional que abriga os GP é quase sempre, ou seja, em 98,9\% das vezes, uma IES. Aspecto mais positivo, em termos do enraizamento da pesquisa, que se mostra capaz de abranger um território próprio, é o fato de que temáticas da comunicação são majoritariamente trabalhadas em GP da área. De outro lado, verificam-se espaços de virtual interdisciplinaridade da Comunicação com outros campos, em particular da educação e da saúde.

Já em termos das Associações Científicas pode-se notar a diversificação das mesmas a partir dos anos de 1990, quando surge mais uma grande associação - a COMPÓS, em 1991 - e são criadas entidades de caráter mais específico. Tal fato seria de se esperar dada a abrangência do campo de estudos, assim os pesquisadores em cinema (SOCINE, 1996), jornalismo (SBPJor, 2001), comunicação organizacional (Abracorp, 2006) e cibercultura (ABPC, 2006) criaram suas entidades . As duas últimas muito recentes ainda , enquanto as duas seguintes - assim como as entidades gerais , grupo que inclui a pioneira INTERCOM (1977), têm desenvolvido uma atuação (congressos anuais, publicações), positiva em 
termos da exposição, crítica e circulação da pesquisa. Note-se, porém, a relativa “juventude” desse tipo de esforço, em termos mais amplos.

A década de 90, em particular seus anos mais adiantados, parece ser, pois, um marco de uma maior consolidação da área ou do campo científico. Vemos, assim, que é também nessa década que a publicação adquire proporções significadas, tanto no plano das revistas técnico-científicas, quanto das teses e dissertações. Em ambos os casos, por sinal, o crescimento continuou ou elevou-se na década posterior. Contudo, essa situação de crescimento quantitativo coloca, em particular para o caso das publicações periódicas, a questão da qualidade. Daí a interrogação sobre o próprio significado do esforço. Vale a pena utilizar tantos recursos em um número tão elevado de publicações? Ou essa situação pode indicar até mesmo, ao contrário, um rebaixamento de padrões da publicação?

Em nosso juízo é interessante observar também essa situação a partir das possibilidades mais positivas, isto é, acreditando que da competição entre várias publicações resulte a eleição - no sentido da escolha dos pesquisadores em termos de leitura, uso e publicação de um conjunto menor. Tal escolha seria talvez menos produtiva se os esforços fossem poucos e descontinuados. É certo, ainda, que existem elementos de indução à melhora qualitativo nessa área, como o sistema de avaliação Qualis. A partir de critérios definidos pelo campo científico, será possível a médio prazo encontrar uma situação de equilíbrio que seja conveniente ao grupo de pesquisadores, em termos da relação entre dispêndio de recursos (e número de publicações) e sua validade. De qualquer forma, a pesquisa publicada e que tenha garantida uma boa visibilidade - aspecto favorecido pelos recursos digitais - é um esforço que permitirá sempre a crítica pelos pares-concorrentes. Situação esta, naturalmente, bem mais positiva do que o trabalho de investigação do qual não resultem produtos publicados/criticados/analisados pelo grupo.

A produção bibliográfica dos docentes-pequisadores analisada mostra que, na média, superou-se o indicador de excelência adotado pela área de 2 produtos bibliográficos por docente. No entanto, isso ocorre por pouco, no conjunto dos PPGCOM, ou seja, 2,3 produto/docente foi a média geral. De outro lado, há grande dispersão entre os programas a esse ponto - sendo que sete (em 18) deles ficaram dessa média. Em relação aos projetos também a certo nível, menor, de dispersão nas médias entre os programas. No entanto, 
deve-se notar que apesar de possíveis situações de menor expressão quantitativa em algum dos PPG, pelo menos, não se verificam "buracos”, nesses quesitos. Embora pouco possamos avançar na expressão qualitativa desses trabalhos, é fato que o sistema de pesquisa na área se consolida. E os que pretendem nele ingressar nele devem possuir um padrão provavelmente mais elevado que no passado.

Ainda quanto às publicações dos docentes dos PPGCOM, o que tem predominado são os artigos em revistas nacionais. A internalização da publicação é pequena, o que indicia interlocução baixa com a comunidade de pesquisadores internacionais da área. O que, por um lado, pode ser correlacionado ao esforço de construção institucional local, que drena ainda parte significativa da energia dos agentes. De outro, sugere o desenho de estratégias para que essa interlocução, através da publicação das investigações em veículos estrangeiros, seja mais elevada e consistente. Outro aspecto a notar, é o fato de que a relativa estabilidade da publicação nos anos de 2001 e 2004 parece mostrar que a adoção de critérios de pertinência (que diminuíram os números de trabalhos em 2001) foi um ponto que não levou esse quesito à diminuição. Ou seja, pelo menos em certo grau parece ter ocorrido um ajuste a propósito desse parâmetro de aceitabilidade por agentes da pesquisa na área.

Observamos nesses dois últimos capítulos a existência efetiva de um conjunto de "atores” institucionais voltados ao "texto" da Comunicação, no palco maior da pesquisa científica no Brasil. Tais atores é que têm, ao longo do tempo, estruturado esse espaço, enfrentando a concorrência externa e seus próprios impasses. Com efeito, o "personagem da comunicação”, em termos de um sentido comum para esses agentes, existe? E como ele é significado? De maneira mais ou menos comum ou , ao contrário, a "comunicação” seria antes de tudo um significante em busca de um significado comum ${ }^{63}$ ? Ou será um personagem sobre cuja natureza os atores nunca chegam a um acordo ou consensos mínimos?

Ora, sem acordos básicos qualquer hipótese sobre um campo científico é negada, pois em tal espaço a interlocução, que permite elaborar as “regras” desse espaço, torna-se inviável.

\footnotetext{
${ }^{63}$ Recuperamos essa idéia de um "significante" em busca de um "significado" do trabalho feito por Smit et al. (2004), que faz esse diagnóstico sobre o conhecimento na área da Ciência da Informação.
} 
E com isso a própria idéia de campo fica prejudicada. Estaríamos, pois, no limite do modelo "segmental” ou talvez mesmo no “conflitivo-destrutivo”.

Nesse sentido, para procurar trazer elementos que indiciem os conteúdos dados pelos agentes ao campo da Comunicação, no próximo Capítulo iremos analisar algumas instâncias de "organização e representação” da área, percebendo como elas se expressam na sua produção de teses e dissertações e nas Linhas de Pesquisa dos PPGCOM. 


\section{Capítulo 6}

\section{Organização e representação dos discursos da Comunicação e de sua produção científica}

O modo de existência de um campo de conhecimento resulta de muitas coisas, particularmente das estratégias e das estruturas discursivas que dão formato ao chamado "Mundo das regras". Portanto, o campo é uma decorrência de ação e de forças e de práticas sociais, históricas e discursivas [...]

Nesses termos, "O Campo da Comunicação" não se trata de um projeto abstrato, mas resultante de iniciativas estipuladas, vivenciadas e reguladas [...]..

(Fausto Neto, 2001, 63)

A constituição de determinados princípios de organização e representação resultam em certas regras e práticas, que terminam por dar contornos mais nítidos a um campo científico. Numa dialética na qual tanto as regras quanto as práticas estruturam-se mutuamente e são objetos da disputa pelos agentes. Nesse sentido, no atual Capítulo iremos analisar certas instâncias de organização dos discursos da Comunicação, discutindo, num primeiro momento, determinados processos e propostas de taxonomia da área. Em seguida utiliza-se a proposta mais avançada, em termos do consenso na área, para a análise da produção (teses e dissertações) dos PPGCOM e das Áreas de Concentração e Linhas de Pesquisa dos mesmos.

Antes de discutir as taxonomias propostas para a Comunicação, é interessante fazer algumas observações sobre o significado das classificações. Em primeiro lugar, pode-se partir do entendimento de que o "estudo fundamental da classificação está intimamente ligado ao estudo do significado e definição” (Langridge apud Souza, 2004). Desse modo, reafirma-se que os aspectos terminológicos-institucionais de um campo científico tendem a refletirem-se num plano cognitivo mais amplo. Assim, quando é elaborada qualquer classificação de uma área de conhecimento, por exemplo, são estabelecidos já alguns marcos sobre a pesquisa considerada aceitável dentro do grupo. É colocado um patamar 
mínimo de inserção ao mesmo e são criadas fronteiras disciplinares. O campo científico passa a ter alguns parâmetros que irão refletir e influenciar sua estrutura, por exemplo, os territórios entendidos como de interface com outras áreas são melhor visualizados.

Com efeito, a feitura de uma classificação nunca se dá num plano de uma completa racionalidade abstrata, mas sim a partir de uma perspectiva histórica, que localiza a pesquisa realizada em determinado tempo e espaço. Diz respeito, pois, a uma trajetória do campo, àquilo que foi, ao longo do tempo, incorporado a uma tradição de estudo - e também ao que foi deixado de lado, visto como fora do conjunto de interesses dos pesquisadores. Esse é outro aspecto que distingue áreas fortemente paradigmáticas daquelas que não o são. Do consenso sobre o paradigma deriva, geralmente, maior nível de acordo terminológico e organizacional. A representação sintética de uma área, garantida por uma classificação, tende, portanto, a ser reconhecida de modo tácito, com baixo nível de dissenso, pelo grupo.

De qualquer modo, é certo que as tentativas de classificações sempre procuram observar a pesquisa realizada, e preocupam-se ainda em analisar os discursos comuns ao grupo, tais como, as linhas de pesquisa efetivamente desenvolvidas, nomenclaturas de designações de GP etc. Ao mesmo tempo, por mais que possam ter uma possível intenção mais descritiva do que normativa, é claro que os atos de classificação e sistematização levam a definições sobre o campo de conhecimento. Em outras palavras, dizem implicitamente o que está “dentro” e o que está “fora”. Assim, o poder de classificar/nomear é também um objeto de disputa dentro de um campo, no qual os agentes procuram movimentar-se conforme seu “interesse”, isto é, de acordo com um entendimento sobre a natureza do campo que possa ser-lhes mais favorável.

É inegável a finalidade e o teor, em termos “externos” e práticos, de uma classificação da qual resulte uma Tabela de Áreas do Conhecimento (TAC). Isso porque ela serve, sobretudo, para orientar o Sistema Nacional de Ciência e Tecnologia do país, contribuindo para sistematizar os campos de conhecimento, como um todo, de modo a poder gerar indicadores representativos de atividades de pesquisa, formação de recursos humanos e produtos, que admitem comparação. Desse modo, os principais usuários são justamente as instituições de Ciência e Tecnologia (C\&T) do país, principalmente seus órgãos 
governamentais e agências de fomento, além da própria comunidade científica (Souza, 2004, 2005).

Mas a esse uso “externo” a um campo científico determinado, corresponde também um uso “interno”, no sentido da construção de uma nomenclatura válida para uma área - que se relaciona com certos objetos, problemas etc. Assim, reforçamos a importância desse poder de nomear que também torna-se algo em disputa, ainda que possa envolver a tentativa de alcançar consensos que expressem um interesse mais geral sobre o que está em discussão. Desse modo, descrever as tentativas de acordos sobre a taxonomia da área da Comunicação será uma tarefa útil para compreender esforços feitos pelo campo em se auto-representar, elaborar um tipo de estrutura específica e comum ao grupo de investigadores.

Uma oportunidade para uma análise como essa é dada pela ocasião da reformulação da Tabela de Áreas do Conhecimento do CNPq, que passamos a discutir no tópico seguinte. Ademais, utilizaremos, na continuidade desse Capítulo, uma das propostas mais avançadas feitas pela área, em termos do consenso do grupo, para analisarmos dados sobre a produção de teses e dissertações dos PPGCOM e discutirmos as atuais Linhas de Pesquisa dos mesmos. 


\subsection{A representação da pesquisa realizada: propostas de taxonomia}

A Tabela atualmente em vigor data de 1984 - sendo que a primeira TAC surgiu em 1976, com baixa participação da comunidade científica em sua elaboração nesse momento. Apesar de reconheceram-se limitações à mesma, ela é também adotada pela CAPES e muitas agências estaduais de fomento. No final da década de 90 já se observava a necessidade de novas reformulações, pela própria dinâmica do conhecimento, por isso o CNPq estimulou discussões nesse sentido. Uma versão preliminar de Tabela com alterações chegou a ser produzida. Entretanto, por razões circunstâncias à época, ela não chegou a ser finalizada e implementada. A questão foi retomada, porém, e foi ponto da agenda de uma Comissão Mista CAPES/CNPq, criada em 2003 (Souza, 2004). E em março de 2005, através de Portaria conjunta CNPq-CAPES-FINEP, foi constituída uma Comissão Especial de Estudos com o objetivo específico de propor uma nova tabela de classificação das áreas do conhecimento. É neste momento que nos encontramos, tendo essa Comissão, após receber sugestões das diferentes áreas de conhecimento, já apresentado uma proposta preliminar para discussão dos pesquisadores (CNPq, 2005b).

Nesse contexto de discussão amplo, a partir da solicitação do CNPq, foi também elaborada uma primeira proposta dos pesquisadores da Comunicação, no âmbito da Associação Nacional de Programas de Pós-Graduação da área - COMPÓS (Lopes, Braga e Samain, 2001). Esta proposta já partia de um reconhecimento sobre o caráter defasado da então - e ainda válida - estrutura de categorias que organizam e representam a pesquisa em Comunicação.

A classificação existente promove uma sistematização do campo "por referência aos principais veículos (mídias) e principais práticas 'de Comunicação Social’ formalmente reconhecidas na sociedade” (Lopes, Braga e Samain, 2001, 2), do que resultavam lacunas, imprecisões descritivas e uma insuficiente abrangência. A seguir, na Tabela 6.10, mostrase essa classificação, sendo que vale a pena relembrar que, na estrutura mais geral da TAC do CNPq, a área da Comunicação situa-se na Grande Área das Ciências Sociais Aplicadas (junto com outras dez áreas) e esta, por sua vez, é uma entre nove Grandes Áreas. Tal estrutura já foi evidenciada no Capítulo 4, nas Tabelas 4.7 e 4.8. 
Tabela 6.1 - Classificação Atual da Área de Comunicação no CNPq

\begin{tabular}{l}
\hline Comunicação (área) \\
\hline 1. Teoria da Comunicação (subárea) \\
\hline 2. Jornalismo e Editoração \\
\hline Teoria e Ética do Jornalismo (especialidade) \\
\hline Organização Editorial de Jornais \\
\hline Organização Comercial de Jornais \\
\hline Jornalismo Especializado (Comunitário, Rural, Empresarial, Científico) \\
\hline 3. Rádio e Televisão \\
\hline Radiodifusão \\
\hline Videodifusão \\
\hline 4. Relações Públicas e Propaganda \\
\hline 5. Comunicação Visual
\end{tabular}

Fonte: CNPq (2006)

Na atual classificação da Comunicação na TAC do CNPq percebe-se com clareza a marca "habilitacional” ou "profissionalizante” dada aos estudos da área, no início, na medida em que as subáreas refletem cursos específicos de graduação (jornalismo, rádio e TV etc.), com exceção de Teoria da Comunicação que, por outro lado, seria um componente básico dos cursos. De qualquer forma, é interessante observar que o argumento sobre a existência de cursos de graduação numa área é um tido como um parâmetro importante para a inclusão de novas áreas na Tabela, isso ocorre hoje (Souza, 2004) e provavelmente também ocorreu da primeira vez que a Comunicação inseriu-se no sistema.

Entretanto a dinâmica da pesquisa em Comunicação, ligada principalmente aos PPGCOM, tornou essa estrutura inadequada e incapaz de refletir o que se produz em termos de investigações, bem como enquadrar convenientemente os projetos de pesquisa da área. Este ponto é evidenciado com clareza pela "inclusão generalizada, na subárea 'Teoria da Comunicação’, de toda a pesquisa que não fosse direcionada por (e para) um dos meios de comunicação ou dos tipos de prática comunicacional reconhecida” (Lopes, Braga e Samain, 2001, 2). Desse modo, um levantamento sobre a auto-classificação dos projetos encaminhados por pesquisadores da Comunicação para o Edital Universal do CNPq de 2004 mostrou que nada menos de 56\% dos mesmos eram da Teoria da Comunicação, certamente pela ausência de outras categorias (Lopes, 2004b). 
Assim, o documento elaborado por Lopes, Braga e Samain (2001), tomando como base texto de reflexão sobre a área e o mapeamento de sua produção científica, buscou produzir uma proposta que "pudesse ser consensualmente aceita como rigorosa, abragentte, suficiente (sem lacunas), e de extensividade co-planar (sem superposições parciais)” (idem, 2). Significativamente tomou como critério teste de validade experimental a possibilidade de garantir a absorção de todas as Linhas de Pesquisa em vigência então nos PPGCOM Chegou, assim, a produzir, a partir de um limite apriorístico de 10 subáreas, a organização que se visualiza na Tabela 6.2, a seguir.

Tabela 6.2 - Classificação da área da Comunicação proposta por Lopes, Braga e Samain no âmbito da COMPÓS

\begin{tabular}{l}
\hline Comunicação (área) \\
\hline 1. Teoria e Epistemologia da Comunicação (subárea) \\
\hline 2. Estudos de Meios \\
\hline 3. Práticas de Comunicação \\
\hline 4. Estudos Interpretativos e Semióticos \\
\hline 5. Estudos de Recepção \\
\hline 6. Sociabilidade, Subjetividade e Comunicação \\
\hline 7. Comunicação e Cultura \\
\hline 8. Comunicação, Arte e Literatura \\
\hline 9. Comunicação, Ciências Humanas e Filosofia \\
\hline 10. Comunicação e Ciências Sociais Aplicadas
\end{tabular}

A respeito da proposta mostrada na Tabela 6.2, vale a pena notar algumas diferenciais da mesma em relação à estrutura vigente. Assim, a mais complexa estrutura concebida permitira “autonomizar” o âmbito da subárea de Teoria da Comunicação, ou seja, torná-la uma categoria específica - nomeada Teoria e Epistemologia da Comunicação. Esta abrangeria uma reflexão teórica para além do natural movimento reflexivo de uma pesquisa qualquer, avançando para uma especificação quanto à investigação que toma a teoria como o próprio objeto da mesma.

De outro lado, a subárea de Práticas de Comunicação englobaria todas as outras subáreas relativas a práticas comunicacionais da tabela tradicional. Foi apontado como vantagem de tal procedimento, o fato de que tais práticas são dinâmicas - nada impede que surjam outras - o que tornaria o processo enumerativo necessariamente lacunar. Daí a proposta de uma subárea abrangente que, de outro lado, dividia tendencialmente com outra área 
abrangente - a de Estudos de Meios - a investigação voltada a meios (que também implicam em práticas ou não) da comunicação, como o "Jornalismo”, “Cinema” etc.

As outras propostas de subáreas correspondiam a domínios nos quais se evidenciavam tradições de pesquisa desenvolvidas na área, em termos mais internos e ligadas à sua história (Estudos Interpretativos e Semióticos; Estudos de Recepção, e Sociabilidade, Subjetividade e Comunicação), e nas interfaces estabelecidas pela mesma, também em sua trajetória, com disciplinas, âmbitos sociais ou objetos que correspondiam a diferentes perspectivas de estudo (Comunicação e Cultura; Comunicação, Arte e Literatura; Comunicação, Ciências Humanas e Filosofia, e Comunicação e Ciências Sociais Aplicadas).

O caráter abrangente da proposta implicava, como reconheciam os autores, na existência de espaços de sobreposições parciais entre as subáreas. No entanto, a proposta defendia a existência de um "núcleo identificador" que atrairia problemas, objetos, perspectivas, objetivos etc. para cada uma das subáreas, tornando-as ao mesmo tempo não redutíveis a outras e fazendo com que adquirissem efetiva consistência pelo reconhecimento e inserção dos pesquisadores nas mesmas. Por fim, notava-se uma efetiva capacidade da proposta de abranger as Linhas de Pesquisa dos PPGCOM - e, por derivação, os projetos desenvolvidos nas mesmas - em suas subáreas.

A despeito das qualidades e bons argumentos dessa proposta - que, ademais, foi encaminhada ao CNPq logo após sua elaboração - ela não recebeu um apoio convicto do conjunto da área. Desse modo, sem resposta da agência, que solicitou novamente uma propostas da área a ser encaminhada à Comissão Especial de Estudos voltada à reformulação da TAC, desta vez em 2005, a proposta de Lopes, Braga e Samain serviu praticamente apenas como subsídio a novas discussões.

As instâncias de discussão (associações, grupos de pesquisadores etc.) da área se movimentaram e havia uma tendência para que fossem encaminhadas mais de uma proposta de classificação. Com efeito, deve-se reconhecer que toda classificação é forçosamente arbitrária; nenhuma delas é perfeita, mas "nada substitui a classificação" (Langridge apud Souza, 2004). Assim, é forçoso que exista por trás de cada proposta 
algum tipo de viés, propósito ou determinação que, como já se disse, faz com que a representação nunca seja apenas descritiva, afinal ou dados poderiam ser organizados de outra forma. De outro lado, há uma dinâmica da pesquisa - em particular numa área relativamente recente como a Comunicação que trabalha objetos que se transformam com rapidez - que pode fazer com que algo adequado num dado momento não pareça ser tanto em outro. Notemos, por exemplo, de que entre 2000 e 2005 houve uma alteração em várias Linhas de Pesquisa dos PPGCOM.

Face ao dissenso que se configurava a respeito das propostas de categorização da Comunicação na TAC, a representante da área no CNPq (a Profa. Dra. Maria Immacolata Vassallo de Lopes) convocou uma reunião/encontro para buscar um possível consenso em determinada estrutura. Este encontro foi realizado em São Paulo, na Escola de Comunicações e Artes da USP, nos dias 20 e 21 de maio de 2005. Nele, participaram, entre os dois dias, 39 pesquisadores - muitos dos líderes da pesquisa na área -, representando entidades ou não. Foram apresentadas, conforme a sugestão da representante, propostas individuais e de entidades, com breves textos de justificação, se fosse o caso ${ }^{64}$. Note-se que algumas das propostas tinham sido elaboradas anteriormente e foram nesse momento somente recolocadas para discussão.

Como observador desse encontro, devemos notar a seriedade e preocupação dos pesquisadores participantes em discutir o tema com profundidade e, ao mesmo tempo, respeito pelas posições divergentes. Mesmo nos momentos de, por vezes, acalorados debates. Os termos com os quais alguns pesquisadores abordaram a importância da ocasião estiveram aparentemente na consciência da maioria. Assim, por exemplo, já nos textos preparatórios da discussão falava-se na feitura da tabela como um possível "instrumento balizador de uma identidade mínima para o campo” (Felinto, 2005, 2), “pretexto para a formação de um consenso sobre a singularidade epistemológica do campo comunicacional” (Sodré, 2005, 1) e viu-se na ocasião do encontro uma "excelente

\footnotetext{
${ }^{64}$ Apresentaram textos (ou enviaram e os mesmos circularam na ocasião do debate) com estruturas de tabela ou subsídios para a discussão os seguintes pesquisadores/entidades, por ordem alfabética: Afonso Albuquerque (UFF), Ana Sílvia Médola (UNESP), Aníbal Bragança (UFF), Antonio Fausto Neto (UNISINOS), Bernardete Lyra (UNIP), Ciro Marcondes Filho (USP), COMPÓS, Eduardo Duarte (UFPE), Eduardo Meditsch (UFSC), Erick Felinto (UERJ), FORCINE, Ivana Bentes (UFRJ), Lucrecia D'Aléssio Ferrara (PUCSP), Maria Immacolata Vassallo de Lopes (USP), Margarida M. K. Kunsch (USP), Muniz Sodré (UFRJ), PPGCOM UMESP, SBPJor. Notamos que colocamos os textos por nós citamos, infelizmente não publicados, em uma parte específica das Referências Bibliográficas.
} 
oportunidade de debater não apenas as características do objeto científico [da Comunicação], mas sobretudo seu lugar como ciência” (Ferrara, 2005, 3).

É possível dividir o conjunto de propostas em dois grandes grupos: um no qual os princípios de organização principais seriam a relativa economia e a estrutura lógicoorgânica das categorias da classificação. Como uma sistematização de Ciro Marcondes Filho (2005) na ocasião mostrou, esse era o grupo no estariam propostas como a de Muniz Sodré, Lucrécia Ferrara, Erick Felinto e outros pesquisadores. Estas implicariam em maior rearranjo na estrutura anterior da tabela, e consequentemente, em certa medida, na própria organização cognitiva do campo. Um aspecto de destaque desse conjunto seria o agrupamento em subáreas de aspecto de diferentes mídias/profissões/práticas da área (jornalismo, cinema etc.), de modo similar ao que ocorria na proposta de Lopes, Braga e Samain. Bastante comum era também o reconhecimento de âmbitos (subáreas) de “interfaces/mediações” sociais (e com outras disciplinas) e manutenção de uma subárea especificamente teórico-metodológica.

De outro lado, o grupo de propostas diverso, tendo como exemplos a do PPGCOM da UMESP e a da SBPJor, advogava maior continuidade em relação à tabela anterior e a aparente tradição de estudos representada por esta. A alteração na tabela seria assim, sobretudo, no sentido de expandir as subáreas, compreendendo mídias e práticas da comunicação emergentes não contempladas na categorização existente. Pode-se dizer, utilizando um termo que um dos pesquisadores usou, ao defender esse modelo, que, nesse caso, o critério de criação de categorias (subáreas) dizia respeito a "paradigmas mais concretos (como Jornalismo, Televisão, etc.)” (Ramos, 2005, 1).

Tanto o fato de que tais "paradigmas" tendem a ser transversais às categorias estruturadas a partir da outra perspectiva, quanto a dificuldade de abranger todos os possíveis “paradigmas” desse tipo, pareciam tornar a conciliação entre os diferentes grupos de propostas difícil. Ademais esses "paradigmas” - bem como, é verdade, as posições do outro grupo - implicavam em concepções de pesquisa ligadas a certas práticas enraizadas, ou com a perspectiva de adquirirem maior legitimidade. Assim, de fato, as discussões se sucederam, e tendo mesmo no horizonte a idéia de uma possível fragmentação do campo já a partir dessa tabela. 
Desse modo, por exemplo, a proposta inicial da FORCINE (2005) era a da criação de uma área específica de Cinema e Audiovisual. Outros assumiam uma postura mais conciliatória, evitando uma "fragilização ainda maior do que a em que já nos encontramos no estágio atual, numa posição muito pouco competitiva em relação a outras áreas de conhecimento" (Meditsch, 2005, 1). Porém, tal postura não deixava de encobrir um viés particular sobre o campo, no caso, assumindo, desde já, sua pluralidade e imaginando que no futuro a consolidação e o crescimento da pesquisa poderiam conduzir o grupo a conseguir estabelecer a Comunicação como uma Grande Área.

No entanto, a despeito das dificuldades produziu-se um consenso possível. É, como discutimos anteriormente e vemos exemplarmente aqui, o caso de um grupo que confrontado com uma exterioridade assume uma tendência de "comunidade" de pesquisadores e age como tal. Assim, certos particularismos são deixados de lado em nome de uma sobrevivência, em melhor situação, coletiva. Mas isso ocorre dentro do “campo”, isto é, dentro do espaço de disputa e discussão que, em sua dinâmica interna, estrutura uma racionalidade comum ao grupo. Com efeito, o documento elaborado ao fim desse encontro reflete linhas de força racionais para as quais convergiram os pesquisadores - abrindo mão, mais ou menos, de suas posturas originais.

Trata-se também de um processo "político", é claro, mas isso, num modelo de espaço científico visto como “campo”, não tem um aspecto, a priori, negativo. Vimos, pois, que para Bourdieu as tomadas de posição científicas são ao mesmo tempo políticas. Todavia, é certo que se a racionalidade que informou as decisões foi, sobretudo, política ou deficiente, os efeitos na estrutura do campo podem ser negativos - diminuindo sua legitimidade puramente científica interna e externamente face a outros grupos.

Seja como for, o documento final tirado dessa reunião apresentava brevemente certos “princípios de classificação da área” e "eixos organizadores” da mesma que, de fato, foram discutidos durante o encontro e suportaram, no nosso entender, a combinação entre as propostas diferentes apresentadas. Dessa forma, descreviam-se os princípios, do seguinte modo: 1) epistemológico, ligado à constituição da Comunicação como área de conhecimento, com sua história, paradigmas, teorias, metodologias, ramificações, etc., 2) 
de autonomização do campo, relativo ao desenvolvimento e acúmulo de conhecimento em determinados setores da pesquisa de Comunicação que autorizariam e legitimariam sua classificação em subáreas, 3) de realidade, ou seja, quanto à expressão concreta da pesquisa realizada na área e 4) de campos “emergentes” dentro da área da Comunicação, relativo a setores de pesquisa ainda em consolidação.

Já os “eixos organizadores”, que estariam presentes em todas as subáreas, indicando níveis ou planos de abordagem feitos nos estudos da área, que se traduziriam em especialidades, eram: 1) Teorias e Metodologias, indicando especificidades nesses âmbitos da área, 2) Fazeres e Linguagens, apontando para a diversidade de práticas e linguagens constitutivas das mídias e dos processos comunicacionais e 3) Diálogos e Interfaces, que traduziriam o caráter dialógico da área, promovendo a inter e a transdisciplinaridade dos estudos.

Foi essa junção entre “princípios” (de maior relevo para as propostas do grupo favorável a "paradigmas concretos”) e “eixos” (no qual se percebe clara inspiração nas propostas do outro grupo) que permitiu uma composição dos pesquisadores da área, então. Assim, o documento final listava 10 subáreas e 73 especialidades, distribuídas nas mesmas. Todavia, o documento que acabou sendo enviado ao CNPq regressou da agência com a solicitação para uma diminuição do número de subáreas. Disso resultaram novas negociações, culminadas numa reunião, ocorrida também na ECA/USP, em 31 de outubro de 2005, da qual resultou outro documento assinado pelos representantes da área no CNPq e na CAPES, e pelos presidentes da INTERCOM, SBPJor, FORCINE e SOCINE. Houve então uma proposta - na qual se sacrificaram subáreas menos consolidadas em termos de pesquisa - com seis subáreas e 233 especialidades, estas, conforme a orientação do CNPq, poderiam servir a mais de uma subárea. O resultado em termos de subáreas é mostrado na Tabela 6.3, a seguir (notamos que o último documento enviado ao $\mathrm{CNPq}$, que foi divulgado aos pesquisadores da Comunicação e trazia a lista de especialistas foi inserido no Volume de Anexos). 
Tabela 6.3 - Classificação da área da Comunicação, para efeito da TAC, proposta pela área ao CNPq

\section{Comunicação (área)}

1. Cibercultura e Tecnologias da Comunicação (subárea)

2. Comunicação Audiovisual: Cinema, Rádio e Televisão

3. Comunicação Organizacional, Relações Publicas e Propaganda

4. Jornalismo e Editoração

5. Mediações e Interfaces Comunicacionais

6. Teorias da Comunicação

Como se pode comparar, o resultado da proposta da área acrescenta numericamente mais uma subárea à estrutura da Comunicação na TAC, passando de cinco para seis subáreas no todo, com a criação de duas não contempladas pela antiga estrutura: a de Cibercultura e Tecnologias da Comunicação e a de Mediações e Interfaces Comunicacionais. De outro lado, a supressão de Comunicação Visual não representa aparente prejuízo, dada a possibilidade de acomodar a pesquisa nessa área em alguma das subáreas efetivas, como Comunicação Audiovisual. As outras subáreas da tabela atualmente em uso sofrem principalmente ampliação, ou seja, à subárea Rádio e TV acrescentou-se o Cinema, resultando na área de Comunicação Audiovisual, já Relações Públicas e Propaganda ganhou o pré-complemento de Comunicação Organizacional.

O processo de reelaboração da TAC não está finalizado, com efeito, a própria tabela preliminar divulgada (CNPq, 2005b) não satisfaz o grupo de pesquisadores, razão pelo qual têm sido feitas diligências para a adoção da proposta da área. Certamente, isso poderá ocorrer no desenvolvimento e finalização do trabalho. Mas, mesmo frisando-se o caráter inconcluso do processo, o que é importante destacar é o fato de que numa discussão interna ao campo chegou-se a determinado mapeamento do que seria relativo à Comunicação, em termos inclusive da classificação dessa pesquisa.

Sendo assim, nos parece pertinente discutirmos dados da produção de teses e dissertações sob a ótica dessa proposta. Ademais, seria possível fazer uma espécie de teste da mesma num corpus recente. Isso será realizado no próximo tópico. De outro lado, ao analisarmos as atuais Linhas de Pesquisa dos PPGCOM, em busca daquilo que lhes é convergente e que 
caracteriza o campo da Comunicação, poderemos ver o quanto a proposta da TAC feita pelos pesquisadores da área ajuda a compreender e corresponde a essas LP.

Por fim, poderemos refletir sobre o entendimento de tal classificação, em termos de suas subáreas, como prováveis "programas de pesquisa” da área da Comunicação. Isso tem implicações quanto ao modelo de integração do grupo, quanto a suas referências bibliográficas, conforme mostraremos no Capítulo seguinte de nosso trabalho.

\subsection{Análise da produção científica: teses e dissertações}

É preciso distinguir a análise que segue nesse tópico das tentativas, complementares à perspectiva adotada, de classificação, facetadas (ver Araújo, 2003, 2005) ou de teor mais tradicional (Dencker, 1988, Dencker e Kunsch, 1997; Stumpf e Capparelli, 1998; Lopes 2000). Nesses casos se opera através da busca-identificação (e categorização) dos assuntos estudados nos trabalhos dentro de uma área. Isso é feito, tanto pelo método facetado, no qual as múltiplas “facetas” privilegiadas representam determinado princípio classificatório (abrangência, prática profissional, suporte, processo envolvido, interface disciplinar etc.), quanto com outros critérios ou procedimentos. Nesses casos, a classificação é feita a partir de algum tipo de análise de discurso ou conteúdo de título/resumos dos trabalhos. As categorias são construídas ou emergem, de modo mais ou menos indutivo, conforme os procedimentos metodológicos.

Naturalmente, pois, ao utilizarmos o sistema de subáreas e suas virtuais especialidades, operamos a partir de uma pré-classificação, que tem a validade, reforçamos, de expressar um relativo consenso dos pesquisadores sobre os âmbitos que dizem respeito ao campo científico da Comunicação. Utilizamos estratégias da chamada “análise de conteúdo” para classificar as teses e dissertações produzidas nos PPGCOM, defendidas em 2004. É, nesse sentido, útil a idéia de que uma análise de conteúdo deve ser julgada "em termos de sua fundamentação nos materiais pesquisados e sua congruência com a teoria do pesquisador, e à luz do seu objetivo de pesquisa” (Bauer, 2002, 191). 
A fundamentação do corpus é dada por sua representatividade e expressão - a pesquisa produzida pelos discentes dos PPGCOM deve refletir a pesquisa da área -, bem como por sua extensão: toda a produção de 2004 é verificada. A “teoria” de nossa análise, por sua vez, pode ser definida como a hipótese de que as categorias de subáreas são índices válidos de organização da pesquisa, permitindo classificar e mostrar indicadores sobre a pesquisa em Comunicação, de modo mais adequado do que ocorria na antiga estrutura. Um critério básico da validade desse princípio é que nenhuma subárea possua um número inexpressivo de trabalhos. Consequentemente, se o objetivo mais imediato da análise é evidenciar características da produção científica em Comunicação, tem-se como objetivo derivado, testar a própria pertinência da organização em subáreas proposta.

O “referencial de codificação” (Bauer, 2002) é a Tabela da área da Comunicação, na qual podemos - nos esforçando por aclarar os procedimentos -, anotar Especialidades que se acomodem às mesmas e aos trabalhos analisados. Todavia, no processo de categorização notou-se uma dificuldade, a respeito da suficiência de uma única categoria para todas as pesquisas. É forçoso reconhecer que existe uma tendência a superposições entre as subáreas - que talvez fossem melhor esclarecidas, no limite, pela leitura do trabalho. No entanto, é evidente, que dado o corpus de 519 trabalhos, isso não está em questão.

Assim, da metodologia possível de leituras dos títulos e resumos desses trabalhos, base de nossa análise de conteúdo, resultaram por vezes indefinições. A identificação de "unidades de registro" (Bardin, 1977), isto é, os termos lexicais que indicam em qual categoria a pesquisa deve ser incluída, nem sempre é monocategorial. Em muitos trabalhos não existe um único viés atuando como “núcleo identificador”. Por vezes, a abragência do conteúdo abordado sugere, sim, uma única classificação - mas nos arriscamos a dizer que em boa parte dos trabalhos isso não ocorre. Tal aspecto representa um problema do ponto de vista analítico, que procuramos resolver da seguinte forma: apelando, por analogia, à idéia de Moragas (1985) que afirma que uma das possibilidades concretas da Comunicação como campo científico se dá em termos da constituição de um espaço de intersecção bidisciplinar. Como destaca o autor, pela própria complexidade que envolve o objeto, isso seria desejável. 
Ora, as subáreas tal como estruturadas por seus formuladores (incluindo âmbitos teóricos e metodológicos, espaços de fazeres/linguagens e diálogos/interfaces), possuem evidentemente um conteúdo “disciplinar” e cognitivo que autoriza compreender um trabalho que utilize saberes de duas das mesmas como categorizado em ambas. No processo de categorização nos limitamos, assim, a no máximo duas categorias (quando necessário, e sem abusar dessa estratégia), justamente pela analogia com essa noção e também para possibilitar a compreensão dessas zonas de interface entre subáreas. Procuramos tornar transparente o processo de categorização, possibilitando a crítica do mesmo, inserindo na síntese de cada trabalho (com nome do autor / título do trabalho / orientador), que se encontra no Anexo, o número correspondente à(s) categoria(s), entre colchetes numerados conforme o número da subárea que aparece na Tabela 6.3 - como os seguintes exemplos: [1] = Cibercultura e Tecnologias da Comunicação; [2] = Comunicação e Audiovisual: Cinema, Rádio e TV etc. Isso também é feito na Tabela que mostra as Linhas de Pesquisa dos PPGCOM.

Seria interessante dar um exemplo de classificação típico no qual tenhamos recorrido à dupla categorização e em que se pode, inclusive, projetar outra possível (mas que foi desconsiderada). Assim, o na tese da USP Noticiário regional [via TV] e a noção de território: a construção de processos identitários evidencia-se, só pelo título, uma possível classificação nas subáreas Jornalismo ("noticiário” - unidade de registro), em Comunicação Audiovisual (“TV”) e Comunicação e Interfaces (“processos identitários”). No entanto, a leitura do resumo, abaixo no Quadro 6.1, deixa mais clara as ênfases nos processos de construção de identidade (portanto a subárea Comunicação e Interfaces) e no Jornalismo. Desse modo, foi nessas categorias que o trabalho foi classificado. Percebemse, claramente, inclusive em quantidade, a maior importância dos léxicos das unidades de registro em que o trabalho foi classificado (os termos no resumo em negrito), predominando em relação àquela descartada (em itálico, Comunicação e Audiovisual). 


\title{
Quadro 6.1 - Exemplo típico de dupla categorização de trabalho em subáreas
}

\section{Título: Noticiário regional e a noção de território: a construção de processos identitários}

Autor: BAZI, Rogério Eduardo Rodrigues

\begin{abstract}
Resumo: Estudo sobre a oferta de efeitos de sentido identitário e os processos da produção da notícia, tendo, como base de análise, dois fatos concomitantes, um genuinamente local e outro global: o assassinato do ex-prefeito de Campinas, Antonio da Costa Santos, e os atentados terroristas aos Estados Unidos, em 11 de setembro de 2001. A pesquisa se apóia, então, numa análise qualitativa do noticiário exibido pela Rede EPTV, afiliada da Rede Globo, na cidade de Campinas, interior de São Paulo, com o auxílio da entrevista semi-estruturada com os jornalistas que participaram nas tomadas de decisões naquele dia. Considera-se que o Jornalismo trabalha na criação ou (re) elaboração de identidades culturais, à medida que auxilia na construção de uma realidade, sob a forma de narrativa e a difunde, convertendo-a em realidade pública. Ao noticiar fatos de interesse público, o Jornalismo e, nesse caso, o de televisão regional, produz sentidos, aguça a memória discursiva dos indivíduos, quando tenta, assim, promover uma certa identificação coletiva. O estudo mostrou que se tem, no território, o principal elemento fundante desse processo. Em tensão com o que acontece global e localmente, o território gera efeitos de sentido identitários que são absorvidos e refletidos pelo noticiário regional que, por sua vez, produz notícia através de mecanismos descritivos e interpretativos, ofertando os processos identitários para a apropriação da recepção local, os quais se articularão nos espaços sociais vividos. Foi possível também demonstrar que a produção da notícia e a rotinização do trabalho jornalístico acentuam-se na mesma intensidade, em diferentes ocasiões.
\end{abstract}

É importante notar ainda que dividimos a categorização, num primeiro momento, entre teses e dissertações (Tabelas 6.4 e 6.5), por PPGCOM, para percebemos se existem diferenças significativas nos âmbitos preferenciais dos trabalhos por nível, inclusive em cada Programa. De outro lado, as “especialidades” (dispostas em tabelas que detalham os dados evidenciados, e que se encontram no Anexo) que compuseram cada subárea foram, na verdade, abrangentes. Assim, seus títulos não corresponderam aos propostos, embora os conteúdos lhes digam respeito. Isso foi feito por uma questão de relativa síntese e pelo maior interesse nos conteúdos das subáreas. Após mostrarmos os trabalhos por nível, a Tabela 6.6 totaliza o resultado e a Tabela 6.7 apresenta os possíveis níveis de interface entre subáreas. 
Tabela 6.4 - Classificação das teses dos PPGCOM em subáreas

\begin{tabular}{l|c|c|c|c|c|c|c|c|c|c|c|c}
\hline $\begin{array}{l}\text { PPGCOMI } \\
\text { Subárea }\end{array}$ & USP & UFRJ & $\begin{array}{c}\text { PUC } \\
\text { SP }\end{array}$ & $\begin{array}{c}\text { UME } \\
\text { SP }\end{array}$ & $\begin{array}{c}\text { UNICA } \\
\text { MP }\end{array}$ & UFBA & $\begin{array}{c}\text { PUC } \\
\text { RS }\end{array}$ & $\begin{array}{c}\text { UNISI } \\
\text { NOS }\end{array}$ & $\begin{array}{c}\text { UF } \\
\text { RGS }\end{array}$ & $\begin{array}{c}\text { TOTAL } \\
\text { (n) }\end{array}$ & $\begin{array}{c}\text { TOTAL } \\
(\%)\end{array}$ & $\begin{array}{c}\text { Total de } \\
\text { trabalhos } \\
(\%)\end{array}$ \\
\hline $\begin{array}{l}\text { 5. Mediações e } \\
\text { Interfaces comunic. }\end{array}$ & 31 & 13 & 32 & 6 & 4 & 5 & 7 & 6 & 1 & 105 & $\mathbf{4 3 , 6}$ & $\mathbf{6 2 , 8}$ \\
\hline $\begin{array}{l}\text { 2. Com. Audiovisual: } \\
\text { Cinema, Rádio e TV }\end{array}$ & 21 & 5 & 9 & - & 3 & 3 & 2 & 6 & - & 49 & $\mathbf{2 0 , 3}$ & $\mathbf{2 9 , 3}$ \\
\hline $\begin{array}{l}\text { 1. Cibercultura e } \\
\text { tecnologias da com. }\end{array}$ & 8 & 4 & 6 & 2 & - & 3 & 3 & 1 & - & 27 & $\mathbf{1 1 , 2}$ & $\mathbf{1 6 , 2}$ \\
\hline $\begin{array}{l}\text { 4. Jornalismo e Edit. } \\
\text { 3. Com. Organizac., } \\
\text { Rel. Públ. e Prop. }\end{array}$ & 5 & - & 5 & 1 & 1 & 1 & 6 & 2 & - & 21 & $\mathbf{8 , 7}$ & $\mathbf{1 2 , 6}$ \\
\hline 6. Teorias da Com. & 3 & 1 & 5 & - & - & - & 2 & 1 & - & 12 & $\mathbf{5 , 0}$ & $\mathbf{7 , 2}$ \\
\hline TOTAL & $\mathbf{8 0}$ & $\mathbf{2 7}$ & $\mathbf{5 8}$ & $\mathbf{1 2}$ & $\mathbf{8}$ & $\mathbf{1 3}$ & $\mathbf{2 2}$ & $\mathbf{1 9}$ & $\mathbf{2}$ & $\mathbf{2 4 1}$ & $\mathbf{1 0 0 , 0}$ & $\mathbf{1 4 4 , 3}$ \\
\hline
\end{tabular}

Foram classificadas 167 teses dos PPGCOM, de 2004, desse modo, 74 trabalhos (44,3\% do total dos mesmos) foram inseridos em dupla categoria. Para os outros 93 trabalhos (63,7\%) a classificação numa única subárea pareceu suficiente. De qualquer modo, a subárea que concentrou mais trabalhos foi a de Mediações e Interfaces Comunicacionais, com 105 dos mesmos - ou seja, 62,8\% das teses foram exclusivamente ou também em outra subárea classificadas nessa categoria. Assim, a subárea de Mediações alcançou mais que o dobro de trabalhos da subárea seguinte, Comunicação Audiovisual: Cinema Rádio e TV, na qual 49 trabalhos foram categorizados. As subáreas de Cibercultura e Tecnologias da Comunicação e Jornalismo e Editoração tiveram o mesmo número de teses categorizadas nas mesmas, 21, que correspondem a 12,6\% do total; em seguida a subárea de Comunicação Organizacional, Relações Públicas e Propaganda teve 21 (8,7\% do total de trabalhos) e Teoria da Comunicação, 12 (5\%).

Embora a ordem apresentada tenda a se manter em todos os programas, certos aspectos numéricos e mesmo de posição chamam a atenção e são aspectos que caracterizam cada um dos PPGCOM. Por exemplo, o relevo da produção que se pode enquadrar na subárea de Comunicação Audiovisual na USP (21 teses), a importância que tem o campo das Mediações na UFRJ (13 trabalhos) e, principalmente, na PUCSP (32 teses), indicando o interesse em áreas como a cultura e a arte nas pesquisas com interfaces com a Comunicação nessas instituições. E também, em termos de um diferencial do programa em relação ao todo, a produção em Comunicação Organizacional na PUCRS (6 trabalhos, sendo a segunda categoria com mais trabalhos, nesse programa) e em Jornalismo na USP (12 teses), são pontos que se destacam. 
Tabela 6.5 - Classificação das dissertações dos PPGCOM em subáreas

\begin{tabular}{|c|c|c|c|c|c|c|c|c|c|c|c|c|c|c|c|c|c|c|c|c|c|}
\hline $\begin{array}{l}\text { PPGCOM/ } \\
\text { Subárea e }\end{array}$ & USP & $\begin{array}{l}\text { UF } \\
\text { RJ }\end{array}$ & $\begin{array}{l}\text { UN } \\
\text { B }\end{array}$ & $\begin{array}{l}\text { Pu } \\
\text { CSP }\end{array}$ & $\underset{\text { ESP }}{\text { UM }}$ & $\begin{array}{l}\text { UNI } \\
C A \\
\text { MP }\end{array}$ & $\begin{array}{l}\text { UF } \\
\text { BA }\end{array}$ & $\begin{array}{l}\mathrm{PU} \\
\mathrm{CR} \\
\mathrm{S}\end{array}$ & $\begin{array}{l}\text { UNI } \\
\text { SIN } \\
\text { OS }\end{array}$ & $\begin{array}{l}\text { UF } \\
\text { RG } \\
\text { S }\end{array}$ & $\begin{array}{l}\mathrm{UF} \\
\mathrm{MG}\end{array}$ & UFF & UTP & $\begin{array}{l}\mathrm{UF} \\
\mathrm{PE}\end{array}$ & $\begin{array}{c}\text { UNI } \\
\text { P }\end{array}$ & $\begin{array}{l}\text { EU } \\
\text { RJ }\end{array}$ & $\underset{\text { ESP }}{\text { UN }}$ & \begin{tabular}{|c|} 
UNI \\
MA \\
R
\end{tabular} & $\underset{(\mathbf{n})}{\text { TOTAL }}$ & $\begin{array}{c}\text { TOTAL } \\
(\%)\end{array}$ & $\begin{array}{c}\text { Total de } \\
\text { trabalhos } \\
(\%)\end{array}$ \\
\hline $\begin{array}{l}\text { 5. Mediações } \\
\text { e Interfaces } \\
\text { comunic. }\end{array}$ & 47 & 15 & 10 & 25 & 10 & 3 & 10 & 5 & 8 & 9 & 9 & 5 & 7 & 4 & 4 & 3 & 5 & 1 & 180 & 34,9 & 51,1 \\
\hline $\begin{array}{l}\text { 2. Com. } \\
\text { Audiovisual: } \\
\text { Cinema, } \\
\text { Rádio e TV }\end{array}$ & 22 & 5 & 6 & 18 & 9 & 10 & 4 & 6 & 7 & 4 & 8 & 6 & 5 & 3 & 9 & 1 & 5 & - & 128 & 24,8 & 36,4 \\
\hline $\begin{array}{l}\text { 4. Jornalismo } \\
\text { e Edit. }\end{array}$ & 13 & 6 & 5 & 11 & 4 & - & 5 & 5 & 3 & 5 & 4 & 7 & 4 & 2 & - & 4 & 3 & 2 & 83 & 16,1 & 23,6 \\
\hline $\begin{array}{l}\text { 1. Cibercult. } \\
\text { e tecn. da } \\
\text { com. }\end{array}$ & 7 & 7 & 2 & 7 & 1 & 3 & 9 & 4 & 4 & 2 & - & 1 & 2 & 2 & 3 & 2 & 2 & - & 58 & 11,2 & 16,5 \\
\hline $\begin{array}{l}\text { 3. Com. } \\
\text { Organizac., } \\
\text { Rel. Públ. e } \\
\text { Prop. }\end{array}$ & 8 & 3 & 1 & 7 & 5 & - & 3 & 8 & 6 & 1 & 2 & 1 & 4 & 4 & 2 & 2 & - & 1 & 58 & 11,2 & 16,5 \\
\hline $\begin{array}{l}\text { 6. Teorias } \\
\text { da Com. }\end{array}$ & 1 & - & - & - & - & - & - & 4 & - & 1 & - & - & - & - & 1 & 1 & 1 & - & 9 & 1,8 & 2,5 \\
\hline Total & 98 & 36 & 24 & 68 & 29 & 16 & 31 & 32 & 28 & 22 & 23 & 20 & 22 & 15 & 19 & 13 & 16 & 4 & 516 & 100,0 & 146,6 \\
\hline
\end{tabular}

Em relação às 352 dissertações dos PPGCOM classificadas nas subáreas, tanto a majoração proveniente da dupla categorização, quanto a ordem por número de trabalhos em que as subáreas ficaram foi similar. Assim, 46,6\% das dissertações (165 das mesmas) receberam dupla classificação nas subáreas, contra 44,3\% das teses. Mediações mantém-se no topo em relação às dissertações, sendo que pouco mais da metade dos trabalhos $(51,1 \%$, 180 deles) pode ser classificada exclusiva ou em conjunto com outra subárea nessa categoria. A ordem, em comparação com as teses, também é igual para Comunicação Audiovisual, porém enquanto Mediações apresentou um decréscimo (foram 62,8\% das teses contra 51,1\% das dissertações), essa subárea teve percentualmente mais dissertações (36,4\%) do que teses (29,3\%). As dissertações apresentaram ainda um número percentual maior do que de teses em Jornalismo (23,6\% versus 16,2\%), o que fez essa subárea isolarse como a terceira com maior número de trabalhos no nível de mestrado.

Também verifica-se aumento percentual nessa classe na subárea Comunicação Organizacional que passa a ter o mesmo índice da de Cibercultura nas dissertações (16,5\% cada). Por fim, a subárea Teoria da Comunicação - como se poderia esperar, dado o teor com menor tendência teórica do que em relação às teses - apresentou decréscimo percentual significativo, apenas 2,5\% (9 trabalhos) foram, exclusivamente ou junto com outra subárea, classificados na mesma. 
Com maior número de cursos em nível de mestrado do que de doutorado, a produção de dissertações dos PPGCOM apresentou uma maior variação em termos da tendência geral de ordem das subáreas entre os mesmos, na comparação com as teses. Embora isso não signifique alterações de larga monta entre os programas. Novamente, o que se mostram são especialidades aparentemente mais relacionadas com cada PPGCOM e sua produção. Isso ocorre, por exemplo, na significativa produção em Comunicação Audiovisual na UNICAMP (10 trabalhos), Cibercultura na UFBA (9 dissertações) e trabalhos que podem ser classificados na subárea Mediações na USP (47), PUCSP (25) e UFRJ (15).

Um aspecto que se apresenta como positivo a respeito da categorização é a relativa ausência de subáreas sem produção nos PPGCOM. Em outros termos, conforme nossa classificação dos trabalhos, não se mostrou necessário recorrer a uma categoria “outros”, existindo uma suficiente inserção dos trabalhos nas subáreas propostas. Por outro lado, a ausência de classificação de dissertações em determinadas subáreas dos PPGCOM ocorre, sobretudo, nos mais recentes e com mais baixo número de orientadores. Nota-se, todavia, que a produção que se caracteriza por ser, se não explicitamente metateórica, pelo menos com forte viés desse tipo (o que justificou a categorização feita aqui) é baixa e apresenta “lacunas” nos programas e, em especial, nas teses nas quais se poderia talvez esperar um número mais elevado de trabalhos.. As totalizações mostradas a seguir permitem fazer mais algumas inferências sobre a categorização e produção dos PPGCOM. 
Tabela 6.6 - Classificação da produção (teses e dissertações) dos PPGCOM em subáreas

\begin{tabular}{l|c|c|c|c}
\hline $\begin{array}{l}\text { TrabalhosI } \\
\text { Subáreas }\end{array}$ & TOTAL (n) & TOTAL (\%) & $\begin{array}{c}\text { Trabalhos categorizados } \\
\text { somente na subárea (\% } \\
\text { sobre o total de trabalhos) }\end{array}$ & $\begin{array}{c}\text { Total de trabalhos } \\
\text { (\%) }\end{array}$ \\
\hline $\begin{array}{l}\text { 5. Mediações e Interfaces } \\
\text { comunicacionais }\end{array}$ & 285 & 37,6 & 23,3 & 54,9 \\
\hline $\begin{array}{l}\text { 2. Com. Audiovisual: Cinema, } \\
\text { Rádio e TV }\end{array}$ & 180 & 23,8 & 14,7 & 34,8 \\
\hline 4. Jornalismo e Editoração & 110 & 14,5 & 7,3 & 21,2 \\
\hline $\begin{array}{l}\text { 1. Cibercultura e tecnologias } \\
\text { da Comunicação }\end{array}$ & 84 & 11,1 & 2,1 & 16,1 \\
\hline $\begin{array}{l}\text { 3. Com. Organizacional, } \\
\text { Relações Públicas e } \\
\text { Propaganda }\end{array}$ & 77 & 10,2 & 5,0 & 14,8 \\
\hline 6. Teorias da Comunicação & 21 & $\mathbf{2 , 8}$ & 1,7 & 4,1 \\
\hline Total (n e \%) & 757 & 100,0 & 54,1 & 145,9 \\
\hline
\end{tabular}

Como mostra a Tabela 6.6 a subárea Mediações e Interfaces Comunicacionais é a que apresenta maior número de trabalhos no conjunto da produção de teses e dissertações dos PPGCOM de 2004. Assim, 286 dentre os 519 trabalhos foram classificados exclusivamente (23,3\% do todo) ou não na mesma, perfazendo um total percentual de 54,9\% do conjunto de trabalhos. A seguir, a subárea Comunicação Audiovisual: Cinema, Rádio e TV teve 180 trabalhos (34,7\% do total de trabalhos) inseridos na mesma, depois veio Jornalismo e Editoração (110 trabalhos, ou 21,2\% do total dos mesmos), Cibercultura e Tecnologias da Comunicação (84, correspondentes a 16,2\%), Comunicação Organizacional, Relações Públicas e Propaganda (77, 14,8\%) e no fim Teorias da Comunicação (21 trabalhos, 4,1\%).

Pode-se dizer que quanto maior é a diferença relativa entre o número de trabalhos que foram classificados exclusivamente na subárea e aqueles que foram nela e em outra, maior a existência de um “diálogo” entre subáreas. Em outros termos, por hipótese, uma pesquisa que esteja em mais de uma subárea deve apelar a um campo de referência bibliográfico interno mais elevado. Assim, a subárea que, em si mesma, apresenta maior característica desse tipo é a de Cibercultura, que teve somente 2,1\% dos trabalhos categorizados exclusivamente nela, mas outros $14 \%$ que também o foram nela e em outra subárea da Comunicação. Ao mesmo tempo, como a subárea de Mediações é um espaço privilegiado para o exercício de possíveis interdisciplinaridades, é significativo o número de trabalhos 
que se situam nela (23,3\% dos mesmos) ou na mesma e em outra subárea (31,6\%). Os prováveis diálogos entre subáreas são evidenciados a seguir.

Tabela 6.7 - Interfaces entre subáreas, conforme a classificação dos trabalhos

\begin{tabular}{|c|c|c|c|c|c|c|c|}
\hline $\begin{array}{l}\text { Subáreas } \\
\text { (números de } \\
\text { trabalhos - n e \%) }\end{array}$ & $\begin{array}{l}\text { 1. Cibercult. } \\
\text { e tecn. da } \\
\text { com. }\end{array}$ & $\begin{array}{l}\text { 2. Com. } \\
\text { Audiov.l: } \\
\text { Cinema, } \\
\text { Rádio e TV }\end{array}$ & $\begin{array}{l}\text { 3. Com. } \\
\text { Org., Rel. } \\
\text { Públ. e } \\
\text { Prop. }\end{array}$ & $\begin{array}{c}4 . \\
\text { Jornalismo } \\
\text { e Edit. }\end{array}$ & $\begin{array}{c}5 . \\
\text { Mediações } \\
\text { e Interfaces } \\
\text { comunic. }\end{array}$ & $\begin{array}{l}\text { 6. Teorias } \\
\text { da Com. }\end{array}$ & $\begin{array}{c}\text { Total de } \\
\text { Trabalhos } \\
\text { (n e \%) }\end{array}$ \\
\hline $\begin{array}{l}\text { 1. Cibercultura e } \\
\text { tecnologias da } \\
\text { com. }\end{array}$ & $\begin{array}{c}11 \\
(2,1 \%)\end{array}$ & $\begin{array}{c}11 \\
(2,1 \%)\end{array}$ & $\begin{array}{c}9 \\
(1,7 \%)\end{array}$ & $\begin{array}{c}12 \\
(2,3 \%)\end{array}$ & $\begin{array}{c}39 \\
(7,5 \%)\end{array}$ & $\begin{array}{c}2 \\
(0,4 \%)\end{array}$ & $\begin{array}{c}84 \\
(16,1 \%)\end{array}$ \\
\hline $\begin{array}{l}\text { 2. Com. Audiovis: } \\
\text { Cinema, Rádio e } \\
\text { TV }\end{array}$ & $\begin{array}{c}11 \\
(2,1 \%)\end{array}$ & $\begin{array}{c}76 \\
(14,7 \%)\end{array}$ & $\begin{array}{c}11 \\
(2,1 \%)\end{array}$ & $\begin{array}{c}18 \\
(3,5 \%)\end{array}$ & $\begin{array}{c}57 \\
(11,0 \%)\end{array}$ & $\begin{array}{c}7 \\
(1,4 \%)\end{array}$ & $\begin{array}{c}169 \\
(32,7 \%)\end{array}$ \\
\hline $\begin{array}{l}\text { 3. Com. Organiz., } \\
\text { Rel. Públ. e } \\
\text { Prop. }\end{array}$ & $\begin{array}{c}9 \\
(1,7 \%)\end{array}$ & $\begin{array}{c}11 \\
(2,1 \%)\end{array}$ & $\begin{array}{c}26 \\
(5,0 \%)\end{array}$ & $\begin{array}{c}3 \\
(0,6 \%)\end{array}$ & $\begin{array}{c}28 \\
(5,4 \%)\end{array}$ & 0 & $\begin{array}{c}57 \\
(11,0 \%)\end{array}$ \\
\hline $\begin{array}{l}\text { 4. Jornalismo e } \\
\text { Editoração }\end{array}$ & $\begin{array}{c}12 \\
(2,3 \%)\end{array}$ & $\begin{array}{c}18 \\
(3,5 \%)\end{array}$ & $\begin{array}{c}3 \\
(0,6 \%)\end{array}$ & $\begin{array}{c}38 \\
(7,3 \%)\end{array}$ & $\begin{array}{c}38 \\
(7,3 \%)\end{array}$ & $\begin{array}{c}1 \\
(0,2 \%)\end{array}$ & $\begin{array}{c}77 \\
(14,8 \%)\end{array}$ \\
\hline $\begin{array}{l}\text { 5. Mediações e } \\
\text { Interfaces } \\
\text { comunic. }\end{array}$ & $\begin{array}{c}39 \\
(7,5 \%)\end{array}$ & $\begin{array}{c}57 \\
(11,0 \%)\end{array}$ & $\begin{array}{c}28 \\
(5,4 \%)\end{array}$ & $\begin{array}{c}38 \\
(7,3 \%)\end{array}$ & $\begin{array}{c}121 \\
(23,3 \%)\end{array}$ & $\begin{array}{c}2 \\
(0,4 \%)\end{array}$ & $\begin{array}{c}123 \\
(23,7 \%)\end{array}$ \\
\hline $\begin{array}{l}\text { 6. Teorias da } \\
\text { Com. }\end{array}$ & $\begin{array}{c}2 \\
(0,4 \%)\end{array}$ & $\begin{array}{c}7 \\
(1,4 \%)\end{array}$ & 0 & $\begin{array}{c}1 \\
(0,2 \%)\end{array}$ & $\begin{array}{c}2 \\
(0,4 \%)\end{array}$ & $\begin{array}{c}9 \\
(1,7 \%)\end{array}$ & $\begin{array}{c}9 \\
(1,7 \%)\end{array}$ \\
\hline $\begin{array}{l}\text { Total de } \\
\text { classificações } \\
\text { (n e \%) }\end{array}$ & $\begin{array}{c}84 \\
(16,1 \%)\end{array}$ & $\begin{array}{c}180 \\
(34,8 \%)\end{array}$ & $\begin{array}{c}77 \\
(14,8)\end{array}$ & $\begin{array}{c}110 \\
(21,2 \%)\end{array}$ & $\begin{array}{c}285 \\
(54,9 \%)\end{array}$ & $\begin{array}{c}21 \\
(4,1 \%)\end{array}$ & $\begin{array}{c}519 \\
(100,0 \%) \\
757 \\
(145,9 \%)\end{array}$ \\
\hline
\end{tabular}

Quanto às relações entre subáreas, observa-se a importância de Mediações $e$ Interfaces Comunicacionais, pois sua dupla categorização junto com outra subárea torna, na maioria dos casos, este espaço de interface o mais expressivo numericamente da outra subárea. É assim com Cibercultura (39 trabalhos, equivalentes a 7,5\% dos mesmos, que recebem essa dupla classificação), com Comunicação Organizacional (28 trabalhos, 5,4\% dos mesmos) e Jornalismo (7,3\%), no qual entretanto o número de 38 trabalhos é igual àqueles que foram classificados exclusivamente nesse subárea. Já no caso de Comunicação Audiovisual o número maior é de trabalhos na própria subárea (76 ou 14,7\% do total), porém o número de trabalhos que dividem a categorização nesse âmbito e em Mediações também é elevado - 57, equivalentes a 11\% do total. Apenas Teorias da Comunicação apresenta número mais baixo (apenas 2 trabalhos, 0,4\% do todo) de trabalhos com essa característica. É 
também na interface dessa subárea com Comunicação Organizacional que houve, em 2004, o único âmbito de relação entre as subáreas sem nenhum trabalho.

Pode-se dizer, por outro lado, que de maneira geral - com a óbvia exceção de Mediações a tônica predominante em parte significativa dos trabalhos classificados numa única subárea tendia ao estudo ou análise de caso(s). Por exemplo, análises fílmicas (Comunicação Audiovisual), estudos de linguagens de veículos jornalísticos (Jornalismo) e análise de organizações ou situações de comunicação interna (Comunicação Organizacional).

Com efeito, sem juízo a respeito da qualidade dos trabalhos, é possível pensar que, de um lado, muitos estudos midiáticos talvez produzam antes um conhecimento voltado ao universo de práticas/profissões da Comunicação. Vemos, por exemplo, que 27\% dos trabalhos foram classificados exclusivamente nas subáreas de Comunicação Audiovisual, Jornalismo e Comunicação Organizacional. Já aqueles trabalhos nos quais existem interfaces entre subáreas, por hipótese, correspondem a um provável alargamento de problemáticas. No caso de Mediações (nos quais 23,3\% dos trabalhos colocam-se exclusivamente), em particular, com vínculo ou teor social talvez mais pronunciado - por exemplo, em trabalhos que articulam questões de comunicação a aspectos políticos, de cidadania e sociedade, identidade, entre outros. 


\subsection{Análise das Áreas de Concentração e Linhas de Pesquisa dos PPGCOM}

A análise das Áreas de Concentração e das Linhas de Pesquisa (LP) de 2006 dos PPGCOM pode ser enriquecida pela comparação com as mesmas no ano de 1998, já que estas foram transcritas no trabalho de Lopes (2001a), no qual há ainda uma reflexão sobre a estrutura representada por elas, em termos globais, feita por Fausto Neto (2001). Assim, observa-se inicialmente a mobilidade terminológica ocorrida - dos 12 PPGCOM existentes em 1998, todos apresentaram algum tipo de mudança em suas LP (acréscimos, supressões e alterações terminológicas), e cinco programas fizeram algum tipo de alteração em suas Áreas.

A mudança foi, porém, mais acentuada nos programas tradicionais, de estrutura mais antiga. Programas como os da USP e da PUCSP passaram por modificações bastante expressivas, no primeiro caso, o desenho departamental que predominava foi substituído por uma estrutura de caráter mais integrado e voltado à pesquisa científica na área. Com isso, também houve uma diminuição no número de Áreas (de cinco para três) e Linhas de Pesquisa (de 19 para 9). Caso similar ao da PUCSP, em que o número de Áreas passou de quatro para uma e as LP de sete para três. No caso da desse programa a mudança se deu principalmente pela exclusão dos conteúdos de uma Área (“Literatura e Comunicação”) e LP (“Ciências Cognitivas e da Informação”) que deixaram de ser enfocadas pelo programa. Ao mesmo tempo, o desenho das LP também se tornou mais próximo da pesquisa e orgânico. Outro caso interessante, implicando numa relativa reorientação do PPGCOM é o da UNICAMP, no qual a modificação nas LP indica o fortalecimento da opção pela pesquisa em Comunicação Audiovisual, em particular em cinema, dada a substituição das linhas existentes em 1998 ("Multimeios e Ciência” e "Multimeios e Artes”) pelas atuais.

Em termos mais gerais, a diminuição e provável maior delimitação das LP, é evidenciada pelo fato de que existiam, em 1998, 53 LP e 20 Áreas de Concentração, nos 12 PPGCOM, o que resultava em médias de 4,4 LP e 1,7 Áreas de Concentração por programa. Já em 2006, como mostra a Tabela 6.8, os 21 PPGCOM apresentam 23 Áreas de Concentração e 56 LP - daí, médias respectivas de 1,1 e 2,6. Ou seja, passou a ocorrer, tanto a tendência à diminuição de ambas, a partir das reorganizações dos PPGCOM, quanto a criação de outros com estrutura sintética - com, tipicamente, uma Área de Concentração e duas/três 
LP. Isso corresponde a uma situação de provável busca de maior identidade científica, do que resulta uma maior diferenciação interna no campo, através da possível maior delimitação e especificidade de LP e Áreas de cada PPGCOM.

Com efeito, como assinala Lopes (2006), houve, ao longo do tempo, um nítido avanço nas estruturas dos PPGCOM, assim, na década de 1970, em razão do número reduzido de programas, a oferta de Áreas era superdimensionada, o que fazia com que o leque de aspectos abarcados fosse muito amplo e as Linhas de Pesquisa mal exercidas. Na década de 1980, já com os doutorados em andamento, não apresentou modificações, nesse sentido. Foi somente na no final dos 90

que começam a aparecer tentativas de especificação do doutorado, com programas que oferecem áreas e linhas de pesquisa exclusivas neste nível de pós-graduação.

De todo modo, é na década de 1990, com o surgimento de novos programas, que se torna visível o processo de caráter identitário na pós-graduação de Comunicação, no sentido dos programas dotarem-se de maior identidade científica. É evidente que isso só pode ser exercitado na medida em que cresce a competência e os recursos científicos do campo, acompanhados pelo aumento da competição científica, no dizer de Bourdieu. (Lopes, 2006, 29)

A Tabela 6.8, a seguir, mostra as Áreas de Concentração e Linhas de Pesquisa dos PPGCOM em 2006. 
Tabela 6.8 - Áreas de Concentração e Linhas de Pesquisa dos PPGCOM (2006)

\begin{tabular}{|c|c|c|}
\hline PPGCOM & Área(s) de Concentração & Linhas de Pesquisa \\
\hline \multirow{9}{*}{ USP } & \multirow{3}{*}{$\begin{array}{l}\text { 1. Teoria e Pesquisa em } \\
\text { Comunicação }\end{array}$} & 1. Epistemologia, Teoria e Metodologia da Comunicação [6] \\
\hline & & 2. Estética e História da Comunicação [1-6] \\
\hline & & 3. Linguagem e Produção de Sentido em Comunicação [1-6] \\
\hline & \multirow{2}{*}{$\begin{array}{l}\text { 2. Estudo dos Meios e da } \\
\text { Produção Mediática }\end{array}$} & 4. Comunicação Impressa e Audiovisual [2-4] \\
\hline & & 5. Técnicas e Poéticas da Comunicação [2] \\
\hline & \multirow{4}{*}{$\begin{array}{l}\text { 3. Interfaces Sociais da } \\
\text { Comunicação }\end{array}$} & 6. Comunicação e Cultura [5] \\
\hline & & 7. Políticas e Estratégias de Comunicação [3] [4] [5] \\
\hline & & 8. Educomunicação [5] \\
\hline & & 9. Tecnologias da Comunicação e Redes Interativas [1] \\
\hline \multirow{2}{*}{ UFRJ } & \multirow{2}{*}{ 1. Comunicação e Cultura } & 1. Tecnologias da Comunicação e Estéticas [1] [5] \\
\hline & & 2. Mídia e Mediações Sócio-Culturais [2-6] \\
\hline \multirow{4}{*}{ UNB } & \multirow{4}{*}{$\begin{array}{l}\text { 1. Comunicação e } \\
\text { Sociedade }\end{array}$} & 1. Imagem e Som [2] \\
\hline & & 2. Políticas de Comunicação [5] \\
\hline & & 3. Jornalismo e sociedade [4] [5] \\
\hline & & 4. Teorias e Tecnologias da Comunicação [6] [1] \\
\hline \multirow{3}{*}{ PUCSP } & \multirow{3}{*}{$\begin{array}{l}\text { 1. Signo e Significação nas } \\
\text { Mídias }\end{array}$} & 1. Sistemas semióticos em ambientes midiáticos [1-5] \\
\hline & & 2. Processos de criação nas mídias [1-4] \\
\hline & & 3. Epistemologia da com. e semiótica das mediações [5] [6] \\
\hline \multirow{2}{*}{ UMESP } & \multirow{2}{*}{ 1. Processos Comunicacionais } & 1. Comunicação Massiva [1-5] \\
\hline & & 2. Comunicação Especializada [1-5] \\
\hline \multirow[t]{2}{*}{ UNICAMP } & \multirow[t]{2}{*}{ 1. Multimeios } & $\begin{array}{l}\text { 1. História, estética e domínios de aplicação do cinema documentário e da } \\
\text { fotografia [2] }\end{array}$ \\
\hline & & 2. Cinema ficcional - história e processos criativos [2] \\
\hline \multirow{2}{*}{ UFBA } & \multirow{2}{*}{$\begin{array}{l}\text { 1. Comunicação e Cultura } \\
\text { Contemporânea }\end{array}$} & 1. Cibercultura [1] [4] [5] \\
\hline & & 2. Análise de Produtos e Linguagens da Cultura Mediática [2] [6] \\
\hline \multirow{2}{*}{ PUCRS } & \multirow{2}{*}{$\begin{array}{l}\text { 1. Comunicação, Cultura e } \\
\text { Tecnologia }\end{array}$} & 1. Práticas Sociopolíticas nas Mídias e Comunicação nas Organizações [3] [5] \\
\hline & & 2. Cultura Midiática e Tecnologias do Imaginário [1] [2] [4] [6] \\
\hline \multirow{3}{*}{ UNISINOS } & & 1. Mídias e processos de significação [6] \\
\hline & 1. Processos Midiáticos & 2. Mídia e processos socioculturais [5] \\
\hline & & 3. Mídia e processos audiovisuais [2] \\
\hline UFRGS & 1. Comunicação e & 1. Comunicação, Representações e Práticas Culturais [2] [4] [5] [6] \\
\hline & Informação & 2. Informação, Tecnologias e Práticas Sociais [1] [5] [6] \\
\hline UFMG & 1. Comunicação e Sociabilidade & 1. Processos Comunicativos e Práticas Sociais [5] \\
\hline UFIVIG & Contemporânea & 2. Meios e Produtos da Comunicação [1-5] \\
\hline & & 1. Tecnologias da Comunicação e da Informação [1] [5[ \\
\hline UFF & 1. Comunicação & 2. Análise da Imagem e do Som [2] \\
\hline & & 3. Comunicação e Mediação [5] \\
\hline & 1. Processos & 1. Análise de Linguagens Midiáticas [2-4] \\
\hline UTP & Comunicacionais & 2. Cibermídia e Meios Digitais [1] \\
\hline & & 1. Linguagem dos Meios [2-4] \\
\hline UFPE & 1. Comunicação & 2. Mídia e processos sociais [5] \\
\hline & & 3. Estética e Cultura Midiática [1] \\
\hline UNIP & 1. Comunicação e Cultura & $\begin{array}{l}\text { 1. Configuração de Linguagens e Produtos Audiovisuais na Cultura Midiática } \\
\text { [2] }\end{array}$ \\
\hline & & 2. Cultura Midiática e Grupos Sociais [5] \\
\hline UFR 1 & 1 Comunicacão Social & 1. Cultura de Massa e Representação Social [5] \\
\hline UERJ & 1. Comunicaçaoo Socıal & 2. Novas Tecnologias e Cultura [1] [5] \\
\hline & & 1. Produção de Sentido na Comunicação Midiática [2-4] \\
\hline UNESP & 1. Comunicação Midiática & 2. Gêneros e formatos na cultura midiática [2-4] \\
\hline & & 3. Gestão da informação e comunicação midiática [3] [5] \\
\hline UNIMAR & 1 Mídia a Cultura & 1. Ficção na Mídia (Linha de Pesquisa) [2] [5] \\
\hline UNIMAR & 1. Midia e Cultura & 2. Produção e Recepção de Mídia [2] [3] [4] \\
\hline PUCR 1 & 1 Comunicacão Social & 1. Cultura de Massa e Representações Sociais [2-5] \\
\hline PUCRJ & 1. Comunicaçao Socıal & 2. Cultura de Massa e Práticas Sociais [2-5] \\
\hline UESM & 1 Comunicacão Midiática & 1. Mídia e Identidades Contemporâneas $[2-5\}$ \\
\hline UFSM & 1. Comunıcaçao Mıdıatıca & 2. Mídia e Estratégias Comunicacionais [3] \\
\hline & & 1. Impactos socioculturais da comunicação orientada para o mercado [3] [5] \\
\hline ESPM & $\begin{array}{l}\text { 1. Comunicaçao com o } \\
\text { Mercado }\end{array}$ & $\begin{array}{l}\text { 2. Estratégias de comunicação e produção de mensagens midiáticas voltadas } \\
\text { às práticas de consumo [3] [5] }\end{array}$ \\
\hline
\end{tabular}

Fonte: Páginas dos PPGCOM na internet (2006) 
As Áreas de Concentração podem ser vistas como espaços nos quais "se definem as especialidades de cada curso, e das possíveis fronteiras existentes entre eles” (Fausto Neto, 2001, 56). E uma análise das mesmas no ano de 2006, conforme a Tabela 6.8, em comparação com dados de 1998, indica os seguintes pontos:

1) A supressão das Áreas eminentemente habilitacionais - em função da reestruturação ocorrida no programa da USP;

2) A continuidade da tendência da Comunicação, em termos de suas Áreas de Concentração, articular-se com um outro âmbito (social, disciplinar): Interfaces Sociais; Cultura; Signo; Sociedade; Cultura Contemporânea; Cultura e Tecnologia; Informação, Sociabilidade Contemporânea e Mercado,

3) Todavia, há a mudança significativa - em função da eliminação de Áreas existentes em 1998, de as mesmas serem presididas fundamentalmente pela área afim, o que ocorria, por exemplo, numa área como “Artes e Comunicação”;

4) Reforço do âmbito midiático dos PPGCOM, tanto pelas mudanças de nomenclatura nos existentes, quanto principalmente pelo surgimento de outros nos quais a Área de Concentração faz menção a essa delimitação, por exemplo, em Comunicação e Cultura Midiática (UNIP), Comunicação Midiática (UNESP e UFSM), Mídia e Cultura (UNIMAR).

5) Outra alteração diz respeito à diminuição, pelo menos na nomenclatura das Áreas, do termo "Tecnologia”, somente encontrado em 2006 na PUCRS.

Assim, é possível dizer que as Áreas de Concentração dos PPGCOM em 2006, em comparação com 1998, tenderam a se adensar em torno de duas grandes problemáticas: 1) a Comunicação voltada a aspectos de interface com práticas sociais e simbólicas - com ênfase em particular na “cultura”, sob enfoques mais ou menos midiáticos e 2) um âmbito mais explicitamente midiático contemplando o estudo dos processos comunicacionais/ midiáticos, em eixos também diferenciados (linguagens, meios, produção etc.).

A partir dessa perspectiva fica mais compreensível a importância que teve a produção de teses em dissertações na subárea Mediações e Interfaces Comunicacionais, em 2004. A despeito da prevalência dos conteúdos de natureza mais acadêmica do que voltados à 
intervenção profissional/social. A respeito das Áreas, se nota também um provável efeito da competição entre os PPGCOM, dando uma direção mais convergente à nomenclatura das mesmas.

Já a propósito das Linhas de Pesquisa (cujas ementas se encontram no Anexo), também vistas em comparação com o que ocorria em 1998, podem-se observar os seguintes aspectos:

1) O fato de que as Linhas Teórico-Metodológicas continuam sendo minoritárias. No entanto há uma maior demarcação do espaço das mesmas - na própria nomenclatura adotada - nas LP de determinados PPGCOM (USP, PUCSP e UNB), enquanto em outros programas as preocupações teórico-metodológicas aparecem (nos conteúdos expressos pelas Linhas) mais relacionadas com análises de produtos midiáticos ou da ambiência cultural-tecnológica da sociedade da comunicação (UFBA, PUCRS, UNISINOS, UFRGS).

2) A estrutura dos PPGCOM mostra maior organicidade na relação entre Áreas e LP, sendo bem menos evidente casos em que as nomenclaturas das LP tendam a repetir/desdobrar as das Áreas.

3) O âmbito habilitacional/profissional deixou também de ser expresso nas LP, em comparação com 1998. Assim, a articulação entre o mundo profissional e a pesquisa científica da Comunicação apresenta uma defasagem mais acentuada ainda, no qual talvez se configure um espaço de atuação para os mestrados profissionais. O próprio direcionamento ao “mercado" é pequeno, apenas um PPGCOM o explicita em suas linhas.

4) A reorganização do programa da UNICAMP levou a estruturação de LP bastante específicas. Isso singulariza esse programa no conjunto dos PPGCOM, no qual, apesar de existiram linhas também específicas, essas tendem a cobrir âmbitos mais diferenciados ou a serem, de outro lado, bastante abrangentes, por exemplo, em termos de Comunicação Massiva e Comunicação Especializada.

5) De outro lado, enfoques de LP muito particulares, como os existentes em 1998 (por exemplo, “Imagem e Som na Educação e na Ciência”) foram eliminados, a partir da incorporação a outras terminologias criadas pela área, de teor mais amplo 
(Educomunicação), ou pela supressão efetiva, em tese, do conteúdo (por exemplo, “Turismo e Lazer”).

6) O reforço do aspecto "midiático" (análise de linguagens, formatos, gêneros e outras problemáticas) percebido nas Áreas também ocorre na LP, com terminologias como Comunicação Impressa e Audiovisual; Análise de Produtos e Linguagens da Cultura Mediática, Mídia e Processos Audiovisuais, Linguagem dos Meios; Produção de Sentido na Cultura Mediática, entre outras.

7) A preocupação com aspectos das "tecnologias" é expressa em nomes de LP de cinco PPGCOM (USP, UFRJ, UNB, PUCRS e UERJ) enquanto o prefixo “ciber” apareça em dois (UFBA e UTP). Ou seja, embora a problemática tecnológica tenha deixado de ocupar a nomenclatura de muitas Áreas continua relevante no conjunto da organização representativa da pesquisa e, consequentemente, em sua produção.

8) Os âmbitos de interface da comunicação com outras áreas de pesquisa e campos sociais é outro eixo que, sob vieses diversificados, configura as LP dos PPGCOM, sendo que a “cultura” é, em particular, bastante destacada, aparecendo já na denominação de doze LP, nas quais o termo recebe por vezes se agrega o prefixo ou complemento “sócio”, “midiática” ou “de massa”.

Uma tentativa de síntese sobre a situação atual das LP é feita na Tabela 6.9, a seguir, que as classifica pelas subáreas da taxonomia proposta pela área. Note-se, de um lado, que procuramos, nessa categorização, avaliar os termos expressos nas ementas conforme sua ênfase, ou seja, é possível exista a produção numa área não assinalada. Isso ocorre principalmente nas subáreas que envolvem análise dos meios. Porém, no nosso entender, isso não invalida a tendência da produção que se busca compreender. De outro lado, é útil também notar que há uma relativa defasagem entre a produção e a organização representacional do campo, na medida em que esta é mais recente que aquela. Assim, embora a organização presida a pesquisa, esta recebe os efeitos depois de algum tempo. Um exemplo típico é a produção que articula “comunicação e informação” que aparece em 2004 na USP e que, dada a reorganização do PPGCOM, tenderá a diminuir consideravelmente. 
Tabela 6.9 - Classificação das Linhas de Pesquisa dos PPGCOM por Subáreas

\begin{tabular}{|c|c|c|c|c|c|c|}
\hline $\begin{array}{l}\text { Subáreas/ LP } \\
\text { dos PPGCOM }\end{array}$ & $\begin{array}{l}\text { 1. Cibercultura } \\
\text { e tecnologias } \\
\text { da comunic. }\end{array}$ & $\begin{array}{c}\text { 2. Com. } \\
\text { Audiovisual } \\
\text { Cinema, Rádio } \\
\text { e TV }\end{array}$ & $\begin{array}{l}\text { 3. Com. } \\
\text { Organizacional, } \\
\text { Rel. Públ. e } \\
\text { Prop. }\end{array}$ & $\begin{array}{l}\text { 4. Jornalismo } \\
\text { e Editoração }\end{array}$ & $\begin{array}{l}\text { 5. Mediações } \\
\text { e Interfaces } \\
\text { comunicionais }\end{array}$ & $\begin{array}{l}\text { 6. Teorias da } \\
\text { Comunicação }\end{array}$ \\
\hline USP & $x$ & $x$ & $x$ & $X$ & $x$ & $x$ \\
\hline UFRJ & $x$ & $x$ & $X$ & $x$ & $x$ & $X$ \\
\hline UNB & $x$ & $x$ & & $x$ & $x$ & $x$ \\
\hline PUCSP & $x$ & $x$ & $x$ & $x$ & $x$ & $x$ \\
\hline UMESP & $x$ & $x$ & $x$ & $x$ & $x$ & \\
\hline UNICAMP & & $x$ & & & & \\
\hline UFBA & $x$ & $x$ & & $X$ & $X$ & $X$ \\
\hline PUCRS & $x$ & $x$ & $X$ & $x$ & $x$ & $x$ \\
\hline UNISINOS & $x$ & $x$ & & $x$ & $x$ & $x$ \\
\hline UFRGS & $x$ & $x$ & & $x$ & $x$ & $x$ \\
\hline UFMG & $x$ & $x$ & $x$ & $x$ & $x$ & \\
\hline UFF & $x$ & $x$ & & & $x$ & \\
\hline UTP & $x$ & $x$ & $x$ & $x$ & & \\
\hline UFPE & & $x$ & $x$ & $x$ & $x$ & $x$ \\
\hline UNIP & & $x$ & & & $x$ & \\
\hline UERJ & $x$ & $x$ & & $x$ & $x$ & \\
\hline UNESP & & $x$ & $x$ & $x$ & $x$ & \\
\hline UNIMAR & & $x$ & $x$ & $x$ & $x$ & \\
\hline PUCRJ & & $x$ & $X$ & $x$ & $x$ & \\
\hline UFSM & & $x$ & $x$ & $x$ & $x$ & \\
\hline ESPM & & & $x$ & & $x$ & \\
\hline Total & 13 & 20 & 13 & 17 & 19 & 8 \\
\hline
\end{tabular}

A Tabela 6.8, sobre as LP dos PPGCOM, mostra que existe congruência entre produção e a organização representada por esta estrutura. Destacam-se, assim, a pesquisa e organização em termos das Mediações da Comunicação (LP de 19 programas), bem como os elementos midiáticos presentes nos processos comunicacionais e que são transversais às LP, mas que caracterizam mais as Linhas ligadas às subáreas Comunicação Audiovisual (Linhas em 20 programas), Jornalismo (LP em 17) e Comunicação Organizacional (LP em 13 PPGCOM). Ao mesmo tempo, a produção teórica é baixa e também menos destacada em termos da estrutura dos programas, existindo 8 PPGCOM que possuem Linhas que, com maior ou menor ênfase, voltam-se a aspectos teórico-metodológicos. Todavia se pode notar maior delimitação e organização nessa linha/área de pesquisa do que 1998.

De modo geral, pode-se dizer que embora a abrangência da pesquisa em Comunicação seja ainda bastante ampla, como se poderia esperar, ela sofreu um adensamento, na comparação com 1998, em torno das questões evidenciadas nas Áreas e LP, o que já tem e continuará a 
produzir efeitos em relação à pesquisa feita no campo científico. Assim, podemos dizer que existe um avanço, numa direção de fortalecimento do campo, a partir desses elementos de organização e representação do grupo de pesquisadores. Restaria discutir em que medida as subáreas podem ser vistas como possíveis “programas de pesquisa” da área da Comunicação, o que é feito no próximo tópico. 


\subsection{Os “programas de pesquisa” em Comunicação}

Deve-se ao filósofo e historiador Imre Lakatos a introdução do conceito de "programa de pesquisa (ou de investigação)”, como um referencial para a compreensão do progresso na ciência. Discípulo e continuador crítico de Popper, Lakatos também se preocupava fundamentalmente com a distinção entre ciência e não-ciência. Nesse sentido, sua metodologia dos programas de pesquisa fornecia um instrumento de reconstrução da racionalidade científica, fundamentalmente interna para o autor, dessa atividade, mas que escaparia aos riscos do “falseacionismo ingênuo”, presente na análise de Popper ${ }^{65}$.

O caráter racional, crítico e dinâmico da ciência seria, segundo Lakatos, resultante da competição entre os programas de pesquisa. Daí sua crítica à noção de Kuhn de "ciência normal". Caberia à história da ciência ser uma "história de programas de pesquisa competitivos (ou, se quiserem, de 'paradigmas'), mas não tem sido, nem deve vir a ser, uma sucessão de períodos de ciência normal: quanto antes se iniciar a competição, tanto melhor para o progresso” (Lakatos, 1979, 191). Nas etapas próximas de uma ciência próxima da idéia de “ciência normal”, o que acontece é, portanto, o monopólio (provisório) de um programa de pesquisa.

Os programas são estruturados a partir de uma série de teorias que configuram um núcleo, que inclui componentes metafísicos - assim, tal núcleo é considerado irrefutável por decisão metodológica de seus praticantes. Ao mesmo tempo, os programas fornecem os problemas de investigação e são formados por regras metodológicas, que indicam as rotas de investigação que devem ser evitadas (“heurística negativa”) e as que devem ser seguidas (“heurística positiva”). Lakatos distingue, e exemplifica em reconstruções na história da ciência, o movimento da dinâmica científica pela competição entre os programas. Estes podem ter fases progressivas, apresentando crescimento teórico e maior conteúdo empírico corroborado, ou estarem em fases degenerativas, quando ocorre o contrário. No entanto,

\footnotetext{
${ }^{65}$ É suficiente, nos termos de nosso trabalho, caracterizar sinteticamente a diferença entre Lakatos e Popper, pela crítica do primeiro à aplicação de critérios absolutos de falsificabilidade, na prática real dos cientistas. Muitas teorias ou "programas" apresentam desde o início anomalias que parecem falsificá-los, todavia, não é por isso - como os exemplos históricos de Lakatos mostram - que são deixados de lado. Segue daí a paráfrase de Kant, feita por Lakatos: "A Filosofia da ciência sem a história da ciência é vazia; a História da ciência sem filosofia da ciência é cega” (Lakatos, 1987, 11). É por isso que a racionalidade científica para Lakatos é não instantânea e revelada por sua metodologia de análise, que corresponderia a uma sofisticação do critério de refutabilidade popperiano. Em outros termos, os "testes-cruciais", que corroboram ou falsificam uma teoria, são sempre retrospectivos.
} 
essa fase regressiva pode ser superada - a heurística positiva do programa pode desenvolver-se numa direção que supere as anomalias e dificuldades. Se isso não ocorre, porém, a estagnação do programa leva ao fim do mesmo. Para esta etapa terminal concorrem, segundo Lakatos (1987), tanto padrões de honestidade intelectual, quanto a coerção do grupo: um cientista que adote um programa em franca regressão terá dificuldade para publicar seus trabalhos ou conseguir financiamentos.

O critério base para que um programa suplante outro(s) é sua força heurística, ou seja, a capacidade para gerar fatos novos, explicar refutações no decurso de seu crescimento e, quando possível, estimular a matemática (Lakatos, 1979).

Com efeito, a metodologia dos programas de pesquisa foi proposta por Lakatos como uma estratégia para compreensão da racionalidade contextual da ciência. Critério também demarcatório (como a noção de paradigma) e circular: a ciência reside no exercício de programas de pesquisa. Como esses programas devem ou podem ser criados, é uma questão que não encontra uma resposta geral. Ao mesmo tempo, tal formulação é também desenvolvida dentro de determinada concepção de ciência, que privilegia o confronto teoria/fato e, portanto, da continuidade ao projeto popperiano. Daí, pois, a dificuldade de pensar o específico das ciências sociais e a conseqüente crítica do autor - em continuidade a Popper - ao marxismo e ao freudismo. "Que fatos novos o marxismo previu desde, digamos, 1917?”, pergunta Lakatos $(1979,170)$.

Assim, apesar do possível uso dessa proposta para a análise das ciências sociais - por exemplo, em González de Gómez, 2000; Mion e Angotti, 2005 -, isso deve ser feito, no nosso entender, com cautela. Dessa forma, devemos ressaltar que nos aproximamos da noção de "programa de pesquisa”, em nossa investigação, antes como um conceito operatório do que propriamente explicativo, que faça remissão ao seu contexto teórico global (a epistemologia de Lakatos).

Em outras palavras, e explicando o uso do mesmo no trabalho, buscaremos, a seguir, ao trabalhar sobre as referências bibliográficas utilizadas pelos praticantes da Comunicação visualizar agrupamentos de autores que configurem possíveis "programas de pesquisa". Pelo que dissemos, num sentido mais “fraco" do que o proposto por Lakatos, no entanto, 
preservando a idéia de "coletivo de pensamento" (evidenciado pela possível linguagem referencial comum) que a noção de “programa de pesquisa” possui.

Ademais, deve-se dizer que a estratégia básica para essa possível visualização do agrupamento de autores é a divisão do campo científico pelas subáreas apresentadas. Ora, é difícil assegurar que aos possíveis conjuntos de autores correspondam somente um programa de pesquisa. Todavia a própria idéia de que existam, de fato, agrupamentos é uma hipótese que temos interesse em investigar. E, nesse sentido, a pesquisa bibliométrica apresentada no próximo Capítulo traz subsídios para avançarmos na discussão sobre o campo científico da Comunicação e suas características a partir dos prováveis modelos de interação entre os pesquisadores, vistos sob a perspectiva de seu "léxico" (os autores mobilizados) comum. 


\section{Capítulo 7}

\section{O “capital científico” da Comunicação em suas referências}

Os textos aparecem, ao mesmo tempo, como uma das modalidades do funcionamento da comunidade discursiva e o que a torna possível; a comunidade se estrutura pelo mesmo movimento que gera os enunciados, suscetíveis, por sua vez, de tematizar, por vezes sutilmente, as instituições que neles estão implicadas e sua própria intrincação com estas últimas. (Maingueneau, 1989, 70)

A articulação entre textos e determinado grupo social a que se refere Maingueneau (1989) é bastante explícita no caso da ciência, onde qualquer produção bibliográfica tende a configurar uma rede intertextual relativa ao seu contexto. Isso evidencia o caráter social da ciência e indica possibilidades de estudos dessa prática por essa perspectiva. Nesse sentido, neste capítulo serão mostradas análises bibliométricas referentes aos PPGCOM, inicialmente situando os estudos métricos da ciência e explicitando como as citações podem ser vistas como uma das formas do “capital científico”. As análises mostram índices de reconhecimento/prestígio de autores e o modo de circulação do “capital científico” nos estudos em Comunicação no país. É por essa via que podemos questionar, a partir desses dados, se o padrão de interação entre os pesquisadores parece ser mais ou menos favorável aos componentes estruturais do campo científico.

Será relevante mostrar como foi feito o estudo, de modo a compartilhar a metodologia bibliométrica com outros pesquisadores, e iremos justificar certas opções em relação ao tratamento do material, de acordo com nossos objetivos e por aspectos práticos.

Cabe ainda notar que, em razão de nosso interesse no campo da Comunicação no Brasil de modo geral, nossas observações particulares sobre os PPGCOM têm como pano de fundo o grupo como um todo, e não essa unidade de análise. Em outros termos, não procuramos 
fazer avaliações restritas a cada PPGCOM, ainda que seja possível descrever e inferir sobre características específicas dos mesmos a partir dos dados. Essa observação é relevante, pois sabemos, como nota Dias Sobrinho, que a “avaliação” possui sempre uma dimensão política e de disputa, nenhuma é neutra.

Todas elas produzem efeitos e afirmam determinados valores, ao mesmo tempo que infirmam outros. Implicam em escolhas de prioridades, seleção de indicadores, limitação do objeto e tudo isso se cumpre segundo hierarquias axiológicas. Seus efeitos também alteram os quadros valorativos. Por isso, não se pode entender as controvérsias no campo da avaliação institucional apenas como se fossem de caráter técnico; as disputas no campo da avaliação, no fundo, são tensões geradas por diferentes concepções [...]. (Dias Sobrinho, 2002, 118)

A avaliação é distinta da mensuração, pois embora possa receber subsídios dos indicadores de medidas, envolve juízos de valor, aos quais se vinculam determinados projetos de construção do futuro (Dias Sobrinho, 2002, 121). O eixo valorativo básico de nossa tese diz respeito à positividade da estruturação de um campo científico na área de estudos em Comunicação. Esse aspecto embasa o conjunto de estratégias metodológicas desenvolvido.

\subsection{Os estudos métricos e a citação como medida do capital científico}

Os estudos métricos da ciência são um meio para gerar indicadores da atividade científica de modo a poder avaliá-la, reforçando o aspecto crítico que a ciência possui. Para Dias Sobrinho (2002, 127), o “caráter público e social da universidade produz a exigência ética da avaliação”. Pode-se dizer o mesmo da ciência, quase integralmente financiada por recursos públicos, principalmente nos países periféricos. De modo geral, os indicadores científicos produzem medidas relativas a aspectos como os inputs (recursos financeiros e pessoal envolvido na atividade) da prática científica; a contagem de prêmios honoríficos recebidos pelos membros de determinado grupo; a contagem do número de publicações e a mensuração do número de citações recebidas (Velho, 1985).

Desse modo as citações são vistas como indicadores de resultados (output), e, no âmbito da Ciência da Informação, desenvolvem-se técnicas e perspectivas de análise dos mesmos. A bibliometria, assim, volta-se particularmente para a comunicação impressa, utilizando a estatística, enquanto a cientometria, segundo Spinak (1988), utiliza técnicas bibliométricas 
num estudo mais amplo do desenvolvimento da ciência e das políticas científicas. O desenvolvimento de técnicas quantitativas para a coleta, tratamento e análise dos dados, realizado nesses contextos, contribui com os sistemas de informação em C\&T e também para a compreensão de aspectos diversos da ciência de modo geral e de áreas de pesquisa. Por isso, existe uma tradição em estudos de citações, tendo em vista a análise do desempenho científico.

Para Spinak (1998) análises bibliométrica de citações permitem perceber quão útil é um trabalho a determinado grupo de pesquisadores. $\mathrm{O}$ autor nota ainda que parece existir uma correlação significativa entre o número das citações recebidas por um trabalho e a qualidade do mesmo. Em outros termos, o impacto de um trabalho científico medido pelas citações recebidas geralmente informa sobre a relevância do mesmo. Por isso é comum o uso análise das citações da produção acadêmica como "uma medida da relevância dessa produção como vista pelos pares, ou seja, é uma medida de influência de um determinado pesquisador” (Issler e Ferreira, 2004, 7).

Existem também críticas à técnica, a principal diz respeito ao fato de que nem sempre existe uma relação direta entre a citação e a qualidade do trabalho. A motivação e a prática da citação, conforme atestam diferentes estudos, nem sempre estão ligadas à expansão do conhecimento de uma área. Existem aspectos, como o “efeito Mateus”66, que distorcem a atribuição de status representada pelo reconhecimento medido em citações. Um trabalho relevante, talvez muito inovador, pode passar muitos anos sem receber citações. Por outro lado, as chamadas citações perfunctórias - não essenciais, feitas somente para impressionar ou para demonstrar a afiliação do autor a determinada teoria ou grupo - e as citações negativas, realizadas para criticar determinada posição do texto referido, também ocorrem. A citação a um trabalho pode relacionar-se ainda a motivações mais prosaicas,

pode depender da disponibilidade dos autores, em função da língua, do tipo de publicação, da existência ou não de bibliotecas e obras de referência a serem consultadas. Esta razão hoje em dia, com o fax, a xerox e a Internet, é menos justificável do que antes, mas ainda existe, e continuará a existir, dado o custo crescente que tem o exame de uma literatura cada vez maior e mais complexa. (Schwartzman, 1997)

\footnotetext{
${ }^{66}$ Esse é o nome dado por Merton (1977) à noção que explica como o reconhecimento retroalimenta-se. Autores que alcançam prestígio elevado tendem a ter mais citações do que os que não obtiveram a mesma valorização por parte de um grupo.
} 
Porém, em nosso trabalho o que é central é a idéia de que e as citações permitem notar o nível de linguagem compartilhada pelo grupo. Por isso, procuramos compreender, a partir de Melo (1999), a citação como parte do “léxico” do grupo, seu repertório a partir do qual são gerados novos.

Esse aspecto social da citação é reforçado pela teoria de Latour (2000) sobre essa prática. Para este, autor, um pesquisador qualquer, ao reportar-se a textos anteriores, procura fortalecer sua argumentação, arregimenta aliados para a posição adotada em seu trabalho, mostrando, assim, que participa dos debates de uma disciplina. Em outras palavras, o conjunto de pesquisadores, por meio de suas referências, estabelece o domínio legítimo da discussão. Esse seria o significado mais importante de uma citação, que estabelece relações entre os membros de um grupo científico. Como nota o autor:

O adjetivo "científico" não é atribuído a textos isolados que sejam capazes de se opor à opinião das multidões por virtude de alguma misteriosa faculdade. Um documento se torna científico quando tem a pretensão a deixar de ser algo isolado [...] (Latour, 2000, 58).

Por fim, relacionamento a citação ao "capital científico", podemos observar, como nota Bourdieu (1983, 125), que, no campo científico, somente o que é

percebido como importante e interessante é o que tem chances de ser reconhecido como importante e interessante pelos outros; portanto, aquilo que tem a possibilidade de fazer aparecer aquele que o produz como importante e interessante aos olhos dos outros.

Desse modo, as citações podem ser vistas, ao captar o que é visto como "importante e interessante” pelos pesquisadores, como elementos que constituem e asseguram a autoridade científica de um agente em particular, sendo uma das dimensões do "capital científico” (Bourdieu, 1989, 2004) disponibilizado e mobilizado por uma área de investigação. Esse "capital” é recebido pelos agentes e circula no campo, o que permite perceber padrões de interação entre o grupo. É justamente enquanto um modo de legitimação e prestígio interno aos pesquisadores que as citações (e outras modalidades, como número de traduções ou trabalhos de um pesquisador) são descritas por esse autor como uma modalidade de "capital científico" mais "puro”, em comparação com o tipo de poder institucional acumulado por um agente no campo científico (Bourdieu, 2004, 35-42). 
É por essa via, pois, que reconhecemos nas citações uma possibilidade para a compreensão do "capital científico" da Comunicação, tanto aquele que lhe diz respeito mais diretamente - ou seja, os produzidos pelos autores identificados com a área -, quanto o que é colocado em circulação, mas proveniente de outros campos de conhecimento.

Assim, nos propomos a investigar esse “capital científico” nos estudos bibliométricos que se seguem. Em primeiro lugar, analisando as bibliografias propostas para o ingresso nos cursos dos PPGCOM e, a seguir, com mais detalhe, estudando o universo de referências das Teses e Dissertações defendidas nos programas da área nos anos de 1977, 1983, 1990, 1997 e 2004. A ênfase da análise, todavia, é quanto ao último ano. 


\subsection{Análise bibliométrica da bibliografia de acesso aos PPGCOM}

Uma primeira abordagem ao "regime de leituras" da Comunicação pode ser feita através da análise daquilo que os PPGCOM consideram importante para o ingresso na área de pesquisa. As bibliografias indicadas para leitura dos candidatos mostram, assim, dimensões sobre o que se entende como relativo aos estudos em Comunicação.

As Tabelas 7.1 e 7.2, a seguir, mostram as nacionalidades dos autores nessas bibliografias. Depois, a Tabela 7.3 aborda os pesquisadores dos PPGCOM que possuem obras cuja leitura é recomendada e as Tabelas 7.5 e 7.6 os outros autores nacionais e os autores estrangeiros, respectivamente. Deve-se notar que cinco Programas (PUCSP, UNICAMP, UFBA, UNISINOS e UNIMAR) não indicaram ou bibliografias.

Tabela 7.1 - Autores nacionais e estrangeiros nas bibliografias de acesso dos PPGCOM

\begin{tabular}{c|c|c|c|c|c}
\hline \multicolumn{2}{c|}{ Autores Nacionais } & \multicolumn{2}{c|}{ Autores Estrangeiros } & \multicolumn{2}{c}{ Total } \\
\hline $\mathrm{N}$ & $\%$ & $\mathrm{~N}$ & $\%$ & $\mathrm{~N}$ & $\%$ \\
\hline 35 & 37,6 & 58 & 62,4 & 93 & 100,0 \\
\hline
\end{tabular}

Foram indicados bem mais autores estrangeiros (58) do que nacionais (35), nas bibliografias que os programas indicaram,

Tabela 7.2 - Autores nacionais e pertencentes a programas em Comunicação nas bibliografias de acesso dos PPGCOM

\begin{tabular}{c|c|c|c|c|c}
\hline \multicolumn{2}{c|}{ Autores PPGCOM } & \multicolumn{2}{c|}{ Outros Autores Nacionais } & \multicolumn{2}{c}{ Total } \\
\hline $\mathrm{N}$ & $\%$ & $\mathrm{~N}$ & $\%$ & $\mathrm{~N}$ & $\%$ \\
\hline 27 & 77,0 & 8 & 23,0 & 35 & 100,0 \\
\hline
\end{tabular}

No universo de leituras recomendadas pelos PPGCOM, houve predomínio dos autores pertencentes a eles, foram 27 (77\% do total) pesquisadores da Comunicação, docentes de programas, contra outros $8(23 \%)$ autores nacionais. Isso representa um indício da consolidação da bibliografia produzida pelos autores identificados com a área, pelo vínculo com os PPGCOM. 
Tabela 7.3 - Autores de PPGCOM nas referências das bibliografias para ingresso nos Programas - citações externas e internas

\begin{tabular}{|c|c|c|c|c|c|c|c|c|c|c|c|c|c|c|c|}
\hline Autores/ PPGCOM & USP & UFRJ & UnB & $\begin{array}{l}\text { UME } \\
\text { SP }\end{array}$ & $\begin{array}{l}\text { PUC } \\
\text { RS }\end{array}$ & $\begin{array}{c}\text { UFRG } \\
\text { S }\end{array}$ & UFMG & UFF & UTP & UFPE & UNIP & $\begin{array}{l}\text { UNE } \\
\text { SP }\end{array}$ & UERJ & $\begin{array}{l}\text { PUC } \\
\text { RJ }\end{array}$ & Total \\
\hline França, V. (UFMG) & - & - & $x$ & - & $x$ & $x$ & - & - & - & - & - & $x$ & - & - & 4 \\
\hline Hohfeldt, A. (PUCRS) & - & - & $x$ & - & $x$ & $x$ & - & - & - & - & - & $x$ & - & - & 4 \\
\hline Martino, L. C. (UNB) & - & - & $x$ & - & $x$ & $x$ & - & - & - & - & - & $x$ & - & - & 4 \\
\hline Moraes, D. (UFF) & - & - & $x$ & - & - & $x$ & - & $x$ & - & $x$ & - & - & - & - & 4 \\
\hline Sodre, M. (UFRJ) & - & $x$ & - & - & $x$ & $x$ & - & - & - & - & - & - & - & - & 3 \\
\hline Lemos, A. (UFBA) & - & - & - & - & - & - & - & - & $x$ & - & - & - & $x$ & - & 2 \\
\hline Lopes, M. I. V. (USP) & $x$ & - & - & - & - & - & - & - & - & - & - & $x$ & - & - & 2 \\
\hline Citelli, A. (USP) & $x$ & - & - & - & - & - & - & - & - & - & - & - & - & - & 1 \\
\hline Kunsch, M. M. K. (USP) & $\mathrm{x}$ & - & - & - & - & - & - & - & - & - & - & - & - & - & 1 \\
\hline Motta, L. G. (UNB) & - & - & $x$ & - & - & - & - & - & - & - & - & - & - & - & 1 \\
\hline Ramos, M. C. (UNB) & - & - & $x$ & - & - & - & - & - & - & - & - & - & - & - & 1 \\
\hline Ramos, F. (UNICAMP) & - & - & $x$ & - & - & - & - & - & - & - & - & - & - & - & 1 \\
\hline Montoro, T. (UNB) & - & - & $x$ & - & - & - & - & - & - & - & - & - & - & - & 1 \\
\hline Ribeiro, L. (UNB) & - & - & $x$ & - & - & - & - & - & - & - & - & - & - & - & 1 \\
\hline Fausto Neto A. (UNISINOS) & - & - & $x$ & - & - & - & - & - & - & - & - & - & - & - & 1 \\
\hline Cogo, Denise (UNISINOS) & - & - & - & - & - & - & - & - & - & - & - & - & $x$ & - & 1 \\
\hline Gomes, I. (UFBA) & - & - & - & - & - & - & $x$ & - & - & - & - & - & - & - & 1 \\
\hline Guimaraes, C. (UFMG) & - & - & - & - & - & - & $x$ & - & - & - & - & - & - & - & 1 \\
\hline Machado, A.(PUCSP) & - & - & - & - & - & - & $x$ & - & - & - & - & - & - & - & 1 \\
\hline Santaella, L. (PUCSP) & - & - & - & - & - & $x$ & - & - & - & - & - & - & - & - & 1 \\
\hline Maia, Rousiley (UFMG) & - & - & - & - & - & - & $x$ & - & - & - & - & - & - & - & 1 \\
\hline Balogh, A. M. (UNIP) & - & - & - & - & - & - & - & - & - & - & $x$ & - & - & - & 1 \\
\hline Adami, A. (UNIP) & - & - & - & - & - & - & - & - & - & - & $x$ & - & - & - & 1 \\
\hline Lopes, L. C. (UFF) & - & - & - & - & - & - & - & - & - & - & - & $x$ & - & - & 1 \\
\hline Aldé, A. (UERJ) & - & - & - & - & - & - & - & - & - & - & - & - & $x$ & - & 1 \\
\hline Felinto, Erick (UERJ) & - & - & - & - & - & - & - & - & - & - & - & - & $x$ & - & 1 \\
\hline Helal, R. (UERJ) & - & - & - & - & - & - & - & - & - & - & - & - & $x$ & - & 1 \\
\hline Total & 3 & 1 & 10 & - & 4 & 6 & 4 & 1 & 1 & 1 & 2 & 5 & 5 & - & 43 \\
\hline
\end{tabular}

Sobre os autores dos PPGCOM que têm obras indicadas nas bibliografias para ingresso nos PPGCOM, nota-se que um número relativamente elevado de autores (27) que tem obra indicada. Além disso, 25 autores têm obra indicada em PPGCOM diferente do seu.

A indicação de obra no próprio PPGCOM pode ser vista como uma modalidade de “citação interna”. Essa prática é conhecida na literatura internacional como "house citation”. Nesse caso, a citação é feita no âmbito ao qual o pesquisador está relacionado, embora isso dependa da unidade de análise, por exemplo, em certos estudos, as citações nacionais são consideradas "house citations". Em nosso trabalho, falaremos de "citação interna” em relação aos PPGCOM. Vale notar que a citação interna, assim como a autocitação, admite duas leituras, não necessariamente excludentes. Uma delas vê menos valor nesse tipo de reconhecimento, e outra que vislumbra aspectos positivos, como o fato dela evidenciar o exercício de uma Linha de Pesquisa. 
De qualquer forma, deve-se notar que a natureza das obras dos quatro autores que são mais indicados, ajuda a entender a posição dos mesmos. França, Hohfeldt, Martino garantem tem essa posição devido à indicação de um único livro, organizados por eles sobre teorias da Comunicação e Moraes por duas coletâneas de textos de autores diversos.

O PPGCOM que mais indicou obras de docentes foi o da UNB (dez autores), seguido do da UFRGS, com seis, e os da UNESP e UERJ (cinco).

Tabela 7.4 - Autores nacionais indicados nas bibliografias para ingresso nos PPGCOM

\begin{tabular}{l|c|c|c|c|c|c|c|c|c|c|c|c|c|c|c}
\hline Autor & USP & UFRJ & UnB & $\begin{array}{c}\text { UME } \\
\text { SP }\end{array}$ & $\begin{array}{c}\text { PUC } \\
\text { RS }\end{array}$ & UFRG & UFMG & UFF & UTP & UFPE & UNIP & $\begin{array}{c}\text { UNE } \\
\text { SP }\end{array}$ & UERJ & $\begin{array}{c}\text { PUC } \\
\text { RJ }\end{array}$ & Total \\
\hline Costa Lima, L. & $\mathrm{x}$ & - & $\mathrm{X}$ & - & - & - & - & - & - & - & - & - & - & - & 2 \\
\hline Genro Filho, A. & - & - & $\mathrm{X}$ & - & - & - & - & - & - & - & - & - & - & - & 1 \\
\hline Moretzsohn, S. & - & - & $\mathrm{X}$ & - & - & - & - & - & - & - & - & - & - & - & 1 \\
\hline Porto, S.D. & - & - & $\mathrm{X}$ & - & - & - & - & - & - & - & - & - & - & - & 1 \\
\hline Bolaño, C.R. & - & - & $\mathrm{X}$ & - & - & - & - & - & - & - & - & - & - & - & 1 \\
\hline Freitas, R. & - & - & - & - & - & - & - & - & - & - & - & - & $\times$ & - & 1 \\
\hline Pesavento, S. & - & - & - & - & - & - & - & - & - & - & - & - & $\times$ & - & 1 \\
\hline Santiago, S. & - & - & - & - & - & - & - & - & - & - & - & - & $\times$ & - & 1 \\
\hline Sevcenko, N. & - & - & - & - & - & - & - & - & - & - & - & - & $\times$ & - & 1 \\
\hline Ortiz, R. & - & - & - & - & - & - & - & - & - & - & - & - & - & $\times$ & 1 \\
\hline Total & - & - & - & 4 & - & 7 & 8 & 3 & 6 & 5 & 4 & 6 & 4 & 1 & $\#$ \\
\hline
\end{tabular}

Parte significativa dos autores que não pertenciam ao quadro docente dos PPGCOM, mas que aparecem nas bibliografias indicadas por estes, como Porto e Genro Filho, em 2006 tem algum vínculo com o campo da Comunicação, pela pesquisa que realizaram ou praticam ainda, de modo mais efetivo. Outros como Santiago, Pesavento e Sevcenko, por exemplo, são mais identificados pela relação com outras áreas de estudo, a de teoria literária, caso do primeiro autor, e história, caso dos dois seguintes. 
Tabela 7.5 - Autores estrangeiros indicados nas bibliografias para ingresso nos PPGCOM

\begin{tabular}{|c|c|c|c|c|c|c|c|c|c|c|c|c|c|c|c|}
\hline Autor & USP & UFRJ & UnB & $\begin{array}{l}\text { UME } \\
\text { SP }\end{array}$ & $\begin{array}{c}\text { PUC } \\
\text { RS }\end{array}$ & $\begin{array}{c}\text { UF } \\
\text { RGS }\end{array}$ & UFMG & UFF & UTP & UFPE & UNIP & $\begin{array}{l}\text { UNE } \\
\text { SP }\end{array}$ & UERJ & $\begin{array}{c}\text { PUC } \\
\text { RJ }\end{array}$ & TOTAL \\
\hline Martin-Barbero, J. & $\mathrm{X}$ & - & $\mathrm{x}$ & - & $\mathrm{x}$ & - & - & - & - & - & $\mathrm{X}$ & - & - & $\mathrm{x}$ & 5 \\
\hline Canclini, N.G. & - & - & - & - & $\mathrm{x}$ & - & - & - & - & - & - & $x$ & $x$ & $x$ & 4 \\
\hline Thompson, J. & - & - & $\mathrm{x}$ & $x$ & - & - & - & - & - & - & - & - & $x$ & $x$ & 4 \\
\hline Baudrillard, J. & $\mathrm{x}$ & $x$ & - & - & $\mathrm{x}$ & - & - & - & - & - & - & - & - & - & 3 \\
\hline Benjamin, W. & $x$ & $X$ & - & - & - & - & $x$ & - & - & - & - & - & - & - & 3 \\
\hline Burke, $P$. & - & - & - & $x$ & - & $x$ & - & - & - & - & - & - & $x$ & - & 3 \\
\hline Castells, M. & $x$ & - & - & $x$ & - & - & - & - & - & - & - & $x$ & - & - & 3 \\
\hline Hall,S & $x$ & - & $x-$ & - & - & - & - & - & - & - & - & - & - & $\mathrm{x}$ & 3 \\
\hline Mattelart, A. e M. & - & - & - & $x$ & - & - & - & $\mathrm{x}$ & - & - & - & - & - & $x$ & 3 \\
\hline Stam, R & - & - & $\mathrm{x}$ & - & - & - & - & $x$ & - & $x$ & - & - & - & - & 3 \\
\hline Traquina, $\mathbf{N}$. & - & - & $\mathrm{X}$ & - & - & - & - & - & - & - & - & - & - & - & 3 \\
\hline Adorno, T. & $x$ & - & - & - & - & - & - & - & - & - & - & - & - & $x$ & 2 \\
\hline Bauman, Z. & $x$ & - & - & - & $x$ & - & - & - & - & - & - & - & - & - & 2 \\
\hline Bourdieu, P. & $x$ & - & - & - & - & - & - & - & $x$ & - & - & - & - & - & 2 \\
\hline Debord, G. & - & $x$ & - & - & $x$ & - & 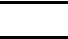 & - & - & - & - & - & - & - & 2 \\
\hline Kellner, D. & - & $x$ & - & - & - & - & - & - & - & $x$ & - & - & - & - & 2 \\
\hline Lévy, P. & $x$ & - & $\mathrm{x}$ & - & - & - & - & - & - & - & - & - & - & - & 2 \\
\hline McLuhan, M. & - & - & $x$ & - & - & - & - & - & - & - & - & - & $x$ & - & 2 \\
\hline Morin, E. & - & - & - & - & $x$ & - & - & - & - & - & - & - & - & $x$ & 2 \\
\hline Sfez, L & $x$ & - & $x$ & - & - & - & - & - & - & - & - & - & - & - & 2 \\
\hline Vattimo, G. & $x$ & - & - & - & $x$ & - & - & - & - & - & - & - & - & - & 2 \\
\hline Wolton, D. & - & - & - & - & $x$ & $x$ & - & - & - & - & - & - & - & - & 2 \\
\hline Bazin, A. & $x$ & - & - & - & - & - & - & - & - & - & - & - & - & - & 1 \\
\hline Burch, N.. & $\mathrm{x}$ & - & - & - & - & - & - & - & - & - & - & - & - & - & 1 \\
\hline Dondis, D.A. & $\mathrm{x}$ & - & - & - & - & - & - & - & - & - & - & - & - & - & 1 \\
\hline Fairclough, N. & - & $x$ & - & - & - & - & - & - & - & - & - & - & - & - & 1 \\
\hline Harvey, D.. & $x$ & - & - & - & - & - & - & - & - & - & - & - & - & - & 1 \\
\hline Kristeva, J. & $x$ & - & - & - & - & - & - & - & - & - & - & - & - & - & 1 \\
\hline Charney / Schwartz & - & $x$ & - & - & - & - & - & - & - & - & - & - & - & - & 1 \\
\hline Deleuze, G. & - & $x$ & - & - & - & - & - & - & - & - & - & - & - & - & 1 \\
\hline Foucault, M. & - & $x$ & - & - & - & - & - & - & - & - & - & - & - & - & 1 \\
\hline Mouillaud, M. & - & - & $\mathrm{x}$ & - & - & - & - & - & - & - & - & - & - & - & 1 \\
\hline Bauer, M. I Gaskell.G. & - & - & $\mathrm{X}$ & - & - & - & - & - & - & - & - & - & - & - & 1 \\
\hline Bobbio, N. & - & - & $\mathrm{x}$ & - & - & - & - & - & - & - & - & - & - & - & 1 \\
\hline Carnoy, M. & - & - & $\mathrm{X}$ & - & - & - & - & - & - & - & - & - & - & - & 1 \\
\hline Charaudeau, P. & - & - & - & - & - & - & - & - & - & $\mathrm{x}$ & - & - & - & - & 1 \\
\hline Chartier, R. & - & - & - & - & - & $x$ & - & - & - & - & - & - & - & - & 1 \\
\hline Dubois, $\mathbf{P}$ & - & - & $x$ & - & - & - & - & - & - & - & - & - & - & - & 1 \\
\hline Ellul, J. & - & - & $x$ & - & - & - & - & - & - & - & - & - & - & - & 1 \\
\hline Flusser, V. & - & - & - & - & - & - & - & - & - & - & - & - & - & - & 1 \\
\hline Gofman, E. & - & - & - & - & - & - & $x$ & - & - & - & - & - & - & - & 1 \\
\hline Guattari, F & - & - & - & - & - & - & - & - & $x$ & - & - & - & - & - & 1 \\
\hline Habermas, J & - & - & - & - & - & - & $x$ & - & - & - & - & - & - & - & 1 \\
\hline Hayles, K. & - & - & - & - & - & - & - & - & - & - & - & - & $x$ & - & 1 \\
\hline Lipovetsky, G. & - & - & - & - & - & - & - & - & - & - & - & - & $x$ & - & 1 \\
\hline Jameson, F & - & - & $x$ & - & - & - & - & - & - & - & - & - & - & - & 1 \\
\hline Johnson, S. & - & - & - & - & - & - & - & - & $x$ & - & - & - & - & - & 1 \\
\hline Kerkhove, D. & - & - & - & - & - & - & - & - & - & - & - & $x$ & - & - & 1 \\
\hline Mafessoli, M. & - & - & - & - & $x$ & - & - & - & - & - & - & - & - & - & 1 \\
\hline Manovich, L. & - & - & - & - & - & - & - & - & $x$ & - & - & - & - & - & 1 \\
\hline Rodrigues, A. D. & - & - & $x$ & - & - & - & - & - & - & - & - & - & - & - & 1 \\
\hline Silverstone, R. & - & - & - & - & - & - & - & - & - & $x$ & - & - & - & - & 1 \\
\hline Sousa, J. P. & - & - & $x$ & - & - & - & - & - & - & - & - & - & - & - & 1 \\
\hline Unesco & - & - & $x$ & - & - & - & - & - & - & - & - & - & - & - & 1 \\
\hline Wertheim, M. & - & - & 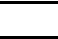 & - & - & - & - & - & - & - & - & - & $x$ & - & 1 \\
\hline Williams, R. & $x$ & & - & - & - & - & - & - & - & - & - & - & - & - & 1 \\
\hline Yudice, G. & - & - & - & - & - & - & - & - & - & - & - & - & $x$ & - & 1 \\
\hline Total & 17 & 8 & 18 & 4 & 9 & 3 & 3 & 2 & 4 & 4 & 1 & 3 & 8 & 7 & 94 \\
\hline
\end{tabular}

Quanto aos dados da Tabela chama bastante a atenção o número elevado de autores (58) indicados no total, bem como a dispersão, a maioria deles (34 autores) aparece num único 
PPGCOM, isso se deve em parte ao amplo leque temático da Comunicação. Por outro lado, alguns autores como Martín-Barbero, Canclini e Thompson têm obras indicados num número mais representativo de Programas, cinco no caso do primeiro autor e quatro no dos outros dois.

Caberia notar, antes de passar para a análise das dissertações que o quanto essas indicações de leitura irão aproximar-se do que é citado. Também é importante que alguns autores, como Velho (1998), notam que os indicadores quantitativos tendem a retratar o tempo passado e não necessariamente prevêem o futuro. Por isso, apesar da diferença de anos entre essas indicações bibliográficas não ser muito elevados quanto à data de defesa dos trabalhos, o número de anos é maior em relação à data de ingresso nos PPGCOM dos autores de 2004. Assim, a comparação poderá permite perceber parcialmente aspectos da maior ou menor consolidação de autores indicados/citados na Comunicação. 


\subsection{Análise bibliométrica da bibliografia das Teses e Dissertações dos PPGCOM: metodologia e características gerais do padrão de citações}

Foram analisados trabalhos defendidos nos 18 PPGCOM então credenciados na CAPES. O ano privilegiado foi 2004. Nossa intenção era fazer uma pesquisa com a mais recente possível bibliografia utilizada, e o que também favoreceu a escolha desse ano foi a divulgação dos relatórios dos PPGCOM pela CAPES, nos quais era disposta a lista do que tinha sido produzido, o que garantia uma organização do corpus com um critérios único.

Após a localização das Teses e Dissertações de interesse, geralmente nas bibliotecas das instituições ${ }^{67}$, era feita cópia da folha da capa, resumo e referências bibliográficas ou, no caso de inexistência desta, bibliografia do trabalho.

Inicialmente pensou-se em trabalhar utilizando um programa de banco de dados, e o trabalho começou assim. Porém, em razão do número elevado de trabalhos (491, entre Teses e Dissertações), notamos que isso seria inviável, ao menos que fizéssemos uma amostragem das citações. Isso teria um efeito positivo na feitura das tabulações, que poderiam ser geradas pelo software, porém decidimos por um método de contagem manual já que as amostragens possuem margens de erro. E não queríamos, em particular quanto aos autores dos PPGCOM, deixar escapar nenhum nome, mesmo que com poucas citações nos trabalhos.

Assim, tendo a lista de docentes dos PPGCOM ${ }^{68}$, também através do site da CAPES, em mãos, resolvemos trabalhar no método manual, elegendo como principais variáveis a nacionalidade/pertencimento institucional do autor (docentes de PPGCOM) e nacionalidade (estrangeiros e nacionais). Cada trabalho foi então escrutinado em detalhe quatro vezes, nas seguintes etapas: 1) a feitura da contagem do número de referências e separação de autores nacionais e estrangeiros, 2) marcação dos autores de PPGCOM, 3) anotação dos autores nacionais relevantes e estrangeiros idem, 4) reexame a partir de

\footnotetext{
${ }^{67}$ Alguns PPGCOM (UFRJ e PUCRS) já haviam disponibilizado teses de 2004 em bibliotecas on-line, assim foi possível fazer a coleta do material pela Internet e depois imprimir as partes dos documentos em que tínhamos interesse.

${ }^{68}$ Notamos que consideramos os docentes visitantes dos Programas como "nacionais" ou "estrangeiros", pois além desse tipo de vínculo ser menos efetivo, seria estranho considerar, por exemplo, um autor como Michel Maffesoli como integrante do campo da Comunicação brasileiro.
} 
referências que pareceram, em determinada etapa, relevantes, mas cuja contagem não tinha sido feita. Sobre a "relevância” que guiou a busca pelos autores que não eram dos PPGCOM, notamos que uma manipulação anterior do matéria, menos estruturada que as mencionadas, ajudou um pouco. Porém o principal foi o conhecimento sobre nomes que usualmente freqüentam os trabalhos da área. No processo de exame dos trabalhos voltamos, algumas vezes a reexaminar teses, pela decisão de acrescentar um autor à coleta. Preferimos tentar errar pelo excesso, coletando mais autores do que o necessário do que por falta.

É possível que tenha escapado alguma citação a autor de PPGCOM, porém em número muito pequeno, dada a atenção com que foi feito o trabalho. $\mathrm{O}$ fato de termos a lista com nomes dos autores dos PPGCOM no computador também ajudou, pois se localizávamos algum autor nacional, digitáveis (com variações) o nome no mesmo na busca do processador de texto para conferir se este autor era docente ou não. Além disso, continuamente aumentava nossa capacidade de distinguir os autores. No caso da classificação entre estrangeiros e nacionais, o processo foi igualmente trabalhoso, e foi graças às ferramentas de busca na Internet que podemos descobrir muitas nacionalidades que não nos eram conhecidas.

Embora tenhamos trabalhado quase exclusivamente com o universo de citações, para alguns dados mais gerais sobre o padrão de citação das pesquisas em Comunicação (tipo de documento, temporalidade etc.) realizamos um procedimento de amostragem. Então, calculamos a amostra é procedemos à coleta dos dados para efetivá-la. A fórmula e o cálculo amostral encontram-se no Anexo.

Outra observação é que excluímos da contagem as citações não bibliográficas (vídeos, sites genéricos, comunicações pessoais etc.) embora tenhamos mantido os artigos de periódicos não científicos (jornais, revistas etc.), pois esse material tem tem relevo na pesquisa em Comunicação.

Notamos que destacamos na análise o ano de 2004, mas também iremos mostrar alguns dados relativos aos anos de 1977, 1983, 1990 e 1997. O processo de montagem do corpus para esses anos foi parecido, exceto quanto à organização das Teses e Dissertações de cada 
PPGCOM, para isso operamos conforme explicamos na parte sobre a produção dos Programas no tópico 5.4. A produção (teses e dissertações) dos PPGCOM - 1974-2004 do Capítulo 5.

Seguem, a seguir, as Tabelas que evidenciam características gerais do padrão de citação das Teses e Dissertações em Comunicação.

Tabela 7.6 - Média de citações nas Dissertações e Teses dos PPGCOM

\begin{tabular}{l|c|c|c}
\hline $\begin{array}{l}\text { Anol Média } \\
\text { de cit. }\end{array}$ & $\begin{array}{c}\text { Média de citações nas } \\
\text { Dissertações }\end{array}$ & $\begin{array}{c}\text { Média de citações nas } \\
\text { Teses }\end{array}$ & Média Geral \\
\hline $\mathbf{1 9 7 7}$ & 45,7 & - & $\mathbf{4 5 , 7}$ \\
\hline $\mathbf{1 9 8 3}$ & 80,8 & 72,0 & $\mathbf{8 0 , 7}$ \\
\hline $\mathbf{1 9 9 0}$ & 80,5 & 102,4 & $\mathbf{8 5 , 3}$ \\
\hline $\mathbf{1 9 9 7}$ & 81,6 & 146,2 & $\mathbf{9 6 , 3}$ \\
\hline $\mathbf{2 0 0 4}$ & 73,5 & 153,3 & $\mathbf{9 9 , 2}$ \\
\hline
\end{tabular}

A média das referências utilizadas variou entre os anos de 1977 e 2004 . No início, naturalmente, era menor dada a existência de uma bibliografia mais limitada. Assim, aumentou continuamente de 45,7 referências, em 1977, para 99,2 em 2004. No entanto, houve uma diminuição, em 2004, da média de citações das Dissertações, talvez devido à diminuição nos prazos para a conclusão dos mestrados. A média encontrada em Comunicação, em 2004, é parecida com a que Noronha (1996) evidenciou em trabalhos da área da saúde, de 90,6 citações por trabalho.

Deve-se dizer que, em 2004, a soma das citações dos trabalhos resultou num universo de 51.472 citações. Para se ter uma idéia do que isso representa, no trabalho bibliométrico de Vanz (2004), que analisa dados dos PPGCOM do Rio Grande do Sul nos anos de 19982000, os 100 trabalhos analisados possuem 7.648 citações. E no trabalho de Melo, com Teses e Dissertações da ciências sócias, as citações forma em número de 30 mil. 
Tabela 7.7 - Média de citações por PPGCOM (2004)

\begin{tabular}{|c|c|c|c|}
\hline PPGCOM & $\begin{array}{l}\text { Média de citações nas } \\
\text { Dissertações }\end{array}$ & $\begin{array}{c}\text { Média de citações nas } \\
\text { Teses }\end{array}$ & Média Geral \\
\hline UMESP & 99,8 & 244,4 & 144,3 \\
\hline UFBA & 80,3 & 224,5 & 124,7 \\
\hline USP & 90,3 & 147,8 & 116,5 \\
\hline UNICAMP & 71,5 & 190,0 & 107,0 \\
\hline UFRGS & 92,7 & 198,0 & 105,1 \\
\hline PUCSP & 69,7 & 147,5 & 105,0 \\
\hline UNISINOS & 64,4 & 148,5 & 97,5 \\
\hline PUCRS & 73,8 & 132,4 & 96,6 \\
\hline UFMG & 85,6 & - & 85,6 \\
\hline UFRJ & 50,9 & 110,7 & 76,8 \\
\hline UFPE & 75,9 & - & 75,9 \\
\hline UFF & 75,0 & - & 75,0 \\
\hline UNB & 62,6 & - & 62,6 \\
\hline UNESP & 57,0 & - & 57,0 \\
\hline UNIP & 55,3 & - & 55,3 \\
\hline UTP & 46,4 & - & 46,4 \\
\hline UERJ & 40,0 & - & 40,0 \\
\hline UNIMAR & 37,3 & - & 37,3 \\
\hline TOTAL & 73,5 & 153,3 & 99,2 \\
\hline
\end{tabular}

Observando as médias de citações de Teses e Dissertações por PGGCOM nota-se diversidade, indo da média da UMESP de 144,3 citações nos trabalhos à média de 37,3 do PPG da UNIMAR. 
Tabela 7.8 - Tipos de documento pela nacionalidade dos autores (amostra -\%)

\begin{tabular}{|c|c|c|c|c|c|c|c|c|c|}
\hline \multirow[t]{2}{*}{$\begin{array}{l}\text { Autores/ } \\
\text { Documentos }\end{array}$} & \multicolumn{2}{|c|}{$\begin{array}{c}\text { Autores } \\
\text { estrangeiros }\end{array}$} & \multicolumn{2}{|c|}{$\begin{array}{c}\text { Autores } \\
\text { nacionais } \\
\text { PPGCOM }\end{array}$} & \multicolumn{2}{|c|}{$\begin{array}{l}\text { Outros Autores } \\
\text { nacionais }\end{array}$} & \multicolumn{2}{|c|}{ Total } & \multirow[t]{2}{*}{$\begin{array}{l}\text { Total } \\
\text { geral } \\
\text { (média) }\end{array}$} \\
\hline & D & M & D & $M$ & D & M & D & M & \\
\hline Livro (uniautoral) & 33,2 & 23,1 & 4,8 & 5,9 & 15,5 & 20,8 & 53,5 & 49,8 & 51,6 \\
\hline Capítulo de livro & 5,1 & 6,2 & 0,8 & 2 & 2,9 & 4,5 & 8,8 & 12,7 & 10,7 \\
\hline Periódicos não científ. & 3,4 & 0,8 & 0,2 & 0,2 & 6,7 & 6,8 & 10,3 & 7,8 & 9,1 \\
\hline Livro multiautoral & 4,7 & 2,9 & 0,4 & 0,5 & 1,8 & 1,9 & 6,9 & 5,3 & 6,1 \\
\hline Artigo de rev. científ. & 1,9 & 2,2 & 0,4 & 1,3 & 1,8 & 4,6 & 4,1 & 8,1 & 6,1 \\
\hline Livro (coletânea / org.) & 1,0 & 0,7 & 1,0 & 0,3 & 2,1 & 1,4 & 4,1 & 2,4 & 3,3 \\
\hline Paper / com. em evento & 0,7 & 0,3 & 0,1 & 0,2 & 1,5 & 1,0 & 2,3 & 1,5 & 1,9 \\
\hline Teses e Dissertações & 0,1 & 0 & 0,3 & 0,2 & 2,0 & 0,5 & 2,4 & 0,7 & 1,5 \\
\hline $\begin{array}{l}\text { Outros (leis, manuais, } \\
\text { relatórios, sites etc.) }\end{array}$ & 2,8 & 2,9 & 0,1 & 1,0 & 4,7 & 7,8 & 7,6 & 11,7 & 9,7 \\
\hline Total & 52,9 & 39,1 & 8,1 & 11,6 & 39,0 & 49,3 & 100,0 & 100,0 & 100,0 \\
\hline
\end{tabular}

A citação a livros predominou, como se poderia esperar dada a proximidade da Comunicação com as ciências sociais e humanas, assim, os livros uniautorias somam $51,6 \%$ dos trabalhos citados, capítulos de livro vem em seguida (10,\%), pouco depois os artigos de periódicos não científicos (9,1\%) e depois novamente livros, agora multiautorais (6,1\%), artigos de periódicos científicos (6,1\%), coletâneas (3,3\%); as comunicações em eventos e as Teses e Dissertações recebem um número bastante pequeno de citações, respectivamente $1,9 \%$ e $1,5 \%$, enquanto $9,7 \%$ foram de outro tipo. 
Tabela 7.9 - Tipos de documento pela temporalidade das citações (amostra -\%)

\begin{tabular}{|c|c|c|c|c|c|c|c|c|c|c|c|c|c|c|c|}
\hline \multirow[t]{2}{*}{$\begin{array}{l}\text { Temporalidadel Tipo de } \\
\text { documento citado }\end{array}$} & \multicolumn{2}{|c|}{$\begin{array}{l}\text { Até } 1 \text { ano } \\
(2004)\end{array}$} & \multicolumn{2}{|c|}{$\begin{array}{c}1-4 \text { anos } \\
(2001-2003)\end{array}$} & \multicolumn{2}{|c|}{$\begin{array}{l}\text { 4-8 anos } \\
(1996-2000)\end{array}$} & \multicolumn{2}{|c|}{$\begin{array}{l}\text { 8-19 anos } \\
(1986-1995)\end{array}$} & \multicolumn{2}{|c|}{$\begin{array}{c}\text { mais de } 19 \\
\text { anos } \\
\text { (até 1985) }\end{array}$} & \multicolumn{2}{|c|}{ Sem data } & \multicolumn{2}{|c|}{ Total } & \multirow[t]{2}{*}{$\begin{array}{c}\text { Total } \\
\text { geral } \\
\text { (média) }\end{array}$} \\
\hline & $\mathbf{D}$ & $\mathbf{M}$ & $\mathbf{D}$ & $\mathrm{M}$ & $\mathbf{D}$ & $\mathbf{M}$ & $\mathbf{D}$ & M & D & $\mathbf{M}$ & $\mathbf{D}$ & $\mathbf{M}$ & $\mathbf{D}$ & $\mathbf{M}$ & \\
\hline Livro uniautoral & 0,1 & 0,4 & 6,6 & 7,2 & 21,2 & 16,7 & 16,5 & 15,1 & 7,9 & 10,2 & 1,2 & 0,2 & 53,5 & 49,8 & 51,6 \\
\hline Capitulo de livro & 0,1 & 0,1 & 1,8 & 3,3 & 2,3 & 3,6 & 2,2 & 3,5 & 2,1 & 2,2 & 0,3 & 0 & 8,8 & 12,7 & 10,7 \\
\hline Periód. não cientifico & 0 & 0,3 & 4,1 & 3,8 & 2,2 & 1,8 & 2 & 0,8 & 1,1 & 0,7 & 0,9 & 0,4 & 10,3 & 7,8 & 9,1 \\
\hline Livro multiautoral & 0 & 0 & 1,5 & 0,8 & 2,1 & 1,7 & 1,3 & 2,1 & 1,7 & 0,7 & 0,3 & 0 & 6,9 & 5,3 & 6,1 \\
\hline $\begin{array}{l}\text { Artigo de revista } \\
\text { cient. }\end{array}$ & 0,2 & 0,1 & 0,9 & 0,9 & 0,9 & 4,2 & 1,1 & 1,8 & 1 & 0,9 & 0 & 0,2 & 4,1 & 8,1 & 6,1 \\
\hline Livro (colet. I org.) & 0,1 & 0 & 0,8 & 0,2 & 1,5 & 1,1 & 1,2 & 0,6 & 0,5 & 0,4 & 0 & 0,1 & 4,1 & 2,4 & 3,3 \\
\hline Paper I event. & 0 & 0 & 1,1 & 1,1 & 0,6 & 0 & 0,4 & 0,2 & 0,1 & 0,2 & 0,1 & 0 & 2,3 & 1,5 & 1,9 \\
\hline Teses e Dissertações & 0 & 0 & 1,1 & 0,7 & 0,8 & 0 & 0 & 0 & 0,5 & 0 & 0 & 0 & 2,4 & 0,7 & 1,5 \\
\hline Outros & 0,4 & 1,3 & 3,8 & 5,7 & 1,3 & 1,8 & 0,1 & 1,7 & 0,9 & 0,8 & 1,1 & 0,4 & 7,6 & 11,7 & 9,7 \\
\hline Total & 0,1 & 2,2 & 6,6 & 23,7 & 21,2 & 30,9 & 16,5 & 25,8 & 7,9 & 16,1 & 1,2 & 1,3 & 53,5 & 100,0 & 100,0 \\
\hline
\end{tabular}

Observando-se a temporalidade dos documentos citados, percebe-se que o maior grupo abrange os livros uniautorias escritos de 4 a 8 anos antes da defesa da Tese ou Dissertação (38,2\% dos trabalhos), as dois outras categorias seguintes com maior número também são de livros uniautorias, com 8 a 19 anos (31,6\%) e com mais de 19 anos (18,1\%).

Tabela 7.10 - Tipos de documento pela língua utilizada (amostra -\%)

\begin{tabular}{|c|c|c|c|c|c|c|c|c|c|c|c|c|c|c|c|}
\hline \multirow{2}{*}{$\begin{array}{l}\text { Idioma } \\
\text { Tipo doc }\end{array}$} & \multicolumn{2}{|c|}{ Português } & \multicolumn{2}{|c|}{ Inglês } & \multicolumn{2}{|c|}{ Espanhol } & \multicolumn{2}{|c|}{ Francês } & \multicolumn{2}{|c|}{ Italiano } & \multicolumn{2}{|c|}{ Outros } & \multicolumn{2}{|c|}{ Total } & \multirow{2}{*}{$\begin{array}{l}\text { Total geral } \\
\text { (média) }\end{array}$} \\
\hline & D & M & D & M & D & M & D & M & D & $\mathbf{M}$ & D & M & D & M & \\
\hline Livro & 56,7 & 61,2 & 9,3 & 4,8 & 4,5 & 2,8 & 2,5 & 1,4 & 0,2 & 0 & 0,1 & 0 & 73,3 & 70,2 & 71,7 \\
\hline Periód. não cient. & 6,2 & 7,5 & 3,2 & 0 & 0,1 & 0 & 0,7 & 0,1 & 0 & 0,2 & 0,1 & 0 & 10,3 & 7,8 & 9,1 \\
\hline Artigo rev. cient. & 2,6 & 3,2 & 0,6 & 2,9 & 0,6 & 1,4 & 0,1 & 0,6 & 0,1 & 0 & 0,1 & 0 & 4,1 & 8,1 & 6,1 \\
\hline Paper / evento & 1,4 & 1,2 & 0,1 & 0,2 & 0,4 & 0 & 0,4 & 0,1 & 0 & 0 & 0 & 0 & 2,3 & 1,5 & 1,9 \\
\hline Teses e Dissert. & 2,0 & 0,7 & 0 & 0 & 0,2 & 0 & 0,2 & 0 & 0 & 0 & 0 & 0 & 2,4 & 0,7 & 1,5 \\
\hline Outros & 4,7 & 9,3 & 1,6 & 1,3 & 0,7 & 0 & 0,5 & 0,5 & 0,1 & 0,6 & 0 & 0 & 7,6 & 11,7 & 9,7 \\
\hline Total & 73,6 & 83,1 & 14,8 & 9,1 & 6,5 & 4,2 & 4,4 & 2,7 & 0,4 & 0,8 & 0,3 & 0 & 100,0 & 100,0 & 100,0 \\
\hline
\end{tabular}

Em relação à língua na qual o documento foi publicado, o livro em português tem maiores percentuais para as Dissertações (56,7\%) e Teses (61,2\%), em segundo lugar também estão os livros, agora em inglês, citados por 9,3 das Teses e 4,8\% das Dissertações e, novamente 
livros, agora em espanhol, sendo 2,8\% das referências totais das Dissertações e 4,5\% das Teses.

\section{11 - Tipos de documentos pela nacionalidade dos autores (amostra -\%)}

\begin{tabular}{|c|c|c|c|c|c|c|c|c|c|c|c|c|c|c|c|c|c|c|c|}
\hline \multirow{2}{*}{$\begin{array}{l}\text { Nacion. I } \\
\text { Tipo de doc }\end{array}$} & \multicolumn{2}{|c|}{ Brasil } & \multicolumn{2}{|c|}{ EUA } & \multicolumn{2}{|c|}{$\begin{array}{l}\text { Amér. } \\
\text { Lat. }\end{array}$} & \multicolumn{2}{|c|}{ Inglat. } & \multicolumn{2}{|c|}{ França } & \multicolumn{2}{|c|}{ Itália } & \multicolumn{2}{|c|}{ Alem. } & \multicolumn{2}{|c|}{ Outros } & \multicolumn{2}{|c|}{ Total } & \multirow{2}{*}{$\begin{array}{l}\text { Total geral } \\
\text { (média) }\end{array}$} \\
\hline & D & $M$ & D & $M$ & D & $M$ & D & $M$ & D & $M$ & D & $M$ & D & $M$ & D & $M$ & D & $M$ & \\
\hline Livro & 30,5 & 45,8 & 8,3 & 5,5 & 3,3 & 3,9 & 5,1 & 3,1 & 12,5 & 2,9 & 1,9 & 2,3 & 1,8 & 1,7 & 9,4 & 5 & 73,3 & 70,2 & 71,7 \\
\hline $\begin{array}{l}\text { Periód. } \\
\text { não cient. }\end{array}$ & 6,4 & 4,5 & 1,9 & 0 & 0,2 & 0,8 & 0,4 & 0,5 & 0,9 & 0 & 0 & 0 & 0,1 & 0 & 0,4 & 1 & 10,3 & 6,8 & 9,1 \\
\hline $\begin{array}{l}\text { Artigo rev. } \\
\text { cient. }\end{array}$ & 2,7 & 3,2 & 0,6 & 1,7 & 0,4 & 1,9 & 0,1 & 0 & 0,2 & 0,5 & 0 & 0 & 0,1 & 0 & 0 & 0,8 & 4,1 & 8,1 & 6,1 \\
\hline $\begin{array}{l}\text { Paper I } \\
\text { event. }\end{array}$ & 1,5 & 1,3 & 0 & 0,2 & 0,2 & 0 & 0,2 & 0 & 0,3 & 0 & 0 & 0 & 0 & 0 & 0,1 & 0 & 2,3 & 1,5 & 1,9 \\
\hline Outros & 3,9 & 0,7 & 1,3 & 0 & 0,5 & 0 & 0,4 & 0 & 0,4 & 0 & 0,1 & 0 & 0,1 & 0 & 0,9 & 0 & 7,6 & 0,7 & 1,5 \\
\hline $\begin{array}{l}\text { Teses e } \\
\text { Dissert. }\end{array}$ & 2,1 & 5,4 & 0 & 1,6 & 0 & 1,9 & 0 & 1,2 & 0 & 0 & 0 & 0 & 0 & 0 & 0,3 & 1,6 & 2,4 & 11,7 & 9,7 \\
\hline Total & 47,1 & 60,9 & 12,1 & 9 & 5,1 & 8,5 & 6,1 & 4,8 & 14,3 & 3,4 & 2 & 2,3 & 2,1 & 1,7 & 11,1 & 8,4 & 100,0 & 100,0 & 100,0 \\
\hline
\end{tabular}

A Tabela 7.11 mostra a predominância dos autores nacionais e do formato livro, no padrão de citações de Teses e Dissertações em Comunicação (são 30,5\% do total das Dissertações e 45,8\% das Teses), seguidas pelos livros de autores franceses (D: 12,5\% e M: 2,9\%), norte-americanos (D: 8,3\% e M: 5,5\%), e depois ingleses livros de autores ingleses (D: 5,1\% e 3,1\%), o que evidencia a influência da literatura européia na pesquisa em Comunicação feita no Brasil.

A seguir, iremos destacar especificamente o capital científico pela análise dos autores citados nas Teses e Dissertações dos PPGCOM. 


\subsection{O “capital científico" da área da Comunicação evidenciado nas referências das teses e dissertações}

A Tabela 7.12 mostra a quantidade de autores nacionais e estrangeiros citados em vários anos, enquanto a seguinte aborda apenas os dados de 2004, detalhando-os por PPGCOM. A Tabela 7.14 mostra os números relativos as citações de autores nacionais e autores pertencentes aos PPGCOM.

Tabela 7.12 - Citações a autores nacionais e estrangeiros na teses dos PPGCOM

\begin{tabular}{l|c|c|c|c|c|c}
\hline \multirow{2}{*}{$\begin{array}{l}\text { Anol Média de } \\
\text { cit. }\end{array}$} & \multicolumn{2}{|c|}{ Autores Nacionais } & Autores Estrangeiros & \multicolumn{2}{c}{ Total } \\
\cline { 2 - 7 } & $\mathbf{N}$ & $\mathbf{\%}$ & $\mathbf{N}$ & $\mathbf{\%}$ & $\mathbf{N}$ & $\%$ \\
\hline $\mathbf{1 9 7 7}$ & 649 & $\mathbf{4 3 , 0}$ & 861 & $\mathbf{5 7 , 0}$ & 1.510 & $\mathbf{1 0 0 , 0}$ \\
\hline $\mathbf{1 9 8 3}$ & 2.399 & $\mathbf{5 3 , 0}$ & 2.120 & $\mathbf{4 7 , 0}$ & 4.519 & $\mathbf{1 0 0 , 0}$ \\
\hline $\mathbf{1 9 9 0}$ & 4.772 & $\mathbf{5 0 , 9}$ & 4.608 & $\mathbf{4 9 , 1}$ & 9.380 & $\mathbf{1 0 0 , 0}$ \\
\hline $\mathbf{1 9 9 7}$ & 9.164 & $\mathbf{4 0 , 1}$ & 13.673 & $\mathbf{5 9 , 9}$ & 22.837 & $\mathbf{1 0 0 , 0 0}$ \\
\hline $\mathbf{2 0 0 4}$ & 24.732 & $\mathbf{4 8 , 0}$ & 26.740 & $\mathbf{5 2 , 0}$ & 51.472 & $\mathbf{1 0 0 , 0}$ \\
\hline
\end{tabular}

A Tabela 12 não mostra um padrão de aumentou ou diminuição dos percentuais de citações a autores nacionais e estrangeiros, pois embora na comparação entre extremos, os autores nacionais sejam em número percentual maior, os índices de 2004 são menores, por exemplo, que os de 1990.

De qualquer forma, em 2004, os autores estrangeiros foram mais citados nos trabalhos (52\%) do que os nacionais (48\%). 
Tabela 7.13 - Citações a autores nacionais e estrangeiros, por PPGCOM (2004)

\begin{tabular}{l|c|c|c|c|c|c}
\hline \multirow{2}{*}{$\begin{array}{l}\text { PPGCOMI } \\
\text { Autores }\end{array}$} & \multicolumn{2}{|c|}{ Autores Nacionais } & \multicolumn{2}{c|}{ Autores Estrangeiros } & \multicolumn{2}{c}{ Total } \\
\cline { 2 - 7 } & $\mathbf{N}$ & $\mathbf{\%}$ & $\mathbf{N}$ & $\mathbf{\%}$ & $\mathbf{N}$ & $\mathbf{1}$ \\
\hline UMESP & 2.310 & $\mathbf{6 1 , 5}$ & 1.442 & $\mathbf{3 8 , 5}$ & 3.752 & $\mathbf{1 0 0 , 0}$ \\
\hline UNB & 613 & $\mathbf{6 1 , 2}$ & 389 & $\mathbf{3 8 , 8}$ & 1.002 & $\mathbf{1 0 0 , 0}$ \\
\hline UNIMAR & 69 & $\mathbf{6 1 , 0}$ & 44 & $\mathbf{3 9 , 0}$ & 113 & $\mathbf{1 0 0 , 0}$ \\
\hline UNESP & 450 & $\mathbf{6 0 , 6}$ & 292 & $\mathbf{3 9 , 4}$ & 742 & $\mathbf{1 0 0 , 0}$ \\
\hline UNIP & 388 & $\mathbf{5 8 , 4}$ & 276 & $\mathbf{4 1 , 6}$ & 664 & $\mathbf{1 0 0 , 0}$ \\
\hline UERJ & 206 & $\mathbf{5 7 , 4}$ & 153 & $\mathbf{4 2 , 6}$ & 359 & $\mathbf{1 0 0 , 0}$ \\
\hline UFBA & 1.721 & $\mathbf{5 3 , 1}$ & 1.521 & $\mathbf{4 6 , 9}$ & 3.242 & $\mathbf{1 0 0 , 0}$ \\
\hline UFMG & 636 & $\mathbf{5 3 , 0}$ & 563 & $\mathbf{4 7 , 0}$ & 1.199 & $\mathbf{1 0 0 , 0}$ \\
\hline UFRGS & 925 & $\mathbf{5 1 , 7}$ & 862 & $\mathbf{4 8 , 3}$ & 1787 & $\mathbf{1 0 0 , 0}$ \\
\hline UFPE & 381 & $\mathbf{5 0 , 2}$ & 378 & $\mathbf{4 9 , 8}$ & 759 & $\mathbf{1 0 0 , 0}$ \\
\hline UTP & 348 & $\mathbf{5 0 , 0}$ & 348 & $\mathbf{5 0 , 0}$ & 696 & $\mathbf{1 0 0 , 0}$ \\
\hline UFF & 483 & $\mathbf{4 9 , 5}$ & 493 & $\mathbf{5 0 , 5}$ & 976 & $\mathbf{1 0 0 , 0}$ \\
\hline UNISINOS & 1.299 & $\mathbf{4 7 , 6}$ & 1.430 & $\mathbf{5 2 , 4}$ & 2.729 & $\mathbf{1 0 0 , 0}$ \\
\hline USP & 6.976 & $\mathbf{4 7 , 2}$ & 7.828 & $\mathbf{5 2 , 8}$ & 14.804 & $\mathbf{1 0 0 , 0}$ \\
\hline UFRJ & 1.331 & $\mathbf{4 6 , 8}$ & 1.510 & $\mathbf{5 3 , 2}$ & 2.841 & $\mathbf{1 0 0 , 0}$ \\
\hline PUCRS & 1.625 & $\mathbf{4 6 , 7}$ & 1.853 & $\mathbf{5 3 , 3}$ & 3.478 & $\mathbf{1 0 0 , 0}$ \\
\hline UNICAMP & 996 & $\mathbf{4 6 , 5}$ & 1145 & $\mathbf{5 3 , 5}$ & 2.141 & $\mathbf{1 0 0 , 0}$ \\
\hline PUCSP & 3.975 & $\mathbf{3 9 , 0}$ & 6.213 & $\mathbf{6 1 , 0}$ & 10.188 & $\mathbf{1 0 0 , 0}$ \\
\hline TOTAL & $\mathbf{2 4 . 7 3 2}$ & $\mathbf{4 8 , 0}$ & $\mathbf{2 6 . 7 4 0}$ & $\mathbf{5 2 , 0}$ & $\mathbf{5 1 . 4 7 2}$ & $\mathbf{1 0 0 , 0}$ \\
\hline & & & & & &
\end{tabular}

A variação entre os PPGCOM quanto à citação de autores nacionais e estrangeiros, indo de um máximo de 61,5\% de autores nacionais na UMESP a um mínimo de 39\% na PUCSP. 
Tabela 7.14 - Citações a autores nacionais e de docentes dos programas, por PPGCOM (2004)

\begin{tabular}{l|c|c|c|c|c|c}
\hline \multirow{2}{*}{$\begin{array}{l}\text { Ano/ Média } \\
\text { de cit. }\end{array}$} & \multicolumn{2}{|c|}{ Autores PPGCOM } & \multicolumn{2}{c|}{ Outros Autores Nacionais } & \multicolumn{2}{c}{ Total } \\
\cline { 2 - 7 } & $\mathbf{N}$ & $\mathbf{\%}$ & $\mathbf{N}$ & $\mathbf{\%}$ & $\mathbf{N}$ & $\mathbf{1}$ \\
\hline UNISINOS & 390 & $\mathbf{3 0 , 0}$ & 909 & $\mathbf{7 0 , 0}$ & 1.299 & $\mathbf{1 0 0 , 0}$ \\
\hline UFMG & 177 & $\mathbf{2 7 , 8}$ & 459 & $\mathbf{7 2 , 2}$ & 636 & $\mathbf{1 0 0 , 0}$ \\
\hline UTP & 91 & $\mathbf{2 6 , 1}$ & 257 & $\mathbf{7 3 , 9}$ & 348 & $\mathbf{1 0 0 , 0}$ \\
\hline UNIP & 101 & $\mathbf{2 6 , 0}$ & 287 & $\mathbf{7 4 , 0}$ & 388 & $\mathbf{1 0 0 , 0}$ \\
\hline UFPE & 98 & $\mathbf{2 5 , 7}$ & 283 & $\mathbf{7 4 , 3}$ & 381 & $\mathbf{1 0 0 , 0}$ \\
\hline PUCSP & 944 & $\mathbf{2 3 , 7}$ & 3.031 & $\mathbf{7 6 , 3}$ & 3.975 & $\mathbf{1 0 0 , 0}$ \\
\hline UNB & 142 & $\mathbf{2 3 , 2}$ & 471 & $\mathbf{7 6 , 8}$ & 613 & $\mathbf{1 0 0 , 0}$ \\
\hline PUCRS & 371 & $\mathbf{2 2 , 8}$ & 1.254 & $\mathbf{7 7 , 2}$ & 1.625 & $\mathbf{1 0 0 , 0}$ \\
\hline UFRGS & 210 & $\mathbf{2 2 , 7}$ & 715 & $\mathbf{7 7 , 3}$ & 925 & $\mathbf{1 0 0 , 0}$ \\
\hline UFF & 100 & $\mathbf{2 0 , 7}$ & 383 & $\mathbf{7 9 , 3}$ & 483 & $\mathbf{1 0 0 , 0}$ \\
\hline UNESP & 91 & $\mathbf{2 0 , 2}$ & 359 & $\mathbf{7 9 , 8}$ & 450 & $\mathbf{1 0 0 , 0}$ \\
\hline UFRJ & 246 & $\mathbf{1 8 , 5}$ & 1.085 & $\mathbf{8 1 , 5}$ & 1.331 & $\mathbf{1 0 0 , 0}$ \\
\hline USP & 1.213 & $\mathbf{1 7 , 4}$ & 5.763 & $\mathbf{8 2 , 6}$ & 6.976 & $\mathbf{1 0 0 , 0}$ \\
\hline UFBA & 279 & $\mathbf{1 6 , 2}$ & 1.442 & $\mathbf{8 3 , 8}$ & 1.721 & $\mathbf{1 0 0 , 0}$ \\
\hline UNICAMP & 121 & $\mathbf{1 2 , 1}$ & 875 & $\mathbf{7 8 , 9}$ & 996 & $\mathbf{1 0 0 , 0}$ \\
\hline UMESP & 268 & $\mathbf{1 1 , 6}$ & 2.042 & $\mathbf{8 8 , 4}$ & 2.310 & $\mathbf{1 0 0 , 0}$ \\
\hline UERJ & 21 & $\mathbf{1 0 , 2}$ & 185 & $\mathbf{8 9 , 8}$ & 206 & $\mathbf{1 0 0 , 0}$ \\
\hline UNIMAR & 5 & $\mathbf{7 , 2}$ & 64 & $\mathbf{9 2 , 8}$ & 69 & $\mathbf{1 0 0 , 0}$ \\
\hline TOTAL & $\mathbf{4 . 8 6 8}$ & $\mathbf{1 9 , 7}$ & $\mathbf{1 9 . 8 6 4}$ & $\mathbf{8 0 , 3}$ & $\mathbf{2 4 . 7 3 2}$ & $\mathbf{1 0 0 , 0}$ \\
\hline & & & & & & \\
\hline
\end{tabular}

O percentual de autores de PPGCOM citados nos Programas, com respeito ao total de autores nacionais vai de um máximo de 30\%, na UNISINOS, a um mínimo de 7,2\% na UNIMAR, como mostra a Tabela 7.14. 
Tabela 7.15 - Citações a autores nacionais em 1977, 1983, 1990 e 1997, por PPGCOM

\begin{tabular}{|c|c|c|c|c|c|c|c|c|c|c|c|}
\hline Autores/PPGCOM - 1977 & USP & UFRJ & UNB & & & & & & & Total $(\mathbf{n})$ & Total $^{*}(\%)$ \\
\hline 01. COHN, Gabriel & 5 & 0 & 4 & & & & & & & 9 & 1,4 \\
\hline 02. SODRÉ, Muniz & 0 & 5 & 4 & & & & & & & 9 & 1,4 \\
\hline 03. FERNANDES, Florestan & 4 & 0 & 4 & & & & & & & 8 & 1,2 \\
\hline 04. FREIRE, Paulo & 0 & 0 & 8 & & & & & & & 8 & 1,2 \\
\hline 05. MARTINS, José de Souza & 2 & 0 & 5 & & & & & & & 7 & 1,1 \\
\hline Autores/PPGCOM - 1983 & USP & UFRJ & UNB & $\begin{array}{l}\text { PUC } \\
\text { SP }\end{array}$ & $\begin{array}{c}\text { UME } \\
\text { SP }\end{array}$ & & & & & Total $(n)$ & Total $^{*}(\%)$ \\
\hline 01. MELO, José Marques de & 4 & 3 & 0 & 0 & 20 & & 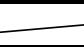 & & & 27 & 1,1 \\
\hline 02. CAMPOS, Haroldo & 0 & 3 & 0 & 22 & 0 & & 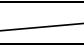 & & & 25 & 1,0 \\
\hline 03. SODRÉ, Muniz & 1 & 18 & 2 & 0 & 1 & & 2 & & & 22 & 0,9 \\
\hline 04. PIGNATARI, Décio & 0 & 4 & 0 & 15 & 0 & & 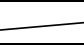 & & & 19 & 0,8 \\
\hline 05. FREIRE, Paulo & 5 & 0 & 4 & 0 & 3 & & 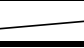 & & & 12 & 0,5 \\
\hline Autores/PPGCOM- 1990 & USP & UFRJ & UNB & $\begin{array}{l}\text { PUC } \\
\text { SP }\end{array}$ & $\begin{array}{l}\text { UME } \\
\text { SP }\end{array}$ & UNICAMP & & & & Total $(\mathbf{n})$ & Total $^{*}(\%)$ \\
\hline 01. MELO, José Marques de & 53 & 1 & 0 & 0 & 8 & 0 & 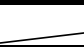 & & & 62 & 1,3 \\
\hline 02. ANDRADE, Mário & 16 & 19 & 0 & 3 & 0 & 3 & 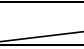 & 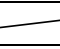 & & 41 & 0,9 \\
\hline 03. PIGNATARI, Décio & 16 & 2 & 2 & 17 & 2 & 0 & 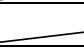 & 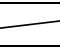 & & 39 & 0,8 \\
\hline 04. FREIRE, Paulo & 32 & 2 & 0 & 0 & 4 & 0 & 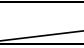 & - & & 38 & 0,8 \\
\hline 05. SANTAELLA, Lúcia & 5 & 0 & 0 & 27 & 2 & 0 & 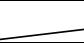 & - & & 34 & 0,7 \\
\hline 06. SODRÉ, Muniz & 12 & 11 & 1 & 1 & 2 & 0 & 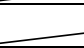 & - & & 27 & 0,6 \\
\hline 06. CAMPOS, Haroldo & 4 & 1 & 0 & 21 & 0 & 1 & 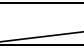 & - & & 27 & 0,6 \\
\hline 08. MARCONDES Fo., Ciro & 15 & 1 & 1 & 2 & 6 & 0 & 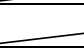 & 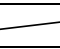 & & 25 & 0,5 \\
\hline 09. CHAUÍ, Marilena & 17 & 5 & 1 & 1 & 0 & 0 & 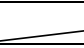 & - & & 24 & 0,5 \\
\hline 10. FADUL, Anamaria & 14 & 0 & 0 & 0 & 2 & 0 & 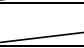 & - & & 16 & 0,3 \\
\hline 10. FERNANDES, Florestan & 14 & 0 & 1 & 0 & 1 & 0 & 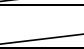 & 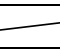 & & 16 & 0,3 \\
\hline 10. ORTIZ, Renato & 13 & 0 & 3 & 0 & 0 & 0 & 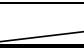 & - & & 16 & 0,3 \\
\hline Autores/PPGCOM- 1997 & USP & UFRJ & UNB & $\begin{array}{l}\text { PUC } \\
\text { SP }\end{array}$ & $\begin{array}{l}\text { UME } \\
\text { SP }\end{array}$ & UNICAMP & UFBA & $\begin{array}{c}\text { PUC } \\
\text { RS }\end{array}$ & UNISINOS & Total $(\mathbf{n})$ & Total$^{*}(\%)$ \\
\hline 01. SANTAELLA, Lúcia & 11 & 0 & 1 & 235 & 3 & 3 & 3 & 2 & 1 & 259 & 2,8 \\
\hline 02. MACHADO, Arlindo & 16 & 2 & 2 & 57 & 3 & 8 & 12 & 5 & 1 & 106 & 1,2 \\
\hline 03. CAMPOS, Haroldo de & 8 & 1 & 1 & 67 & 0 & 0 & 1 & 0 & 0 & 78 & 0,9 \\
\hline 04. MELO, José Marques de & 12 & 0 & 1 & 2 & 39 & 4 & 0 & 14 & 0 & 72 & 0,8 \\
\hline 04. PIGNATARI, Décio & 7 & 0 & 0 & 58 & 4 & 2 & 0 & 1 & 0 & 72 & 0,8 \\
\hline 06. ORTIZ, Renato & 14 & 6 & 5 & 4 & 12 & 0 & 6 & 19 & 0 & 66 & 0,7 \\
\hline 07. MARCONDES Fo, Ciro & 17 & 3 & 5 & 2 & 10 & 3 & 1 & 13 & 1 & 55 & 0,6 \\
\hline 08. XAVIER, Ismail & 22 & 10 & 3 & 12 & 0 & 1 & 5 & 0 & 0 & 53 & 0,6 \\
\hline 09. COELHO No ${ }^{\circ}$ J. Teixeira & 17 & 1 & 1 & 22 & 1 & 0 & 1 & 5 & 1 & 49 & 0,5 \\
\hline 10. ANDRADE, Mário de & 5 & 0 & 1 & 37 & 0 & 0 & 4 & 0 & 0 & 47 & 0,5 \\
\hline 11. CHALUB, Samira & 2 & 0 & 0 & 42 & 0 & 0 & 0 & 1 & 0 & 45 & 0,5 \\
\hline 12. FAUSTO NETO, Antonio & 3 & 7 & 5 & 2 & 1 & 0 & 1 & 24 & 1 & 44 & 0,5 \\
\hline 13. SALLES, Cecília Almeida & 0 & 0 & 0 & 42 & 0 & 0 & 0 & 0 & 0 & 42 & 0,5 \\
\hline 14. SODRÉ, Muniz & 1 & 18 & 2 & 7 & 2 & 0 & 3 & 8 & 0 & 41 & 0,4 \\
\hline 15. IANNI, Octávio & 11 & 8 & 0 & 3 & 6 & 0 & 1 & 8 & 0 & 37 & 0,4 \\
\hline 16. CHAUÍ, Marilena & 6 & 3 & 3 & 13 & 7 & 0 & 1 & 2 & 1 & 36 & 0,4 \\
\hline 17. PLAZA, Júlio & 4 & 0 & 0 & 23 & 0 & 3 & 1 & 1 & 0 & 32 & 0,3 \\
\hline 18. CANDIDO, Antônio & 5 & 5 & 8 & 9 & 1 & 0 & 0 & 0 & 1 & 29 & 0,3 \\
\hline 18. LOPES, M. Immacolata V. & 13 & 1 & 1 & 1 & 4 & 0 & 0 & 8 & 1 & 29 & 0,3 \\
\hline 18. MEDINA, Cremilda & 10 & 1 & 3 & 1 & 1 & 0 & 0 & 13 & 0 & 29 & 0,3 \\
\hline
\end{tabular}

* Percentual em relação ao total de citações a autores nacionais no ano. 
A Tabela 7.15, sobre os autores nacionais mais citados pelos PPGCOM nos anos de 1977, 1983, 1990 e 1997, mostra como foi se compondo o referencial de autores nacionais da área. Logo na primeiro etapa já existem autores identificados com o campo ainda hoje (como Sodré), além do enfoque da sociologia da comunicação ou divulgação da pesquisa internacional feita por Cohn. Chama a atenção, no período seguinte, a presença significativa de Haroldo de Campos, citado principalmente no PPGCOM da PUCSP, provavelmente em função da origem desse PPG a partir de outro voltado à literatura. Além disso, as citações a Melo e Pignatari, autores representativos do surgimento e crescimento da área acadêmica. Assim como, no período de 1990, a introdução (nessa periodização) de autores como Marcondes e Santaella, também representativos da pesquisa em Comunicação.

Porém, é só em 1997 que se percebe um número mais expressivo de autores nacionais identificados com a Comunicação tendo um impacto num volume de pesquisa mais relevante. É nesse contexto que aparecem nomes como o de Machado, Xavier, Fausto Neto, entre outros.

A seguir, a Tabela 7.16 mostra um movimento similar, embora não tão nítido, de crescimento dos autores (dessa vez, estrangeiros) que se pode identificar com a área da Comunicação. Em 1977 já aparece um autor como Adorno; em 1983 os três primeiros autores mais citados (Eco, Barthes e Véron) provavelmente indicam o interesse quanto aos problemas da linguagem na pesquisa da época. Autores dessa natureza continuam a surgir, como mais citados nas Teses e Dissertações, no período seguinte, que é marcado também pela presença de Peirce na PUCSP. O ano de 1997 também mostra muitos novos autores sendo incorporados ao campo. É interessante notar alguns aspectos: a ausência como autores mais citados de representantes da pesquisa funcionalista, a força da influência européia e o fato de que os autores tendem a continuar sendo usados pesquisa, desde que começam a ser incorporados pela pesquisa em Comunicação.

Existem algumas tendências de citações a determinados autores de menor impacto nos outros programas, por PPGCOM, como o caso de Peirce na PUCSP, todavia, essa não é a tendência geral, que poderia indicar um "modelo segmental” de relacionamento entre os pesquisadores. 
Tabela 7.16 - Autores estrangeiros mais citados em 1977, 1983, 1990 e 1997, por PPGCOM

\begin{tabular}{|c|c|c|c|c|c|c|c|c|c|c|c|}
\hline Autores/PPGCOM - 1977 & USP & UFRJ & UNB & & & & & & & Total (n) & Total $^{*}(\%)$ \\
\hline 01. FREUD, Sigmund & 0 & 12 & 6 & & & & & & & 18 & 2,1 \\
\hline 02. BARTHES, Roland & 0 & 6 & 12 & & & & & & & 18 & 2,1 \\
\hline 03. MATTELLART, Armand & 1 & 5 & 9 & & & & & & & 15 & 1,7 \\
\hline 04. MARCUSE, Herbert & 0 & 0 & 14 & & & & & & & 14 & 1,6 \\
\hline 05. ADORNO, Theodor W. & 2 & 1 & 9 & & & & & & & 12 & 1,4 \\
\hline Autores/PPGCOM - 1983 & USP & UFRJ & UNB & $\begin{array}{l}\text { PUC } \\
\text { SP }\end{array}$ & $\begin{array}{l}\text { UME } \\
\text { SP }\end{array}$ & & & & & Total $(\mathrm{n})$ & Total* $^{*}(\%)$ \\
\hline 01. BARTHES, Roland & 13 & 14 & 3 & 15 & 0 & & & & & 45 & 5,2 \\
\hline 02. ECO, Umberto & 11 & 17 & 0 & 7 & 0 & & & & & 35 & 4,1 \\
\hline 03. VERÓN, Eliseo & 10 & 19 & 3 & 1 & 0 & & 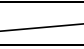 & & & 33 & 3,8 \\
\hline 04. LACAN, Jacques & 0 & 17 & 0 & 5 & 0 & & 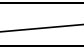 & & & 22 & 2,6 \\
\hline 05. MCLUHAN, Marshall & 3 & 9 & 0 & 9 & 0 & 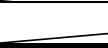 & 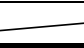 & & & 21 & 2,4 \\
\hline Autores/PPGCOM- 1990 & USP & UFRJ & UNB & $\begin{array}{l}\text { PUC } \\
\text { SP }\end{array}$ & $\begin{array}{l}\text { UME } \\
\text { SP }\end{array}$ & UNICAMP & & & & Total (n) & Total $^{*}(\%)$ \\
\hline 01. BARTHES, Roland & 34 & 26 & 1 & 25 & 5 & 1 & 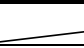 & & & 92 & 2,0 \\
\hline 02. ECO, Umberto & 23 & 14 & 3 & 13 & 4 & 0 & 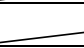 & 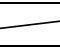 & & 57 & 1,2 \\
\hline 03. BAUDRILLARD, Jean & 19 & 11 & 4 & 3 & 0 & 0 & 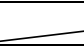 & 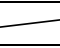 & & 37 & 0,8 \\
\hline 04. BENJAMIN, Walter & 12 & 3 & 2 & 7 & 0 & 4 & 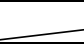 & - & & 28 & 0,6 \\
\hline 05. FOUCAULT, Michel & 5 & 10 & 0 & 6 & 0 & 5 & 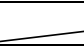 & - & & 26 & 0,6 \\
\hline 05. GOMBRICH, Ernst H. & 11 & 2 & 0 & 12 & 0 & 1 & 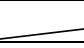 & - & & 26 & 0,6 \\
\hline 07. PEIRCE, Charles & 4 & 1 & 0 & 19 & 0 & 1 & 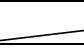 & - & & 25 & 0,6 \\
\hline 08. JAKOBSON, Roman & 5 & 0 & 0 & 17 & 2 & 0 & 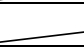 & 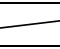 & & 24 & 0,5 \\
\hline 09. ADORNO, Theodoro & 15 & 4 & 3 & 0 & 1 & 0 & 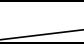 & - & & 23 & 0,5 \\
\hline 09. DELEUZE, Gilles & 5 & 11 & 0 & 1 & 0 & 6 & 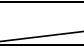 & - & & 23 & 0,5 \\
\hline 09. MARTÍN BARBERO, Jesús & 22 & 0 & 0 & 0 & 1 & 0 & 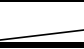 & - & & 23 & 0,5 \\
\hline Autores/PPGCOM- 1997 & USP & UFRJ & UNB & $\begin{array}{l}\text { PUC } \\
\text { SP }\end{array}$ & $\begin{array}{l}\text { UME } \\
\text { SP }\end{array}$ & UNICAMP & UFBA & $\begin{array}{c}\text { PUC } \\
\text { RS }\end{array}$ & UNISINOS & Total (n) & Total $^{*}(\%)$ \\
\hline 01. ECO, Umberto & 31 & 14 & 14 & 60 & 7 & 3 & 10 & 21 & 23 & 183 & 1,3 \\
\hline 02. BARTHES, Roland & 29 & 15 & 5 & 72 & 0 & 7 & 12 & 18 & 11 & 169 & 1,2 \\
\hline 03. FREUD, Sigmund & 5 & 100 & 0 & 41 & 0 & 0 & 1 & 1 & 1 & 149 & 1,1 \\
\hline 04. DELEUZE, Gilles & 12 & 85 & 4 & 25 & 0 & 5 & 3 & 2 & 1 & 137 & 1,0 \\
\hline 05. FOUCAULT, Michel & 6 & 46 & 4 & 40 & 0 & 1 & 2 & 21 & 11 & 131 & 1,0 \\
\hline 06. PEIRCE, Charles & 6 & 1 & 2 & 94 & 1 & 1 & 0 & 2 & 8 & 115 & 0,8 \\
\hline 07. LACAN, Jacques & 21 & 55 & 0 & 32 & 0 & 0 & 0 & 3 & 1 & 109 & 0,8 \\
\hline 08. BENJAMIN, Walter & 14 & 16 & 6 & 40 & 3 & 4 & 9 & 2 & 0 & 94 & 0,7 \\
\hline 09. BAUDRILLARD, Jean & 13 & 24 & 0 & 13 & 7 & 4 & 7 & 11 & 5 & 89 & 0,7 \\
\hline 10. MORIN, Edgar & 9 & 8 & 1 & 36 & 13 & 0 & 1 & 17 & 0 & 85 & 0,6 \\
\hline 11. BAKHTIN, Mikhail & 9 & 12 & 6 & 29 & 0 & 0 & 1 & 9 & 4 & 70 & 0,5 \\
\hline 12. GREIMAS, Algirdas J. & 17 & 0 & 1 & 23 & 1 & 1 & 0 & 2 & 22 & 67 & 0,5 \\
\hline 13. LÉVY, Pierre & 7 & 10 & 2 & 28 & 1 & 2 & 2 & 8 & 1 & 61 & 0,4 \\
\hline 14. HABERMAS, Jürgen & 10 & 6 & 12 & 6 & 12 & 0 & 1 & 3 & 0 & 50 & 0,4 \\
\hline 14. JAKOBSON, Roman & 10 & 4 & 0 & 33 & 0 & 0 & 1 & 0 & 2 & 50 & 0,4 \\
\hline 16. VIRILIO, Paul & 12 & 5 & 0 & 15 & 1 & 9 & 5 & 2 & 0 & 49 & 0,4 \\
\hline 17. MCLUHAN, Marshall & 7 & 0 & 4 & 17 & 5 & 6 & 8 & 1 & 0 & 48 & 0,4 \\
\hline 19. AUMONT, Jacques & 20 & 1 & 0 & 14 & 0 & 3 & 8 & 2 & 3 & 47 & 0,3 \\
\hline 20. BACHELARD, Gaston & 8 & 8 & 0 & 25 & 0 & 3 & 0 & 3 & 0 & 47 & 0,3 \\
\hline 20. MERLEAU-PONTY, M. & 16 & 1 & 0 & 18 & 0 & 3 & 6 & 1 & 0 & 45 & 0,3 \\
\hline
\end{tabular}

* Percentual em relação ao total de citações a autores estrangeiros no ano. 
Agora passaremos a analisar dados de 2004, como os autores nacionais (Tabela 7.17), os autores estrangeiros (Tabela 7.18) e os autores dos PPGCOM.

Tabela 7.17 - Autores nacionais mais citados em 2004

\begin{tabular}{|c|c|c|c|c|c|c|c|c|c|c|c|c|c|c|c|c|c|c|c|c|}
\hline $\begin{array}{l}\text { PPGOM/ } \\
\text { Autor }\end{array}$ & USP & $\begin{array}{l}\text { UF } \\
\text { RJ }\end{array}$ & UNB & $\begin{array}{l}\text { Puc } \\
\text { SP }\end{array}$ & $\underset{\text { SPE }}{\text { UME }}$ & $\begin{array}{l}\text { UNIC } \\
\text { AMP }\end{array}$ & $\begin{array}{l}\mathrm{UF} \\
\mathrm{BA}\end{array}$ & $\underset{\mathrm{RS}}{\mathrm{PUC}}$ & $\begin{array}{l}\text { UNIS } \\
\text { INOS }\end{array}$ & $\begin{array}{l}\text { UFR } \\
\text { GS }\end{array}$ & $\begin{array}{l}\text { UF } \\
\text { MG }\end{array}$ & UFF & UTP & $\begin{array}{l}\mathrm{UF} \\
\mathrm{PE}\end{array}$ & UNIP & $\begin{array}{l}\text { UNI } \\
\text { MAR }\end{array}$ & $\begin{array}{l}\text { UNE } \\
\text { SP }\end{array}$ & $\begin{array}{l}\text { EU } \\
\text { RJ }\end{array}$ & $\begin{array}{c}\text { Total } \\
\text { (n) }\end{array}$ & $\begin{array}{c}\text { Total }^{*} \\
(\%)\end{array}$ \\
\hline ORTIZ, Renato & 42 & 4 & 4 & 9 & 7 & 2 & 15 & 9 & 12 & 8 & 3 & 4 & 1 & 7 & 4 & 0 & 2 & 2 & 135 & 0,7 \\
\hline ORLANDI, Eni & 12 & 2 & 6 & 9 & 1 & 2 & 9 & 4 & 6 & 20 & 0 & 16 & 3 & 15 & 1 & 0 & 2 & 2 & 110 & 0,5 \\
\hline FREIRE, Paulo & 25 & 2 & 5 & 10 & 19 & 0 & 0 & 8 & 5 & 0 & 0 & 0 & 0 & 0 & 0 & 0 & 3 & 0 & 77 & 0,4 \\
\hline CHAUÍ, Marilena & 25 & 3 & 2 & 7 & 4 & 2 & 6 & 1 & 3 & 1 & 0 & 0 & 1 & 2 & 5 & 1 & 3 & 1 & 67 & 0,3 \\
\hline SANTOS, Milton & 12 & 0 & 1 & 7 & 0 & 0 & 9 & 12 & 16 & 0 & 2 & 1 & 0 & 0 & 3 & 1 & 1 & 0 & 65 & 0,3 \\
\hline $\begin{array}{l}\text { RUBIM, Antonio } \\
\text { Albino C. }\end{array}$ & 11 & 3 & 3 & 2 & 2 & 1 & 13 & 7 & 5 & 10 & 0 & 2 & 0 & 4 & 0 & 0 & 0 & 0 & 63 & 0,3 \\
\hline LAGE, Niton & 10 & 7 & 2 & 6 & 1 & 0 & 2 & 4 & 9 & 4 & 4 & 4 & 1 & 2 & 0 & 0 & 0 & 1 & 57 & 0,3 \\
\hline FIORIN, José Luis & 8 & 1 & 0 & 34 & 1 & 0 & 3 & 0 & 1 & 0 & 2 & 0 & 3 & 1 & 0 & 1 & 0 & 0 & 55 & 0,3 \\
\hline CAMPOS, Haroldo de & 2 & 0 & 0 & 39 & 1 & 0 & 0 & 0 & 0 & 0 & 0 & 0 & 0 & 0 & 0 & 0 & 6 & 0 & 48 & 0,2 \\
\hline BUCCl, Eugenio & 11 & 1 & 7 & 4 & 9 & 0 & 3 & 1 & 4 & 5 & 0 & 1 & 0 & 0 & 1 & 0 & 0 & 0 & 47 & 0,2 \\
\hline $\begin{array}{l}\text { BARROS, Diana } \\
\text { Pessoa L.de }\end{array}$ & 7 & 0 & 1 & 25 & 0 & 0 & 1 & 0 & 2 & 1 & 1 & 0 & 8 & 0 & 0 & 0 & 0 & 0 & 46 & 0,2 \\
\hline BORELLI, Silvia & 8 & 0 & 1 & 5 & 3 & 1 & 0 & 4 & 3 & 3 & 5 & 0 & 1 & 3 & 1 & 0 & 0 & 0 & 38 & 0,2 \\
\hline MEDISTCH, Eduardo & 15 & 3 & 3 & 5 & 0 & 0 & 0 & 1 & 3 & 4 & 2 & 0 & 0 & 0 & 0 & 0 & 0 & 2 & 38 & 0,2 \\
\hline PLAZA, Júlio & 5 & 2 & 0 & 23 & 0 & 2 & 2 & 0 & 0 & 0 & 0 & 0 & 1 & 0 & 1 & 0 & 2 & 0 & 38 & 0,2 \\
\hline DEMO, Pedro & 16 & 0 & 7 & 0 & 1 & 0 & 0 & 12 & 0 & 1 & 0 & 0 & 0 & 0 & 0 & 0 & 0 & 0 & 37 & 0,2 \\
\hline $\begin{array}{l}\text { GOMES, Paulo Emílio } \\
\text { Salles }\end{array}$ & 1 & 0 & 2 & 4 & 0 & 19 & 1 & 2 & 1 & 0 & 0 & 1 & 1 & 2 & 1 & 0 & 0 & 0 & 35 & 0,2 \\
\hline CANDIDO, Antonio & 6 & 7 & 4 & 11 & 1 & 2 & 0 & 0 & 0 & 1 & 0 & 1 & 0 & 0 & 0 & 1 & 0 & 0 & 34 & 0,2 \\
\hline BELTRÃO, Luis & 4 & 1 & 1 & 1 & 5 & 0 & 4 & 3 & 4 & 3 & 3 & 0 & 0 & 0 & 0 & 2 & 1 & 0 & 32 & 0,2 \\
\hline $\begin{array}{l}\text { TORQUATO do } \\
\text { REGO, Francisco } \\
\text { Gaudêncio }\end{array}$ & 3 & 0 & 0 & 1 & 10 & 0 & 0 & 15 & 1 & 0 & 0 & 1 & 1 & 1 & 0 & 0 & 0 & 0 & 33 & 0,2 \\
\hline $\begin{array}{l}\text { BOLAÑO, César } \\
\text { Ricardo Siqueira }\end{array}$ & 9 & 0 & 1 & 0 & 2 & 0 & 13 & 0 & 6 & 0 & 0 & 0 & 0 & 0 & 0 & 0 & 0 & 0 & 31 & 0,2 \\
\hline BOSI, Alfredo & 14 & 2 & 0 & 4 & 2 & 1 & 1 & 0 & 0 & 0 & 0 & 1 & 0 & 0 & 2 & 1 & 3 & 0 & 31 & 0,2 \\
\hline DA MATTA, Roberto & 7 & 4 & 0 & 6 & 0 & 0 & 2 & 1 & 5 & 0 & 1 & 3 & 0 & 1 & 0 & 0 & 1 & 0 & 31 & 0,2 \\
\hline
\end{tabular}

* Percentual em relação ao total de citações a autores nacionais (excluídos os de PPGCOM).

A Tabela 7.17 mostra alguns autores identificados, por sua produção científica, com a Comunicação que, circunstancialmente não pertenciam a PPGCOM, caso de Rubim e outros. Mas há também autores de outros campos, como a sociologia, com o destaque para Ortiz, o mais citado dentre esses autores, Orlandi, da área da lingüística, a segunda, a filósofa Chauí e o geógrafo Milton Santos. Poderiam ser tirados outros exemplos dessa tabela, porém, esses são suficientes para mostrar um aspecto interessante que aparece aqui que é o diálogo entre disciplinas diversas com a Comunicação a partir do quadro de referências das Teses e Dissertações. A seguir, são mostrados os índices de citações de autores estrangeiros pelos PPGCOM 
Tabela 7.18 - Citações a autores estrangeiros, por PPGCOM (2004) - autores mais citados

\begin{tabular}{|c|c|c|c|c|c|c|c|c|c|c|c|c|c|c|c|c|c|c|c|c|}
\hline PPGOM/ Autor & USP & $\begin{array}{l}\text { UF } \\
\text { RJ }\end{array}$ & UNB & $\begin{array}{l}\text { Puc } \\
\text { SP }\end{array}$ & $\begin{array}{l}\text { UME } \\
\text { SP }\end{array}$ & $\begin{array}{l}\text { UNI } \\
\text { CAM } \\
\text { P }\end{array}$ & $\begin{array}{l}\mathrm{UF} \\
\mathrm{BA}\end{array}$ & $\begin{array}{c}\text { Puc } \\
\text { RS }\end{array}$ & $\begin{array}{c}\text { UNIS } \\
\text { INO } \\
\text { S }\end{array}$ & $\begin{array}{l}\text { UFR } \\
\text { GS }\end{array}$ & $\begin{array}{l}\text { UF } \\
\text { MG }\end{array}$ & UFF & UTP & $\underset{\mathrm{PE}}{\mathrm{UF}}$ & UNIP & $\begin{array}{l}\text { UNI } \\
\text { MAR }\end{array}$ & $\begin{array}{l}\text { UNE } \\
\text { SP }\end{array}$ & $\begin{array}{l}\mathrm{EU} \\
\mathrm{RJ}\end{array}$ & $\begin{array}{l}\text { Total } \\
\text { (n) }\end{array}$ & $\begin{array}{c}\text { Total* } \\
(\%)\end{array}$ \\
\hline MORIN, Edgar & 87 & 12 & 4 & 82 & 13 & 0 & 5 & 121 & 10 & 8 & 5 & 0 & 5 & 1 & 17 & 1 & 0 & 1 & 372 & 1,4 \\
\hline LEVY, Pierre & 56 & 26 & 2 & 64 & 10 & 4 & 30 & 14 & 11 & 4 & 2 & 2 & 5 & 6 & 5 & 0 & 5 & 1 & 247 & 0,9 \\
\hline BARTHES, Roland & 45 & 17 & 3 & 29 & 2 & 3 & 13 & 64 & 11 & 3 & 6 & 11 & 4 & 4 & 4 & 1 & 9 & 1 & 230 & 0,9 \\
\hline ECO, Umberto & 53 & 5 & 2 & 44 & 9 & 6 & 20 & 15 & 13 & 4 & 12 & 2 & 7 & 3 & 3 & 3 & 4 & 3 & 208 & 0,8 \\
\hline BOURDIEU, Pierre & 42 & 15 & 3 & 7 & 3 & 5 & 29 & 10 & 42 & 30 & 4 & 12 & 1 & 1 & 1 & 0 & 0 & 0 & 205 & 0,8 \\
\hline FOUCAULT, Michel & 35 & 38 & 2 & 18 & 1 & 9 & 15 & 11 & 22 & 6 & 11 & 16 & 1 & 6 & 1 & 0 & 1 & 5 & 198 & 0,7 \\
\hline MARTíN-BARBERO, J. & 64 & 11 & 4 & 4 & 11 & 0 & 9 & 10 & 38 & 15 & 4 & 2 & 0 & 3 & 3 & 0 & 2 & 3 & 183 & 0,7 \\
\hline GARCIAA-CANCLINI, N. & 50 & 14 & 4 & 9 & 7 & 0 & 19 & 11 & 31 & 10 & 5 & 2 & 0 & 6 & 3 & 0 & 1 & 1 & 173 & 0,6 \\
\hline DELEUZE, Gilles & 15 & 33 & 2 & 71 & 0 & 20 & 2 & 4 & 3 & 1 & 12 & 4 & 1 & 1 & 1 & 1 & 0 & 0 & 171 & 0,6 \\
\hline BAKTHIN, Mikail & 48 & 4 & 2 & 35 & 2 & 4 & 10 & 1 & 12 & 3 & 5 & 5 & 3 & 13 & 2 & 1 & 3 & 0 & 153 & 0,6 \\
\hline HALL, Stuart & 21 & 19 & 14 & 3 & 4 & 1 & 21 & 8 & 14 & 22 & 12 & 3 & 0 & 7 & 1 & 0 & 0 & 1 & 151 & 0,6 \\
\hline BAUDRILLARD, Jean & 34 & 13 & 0 & 25 & 8 & 2 & 12 & 21 & 9 & 2 & 3 & 5 & 6 & 0 & 2 & 0 & 3 & 0 & 145 & 0,5 \\
\hline CASTELLS, Manuel & 31 & 10 & 6 & 8 & 3 & 0 & 20 & 16 & 17 & 10 & 5 & 4 & 1 & 3 & 2 & 0 & 4 & 3 & 143 & 0,5 \\
\hline BENJAMIN, Walter & 32 & 13 & 4 & 52 & 2 & 4 & 5 & 2 & 7 & 1 & 1 & 2 & 2 & 3 & 0 & 0 & 2 & 1 & 133 & 0,5 \\
\hline MATTELART, A. & 32 & 8 & 4 & 15 & 5 & 2 & 6 & 18 & 20 & 5 & 2 & 0 & 3 & 1 & 0 & 3 & 0 & 0 & 124 & 0,5 \\
\hline MAFFESOLI, Michel & 33 & 6 & 1 & 2 & 2 & 0 & 15 & 39 & 3 & 3 & 0 & 1 & 0 & 0 & 0 & 0 & 1 & 0 & 106 & 0,4 \\
\hline MCLUHAN, Marshal & 16 & 5 & 1 & 26 & 7 & 1 & 7 & 7 & 11 & 4 & 0 & 0 & 2 & 1 & 1 & 0 & 9 & 2 & 100 & 0,4 \\
\hline ADORNO, Theodor & 18 & 9 & 13 & 14 & 4 & 2 & 9 & 4 & 7 & 0 & 6 & 1 & 3 & 4 & 0 & 0 & 1 & 3 & 98 & 0,4 \\
\hline GREIMAS, Algirdas & 16 & 2 & 0 & 50 & 2 & 1 & 0 & 0 & 8 & 0 & 1 & 0 & 4 & 0 & 0 & 0 & 14 & 0 & 98 & 0,4 \\
\hline HABERMAS, Jurgen & 15 & 3 & 5 & 2 & 3 & 0 & 7 & 9 & 9 & 6 & 18 & 2 & 2 & 8 & 0 & 0 & 6 & 2 & 97 & 0,4 \\
\hline GUATTARI, Félix & 3 & 22 & 0 & 36 & 1 & 8 & 2 & 6 & 1 & 2 & 6 & 3 & 0 & 0 & 0 & 1 & 0 & 1 & 92 & 0,3 \\
\hline VERON, Eliseo & 2 & 10 & 0 & 1 & 1 & 0 & 19 & 1 & 45 & 9 & 0 & 0 & 0 & 1 & 0 & 0 & 0 & 0 & 89 & 0,3 \\
\hline $\begin{array}{l}\text { RODRIGUES, } \\
\text { Adriano Duarte }\end{array}$ & 18 & 5 & 0 & 5 & 0 & 0 & 5 & 0 & 30 & 11 & 10 & 0 & 0 & 3 & 0 & 0 & 0 & 0 & 87 & 0,3 \\
\hline THOMPSON, John B. & 16 & 7 & 2 & 1 & 1 & 0 & 3 & 10 & 13 & 8 & 13 & 3 & 1 & 0 & 0 & 1 & 3 & 4 & 86 & 0,3 \\
\hline AUMONT, Jacques & 35 & 2 & 2 & 5 & 1 & 10 & 3 & 2 & 5 & 2 & 2 & 3 & 7 & 2 & 2 & 0 & 1 & 0 & 84 & 0,3 \\
\hline GIDDENS, Anthony & 15 & 11 & 0 & 3 & 3 & 0 & 7 & 1 & 12 & 2 & 10 & 0 & 0 & 6 & 0 & 0 & 3 & 3 & 76 & 0,3 \\
\hline MATTELART, M. & 23 & 5 & 3 & 7 & 1 & 1 & 2 & 9 & 12 & 4 & 2 & 0 & 3 & 1 & 0 & 0 & 0 & 0 & 73 & 0,3 \\
\hline FREUD, Sigmund & 18 & 4 & 0 & 24 & 2 & 1 & 10 & 5 & 2 & 0 & 1 & 0 & 0 & 0 & 2 & 0 & 1 & 1 & 71 & 0,3 \\
\hline $\begin{array}{l}\text { PEIRCE, Charles } \\
\text { Sanders }\end{array}$ & 4 & 5 & 1 & 46 & 0 & 4 & 0 & 2 & 0 & 1 & 3 & 0 & 4 & 0 & 1 & 0 & 0 & 0 & 71 & 0,3 \\
\hline WOLF, Mauro & 16 & 2 & 6 & 7 & 5 & 0 & 2 & 9 & 6 & 6 & 2 & 0 & 2 & 1 & 1 & 0 & 3 & 3 & 71 & 0,3 \\
\hline LANDOWSKI, Eric & 1 & 2 & 0 & 56 & 0 & 0 & 0 & 3 & 0 & 3 & 0 & 1 & 0 & 1 & 0 & 0 & 0 & 0 & 67 & 0,3 \\
\hline BAUMAN, Zygmunt & 3 & 26 & 0 & 10 & 1 & 1 & 3 & 1 & 7 & 2 & 4 & 0 & 0 & 1 & 1 & 0 & 0 & 3 & 63 & 0,2 \\
\hline JAMESON, Fredric & 21 & 2 & 2 & 17 & 1 & 0 & 1 & 1 & 4 & 4 & 0 & 2 & 1 & 2 & 2 & 0 & 1 & 0 & 61 & 0,2 \\
\hline KOTLER, Philip & 17 & 1 & 0 & 9 & 15 & 0 & 1 & 8 & 1 & 0 & 0 & 2 & 0 & 4 & 0 & 0 & 0 & 1 & 59 & 0,3 \\
\hline $\begin{array}{l}\text { SANTOS, Boaventura } \\
\text { Sousa }\end{array}$ & 24 & 3 & 3 & 3 & 3 & 0 & 7 & 4 & 7 & 2 & 3 & 0 & 0 & 0 & 0 & 0 & 0 & 0 & 59 & 0,2 \\
\hline MAINGUENEAU, D. & 9 & 6 & 1 & 3 & 1 & 0 & 10 & 0 & 6 & 6 & 4 & 2 & 1 & 5 & 0 & 0 & 0 & 1 & 55 & 0,2 \\
\hline TRAQUINA, Nelson & 3 & 2 & 9 & 3 & 0 & 0 & 2 & 2 & 13 & 13 & 4 & 1 & 0 & 1 & 0 & 0 & 0 & 1 & 54 & 0,2 \\
\hline ARNHEIM, Rudolf & 19 & 5 & 0 & 19 & 1 & 1 & 2 & 2 & 0 & 1 & 0 & 0 & 3 & 0 & 0 & 0 & 0 & 0 & 53 & 0,2 \\
\hline LIPOVETSKY, Gilles & 13 & 5 & 0 & 5 & 1 & 0 & 11 & 7 & 5 & 2 & 2 & 0 & 0 & 0 & 0 & 0 & 0 & 1 & 52 & 0,2 \\
\hline HARVEY, David & 8 & 4 & 0 & 10 & 2 & 1 & 8 & 6 & 4 & 3 & 0 & 1 & 0 & 1 & 1 & 0 & 3 & 0 & 52 & 0,2 \\
\hline HOBSBAWM, Eric & 19 & 4 & 0 & 5 & 2 & 1 & 5 & 2 & 6 & 0 & 2 & 2 & 0 & 2 & 0 & 0 & 0 & 0 & 50 & 0,2 \\
\hline WILLIAMS, Raymond & 7 & 1 & 4 & 9 & 1 & 0 & 6 & 11 & 2 & 5 & 0 & 0 & 0 & 2 & 1 & 0 & 0 & 1 & 50 & 0,2 \\
\hline CERTEAU, Michel De & 10 & 1 & 1 & 6 & 1 & 2 & 3 & 1 & 11 & 0 & 10 & 1 & 0 & 1 & 1 & 0 & 0 & 0 & 49 & 0,2 \\
\hline WOLTON, Dominique & 10 & 0 & 1 & 4 & 0 & 0 & 3 & 22 & 1 & 2 & 1 & 1 & 0 & 2 & 0 & 0 & 0 & 0 & 47 & 0,2 \\
\hline
\end{tabular}


A Tabela 7.18 evidencia um padrão de citações de autores estrangeiros, em 2004, que tendeu também a estabelecer relações com vários âmbitos disciplinares, provavelmente em função da natureza com que o campo se estrutura no Brasil. Novamente aqui, existem citações em que determinados autores são mais influentes ou importantes em relação a alguns PPGCOM do que em outros. Porém, sem dúvida, isso se deve a características conjunturais, em menor grau, o tipo de pesquisa finalizada no ano de nosso corpus e as especificidades das tradições de pesquisa dos PPG da área. Todavia, não existe uma tendência à apropriação “segmental” dos autores mais citados.

Assim, é plausível supor que tais autores estrangeiros, sobretudo os do topo da tabela, têm formado uma espécie de “chão comum” para o campo da Comunicação no Brasil. O fato de boa parte deles serem antes pensadores e teóricos sociais, como Morin (bem citado vários PPGCOM), Levy, Barthes, Eco, do que autores de contribuição mais específica, reforça essa interpretação. Poucos autores são identificados com um grau de reflexão mais especificamente midiática, embora os objetos da comunicação sejam tema de vários desses autores. 
Tabela 7.19 - Citações a autores de PPGCOM (2004) - autores mais citados

\begin{tabular}{|c|c|c|c|c|c|c|c|c|c|c|c|c|c|c|c|c|c|c|c|c|}
\hline Nome / Programa & USP & $\begin{array}{l}\mathrm{UF} \\
\mathrm{RJ} \\
\end{array}$ & UNB & Pucsp & \begin{tabular}{|c|c} 
UMES \\
$\mathrm{P}$ \\
\end{tabular} & $\begin{array}{c}\text { UNICA } \\
\text { MP }\end{array}$ & \begin{tabular}{|l|l} 
UF & P \\
BA
\end{tabular} & PUCRS & $\begin{array}{l}\text { UNISIN } \\
\text { OS }\end{array}$ & \begin{tabular}{|l} 
UF \\
RGS \\
\end{tabular} & $\begin{array}{l}\mathrm{UF} \\
\mathrm{MG} \\
\end{array}$ & UFF & UTP & $\begin{array}{l}\mathrm{UF} \\
\mathrm{PE} \\
\mathrm{PE}\end{array}$ & UNIP & $\begin{array}{ll}\text { UNIMA } \\
\mathbf{R}\end{array}$ & UNESP & $\begin{array}{ll}\mathrm{UE} \\
\mathrm{RJ} \\
\end{array}$ & TOTAL & TOTAL* \\
\hline SANTAELLA, Lúcia (PUCSP) & 30 & 14 & 10 & 162 & 4 & 1 & 4 & 11 & 6 & 0 & 6 & 0 & 9 & 11 & 14 & 0 & 2 & 0 & 284 & 5,8 \\
\hline MACHADO, Arlindo (PUCSP) & 35 & 14 & 4 & 62 & 4 & 4 & 3 & 3 & 21 & 3 & 4 & 2 & 6 & 11 & 3 & 0 & 3 & 1 & 183 & 3,7 \\
\hline SODRÉ, Muniz (UFRJ) & 24 & 42 & 8 & 23 & 5 & 3 & 12 & 5 & 27 & 6 & 3 & 7 & 1 & 4 & 6 & 0 & 1 & 3 & 180 & 3,7 \\
\hline $\begin{array}{l}\text { MELO, José Marques de } \\
\text { (UMESP) }\end{array}$ & 21 & 3 & 8 & 13 & 26 & 0 & 2 & 20 & 5 & 5 & 2 & 0 & 0 & 4 & 0 & 1 & 8 & 0 & 118 & 2,4 \\
\hline $\begin{array}{l}\text { LOPES, Maria Immacolata } \\
\text { Vassallo de (USP) }\end{array}$ & 58 & 3 & 1 & 4 & 6 & 0 & 3 & 12 & 6 & 2 & 5 & 1 & 0 & 2 & 0 & 0 & 0 & 0 & 103 & 2,1 \\
\hline MARCONDES Fo, Ciro (USP) & 28 & 7 & 6 & 15 & 4 & 0 & 4 & 7 & 7 & 6 & 1 & 0 & 1 & 0 & 4 & 0 & 5 & 1 & 96 & 2,0 \\
\hline IANNI, Octávio (USP) & 50 & 5 & 1 & 2 & 10 & 2 & 5 & 3 & 13 & 1 & 0 & 1 & 0 & 0 & 1 & 0 & 1 & 0 & 95 & 2,0 \\
\hline $\begin{array}{l}\text { FAUSTO NETO, Antonio } \\
\text { (UNISINOS) }\end{array}$ & 3 & 11 & 0 & 12 & 2 & 0 & 3 & 6 & 25 & 25 & 0 & 1 & 0 & 6 & 0 & 0 & 0 & 1 & 95 & 2,0 \\
\hline XAVIER, Ismail (USP) & 28 & 3 & 9 & 10 & 0 & 8 & 6 & 1 & 1 & 0 & 1 & 9 & 5 & 4 & 6 & 0 & 0 & 0 & 91 & 1,9 \\
\hline $\begin{array}{l}\text { TEIXEIRA COELHO, José } \\
\text { (USP) }\end{array}$ & 39 & 0 & 0 & 19 & 1 & 4 & 10 & 5 & 3 & 3 & 1 & 0 & 2 & 3 & 1 & 0 & 0 & 0 & 91 & 1,9 \\
\hline $\begin{array}{l}\text { BAITELLO JUNIOR, Norval } \\
\text { (PUCSP) }\end{array}$ & 20 & 0 & 0 & 56 & 0 & 0 & 0 & 3 & 0 & 0 & 0 & 0 & 0 & 0 & 0 & 0 & 1 & 0 & 80 & 1,6 \\
\hline MEDINA, Cremilda (USP) & 43 & 3 & 4 & 9 & 3 & 0 & 1 & 4 & 6 & 2 & 0 & 0 & 0 & 0 & 0 & 0 & 2 & 1 & 78 & 1,6 \\
\hline $\begin{array}{l}\text { BERNARDET Jean Claude G. } \\
\text { R. (USP) }\end{array}$ & 14 & 0 & 6 & 4 & 0 & 24 & 4 & 3 & 2 & 0 & 0 & 7 & 3 & 1 & 2 & 0 & 0 & 0 & 70 & 1,4 \\
\hline $\begin{array}{l}\text { BRAGA, José Luiz } \\
\text { (UNISINOS) }\end{array}$ & 2 & 3 & 6 & 1 & 0 & 0 & 0 & 3 & 28 & 2 & 15 & 0 & 2 & 0 & 0 & 0 & 0 & 0 & 62 & 1,3 \\
\hline GOMES, Wilson (UFBA) & 2 & 0 & 1 & 3 & 0 & 0 & 15 & 8 & 10 & 19 & 3 & 0 & 0 & 1 & 0 & 0 & 0 & 0 & 62 & 1,3 \\
\hline LEMOS, André (UFBA) & 4 & 2 & 2 & 5 & 0 & 2 & 21 & 4 & 8 & 3 & 0 & 5 & 1 & 1 & 0 & 0 & 1 & 0 & 59 & 1,2 \\
\hline $\begin{array}{l}\text { SALLES, Cecília Almeida } \\
\text { (PUCSP) }\end{array}$ & 4 & 0 & 0 & 53 & 0 & 0 & 0 & 0 & 0 & 0 & 0 & 0 & 0 & 1 & 0 & 0 & 0 & 0 & 58 & 1,2 \\
\hline PIGNATARI, Décio (UTP) & 9 & 0 & 0 & 25 & 1 & 1 & 2 & 0 & 2 & 0 & 1 & 0 & 2 & 2 & 1 & 0 & 7 & 0 & 53 & 1,1 \\
\hline FRANÇA, Vera (UFMG) & 4 & 1 & 0 & 3 & 1 & 0 & 0 & 8 & 3 & 4 & 25 & 0 & 1 & 1 & 0 & 0 & 0 & 1 & 52 & 1,1 \\
\hline PARENTE, André (UFRJ) & 9 & 9 & 0 & 15 & 0 & 4 & 6 & 0 & 0 & 0 & 1 & 2 & 0 & 0 & 2 & 0 & 2 & 0 & 50 & 1,0 \\
\hline MORAES, Denis de (UFF) & 13 & 5 & 0 & 2 & 1 & 0 & 8 & 0 & 11 & 3 & 1 & 4 & 1 & 0 & 0 & 0 & 0 & 0 & 49 & 1,0 \\
\hline PINTO, Milton José (UFRJ) & 3 & 14 & 1 & 8 & 1 & 0 & 8 & 2 & 4 & 1 & 1 & 1 & 1 & 1 & 0 & 0 & 1 & 0 & 47 & 1,0 \\
\hline $\begin{array}{l}\text { OLIVEIRA, Ana Claudia Mei } \\
\text { Alves de (PUCSP) }\end{array}$ & 0 & 0 & 0 & 43 & 0 & 0 & 1 & 0 & 0 & 0 & 0 & 0 & 0 & 1 & 0 & 0 & 1 & 0 & 46 & 0 \\
\hline $\begin{array}{l}\text { BACCEGA, Maria Aparecida } \\
\text { (USP) }\end{array}$ & 30 & 0 & 0 & 2 & 4 & 2 & 0 & 0 & 2 & 0 & 1 & 0 & 0 & 2 & 0 & 0 & 0 & 0 & 43 & 0,9 \\
\hline $\begin{array}{l}\text { FERRARA, Lucrecia D'Aléssio } \\
\text { (PUCSP) }\end{array}$ & 6 & 0 & 0 & 24 & 0 & 0 & 1 & 0 & 1 & 0 & 1 & 0 & 5 & 0 & 1 & 0 & 3 & 0 & 42 & 0,9 \\
\hline $\begin{array}{l}\text { PERUZZO, Cicilia Maria } \\
\text { Krohling (UMESP) }\end{array}$ & 9 & 2 & 2 & 1 & 12 & 1 & 2 & 5 & 4 & 2 & 2 & 0 & 0 & 0 & 0 & 0 & 0 & 0 & 42 & 0,9 \\
\hline $\begin{array}{l}\text { SOARES, Ismar de Oliveira } \\
\text { (USP) }\end{array}$ & 23 & 0 & 4 & 0 & 10 & 1 & 0 & 1 & 0 & 0 & 1 & 0 & 0 & 0 & 0 & 0 & 1 & 0 & 41 & 0,8 \\
\hline $\begin{array}{l}\text { KUNSCH, Margarida Maria } \\
\text { Krohling (USP) }\end{array}$ & 9 & 0 & 0 & 1 & 7 & 0 & 0 & 19 & 2 & 1 & 0 & 0 & 0 & 0 & 0 & 0 & 2 & 0 & 41 & 0,8 \\
\hline $\begin{array}{l}\text { CAPPARELLI, Sérgio } \\
\text { (UFRGS) }\end{array}$ & 5 & 0 & 1 & 1 & 3 & 3 & 8 & 6 & 4 & 7 & 0 & 1 & 0 & 1 & 0 & 0 & 1 & 0 & 41 & 0,8 \\
\hline BENI, Mario Carlos (USP) & 37 & 0 & 0 & 0 & 0 & 0 & 0 & 2 & 0 & 0 & 0 & 0 & 0 & 0 & 0 & 0 & 0 & 0 & 39 & 0,8 \\
\hline $\begin{array}{l}\text { HOHLFELDT, Antonio } \\
\text { (PUCRS) }\end{array}$ & 6 & 3 & 0 & 1 & 2 & 0 & 0 & 15 & 2 & 4 & 0 & 0 & 2 & 0 & 1 & 0 & 0 & 1 & 37 & 0,6 \\
\hline $\begin{array}{l}\text { BUENO, Wilson da Costa } \\
\text { (UMESP) }\end{array}$ & 1 & 2 & 2 & 0 & 28 & 0 & 0 & 3 & 0 & 0 & 0 & 0 & 0 & 0 & 0 & 0 & 0 & 0 & 36 & 0,6 \\
\hline PALÁCIOS, Marcos (UFBA) & 5 & 0 & 3 & 1 & 1 & 1 & 15 & 0 & 5 & 2 & 0 & 1 & 1 & 0 & 0 & 0 & 0 & 0 & 35 & 0,7 \\
\hline KOSSOY, Boris (USP) & 15 & 0 & 0 & 7 & 0 & 2 & 2 & 0 & 1 & 0 & 0 & 0 & 4 & 0 & 0 & 0 & 4 & 0 & 35 & 0,7 \\
\hline MOREIRA, Sonia V. (UERJ) & 14 & 5 & 0 & 1 & 5 & 2 & 2 & 0 & 3 & 0 & 0 & 0 & 0 & 0 & 0 & 1 & 2 & 0 & 35 & 0,7 \\
\hline RAMOS, Fernão & 4 & 0 & 2 & 1 & 0 & 10 & 2 & 0 & 3 & 1 & 0 & 4 & 4 & 1 & 1 & 0 & 0 & 0 & 33 & 0,7 \\
\hline $\begin{array}{l}\text { CHAPARRO, Manuel Carlos } \\
\text { (USP) }\end{array}$ & 20 & 1 & 0 & 2 & 4 & 0 & 0 & 4 & 1 & 1 & 1 & 0 & 0 & 0 & 0 & 0 & 0 & 0 & 34 & 0,7 \\
\hline $\begin{array}{l}\text { RÜDIGER, Francisco } \\
\text { (PUCRS) }\end{array}$ & 1 & 0 & 1 & 0 & 1 & 1 & 2 & 18 & 4 & 1 & 1 & 0 & 2 & 0 & 0 & 0 & 0 & 1 & 33 & 0,7 \\
\hline
\end{tabular}


Observando-se a Tabela 7.19 com a relação de autores de PPGCOM mais citados, percebese que a maioria deles tem mais citações no próprio Programa do que em outros. Como já disse, a citação interna tem duas interpretações; além disso, pode sugerir, em outra perspectiva crítica, um reforço a características de isolamento entre o grupo. Porém, pelo fato de que os autores também chegam a obter o reconhecimento medido por citações em outros Programas, esse aspecto se atenua. A autora que recebeu mais citações em 2004 foi Santaella da PUCSP com 5,8\% das citações a autores de PPPGCOM, seguida por Machado (PUCSP) e Sodré (UFRJ), ambos com 3,7\% das citações a autores da área. Em seguida, perfazendo os cinco autores com maior número total de citações estão Melo (UMESP), com 2,4\%, e Lopes (USP), com 2,1\%.

Em função da característica saliente de citações internas entre os pesquisadores, é relevante observar o posicionamento dos autores dos PPGCOM, pela reclassificação dos mesmos, a partir dos índices de citações externas, o que é feito na Tabela 7.20, a seguir. 
Tabela 7.20- Citações a autores-docentes dos programas, por PPGCOM (2004), contagem com exclusão das auto-citações - autores mais citados

\begin{tabular}{|c|c|c|c|c|}
\hline PPGOMI Autor & $\begin{array}{l}\text { Citações } \\
\text { Internas }\end{array}$ & $\begin{array}{l}\text { Citações } \\
\text { Externas }\end{array}$ & $\begin{array}{l}\text { TOTAL } \\
\text { (n) }\end{array}$ & $\begin{array}{l}\text { Total }^{*}(\%)- \\
\text { Cit. externas }\end{array}$ \\
\hline SODRÉ, Muniz Sodré (UFRJ) & 42 & 138 & 180 & 2,8 \\
\hline SANTAELLA, Lúcia (PUCSP) & 162 & 122 & 284 & 2,5 \\
\hline MACHADO, Arlindo (PUCSP) & 62 & 121 & 183 & 2,5 \\
\hline MELO, José Marques de (UMESP) & 26 & 92 & 118 & 1,9 \\
\hline FAUSTO NETO, Antonio (UNISINOS) & 25 & 70 & 95 & 1,4 \\
\hline MARCONDES FILHO, Ciro (USP) & 28 & 68 & 96 & 1,4 \\
\hline XAVIER, Ismail (USP) & 28 & 63 & 91 & 1,3 \\
\hline BERNARDET Jean Claude G. R. (USP) & 14 & 56 & 70 & 1,2 \\
\hline TEIXEIRA COELHO, José (USP) & 39 & 52 & 91 & 1,1 \\
\hline PIGNATARI, Décio (UTP) & 2 & 51 & 53 & 1,0 \\
\hline GOMES, Wilson (UFBA) & 15 & 47 & 62 & 1,0 \\
\hline LOPES, Maria Immacolata Vassallo de (USP) & 58 & 45 & 103 & 0,9 \\
\hline IANNI, Octávio (USP) & 50 & 45 & 95 & 0,9 \\
\hline MORAES, Denis de (UFF) & 4 & 45 & 49 & 0,9 \\
\hline PARENTE, André (UFRJ) & 9 & 41 & 50 & 0,8 \\
\hline LEMOS, André (UFBA) & 21 & 38 & 59 & 0,8 \\
\hline MEDINA, Cremilda (USP) & 43 & 35 & 78 & 0,7 \\
\hline MOREIRA, Sonia Virginia (UERJ) & 0 & 35 & 35 & 0,7 \\
\hline BRAGA, José Luiz (UNISINOS) & 28 & 34 & 62 & 0,7 \\
\hline CAPPARELLI, Sérgio (UFRGS) & 7 & 34 & 41 & 0,7 \\
\hline PINTO, Milton José (UFRJ) & 14 & 33 & 47 & 0,7 \\
\hline KUNSCH, Margarida Maria Krohling (USP) & 9 & 32 & 41 & 0,7 \\
\hline PERUZZO, Cicilia Maria Krohling (UMESP) & 12 & 30 & 42 & 0,6 \\
\hline FRANÇA, Vera R. V. (UFMG) & 25 & 27 & 52 & 0,6 \\
\hline BAITELLO JUNIOR, Norval (PUCSP) & 56 & 24 & 80 & 0,5 \\
\hline RAMOS, Fernão (UNICAMP) & 10 & 23 & 33 & 0,5 \\
\hline HOHLFELDT, Antonio (PUCRS) & 15 & 22 & 37 & 0,5 \\
\hline KOSSOY, Boris (USP) & 15 & 20 & 35 & 0,4 \\
\hline PALÁCIOS, Marcos Silva (UFBA) & 15 & 20 & 35 & 0,4 \\
\hline FERRARA, Lucrecia D’Aléssio (PUCSP) & 24 & 18 & 42 & 0,4 \\
\hline SOARES, Ismar de Oliveira (USP) & 23 & 18 & 41 & 0,4 \\
\hline RÜDIGER, Francisco (PUCRS) & 18 & 15 & 33 & 0,3 \\
\hline CHAPARRO, Manuel Carlos (USP) & 20 & 14 & 34 & 0,3 \\
\hline BACCEGA, Maria Aparecida (USP) & 30 & 13 & 43 & 0,3 \\
\hline BUENO, Wilson da Costa (UMESP) & 28 & 8 & 36 & 0,2 \\
\hline SALLES, Cecília Almeida (PUCSP) & 53 & 5 & 58 & 0,1 \\
\hline OLIVEIRA, Ana Claudia Mei Alves de (PUCSP) & 43 & 3 & 46 & 0,1 \\
\hline BENI, Mario Carlos (USP) & 37 & 2 & 39 & 0,05 \\
\hline
\end{tabular}

* Percentual em relação ao total de citações a autores pertencentes a PPGCOM. 
Conforme observa-se na Tabela 7.20, com a contagem das citações internas, os quatro autores que receberam mais citações continuam os mesmos, mas a ordem se altera. Sodré passa a ser o autor com mais citações (2,8\% do total de citações a autores de PPGCOM), em seguida estão Santaella e Machado (ambos com 2,5\%) e Melo continua no quarto lugar, agora com 1,9\% das citações. Verifica-se que alguns autores têm um forte impacto local, mas não no ambiente extra o seu Programa. Mas há também um número expressivo de autores que consegue o oposto, adquirindo mais reconhecimento externo.

De qualquer forma, tendo em vista uma análise mais global sobre a circulação do conhecimento, a Tabela 7.21 destaca as influências entre os PPGCOM, realçando a circulação do capital científico representada pela citação aos autores nos âmbitos interno e externo dos Programas. 


\section{Tabela 7.21 - Influências / circulação do conhecimento entre os PPGCOM}

\begin{tabular}{|c|c|c|c|c|c|c|c|c|c|c|c|c|c|c|c|c|c|c|c|c|c|c|c|c|c|c|c|c|c|c|c|c|c|c|c|c|c|c|}
\hline \multirow{2}{*}{$\begin{array}{l}\text { PPGCOMI } \\
\text { PPGCOM } \\
\text { citados }\end{array}$} & \multicolumn{2}{|c|}{ USP } & \multicolumn{2}{|c|}{ UFRJ } & \multicolumn{2}{|c|}{ UNB } & \multicolumn{2}{|c|}{ PUCSP } & \multicolumn{2}{|c|}{ UMESP } & \multicolumn{2}{|c|}{ UNICAMP } & \multicolumn{2}{|c|}{ UFBA } & \multicolumn{2}{|c|}{ PUCRS } & \multicolumn{2}{|c|}{ UNISINOS } & \multicolumn{2}{|c|}{ UFRGS } & \multicolumn{2}{|c|}{ UFMG } & \multicolumn{2}{|c|}{ UFF } & \multicolumn{2}{|c|}{ UTP } & \multicolumn{2}{|c|}{ UFPE } & \multicolumn{2}{|c|}{ UNIP } & \multicolumn{2}{|c|}{ UNIMAR } & \multicolumn{2}{|c|}{ UNESP } & \multicolumn{2}{|c|}{ UERJ } & TO & \\
\hline & $\mathrm{n}$ & $\%$ & $\mathrm{n}$ & $\%$ & $\mathrm{n}$ & $\%$ & $\mathrm{n}$ & $\%$ & $\mathrm{n}$ & $\%$ & $n$ & $\%$ & $\mathrm{n}$ & $\%$ & $\mathrm{n}$ & $\%$ & $\mathrm{n}$ & $\%$ & $n$ & $\%$ & $\mathrm{n}$ & $\%$ & $\mathrm{n}$ & $\%$ & $\mathrm{n}$ & $\%$ & $\mathrm{n}$ & $\%$ & $\mathrm{n}$ & $\%$ & $n$ & $\%$ & $n$ & $\%$ & $\mathrm{n}$ & $\%$ & $\mathrm{n}$ & $\%$ \\
\hline USP & 797 & 67 & 30 & $\begin{array}{c}12, \\
1 \\
\end{array}$ & 39 & $\begin{array}{c}27, \\
1\end{array}$ & $\begin{array}{c}10 \\
0 \\
\end{array}$ & $\begin{array}{c}10, \\
8\end{array}$ & 74 & $\begin{array}{c}28, \\
4 \\
\end{array}$ & 48 & 40 & 48 & $\begin{array}{c}18, \\
3\end{array}$ & 90 & \begin{tabular}{|c|}
24, \\
6 \\
\end{tabular} & 69 & $\begin{array}{c}17, \\
8 \\
\end{array}$ & 25 & $\begin{array}{c}12, \\
2\end{array}$ & 22 & $\begin{array}{c}13 \\
8\end{array}$ & 29 & $\begin{array}{c}29, \\
9\end{array}$ & 24 & $\begin{array}{c}29, \\
6\end{array}$ & 18 & $\begin{array}{c}17, \\
8\end{array}$ & 17 & 18 & 1 & 6,7 & 21 & $\begin{array}{c}32, \\
3\end{array}$ & 3 & $\begin{array}{c}14, \\
3\end{array}$ & 1455 & 30,7 \\
\hline UFRJ & 51 & 4,5 & \begin{tabular}{|c|}
12 \\
6 \\
\end{tabular} & $\begin{array}{c}50, \\
8 \\
\end{array}$ & 15 & $\begin{array}{c}10, \\
4\end{array}$ & 68 & 7,3 & 10 & 3,8 & 16 & $\begin{array}{c}13, \\
3\end{array}$ & 40 & $\begin{array}{c}15, \\
2\end{array}$ & 11 & 3 & 38 & 9,8 & 16 & 7,8 & 15 & 9,4 & 21 & $\begin{array}{c}21, \\
7\end{array}$ & 3 & 3,7 & 5 & 5 & 9 & 9,6 & 1 & 6,7 & 4 & 6,2 & 3 & $\begin{array}{c}14, \\
3\end{array}$ & 452 & 9,5 \\
\hline UNB & 8 & 0,5 & 4 & 1,7 & 29 & $\begin{array}{c}20, \\
1\end{array}$ & 6 & 0,6 & 1 & 0,4 & 0 & 0 & 5 & 1,9 & 12 & 3,3 & 6 & 1,5 & 10 & 4,9 & 10 & 6,3 & 1 & 1 & 2 & 2,5 & 0 & 0 & 0 & 0 & 0 & 0 & 1 & 1,5 & 2 & 9,5 & 97 & 2 \\
\hline PUCSP & 121 & 10 & 29 & $\begin{array}{c}11, \\
7\end{array}$ & 15 & $\begin{array}{c}10, \\
4 \\
\end{array}$ & $\begin{array}{c}61 \\
4 \\
\end{array}$ & $\begin{array}{c}66, \\
2 \\
\end{array}$ & 12 & 4,6 & 8 & 6,7 & 16 & 6,1 & 19 & 5,2 & 35 & 9 & 5 & 2,4 & 12 & 7,5 & 2 & 2,1 & 22 & $\begin{array}{c}27, \\
1 \\
\end{array}$ & 26 & $\begin{array}{c}25, \\
7 \\
\end{array}$ & 19 & $\begin{array}{c}20, \\
2 \\
\end{array}$ & 0 & 0 & 11 & 17 & 4 & 19 & 970 & 20,5 \\
\hline UMESP & 56 & 4,5 & 7 & 2,8 & 14 & 9,7 & 19 & 2,1 & 117 & $\begin{array}{c}44, \\
8 \\
\end{array}$ & 1 & 0,8 & 7 & 2,7 & 35 & 9,6 & 15 & 3,9 & 11 & 5,4 & 4 & 2,5 & 0 & 0 & 2 & 2,5 & 9 & 8,9 & 2 & 2,1 & 3 & 20 & 8 & $\begin{array}{c}12, \\
3\end{array}$ & 0 & 0 & 310 & 6,5 \\
\hline UNICAMP & 13 & 1 & 0 & 0 & 5 & 3,5 & 12 & 1,3 & 4 & 1,5 & 29 & $\begin{array}{c}24, \\
2 \\
\end{array}$ & 12 & 4,6 & 2 & 0,5 & 4 & 1 & 1 & 0,5 & 1 & 0,6 & 6 & 6,2 & 6 & 7,4 & 5 & 4,9 & 2 & 2,1 & 0 & 0 & 0 & 0 & 0 & 0 & 102 & 2,1 \\
\hline UFBA & 16 & 1,5 & 2 & 0,8 & 7 & 4,8 & 11 & 1,2 & 2 & 0,8 & 3 & 2,5 & 75 & $\begin{array}{c}28, \\
5\end{array}$ & 15 & 4,1 & 33 & 8,5 & 25 & $\begin{array}{c}12, \\
2\end{array}$ & 8 & 5 & 7 & 7,2 & 3 & 3,7 & 2 & 2 & 0 & 0 & 0 & 0 & 1 & 1,5 & 0 & 0 & 210 & 4,4 \\
\hline PUCRS & 20 & 1,5 & 13 & 5,3 & 4 & 2,8 & 8 & 0,9 & 5 & 1,9 & 1 & 0,8 & 6 & 2,3 & $\begin{array}{c}12 \\
4\end{array}$ & $\begin{array}{c}33, \\
9\end{array}$ & 16 & 4,1 & 20 & 9,7 & 2 & 1,3 & 0 & 0 & 7 & 8,6 & 2 & 2 & 1 & 1,1 & 0 & 0 & 0 & 0 & 2 & 9,5 & 231 & 4,9 \\
\hline UNISINOS & 13 & 1 & 18 & 7,2 & 6 & 4,2 & 19 & 2,1 & 6 & 2,3 & 1 & 0,8 & 8 & 3 & 14 & 3,8 & $\begin{array}{c}12 \\
0\end{array}$ & 31 & 32 & $\begin{array}{c}15, \\
6\end{array}$ & 19 & 12 & 2 & 2,1 & 2 & 2,5 & 6 & 5,9 & 1 & 1,1 & 0 & 0 & 2 & 3,1 & 1 & 4,8 & 270 & 5,7 \\
\hline UFRGS & 18 & 1,5 & 2 & 0,8 & 1 & 0,7 & 5 & 0,5 & 6 & 2,3 & 3 & 2,5 & 10 & 3,8 & 24 & 6,5 & 12 & 3,1 & 44 & $\begin{array}{c}21, \\
5\end{array}$ & 4 & 2,5 & 1 & 1 & 2 & 2,5 & 2 & 2 & 0 & 0 & 0 & 0 & 1 & 1,5 & 0 & 0 & 135 & 2,8 \\
\hline UFMG & 6 & 0,5 & 1 & 0,4 & 0 & 0 & 3 & 0,3 & 1 & 0,4 & 2 & 1,7 & 4 & 1,5 & 8 & 2,2 & 6 & 1,5 & 6 & 2,9 & 51 & $\begin{array}{c}32, \\
1\end{array}$ & 1 & 1 & 1 & 1,2 & 2 & 2 & 0 & 0 & 0 & 0 & 0 & 0 & 1 & 4,8 & 93 & 2,0 \\
\hline UFF & 15 & 1 & 7 & 2,8 & 3 & 2,1 & 5 & 0,5 & 2 & 0,8 & 3 & 2,5 & 18 & 6,8 & 7 & 1,9 & 18 & 4,7 & 6 & 2,9 & 1 & 0,6 & 25 & $\begin{array}{c}25, \\
8\end{array}$ & 2 & 2,5 & 1 & 1 & 4 & 4,2 & 0 & 0 & 0 & 0 & 0 & 0 & 117 & 2,5 \\
\hline UTP & 9 & 1 & 0 & 0 & 1 & 0,7 & 25 & 2,7 & 1 & 0,4 & 1 & 0,8 & 2 & 0,8 & 0 & 0 & 2 & 0,5 & 0 & 0 & 1 & 0,6 & 0 & 0 & 2 & 2,5 & 9 & 8,9 & 1 & 1,1 & 0 & 0 & 7 & $\begin{array}{c}10, \\
8 \\
\end{array}$ & 0 & 0 & 61 & 1,3 \\
\hline UFPE & 3 & 0,5 & 1 & 0,4 & 0 & 0 & 1 & 0,1 & 0 & 0 & 0 & 0 & 4 & 1,5 & 0 & 0 & 7 & 1,8 & 1 & 0,5 & 2 & 1,3 & 0 & 0 & 0 & 0 & 10 & 9,9 & 0 & 0 & 0 & 0 & 0 & 0 & 0 & 0 & 29 & 0,6 \\
\hline UNIP & 18 & 1,5 & 2 & 0,8 & 1 & 0,7 & 18 & 1,9 & 1 & 0,4 & 2 & 1,7 & 0 & 0 & 0 & 0 & 0 & 0 & 1 & 0,5 & 2 & 1,3 & 1 & 1 & 1 & 1,2 & 3 & 3 & 31 & 33 & 7 & $\begin{array}{c}46, \\
6\end{array}$ & 1 & 1,5 & 0 & 0 & 84 & 1,8 \\
\hline UNIMAR & 1 & 0 & 0 & 0 & 1 & 0,7 & 0 & 0 & 3 & 1,1 & 0 & 0 & 0 & 0 & 0 & 0 & 0 & 0 & 0 & 0 & 0 & 0 & 0 & 0 & 0 & 0 & 0 & 0 & 0 & 0 & 2 & $\begin{array}{c}13, \\
3\end{array}$ & 1 & 1,5 & 0 & 0 & 8 & 0,2 \\
\hline UNESP & 3 & 0,5 & 0 & 0 & 0 & 0 & 11 & 1,2 & 5 & 1,9 & 0 & 0 & 1 & 0,4 & 4 & 1,1 & 0 & 0 & 1 & 0,5 & 2 & 1,3 & 0 & 0 & 2 & 2,5 & 0 & 0 & 3 & 3,2 & 0 & 0 & 5 & 7,7 & 0 & 0 & 37 & 0,8 \\
\hline UERJ & 16 & 1,5 & 5 & 2 & 0 & 0 & 2 & 0,2 & 10 & 3,8 & 2 & 1,7 & 4 & 1,5 & 0 & 0 & 3 & 0,8 & 0 & 0 & 0 & 0 & 0 & 0 & 0 & 0 & 0 & 0 & 1 & 1,1 & 1 & 6,7 & 2 & 3,1 & 1 & 4,8 & 47 & 1,0 \\
\hline PUCRJ & 8 & 0,5 & 1 & 0,4 & 3 & 2,1 & 1 & 0,1 & 1 & 0,4 & 0 & 0 & 3 & 1,1 & 1 & 0,3 & 4 & 1 & 1 & 0,5 & 3 & 1,9 & 1 & 1 & 0 & 0 & 1 & 1 & 3 & 3,2 & 0 & 0 & 0 & 0 & 4 & 19 & 35 & 0,7 \\
\hline TOTAL & 1192 & 100 & 248 & 100 & 144 & 100 & 928 & 100 & 261 & 100 & 120 & 100 & 263 & 100 & 366 & 100 & 388 & 100 & 205 & 100 & 159 & 100 & 97 & 100 & 81 & 100 & 101 & 100 & 94 & 100 & 15 & 100 & 65 & 100 & 21 & 100 & 4741 & 100 \\
\hline
\end{tabular}


Dois aspectos importantes a serem notados na Tabela 7.21 são o somatório das citações internas que é possível fazer, resultando num total de 2.206 citações, que representam um percentual de 47,7\% do total das referências feitas aos pesquisadores dos PPGCOM. As citações externas são portanto 52,3\%. Há um equilíbrio entre citações externas e internas e quando se nota que os Programas que possuem mais autores entre os mais citados são geralmente mais influentes que os novos e, ao mesmo tempo, tem índices expressivos de citações internas esses dados parecem possuir correlação. Por outro lado, poder-se-ia apontar uma série de jovens lideranças da pesquisa, em posições intermediárias. Elas disputam o capital científico nesse momento e, assim, é possível pensar que ocorre uma competição positiva do ponto de vista da estruturação do campo científico em Comunicação.

De outro lado, seria interessante refletir sobre o papel “transversal” e conformador da áera dos autores mais citados pelas Teses e Dissertações e as implicações em termos de interação científica disso. Optamos por desenvolver uma estratégia distribuindo as citações pelas subáreas, nas quais, na análise podemos voltar ao tema dos “programas de pesquisa”. Assim, a Tabelas 7.22, 7.23 e 7.24 irão mostrar esse aspecto. 
Tabela 7.22 - Autores dos PPGCOM mais citados por subáreas da Comunicação

\begin{tabular}{|c|c|c|c|c|c|c|c|c|c|c|c|}
\hline \multicolumn{2}{|c|}{$\begin{array}{l}\text { Cibercultura e } \\
\text { Tecnologias da } \\
\text { Comunicação } \\
\end{array}$} & \multicolumn{2}{|c|}{$\begin{array}{l}\text { Comunicação Audiovisual: } \\
\text { Cinema, Rádio e TV }\end{array}$} & \multicolumn{2}{|c|}{$\begin{array}{c}\text { Comunicação } \\
\text { Organizacional, Relações } \\
\text { Públicas e Propaganda }\end{array}$} & \multicolumn{2}{|c|}{ Jornalismo e Editoração } & \multicolumn{2}{|c|}{$\begin{array}{l}\text { Mediações e Interfaces } \\
\text { Comunicacionais }\end{array}$} & \multicolumn{2}{|c|}{ Teorias da Comunicação } \\
\hline Autor & cit. & Autor & cit. & Autor & cit. & Autor & cit. & Autor & cit. & Autor & cit. \\
\hline Santaella, Lúcia & 58 & Machado, Arlindo & 124 & Santaella, Lúcia & 49 & Sodré, Muniz & 78 & Santaella, Lúcia & 131 & Santaella, Lúcia & 29 \\
\hline Lemos, André & 53 & Santaella, Lúcia & 116 & Machado, Arlindo & 29 & Medina, Cremilda & 62 & Sodré, Muniz & 115 & Lopes, Maria Immacolata V. & 19 \\
\hline Machado, Arlindo & 39 & Xavier, Ismail & 88 & Kunsch, Margarida M. K. & 26 & Melo, José Marques de & 62 & Lopes, M. Immacolata V. & 71 & Melo, José Marques de & 19 \\
\hline Palácios, Manuel & 28 & Bernadet, Jean Claude & 69 & Teixeira Coelho, José & 25 & Marcondes Filho, Ciro & 55 & Fausto Neto, Antônio & 70 & Baitello, Norval & 17 \\
\hline Moraes, Denis de & 19 & Sodré, Muniz & 63 & Oliveira, Ana Cláudia Mei & 24 & Fausto Neto, Antônio & 49 & Ianni, Octavio & 58 & Fausto Neto, Antônio & 10 \\
\hline Sodré, Muniz & 19 & Lopes, M. Immacolata V. & 61 & Simões, Roberto Porto & 20 & Chaparro, Manuel Carlos & 33 & Melo, José Marques de & 51 & Pinto, Milton José & 9 \\
\hline Marcondes FIlho, Ciro & 18 & lanni, Octavio & 46 & Lopes, M. Immacolata V. & 17 & Santaella, Lúcia & 29 & Teixeira Coelho, José & 51 & Rudiger, Francisco & 9 \\
\hline Parente, André & 16 & Teixeira Coelho, José & 37 & Fausto Neto, Antônio & 16 & Pinto, Milton José & 22 & Baitello, Norval & 48 & Sodré, Muniz & 7 \\
\hline Bairon, Sérgio & 14 & Braga, José Luiz & 33 & Melo, José Marques de & 16 & Ianni, Octavio & 21 & Gomes, Wilson & 47 & Ballogh, Ana Maria & 6 \\
\hline Ianni, Octavio & 14 & Parente, André & 33 & Rocha, Everardo & 16 & Machado, Arlindo & 21 & Machado, Arlindo & 46 & Bernadet, Jean Claude & 6 \\
\hline Ferreira, Maria Nazaré & 13 & Ramos, Fernão & 33 & Ianni, Octavio & 14 & Palácios, Manuel & 20 & Beni, Mário Carlos & 42 & Capparelli, Sérgio & 6 \\
\hline Machado, Elias & 12 & Melo, José Marques de & 30 & Sodré, Muniz & 14 & Hohfeldt, Antônio & 19 & Braga, José Luiz & 41 & Escosteguy, Ana Carolina & 6 \\
\hline Vaz, Paulo R.G. & 12 & Marcondes Filho, Ciro & 29 & Gomes, Wilson & 13 & Kucinski, Bernardo & 19 & Marcondes F, Ciro & 39 & Hohfeldt, Antônio & 6 \\
\hline Vigneron, Jacques & 11 & Campedelli, Samira Y. & 27 & Brittos, Valério Cruz & 12 & Squira, Sebastião & 19 & Salles, Cecília de A. & 39 & Ianni, Octavio & 6 \\
\hline Adghirni, Zélia Leal & 10 & Kossoy, Boris & 27 & França, Vera V. & 12 & Motta, Luiz Gonzaga & 18 & Soares, Ismar de O. & 39 & Stumpf, Ida Regina & 6 \\
\hline Gomes, Wilson & 10 & Moreira, Sonia Virgínia & 27 & & & & & & & Xavier, Ismail & 6 \\
\hline Medina, Cremilda & 10 & Pignatari, Décio & 27 & & & & & & & & \\
\hline Melo, José Marques de & 10 & & & & & & & & & & \\
\hline
\end{tabular}

\section{Legenda:}

Autor Citado em 6 subáreas

Autor Citado em 3 subáreas

Autor Citado em 5 subáreas

Autor Citado em 2 subáreas

Autor Citado em 4 subáreas

Autor Citado em 1 subárea 
Estabelecemos como critérios para a seleção desses líderes de pesquisa a coleta do autor até o $15^{\circ}$ lugar entre os mais citados, quando há empate no final, aumenta-se o número de autores, e estabelecemos um mínimo de 5 citações para a inserção nesse grupo.

Em relação aos autores dos PPGCOM, aspecto central a essa tese, pode-se observar, de acordo com os dados da Tabela 7.22 que existe autores com grande capacidade de obter reconhecimento em todas às subáreas, são eles: Santaella, Sodré, Ianni e Mello. Estes pesquisadores estão entre os mais citados em todas as subáreas. Logo a seguir, Machado está posicionado em 5 áreas, a seguir os autores que aparecem em 4 das subáreas são: Marcondes Filho, Lopes e Fausto Neto. Em três subáreas pelo menos: Gomes, Teixeira Coelho, e em duas: Palácios, Parente, Medina, Xavier, Bernardet, Braga, Pinto, Hohfeldt e Baitello Júnior.

É possível pressupor, a partir dos indicadores analisados, que estes pesquisador estão, em posições mais ou menos dominantes constituindo o núcleo disciplinar da Comunicação no Brasil. A idéia de "programa de pesquisa” tornar-se-ia mais clara se houvesse um conjunto muito típico de autores muito citados, mas numa única subárea, isso só ocorre parcialmente, com Lemos, Kunsch e Chaparro. Apesar disso, muitos autores de Comunicação Visual estão nela e apenas em mais uma, o que é o caso de Xavier e Bernardet que são líderes da pesquisa na área de cinema, área que talvez constitua um “programa” nos termos exposto..

Por outro lado, é muito importante destacar que a transversalidade de muitos autores dá uma espécie de “unidade” à área de estudos, que reforça o sentido do campo.

Agora, finalizando essa análise e dirigindo-se para as conclusões da tese, veremos como os outros autores nacionais e os estrangeiros aparecem nas subáreas. 
Tabela 7.23 - Autores nacionais mais citados por subáreas da Comunicação

\begin{tabular}{|c|c|c|c|c|c|c|c|c|c|c|c|}
\hline \multicolumn{2}{|l|}{$\begin{array}{l}\text { Cibercultura e } \\
\text { Tecnologias da } \\
\text { Comunicação }\end{array}$} & \multicolumn{2}{|c|}{$\begin{array}{l}\text { Comunicação Audiovisual: } \\
\text { Cinema, Rádio e TV }\end{array}$} & \multicolumn{2}{|c|}{$\begin{array}{c}\text { Comunicação } \\
\text { Organizacional, Relações } \\
\text { Públicas e Propaganda }\end{array}$} & \multicolumn{2}{|c|}{ Jornalismo e Editoração } & \multicolumn{2}{|c|}{$\begin{array}{l}\text { Mediações e Interfaces } \\
\text { Comunicacionais }\end{array}$} & \multicolumn{2}{|c|}{ Teorias da Comunicação } \\
\hline Autor & cit. & Autor & cit. & Autor & cit. & Autor & cit. & Autor & cit. & Autor & cit. \\
\hline Freire, Paulo & 14 & Ortiz, Renato & 79 & Torquato do Rego, F. G. & 25 & Orlandi, Eni & 54 & Ortiz, Renato & 70 & Bosi, Ecléa & 5 \\
\hline Santos, Milton & 13 & Orlandi, Eni & 39 & Orlandi, Eni & 23 & Lage, Nilson & 48 & Orlandi, Eni & 62 & Ortiz, Renato & 5 \\
\hline Leão, Lúcia & 12 & Boreli, Silvia & 37 & Pinho, José Benedito & 22 & Ortiz, Renato & 31 & Freire, Paulo & 61 & & \\
\hline Medistsch, Eduardo & 12 & Gomes, Paulo Emílio S. & 33 & Barros, Diana P. L. & 20 & Bucci, Eugênio & 29 & Santos, Milton & 52 & & \\
\hline Ortriwano, Gisela & 12 & Bolaño. César R. S. & 25 & Fiorin, José Luiz & 18 & Meditsch, Eduardo & 29 & Rubim, Antonio A. C. & 51 & & \\
\hline Plaza, Júlio & 11 & Chauí, Marilena & 25 & Gracioso, Francisco & 15 & Beltrão, Luiz & 22 & Chauí, Marilena & 43 & & \\
\hline Prado, Gilberto & 11 & Freire, Paulo & 25 & Ortiz, Renato & 14 & Dines, Alberto & 22 & Campos, Haroldo & 40 & & \\
\hline Campos, Haroldo de & 10 & Bucci, Eugênio & 22 & Andrade, Candido T. & 12 & Sodré, Nelson Werneck & 19 & Fiorin, José Luiz & 37 & & \\
\hline Mielniczuh, Luciana & 9 & Da Matta, Roberto & 22 & Freire, Paulo & 11 & Bahia, Juarez & 18 & Demo, Pedro & 31 & & \\
\hline Ortiz, Renato & 9 & Pallotini, Renata & 22 & Sampaio, Rafael & 10 & Lins e Silva, Carlos E. & 18 & Barros, Diana P. L. & 27 & & \\
\hline Lage, Nilson & 8 & Rubim, Antonio Albino C. & 20 & Giacomini Filho, Gino & 9 & Moretzsohn, Sylvia & 17 & Da Matta, Roberto & 27 & & \\
\hline Bolaño. César R. S. & 6 & Bosi, Alfredo & 16 & Cobra, Marcos & 8 & Arbex, José & 16 & Morán, José Manuel & 22 & & \\
\hline Rubim, Antonio Albino C. & 7 & Bosi, Ecléa & 16 & Santos, Milton & 8 & Rubim, Antonio Albino C. & 16 & Boreli, Silvia & 21 & & \\
\hline Torquato do Rego, F. G. & 7 & Candido, Antonio & 16 & Bolaño. César R. S. & 7 & Amaral, Luis & 15 & Bosi, Ecléa & 20 & & \\
\hline Beltrão, Luiz & 6 & Plaza, Júlio & 16 & Fleury, Maria Tereza L. & 7 & Fiorin, José Luiz & 15 & Bucci, Eugênio & 20 & & \\
\hline \multirow[t]{2}{*}{ Chauí, Marilena } & 6 & & & Carvalho, Nelly de & 7 & & & Trigo, Luciano G. G. & 20 & & \\
\hline & & & & Guareschi, Pedrinho & 7 & & & & & & \\
\hline
\end{tabular}

\section{Legenda:}

Autor Citado em 6 subáreas

Autor Citado em 3 subáreas

Autor Citado em 5 subáreas

Autor Citado em 2 subáreas

Autor Citado em 4 subáreas

Autor Citado em 1 subárea 
Os autores nacionais não pertencentes aos PPGCOM, no todo são menos transversais às subáreas que os autores de PPGCOM. Apenas um aparece em todas as subáreas (Ortiz), por outro lado mantiveram-se nessa recategorização dos dados os autores que realmente podem também ser visto como pertencentes ao campo da Comunicação, caso de Rubim, que aparece em 5 subáreas. Destacável também é o agrupamento de autores que aparecem apenas na área de jornalismo, o que pode indicar, tanto o apoio de uma bibliografia especializada, quanto elementos de um “programa de pesquisa”. De outro lado, mantém-se em destaque autores pertencentes a áreas diversas das ciências humanas, como Freire, Orlandi e outros. 
Tabela 7.24 - Autores estrangeiros mais citados por subáreas da Comunicação

\begin{tabular}{|c|c|c|c|c|c|c|c|c|c|c|c|}
\hline \multicolumn{2}{|l|}{$\begin{array}{l}\text { Cibercultura e } \\
\text { Tecnologias da } \\
\text { Comunicação }\end{array}$} & \multicolumn{2}{|c|}{$\begin{array}{l}\text { Comunicação Audiovisual: } \\
\text { Cinema, Rádio e TV }\end{array}$} & \multicolumn{2}{|c|}{$\begin{array}{c}\text { Comunicação } \\
\text { Organizacional, Relações } \\
\text { Públicas e Propaganda }\end{array}$} & \multicolumn{2}{|c|}{ Jornalismo e Editoração } & \multicolumn{2}{|c|}{$\begin{array}{l}\text { Mediações e Interfaces } \\
\text { Comunicacionais }\end{array}$} & \multicolumn{2}{|c|}{ Teorias da Comunicação } \\
\hline Autor & cit. & Autor & cit. & Autor & cit. & Autor & cit. & Autor & cit. & Autor & cit. \\
\hline Lévy, Pierre & 142 & Barthes, Roland & 104 & Morin, Edgar & 76 & Morin, Edgar & 90 & Morin, Edgar & 202 & Morin, Edgar & 26 \\
\hline Castells, Manuel & 67 & Eco, Umberto & 99 & Baudrillard, Jean & 46 & Barthes, Roland & 79 & Bourdieu, Pierre & 132 & Pierce, Charles S. & 22 \\
\hline Mcluhan, Marshal & 41 & Morin, Edgar & 95 & Kotler, Philip & 41 & Foucault, Michel & 71 & Foucault, Michel & 131 & Eco, Umberto & 17 \\
\hline Foucault, Michel & 28 & Martín Barbero, Jesús & 85 & Bourdieu, Pierre & 40 & Bourdieu, Pierre & 65 & Lévy, Pierre & 129 & Wolton, Dominique & 15 \\
\hline Habermas, Jurgen & 27 & Aumont, Jacques & 71 & Greimas, Algirdas & 36 & Eco, Umberto & 48 & Canclini, Nestor G. & 121 & Foucault, Michel & 14 \\
\hline Eco, Umberto & 25 & Bourdieu, Pierre & 69 & Lévy, Pierre & 34 & Traquina, Nelson & 46 & Martín-Barbero, J. & 118 & Barthes, Roland & 12 \\
\hline Deleuze, Gilles & 24 & Benjamim, Walter & 68 & Barthes, Roland & 29 & Veron, Eliseo & 43 & Deleuze, Gilles & 117 & Maffesoli, Michel & 11 \\
\hline Martín-Barbero, Jesús & 24 & Canclini, Nestor García & 66 & Foucault, Michel & 28 & Bahktin, Mikhail & 40 & Barthes, Roland & 107 & Bordwell, David & 10 \\
\hline Morin, Edgar & 24 & Hall, Stuart & 66 & Castells, Manuel & 25 & Martín-Barbero, Jesús & 40 & Hall, Stuart & 98 & Hall, Stuart & 10 \\
\hline Wolton, Dominique & 24 & Bahktin, Mikhail & 65 & Eco, Umberto & 25 & Lévy, Pierre & 35 & Eco, Umberto & 91 & Jameson, Fredric & 10 \\
\hline Johnson, Steven & 22 & Adorno, Theodor & 59 & Landowski, Eric & 25 & Hall, Stuart & 34 & Baudrillard, Jean & 89 & Marcuse, Herbert & 10 \\
\hline Negroponte, Nicholas & 22 & Deleuze, Gilles & 58 & Lipovetisky, Gilles & 24 & Canclini, Nestor García & 33 & Castells, Manuel & 85 & Martín-Barbero, Jesús & 10 \\
\hline Canclini, Nestor García & 19 & Foucault, Michel & 48 & Mattelart, Armand & 24 & Souza, Jorge Pedro & 33 & Bahktin, Mikhail & 84 & Lacan, Jacques & 9 \\
\hline Hall, Stuart & 18 & Mattelart, Armand & 45 & Canclíni, Nestor García & 21 & Wolf, Mauro & 33 & Benjamin, Walter & 77 & Mattelart, Armand & 9 \\
\hline \multirow[t]{2}{*}{ Maffesoli, Michel } & 18 & Lévy, Pierre & 42 & Rodrigues, Adriano D. & 20 & Castells, Manuel & 31 & Guattari, Felix & 73 & Williams, Raymond & 9 \\
\hline & & & & & & & & Mattelart, Armand & 73 & & \\
\hline
\end{tabular}

\section{Legenda:}

Autor Citado em 6 subáreas

Autor Citado em 3 subáreas

Autor Citado em 5 subáreas

Autor Citado em 2 subáreas

Autor Citado em 4 subáreas

Autor Citado em 1 subárea 
Em relação aos autores estrangeiros citados pelas Teses e Dissertações dos PPGCOM, nota-se algo similar ao que ocorre com os pesquisadores dos PPGCOM citados, ou seja, vários autores aparecem em muitas subáreas. Assim, Foucault, Eco e Morin estão nas 6, Lévy, Martín-Barbero (o mais citado nas bibliografias dos PPGCOM de 2006), Hall, Barthes, Canclini; em 4, estão Castells, Bourdieu e Mattelart em 5. Ainda, Deleuze e Bakhtin aparecem em duas subáreas. Bem menos autores aparecem somente em uma ou duas subáreas.

Ora, assim, reforça-se ainda mais um possível modo de constituição interdisciplinar da Comunicação como campo científico? Ou o que se visualiza é, sobretudo, a dependência e falta de contato com pesquisadores em Comunicação de outros países, com os quais o grupo poderia interagir, talvez de modo mais produtivo. Esse falta de contato seria expressa aqui pelos dados que mostram que os autores mais citados não são, na maioria, “tipicamente comunicacionais”.Embora a expressão seja um tanto problemática, creio que é possível dizer que autores muito citados e que aparecem em várias subáreas, como Martín-Barbero, Mattelart e Canclini possuem um relacionamento mais próximo com a Comunicação do que outros.

A questão de como se dá a incorporação dos autores ao "léxico" da Comunicação e demandaria uma abordagem mais qualitativa do que a nossa, porém, nossa pesquisa sugere hipóteses e indagações a esse respeito.

Finalmente, nas Conclusões finais do trabalho, faço uma recapitulação dos pontos mais relevantes para falar sobre o campo, sob o ponto de vista do modelo de interação que nos serve de instrumento. 


\section{Conclusões finais}

Agora iremos retomar as hipóteses e formular nossas conclusões a respeito do estudo

- A primeira hipótese era de que se estruturou, ao menos parcialmente, um campo científico da Comunicação no Brasil.

A partir do modelo de interação de Galtung, em sua articulação com a análise do capital científico, principalmente, afirmamos que essa hipótese se confirma. De uma situação no qual existiam poucos autores dedicados à temática e que obtinham reconhecimento do grupo, passamos hoje a um estágio no qual o campo passou a ser preenchido por pesquisadores que têm obtido reconhecimento e interagido com seus pares.

As disputas pela definição da especificidade do conhecimento em Comunicação, mais ou menos "aberto", seguindo debates que ocorrem no contexto amplo da ciência parecem interessar mais aos investigadores.

- Daí, um aumento volume do debate sobre a "natureza” do campo e uma maior atenção ao mesmo.

Tal aspecto faz com que nossa primeira hipótese específica, de que a preocupação com a legitimidade do campo favorece os fundamentos científicos dos mesmo, também seja vista como verdade. Com efeito, observamos que a discussão tem se dado sem que se projete um modelo de interação “conflitivo-destrutiva”, ou seja, ocorre nos espaços institucionais nos quais a Comunicação se inseriu (órgãos governamentais de apoio à $\mathrm{C} \& \mathrm{~T}$ ) e naquelas que o grupo tem engendrado (Associações de Pesquisadores, Grupos de Pesquisa, Seminários etc.) para interaturar, e o debate ocorre a partir de critérios em que a procura de uma racionalidade tem se dado com freqüência.

- A segunda hipótese específica era a de que existe um acúmulo de capital científico produzido no campo da Comunicação no país. 
Como já se observou, a respeito da hipótese mais ampla, isso também é verdade. Mas esse aspecto merece mais estudos a respeito da natureza deste conhecimento. Num primeiro aspecto, seria importante compreener melhor o acentuado de capital científico que circula em âmbitos restritos, ou seja, as citações que um PPGCOM faz a si mesmo. O tema é complexo, e embora o capital obtido por esses PPGCOM, sobretudo os mais antigos, externamente tenda a ser mais maior, esse é um ponto que merece análise. É um elemento talvez se modifique com o tempo, a partir naturalmente das disputas dos agentes pelo capital científico e pela definição do conceito de ciência adotado pela área. Nota-se, porém, que o padrão do capital científico voltado a autores estrangeiros indica, de um lado, clara preferência pelo contexto europeu de pesquisa, de outro lado, traz elementos para a reflexão sobre o caráter trans/inter/disciplicinar do campo. Isso poderá ser visto e discutido, no campo científico que se configura, positiva ou negativamente.

- Quanto à terceira hipótese secundária, de que o padrão de interação assumido pelos pesquisadores da área da Comunicação tem um perfil de “conflito-construtivo”, acreditamos que os elementos mostrados até agora justificam a confirmação dessa hipótese.

- Naturalmente não chegamos a perceber um paradigma dominante na área e mesmo em relação à quinta hipótese específica, de que seria possível perceber, pela análise do capital científico referente às citações, a existência de determinados "programas de pesquisa”, pensamos que isso não se confirmou

Talvez porém isso tenha ocorrido por uma operacionalização do conceito menos interessante do que poderia ser, por exemplo, infelizmente não realizamos nesse estudo análises de co-citações que, talvez, pudessem indicar melhor possíveis zonas de confluência capazes de representarem os chamados "programas de pesquisa”.

- Por fim, a última hipótese específica, de que existe uma circulação de capital científico na área é provada pelo fato de que, percentualmente 52,3\% do índice de citações a autores de PPGCOM é externa, ou seja, um Programa interatuando com outro, reconhecendo, seja por meio da crítica ou da aprovação de propostas. 
Concluindo, diríamos que os dados bibliométricos que geramos poderiam e devem ser melhor explorados, por exemplo, em análises de co-citações ou em representações gráficas dos domínios científicos que os possíveis agrupamentos de citações indiquem. No entanto isso será feito por nós, em outra oportunidade, ou por outros pesquisadores.

Ao mesmo tempo, temos especial interesse que outros pesquisadores critiquem e aperfeiçoem o modelo de análise de campos científicos aqui exposto. No nosso entender ele tem muitos aspectos positivos e foi - sobretudo a partir da incorporação do modelo de interação dos grupos articulado com a proposta de campo de Bourdieu - de muita utilidade para guiar o olhar sobre os dados, tornando mais operacionais certas dimensões do suposto (espero que, agora, não tanto assim) campo da Comunicação. 


\section{Referências Bibliográficas}

ANSALDI, Waldo. 1991. La búsqueda de América Latina. Facultad de Ciencias Sociales (UBA), Buenos Aires. Disponível em: $<$ http://www.catedras.fsoc.uba.ar/udishal/art/busqueda_de_al.pdf $>$. Acesso em 18 nov. 2006.

ARAÚJO, Carlos Alberto Ávila. 2005. Análise temática da produção científica em comunicação no Brasil baseada em um sistema classificatório facetado. Tese em Ciência da Informação. Belo Horizonte, UFMG.

.2003. Contribuições da classificação facetada no mapeamento do campo da Comunicação. XIII ENDOCOM, Belo Horizonte.

ARRUDA, Maria Arminda do Nascimento. 2001. A modernidade possível: cientistas e Ciências Sociais em Minas Gerais. In: MICELI, Sergio. História das Ciências Sociais no Brasil. São Paulo, Sumaré/ FAPESP, v. 1, 2ª ed., pp. 277-368.

ASSIS, Jesus de Paula. 1993. Kuhn e as ciências sociais. Estudos Avançados, vol. 7, n. 19, pp. 133-64.

BACHELARD, Gaston. 1996. A formação do espírito científico. Rio de Janeiro, Contraponto ( $1^{\mathrm{a}}$ ed. 1938).

.1988. O novo espírito científico. São Paulo, Nova Cultural (Col. Os Pensadores - Bachelard) ( $1^{\text {a }}$ ed. 1934).

.1988a. A poética do espaço. São Paulo, Nova Cultural (Col. Os Pensadores - Bachelard) ( $1^{\text {a }}$ ed. 1957).

BARATA, Rita Barradas, GOLDBAUM, Moisés. 2003. Perfil dos pesquisadores com bolsa de produtividade em pesquisa do $\mathrm{CNPq}$ da área de saúde coletiva. Cad. Saúde Pública. Nov./Dec., vol.19, no.6 [cited 03 January 2006], pp.1863-1876. Disponível em:

$<$ http://www.scielo.br/ scielo.php?script=sci_arttext\&pid=S0102311X2003000600031\&lng=en\&nrm=isso $>$. Acesso em $1^{\circ}$ nov. 2005.

BARROS, Laan Mendes de. 2003. Para que pesquisar? Comunicação: uma ciência social aplicada. In: LOPES, Maria Immacolata V. (org.). Epistemologia da Comunicação. São Paulo, Loyola, pp. 227-41.

BARROS FILHO, Clóvis e SÁ, Luís Mauro Sá. 2004. O habitus da comunicação. São Paulo, Paulus.

BAUER, Martin W. 2002. Análise de conteúdo clássica: uma revisão. In: $\mathrm{e}$ GASSKELL, George (orgs.). Pesquisa qualitativa com texto, imagem e som: um manual prático. Petrópolis, Vozes, pp. 189-217.

BONELLI, Maria da Gloria. 1993. As Ciências Sociais no sistema profissional brasileiro. BIB - Boletim Informático e Bibliográfico de Ciências Sociais. Rio de Janeiro, n. 36, $2^{\circ}$. Semestre, pp. 31-61.

BORTOLOZZI, Flávio e BERGMANN, José Ricardo. S.d. Subsídios para os modelos de Pós-Graduação.

CAPES/MEC.

Disponível

em 
$<$ http://www.capes.gov.br/capes/portal/conteudo/

SubsidiosModelos_PG_PNPG_Bergmann_Bortolozzi.pdf> Acesso 20 nov. 2005.

BOURDIEU, Pierre. 2004. Os usos sociais da ciência. São Paulo, Ed. UNESP.

. 2001. Meditações pascalinas. Rio de Janeiro, Bertrand Brasil.

BOURDIEU, Pierre; CHAMBOREDON, Jean-Claude e PASSERON, Jean-Claude. 1999. A Profissão do Sociólogo: preliminares epistemológicas. Petrópolis, Vozes.

BOURDIEU, Pierre. 1996. A dupla ruptura. In: Razões práticas - sobre a teoria da ação. Campinas, Papirus, pp. 83-9.

.1996a. Questão de método. In: As regras da arte. São Paulo, Companhia das Letras, pp. 203-37.

BOURDIEU, Pierre. 1996b. Por um corporativismo do universal. In: As regras da arte. São Paulo, Companhia das Letras, pp. 369-78. 1992. A economia das trocas simbólicas. São Paulo, Perspectiva, $3^{\mathrm{a}}$ ed.

Brasiliense, pp. 77-95

1990. Das regras às estratégias. In: Coisas ditas, São Paulo, 1989. O poder simbólico. Lisboa, Difel. 1984. Homo academicus. Paris, Éditions de Minuit.

1983. O campo científico. In: ORTIZ, Renato (org.). Pierre Bourdieu (Col. Grandes Cientistas Sociais), São Paulo, Ática, pp. 122-55.

1983a. Questões de sociologia. Rio de Janeiro, Marco Zero.

1968. Campo intelectual e projeto criador. In: POUILLON, Jean (org.). Problemas do estruturalismo. Rio de Janeiro, Zahar, pp. 105-46.

BRAGA, José Luis. 2004. Os estudos de interface como espaço de construção do Campo da Comunicação. Encontro Nacional da Compós, São Bernardo do Campo, 8.

2000. Sobre os mestrados profissionais. Observatório da Imprensa,

20 de novembro. Disponível em:
$<$ http://observatorio.ultimosegundo.ig.com.br/artigos/da201120003.htm>. Acesso em 14 jun. 2006.

CAPES. 2004. Plano Nacional de Pós-Graduação (PNPG) - 2005-2010. Brasília, CAPES/MEC, dezembro. Disponível em: <www.mec.gov.br/acs/pdf/DocFinal_PNPG04.pdf>. Acesso em 12 de nov. 2005.

CAPES. 2004a. Critérios de Avaliação 2004: Ano Base 2001_2002_2003 - Comunicação / Ciência da Informação. Brasília, Capes. Disponível em: <www.capes.gov.br>. Acesso em 16 jul. 2004.

CAPES. 2004b. Qualis de Periódicos Científicos - Ciências Sociais Aplicadas I Comunicação e Ciência da Informação. Critérios de Qualificação de Periódicos Científicos da Área. - Ano de Referência - 2001-2002. Brasília, Capes. Disponível em: $<$ http://qualis.capes.gov.br/Qualis>. Acesso em 23 mar. 2004.

CAPES. 2004c. QUALIS é o resultado... Brasília, Capes. Disponível em: $<$ http://qualis.capes.gov.br/Qualis>. Acesso em 23 mar. 2004.

CAPES. 2001. Documento de Área (1998-2000): Comunicação/Ciência da Informação. Brasília, Capes.

Disponível

em 
<www.capes.gov.br/capes/portal/conteudo/2000_031_Doc_Area.pdf > . Acesso em out. 2002.

CAPPARELLI, Sérgio. 1980. Situação da pesquisa em Comunicação na América Latina e no Brasil. In: . Comunicação de massa sem massa. São Paulo, Cortez.

e MARQUES DE MELO, José. 1990. A pesquisa em Comunicação no Brasil: avaliação e perspectivas - CNPq. Revista Brasileira de Comunicação, 62/63, São Paulo, Intercom, pp. 5-46.

CAPPARELLI, Sérgio \& STUMPF, Ida Regina C. 2001. El campo académico de la comunicación, revisitado. In: LOPES, Maria Immacolata Vassallo de e FUENTES NAVARRO, Raúl (comps.). 2001. Comunicación: campo y objeto de estúdio: perspectivas reflexivas latino-americanas. ITESO/Univ. Autônoma de Aguascalientes/Univ. de Colima/Univ. de Guadalajara, pp. 59-73

CAPPARELLI, Sérgio \& STUMPF, Ida Regina C. 1998. A constituição da Comunicação no Brasil como campo de conhecimento multidisciplinar. I Conferência Científica da UFRGS, Porto Alegre.

1996. Perfil do ensino e da pesquisa em Programas de Pósgraduação em Comunicação no Brasil (1992-1995). INTERCOM - I Encontro de Ensino e Pesquisa do Mercosul, Londrina.

CARDOSO, Ciro Flamarion. 1997. História e paradigmas rivais. In: e VAINFAS, R. (orgs.). Domínios da história: ensaios de teoria e metodologia. Rio de Janeiro, Elsevier, $13^{\mathrm{a}}$. reimpr., pp. 1-23.

CASTRO, Claudio de Moura. S.d. A hora do mestrado profissional. Brasília, CAPES/MEC. Disponível em: <www.faculdadepitagoras.com.br/Documentos/SAIBA/Artigo/A\%20hora\%20do\%20 mestrado \%20profissional_67.doc>. Acesso em 20 nov. 2005.

CHAUÍ, Marilena. O mal estar na universidade: o caso das humanidades e ciências sociais. In: Escritos sobre a universidade. São Paulo, Ed. UNESP, pp. 157-73.

CNPq - Assessoria de Estatísticas e Informação. 2005. Sinopse Estatística do CNPq (Julho 2005). Brasília, CNPq. Disponível em: <www.cnpq.br/servicos/estatisticas/index.htm> Acesso em 15 jan. 2006.

CNPq - Assessoria de Estatísticas e Informação. 2005a. Estatísticas e Indicadores da Pesquisa no Brasil segundo Grandes Áreas do Conhecimento (2000-2004). Brasília, CNPq. Disponível em: <http://ftp.cnpq.br/pub/doc/aei/indpesq_area.pdf $>$. Acesso em 07 mar. 2006.

CNPq. 2005b. Nova Tabela das Áreas do Conhecimento (versão preliminar - proposta para discussão). Brasília, CNPq. Disponível em <http://www.memoria.cnpq.br/areas/cee/proposta.htm>. Acesso em 25 nov. 2005.

CNPq. 2004. Relatório Institucional do CNPq - 2004. Brasília, CNPq. Disponível em: $<$ http://www.cnpq.br/sobrecnpq/informacoesinstitucionais/relatorio_cnpq_2004.pdf >. Acesso em 12 abr. 2005.

COHN, Gabriel (org.). 1975. Comunicação e indústria cultural. São Paulo, Editora Nacional.

COHN, Gabriel. 1973. Sociologia da comunicação: teoria e ideologia. São Paulo, Pioneira. 
CRAIG, Robert. 1993. Why are there so many communication theories? Journal of Communication, vol. 43, n.3, pp. 26-33.

CRESPI, Franco e FORNARI, Fabrizio. 2000. A sociologia da ciência. In: Introdução à sociologia do conhecimento. Bauru, EDUSC, pp. 169-209.

CUNHA, Luiz Antônio. 2003. Ensino superior e Universidade no Brasil. In: LOPES, Eliana M. T. et al. (orgs.). 500 anos de Educação no Brasil. Belo Horizonte, Autêntica, $3^{\mathrm{a}}$. ed., pp. 151-204.

DENCKER, Ada de Freitas M. 1988. A configuração da pesquisa de Comunicação no Brasil. Dissertação de mestrado, ECA/USP.

DERVIN, Brenda. 1993. Verbing commucation: mandate for disciplinary invention. Journal of Communication, vol. 43, n.3, pp. 45-53.

DIAS, Carolina Guimarães de Souza. 2006. Periódicos na comunicação científica: produção e difusão de periódicos e panorama dos veículos brasileiros da área de Comunicação na base Qualis. Dissertações de mestrado em Comunicação. Rio de Janeiro, ECO-UFRJ. Disponível em: $<$ http://www.pos.eco.ufrj.br/modules.php?name=Downloads\&d_op=getit\&lid=187>. Acesso em 25 jun. 2006.

DIAS SOBRINHO, José. 2002. Desafios da avaliação universitária na América Latina. In: TRINDADE, Hélgio e BLANQUER, Jean-Michel (orgs.). 2002. Os desafios da educação na América Latina. Petrópolis, Vozes, pp. 115-56.

EPSTEIN, Isaac. 1988. Revoluções científicas. São Paulo, Ática.

FARO, José S. 1992. A Universidade fora de si: a INTERCOM e a organização dos estudos de comunicação no Brasil. São Paulo, Intercom/ALAIC.

FAUSTO NETO, Antônio. 2001. Sobre um "modo de existência" do campo da comunicação: uma leitura dos programas de Pós-Graduação. In: LOPES, M. I. V. Avaliação dos egressos dos Programas de Pós-graduação em Comunicação no Brasil, Relatório de Pesquisa CNPq, São Paulo: NUPEM/COMPÓS, pp. 52-63.

FAUSTO NETO, Antônio. 2002. A pesquisa vista “de dentro de casa”. In: WEBER, Maria Helena, BENTZ e HOHLFELDT, Antonio (orgs.). 2002. Tensões e objetos da pesquisa em Comunicação. Porto Alegre, Sulina, pp. 21-35.

FERREIRA, Giovandro M. 2003. Em busca da disciplinarização da Comunicação: da noção de campo aos domínios de pesquisa. In: LOPES, Maria Immacolata. V. (org.). Epistemologia da Comunicação. São Paulo, Loyola, pp. 253-76.

FERREIRA, Jairo. 2004. Campo acadêmico e epistemologia da comunicação. In: LEMOS, André et al. (orgs.). Mídia.br, Porto Alegre, Sulina, pp. 115-29.

FIGUERÔA, Silvia. 1997. As Ciências Geológicas no Brasil: uma história social e institucional. São Paulo, Hucitec.

FUENTES NAVARRO, Raúl. 1994. La institucionalización del campo académico - un primer acercamiento comparativo. Revista Brasileira de Comunicação, vol. 17, n.1, São Paulo, Intercom, pp. 10-32.

CONEICC.

1991. La comunidad desapercibida. Guadalaraja, ITESO/

1998. La emergencia de un campo académico: continuidad utópica y estruturación científica de la investigación de la comunicación en México. Guadalajara, ITESO/ Universidad de Guadalajara. 
GALTUNG, Johan. 1965. Los factores socioculturales y el desarrollo de la sociología en América Latina. Revista Latinoamericana de Sociología, I, 1, pp. 72-102.

GARCIA, Maria Manuela Alves. 1996. O campo das produções simbólicas e o campo científico em Bourdieu. Cadernos de Pesquisa, São Paulo: Fund. Carlos Chagas, n. 97, pp. 64-72, maio.

GARCÍA-GUADILLA, Carmem. 2002. Educación superior en América Larina: una perspectiva comparada de la década de los noventa. In: TRINDADE, Hélgio e BLANQUER, Jean-Michel (orgs.). Os desafios da educação na América Latina. Petrópolis, Vozes, pp. 32-60.

GEERTZ, Clifford. 2001. Nova luz sobre a antropologia. Rio de Janeiro, Jorge Zahar Editor.

GOLDSCHMIDT, Victor. 1963. Tempo histórico e tempo lógico na interpretação de sistemas filosóficos. In: A Religião de Platão. 2. ed. São Paulo, DIFEL, pp. 139-47.

GOMES, Wilson. 2004. As revistas científicas de comunicação no sistema Qualis de avaliação da Capes. Jornal Brasileiro de Ciências da Comunicação, ano 7, n. 261 - São Bernardo do Campo, São Paulo, agosto. Disponível em $<$ http://www2.metodista.br/unesco/jbcc/jbcc_mensal/ jbcc261/polemicas_wilson.htm>. Acesso em 14 de jan. 2005.

GOMES, Wilson. 2003. O estranho caso de certos discursos epistemológicos que visitam a área da Comunicação. In: LOPES, Maria Immacolata. V. (org.). Epistemologia da Comunicação. São Paulo, Loyola, pp. 313-30.

GRANGER, Gilles-Gaston. 1989. Verdadeiras e falsas ciências. In: Por um conhecimento filosófico. São Paulo, Papirus, pp. 131-60.

GONZÁLEZ DE GÓMEZ, Maria Nélida. 2000. Metodologia de pesquisa no campo da Ciência da Informação. DataGramaZero - Revista de Ciência da Informação. V.1, n.6, dez. Disponível em: <http://www.dgz.org.br/dez00/Art_03.htm>. Acesso em 20 de dez. 2005.

GREIMAS, Algirdas J. 1976. Semiótica e ciências sociais. São Paulo, Cultrix.

HABERMAS, Jurgüen. 2001. Ciência e técnica como ideologia. Lisboa, Edições 70.

HOCHMAN, Gilberto. 1994. A ciência entre a comunidade e o mercado: leituras de Kuhn, Bourdieu, Latour e Knorr-Cetina. In: PORTOCARRERO, Vera (org.). Filosofia, História e Sociologia das Ciências: abordagens contemporâneas. Rio de Janeiro, FIOCRUZ., pp. 199-232.

IANNI, Octavio. 2004. Variações sobre Ciência e Arte. São Paulo, SDI/FFLCH/USP.

IANNI, Octavio. 2003. A polêmica sobre Ciências e Humanidades. Seminários Unicamp: Diversidade na Ciência. 27 e 28 de Março. Disponível em: <http://www.prpg.unicamp.br/IanniTalkOK.PDF>. Acesso em 10 mar. 2005.

IANNI, Octavio. 1998. As Ciências Sociais na época da globalização. Revista Brasileira de Ciências Sociais, vol. 13, n. 37, pp. 33-41. Disponível em: $<$ http://www.scielo.br/scielo. php?script= sci_arttext\&pid=S010269091998000200002\&lng=en\&nrm=iso>. Acesso em 26 jun. 2006.

IANNI, Octavio. 1997. A Sociedade Global. Rio de Janeiro, Civilização Brasileira.

IANNI, Octavio. 1994. Globalização: novo paradigma das ciências sociais. Estudos Avançados, 21, São Paulo, IEA-USP. Disponível em: 
$<$ http://www.iea.usp.br/iea/revista/coletaneas/globalizacao/ iannirev21.html>. Acesso em 20 de jun. 2006.

IANNI, Octavio. 1992. A crise de paradigma em Sociologia. IFCH, UNICAMP, Campinas, 1992.

ISSLER, João Victor e FERREIRA, Rachel Couto. 2004. Avaliando Pesquisadores e Departamentos de Economia no Brasil a partir de Citações Internacionais. Ensaios Econômicos, $\quad$ n. 550, junho. $\quad$ Disponível em $<$ http://epge.fgv.br/portal/arquivo/1636.pdf.>. Acesso em 15 de mar. 2006.

JANINE RIBEIRO, Renato. 2003. A universidade e a vida atual. Fellini não via filmes. São Paulo, Campus.

JAPIASSÚ, Hilton. 1997. A revolução científica moderna. São Paulo, Letras \& Letras.

KROPF, Simone Petraglia e LIMA, Nísia Trindade. 1999. Os valores e a prática institucional da ciência: as concepções de Robert Merton e Thomas Kuhn. História, Ciências, Saúde - Manguinhos, V(3), pp. 565-81. Disponível em: $<$ http://www.scielo.br/scielo.php?pid=S0104-

59701999000100002\&script=sci_arttext>. Acesso em 15 out. 2005.

KUHN, Thomas S. 2006. As ciências naturais e as ciências humanas. In:. O caminho desde a estrutura. São Paulo, Ed. UNESP, pp. 265-73.

KUHN, Thomas S. 1976. A estrutura das revoluções científicas. São Paulo, Perspectiva (1 $1^{a}$ ed 1962).

KUNSCH, Margarida M. Krohling e DENCKER, Ada de Freitas M. (coords.). 1997. Produção científica brasileira em Comunicação - década de 80: análises, tendências e perspectivas. São Paulo, PORTCOM/INTERCOM/EDICON.

LAHIRE, Bernard. 2002. Reprodução ou prolongamentos críticos. Educação e Sociedade, Campinas, CEDES, n. 78, abril, pp. 37-55.

LAKATOS, Imre. 1987. Historia de las ciencias y sus reconstrucciones racionales. Madrid, Tecnos.

LAKATOS, Imre. 1979. O falseamento e a metodologia dos programas de pesquisa científica. In: LAKATOS, Imre e MUSGRAVE, A. (orgs.). A crítica e o desenvolvimento da ciência. São Paulo, Cultrix/EDUSP, pp. 109-243.

LATOUR, Bruno. 2000. Ciência em ação. São Paulo, Ed. UNESP.

LATOUR, Bruno e WOOLGAR, Steve. 1997. A vida de laboratório: a produção dos fatos científicos. Rio de Janeiro, Relume Dumará.

LATOUR, Bruno. 1994. Jamais fomos modernos. Rio de Janeiro, Ed. 34.

LIEDKE FILHO, Enno Dagoberto. 2003. Sociologia brasileira: tendências institucionais e epistemológicas. Sociologias. Porto Alegre, ano 5, n. 9, jan./jun. Disponível em: $<$ www.scielo.br/pdf/soc/n9/n9a08.pdf>. Acesso em 10 mar. 2006.

LIMA, Venício A. de. 2001. Breve roteiro introdutório ao campo de estudo da Comunicação Social no Brasil. In: . Mídia: teoria e política. São Paulo. Fund. Perseu Abramo, pp. 21-53.

LIMA, Venício A. de. 1983. Repensando as teorias da Comunicação: notas para um debate. In: MARQUES DE MELO, José. Teoria e pesquisa em Comunicação: panorama latino-americano. São Paulo, Cortez/INTERCOM/CIID, pp. 85-99. 
LOPES, Maria Immacolata Vassallo de. 2006. O campo da Comunicação: sua constituição, desafios e dilemas. Revista FAMECOS, Porto Alegre, $n^{0}$ 30, agosto, pp. 16-30.

LOPES, Maria Immacolata Vassallo de e ROMANCINI, Richard. 2006. Teses e dissertações: estudo bibliométrico na área da Comunicação. In: POBLACIÓN, Dinah A. et al (orgs.). Comunicação e produção científica: contexto, indicadores e avaliação. São Paulo, Angellara, pp. 139-61.

LOPES, Maria Immacolata Vassallo de. 2004. As fronteiras entre as ciências sociais vistas da comunicação: Uma aproximação aos estudos sociais das ciências. e-compós Revista da Associação Nacional dos Programas de Pós-Graduação em Comunicação, n. 1, dezembro. Disponível em: <http://www.compos.org.br/ecompos/adm/documentos/MARIA\%20IMMACO LA TA.pdf>. Acesso em 07 mar. 2005.

2004a. Por um paradigma transdisciplinar para o campo da comunicação. VII Congresso da ALAIC, La Plata, Universidad Nacional de La Plata. Disponível em: <http://www. eca.usp.br/alaic/trabalhos2004/gt17/Maria\%20Immacolata.htm>. Acesso em 15 jul. 2006.

Point.

2004b. A área da Comunicação no CNPq. Apresentação em Power (org.). 2003. Epistemologia da Comunicação. São Paulo, Loyola. .2003a. Sobre o estatuto disciplinar do campo da Comunicação. In: (org.). Epistemologia da Comunicação. São Paulo, Loyola, pp. 277-93.

(org.). 2003b. Diversidade \& Interdisciplinaridade: teses $e$ dissertações - Ciências da Comunicação, 1972-2002. São Paulo, NUPEMECA/USP.

LOPES, Maria Immacolata Vassallo de e FUENTES NAVARRO, Raúl (comps.). 2001. Comunicación: campo y objeto de estúdio: perspectivas reflexivas latinoamericanas. ITESO/Univ. Autônoma de Aguascalientes/Univ. de Colima/Univ. de Guadalajara.

LOPES, Maria Immacolata Vassallo de (coord.). 2001a. Avaliação dos egressos dos programas de pós-graduação em Comunicação no Brasil. Relatório de pesquisa CNPq, NUPEM/COMPÓS, São Paulo.

LOPES, Maria Immacolata Vassallo de, BRAGA, José Luiz e SAMAIN, Etienne. 2001b. Proposta de atualização da categorização do Campo da Comunicação em subáreas. In: FAUSTO NETO, Antonio; PRADO, José Luiz Aidar; PORTO, Sérgio Dayrell. (orgs.). Campo da Comunicação - caracterização, problematizações e perspectivas. João Pessoa, 2001, pp. 91-108.

LOPES, Maria Immacolata Vassallo de. 2000. A institucionalização dos estudos de comunicação no Brasil. In: e BUONANNO, Milly (orgs.). Comunicação no plural. São Paulo: Intercom/ EDUC, pp. 49-65.

(org.). 1999. Vinte anos de Ciências da Comunicação no Brasil: avaliação e perspectivas. Santos, Universidade Santa Cecília.

(coord.). 1998. Campo profissional e mercados de trabalho em Comunicação no estado de São Paulo. São Paulo, Relatório FAPESP. 
1998a. Mercado de trabalho dos egressos dos cursos de Comunicação Social no Brasil. Tese de Livre-Docência, São Paulo, ECA-USP.

LOPES, Maria Immacolata Vassallo de, POBLACIÓN, Dinah A e DA VIÁ, Sarah C. 1992 e 1994. O mercado de trabalho em comunicações e artes e os profissionais formados pela ECA nas décadas de 70 e 80 . Vol. I e Vol. II. São Paulo, ECA-USP.

LOPES, Maria Immacolata Vassallo de. 1990. Pesquisa em Comunicação: formulação de um modelo metodológico. São Paulo, Loyola.

LOVISOLO, Hugo. 2002. "Epistemologia prática” no campo da comunicação. Contracampo, Niterói, julho, pp. 125-36. Disponível em: $<$ http://revcom.portcom.intercom.org.br/scielo.php?script= $\quad$ sci_pdf\&pid=S141474832002000700009\&lng=pt\&nrm=iso\&tlng=pt $>$. Acesso em 11 nov. 2005.

LYOTARD, Jean François. 1996. A condição pós-moderna. Rio de Janeiro, José Olympio.

MAINGUENEAU, Dominique. 1989. Uma prática discursiva. In: Novas tendências de análise do discurso. Campinhas, Pontes/Ed. UNICAMP, pp.53-71.

MALDONADO, Alberto Efendy. 2003. Explorações sobre a problemática epistemológica no campo das ciências da Comunicação. In: LOPES, Maria Immacolata V. Epistemologia da Comunicação. São Paulo, Loyola, pp.205-25.

MANNHEIM, Karl. 1967. O problema de uma sociologia do conhecimento. In: BERTELLI, Antônio Roberto et Al. (orgs.). Sociologia do conhecimento. Rio de Janeiro, Zahar, pp. 13-80 (1 $1^{\text {a }}$ ed 1925).

MARQUES DE MELO, José. 2003. Midiologia brasileira: o resgate das fontes paradigmáticas. In: LOPES, Maria Immacolata V. (org.). Epistemologia da Comunicação. São Paulo, Loyola, pp. 105-19.

2003a. História do pensamento comunicacional. São Paulo, Paulus.

2000. Communication schools and the work market in Brazil: trying to overcome the ngap between education and praxis. Anuário Unesco/Umesp de Comuncação Regional. São Bernardo do Campo, v.3, pp. 205-18.

(org.). 1999. Pesquisa em Comunicação no Brasil: tendências e perspectivas. São Paulo, Cortez/INTERCOM.

MARQUES DE MELO, José e GOBBI, Maria Cristina (org.). 1999. Gênese do pensamento comunicacional latino-americano: o protagonismo das instituições pioneiras CIESPAL, ICINFORM, ININCO. São Bernardo do Campo, UMESP/Cátedra Unesco.

MARQUES DE MELO, José, PEREIRA DA LUZ, Inez e ALVARES PEREIRA. 1992. Periódicos brasileiros de comunicação das décadas de 60 e 70. São Paulo, PortCOM/INTERCOM, ALAIC.

MARQUES DE MELO, José. 1984. Inventário da Pesquisa em Comunicação Social no Brasil, São Paulo, PORTCOM / INTERCOM.

(coord.). 1983. Teoria e pesquisa em Comunicação: panorama latino-americano. São Paulo, Cortez/INTERCOM/CIID.

MARTINO, Luiz C. 2004. História e identidade: apontamentos epistemológicos sobre a fundação e fundamentação do campo comunicacional. e-compós - Revista da Associação Nacional dos Programas de Pós-Graduação em Comunicação, n. 1, 
dezembro. Disponível em $\quad<$ http://www. compos.org.br/ecompos/adm/documentos/LUIZMARTINO.pdf>. Acesso em 10 mar. 2006.

MARTINO, Luiz C. 2004a. Ceticismo e interdisciplinaridade: paradoxos e impasses da teoria da comunicação. VII Congresso da ALAIC, La Plata, Universidad Nacional de La Plata. Disponível em: $<$ http://www.alaic.net/VII_congreso/gt/gt_17/gt17\%20p4.html>. Acesso em 15 jul. 2006.

2001. Elementos para uma epistemologia da comunicação. In: LOPES, Maria Immacolata V. e FUENTES NAVARRO, Raúl (comps.). Comunicación: campo y objeto de estúdio: perspectivas reflexivas latino-americanas. ITESO/Univ. Autônoma de Aguascalientes/Univ. de Colima/Univ. de Guadalajara, pp. 75-90.

2001a. Ceticismo e Inteligibilidade do Saber Comunicacional. Ciberlegenda, n. 5. Disponível em: <www.uff.br/mestcii/martino1.htm>. Acesso em 30 set. 2005.

MARTINS, Carlos Benedito, VILLAS BOAS, Gláucia, BARBOSA, Maria Lígia de Oliveira e MAGGIE, Yvone. 2002. Mestres e doutores em Sociologia. BIB - Revista Brasileira de Informação Bibliográfica em Ciências Sociais. São Paulo, n. 53, $1^{\circ}$. Semestre, pp. 119-44.

MATTELART, Armand. 1999. Vinte anos de pesquisa ou das certas para a ambivalência. In: LOPES, Maria Immacolata V. (org.). Vinte anos de Ciências da Comunicação no Brasil: avaliação e perspectivas. Santos, Universidade Santa Cecília, pp. 15-30.

MATTELART, Armand e MATTELART, Michele. 2005. História das teorias da comunicação. São Paulo, Loyola, $8^{\mathrm{a}}$ ed.

MEADOWS, A. J. A comunicação científica. Brasília: Briquet de Lemos, 1999.

MELO, Manuel Palácios da Cunha. 1999. Quem explica o Brasil. Juiz de Fora: Ed. UFJF.

1994. O Programa Forte da sociologia do conhecimento e o princípio da causalidade. In: PORTOCARRERO, Vera (org.). Filosofia, História e Sociologia das Ciências: abordagens contemporâneas. Rio de Janeiro, FIOCRUZ, pp. 175-98.

MENEGHINI, Rogério. 1998. Avaliação da produção científica e o Projeto SciELO. Ciência da Informação, Brasília, v. 27, n. 2, maio/ago., pp. 219-220.

MERTON, Robert K. 1979. A ambivalência sociológica. Rio de Janeiro, Zahar.

MERTON, Robert K. 1979a. A ambivalência dos cientistas. In: A ambivalência sociológica. Rio de Janeiro, Zahar, pp. 52-81.

MERTON, Robert K. 1979b. A análise estrutural na Sociologia. In: A ambivalência sociológica. Rio de Janeiro, Zahar, pp. 147-193.

MERTON, Robert K. 1977. La sociologia de la ciencia. Madrid, Allianza Editorial.

MERTON, Robert K. 1970. Sociologia: teoria e estrutura. São Paulo, Mestre Jou (1 $1^{\text {a }}$ ed. 1945).

MEZAN, Renato. 1999. Psicanálise e Pós-Graduação: Notas, Exemplos, Reflexões. Disponível em: <http://www.estadosgerais.org/historia/56psicanalise_e_pos_graduacao.shtml>. Acesso em 01 fev. 2006.

MICELI, Sergio. 2001. Intelectuais à brasileira. São Paulo, Companhia das Letras. 
MICELI, Sergio (org.). 2001a. História das Ciências Sociais no Brasil. São Paulo, Sumaré/ FAPESP, v. 1, 2a . ed.

MICELI, Sergio. 1999. Intelectuais brasileiros. In: ___ (org.). O que ler na ciência social brasileira, vol. 3, São Paulo, Sumaré/ANPOCS, Brasília, CAPES, pp. 109-145.

(org.). 1995. História das Ciências Sociais no Brasil. São Paulo, Sumaré/ FAPESP, v. 2.

MION, Rejane A. e ANGOTTI, José André Peres. 2005. Em busca de um perfil epistemológico para a prática educacional em Educação em Ciências. Ciência \& Educação. V. 11, n. 2, pp. 165-180. Disponível em: $<$ http://www2.fc.unesp.br/cienciaeeducacao/include/getdoc.php?id=252\& article $=69 \&$ mode $=$ pdf $>$. Acesso em 12 jan. 2006 .

MONTARDO, Sandra Portella. 2005. Comunicação: campo de mediações e de complexidade. BOCC - Biblioteca On-line de Ciências da Comunicação. Disponível em: $\quad<$ http://www.bocc.ubi.pt/ pag/montardo-sandra-comunicacao-mediacaocomplexidade.pdf $>$. Acesso em 19 out. 2006.

MORAGAS SPÁ, Miguel. 1985. Ubicación epistemológica e ideológica de la comunicación. In: FERNANDEZ, Fatima et al. Comunicación y teoría social. México, UNAM, pp. 33-46.

MORIN, Edgar. 2005. Ciência com consciência. Rio de Janeiro, Bertrand Brasil, $6^{\mathrm{a}}$ ed.

MORIN, Edgar. 2003. A comunicação pelo meio (teoria complexa da comunicação). Revista Famecos. Porto Alegre, vol. 1, $\mathrm{n}^{0}$ 20, abril, pp. 7-12. Disponível em: $<$ http://revcom2.portcom.

intercom.org.br/famecos/ojs/include/getdoc.php?id=309\&article=112\&mode=pdf\&O JSSID=0690112f78d6f90c248ac97bd9b6882a $>$. Acesso em 10 jul. 2006.

MORIN, Edgar. 1989. As estrelas, mito e sedução no cinema. Rio de Janeiro, José Olympio ( $1^{\text {a }}$ ed. 1957$)$.

MORIN, Edgar. 1986. Cultura de massa no século XX: o espírito do tempo II: necrose. Rio de Janeiro, Forense-Universitária, $2^{\mathrm{a}}$ ed. (1 ${ }^{\mathrm{a}}$ ed. 1962).

MORIN, Edgar. 1975. Cultura de massas no século XX: o espírito do tempo I: neurose. Rio de Janeiro, Forense-Universitária (1 $1^{\text {a }}$ ed. 1962).

MORIN, Edgar. 1970. O cinema ou o homem imaginário. Lisboa, Moraes (1ª ed. 1956).

MOSTAFA, Solange Puntel. 2002. Citações epistemológicas no campo da educomunicação. Comunicação e Educação. n. 24, maio/ago, p. 15-28.

NORONHA, Daisy Pires. 1998. Análise das citações das dissertações de mestrado e teses de doutorado em saúde pública (1990-1994): estudo exploratório. Ciência da Informação, Brasília, v.27, n.1, p. 66-75, 1998. Disponível em: $<$ www.ibict.br/cienciadainformacao/include/getdoc.php?

id=706\&article=391\&mode=pdf $>$. Acesso em 01 fev. 2006.

OLIVA, Alberto. 1994. O normal e o revolucionário na reprodução da racionalidade científica. In: PORTOCARRERO, Vera (org.). Filosofia, História e Sociologia das Ciências: abordagens contemporâneas. Rio de Janeiro, FIOCRUZ, pp. 67-102.

OLIVEIRA, Inês Barbosa de e ALVES, Nilda. 2006. A pesquisa e a criação de conhecimentos na pós-graduação em educação no Brasil: conversas com Maria Célia Moraes e Acácia Kuenzer. Educação \& Sociedade [online], vol. 27, no. 95, pp. 577- 
99. Disponível em: <http://www. scielo.br/scielo.php?script=sci_arttext\&pid=S0101$73302006000200013 \& \operatorname{lng}=$ en\&nrm= iso>. Acesso em 22 abr. 2005.

OROZOCO GÓMEZ, Guillermo. 1997. La investigación de la Comunicación dentro y fuera de América Latina: tendencias, perspectivas y desafios del estúdio de los medios. La Plata, Universidad Nacional de La Plata.

ORTIZ, Renato. 2004. As ciências sociais e o inglês. Revista Brasileira de Ciências Sociais. Vol. 19, $\mathrm{n}^{\circ}$. 54, fevereiro, pp. 5-23. Disponível em: $<$ http://www.scielo.br/scielo.php?pid=S0102-69092004000100001\&script=sci_pdf>. Acesso em 18 mar. 2006.

OTERO, Edison. 2006. El "estado del arte” en teoría de la comunicación: un ejercicio kuhniano. Intercom - Revista Brasileira de Ciências da Comunicação, São Paulo, v. 29, n. 1, jan/jun, pp.57-83.

PASSERON, Jean-Claude. 1995. O raciocínio sociológico: o espaço não-popperiano do raciocínio natural. Petrópolis, Vozes.

PEIRANO, Mariza G.S. 1992. A favor da etnografia. Brasília, UNB. Disponível em: <http://www.unb.br/ics/dan/Serie130empdf.pdf>. Acesso em 17 abr. 2004.

PERUZZO, Cicilia M. Krohling. 2002. Em busca cós objetos de pesquisa em comunicação no Brasil. In: WEBER, Maria Helena, BENTZ e HOHLFELDT, Antonio (orgs.). Tensões e objetos da pesquisa em Comunicação. Porto Alegre, Sulina, pp. 52-72.

PESSOA Jr. Osvaldo. 1993. Filosofia \& Sociologia da Ciência. Campinas, UNICAMP. Disponível em: <http://www.fflch.usp.br/df/opessoa/Soc1.pdf>. Acesso em 15 ago. 2006.

POBLACIÓN, Dinah A., WITTER, Geraldina P. e SILVA, José Fernando Modesto da. 2006. Comunicação e produção científica: contexto, indicadores e avaliação. São Paulo, Angellara.

POBLACIÓN, Dinah A. 2005. Visibilidade da produção científica gerada pelos docentes e egressos dos Programas de Pós-graduação em Ciência da Informação e as interfaces com os Grupos de Pesquisa da área, constantes do Diretório do CNPq. DataGramaZero - Revista de Ciência da Informação - v.6, n.1, fev. Disponível em: $<$ http://www.dgzero.org/out06/F_I_aut.htm>. Acesso em 18 set. 2006.

POBLACIÓN, Dinah A. (coord.). 2001. Produção científica: características das comunidades científicas brasileiras da área de Ciência da Informação segundo parâmetros cienciométricos. Relatório final de pesquisa - CNPq. São Paulo, NPC/ECA-USP. Disponível em: $<$ http://www.eca.usp.br/nucleos/pc/RELAT_RIO_CNPq_2001_II.pdf $>$. Acesso em 18 set. 2006.

POPPER, Karl R. 1980. A lógica da descoberta científica. São Paulo, Abril Cultural (Col. Os Pensadores - Popper) (1 $1^{\mathrm{a}}$ ed. 1935).

PORTO, Sérgio Dayrell (coord.). 1982. A produção científica do mestrado em Comunicação da Universidade de Brasília. Cadernos de Comunicação do Departamento de Comunicação da UnB. Brasília, UNB, n. 3.

PORTOCARRERO, Vera (org.). 1994. Filosofia, História e Sociologia das Ciências: abordagens contemporâneas. Rio de Janeiro, FIOCRUZ. 
PRADO, José Luiz Aidar. 2003. O campo da comunicação e a comunicação entre os campos na era da globalização. In: LOPES, Maria Immacolata V. (org.). 2003. Epistemologia da Comunicação. São Paulo, Loyola, pp. 135-53.

REIS, José. 1995. Aluno ruim, Pasteur só era notado como mestre no desenho em pastel. Folha de S. Paulo, 24 de setembro.

REZENDE, Sérgio. 1994. Avaliação da área e proposições para a Física no Brasil. São Paulo, Escola de Administração de Empresas de São Paulo/Fundação Getúlio Vargas. Disponível em: <www.schwartzman.org.br/simon/scipol/pdf/fisica.pdf>. Acesso em 30 set. 2005.

ROMANCINI, Richard. 2004. Periódicos brasileiros em Comunicação: histórico e análise preliminar. XXVII INTERCOM, IV Encontro dos Núcleos de Pesquisa, Porto Alegre.

ROJAS, Álvaro, RONDEROS N., Luis Fernando. 2005. Excelencia Académica y Acreditación en las Escuelas de Comunicación de América Latina. Cali, FELAFACS. Disponível em: <http://www.felafacs.org/files/final_excelencia_academica.pdf $>$. Acesso em 05 nov. 2005.

ROSENGREN, Erik. 1983. Communication research: one paradigm, or four? Journal of Communication, v. 33, n. 3, pp. 185-207.

RÜDIGER, Francisco. 2002. Trajetórias da pesquisa em Comunicação. In: . Ciência Social Crítica e Pesquisa em Comunicação. São Leopoldo, Ed. Unisinos.

SANTAELLA, Lúcia. 1999. Literatura, arte e meios de reprodução técnica. In: MARQUES DE MELO, José. (org.). Pesquisa em Comunicação no Brasil: tendências e perspectivas. São Paulo, Cortez/INTERCOM, pp. 152-6.

SCHRAMM, Wilburn. 1983. The unique perspective of communication: a retrospective review. Journal of Communication, vol. 33, n.3, pp. 6-17.

SCHWARTZMAN, Simon. 2001. Um espaço para a ciência: a formação da comunidade científica no Brasil. Brasília, CNPq.

SCHWARTZMAN, Simon. 2000. A Revolução Silenciosa do Ensino Superior. In: DURHAM, Eunice Ribeiro e SAMPAIO, Helena (orgs.). O Ensino Superior em Transformação. São Paulo, NUPES/USP, pp. 13-30. Disponível em www.schwartzman.org.br/simon/pdf/nupes2000.pdf.

SCHWARTZMAN, Simon. 1997. A redescoberta da cultura, São Paulo, Edusp.

SCHWARTZMAN, Simon. 1971. O dom da eterna juventude. Dados, vol. 8, pp. 26-46. Disponível em http://www.schwartzman.org.br/simon/juvent.htm.

SCHWARZ, Roberto. 1987. O nome do bispo: um romance paulista. In: Que horas são? São Paulo, Companhia das Letras, pp. 67-77.

SHEPHERD, Greogry J. 1993. Building a discipline of communication. Journal of Communication, vol. 43, n.3, pp. 83-91.

SILVA, Mario Camarinha da e CAVALCANTI, Ilce Gonçalves Milet. 1989. Catálogo de teses e dissertações: 1972/1987. Rio de Janeiro, ECO-UFRJ.

SMIT, Johanna W.; TÁLAMO, Maria de Fátima G. M. e KOBASHI, Nair Y. 2004. A determinação do campo científico da Ciência da Informação: uma abordagem terminológica. DataGramaZero - Revista de Ciência da Informação, v.5 n.1, fev. Disponível em: <http://www.dgz.org.br/ fev04/Art_03.htm>. Acesso em 15 jul. 2005.

SNOW, C. P. As duas culturas e uma segunda leitura. São Paulo, EDUSP. 
SOARES, Liziane do Espírito Santo. 2004. Pesquisa em Comunicação Social: um inventário das teses e dissertações defendidas no programa de pós-graduação da FAMECOS/PUCRS. Dissertação de mestrado em Comunicação, PUCRS.

SOARES, Luiz Carlos (org.). 2001. Da revolução científica à big science. São Paulo/Niterói, Hucitec/ Eduff.

2001a. O nascimento da Ciência Moderna: os diversos caminhos da Revolução Científica nos século XVI e XVII. In: à big science. São Paulo/Niterói, Hucitec/ Eduff, pp. 17-66.

SOARES, Maria Susana Arrosa (coord.). 2002. A educação superior no Brasil. Porto Alegre. IESALC/UNESCO.

SOKAL, Alan e BRICMONT, Jean. 1999. Imposturas intelectuais. Rio de Janeiro, Record.

SOUZA, Rosali Fernandez de. 2005. Uma Nova Tabela de Áreas do Conhecimento. DataGramaZero - Revista de Ciência da Informação, v.6, n.5, outubro. Disponível em: <http://www.dgz.org.br/ out05/F_I_com.htm>. Acesso em 20 fev. 2006.

2004. Áreas do Conhecimento. DataGramaZero - Revista de Ciência da Informação, v.5, n.2. Disponível em http://www.dgz.org.br/abr04/Art_02.htm.

SOUSA SANTOS, Boaventura de. 2003. Um discurso sobre as ciências. São Paulo, Cortez.

SOUSA SANTOS, Boaventura de (org.). 2005. Conhecimento prudente para uma vida decente: “Um discurso sobre as ciências” revisitado. São Paulo, Cortez.

SOUSA SANTOS, Boaventura de. Introdução a uma ciência pós-moderna. Rio de Janeiro, Graal, 1989.

STENGERS, Isabelle. 2002. A invenção das ciências modernas. São Paulo, Ed. 34.

TRINDADE, Hélgio e BLANQUER, Jean-Michel (orgs.). 2002. Os desafios da educação na América Latina. Petrópolis, Vozes.

UFBA. s.d. Dissertações de Mestrado e Teses de Doutorado defendidas no PPGCOM da UFBA. Salvador, Universidade Federal da Bahia. Disponível em. $<$ http://www.poscom.ufba.br/secoes.asp? idsecao=8\&idsubsecao=30>. Acesso em 15 mar. 2005.

UFRJ. s.d. Teses e dissertações desenvolvidas na Escola de Comunicação (ECO-UFRJ). Rio de Janeiro, Universidade Federal do Rio de Janeiro. Disponível em : <http://www.eco.ufrj.br/portal/pesquisa/ bancoECO.html>. Acesso em 20 mar. 2005.

UMESP. s.d. Dissertações de Mestrado e Teses de Doutorado defendidas no Programa de Pós-Graduação em Comunicação, Lato Sensu da Universidade Metodista de São Paulo. São Bernardo do Campo, Universidade Metodista de São Paulo. Disponível em <http://www.metodista.br/ poscom/tesedicerta.php>. Acesso em 15 abr. 2005.

VANZ, Samile Andréa de Souza. 2004. A produção discente em Comunicação: análise das citações das dissertações defendidas nos programas de pós-graduação do Rio Grande do Sul. Dissertação de mestrado em Comunicação, UFRGS.

VELHO, Lea M. S. 2001. Estratégias para um sistema de indicadores de C\&T no Brasil. Parcerias Estratégicas, $\mathrm{n}^{\circ}$. 13, p. 109-21, dezembro. Disponível em: <http://www.mct.gov.br/CEE/revista/ parcerias13/6.pdf>. Acesso em 01 fev. 2006. 
VELHO, Lea M. S. 1998. Indicadores científicos. Aspectos Aspectos teóricos y metodológicos e impactos en la política cientifica. In: Indicadores de Ciência e Tecnologia, Caracas, Nueva sociedad, pp. 23-52. 1985. Como media a ciência? Revista Brasileira de Tecnologia. Brasília, v. 16, n. 1, pp. 3-9.

.VELLOSO, Jacques. 2004. Mestres e Doutores no País: destinos profissionais e políticas de pós-graduação. Cadernos de Pesquisa, v. 34, n. 123, set./dez., pp. 583-611. Disponível em: <www.scielo.br/pdf/cp/v34n123/a05v34123.pdf>. Acesso em 12 nov. 2005.

VILHENA, Valéria e CRESTANA, Maria Fazanelli. 2002. Produção científica: critérios de avaliação de impacto. Revista da Associação Médica Brasileira. Vol. 48, n.1, pp. 20-21. Disponível em: <http://www.scielo.br/cgi-bin/fbpe/fbtext?pid=S010442302002000100024>. Acesso em 10 mai. 2004.

WALLERSTEIN, Immanuel. 1997. La historia de las Ciencias Sociales. UNAM, Cidade do México.

WALLERSTEIN, Immanuel. 1996. Para abrir as ciências sociais. São Paulo, Cortez.

WEBER, Maria Helena, BENTZ, Ione e HOHLFELDT, Antonio (orgs.). 2002. Tensões e objetos da pesquisa em Comunicação. Porto Alegre, Sulina.

WEBER, Max. 1991. A “objetividade” do conhecimento nas Ciências Sociais. In: COHN, Gabriel (org.). Weber. São Paulo, Ática, pp. 79-127.

WERNECK VIANNA, Luiz, CARVALHO, Maria Alice, MELO, Manuel Palácios da Cunha. 1995. As Ciências Sociais no Brasil: a formação de um sistema nacional de ensino e pesquisa. BIB - Boletim Informativo e Bibliográfico de Ciências Sociais. Rio de Janeiro, n. 40, $2^{\circ}$. Semestre, pp. 27-63.

\section{Textos (corpus) apresentados na reunião para a discussão da TAC da Comunicação}

FELINTO, Erick. 2005. Notas sobre o Campo da Comunicação. São Paulo, Reunião para discussão da TAC, ECA-USP-São Paulo, 20 e 21 de maio.

FERRARA, Lucrecia D’Aléssio. 2005. Pontos a considerar em uma proposta de revisão. Reunião para discussão da TAC, ECA-USP-São Paulo, 20 e 21 de maio.

FORCINE. Quanto à pesquisa e ao ensino de pós-graduação. Reunião para discussão da TAC, ECA-USP-São Paulo, 20 e 21 de maio.

MARCONDES FILHO, Ciro. 2005. Contribuição para os debates. São Paulo, Reunião para discussão da TAC, ECA-USP-São Paulo, 20 e 21 de maio.

MEDITSCH, Eduardo. 2005. Rumo a uma Grande Área: para o crescimento sustentável das Ciências da Comunicação. Reunião para discussão da TAC, ECA-USP-São Paulo, 20 e 21 de maio.

RAMOS, Fernão. 2005. Texto para discussão. Reunião para discussão da TAC, ECAUSP-São Paulo, 20 e 21 de maio.

SODRÉ, Muniz. 2005. Proposta. Reunião para discussão da TAC, ECA-USP-São Paulo, 20 e 21 de maio. 


\section{Sites consultados}

ALAIC - http://www.alaic.net/

ANPOCS - http://www.anpocs.org.br/

CNPq - http://www.cnpq.br

CAPES - http://www.capes.gov.br

COMPÓS - http://www.compos.org.br

IAMCR - http://www.iamcr.org/

INTERCOM - http://www.intercom.org.br

PPGCOM

ESPM

http://www.espm.br/ESPM/pt/Unidades/SP/Menu/PosGraduacao/PosComunicacaoMercado/

PUCRJ - http://www.puc-rio.br/ensinopesq/ccpg/progcom.html

PUCRS - http://www.pucrs.br/famecos/pos/

PUCSP - http://www.pucsp.br/pos/cos/index.htm

UERJ - http://www2.uerj.br/ fcs/posgraduacao/mestrado.htm

UFBA - http://www.poscom.ufba.br/

UFF - http://www.uff.br/mestcii/index.htm

UFMG - http://www.fafich.ufmg.br/ ppgcom/index.html

UFPE - http://www.ufpe.br/ppgcom/

UFRGS - http://www.ppgcom.ufrgs.br/

UFRJ - http://www.pos.eco.ufrj.br/

UFSM- http://www.ufsm.br/poscom/

UMESP - http://www.metodista.br/poscom/index.php

UNB - http://www.unb.br/fac/posgraduacao/

UNESP - http://www.faac.unesp.br/posgraduacao/comunicacao

UNICAMP - http://www.iar.unicamp.br/pg/index.mm.php

UNIMAR - http://www.unimar.br/pos/pos_comunicacao.php

UNIP - http://www5.unip.br/ensino/pos_graduacao/strictosensu/ss_comunicacao.aspx

UNISINOS - http://www.unisinos.br/ppg/comunicacao/

USP - http://poseca.incubadora.fapesp.br/portal/comunicacao/

UTP - http://www.utp.br/mcl/

PORTCOM - http://portcom.intercom.org.br

Prossiga - http://prossiga.ibict.br/

Rede Alfredo de Carvalho - http://www.jornalismo.ufsc.br/redealcar/rede.htm

REVCOM - http://revcom2.portcom.intercom.org.br

SBPJor - http://www.sbpjor.org.br

Scielo - http://www.scielo.br

SOCINE - http://www.socine.org.br 